UNIVERSIDAD DE SALAMANCA

FACULTAD DE DERECHO

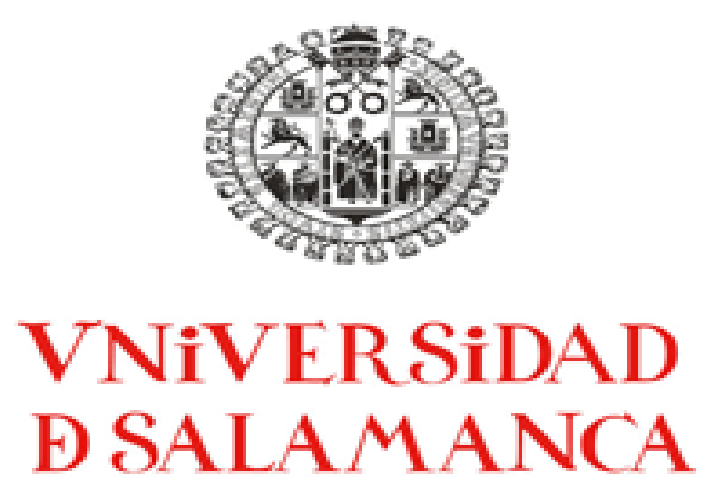

\title{
EL ACCESO IGUALITARIO A LA FUNCIÓN PÚBLICA: ANÁLISIS DEL DERECHO ESPAÑOL Y BRASILEÑO
}

\section{TESIS DOCTORAL}

PROGRAMA DE DOCTORADO "DERECHO ADMINISTRATIVO DE LA SOCIEDAD DEL CONOCIMIENTO”

DOCTORANDO: FÁBIO LINS DE LESSA CARVALHO

DIRECTORA: DR ${ }^{\mathrm{a}}$ MARÍA ÁNGELES GONZÁLEZ BUSTOS

SALAMANCA, 2010 


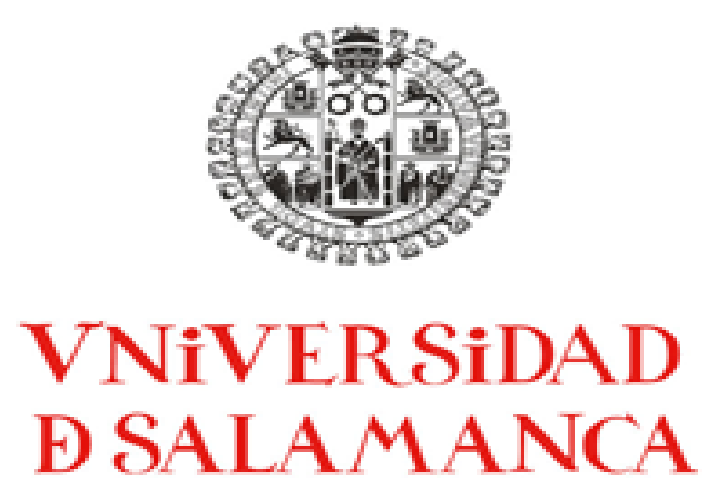

\section{EL ACCESO IGUALITARIO A LA FUNCIÓN PÚBLICA: ANÁLISIS DEL DERECHO ESPAÑOL Y BRASILEÑO}

Tesis doctoral presentada por D. Fábio Lins de Lessa Carvalho para obtener el grado de Doctor en Derecho por la Universidad de Salamanca, dirigida por la Doctora María Ángeles González Bustos, Profesora Titular de Derecho Administrativo de la Universidad de Salamanca, habiendo obtenido la Suficiencia Investigadora en el marco académico del Programa de Doctorado "Derecho Administrativo de la Sociedad del Conocimiento"

La Directora de la Tesis

Fdo. Dra Mángeles González Bustos

El Doctorado

Fdo. Fábio Lins de Lessa Carvalho 
Dedico esta tesis doctoral a mis padres Reinaldo y Mabel, que siempre me han amado y apoyado de forma incondicional, y que por las lecciones de vida que me han proporcionado, deben sentirse en este momento coautores de este trabajo. A mi esposa Alessandra, verdadera compañera que ha quedado a mi lado en esta odisea española. A mi familia, amigos, compañeros de trabajo y alumnos, que han creído en este intento y que han contribuido a su realización. 
Agradezco a la Directora de esta tesis doctoral, Prof ${ }^{a}$ Dr $^{\mathrm{a}}$ María Ángeles González Bustos, genuino ejemplo de persona que brilla en el campo personal y profesional, por su disposición a ayudarme en todos los momentos posibles y por sus contribuciones valiosas a la realización de este trabajo; a los demás profesores y pas del Departamento de Derecho Administrativo de la Universidad de Salamanca; a la Universidade Federal de Alagoas - UFAL, y a la Procuradoria Geral do Estado de Alagoas - PGE/AL (Brasil), que han comprendido la necesidad de capacitación del funcionario público, sea en la función de Profesor o de Abogado del Estado; a los ciudadanos españoles y brasileños que buscan la realización del sueño del empleo público, creyendo que la actuación de los funcionarios públicos consiste en un factor de transformación social, y que me han servido de motivación e inspiración para la elaboración de este trabajo; a los amigos de Maceió (Brasil), que desde lejos me han incentivado, y a los que he conocido en Salamanca y Barcelona, que me han proporcionado experiencias inolvidables. 


\section{CAPÍTULO 1 - EL PRINCIPIO DE IGUALDAD: ESPECIAL REFERENCIA A LOS ORDENAMIENTOS CONSTITUCIONALES ESPAÑNOL Y BRASILEÑO}

1.1- Igualdad y acceso meritorio a la función pública....

1.2 - El principio de igualdad, en España y en Brasil.

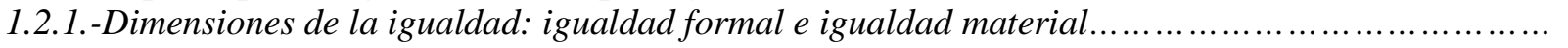

1.2.2- Manifestaciones de la igualdad.

1.2.2.1 - Igualdad ante la ley.

1.2.2.2 - Igualdad en la aplicación de la ley.....

1.2.2.3 - Igualdad en la ley....

1.2.3 - Técnicas de la igualdad.

1.2.3.1 - Generalización.

1.2.3.2 - Equiparación.

1.2.3.3 - Diferenciación.

1.2.4 - Igualdad y no discriminación.

1.2.4.1 - Diferenciación y discriminanción.

1.2.4.2 - ¿Cuándo se puede aceptar una diferenciación?.

1.2.4.3 - ¿Cómo se debe diferenciar?.

1.2.4.3.1 - La búsqueda de la finalidad de la norma diferenciadora.....

1.2.4.3.2 - La conexión entre la finalidad de la norma diferenciadora con un interés jurídicamente relevante......

1.2.4.3.3 - La utilización de criterios diferenciadores con proporcionalidad.......

\section{CAPÍTULO 2 - EL PRINCIPIO DE IGUALDAD EN EL ACCESO A LA FUNCIÓN PÚBLICA ESPAÑOLA Y BRASILEÑA}

2.1 - El acceso a la función pública.

2.1.1 - El acceso a la función pública en condiciones de igualdad: aspectos históricos, políticos y sociológicos.

2.1.1.1 - El acceso a la función pública en los modelos patrimonialista, burocrático y gerencial......

2.1.1.2 - El acceso meritorio a la función pública y la exigencia de actuación objetiva y eficaz de la Administración Pública.

2.1.1.3 - Las ventajas del acceso meritorio.

2.1.1.4 - La relación entre formas de acceso a la función pública y prevención a la corrupción.

2.1.1.5 - El derecho de acceso a la función pública en condiciones de igualdad como derecho de participación del ciudadano.

2.1.2 - El derecho de acceso a la función pública en condiciones de igualdad. 
2.1.2.1.1- El derecho de acceso a la función pública en condiciones de igualdad como derecho de carácter reaccional.

2.1.2.1.2- El derecho de acceso a la función pública en condiciones de igualdad como derecho de configuración legal......

2.1.2.1.3 - El alcance del derecho previsto en el art. 23.2 CE.

2.1.2.1.4 - El acceso meritorio como mandamiento constitucional...

2.1.2.2 - En la Constitución brasileña de 1988.

2.1.2.2.1 - Análisis de las normas constitucionales relativas al acceso meritorio.

2.1.2.2.2 - El concurso público en la realidad brasileña.

168

2.1.2.2.3 - La utilización indebida de las excepciones constitucionales del concurso público.

172

174

\section{CAPITULO 3 LA IGUALDAD EN LOS REQUISITOS DE ACCESO A LA FUNCIÓN PÚBLICA ESPAÑOLA Y BRASILEÑA}

3.1 - Análisis de los requisitos de acceso a la función pública.

3.2.- Requisitos positivos

3.2.1- Nacionalidad.

3.2 2- Conocimiento lingüístico.

3.2.3-Edad

3.2.4 - Género.

3.2.4.1 - El acceso de la mujer a la función pública.

3.2.4.2 - La partipación de la mujer en los procesos selectivos.

3.2.5 - Capacidad funcional.

3.2.5.1 - La cuestión de las personas con discapacidad: nuevos paradigmas.

3.2.5.2 - El acceso de las personas cn discapacidad a la función pública.

3.2.6 - Cuestiones raciales.

3.2.7 - Cuestiones religiosas.

3.2.8 - Cuestiones de orientación sexual.

3.2.9 - Goce de los derechos políticos.

3.2.10 - Cumplimiento de las obligaciones electorales y militares.

3.2.11 - Titulación

3.2.12 - Experiencia y servicios prestados a la Administración..

3.3 - Requisitos negativos

3.3.1 - En el derecho español.

3.3.1.1 - Ausencia de separación del servicio.

3.3.1.2 - Ausencia de inhabilitación para el ejercicio de funciones públicas.....

3.3.1.3 - Los requisitos negativos para los nacionales de otros Estados.

3.3.2 - En el derecho brasileño. 
3.3.2.3 - No suspensión de los derechos políticos por acto de improbidad administrativa......

3.3.2.4 - No permanencia de los efectos de la sentencia criminal condenatoria y la cuestión de la investigación social.

\section{CAPÍTULO 4 - LA IGUALDAD Y LOS PRINCIPIOS DE LOS PROCESOS} SELECTIVOS PARA ACCESO A LA FUNCIÓN PÚBLICA ESPAÑOLA Y BRASILEÑA

4.1 - Características de los procesos selectivos de acceso a la función pública en España y en Brasil.

4.1.3 - Carácter reglado.

4.1.4 - Carácter controlado.

4.1.5 - Carácter eficaz.

4.2 - Los principios de los procesos selectivos de acceso a la función pública...................

4.2.1. - Competitividad.

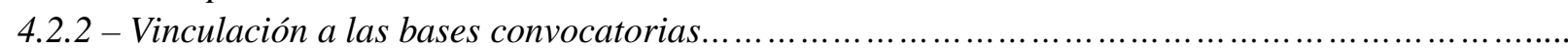

4.2.3 - Publicidad.

4.2.4 - Transparencia.

4.2.5 - Sumisión a control.

4.2.5.1 - La relevancia del control de los procesos selectivos de acceso a la función pública.

4. 2.5.2 - Las hipótesis en que cabe el control.

4.2.5.3 - Modalidades de control de los procesos selectivos.

4.2.5.3.1 - Control administrativo.

4.2.5.3.2 - Control judicial......

4.2.5.4 - Actos del procedimiento de selección sujetos a control.

4.2.5.5 - Legitimidad para el ejercicio del control del proceso de selección.

4.2.6 - Imparcialidad y profesionalidad de los miembros de los órganos de selección.

4.2.7 - Independencia y discrecionalidad técnica en la actuación de los órganos de selección.

4.2.7.1 - La discrecionalidad técnica en el derecho español...

4.2.7.2 - La discrecionalidad técnica en el derecho brasileño

4.2.8 - Adecuación entre el contenido de los procesos selectivos y las funciones o tareas a desarrollar.... 4.2.9- Agilidad.

\section{CAPÍTULO 5 - LA IGUALDAD EN EL PROCEDIMIENTO SELECTIVO DE ACCESO A LA FUNCIÓN PÚBLICA ESPAÑOLA Y BRASILEÑA}

5.1 - Competencia para la reglamentación de los procesos selectivos de acceso a la función pública.

5.1.1.1 - Las normas básicas.

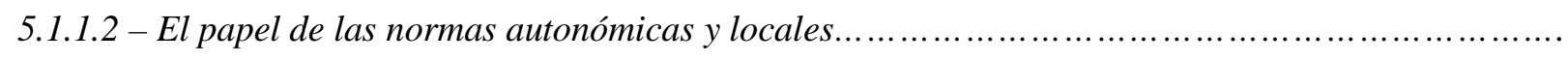

5.1.2 - En Brasil. 
5.2 - Los sistemas selectivos para acceso a la función pública.

5.2.1 - En el Derecho español.

5.2.1.1 - Oposición.

5.2.1.2 - Concurso

5.2.1.3 - Concurso-oposición.

5.2.2 - En el Derecho brasileño.

5.2.2.1 - El concurso público de pruebas (provas).

5.2.2.2 - El concurso público de pruebas y méritos (provas e títulos).

5.3 - El procedimiento selectivo de acceso a la función pública española y brasileña. ...

5.3.1 - Evaluación de las necesidades de personal: la oferta de empleo público española y la previsión presupuestaria brasileña.

5.3.2 - Organización del proceso selectivo: los órganos de selección españoles y la contratación de entidades externas en Brasil.

5.3.3 - Elaboración de la convocatoria.

5.3.3.1 - Contenido de las bases de la convocatoria.

5.3.3.2 - Publicación de la convocatoria y de los demás actos del proceso.

5.3.4 - Solicitudes de participación y admisión de candidatos.

5.3.5 - Celebración de las pruebas.

5.3.5.1 - Las pruebas escritas y los exámenes tipo test......

5.3.5.2 - Las pruebas orales...

5.3.5.3 - Las pruebas prácticas.

5.3.5.4 - Las pruebas físicas.

5.3.5.5 - Los tests psicotécnicos.

5.3.5.6 - Otros medios.

5.3.6 - Divulgación de la relación de aprobados.

5.3.7 - Aportación de documentos.

5.3.8 - Período de prácticas y cursos selectivos......... 


\section{ABREVIATURAS}

CA Comunidad Autónoma (España)

CB o CF Constitución Brasileña de 1988

CE Constitución Española de 1978

EBEP Estatuto del Empleado Público (Ley 07/2007 - España)

OEP Oferta de Empleo Público (España)

LMFP Ley de Medidas para Reforma de la Función Pública (Ley 30/1984 - España)

LRF Lei de Responsabilidade Fiscal (Ley Complementar 101/2000 - Brasil)

LPAC Ley de Régimen Jurídico de las Administraciones Públicas y del Procedimiento Administrativo Común (Ley 30/1992 - España)

MS Mandado de Segurança (Brasil)

RD Real Decreto (España)

RE Recurso Extraordinario (Brasil)

RO Recurso Ordinario (Brasil)

STC Sentencia del Tribunal Constitucional (España)

STS Sentencia del Tribunal Supremo (España)

STF Supremo Tribunal Federal (Brasil)

STJ Superior Tribunal de Justiça (Brasil)

STSJ Sentencia del Tribunal Superior de Justicia (España)

TC Tribunal Constitucional (España)

TJ Tribunal de Justiça (Brasil)

TRF Tribunal Regional Federal (Brasil)

TS Tribunal Supremo (España) 


\section{INTRODUCIÓN}

La capacidad emprendedora ha sido una de las características más determinantes de la humanidad, ya que ha hecho que las más distintas sociedades siempre hayan tenido, por las más distintas circunstancias y necesidades, el constante interés por la superación, por el avance y por el perfeccionamento, lo que, aunque con algunos retrocesos, ha permitido la evolución del genero humano.

Entre las distintas reclamaciones de la humanidad (especialmente se ha tomado en consideración los últimos dos siglos), pocas ocupan un espacio tan destacado como la exigencia de trato igualitario, sea en las relaciones privadas, como en las establecidas con los Poderes Públicos.

Todos los avances alcanzados en dicha misión han conseguido reducir paulatinamente las inmensas diferencias existentes entre los seres humanos en el plan de relaciones sociales, fundamentalmente a partir del amplio reconocimiento en el que todos los individuos están dotados de la misma dignidad. 
En el contexto arriba destacado, el papel ejercido por el ordenamiento jurídico es notable, ya que cabe a este la imprescindible tarea de consolidación de los progresos alcanzados, a partir de la consagración de los valores sociales más relevantes en sus normas.

Es notorio que el Derecho muchas veces es utilizado para la manutención de determinadas relaciones sociales y económicas de dominación. Sin embargo, tampoco se puede negar que el referido instrumento puede ser utilizado por la sociedad para la transformación de la realidad.

Por la razón arriba indicada, cabe a cada sociedad elegir el papel que, a cada momento, se pretende atribuir a las normas jurídicas (preservación o transformación), en que pese a los dos objetivos mencionados no sean necesariamente excluyentes, debido a que los mismos generalmente actúan de forma conjunta, sea cuando se necesita consolidar ciertos cambios o cuando se requiera determinadas reformas para que sea posible la preservación de determinados valores.

En el contexto de la igualdad, el raciocinio anteriormente expuesto puede ser comprendido de la siguiente forma: siempre habrá la necesidad del Derecho de introducir las debidas transformaciones, con el fin de que las normas jurídicas establezcan situaciones que favorezcan cada vez más la igualdad entre las personas. Por esta razón, son constantes las leyes que sancionan determinados comportamientos discriminatorios o implantan políticas de compensación (acciones positivas).

No obstante, se impone que las mencionadas transformaciones sean consolidadas. En otras palabras, se exige que los nuevos paradigmas de conducta sean fortalecidos, para que estos puedan transponer el mundo jurídico, adentrar en el mundo de las relaciones sociales y allí arraigarse.

Así, una vez instaladas las debidas transformaciones sociales introducidas por los cambios normativos que amplían los espacios de igualdad entre las personas, conviene que estas sean reforzadas, lo que requiere que la sociedad no se acomode, ni tampoco se descuide ni un solo instante.

Sin embargo, como las relaciones sociales no son estáticas, se exige del Derecho una actuación cada vez más emprendedora, sea para que atienda las nuevas 
reclamaciones, o bien (lo que aquí interesa), para que las conquistas alcanzadas no sean perecederas o hasta olvidadas.

En el panorama delineado, el estudio comparativo de dos o más ordenamientos jurídicos puede ofrecer una gran contribución, en la medida en que aporta las experiencias vivenciadas por determinadas sociedades, permitiendo el análisis crítico de los aspectos positivos, que podrán servir como modelo (con sus debidas adaptaciones), y de los negativos, que deberán ser evitados o redimensionados.

En el caso específico de este trabajo, el cotejo entre dos sistemas jurídicos permitirá el examen respecto a los intentos, ni siempre exitosos, de garantizar, en el plan de la realidad, la igualdad jurídica entre los ciudadanos prevista en las Constituciones.

Es posible añadir que el referido estudio comparativo es aún más provechoso cuando lleva en consideración dos sociedades que, aunque posean características bien particulares, conservan rasgos comunes. Tal circunstancia permite que la investigación científica verifique, a través de un análisis crítico, cuáles fueron las soluciones específicas adoptadas por cada una de las diferentes comunidades, cuando enfrentaron los mismos retos.

En este contexto, España y Brasil son países que aunque posean características históricas, sociales, políticas y económicas reconocidamiente diferenciadas, también tienen rasgos culturales y jurídicos semejantes, lo que permite la identificación de problemas análogos.

Entre los aspectos culturales que permiten un paralelismo entre los citados países, puede ser destacado el hecho de que los mismos están sometidos a la influencia del mundo latino, las referidas sociedades tienen un carácter expansivo y poseen cierta resistencia a la instalación de valores impersonales, entre ellos, la igualdad.

En lo que se refiere a los rasgos jurídicos semejantes, se puede subrayar la circunstancia de que los dos ordenamientos adoptan el sistema romano germánico, donde hay la primazia de la ley, amparan el Estado Social de Derecho, tienen democracias consolidadas y Constituciones promulgadas en el mismo período histórico (la española es 1978, y la brasileña de 1988), que consagrarón en sus textos la igualdad como uno de los valores supremos de la vida social. 
Respecto al acceso a la función pública, sea en España, como en Brasil, se puede constatar una demanda extraordinaria por el empleo público, probablemente debido a la estabilidad económica y status social que proporciona, lo que hace que miles de ciudadanos estén dedicándose en este exacto momento a la preparación para las oposiciones y concursos públicos, que son cada vez más disputados.

Aunque se pueda afirmar que tanto España como Brasil, cada uno a su manera, han concebido modelos racionales de acceso a la función pública (procesos selectivos competitivos y transparentes), que intentan alejarse de los vicios patrimonialistas, también es innegable que ellos no siempre han conseguido garantizar una selección igualitaria.

Tras todo esto que fue expuesto, cabe destacar que este trabajo pretende analizar el derecho fundamental del ciudadano a acceder a la función pública en condiciones de igualdad en los ordenamientos jurídicos español y brasileño, y para tal, se partirá de la premisa que es imperioso conocer las condiciones que envuelven la aplicación de una de las más relevantes derivaciones del derecho de igualdad, a partir de la verificación de su significado, sus repercusiones en la actuación administrativa y en la situación jurídica de los administrados, así como los obstáculos que dificultan su efectiva consolidación en cada uno de los citados sistemas jurídicos.

El acceso a la función pública es un tema cuya magnitud, en términos de relevancia para la mejoría de las condiciones sociales, es indiscutible, especialmente en una sociedad que se relaciona con la Administración Pública de forma tan intensa.

Se puede subrayar que la selección de los funcionarios públicos es un asunto complejo y que necesita ser tratado bajo distintas e igualmente relevantes consideraciones, entre las cuales se puede destacar las relacionadas a las políticas públicas de personal, que se dedican a las tareas de identificación de los problemas de los recursos humanos de la Administración Pública, a partir de su evaluación y consecuente planificación de medidas de selección, formación y desarrollo de las carreras administrativas, que puedan solucionar las referidas dificultades.

También aportan importantes consideraciones al estudio de la selección de funcionarios los que se dedican al análisis sociológico del tema, especialmente cuando se procura establecer las debidas relaciones entre el acceso y el buen desempeño de las 
actividades administrativas, así como la vinculación entre el referido asunto y la actuación imparcial y objetiva de los organismos públicos.

En este contexto, son inestimables los estudios sobre corrupción, patrimonialismo, clientelismo y utilización del modelo gerencial, entre otros temas que hacen parte del debate social, político y jurídico de los días actuales, sea en la realidad brasileña como en la española.

En este trabajo, se buscará no olvidar las relevantes contribuciones que los mencionados estudios pueden aportar para la comprensión multidisciplinar del tema. Sin embargo, sus grandes discusiones envuelven cuestiones que exigen el manejo de conocimientos de naturaleza jurídica (que ciertamente no se resumen al trato del Derecho positivo), según se verá a continuación.

La primera gran cuestión a ser investigada en el presente trabajo trata el significado de la igualdad, comprendida esta como valor superior de la sociedad, y acogida como principio fundamental de la mayoría de las Constituciones, incluso de la española y de la brasileña.

En esta tarea, serán estudiadas las dimensiones de la igualdad (formal y material), y sus manifestaciones (igualdad ante la ley, en la aplicación de la ley y en la ley). También serán analizadas las variadas técnicas utilizadas por el ordenamiento jurídico para que sea posible establecer, delante de situaciones distintas, una efectiva igualdad entre las personas.

En este momento, aunque los aspectos teóricos de la igualdad sean relativamente comunes a los ordenamientos jurídicos bajo estudio, habrá la aportación de las contribuciones de la doctrina y de las interpretaciones de la jurisprudencia de cada país, lo que tornará más fértil la investigación del tema.

Posteriormente, siempre destacando los contextos de los derechos español y brasileño, conviene que sea investigado el tema de la discriminación, así como de los presupuestos teóricos para que el ordenamiento jurídico pueda válidamente establecer tratos diferenciados.

Superado este primer aspecto de carácter más general, será necesaria la inserción en la cuestión del acceso a la función pública, especialmente a partir del 
análisis de los artículos de las Constituciones española y brasileña que consagran el derecho del ciudadano a acceder a la función pública en condiciones de igualdad y el sistema meritorio de acceso.

En el apartado referido, se indagará respecto al significado y alcance de la sobredicha manifestación de la igualdad, destacando su incidencia en la realidad de cada uno de los sistemas jurídicos bajo investigación, lo que será muy relevante para que de él puedan ser extraídos sus máximos efectos.

También deberán ser investigados los contextos histórico y sociológico del acceso a la función pública, así como sus peculiaridades en los modelos de Administración Pública patrimonialista, burocrático y gerencial, que fueron y están siendo experimentadas en España y en Brasil, aunque con matices propios en cada país.

Asimismo, se procederá al análisis de la posibilidad del derecho de acceso a las funciones públicas en condiciones de igualdad por estar relacionado al derecho de participación del ciudadano en los asuntos públicos.

Igualmente relevante será la búsqueda de las conexiones entre el mérito y la capacidad en la selección de los funcionarios como garantía de igualdad, de eficacia administrativa y como forma de prevención a la corrupción.

Como se supone que el derecho de acceso a la función pública en condiciones de igualdad posee límites, serán investigados los requisitos establecidos en en cada uno de los referidos ordenamientos jurídicos que condicionan la participación de los ciudadanos en los respectivos procesos selectivos.

En el citado apartado, se procederá a la verificación de las condiciones para el acceso igualitario en España y en Brasil de segmentos importantes de la sociedad, como los extranjeros, las mujeres, las personas con discapacidad, los jóvenes, los mayores, los homosexuales, entre otros.

Del mismo modo, serán analizadas cuestiones polémicas, como la exigencia de conocimiento de lenguas cooficiales en las oposiciones y el peso atribuido a los servicios prestados a la Administración Pública en los procesos selectivos, temas muy controvertidos en el derecho español; así como la posibilidad de la definición de cotas para negros e indios, y la previsión de reglas especiales para garantizar la participación 
de grupos religiosos minoritários, asuntos que despiertan mucho interés en el debate del acceso a la función pública en Brasil.

Teniendo en consideración que la igualdad representa un valor superior de los ordenamientos jurídicos español y brasileño, y que fundamenta todos los actos del proceso selectivo de acceso a la función pública en los citados países, se impone la investigación de las características y de los principios que forzosamente provienen de la referida exigencia, y que servirán para reforzar la reclamación de trato igualitario entre los ciudadanos.

En esta parte del trabajo, se indagará respecto a las garantías (administrativas y judiciales) que el ordenamiento jurídico ofrece para que la igualdad de acceso a la función pública pueda ser efectiva.

En este contexto, serán analizados temas como la relevancia del control de los procesos selectivos de acceso a la función pública, las hipótesis en que debe ocurrir la fiscalización de la actuación administrativa, las modalidades de control, los actos del procedimiento de selección sujetos a control, y la legitimidad para el ejercicio de la referida potestad.

Además, será atribuida especial atención al tema del control de la discrecionalidad técnica de los órganos seleccionadores, puesto que este aspecto suele ser el más decisivo respecto al control jurisdiccional de los procesos selectivos, tanto en la realidad española como en la brasileña.

La igualdad para que se pueda competir se supone relevante, pero también habrá de ser asegurada la igualdad en la propia competición. Por esta razón, deberán ser estudiadas las exigencias de la igualdad en el procedimiento administrativo de selección de los funcionarios públicos.

Lo que se buscará es la respuesta al siguiente estudio: ¿Los ordenamientos jurídicos español y brasileño garantizan que todos los aspirantes competirán teniendo las mismas oportunidades?

En este contexto, como se ha destacado, tanto serán analizados los principios que caracterizan los procesos selectivos y que contribuyen para la efectiva 
igualdad entre los candidatos, así como los actos del procedimiento, siempre llevando en consideración la necesidad de investigar las repercusiones de la igualdad sobre los mismos y el cotejo crítico de las soluciones adoptadas en los sistemas jurídicos de España y de Brasil.

En la referida parte del trabajo, serán estudiadas las diferentes formas de selección, así como las distintas modalidades de pruebas que son impuestas a los candidatos. Cabrá, en ese momento, verificar si la ejecución de los actos de selección es llevada a cabo teniendo en cuenta la igualdad entre los competidores.

Como ya fue destacado, la metodología empleada en este trabajo consistirá en la realización de un estudio multidisciplinar y comparativo del tema, utilizando las necesarias aportaciones de otras disciplinas.

Es imprescindible que se tenga en consideración que la comprensión de las complejidades del entorno que caracteriza la actividad seleccionadora de cada Estado exige la aportación de datos que provienen de distintas disciplinas, especialmente de la historia, de la sociología, de la política y de la ciencia de la administración, y que repercuten de forma decisiva en la conformación y aplicación de las normas jurídicas.

El manejo de las circunstancias (históricas, sociales, políticas y administrativas) que envuelven la creación de los institutos jurídico administrativos, así como los cambios normativos introducidos en los modelos de selección para el acceso a la función pública adoptados en España y en Brasil será una relevante herramienta para el análisis de las condiciones jurídicas para la efectividad de la igualdad en los mencionados contextos.

Respecto al análisis jurídico del tema, debido a su complejidad, cabe añadir que el presente estudio tomará como objeto de sus consideraciones exclusivamente las condiciones referentes a la igualdad en el acceso a través de los procesos selectivos de carácter meritorio y para las plazas reservadas a los funcionarios de carrera.

De esta forma, la mencionada circunstancia excluye del objeto del trabajo la investigación de los mecanismos de acceso que están relacionados a la libre designación, así como las formas de ingreso que aunque sean meritorias, otorgan al 
ciudadano otras modalidades de sujeciones con la Administración, distintas de las funcionales (como ejemplo, las laborales).

Ciertamente, la constatación arriba no impedirá que, durante el desarrollo de la investigación, sean expuestas algunas circunstancias que dicen respecto al acceso de las más distintas clases de empleados públicos.

Sin embargo, esto se lo hará de forma incidental, muchas veces con el objetivo de comparación entre los modelos y para que uno tenga paradigmas que sirvan para rechazar las modalidades de acceso que no garantizan la igualdad.

Sobre el objeto de estudio, también es relevante que sea subrayado que, en general, serán analizadas las normas que están vigentes y que han sido creadas por el Estado (en España) y por la Unión Federal (en Brasil), sean las que se aplican a la totalidad de las Administraciones Pública españolas (entidades estatales, autonómicas y locales) y brasileñas (administración federal, estadual y municipal), y, en algunos casos, las que hayan sido elaboradas por la mencionada entidad central para su propia Administración.

Esta opción tiene como justificativa la gran cantidad y diversidad de normas sobre acceso a la función pública que ya fueron creadas a largo de la historia española y brasileña, así como las provenidas de las numerosas entidades autonómicas y locales españolas y federales brasileñas, hecho que sería incompatible con el objetivo de este trabajo.

Es cierto que los Derechos positivos de Brasil y de España ofrecen distintas formas de garantizar el acceso igualitario a la función pública, y cada uno de ellos puede beneficiarse del otro, en la medida que pase a utilizar las fórmulas adoptadas en el otro, con las debidas adaptaciones.

En este contexto, el ambiente jurídico brasileño puede recibir la influencia del derecho español, que ha desarrollado leyes que detallan los comportamientos administrativos en el curso del proceso selectivo, circunstancia aún no presente en Brasil, que todavía no posee ley que regulamente los concursos públicos.

A su vez, los españoles pueden tener la oportunidad de conocer la experiencia brasileña, que ha conseguido realizar concursos públicos con considerable 
grado de idoneidad, aunque con la participación, en algunos casos, de más de un millión de candidatos.

Así, aunque considerando los distintos grados de desarrollo legislativo de cada país, y las circunstancias (históricas, políticas, económicas, etc.) peculiares a cada realidad social, el trato de las cuestiones relacionadas al derecho del ciudadano acceder a la función pública en condiciones de igualdad y al sistema meritorio de selección puede ser perfeccionado a partir del análisis critico de otro referencial jurídico, y a través de una investigación comparativa, que estudie cuál es el significado y alcance de la sobredicha manifestación de la igualdad, lo que será muy relevante para que de él puedan ser extraídos sus máximos efectos.

Además del análisis de las normas vigentes, en la verificación de los aspectos jurídicos que envuelven cada discusión, no se olvidará la utilidad del conocimiento de los entendimientos doctrinales, ni tampoco la relevancia de las contribuciones jurisprudenciales.

La doctrina española ha dedicado muchos estudios a la cuestión de la igualdad, una buena cantidad al acceso a la función pública, y pocos a la intersección entre los dos temas, circunstancia que amplía la relevancia académica de la presente investigación. Evidentemente, la contribución que los estudios doctrinales pueden aportar al presente trabajo es inestimable, lo que será considerado.

A su vez, quizás debido a la existencia de la Justicia ContenciosoAdministrativa, los Tribunales españoles han desarrollado una considerable jurisprudencia respecto a las cuestiones que envuelven el derecho fundamental de la igualdad, y sobre su aplicación al ámbito del acceso a la función pública, hay relevantes decisiones cuyo análisis será muy útil a la presente investigación.

En Brasil, que es un Estado Federal, hasta los días de hoy, todavía no hay una legislación nacional que trate uniformemente del acceso a la función pública, ni tampoco hay una Justicia Contencioso-Administrativa, lo que hizo con que la doctrina haya tenido una relevante función interpretativa de las normas constitucionales y desarrollado importantes estudios sobre el tema. A lo mejor Brasil es el país latinoamericano que ha desarrollado el mejor sistema de acceso meritorio a la función pública, lo que necesariamente no signifique que no posea muchos problemas. 
Así, a priori, tanto se puede destacar las muchas posibilidades de aportaciones de la jurisprudencia y legislaciones españolas al derecho brasileño, como de las investigaciones doctrinarias brasileñas al derecho español.

En este trabajo, con el fin de facilitar la exposición de los más distintos temas relacionados al objeto de la investigación, se ha optado por una metodología que consiste, a cada nuevo asunto, en su presentación, a partir del destaque de los aspectos generales y sus cuestiones más relevantes, especialmente para el trato de la igualdad.

A continuación, habrá el análisis simultáneo de las repercusiones del tema en las realidades española y brasileña. Sin embargo, en el primer momento, siempre serán expuestas las consideraciones respecto al contexto español, donde serán destacados los aspectos jurídicos (legislación, doctrina y jurisprudencia), sin que haya el olvido de las cuestiones de naturaleza sociológica, política, histórica y administrativa.

Tras la investigación del alcance de la igualdad en cada uno de los temas que repercuten en los procesos selectivos de acceso a la función pública en España, será realizada la referida labor en el ámbito del contexto brasileño, oportunidad en que serán realizadas las observaciones respecto a las similitudes y distinciones entre los referidos ordenamientos jurídicos.

En el mencionado examen, siempre habrá la averiguación respecto a la posibilidad de adopción, en determinado sistema jurídico, de algunas de las medidas previstas en el otro, ya que las principales finalidades de la presente investigación son la exposición y análisis critico de las respuestas jurídicas ofertadas por diferentes sociedades (intercambio de experiencias), así como la proposición de modificaciones legislativas inspiradas en otros ordenamientos (reproducción, con las debidas adaptaciones, de soluciones).

La presente opción (análisis inicial del contexto español, seguido de la inmediata investigación de la realidad brasileña) tiene como fundamento una de las justificaciones del presente trabajo: como este doctorando es brasileño, él mismo utilizará el derecho español como parámetro para investigación del grado de desarrollo del tema en la realidad brasileña. 
En lo que refiere a la hipótesis de investigación que motiva la elaboración del presente trabajo, esta consiste en la indagación respecto a las reales condiciones de efectividad de la igualdad de los ciudadanos en el acceso a la función pública española y brasileña, lo que exigirá el énfasis del análisis de las repercusiones del citado derecho, de los obstáculos a su realización y de cómo estos podrán ser alejados.

En el citado contexto, se investigará si las reglas constitucionales que garantizan que todos los españoles y brasileños tienen el derecho fundamental de acceder a la función pública en condiciones de igualdad, tras más de tres (en el caso de España) y dos (en el contexto brasileño) décadas de su elaboración ya ha alcanzado lograr sus objetivos, y cuáles serían los argumentos que autorizarían una eventual contestación en sentido positivo o negativo.

Ciertamente, aquí no está delante de una indagación cuya respuesta pueda ser definitiva, y que podría resumirse a un sencillo "sî" o "no". En verdad, deberán existir circunstancias que confirman el alcance de algunos de los efectos deseados de la norma (repercusiones del citado derecho). Sin embargo, existirán otras conclusiones que evidenciarán las dificultades para que la igualdad en el acceso a la función pública sea plena o quizá presente (obstáculos a su realización).

En las circunstancias favorables de la respuesta, se impone que sean indicados los aspectos que han sido perfeccionados en los referidos ordenamientos jurídicos y cómo estos reflejen en la actuación cada vez más imparcial de la Administración Pública. A su vez, en los aspectos negativos de la contestación, conviene que sean apuntados los problemas detectados, su origen y sus posibles soluciones.

En las dos mencionadas tareas, no se debe olvidar que el acceso igualitario a la función pública, aunque también tenga su repercusión en la vida de cada individuo, no sólo es un derecho fundamental del ciudadano, sino una exigencia de toda sociedad, y la lucha por la maximización de sus efectos es un reto colectivo del cual todos deben contribuir, lo que garantizará el proceso de consolidación del Estado Democrático y Social de Derecho. 
CAPÍTULO 1 - EL PRINCIPIO DE IGUALDAD: ESPECIAL REFERENCIA A LOS ORDENAMIENTOS CONSTITUCIONALES ESPAÑOL Y BRASILEÑO 


\section{1- Igualdad y acceso a la función pública}

Considerada como una de las claves del éxito o del fracaso de las Administraciones Públicas, la selección de los funcionarios públicos es un tema que envuelve ideas que constituyen pilares del Estado democrático de Derecho, como la necesidad de igualdad entre los ciudadanos en el trato con la Administración, la objetividad de la actuación administrativa y la exigencia de eficacia de los órganos públicos. ${ }^{1}$

Todos estos valores (igualdad, objetividad y eficacia, entre otros) están previstos en la Constitución española de 1978 y en la brasileña de 1988, e influyen decisivamente en las reglas de acceso a la función pública de los dos referidos Estados. Como principios constitucionales sirven de inspiración para la definición de las leyes, así como para su adecuada interpretación y aplicación. Sin embargo, tales principios no actúan de forma aislada, sino a través de una conexión muy estrecha.

Garantizar el respecto a la igualdad entre los ciudadanos sin seleccionar los más capaces es olvidar la necesidad de eficiencia administrativa. No obstante, elegir aspirantes que sean aptos al desempeño de las funciones públicas sin preocuparse por una participación universal en la selección significa relegar los derechos de los ciudadanos a acceder a las funciones públicas.

Lo que los ordenamientos jurídicos español y brasileño exigen es una Administración Pública que actúe de forma profesional (lo cual requiere que la selección de los funcionarios públicos utilice los criterios de mérito y capacidad) y al mismo democrática (lo cual impone que todos los ciudadanos tengan el derecho de competir en condiciones de igualdad por las plazas, y a su vez, tengan la oportunidad de participar de la vida pública en su dimensión estatal).

\footnotetext{
${ }^{1}$ SANCHÉZ MORÓN; Miguel. Derecho de la Función Pública, 5a edición, Tecnos, Madrid, 2008, p. 114.
} 
En el derecho constitucional español, mientras la igualdad sirve fielmente a las ideas de integración y actuación democrática en lo público (art. 23.2, CE), el mérito y la capacidad se constituyen como los únicos criterios validos para la selección ${ }^{2}$ (art. 103.3, CE), lo que favorece a la objetividad y la eficacia administrativa (art. 103.1, CE).

A su vez, el ordenamiento jurídico-constitucional brasileño, tras determinar que la igualdad es uno de los derechos fundamentales del ciudadano (art. $5^{\circ}, \mathrm{CB}$ ), impone la accesibilidad universal a los cargos y empleos públicos (art. 37, I y II, CB) como forma de garantizar los principios constitucionales de legalidad, impersonalidad, moralidad, publicidad y eficiencia (art. 37, caput, CB).

Los mencionados principios fueron conquistados históricamente $^{3}, \quad \mathrm{y}$ traducen la opción jurídico-política por el rechazo a los privilegios, inmunidades y a las nefastas conductas clientelistas que prevalecieron durante siglos en el ámbito estatal. Producto del pensamiento burocrático, el acceso meritorio a las funciones públicas es lo más racional y lo más eficaz, pese a ser objeto de diversas críticas.

Así, en España, hace muchísimos más de un siglo que se afirma que el ingreso en las carreras de la Administración se verifica de un modo exclusivo y mediante examen ${ }^{4}$. Sin embargo, acerca del sistema selectivo de los funcionarios públicos en el referido Estado europeo, en un análisis pragmático también se destaca que "por muy rigurosos que sean, no pueden evitar el "amiguismo", el "particularismo", el "localismo", "ismos" todos aún subsistentes en nuestro país.",

\footnotetext{
${ }^{2}$ FERNÁNDEZ DOMÍNGUEZ, Juan J. y RODRÍGUEZ ESCANCIANO, Susana. El acceso al empleo público, Ediciones Estudios Financieros, Madrid, 2005, p.23.

Aunque los procesos históricos que condujeron a la elaboración de las Constituciones española y brasileña sean muy distintos, es posible establecer puntos comunes, como la necesidad de redemocratización tras gobiernos de carácter autoritario (el franquismo en España y la dictadura militar en Brasil). En los dos países, el acceso meritorio ya estaba consagrado en sus respectivas Constituciones, aunque solamente después de la redemocratización, el mencionado sistema de acceso a la función pública fue utilizado de forma amplia. Debido a factores históricos y hasta mismo cronológicos (la Constitución española es 10 años anterior a la brasileña), siempre es relevante tener en cuenta que España ha desarrollado hace más tiempo los instrumentos jurídico-administrativos de acceso meritorio.

${ }^{4}$ MARTHÍN Y GUIX, E. Manual del empleado (1905), Ministerio de Administraciones Públicas, 2007, Madrid, p. 49.

${ }^{5}$ RODRÍGUEZ GARCÍA, E.B., Prólogo del libro "Acceso a la función pública local (Políticas selectivas y control jurisdiccional)", CASTILLO BLANCO, Federico.A., Editorial Comares, Granada, 1993, p.V.
} 
En Brasil, a pesar del carácter moderno de su sistema jurídico sea, "o mau hábito cultivado por décadas tem levado a Administração a tentar algumas escaramuças com a finalidade de relegar a segundo plano a exigência do concurso.",6

De hecho, muchos cambios fueron introducidos en el último siglo en el discurso jurídico y en la praxis administrativa, sea española o brasileña, respecto al acceso a la función pública. Es posible afirmar que cada una de las mencionadas sociedades ha establecido mecanismos propios para hacer con que la igualdad de oportunidades en el ingreso en los cuadros del servicio público sea efectiva.

Seguramente, en este panorama, hay éxitos y fracasos, medidas acertadas y soluciones equivocadas. En este contexto, es relevante que uno conozca no solo las situaciones en las cuales el otro ordenamiento jurídico ha logrado instituir un mecanismo adecuado, sino también los intentos fracasados, a fin de que a partir de ellos, sea posible el perfeccionamiento de su propia realidad.

En España, en la Constitución de 1978 "se pone de manifiesto la importancia que la regulación del sistema selectivo representa en la eficaz prestación de los servicios públicos y efectiva consecución de los intereses generales."7

Sobre esta temática, partiendo de lo más genérico para una mayor especificación, la Constitución española destaca en su artículo 14.1 el principio de igualdad, imponiendo la equidad de todos los españoles en derechos y la prohibición de imposiciones discriminatorias que no sean razonables. También debe tenerse en cuenta el artículo 9.2, que impone a los Poderes Públicos la promoción de las condiciones para efectividad de la igualdad formal (igualdad material).

De una igualdad genérica ante la ley, la Constitución de 1978 llega a una de las más importantes derivaciones de aquel principio: la igualdad de todos los ciudadanos en el acceso a la función pública, lo cual realiza en el artículo 23.1

\footnotetext{
${ }^{6}$ SANTOS CARVALHO FILHO, José dos. Manual de Direito Administrativo, $17^{\mathrm{a}}$ ed. Lumen Juris Editora, Rio de Janeiro, 2007, p. 543.

${ }^{7}$ ILDEFONSO HUERTAS, Rosa María. en Lecciones de función pública, Federico A. Castillo Blanco (Director), Ana Olmedo Gaya (Coordinadora), CEMCi, Granada, 2002, p. 203.
} 
Si todos son iguales ante la ley (art. 14.1), y si por ello, todos los ciudadanos tienen el derecho de acceder a las funciones públicas en condiciones de igualdad (art. 23.1), la Constitución tendría que establecer cuáles serían los criterios válidos para que la selección de los funcionarios no se alejase de la igualdad. Así, acertadamente, previó que la realización de la igualdad entre los aspirantes a las funciones públicas solamente podría manifestarse a través de un sistema donde la elección de los más idóneos se basara en criterios objetivos, independientes de los lazos de sangre, de la política o de la amistad. E incluso que premiara los esfuerzos personales de cada individuo, sustituyendo el principio aristocrático que solía discriminar por razón de nacimiento. ${ }^{8}$

El sistema arriba mencionado está previsto en el artículo 103.1 de la Constitución española, que condiciona la selección de los funcionarios públicos al mérito y a la capacidad de los aspirantes.

Estos tres dispositivos de la Constitución española forman la base de la configuración del sistema selectivo de los funcionarios públicos, lo que impone un análisis más profundo de cada uno de ellos.

En Brasil, por motivos históricos, su Constitución es analítica, lo que permitió la introducción de una gran cuantidad de normas respecto a la igualdad, así como al acceso meritorio a la función pública. Además, como se trata de una república, la doctrina brasileña sostiene que esta forma de Gobierno tiene consecuencias jurídicas, entre las cuales se destaca la imposición de acceso igualitario a la función pública:

\footnotetext{
"Estampado no caput do art. $1^{\circ}$ da Constituição de 1988, esse princípio traduz a nossa opção por uma república constitucional, ou seja, por uma forma de governo na qual - em igualdade de condições ou sem distinções de qualquer natureza - a investidura no poder e o acesso aos cargos públicos em geral - do Chefe de Estado ao mais humilde dos servidores - são franqueados a todos os indivíduos que preencham tão-somente as condições de capacidade estabelecidas na
}

\footnotetext{
${ }^{8}$ BOBBIO, Norberto. Igualdad y libertad, Ediciones Paidós, 1993, Barcelona, p. 73.
} 
própria Constituição ou, de conformidade com ela, em normas infraconstitucionais." $"$

En la Constitución brasileña de 1988, la igualdad está presente en el preámbulo ${ }^{10}$, en los objetivos fundamentales del art. $3^{\mathrm{o} 11}$, y como derecho fundamental del ciudadano, conforme redacción del art. $5^{\circ}{ }^{12}$ En el contexto específico del acceso a la función pública, la igualdad se materializa en la regla que exige la realización de concurso público para acceso a los cargos y empleos públicos (art. 37, I y II; CB).

Como ya se ha destacado, en la Constitución brasileña, el art. 37 impone principios que deberán ser observados por la Administración Pública (legalidad, impersonalidad, moralidad, publicidad y eficiencia), todos con repercusión directa en el acceso igualitario del ciudadano a la función pública, ya que una Administración que sea sometida a reglas, que trate los administrados de forma impersonal, que actúe con honestidad, de forma transparente y que persiga los mejores resultados para la sociedad deberá, necesariamente, .observar las reglas que garantizan el acceso meritorio al servicio público.

Sin embargo, en este primer capítulo, serán estudiadas las cuestiones más genéricas relativas al principio de igualdad, para que sean formadas las bases que posibilitaran el estudio posterior que venga a destacar las repercusiones que la exigencia de trato igualitario tiene en el sistema de acceso a la función pública.

\footnotetext{
${ }^{9}$ FERREIRA MENDES, Gilmar; MÁRTIRES COELHO, Inocêncio; GONET BRANCO, Paulo Gustavo. Curso de direito constitucional. $2^{\mathrm{a}}$ ed., Editora Saraiva, São Paulo, 2008, p. 147-148.

10 “Nós, representantes do povo brasileiro, reunidos em Assembléia Nacional Constituinte para instituir um Estado Democrático, destinado a assegurar o exercício dos direitos sociais e individuais, a liberdade, a segurança, o bem-estar, o desenvolvimento, a igualdade e a justiça como valores supremos de uma sociedade fraterna, pluralista e sem preconceitos, fundada na harmonia social e comprometida, na ordem interna e internacional, com a solução pacífica das controvérsias, promulgamos, sob a proteção de Deus, a seguinte CONSTITUIÇÃO DA REPÚBLICA FEDERATIVA DO BRASIL."

11 "Art. $3^{\circ}$ Constituem objetivos fundamentais da República Federativa do Brasil: (...)

III - erradicar a pobreza e a marginalização e reduzir as desigualdades sociais e regionais;

IV - promover o bem de todos, sem preconceitos de origem, raça, sexo, cor, idade e quaisquer outras formas de discriminação".

12 "Art. $5^{\circ}$ Todos são iguais perante a lei, sem distinção de qualquer natureza, garantindo-se aos brasileiros e aos estrangeiros residentes no País a inviolabilidade do direito à vida, à liberdade, à igualdade, à segurança e à propriedade (...)"
} 
La tarea anteriormente referida es imprescindible para la continuación de la presente investigación, no sólo porque es un método científicamente adecuado (partir de lo más genérico para lo más específico), sino también porque es relevante que se pueda establecer parámetros comunes del principio de igualdad que puedan ser aplicados a dos ordenamientos jurídicos distintos ${ }^{13}$, lo que permitirá una comparación entre ellos, con el consecuente cambio de experiencias.

Además, la compleja labor que esta investigación va a realizar exige un buen manejo inicial de datos teóricos, para que se pueda, al fin, detectar las amenazas a la igualdad en los procesos selectivos y proponer los necesarios cambios, sean estos originales o extraídos del otro ordenamiento jurídico objeto de comparación de esto estudio científico. En los términos anteriormente mencionados, se puede añadir que:

\begin{abstract}
"Saber quem são os iguais e os desiguais em matéria de concurso público constitui uma tarefa deveras tormentosa (...), visto que, infelizmente, a nossa realidade histórica ainda registra índices alarmantes de desvios e perseguições das bancas examinadoras em desfavor de candidatos-administrados, por motivos de toda ordem, compreendendo fatores ideológicos, sociológicos, raciais, físicos, geográficos e socioeconômicos. Para alcançar tal mister, é preciso estabelecer, de logo, parâmetros objetivos para se detectar, ictu oculi, os casos de manifesta violação ao postulado da igualdade na seara da atividade administrativa dos concursos públicos" 14
\end{abstract}

\title{
1.2.1- El principio de igualdad, en España y en Brasil.
}

Indudablemente, el principio de igualdad ante la Ley es una de las más relevantes garantías del ciudadano en sus relaciones con el Poder Público. Por supuesto, es uno de los pilares del ordenamiento jurídico, pues es un límite para el legislador, un

\footnotetext{
${ }^{13}$ Estos parámetros comunes no significan que no existan distinciones respecto a la aplicación del principio de igualdad a dos Estados tan distintos como Brasil (país latinoamericano en proceso de desarrollo) y España (país europeo desarrollado). Sin embargo, los puntos comunes son paradigmas generales que han sido abordados por la Ciencia Jurídica y que poseen una relativa validez universal. ${ }^{14}$ BARBOSA MAIA, Márcio, y PINHEIRO DE QUEIROZ, Ronaldo. O regime jurídico do concurso público e o seu controle jurisdicional, Editora Saraiva, São Paulo, 2007, p. 25.
} 
criterio de aplicación de las normas para el administrador público y un modelo de interpretación para los Tribunales.

La necesidad de combatir los privilegios indebidos y las discriminaciones arbitrarias es un reto que, en todos los tiempos ${ }^{15}$, la humanidad ha tenido y tendrá que afrontar $^{16}$. En este camino, se puede subrayar que "a igualdade é princípio que visa a duplo objetivo, a saber: de um lado propiciar garantia individual (...) contra perseguições e, de outro, tolher favoritismos." 17

Como he dicho anteriormente, la idea de igualdad como principio de organización estuvo presente en algunas sociedades primitivas, que antes de la aparición de la propiedad privada, ya "intentaban garantizar mediante reglas la distribución equivalente de los bienes o la utilización comunitaria de los mismos." 18

Además, se puede añadir que la discusión respecto a la igualdad no ha interesado solamente a todas las sociedades, sino también a distintos campos del conocimiento humano, como el Derecho, la Filosofía, la Política, la Religión, entre otras

\footnotetext{
${ }^{15}$ Muy interesante el siguiente análisis de la comprensión de la igualdad durante distintas épocas:" $L a$ igualdad no es, sin embargo, una Idea que nazca con las revoluciones del siglo XVIII, sino que ha estado presente, de una manera u otra, con un contenido y un alcance variable, en los distintos modos de organización política, jurídica y económica y en las diversas teorías filosóficas y religiosas a lo largo de toda la Historia (al igual que las ideas de libertad y dignidad, si bien que sólo después del Renacimiento empezaron todas ellas a formularse como derechos). Ahora bien, el de igualdad es un concepto eminentemente evolutivo, y ello es lo que se pretende poner en relieve en este estudio histórico, que se divide en tres partes: I - la primera se extiende hasta las revoluciones del siglo XVIII, un largo período en el que será posible constatar cómo la igualdad jurídica (el máximo triunfo de la Revolución Francesa) existió sólo excepcionalmente al largo de la Historia anterior a 1789...II - la segunda parte comienza con un análisis del sentido de las proclamaciones formales de igualdad en los contextos de las revoluciones francesa y americana, para continuar con un estudio de la plasmación del principio (ya positivado) de igualdad en los textos constitucionales europeos del siglo XIX; III - la tercera parte se centra en la evolución de este principio a lo largo del siglo XX, un siglo en el cual se han incorporado nuevas dimensiones a la noción de igualdad, en el contexto del Estado social y democrático de Derecho..." (MARTÍN VIDA, María Ángeles. Evolución histórica del principio de igualdad y paradojas de exclusión, Colección Feminae (Instituto de Estudios de la Mujer), Editorial Universidad de Granada, Granada, 2004, p.20)

${ }^{16}$ Para el constitucionalista brasileño José Afonso da Silva, "o direito de igualdade não tem merecido tantos discursos como a liberdade. As discussões, os debates doutrinários e até as lutas em torno desta obnubilaram aquela. .É que a igualdade constitui o signo fundamental da democracia. Não admite privilégios e distinções que um regime simplesmente liberal consagra. Por isso é que a burguesia, cônscia de seu privilégio de classe, jamais postulou um regime de igualdade como reivindicara o de liberdade. É que um regime de igualdade contraria seus interesses e dá à liberdade sentido material que não se harmoniza com o domínio de classe em que assenta a democracia liberal burguesa.". (DA SILVA, José Afonso. Curso de Direito Constitucional Positivo, 23ª ed., Editora Malheiros, São Paulo, 2004, p. 210).

${ }^{17}$ BANDEIRA DE MELLO, Celso Antônio. Conteúdo jurídico do princípio da igualdade, $3^{\mathrm{a}}$ ed., Editora Malheiros, São Paulo, 1999, p. 23.

${ }^{18}$ MARTÍN VIDA, María Ángeles. Op.cit., p. 23.
} 
ramas que han permitido que la humanidad reflexione acerca del contenido de la igualdad y de cómo las leyes pueden traducir el consenso del momento en determinada región. En esto camino, es posible destacar que:

"o tema da igualdade do homem em sua ambientação política não é recente nem tem conteúdo exclusivo ou predominantemente jurídico. É indagação humana que atravessa o tempo como preocupação permanente e questão incerta, porém de configuração essencial para o aperfeiçoamento do Direito e para se atingir uma sociedade justa."19

La propia noción de Estado de Derecho está asociada al fin de los privilegios $^{20} \mathrm{y}$ al establecimiento de un orden jurídico donde las leyes sean generales e impersonales, y donde todos los hombres tengan los mismos derechos y las mismas obligaciones.

Debido al hecho de que la necesidad de trato igualitario entre los individuos posee matices propios en cada sociedad y produce repercusiones distintas en cada época, es posible destacar que:

\footnotetext{
“a igualdade como Direito é problema histórico que se dá à solução do sistema jurídico. Enquanto o princípio ideal da igualdade posta-se no plano moral e espiritual e abriga-se mais na área da filosofia que do Direito, o princípio jurídico poe-se no âmbito do sistema normativo de cada sociedade estatal e é nesta seara que busca o seu continente e o seu conteúdo."21
}

En los términos arriba consignados, lo que se pretende en esto trabajo es la demostración de un núcleo común de la igualdad, en sus aspectos jurídicos, históricos y filosóficos, sin que haya el olvido de las peculiaridades de la incidencia de la igualdad en las distintas sociedades, como es el caso de la brasileña y de la española.

\footnotetext{
19 ANTUNES ROCHA, Cármen Lúcia. O principio constitucional da igualdade. Editora Lê, Belo Horizonte, 1990, p.12-13.

${ }^{20}$ Es que "a lei não deve ser fonte de privilégios ou perseguições, mas instrumento regulador da vida social que necessita tratar equitativamente todos os cidadãos. Esse é o conteúdo político-ideológico absorvido pelo princípio da isonomia e juridicizado pelos textos constitucionais em geral, ou de todo modo assimilado pelos sistemas normativos vigentes" (BANDEIRA DE MELLO, Celso Antônio. Op.cit., p. 10).

${ }^{21}$ ANTUNES ROCHA, Cármen Lúcia. Op.cit., p.13.
} 
La Constitución española ${ }^{22}$, como en general, la mayoría de las Constituciones $^{23}$, establece que la igualdad es un valor superior que debe ser promovido por los Poderes Públicos y está en la base del ordenamiento jurídico ${ }^{24}$, con el mismo grado de excelencia de la libertad, justicia y pluralismo político:

La ubicación de la igualdad en el artículo $1^{\circ}$ de la CE no es una casualidad, sino una inequívoca demostración de que este valor supremo debe influir en la construcción de todo sistema jurídico.

Aunque las personas sean efectivamente desiguales, lo que la Constitución pretende crear es un ambiente favorable a la disminución de las desigualdades y a la ecualización de las oportunidades. Debido a ello, no serán toleradas las leyes que se alejen de la constatación arriba mencionada y, consecuentemente, serán rechazados los actos administrativos y las decisiones judiciales que traduzcan discriminaciones razonables y adecuadas.

El principio de igualdad está presente de forma más destacada en el art. 14 de la $\mathrm{CE}^{25}$ : Este dispositivo constitucional traduce la opción por la aceptación de las diferencias, que es una exigencia de la democracia. El pluralismo existente en la sociedad civil debe ser objeto de especial protección estatal. El postulado de la igualdad no es el reconocimiento de que las personas (españoles, por ejemplo) sean iguales

\footnotetext{
22 "Artículo $1^{\circ}$. 1. España se constituye en un Estado social y democrático de Derecho, que propugna como valores superiores de su ordenamiento jurídico la libertad, la justicia, la igualdad y el pluralismo político."

${ }^{23}$ Como ya se ha destacado, la Constitución brasileña de 1988 establece que: "Art. $3^{o}$. Constitui objetivo da República Federativa do Brasil: (...) IV - promover o bem de todos, sem preconceitos de origem, raça, sexo, cor, idade e quaisquer outras formas de discriminação. " - y que "Art. $5^{\circ}$ Todos são iguais perante a lei, sem distinção de qualquer natureza, garantindo-se aos brasileiros e aos estrangeiros residentes no País a inviolabilidade do direito à vida, à liberdade, à igualdade, à segurança e à propriedade, nos termos seguintes..."

${ }^{24}$ No hay quien no reconozca la relevancia del principio de igualdad en el constitucionalismo español. Sin embargo, merece la pena destacar que: "el art. 14 CE (...) ha sido probablemente uno de los preceptos que menos discusiones ocasionó durante la elaboración de la Constitución por las Cortes Constituyentes. Esta escasa discusión del precepto refleja que la plasmación constitucional del principio de igualdad respondía a la existencia de unos parámetros normativos comunes en la mayoría de las sociedades democráticas occidentales de finales de los años setenta, al menos dentro del contexto europeo (...), y de unas similares bases de fundamentación teórica cuyas raíces se pueden encontrar en el pensamiento griego clásico y que en sus sucesivas evoluciones se han incorporado al acervo valorativo de dichas sociedades."(GAVARA DE CARA, J.C., Contenido y función del término de comparación en la aplicación del principio de igualdad, Cuadernos Aranzadi del Tribunal Constitucional, Thompson Aranzadi, Cizur Menor (Navarra), 2005, p. 33.)

25 "Art. 14 Los españoles son iguales ante la Ley, sin que pueda prevalecer discriminación alguna por razón de nacimiento, raza, sexo, religión, opinión o cualquier otra condición o circunstancia personal o social."
} 
(porque efectivamente no lo son), sino la declaración de que las diferencias entre las personas no las imposibilitarán a la hora de ejercer sus derechos, ni les impedirán buscar sus proyectos personales.

En este camino, se entiende que "la igualdad no se opone a las diferencias, sino a las desigualdades. La igualdad impone el respecto a las diferencias y la lucha contra las desigualdades.",26

Ciertamente, se puede afirmar que:

"Decir que la igualdad es una de las piezas claves informadoras de la Constitución española de 1978 es algo que saben o intuyen buena parte de ciudadanos. Reconocer que la igualdad ha sido una de las categorías más invocadas y utilizadas en nuestra incipiente experiencia jurídico-constitucional tampoco habrá de resultar novedoso para cualquier profesional del derecho mínimamente avisado. Ahora bien, tratar de dar cuenta de la significación y alcance de la igualdad en nuestro sistema constitucional supone, para el filósofo o el teórico del derecho, una tarea ardua e indócil, que resiste a ser cumplida plena y satisfactoriamente." 27

En la Constitución brasileña de 1988, la instalación de una sociedad más igualitaria ha sido considerada un verdadero y arduo reto para el Estado, ya que el mencionado país posee acentuados desequilibrios sociales y económicos, existiendo un gran abismo entre los ricos y pobres, blancos y negros, los del norte y los del sur, los con y los sin alfabetización, entre otros casos que demuestran la discrepancia entre distintos segmentos de la sociedad brasileña.

Así, mientras la sociedad española ya ha alcanzado un satisfactorio grado de igualdad, lo que hace que las discusiones jurídicas ya hayan alcanzado cuestiones más

\footnotetext{
${ }^{26}$ FERNÁNDEZ, Encarnación. Igualdad y derechos humanos, Tecnos, Madrid, 2003, p. 20.

${ }^{27}$ PÉREZ LUÑO, Antonio Enrique. Dimensiones de la igualdad, $2^{\mathrm{a}}$ ed., Dykinson, Madrid, 2007, p. 75.
} 
específicas $^{28}$, la sociedad brasileña aún intenta llegar a una situación de aceptabilidad mínima ${ }^{29}$, lo que demanda una intervención más activa del Estado.

Sin embargo, también es imprescindible destacar que como Brasil se destaca positivamente entre los países en vía de desarrollo, los dos países cada vez más se acercan, lo que hace que las condiciones de vida de sus poblaciones se asemejen, incluso más que uno suele imaginar ${ }^{30}$.

Seguramente, las distinciones entre la realidad brasileña y española superan las cuestiones meramente económicas. En Brasil, como en general, en los demás países latinoamericanos, subsisten factores históricos y culturales que dificultan la efectividad de valores como la igualdad. La manutención de determinadas características patrimonialistas en una circunstancia innegable, lo que no suele suceder con tanta intensidad en los países europeos, como España.

\footnotetext{
${ }^{28}$ Como ejemplo, se puede citar la preocupación con la ingreso de las mujeres en los puestos de decisión de la Administración Pública. La sociedad española, tras garantizar el acceso igualitario de hombres y mujeres a la función pública a través de procesos selectivos meritorios, no quedó satisfecha. Así, pasó a exigir que hubiese paridad de género en el ingreso en los cargos de libre designación.

${ }^{29}$ Aunque sea considerada una sociedad plural, en Brasil, es necesario que haya la previsión de cotas para los estudiantes negros en las universidades públicas, ya que la mayoría absoluta de las plazas tradicionalmente eran ocupadas por los blancos.

${ }^{30}$ Un ejemplo que puede aclarar el mencionado acercamiento de Brasil y España respecto a las condiciones de vida de la población dice respecto a la extensión de la clase media. En España, "en los años 70 y 80, la clase media en España era mayoritaria. El 58\% de la población estaba incluida en este rango. Inició su repunte en los 60: cada familia tenía un televisor y un Seat, pagaba un pisito y disfrutaba de vacaciones en la playa. Hoy, sin embargo, los hogares con ingresos superiores a 20.000 euros (tasa mínima anual estimada para la clase media) se han reducido notablemente $(42,9 \%)$ aumentando, al contrario, los extremos: los más ricos y los más pobres. Desde 2000, la clase media ha perdido un millón de integrantes: 880.000 pasaron al bando más desfavorecido. Mientras, los milmillonarios se han triplicado" (Retirado del reportaje "Papá, ¿qué es la clase media?, extraído del sitio http://blogs.que.es/mirandoelhorizonte/2009/6/6/papa-es-clase-media), publicado en el día 06 de junio de 2009 y con acceso en 10 de mayo de 2010.) A su vez, en Brasil la clase media solía ser pequeña, situación que ha empezado a cambiar en los años 90. Según la Fundación Getúlio Vargas, en 2008 el $52 \%$ de la población hacía parte de la clase media en Brasil (42\% en 2002). Sobre esta situación, se puede subrayar que: "Ridiculizada por poetas y libertinos; idolatrada por moralistas; destinataria de los discursos de políticos, papas, popes y cuantos se suben alguna vez a un púlpito en busca de votantes o de adeptos; adulada por anunciantes; recelosa de heterodoxias y huidiza de revoluciones; pilar de familias y comunidades; principal sustento de las Haciendas públicas y garante del Estado de bienestar. La clase media es el verdadero rostro de la sociedad occidental. En un mundo globalizado, en el que hasta en el más mísero país siempre se puede encontrar a alguien con suficientes medios para darse un paseo espacial, sólo la preeminencia de la clase media distingue los Estados llamados desarrollados del resto. Los países dejan de ser pobres no por el puesto que ocupan sus millonarios en el ranking de los más ricos -de ser así, México o la India estarían a la cabeza del mundo dada la fortuna de sus potentados-, sino por la extensión de su clase media." (Texto extraído del reportaje Adiós clase media, adiós, la recesión golpea con dureza al principal sustento del Estado del bienestar, publicado en elpais.com, (http://www.elpais.com/articulo/primer/plano/Adios/clase/media/adios/elpepueconeg/20090531elpneglse _2/Tes), en el día 31 de mayo de 2009 y con acceso en el día 10 de mayode 2010.
} 
En el sentido de la afirmación anterior, conviven en Brasil un sistema jurídico y instituciones modernas y racionales con el flagrante incumplimiento de las leyes y incluso de la Constitución. Así, se puede afirmar que:

"o constitucionalismo brasileiro sempre adotou o princípio da igualdade em suas Cartas, o que não significa, porém, que tenha havido sempre respeito e acatamento a ele, mesmo se lhe tomar apenas em sua acepção formal. Tanto que na primeira fase do constitucionalismo positivo brasileiro, a imperial, o princípio posto na Lei Magna coexistiu com a escravidão...”31

No obstante, el hecho de que el incumplimiento de las reglas jurídicas sea una situación muy usual en Brasil hace que la exigencia de la igualdad sea cada vez más intensa. En una sociedad donde los comportamientos no siempre son caracterizados por la observancia de las leyes, los riesgos y las amenazas a los derechos fundamentales de los más débiles son aun más presentes. Por esa razón, se puede defender que "poucos princípios tiveram e têm tanta importância no sistema jurídico brasileiro como a igualdade, talvez pela ineficácia de nossas leis para tornar concreta a norma que a acolhe como coluna de sustentação dos direitos dos indivíduos." ${ }^{32}$

Hay muchos otros argumentos que enfatizan la relevancia de la igualdad en el contexto social y jurídico brasileño. Entre las opiniones que resaltan la peculiar incidencia del principio de igualdad en la realidad de esto país latinoamericano, una de ellas se destaca: la necesidad de protección de las dichas "minorías" impone la ardua labor del Estado en la realización de políticas públicas que envuelvan decenas de millones de personas, como se puede percibir a partir de la transcripción siguiente:

"Em nosso país convive-se com o grave problema da pobreza, que ao extremo impossibilita inclusive a efetivação do princípio da dignidade da pessoa humana. Problemas que seriam "das minorias", no Estado brasileiro, infelizmente, atingem um grande percentual da população, que necessita da instituição de programa e políticas públicas voltadas à erradicação da pobreza e, conseqüientemente, da marginalidade. $\mathrm{O}$ art. $3^{\circ}$, IV, da Constituição Federal traz com um dos objetivos da

\footnotetext{
${ }_{31}^{31}$ ANTUNES ROCHA, Cármen Lúcia. Op.cit., p. 62.

${ }^{32}$ ANTUNES ROCHA, Cármen Lúcia. Op.cit, p.15.
} 
República Federativa do Brasil "promover o bem de todos, sem preconceitos de origem, raça, sexo, cor, idade e quaisquer outras formas de discriminação". Assim, pretende o dispositivo a realização de ações afirmativas voltadas a promover o bem de todos, sem discriminações, minimizando os efeitos das diferenças existenciais dos cidadãos. "33

Debido a todas las circunstancias anteriormente destacadas, el principio de igualdad ejerce un papel fundamental en el sistema jurídico brasileño. La igualdad está presente en distintas normas de la Constitución brasileña, incluso en su preámbulo ${ }^{34}$, en los artículos que establecen los objetivos fundamentales de la República Federativa do Brasil (art. $3^{\circ}$, III y IV), los derechos y garantías fundamentales (art. $5^{\circ}$, caput y I), en la regla que prohíbe a los entes de la Federación "criar distinções entre brasileiros ou preferências entre si”, según el art. 19, III; en los principios generales del orden económica (art. 170, VII) y del orden social (art. 190).

Delante de tantas normas que consagran la igualdad en el derecho constitucional brasileño, se puede afirmar que "a Constituição vigente é mais veemente e mais abrangente na condenação nas desequiparaçoes entre pessoas"35.

Cabe añadir que la igualdad es un valor que también está presente en la Constitución brasileña en los distintos sectores de la sociedad (salud, educación, Administración Pública, seguridad social, tributación, economía, aplicación de las penas, etc.). Por eso, para la doctrina brasileña:

"O princípio de igualdade não é, como se vê, apenas declarado na Constituição da República: é aplicado em todos os campos considerados importantes segundo a idéia de Direito que a perpassa, isto é, de acordo com os valores ali consubstanciados, frutos de um consenso conquistado a duras penas pelos brasileiros, durante os

\footnotetext{
${ }^{33}$ TOURINHO, Rita. Concurso público no ordenamento jurídico brasileiro, Lumen Juris Editora, Rio de Janeiro, 2008, p. 128.

${ }^{34}$ Sobre este hecho, ya se ha destacado que: "Pela primeira vez, na história constitucional brasileira, a igualdade comparece ao Preâmbulo de uma Carta Magna como princípio determinante da elaboração que a seguir é posta como sistema normativo fundamental"(ANTUNES ROCHA, Cármen Lúcia. Op.cit., p. 67)

35 SILVA, José Afonso da. Curso de Direito Constitucional Positivo, $23^{\text {a }}$ Ed., Editora Malheiros, São Paulo,2004, p. 222
} 
trabalhos da Assembléia Constituinte de 1987. Assim, são corolários imediatos do princípio da igualdade: (...) a igualdade no acesso à função pública, em regra por via de concurso (art. 37, I)...”36

La posición de magnitud del principio de igualdad en el sistema jurídico brasileño es reconocida por todas las voces de la doctrina de aquel país. En esto camino, es interesante destacar que la determinación prevista en la Constitución brasileña, en el art. $3^{\circ}$, I, que impone como uno de los objetivos del Estado (quizá el primero, no solo en la disposición del artículo) la construcción de una sociedad libre, justa y solidaria, hace que solamente a través de la observancia y experiencia cotidiana de la igualdad sea posible la consecución de tal finalidad.

Además, cuando la Constitución brasileña define los derechos y garantías fundamentales (art. $5^{\circ}$ ), la primera medida que toma es declarar que "Todos são iguais perante a lei, sem distinção de qualquer natureza (...)”. La preeminencia de la igualdad en la Constitución de Brasil es enfatizada por la doctrina:
"Ao contrário do modelo normativo constitucional que se vinha repetindo no Direito Brasileiro desde a Carta Imperial, a Constituição de 1988 começa pela definição peremptória da igualdade de todos perante a lei. A definição da igualdade jurídica no início do artigo que cuida dos direitos individuais e coletivos coloca em posição de relevo o princípio e determina-o norteador dos direitos reconhecidos e assegurados no dispositivo." ${ }^{37}$

Cabe insistir que el concepto y el alcance del derecho de igualdad van a cambiar de acuerdo con las condiciones de la sociedad. Esto es, en cada tiempo y en cada lugar, las exigencias de igualdad serán distintas. La situación de las mujeres puede servir perfectamente como ejemplo para la afirmación mencionada arriba. Es que:

"o que ontem era ideologia, hoje pode ser norma; o que antes era regra hoje pode ser aconselhamento; o que foi Direito, hoje pode ser

\footnotetext{
${ }^{36}$ GUIMARAES TABORDA, Maren. O princípio da igualdade em perspectiva histórica: conteúdo, alcance e direções, en Revista de Direito Administrativo, n 211, enero-marzo 1998, Renovar - FGV, Rio de Janeiro, p. 265.

${ }^{37}$ ANTUNES ROCHA, Cármen Lúcia. Op.cit., p. 70.
} 
história. O homem faz-se a cada manha. O seu Direito - e o Direito somente é legítimo quando é seu, retrato de sua alma e de seu sonho, sua tendência e sua busca - altera-se a cada dia na tentativa de acompanhar-lhe o passo ou abrir-lhe o caminho."38

Evidentemente, como la idea de igualdad no es precisa, ésta "se invoca desde todos los posicionamientos jurídicos, aunque de inmediato se mantengan eventualmente opiniones muy diferentes respecto al tratamiento igualitario que en realidad se procede aplicar." ${ }^{39}$ En cambio, que pese su posible maleabilidad, es el orden constitucional vigente el que establecerá los contornos de la igualdad en determinada sociedad, sin desconsiderar las influencias político-sociales.

De este modo, cuando la Constitución española afirma que "Los españoles son iguales ante la Ley..." y la brasileña determina que "Todos são iguais perante a lei, sem distinção de qualquer natureza, garantindo-se aos brasileiros e aos estrangeiros residentes no País (...) a igualdade”, se puede afirmar, de forma, en principio contradictoria, que los citados textos dicen muchísimo, pero casi nada de efectivo, pues estas clausulas generales, aunque sean muy amplias, elásticas y lapidarias, y el segundo parámetro más utilizado por los Tribunales españoles (después de la tutela judicial) y la "pedra de toque" ${ }^{40}$ del derecho brasileño, por su naturaleza relativa y poseyeren una escasa densidad normativa y regulativa, necesitan ser debidamente interpretadas y aplicadas, en un determinado contexto relacional, para alcanzar todas sus posibilidades. ${ }^{41}$

En este mismo sentido, en España se ha destacado que:

"El derecho a la igualdad es uno de los que mayor número de pronunciamientos ha suscitado, probablemente por carecer de un ámbito material específico y poder ser así invocable potencialmente en cualesquiera de los campos propios de los restantes derechos

\footnotetext{
${ }^{38}$ ANTUNES ROCHA, Cármen Lúcia. Op.cit., p.13.

${ }^{39}$ VILACORTA MANCEBO, Luis. Principio de igualdad y Estado Social, Servicio de publicaciones de la Universidad de Cantabria, Santander, 2006, p. 25.

${ }^{40}$ Respecto a la referida expresión, se puede añadir que"O princípio jurídico da igualdade passa a ser, então, especialmente em países pobres e com grossas esferas de desigualdade sócio-econômica, a pedra de toque do sistema jurídico para a construção ou reconstrução de uma sociedade justa. (ANTUNES ROCHA, Cármen Lúcia. Op.cit., p. 40).

${ }^{41}$ VILACORTA MANCEBO, Luís. Op.cit., p. 27.
} 
fundamentales e, incluso, de simples derechos subjetivos o mero intereses." 42

Además, el princípio de igualdade es en la mayor parte de los ordenamientos jurídicos ocidentales: "um princípio fundante e estruturador de toda a ordem jurídica, sendo impositivo em todos os seus campos, ao não assegurar aos indivíduos nenhuma situação jurídica específica, mas garanti-lo contra "toda má utilização que possa ser feita",,43

También merece la pena transcribir otra posición adoptada por la doctrina, que, al analizar el art. 14 de la Constitución española, subraya que del mismo no es deducible como contenido ningún criterio de medida:

"La aplicación práctica del principio de igualdad en la ley plantea importantes problemas, puesto que este principio no dice lo que es igual, sino que sólo determina que lo igual debe ser tratado igual; también lo contrario, que lo que no es igual debe ser tratado desigualmente. “44

Lo que conviene destacar en este momento es que la indeterminación de la igualdad proviene de su carácter relacional. Esto significa decir que la igualdad solamente puede ser comprendida si uno contesta a dos preguntas fundamentales: ¿Igualdad entre quiénes?, e ¿Igualdad en qué?

Respecto a la necesidad de análisis del contenido de la igualdad, ya se ha afirmado que todos aquellos que tratan de cuestiones jurídicas aceptan unánimemente el principio de igualdad como válido. Sin embargo:

"cumpre, todavia, buscar precisões maiores, porque a matéria,
inobstante a limpidez das assertivas feitas, ressente-se da excessiva
generalidade destes enunciados. Demais disso, para desate do
problema é insuficiente recorrer à notória afirmação de Aristóteles,

${ }^{42}$ SANTAMARIA PASTOR, Juan Alfonso y PAREJO ALFONSO, Luciano. Derecho Administrativo: la jurisprudencia del Tribunal Supremo, Editorial Centro de Estudios Ramon Areces S.A., Madrid, 1989, p. 168.

${ }^{43}$ GUIMARAES TABORDA, Maren. Op.cit., p. 245.

${ }^{44}$ RODRÍGUEZ-PIÑERO, Miguel y FERNÁNDEZ LÓPEZ, María Fernanda. Igualdad y discriminación, Tecnos, Madrid, 1986, p. 46. 
assaz de vezes repetida, segundo cujos termos a igualdade consiste em tratar igualmente os iguais e desigualmente os desiguais. Sem contestar a inteira procedência do que nela se contém e reconhecendo, muito ao de ministro, sua validade como ponto de partida, deve-se negar-lhe o caráter de termo de chegada, pois entre um e outro extremo serpeia um poço de incertezas cavado sobre a intuitiva pergunta que aflora ao espírito: Quem são os iguais e quem os desiguais?"45

Sobre esa cuestión, se ha utilizado la siguiente comparación:

"mientras la libertad es una cualidad o propiedad de la persona...., la igualdad es pura y simplemente un tipo de relación formal, que se puede colmar de los más diversos contenidos. Tanto es así que, mientras "X es libre" es una preposición dotada de sentido, "X es igual" es una preposición sin sentido, antes bien remite, para adquirir sentido, a la respuesta a la pregunta “¿Igual a quién?"46

Es siempre relevante que se tenga en cuenta la interacción entre los valores arriba destacados ${ }^{47}$. Otra asociación entre igualdad y libertad, valores que se complementan, ha sido realizada por la doctrina brasileña, lo que merece transcripción:

"Em termos políticos, a idéia de igualdade sempre foi relacionada à de liberdade. Foi na "polis" grega que o homem se descobriu hómoioi (semelhante), e, depois, de maneira abstrata, como isoi (igual), na condução dos negócios públicos, porque, apesar das diferenças existentes no plano da realidade da vida social (diferenças de classes, de riqueza), conseguiu abstrair-se dessa realidade e se conceber, no plano político, como unidade permutável "no interior de um sistema

\footnotetext{
${ }^{45}$ BANDEIRA DE MELLO, Celso Antônio. Op.cit., p. 10-11.

${ }^{46}$ BOBBIO, Norberto. Op.cit., p. 54

${ }^{47}$ En el contexto analizado en este trabajo (acceso a la función pública), en los momentos oportunos, se verá que aunque el Derecho establezca un trato igualitario para los candidatos en el procedimiento de selección, la efectiva igualdad en el acceso a la función pública depende de la disminución de las diferencias sociales y económicas entre los aspirantes, cuando tales circunstancias son verdaderos obstáculos al acceso equilibrado a las fuentes del conocimiento científico y a otras oportunidades que hagan con que todos puedan competir en condiciones de aceptable equivalencia. Así, la situación de libertad, que existe hasta el momento de la inscripción en el proceso selectivo, conduce a una diversidad de perfiles de candidatos, muchos de ellos sin que hayan tenido las debidas oportunidades (es lo que pasa con los estudiantes de los institutos públicos en Brasil), lo que seguramente afectará a la disputa igualitaria. Así, es necesario que el Estado establezca mecanismos compensatorios, sea a través de cotas (siempre polémicas), o mediante el complemento de la formación de los candidatos desfavorecidos.
} 
cuja lei é o equilíbrio, cuja norma é a igualdade. Essa imagem do mundo encontrará no século VI sua expressão rigorosa em um conceito, o de isonomia: igual participação de todos os cidadãos no exercício do poder", ou, especificamente, igualdade das leis para todos (isos = igual; nómos = lei). ${ }^{, 48}$

Lo que interesa, por fin, es que sea en España o en Brasil, la igualdad ha sido elegida como valor supremo del sistema jurídico y necesita ser bien dimensionada, para que de ella puedan ser extraídos todos sus efectos favorables a la sociedad.

Cabe añadir que la igualdad, no importa en que sistema jurídico, se puede construir a partir de trés idéas: "universalização de iguais oportunidades para as pessoas, o respeito às individualidades e a garantia de subsistência das diferenças." ${ }^{49}$

Para que sea posible una investigación más apurada del principio de igualdad, deben ser aclaradas algunas situaciones, una vez que son relevantes al desarrollo del tema. Debe ser mencionado que la expresión "igualdad" tiene múltiples acepciones.

En algunos casos, traduce el derecho previsto en los textos jurídicos (igualdad formal), mientras que en otras situaciones, representa una circunstancia de hecho que se pretende alcanzar (igualdad material).

Otra cuestión preliminar que deberá ser analizada son las distintas manifestaciones de la igualdad (ante la ley, en la aplicación de la ley, en la ley), y las técnicas utilizadas para llevar a cabo la igualdad (generalización, equiparación, diferenciación).

Por fin, a continuación, para un mejor análisis del tema, también será investigado el tema de la discriminación, o sea, cuándo es y cuándo no es jurídicamente aceptado un tratamiento distinto entre dos o más personas. Además, serán tenidas en cuenta las condiciones en las cuales la Administración Pública debe hacer distinciones (justificación, racionalidad y proporcionalidad).

\footnotetext{
${ }^{48}$ GUIMARAES TABORDA, Maren. Op.cit., p. 243.

49 ANTUNES ROCHA, Cármen Lúcia. Princípios constitucionais dos servidores públicos, Editora Saraiva, São Paulo, 1999, p. 149.
} 


\subsubsection{1- Dimensiones de la igualdad: igualdad formal e igualdad material}

Probablemente, todas las personas, aunque muchas no posean conocimientos de derecho y política y aunque que lo hagan de forma intuitiva, consiguen percibir las diferencias entre la igualdad formal y material, las llamadas dimensiones de la igualdad ${ }^{50}$. Esto ocurre porque se constata fácilmente que la igualdad introducida en las leyes como una prescripción, un deber-ser (igualdad formal o jurídica) no se confunde con el efectivo establecimiento de relaciones donde las personas deberían ser tratadas de forma igualitaria (igualdad material o sustancial). ${ }^{51}$

La igualdad entre los hombres es un ideal que siempre ha necesitado de la intervención del ordenamiento jurídico para llegar a buen término. Y además: siempre la necesitará, ya que las exigencias de igualdad son cambiantes y, por supuesto, de ningún modo susceptibles de una plena consumación.

Además, como ha sido destacado anteriormente, “...la igualdad, en todo caso, no es una realidad natural (esto es, salvo en su esencia como seres humanos no existen dos personas iguales en todos los aspectos), sino el resultado de un determinado modo de organización de la sociedad." 52

Cuando la humanidad tuvo que establecer los valores más relevantes para que fueran formulados los asientos de los sistemas jurídicos (en la modernidad, primordialmente en las Constituciones), necesitó instituir pautas generales y una de las

\footnotetext{
${ }^{50}$ Utilizando el vocablo "dimensión" en un sentido poco usual, y distinto del adoptado en este trabajo, Fernando Rey Martínez considera que las dimensiones de la igualdad en la Constitución española derivan de la concepción del "Estado social y democrático de Derecho", y serían tres: la dimensión liberal, que "conlleva la idea de igualdad en la aplicación del Derecho"; la dimensión democrática, que "implica el derecho de todos los ciudadanos a participar en condiciones de igualdad en el ejercicio del poder político y en el acceso a las funciones y cargos públicos (art. 23 CE)"; y la dimensión social, donde "el principio de igualdad cumple la función de eliminar las desigualdades de hecho (políticas, económicas, sociales, culturales) para conseguir la igualdad real y efectiva de individuos y grupos (art. 14 en relación con el art. 9.2 CE)."(REY MARTÍNEZ, Fernando. El derecho fundamental a no ser discriminado por razón de sexo, McGraw-Hill, Madrid, 1995, p. 41-42.)

${ }^{51}$ Evidentemente, las dimensiones de la igualdad no contrarían su carácter unitario, según destaca la doctrina: "No obstante, es importante subrayar desde el principio el carácter unitario y dinámico de la igualdad, como valor y principio ético, político y jurídico que presenta dos vertientes, pero que no son incompatibles, sino complementarías entre sí. No hay dos igualdades, la "formal" y la "real". No hay una diferencia insalvable entre la igualdad jurídica o "formal" y la igualdad económica o "real". La igualdad es un valor bifronte, pero unitario y omnicomprensivo (formal-material)."(FERNÁNDEZ, Encarnación. Op.cit., p.24)

${ }^{52}$ MARTÍN VIDA, María Ángeles. Op.cit.,, p. 20.
} 
máximas más utilizadas fue la que proclama que "todos los hombres son (o nacen) iguales". 53

Según la doctrina, la mencionada máxima sirvió de fundamento para todo el pensamiento político occidental:

\begin{abstract}
"desde los estoicos al cristianismo primitivo, para renacer con un nuevo rigor durante la Reforma, asumir forma filosófica en Rousseau y los socialistas utópicos y expresarse en forma de verdadera y propia regla jurídica en las declaraciones de los derechos humanos desde finales del siglo dieciocho hasta hoy.....No se puede eludir, en efecto, el significado polémico y revolucionario de este "todos", que se contrapone a situaciones u ordenamientos en los cuales no todos, sino más bien pocos o poquísimos, disfrutan de bienes y derechos de los que otros carecen." 54
\end{abstract}

Por consiguiente, la primera gran conquista para ser implantada por las más diversas sociedades fue la de cambiar el discurso oficial del Derecho (hasta aquel momento, legitimador de los privilegios, inmunidades y discriminaciones), y pasar a fundar un ambiente jurídico favorable a la búsqueda por la igualdad de los hombres en los más distintos sectores.

Hay que reconocer que la definición de la igualdad en los textos jurídicos (lo que aquí ha sido denominado igualdad formal), si hoy es algo insuficiente, ha sido objeto de mucho esfuerzo de distintas generaciones, y el hecho de haber reconocido la igualdad por el Derecho es, seguramente, el primer paso para la instalación de una sociedad más igualitaria en relación a los derechos, oportunidades y condiciones socioeconómicas de las personas.

Así, "la igualdad formal suele identificarse con las exigencias jurídicopolíticas sintetizadas en el principio de igualdad ante la ley. Dicho principio garantiza la

\footnotetext{
${ }^{53}$ La Declaración de Independencia de los Estados Unidos de América, de 4 de julio de 1776, empieza estableciendo que: "Consideramos como verdades evidentes en sí mismas que todos los hombres han sido creados iguales". La francesa Declaración de Derechos del Hombre y del Ciudadano, de 26 de agosto de 1789, en su primer artículo, proclama que: "Los hombres nacen y permanecen libres e iguales en derechos; las distinciones sociales sólo pueden fundarse en la utilidad común".

${ }^{54}$ BOBBIO, Norberto. Op.cit.,, p. 68.
} 
paridad de trato en la legislación y en la aplicación del Derecho. Es la igualdad en el ámbito del sistema jurídico." 55

Como ya se ha destacado anteriormente, la dimensión formal de la igualdad es muy relevante para la instauración del marco jurídico del tema, lo cual repercute de forma decisiva en la vida del Estado y de la sociedad civil. Sin embargo, es con el fomento de la igualdad que se llega a su dimensión material. En este contexto, debe la Administración Pública tanto realizar acciones positivas ${ }^{56}$ para la promoción de la igualdad $^{57}$, como también remover las dificultades que las personas encuentran para desarrollar sus potencialidades. ${ }^{58}$

Las acciones positivas son "medidas o planes vinculados de un modo u otro al Derecho, destinadas a hacer desaparecer la igualdad entre los individuos" ${ }^{\text {59 }}$. Según la mencionada doctrina, una acción positiva es formada por medidas legislativas, económicas o de cualquier otra naturaleza, y "es un instrumento esencial siempre que exista voluntad política de acelerar el proceso para lograr la igualdad y eliminar la discriminación oculta; y se contemplan como algo temporal hasta que se alcance la igualdad de trato y de oportunidades" ${ }^{\prime 60}$.

\footnotetext{
${ }_{56}^{55}$ FERNÁNDEZ, Encarnación. Op.cit., , p. 22

${ }^{56}$ La acción positiva es la traducción de la affirmative action utilizada en los Estados Unidos. En el mencionado contexto, con énfasis en la situación española, pueden ser citadas “...las políticas de becas, de promoción de viviendas más baratas para familias con pocos ingresos, los incentivos crediticios, fiscales, etc. para las inversiones en las zonas menos desarrolladas de un país, o para la contratación de jóvenes..." (FERNÁNDEZ, Encarnación. Op.cit.,, p. 90)

${ }^{57}$ En países en desarrollo, son muchos los ejemplos de políticas públicas que intentan disminuir las diferencias sociales entre ricos y pobres. En Brasil, el problema de la pobreza absoluta está siendo combatido por programas sociales de transferencia de renta, como el "Programa Bolsa Familia", del Ministério de Desenvolvimento (Desarrollo) Social, que ofrece dinero (aunque hay exigencias como contrapartida) para complementar la renta de la familias que reciben sueldos inferiores al mínimo establecido para las necesidades básicas. Para más información en el sitio web:www.mds.gov.brlbolsafamilia

${ }^{58}$ En este otro contexto, hay una acción que está siendo desarrollada en Brasil para ofrecer oportunidades de acceso a las universidades públicas (gratuitas) a los jóvenes que usualmente no consiguen plazas, debido a la mala formación educacional que recibieron (por ejemplo, los pobres, negros y estudiantes de escuelas públicas), a través de la estipulación de cotas en las universidades públicas, lo que es una acción polémica y muy criticada, pero con un cierto éxito. También en la educación brasileña, merece mención el Fundo de Financiamento ao Estudante do Ensino Superior (FIES), que objetiva facilitar el acceso de estudiantes pobres a las universidades privadas. Más información en la web del Ministerio de Educación brasileño (www.portal.mec.gov.br)

59 GONZÁLEZ BUSTOS, María Ángeles. La mujer ante el siglo XXI. Una perspectiva desde el ordenamiento jurídico-administrativo, Editorial @ becedario, Badajoz, 2006, p. 28.

${ }^{60}$ GONZÁLEZ BUSTOS, María Ángeles. Op.cit., p. 29.
} 
Conviene que no se olvide que el Estado Democrático y Social del Derecho fue proyectado como alternativa para la superación del viejo Estado Liberal de Derecho, que satisfecho con el discurso de la igualdad formal, estuvo lejos de alcanzar la efectiva igualdad en las relaciones sociales, y por el contrario, amplió las desigualdades.

En dicho contexto, se puede afirmar que los elementos formales configuradores del Estado de Derecho, “...que se erigieron como límites necesarios frente al poder del Estado con el objetivo de garantizar la autonomía de la Sociedad durante la vigencia del viejo Estado legal, sufre una determinante transformación al incorporárseles ahora los contenidos de la justicia social."61

Debido a ello, se pasa de una visión restrictiva de la igualdad, que tenía la tarea de garantizar derechos individuales y que ya estaban reconocidos por el ordenamiento jurídico (función estabilizadora), a una concepción más amplia del referido principio, con una evidente preocupación social. Todo esto conlleva un papel más decisivo del Derecho y una postura más actuante del Estado (función transformadora).

Tras las consideraciones anteriormente expuestas, es posible destacar respecto al nuevo perfil de la igualdad que:

"O conteúdo da isonomia ganhou contornos novos, finalidades específicas. Quer-se a igualdade social, econômica, política, realizada segundo o Direito. O Direito que iguala para dignificar o Homem e traduzir a Justiça material, que se pretende fazer realizar. Mudar estruturas sociais, transformar, pela aplicação do princípio, o aparato estatal e a conduta política do grupo social para que a diversidade iguale em condições e oportunidades a pluralidade humana e a igualação seja a forma de respeito das diferenças." ${ }^{62}$

En la Constitución española de 1978, la dimensión formal de la igualdad está contemplada en el art. 14, mientras su dimensión material está prevista en el art. $9^{\circ} . I^{63}$. Sobre los papeles ejercidos por los mencionados dispositivos, el Tribunal

\footnotetext{
${ }^{61}$ VILACORTA MANCEBO, Luís. Op.cit., p. 66.

${ }^{62}$ ANTUNES ROCHA, Cármen Lúcia. Op.cit., p.14.

63 “Corresponde a los poderes públicos promover las condiciones para que la libertad y la igualdad del individuo y de los grupos en que se integra sean reales y efectivas; remover los obstáculos que impidan o
} 
Constitucional entiende que los artículos 9.2 y 14 de la Constitución española se complementan: "El art.9.2 puede actuar como un principio matizado de la igualdad formal consagrada en el art. 14 de la Constitución, permitiendo regulaciones cuya desigualdad formal se justifica en la promoción de la igualdad material..." (STC 98/1985, FJ 9)"64

Parece evidente que la Constitución española, cuando impone el mandamiento del art. 9.2, tiene especial preocupación por la efectividad de la igualdad, y que esta se identifica con el equilibrio de bienes y de situaciones económicas y sociales ${ }^{65}$.

Sobre el contenido del art. 9.2 de la Constitución española, la doctrina entiende que este proviene de la otorga de los constituyentes a los poderes públicos del deber de “...transformar la estructura socioeconómica del país, y lograr así una real y efectiva igualdad."66

Importante aspecto en esta discusión es que el Tribunal Constitucional, desde la Sentencia 42/82, de 14 de julio de 1982, reconoció claramente la igualdad como derecho subjetivo:

"El art. $14 \mathrm{CE}$, al establecer el principio general de que todos los españoles son iguales ante la ley, establece un derecho subjetivo a obtener un trato igual, impone una obligación a los Poderes Públicos de llevar a cabo ese trato igual y, al mismo tiempo, limita al poder legislativo y los poderes de los órganos encargados de la aplicación de las normas jurídicas."

En realidad, la igualdad tanto tiene naturaleza de principio, vinculante para los poderes públicos, como de derecho subjetivo. Esta circunstancia es esencial, como explica la doctrina:

dificulten su plenitud y facilitar la participación de todos los ciudadanos en la vida política, económica, cultural y social."

${ }^{64}$ PÉREZ LUÑO, Antonio .Enrique. Dimensiones de la igualdad, $2^{\mathrm{a}}$ edición, Dykinson, Madrid, 2007, p. 37.

${ }^{65}$ ALEGRET BURGUÉS, María Eugenia. en presentación e introducción del libro La discriminación positiva, Directora María Eugenia Alegret Burgués, Consejo General del Poder Judicial, Madrid, 2006, p.26-27.

${ }^{66}$ SUAY RINCÓN, José. El principio de igualdad en la Justicia Constitucional, Instituto de Estudios de Administración Local, Madrid, 1985, p. 30.

${ }^{67}$ STC 49 de 1982. 
“...casi todo el enorme potencial que el principio de igualdad lleva consigo sería papel mojado si la Constitución de 1978 se hubiera limitado a configurarlo como un principio (aun cuando fuera vinculante). Para muy poco serviría, ciertamente, si el ciudadano no pudiera invocarlo frontal y directamente ante los tribunales, si no pudiera fundamentar una demanda por su infracción. Y eso es lo que sucedería si no fuera más que un principio. Para dar remedio a tal situación, los redactores de la Constitución, que seguramente no ignoraban este dato, articularon técnicamente el principio como un derecho subjetivo (art. 53.2 CE), quedando el ciudadano investido de la legitimación necesaria para acudir ante los tribunales ante una infracción del principio de igualdad." ${ }^{68}$

A su vez, el derecho constitucional brasileño, además de establecer que la igualdad en uno de los valores supremos del sistema jurídico (art. 5º caput y 19, III), impone que el Estado deba realizar distintas medidas a fin de que sea posible la erradicación de la pobreza y de la marginalización, siempre con el objetivo de "reduzir as desigualdades sociais e regionais" (art. $3^{\circ}$, III, CB).

No satisfecha, la Constitución brasileña de 1988 ha consagrado como objetivo fundamental de la República Federativa do Brasil la promoción de bienestar de todos, "sem preconceitos de origem, raça, sexo, cor, idade e quaisquer outras formas de discriminação" (art. $\left.3^{\circ}, \mathrm{IV}, \mathrm{CB}\right)$.

Las dos normas destacadas son la perfecta traducción de la búsqueda de la igualdad material en la Constitución brasileña. Tal circunstancia hace con que el Estado deba tener una postura proactiva ${ }^{69}$, siempre intentando aproximar los ciudadanos y les

\footnotetext{
${ }^{68}$ SUAY RINCÓN, José. Op.cit., p. 153.

${ }^{69}$ El panorama y alcance de la igualdad en la Constitución brasileña de 1988 puede ser expresado en la siguiente opinión doctrinaria: "Mas a Constituição de 1988 não se contentou com a igualdade formal. Foi mais além, para também consagrar a igualdade material, na medida em que elegeu como objetivo fundamental do Estado erradicar a pobreza e reduzir as desigualdades sociais e regionais (art. $3^{\circ}$, III); como finalidade da ordem econômica assegurar a todos existência digna, conforme os ditames da justiça social (art. 170) e como objetivo da ordem social o bem estar e a justiça sociais (art. 193). Nesse passo, a Constituição preocupou-se em garantir a todos igualdade de oportunidades, abrindo um especial espaço para a adoção de ações afirmativas, que consistem num conjunto de medidas administrativas $e$ legislativas de política pública que visam compensar desigualdades históricas decorrentes da marginalização social. Essas ações afirmativas inserem-se no âmbito de uma política social de discriminação positiva, voltada a corrigir desigualdades históricas. Vale dizer, busca-se igualar desigualando, como se verifica ultimamente através da política de cotas. A própria Constituição já
} 
otorgar el máximo de dignidad humana (art. $1^{\circ}$, III, CB) y construyendo una sociedad libre, justa y solidaria (art. $3^{\circ}$, I, CB). Este deber del Estado de promoción de la igualdad previsto en los arts. $1^{\circ}, 3^{\circ}, 19,170$ y 193, entre otros, de la Constitución brasileña es añadido del correspondiente derecho del ciudadano a un trato igualitario, según el art. $5^{\circ}$, caput.

En los términos arriba destacados, siendo la igualdad un derecho subjetivo exigible por los ciudadanos, lo que atribuye un consecuente deber de actuación a los poderes públicos, conviene que el mencionado derecho deba poseer distintas manifestaciones, y que estas envuelvan múltiples aspectos. Así, se impone que ocurra igualdad ante la ley, en la aplicación de la ley, y en la propia ley.

La convivencia de las tres manifestaciones de la igualdad es condición sine qua non de efectividad del citado derecho, circunstancia que impone su estudio a continuación.

\subsubsection{2- Manifestaciones de la igualdad}

\subsubsection{1 - Igualdad ante la ley}

El texto consolidado en el art. 14 de la Constitución española es consecuencia de una tradición de doscientos años, y que traduce la preocupación de someter todos los ciudadanos a un mismo ordenamiento jurídico, y que este sea igual para todos. Esta fue la idea que marcó las Revoluciones Liberales, rompiendo con un pasado desigualitario de la sociedad estamental y rechazando privilegios y exenciones. ${ }^{70}$

El primer paso tras la ruptura del antiguo régimen fue la modificación de los paradigmas sobre los cuales se asentaban la sociedad, el derecho y el Estado. Si la sociedad estamental era aceptada y legitimada por el orden jurídico entonces vigente, los revolucionarios decidieron cambiar las leyes, estableciendo nuevos valores, aunque en un plano destacadamente teórico.

determina algumas ações afirmativas, que não podem ser negligenciadas pelo legislador ordinário, como, por exemplo, a proteção do mercado de trabalho da mulher, mediante incentivos específicos (art. $\left.7^{\circ}, X X\right)$ e a determinação de reserva de percentual dos cargos e empregos públicos para as pessoas portadoras de deficiência (art. 37, VIII)." (CUNHA JÚNIOR, Dirley da. Curso de Direito Constitucional, $2^{\text {a }}$ ed., Editora Podium, Salvador, 2008, p. 645).

${ }^{70}$ RODRÍGUEZ-PIÑERO, Miguel. y FERNÁNDEZ LOPEZ, María Fernanda. Op.cit., p. 19. 
Indudablemente, la igualdad fue el valor más propagado y que sirvió de bandera para instalación de un nuevo tiempo, aunque la libertad fuera la verdadera preocupación de la burguesía.

La relevancia del nuevo paradigma hizo con que todo el Derecho experimentara un cambio profundo, que ciertamente no más estará sujeto a retroceso. En esto sentido, con la nueva concepción de las relaciones sociales:

"Estabelece-se, então, um Direito que se afirma fundado no
reconhecimento da igualdade dos homens, igualdade em sua
dignidade, em sua condição essencial de ser humano. Positiva-se o
princípio da igualdade. A lei, diz-se então, será aplicada igualmente a
quem sobre ela se encontre submetida. Preceitua-se o princípio de
igualdade perante a lei." 71

Lo que se proponía era que los privilegios, excepciones e inmunidades fueran abandonados, para dar lugar a la generalización de derechos y deberes. En otras palabras, todos debían recibir del ordenamiento jurídico el mismo trato, fuera en relación a situaciones jurídicas favorables o no. Esta es la igualdad ante la ley, que es una manifestación de igualdad formal.

De inspiración liberal, la igualdad ante la ley traducía las ambiciones de la burguesía, que construyó un Estado con casi ninguna aspiración transformadora. Así, "la idea de ley abstracta y general correspondía con un Estado que se limitaba a crear unas condiciones mínimas para que la sociedad autorregulada pudiese actuar de acuerdo con sus propios mecanismos y con su propia lógica." ${ }^{72}$

Según el nuevo discurso, en las relaciones estatales, la arbitrariedad del gobernante es sustituida por la voluntad de la ley derivada de la soberanía popular, y el Estado deja de ser identificado con la persona del Rey, pasando a actuar de forma impersonal, destacadamente en el momento de creación de las leyes.

El artículo 6 de la Declaración de Derechos del Hombre y del Ciudadano del 26 de agosto de 1789 resume muy bien este panorama:

\footnotetext{
${ }^{71}$ ANTUNES ROCHA, Cármen Lúcia. Op.cit., p. 35

${ }^{72}$ MARTÍN VIDA, María Ángeles. Op.cit., p. 153.
} 
"La ley es la expresión de la voluntad general. Todos los ciudadanos tienen el derecho de participar personalmente o por medio de representantes en su formación. Debe ser la misma para todos, tanto si protege como si castiga. Todos los ciudadanos, al ser iguales ante ella, son igualmente admisibles a todos las dignidades, puestos y empleos públicos, según su capacidad y sin otra distinción que la de sus virtudes y la de sus talentos."

Sobre esta norma, fue dicho que "en este artículo se recogen las tres exigencias conexas que incluye el principio de igualdad ante la ley en la concepción liberal del mismo: La igualdad política, la igualdad ante la ley en sentido estricto y la llamada igualdad de acceso."73

Fácilmente se puede percibir que la igualdad ante la ley es insuficiente, una vez que no impone ningún límite, sea positivo o negativo, al contenido de las leyes ${ }^{74}$. Así, "la igualdad ante la ley satisfacía las aspiraciones de los revolucionarios franceses, que no incorporaron a la Declaración ninguna referencia a la igualdad de los medios económicos." 75

En realidad, ¿cuál es la utilidad de la igualdad ante la ley si uno no dispone de los medios necesarios para ejércelos? Probablemente, sólo en términos históricos se puede encontrar la relevancia de la igualdad ante la ley, una vez que hubo la necesidad de ruptura ante el Antiguo Régimen ${ }^{76}$, y que fueran fijados nuevos paradigmas.

En el derecho constitucional brasileño, desde la primera Constitución (la imperial, de 1824), la igualdad ante la ley ha estado presente en el sistema jurídico. Sin

\footnotetext{
${ }^{73}$ FERNÁNDEZ, Encarnación. Op.cit., p. 58

74 Para la doctrina:"Esta interpretação da expressão "iguais perante a lei” propiciou situações observadas até há muito pouco tempo em que a igualdade jurídica convivia com a separação dos desigualados, vale dizer, havia tratamento igual para os igualados dentro de uma estrutura na qual se separavam os desigualados, inclusive territorial e socialmente. É o que se verificava nos Estados Unidos em que a igualdade não era considerada desrespeitada, é o advento do caso Broen Versus Board of Education. Até o julgamento deste caso pela Suprema Corte Norte Americana, entendia-se nos Estados Unidos da América que os negros não estavam sendo comprometidos em seu direito ao tratamento jurídico igual se, mantidos em escolas de negros, fossem ali tratados igualmente. Não havia para os norte-americanos o direito, por parte dos cidadãos, ou o dever, por parte do Poder Público, de garantir a não discriminação em escolas públicas, de tal sorte a impedir que houvesse escolas de negros e escolas de branco. O que havia era tão-somente e insuficientemente o entendimento de que os negros receberiam idêntico tratamento entre si, o mesmo ocorrendo com os brancos." (ANTUNES ROCHA, Cármen Lúcia. Op.cit., pp. 36-37)

${ }^{75}$ MARTÍN VIDA, María Ángeles. Op.cit., p. 90

${ }^{76}$ MARTÍN VIDA, María Ángeles, idem, p. 91
} 
embargo, al menos en los debates doctrinarios, ha prevalecido el entendimiento que sostiene que tanto el legislador como el ejecutor de las leyes son los destinatarios de la igualdad ante la ley.

La afirmación arriba destacada puede ser comprobada a través de la lectura del siguiente fragmento de artículo que ha analizado las repercusiones históricas del principio de igualdad en Brasil:

\begin{abstract}
"A discussão sobre o destinatário do princípio da igualdade, que tanto divide os doutrinadores estrangeiros e ainda divide os entendimentos, surpreendentemente, não se estabeleceu no Brasil, pois a doutrina sempre concebeu ser o legislador também destinatário do princípio, a par de aceitar a idéia de que a lei é o critério de distinção que engloba as desigualdades aceitáveis ou não, embora, claramente, só o texto da Carta Magna de 1824 tenha cogitado acerca do conteúdo interno da legislação. Os demais textos, pelo menos até 1988, apenas repetiram a formulação da igualdade perante a lei, sendo que, em alguns - 1934 e 1946 - agregam-se, em outros dispositivos, normas que objetivaram materializar critérios de justiça. Mas a hermenêutica dos textos, feita pelos juristas, sempre se direcionou no sentido de que tanto o legislador quanto o executor da lei estavam vinculados ao princípio da igualdade" 77
\end{abstract}

Tras todas las consideraciones anteriormente analizadas, se puede afirmar que el reconocimiento de que todos deben someterse a las mismas reglas jurídicas fue esencial para la superación de una sociedad de privilegios y inmunidades.

Sin embargo, otros pasos eran imprescindibles para permitir el triunfo social (efectividad) del principio de igualdad. Así, no pasó mucho tiempo sin que voces se levantaran para exigir igualdad en la aplicación de la ley, y en el propio contenido de la ley, lo cual será ahora analizado.

\title{
1.2.1.2.2 - Igualdad en la aplicación de la ley
}

La mencionada manifestación de la igualdad traduce la exigencia que impone que la ley sea aplicada de modo igual a todos aquellos que se encuentran en la

\footnotetext{
${ }^{77}$ GUIMARAES TABORDA, Maren. Op.cit., p. 261.
} 
misma situación, "sin que el aplicador pueda establecer diferencia alguna en razón de las personas, o de circunstancias que no sean precisamente las presentes en la norma."78

En el derecho español, cuando el art. 14 CE impone la exigencia de igualdad entre todos los españoles, se exige que la igualdad en cuestión no sea limitada a su manifestación más formal (igualdad ante la ley), sino que también alcance la igualdad de los ciudadanos en el trato concedido por los poderes públicos.

La igualdad en la aplicación de la ley puede ser aceptada como una consecuencia lógica de la igualdad ante la ley, ya que los órganos administrativos y jurisdiccionales, como están subordinados al principio de legalidad, tendrían forzosamente que ejecutar los mandamientos legales que establecen que los ciudadanos deban someterse a las mismas reglas jurídicas.

Así, si " $A$ ” y " $B$ ” poseen el mismo derecho o la misma obligación prevista en una determinada ley, la Administración Pública y el Poder Jurisdiccional tendrían que actuar de acuerdo a esta situación de igualdad creada por la ley, concediendo a los dos el mismo trato.

Según la doctrina:

"esa igualdad ante la ley va a producir efectos significativos en el plano de la puesta en ejecución de la propia ley, es decir, en el momento de la aplicación de la ley. La igualdad ante la ley progresivamente será entendida (y ello más por fruto del Derecho Administrativo que del propio Derecho Constitucional) como igualdad en la aplicación de la ley: ya no se trata que la ley sea general e impersonal, sino que su aplicación por los poderes públicos encargados de esa tarea se haga "sin excepciones, sin consideraciones personales.” “79

De hecho, tanto es posible, como muchas veces usual, que las leyes sean creadas de forma general, sometiendo a todos a las mismas reglas (respetando la igualdad ante la ley), pero su aplicación, dependiendo de diversos factores, como el

\footnotetext{
${ }^{78}$ PÉREZ LUÑO, Antonio Enrique. Op.cit., p. 21.

${ }^{79}$ RODRÍGUEZ-PIÑERO, Miguel y FERNÁNDEZ LÓPEZ, María Fernanda. Op.cit., p. 20.
} 
destinatario del acto administrativo o de la sentencia, es distinta para cada realidad concreta.

Los hechos arriba mencionados ocurren con demasiada frecuencia porque entre la elaboración de la ley y su aplicación concurren distintos factores, de distintas naturalezas (sociológicos, políticos, jurídicos, etc.) que no permiten que haya el deseado acercamiento entre las prescripciones legales y la actuación de los poderes públicos encargados de su ejecución.

En el ámbito de la administración pública, el modelo burocrático intentó garantizar una especie de "neutralidad" en la actuación de los órganos públicos, a través de la creación de diversos reglamentos, que, a su vez, pasaron a establecer los más distintos procedimientos administrativos para cada situación que exige la actuación de la Administración.

Sin embargo, la aplicación de las leyes por la Administración Pública no es un proceso automático, sino dependiente de la intervención interpretativa humana (especialmente cuando se trata de discrecionalidad administrativa), circunstancia que, irremediablemente, genera, en muchos casos, distintas aplicaciones de una misma regla.

Pese a la constatación arriba mencionada, la igualdad en la aplicación de la ley es violada "cuando un mismo precepto se aplica en casos iguales con notoria desigualdad por razones arbitrarias “ $₫ 80$

La doctrina hace una relevante distinción entre la aplicación desigual de la ley cuando el margen de apreciación de la norma jurídica es escasa o cuando es amplia. En el primer caso, la aplicación desigual de la ley se confunde con el incumplimiento de la ley, lo que se resuelve con la evocación del principio de legalidad.

A su vez:

"en los casos en los que existe un margen de apreciación o incluso una discrecionalidad, donde junto a las técnicas tradicionales del Derecho Administrativo (inderogabilidad singular de los reglamentos, desviación de poder, concepto jurídico indeterminado, etc.) la igualdad en la aplicación de la ley puede ofrecer una apoyatura

${ }^{80}$ SUAY RINCÓN, José. Op.cit., p. 187. 
importante para forzar a una actuación justa y no arbitraria en esa fase de aplicación de la ley."

En los términos mencionados, la exigencia de igualdad en la aplicación de la ley se convierte en uno de los más relevantes instrumentos de control de la discrecionalidad administrativa. Así, en una hipótesis discrecional, si la Administración procede de una determinada forma delante de un determinado ciudadano, los demás que estuvieran en la misma situación pasarían a tener el derecho de recibir el mismo trato.

Por lo tanto, como ya se ha destacado, a consecuencia de que resulta difícil el control de los actos administrativos discrecionales a través del principio de legalidad, que pasa a ser sustituido por la exigencia de igualdad en la aplicación de la ley, "la jurisprudencia construye así el concepto de vinculación al precedente administrativo, cuyo fundamento constitucional se encuentra en el principio de igualdad hoy reconocido en el artículo 14 de la Constitución." 82

Sobre este concepto, el Tribunal Constitucional decidió que:

"La regla general de la igualdad ante la ley contenida en el artículo 14 de la Constitución contempla, en primer lugar, la igualdad en el trato dado por la ley o la igualdad en la ley y constituye, desde este punto de vista, un límite puesto al ejercicio del poder legislativo, pero es asimismo igualdad en la aplicación de la ley, lo que impone que un mismo órgano no puede modificar arbitrariamente el sentido de sus decisiones en casos sustancialmente iguales y que cuando el órgano en cuestión considere que debe apartarse de sus precedentes tiene que ofrecer para ello una fundamentación suficiente y razonable." ${ }^{.3}$

Es imprescindible añadir que el fallo citado no significa que la interpretación de las normas jurídicas no pueda evolucionar (ya que esto es tan posible como deseable), pero sí la garantía de que los ciudadanos no serán tratados por los poderes públicos de forma arbitraria. Esta regla hace que "los ciudadanos posean una razonable convicción acerca de la correcta interpretación y aplicación de la legalidad y puedan ajustar a ella su comportamiento sin verse obligados a deducirla con una

\footnotetext{
${ }^{81}$ RODRÍGUEZ-PIÑERO, Miguel y FERNÁNDEZ LÓPEZ, María Fernanda. Op.cit., p. 21

${ }^{82}$ FERNÁNDEZ, Encarnación. Op.cit., p. 63.

${ }^{83}$ STC 49 de 14 de julio de 1982.
} 
siempre difícil y a veces infructuosa reinterpretación de una línea jurisprudencial mudable." 84

Conviene destacar que los órganos jurisdiccionales también están sometidos a la igualdad en la aplicación de la ley. Sobre este tema, el Tribunal Constitucional decidió que:

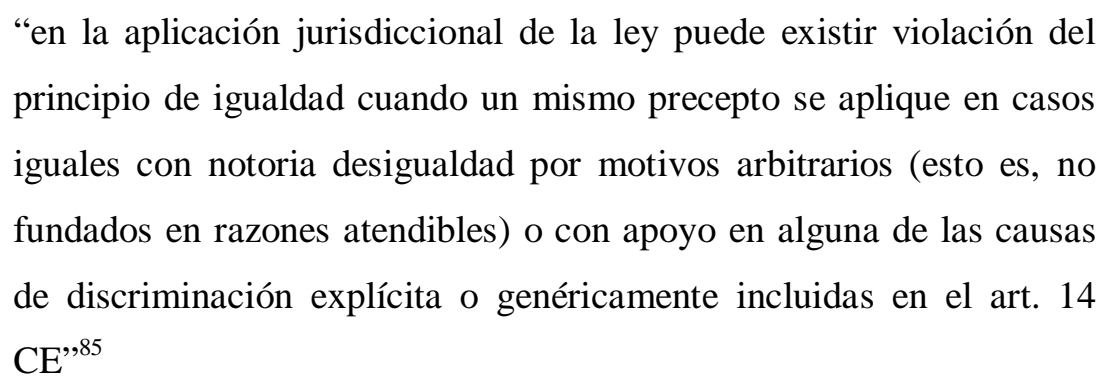

En el sistema jurídico-constitucional brasileño, como ya se ha visto, en general, no solía prevalecer el entendimiento que sostiene que la igualdad ante la ley no tenía como destinatario el ejecutor de las leyes. En esto camino, se puede transcribir la opinión de la doctrina que sostiene que "O mandamento da Constituição se dirige particularmente ao legislador e, efetivamente, somente ele poderá ser o destinatário útil de tal mandamento. O executor da lei já está, necessariamente, obrigado a aplicá-la de acordo com os critérios constantes da própria lei." 86

Como se puede percibir, la mencionada cuestión no es menospreciada por la doctrina brasileña, que siempre ha destacado la necesidad de que la igualdad alcance la actuación de aquellos que están encargados de ejecutar las normas jurídicas, en especial, los que hacen parte de la Administración Pública.

En el sentido arriba destacado, ya se ha subrayado que "o preceito magno da igualdade, como já tem sido assinalado, é norma voltada quer para o aplicador da lei quer para o próprio legislador ${ }^{87,}$.

\footnotetext{
${ }^{84}$ RODRÍGUEZ-PIÑERO, Miguel y FERNÁNDEZ LÓPEZ, María Fernanda. Op.cit., p. 27

${ }^{85}$ STC de 30 de marzo de 1981.

${ }^{86}$ SILVA, José Afonso da. Op.cit., p. 215.

${ }^{87}$ BANDEIRA DE MELLO, Celso Antônio. Op.cit., p. 9.
} 
En el derecho administrativo brasileño, la doctrina ha destacado el papel ejercido por el principio de impersonalidad (impessoalidade, en portugués), previsto en el art. 37 de la Constitución brasileña, como límite de actuación del administrador público. Para la doctrina brasileña, el principio de impersonalidad "objetiva a igualdade de tratamento que a Administraçao deve dispensar aos administrados que se encontrem em situaçao jurídica idêntica. Neste ponto, representa uma faceta do princípio da isonomia." $" 88$

La exigencia de trato impersonal por la Administración Pública no es nada sino la igualdad en la aplicación de la ley. En otra oportunidad, hemos escrito que:

\begin{abstract}
"Ressalte-se que a isonomia é princípio mais genérico que a impessoalidade, pois se aplica, indistintamente, a qualquer situação, seja ela pública, seja privada. Pode-se dizer que a impessoalidade é uma exigência da isonomia, mas com ela não se confunde. Conforme lição magistral, enquanto a isonomia é um direito do administrado, a impessoalidade é um dever para a Administração." ${ }^{89}$
\end{abstract}

La impersonalidad (impessoalidade) presente en la Constitución brasileña como principio de la Administración Pública a lo mejor ha recibido la inspiración de las Constituciones europeas, aunque estas hayan consagrado el principio de imparcialidad. ${ }^{90}$ Según apunta la doctrina española, en el contexto de la Administración Pública del referido país, la imparcialidad está "en la misma línea de objetivación de la actividad administrativa y de preservar ésta de los influjos partidistas de los políticos".91

A partir del análisis del principio de impersonalidad brasileño y del principio de imparcialidad español, se puede fácilmente percibir sus puntos comunes: la exigencia de objetividad, de trato sin privilegios a los ciudadanos y de búsqueda exclusiva del interés público. Debido a su relevancia en el contexto de este trabajo, en el

\footnotetext{
${ }^{88}$ DOS SANTOS CARVALHO FILHO, José. Op.cit., p. 17.

${ }^{89}$ LINS DE LESSA CARVALHO, Fábio. O princípio da impessoalidade nas licitações, Edufal, Maceió, 2005 , p. 59.

${ }^{90}$ El mencionado principio de imparcialidad está previsto en las Constituciones de Itália (art. 97), de Portugal (art. 267.1) y de España (art. 103.3).

91 GARCÍA DE ENTÉRRIA, Eduardo. Democracia, jueces y control de la Administración, $4^{\mathrm{a}}$ ed., Editorial Civitas, Madrid, 1998, p. 120.
} 
capítulo segundo serán dedicadas algunas páginas a la relación entre el acceso meritorio y la actuación imparcial, objetiva y eficaz de la Administración Pública.

Además de la impersonalidad, hay muchos otros principios del Derecho Administrativo brasileño que exigen la buena actuación de la Administración Pública, lo que, necesariamente, conduce al trato igualitario. Es lo que se puede decir respecto a los principios de finalidad, moralidad administrativa, buena fe, razonabilidad, proporcionalidad, entre otros que incluso poseen previsión constitucional. En esto sentido, hay que subrayar que "a disciplina constitucional administrativa traz, então, novos arsenais jurídicos para alteração do quadro tradicional de uma Administração Pública marcada pela pouca atenção dispensada aos direitos e garantias integrantes do patrimônio do cidadão-administrado.",92

Aunque la igualdad en la aplicación de la ley haya sido una relevante construcción teórica, se puede sencillamente percibir que esta no es suficiente para garantizar la igualdad material, ya que, suponiendo el contenido de las leyes, podría simplemente establecer discriminaciones arbitrarias, lo que haría inútil la tesis de igualdad en la aplicación de la ley ${ }^{93}$. En estos términos, fue necesario avanzar hasta la igualdad en la ley, lo que será analizado a continuación.

\subsubsection{3 - Igualdad en la ley}

Como ya se ha destacado, la igualdad ante la ley fue manifestada en las primeras Constituciones, que pasaron a reconocer de forma general los derechos de todos los hombres, rompiendo con un régimen de privilegios e inmunidades. A su vez, la igualdad en la aplicación de la ley fue destinada a los órganos encargados de ejecutar las prescripciones legales (Administración Pública y Poder Jurisdiccional), exigiéndoles un comportamiento imparcial en el trato a los ciudadanos.

\footnotetext{
${ }^{92}$ BACELLAR FILHO, Romeu Felipe. Profissionalização da função pública: a experiência brasileira, en La profesionalización de la Función Pública en Iberoamérica, Instituto Nacional de Administración Pública - INAP, Madrid, 2002, p. 93.

${ }^{93}$ Por ejemplo, sería poca o ninguna la utilidad de la igualdad en la aplicación de la ley, para la realización de la igualdad material, si las bases de una convocatoria de una oposición establecieran, sin cualquier razón relevante y justificada, que sólo pudieran ser candidatos como opositores las personas del sexo masculino, los creyentes de una religión especifica o los vecinos de determinado pueblo. En ese caso, la utilización aislada de la igualdad en la aplicación de la ley solamente serviría para legitimar una situación desigual prevista en la norma jurídica aplicable.
} 
En estos términos, se echaba de menos una manifestación de la igualdad que condicionara el propio contenido de las leyes, que hasta entonces, se preocupaba mucho más en garantizar la libertad.

Las fórmulas de igualdad vigentes en el Estado Liberal no fueron capaces de permitir la instalación de una sociedad más igualitaria. Al contrario, profundizaron las diferencias sociales y económicas entre las personas, lo cual provocó diversos pensamientos críticos hacia el liberalismo. Tras un largo proceso histórico, los movimientos sociales consiguieron, al menos, relativizar el modelo capitalista, que introdujo un Estado que empezó a buscar la efectiva igualdad entre los hombres, el Estado Social de Derecho.

La sociedad exigió, "em concorde unanimidade, que o alcance do princípio não se restringe a nivelar os cidadãos diante da norma legal posta, mas que a própria lei não pode ser editada em desconformidade com a isonomia." 94

Por tanto, para que el Estado pudiera actuar de forma más eficaz, la igualdad también debía pasar a ser exigida por el legislador, que hasta entonces, no elaboraba leyes que tuvieran la finalidad de disminuir las diferencias sociales y económicas entre las personas. En ese nuevo momento histórico:

"el Legislador había dejado de ser omnipotente al estar limitado en el nuevo ordenamiento por las garantías constitucionales de los derechos fundamentales del individuo...entre los que se incluye el principio de igualdad y su protección frente al poder discrecional del propio legislador...No deja de ser una ironía considerar que hasta entonces era respectada la igualdad si en realidad sólo a ella los órganos encargados de la aplicación y no los encargados de la creación normativa." 95

Las leyes pasan a servir de instrumento de la sociedad para promoción de los cambios sociales (función transformadora del Derecho). Por eso, cuando el art. 9.2 de la Constitución española determina que "Corresponde a los poderes públicos promover las condiciones para que la libertad y la igualdad del individuo y de los

\footnotetext{
${ }^{94}$ BANDEIRA DE MELLO, Celso Antônio. Op.cit., p. 9.

${ }^{95}$ VILACORTA MANCEBO, Luís. Op.cit., p. 40.
} 
grupos en que se integra sean reales y efectivas...”, su primer destinatario es el Poder Legislativo, y lo mismo se puede decir respecto al art.3ㅇ, IV, de la Constitución brasileña, que establece como objetivo fundamental de la Estado brasileño la promoción del bienestar de todos “ sem preconceitos de origem, raça, sexo, cor, idade e quaisquer outras formas de discriminação".

La igualdad en la ley es, así, la última etapa en el proceso de desarrollo del alcance y significado de la igualdad jurídica. Sin embargo, esto no significa que la igualdad ya ha alcanzado sus máximas potencialidades jurídicas, sino que ahora se aplica a todos los cuadrantes del Derecho. Por esta razón, se ha destacado que:

"O que se pretende sob este novo enfoque, portanto, é que o próprio legislador seja cingido pelo princípio constitucionalmente posto, de tal sorte que a lei não abrigue desigualdades sem qualquer fundamentação que não se equacione pela Justiça. Não se lê, pois, o princípio como pretendendo apenas que a norma se aplique de maneira igual, mas que a norma seja feita em estrita remissão e obediência a este princípio, quer-se dizer, que não se criem nela, ou nela se mantenham, desigualdades entre pessoas em situações jurídicas ou em circunstâncias pessoais iguais." ${ }^{96}$

La igualdad en la ley es una exigencia de contenido, que hace con que el mandado de igualdad tan solo vincule concretamente el legislador si la fórmula que determina que se debe tratar igualmente a los iguales y desigualmente a los desiguales "é interpretada como uma exigência de conteúdo, ou um mandado de igualdade material, obrigando o legislador à criação de um direito igual para todos.",97

La vinculación de legislador al principio de igualdad hace que la ley que no observa este límite será inconstitucional. ${ }^{98}$ Otro dato relevante es que la palabra "ley", presente en la expresión "igualdad en la ley", debe ser comprendida en sentido amplio, también abarcando los reglamentos y la negociación colectiva. En este camino, "el límite de ejercicio de la potestad normativa se despliega, por otra parte, en relación con

\footnotetext{
${ }^{96}$ ANTUNES ROCHA, Cármen Lúcia. Op.cit., p. 38.

${ }^{97}$ GUIMARAES TABORDA, Maren. Op.cit., p. 260.

${ }^{98}$ STC de 10 de noviembre de 1981.
} 
todos aquellos poderes, estatales o sociales, a los que les está reconocida la facultad de crear normas." 99

En el contexto del presente trabajo, la importancia de la conclusión arriba mencionada es notable, ya que, en la definición de las bases de las convocatorias de los procesos selectivos para acceso a la función pública, la Administración Pública está limitada por el principio de igualdad, no sólo en la aplicación de las referidas reglas.

En suma, las distintas manifestaciones del principio de igualdad son caras de una misma realidad. Y el Tribunal Constitucional, desde sus primeras decisiones, entiende que el art. 14 de la Constitución española:
"contempla, en primer lugar, la igualdad en el trato dado por la ley o igualdad en la ley y constituye desde este punto de vista un límite puesto al ejercicio del poder legislativo, pero es asimismo igualdad en la aplicación de la ley, lo que impone que un mismo órgano no puede modificar arbitrariamente el sentido de sus decisiones en casos sustancialmente iguales y que cuando el órgano en cuestión considere que debe apartarse de sus precedentes tiene que ofrecer para ello una fundamentación suficiente y razonable." 100

Ciertamente, la exigencia de igualdad en la ley no significa que el legislador esté obligado a establecer en las leyes un trato de absoluta equivalencia entre las personas. Al contrario:
"el principio de igualdad no excluye, de una manera absoluta e incondicionada, las diferencias de trato normativo. El principio de igualdad no impide que el Derecho y los órdenes normativos en general tomen en consideración la diversidad de situaciones para darles un trato normativo diferenciado. Lo contrario conduciría a la creación de normas no funcionales, disparatadas e injustas."101

Cabe añadir que una de las manifestaciones más relevantes en el desarrollo del papel del Estado como promotor de transformaciones sociales es la utilización de la tesis de la igualdad de oportunidades. Esa idea, que consiste en situar a todos los

\footnotetext{
${ }^{99}$ RODRÍGUEZ-PIÑERO, Miguel y FERNÁNDEZ LÓPEZ, María Fernanda. Op.cit., p. 40.

${ }^{100}$ STC 49 de 1982.

${ }^{101}$ FERNÁNDEZ, Encarnación. Op.cit., p. 72.
} 
individuos en iguales puntos de partida, tiene particular aplicación en las situaciones donde hay personas en competición, lo que conecta directamente esta cuestión con el tema del presente trabajo.

Para la doctrina, mientras la igualdad ante la ley fue el soporte del Estado Liberal, la igualdad de oportunidades es uno de los fundamentos del Estado Social. Además, afirma el citado autor que la igualdad de oportunidades es la aplicación de la regla de justicia a una situación en la cual haya personas en competición entre sí para la obtención de un objetivo único, que sólo puede ser alcanzado por uno de los competidores. Añade que:

"Nada hay de particularmente progresivo o regresivo en el hecho de que quienes juegan al tute tengan de partida en mismo número de cartas, o que los jugadores de ajedrez dispongan del mismo número y del mismo tipo de piezas, que los duelistas estén provistos de la misma arma, que los corredores partan de la misma línea, o que los participantes en una oposición tengan el mismo título, puedan servirse en el examen de los mismos libros, o todos desconozcan el tema que tengan que desarrollar.",102

Sin embargo, el mismo autor destaca la extensión de la utilización del mencionado principio, ya que, con el carácter global de la sociedad actual, la competición que se presenta es por la propia vida. Así, a todos los miembros de una determinada sociedad deben ser concedidas las mismas oportunidades sociales y económicas para acceso a las conquistas más significativas, partiendo todos de posiciones iguales. $^{103}$

Por ello, la propia Constitución española, en el art. 9.2, cuando reconoce que cabe a los poderes públicos la promoción de las condiciones para que la igualdad sea real y efectiva, impone el establecimiento de la igualdad de derecho, y esa comprende la igualdad de oportunidades. ${ }^{104}$

A su vez, la exigencia de igualdad de oportunidades hizo surgir las acciones afirmativas, que son "política públicas (e também privadas) voltadas à concretização do

\footnotetext{
${ }^{102}$ BOBBIO, Norberto. Op.cit., p. 77.

${ }^{103}$ BOBBIO, Norberto. Op.cit., p. 78.

${ }^{104}$ REY MARTÍNEZ, Fernando. Op.cit., p. 54.
} 
princípio constitucional da igualdade material e à neutralização dos efeitos da discriminação racial, de gênero, de idade, de origem nacional e de compleição física" ${ }^{105}$

En el derecho brasileño, es evidente que también se reconoce que "não só perante a norma posta se nivelam os indivíduos, mas, a própria edição dela assujeita-se ao dever de dispensar tratamento equânime às pessoas."

No obstante, hay que se destacar que, más una vez, la incidencia del principio de igualdad en Brasil ha tenido matices propios. Como ya se ha destacado en otras dos oportunidades, la fecunda discusión sobre las manifestaciones de la igualdad ocurrida en otros países (sobre todo en Europa) no sucedió con los mismos colores en Brasil, ya que, en general, la fórmula genérica de la igualdad ya era comprendida en sus tres manifestaciones (ante, en la aplicación y en la ley).

El distinto trato que la comunidad jurídica brasileña ofreció al tema se puede percibir a partir de la lectura del pensamiento de uno de los más importantes constitucionalistas brasileños, cuando comentó respecto a la igualdad ante la ley (igualdade perante a lei, en portugués):

"Entre nós, essa distinção é desnecessária, porque a doutrina e a jurisprudência já firmaram, há muito, a orientação, de que a igualdade perante a lei tem o sentido que, no exterior, se dá à expressão igualdade na lei, ou seja, o princípio tem como destinatários tanto o legislador como os aplicadores da lei." ${ }^{107}$

Respecto a las acciones afirmativas en Brasil, las mismas son hasta mismo más urgentes en esto país que en otros en los cuales la situación de desequilibrio social no es tan intensa, como es el caso español. Sobre las referidas medidas en Brasil, ya se ha dicho que:

\footnotetext{
105 BARBOSA GOMES, Joaquim Benedito. Ação afirmativa e princípio constitucional da igualdade, Editora Renovar, Rio de Janeiro, 2001, p. 6.

${ }^{106}$ BANDEIRA DE MELLO, Celso Antônio. Op.cit., p. 9.

${ }^{107}$ SILVA, José Afonso da. Op.cit., p. 214.
} 
"No Brasil, os programas de ações afirmativas surgiram, com fundamento na própria Constituição da República de 1988, que, em inúmeros dispositivos, ressalta a necessidade de proteção e tratamento diferenciado a alguns grupos, para que possam se integrar, socialmente, em condições de igualdade. Posteriormente, apontamos, com base legal dos programas de ações afirmativas no Brasil, as mencionadas legislações de proteção e incentivo aos portadores de necessidades especiais. Aos poucos, estes programas vêm sendo estendido a outros grupos sociais, que passaram a ser denominados de minorias, como os afro-descendentes e os índios. Encontram-se em pauta no Congresso Nacional projetos de lei, prevendo reserva de cotas para afro-descendentes, em concursos públicos, na esfera federal. Há, também, um outro projeto, de autoria do Senador Paulo Paim, obrigando a iniciativa privada a contratar $20 \%$ de negros, em todas as áreas e em todos escalões da empresa. Recentemente, a Universidade de Brasília divulgou a previsão de cotas, em edital de vestibular, para o ingresso em todos os cursos, aos índios." 108

Como se puede fácilmente percibir, el tema de las acciones afirmativas en Brasil es muy actual, y abarca distintos segmentos de la sociedad, considerados minoritarios (aunque correspondan a grandes contingentes de la población), como los negros, los indígenas, las personas con discapacidad, y, incluso, las personas pobres o que hayan estudiado en institutos públicos.

Sobre la gran extensión de determinadas acciones afirmativas, y los riesgos que ellas puedan causar, cabe subrayar que "não se pretende a realização de novas discriminações através das ações afirmativas, agora em desfavor das maiorias. Desta forma, para se evitar a ocorrência do extremo oposto, os planos e programas de ações

\footnotetext{
$\overline{108}$ DIAS DA SILVEIRA, Raquel. Discriminações legais em concursos públicos e o princípio da igualdade: um estudo sob o paradigma das ações afirmativas e das políticas públicas de inclusão das minorias nas últimas décadas. Revista Eletrônica de Direito do Estado (REDE), Instituto Brasileiro de Direito Público, Número 19, julho, agosto e setembro de 2009, Salvador, disponible en internet: http://www.direitodoestado.com.br/rede.asp.
} 
afirmativas adotados devem observar a fixação de percentuais mínimos garantidores da presença das minorias que por eles se buscavam igualar."109

Evidentemente, para que haya igualdad real y efectiva, surge la necesidad de utilización de diversas técnicas normativas (generalización, equiparación, diferenciación), cada una de ellas adecuada delante de determinadas condiciones. Es por esa razón que, en un cierto caso, deberá la ley establecer un trato distinto para dos personas, mientras que en otra situación, la mencionada diferenciación no será admitida. Las distintas técnicas de la igualdad serán investigadas en las próximas líneas.

\subsubsection{3 - Técnicas de la igualdad}

Para que la igualdad sea un valor efectivo, el proceso de creación de las leyes debe estar influenciado por distintas técnicas, lo que impone al legislador conocimientos más lúcidos de la realidad social y de las necesidades de cambio que pueden emanar de las leyes.

Ciertamente, el legislador no puede desconocer la circunstancia de que hay muchos casos en que las normas jurídicas deben declarar oficialmente la igualdad que existe en las situaciones de hecho. Por ejemplo: como todos los hombres son iguales en su condición humana, las leyes reconocen que todos poseen derechos fundamentales y que todos pueden ejércelos sin dificultad y con las garantías del ordenamiento jurídico. Es la técnica de generalización.

Sin embargo, en otros casos, el deber del legislador es percibir diferencias de hecho entre las personas, e instaurar una situación de igualdad jurídica en las leyes, cuando se quiere establecer una aproximación entre desiguales. Esto sucede cuando una ley permite que un extranjero pueda votar en las elecciones municipales o acceder a determinadas funciones públicas. De hecho, españoles y extranjeros poseen diferencia en relación a la nacionalidad, pero esta circunstancia no fue tenida en consideración por la ley, cuando esta estableció que aquellos podrían participar en las elecciones municipales o acceder a determinadas funciones públicas. El nombre concedido a esta técnica es equiparación.

\footnotetext{
${ }^{109}$ TOURINHO, Rita. Op.cit., p. 128.
} 
No obstante, hay situaciones donde el legislador, al reconocer las diferencias de hecho, busca mantenerlas en las leyes, pues, en estas situaciones, un eventual acercamiento introducido por el derecho sería perjudicial a uno de los destinatarios de la ley o hacia la propia sociedad. En este contexto, se puede mencionar los varios tratamientos diferenciados (y más favorables) establecidos en la legislación laboral para las mujeres, como licencias especiales cuando están embarazadas, después del nacimiento de un hijo o para la lactancia. Es la técnica de diferenciación.

Por el contrario, la diferenciación también ocurre en la búsqueda de una aproximación entre las personas que poseen distinciones, a través de acciones positivas, de promoción de segmentos más desprestigiados de la sociedad. En este camino, se puede destacar las cotas destinadas a estudiantes negros en las universidades o la separación de plazas en las oposiciones para las personas con discapacidad.

Las diferentes técnicas mencionadas provienen de las diferentes concepciones de justicia retributiva y justicia atributiva: "la relación entre la justicia retributiva y atributiva y la regla de justicia puede precisarse del siguiente modo: la primera es constitutiva o reconstitutiva de la igualdad social; la segunda tiende a mantenerla en los modos y formas que ha sido establecida." $" 10$

En las expresiones arriba mencionadas, se percibe que el derecho actúa de forma distinta, cuando pretende establecer relaciones de igualdad. Por ello, se impone la investigación de las diversas técnicas de la igualdad.

\subsubsection{1 - Generalización}

La primera técnica utilizada por el legislador (y observada por los aplicadores del Derecho) es la generalización, que puede ser considerada como "la tipificación en términos impersonales y universales de los supuestos que han de servir de base a la atribución de determinadas consecuencias jurídicas."111

La generalidad de la norma jurídica es un ideal soñado por la humanidad, que solamente se alcanzó (aunque no plenamente) con las revoluciones del siglo XVIII.

\footnotetext{
${ }^{110}$ BOBBIO, Norberto. Op.cit., p. 65-66.

111 PÉREZ LUÑO, Antonio Enrique. Op.cit., p. 23
} 
La exigencia de igual trato jurídico de todos los ciudadanos (igualdad ante la ley) permitió la universalización de los derechos fundamentales.

En esos términos, las Constituciones (incluso las actuales, como la Constitución española de 1978 y la brasileña de 1988) pasan a utilizar expresiones genéricas e impersonales.

En la Constitución de España, se puede citar como ejemplos de generalidad y impersonalidad las expresiones como "todos" (arts. 15, 17, 28, 31.1, 45.1...); "toda persona" (arts. 17.1 y 3); "todas las personas" (art. 24.1); "nadie" (arts. 16.2, 17.1, $25 \ldots . . .{ }^{112}$ Además, se puede también destacar las expresiones "los ciudadanos" (art. 23); "los españoles" (art. 29.1 y 30.1); "todos los españoles" (art. 27.1, 28.1, 29.1, 31.1 y 45.1) que hacen referencia a la generalización de los derechos y deberes.

Tras referirse al pensamiento arriba citado, la doctrina defiende que la gran cantidad de tales referencias en la Constitución española "nos viene a indicar que los poderes públicos, y también el legislador (art. 53), han de respectar ese mandato de generalización en la concesión de los derechos fundamentales." 113

También merece especial atención la relación íntima entre la generalidad de las normas de la igualdad en la aplicación del Derecho: "ésta supone que las normas son aplicables a más de una persona, es decir, que no son normas singulares, sino dirigidas a una pluralidad de sujetos." 114

Sin embargo, el sentido de destinatario genérico de las normas jurídicas debe ser bien comprendido ${ }^{115}$. Aunque el derecho utilice fórmulas extremamente genéricas, las leyes se establecen "para un destinario abstracto, no identificable ad

${ }_{112}$ PÉREZ LUÑO, Antonio Enrique. Op.cit., p. 24

${ }^{113}$ RODRÍGUEZ-PIÑERO, Miguel y FERNÂNDEZ LÓPEZ, María Fernanda. Op.cit., p. 36.

${ }_{114}^{114}$ FERNÁNDEZ, Encarnación. Igualdad y derechos humanos, Tecnos, Madrid, 2003, p. 69.

${ }^{115}$ Según Bobbio, al explicar el sentido de la expresión "todos", presente en las declaraciones del siglo XVIII,:"por "todos" no se dice que se entienda la totalidad de los hombres (...). La idea que la máxima expresa es la que los hombres sean considerados iguales y tratados como iguales respectos de aquellas cualidades que, según las diferentes concepciones del hombre y de la sociedad, constituyen la esencia del hombre, de la naturaleza humana distinta de la naturaleza de los demás seres, como el libre uso de la razón, la capacidad jurídica, la libertad de poseer, la "dignidad social”(...), o más brevemente, la "dignidad".....En ese sentido, la máxima no tiene un significado unívoco, sino tantos significados como respuestas hay a la pregunta: "Todos iguales, pero, ¿en qué?”. Una vez interpretado el significado específico a través del análisis de las ideas morales, sociales y políticas de la doctrina que la ha formulado, su significado emotivo depende precisamente del valor que toda doctrina atribuye a esa cualidad respecto a la cual se exige que todos los hombres sean tratados de la misma manera." (BOBBIO, Norberto. Op.cit., p. 69-70). 
personam, que suele ser el ciudadano en general o, en todo caso, un tipo genérico (el comprador, el vendedor, el menor, el mayor de edad, el funcionario, el administrado, etc.)." 116

Citando a Rousseau, la doctrina diferencia las desigualdades naturales de las sociales, destacando que como las primeras son benéficas o moralmente indiferentes, son las últimas que deben ser eliminadas. ${ }^{117}$. Así, se puede afirmar que a través de la técnica de generalización, las normas jurídicas reconocen que todas las personas, por su coincidente condición humana, son igualmente merecedoras de tener declarados y garantizados sus derechos fundamentales por el ordenamiento jurídico, sin que existan privilegios e inmunidades a determinados grupos sociales.

Por supuesto, la necesidad de generalización de los derechos también ha estado presente en el constitucionalismo brasileño. En la Constitución brasileña de 1988, ella ocurre cuando, por ejemplo, se establece que uno de los objetivos del Estado es la promoción del bien estar de todos (art. $3^{\circ}, \mathrm{IV}$ ); cuando se declara que todos son iguales ante la ley $\left(\operatorname{art} .5^{\circ}\right)$; cuando se expresa que nadie será obligado a hacer o dejar de hacer algo sino por ley (art. 5, II); o que nadie será privado de sus bienes o de su libertad sin el debido proceso legal (art. 5, LIV), entre tantas otras situaciones.

En verdad, la generalización es el primer paso para la igualdad material y debe ser extendida a todos los derechos y a todas las personas, siguiendo una "tendência de alargamento de seu conteúdo e de generalização de sua aplicação, pela qual a igualdade das pessoas seja sempre em razão de sua condição humana mesma, abarcando, cada vez mais, um número maior de titulares do direito em que se mostra e se dá aplicação o princípio." 118

No obstante, si la utilización de la referida técnica no fuera seguida por las demás (equiparación y diferenciación), la sociedad no estaría debidamente protegida, pues la generalización suele declarar derechos, pero no impone medidas concretas para disminución de las desigualdades. En esto contexto, en Brasil, como ya se ha expresado, hay factores adicionales que comprometen la efectividad del discurso de objetividad, generalidad y impersonalidad, signos de la igualdad. Así, se puede decir que:

\footnotetext{
${ }^{116}$ FERNÁNDEZ, Encarnación. Op.cit., p. 70-71.

${ }_{117}$ BOBBIO, Norberto. Op.cit., p. 70.

${ }^{118}$ ANTUNES ROCHA, Cármen Lúcia. Op.cit., p. 35.
} 


\begin{abstract}
"Acompanhando as conquistas da humanidade, o Brasil reproduziu nos textos constitucionais e na legislação ordinária o mesmo discurso de generalidade da lei, de imparcialidade do juiz e de impessoalidade da Administração Pública. Do discurso à realidade, ainda há um abismo considerável a ser superado. A presença de leis casuísticas baixadas por Casas Legislativas cujos membros representam tãosomente seus próprios interesses políticos, de sentenças parciais emitidas por magistrados que fazem de sua função uma atividade comercial, e de atos administrativos personalistas movidos pela finalidade de conceder favorecimentos a determinados grupos ou promover perseguições a outros, indica que o ideal republicano ainda está longe se ser alcançado no Brasil." ${ }^{119}$
\end{abstract}

\title{
1.2.1.3.2 - Equiparación
}

Otra técnica para la obtención de la igualdad es la equiparación, que parte de la desconsideración, para efectos del Derecho, de las diferentes circunstancias de hecho que existen entre las personas, para establecer un mismo trato entre las mismas en la ley y en su aplicación.

Se puede afirmar que "mientras la generalidad entraña el trato igual de lo igual, la equiparación supone un trato igual de lo que no es en el plano fáctico, pero se estima jurídicamente que debe serlo."120

Aun reconociendo que la generalización de los derechos fundamentales fue una etapa muy relevante para la consolidación de un estatuto jurídico que favoreciera toda la humanidad, es la equiparación la técnica más frecuentemente utilizada para la obtención de la igualdad jurídica.

Sobre el entendimiento del párrafo anterior, se puede destacar que "en la mayor parte de las ocasiones, la igualdad implica un juicio de equiparación de una pluralidad de objetos, situaciones o personas en un determinado aspecto, aún admitiendo su disparidad en otros $(\mathrm{a}=\mathrm{b}) ., 121$

\footnotetext{
${ }^{119}$ LINS DE LESSA CARVALHO, Fábio. Op.cit., p. 29.

${ }^{120}$ PÉREZ LUÑO, Antonio Enrique. Op.cit., p. 25.

${ }^{121}$ PÉREZ LUÑO, Antonio Enrique. Op.cit., p. 25.
} 
Así, el contenido del art. 14 de la Constitución española, en un primer momento, declara que "Los españoles son iguales ante la Ley", generalización que traduce el reconocimiento jurídico de una similitud fáctica, ya que todos los españoles poseen un rasgo coincidente, que es la misma nacionalidad. Sin embargo, el art. 14, cuando prevé "sin que pueda prevalecer discriminación alguna por razón de nacimiento, raza, sexo, religión, opinión o cualquier otra condición o circunstancia personal o social."), establece una equiparación de derechos entre personas que, a pesar de que ostenten la misma nacionalidad, también poseen rasgos distintos.

Lo mismo se puede decir respecto al art. $5^{\circ}$ de la Constitución brasileña, que tras declarar, de forma genérica, en su art. $5^{\circ}$ que "Todos são iguais perante a lei" por la igual condición y dignidad humana que todos que residen en territorio brasileño poseen, aclara a continuación que la igualdad es garantida "aos brasileiros e aos estrangeiros residentes no País", equiparándoles en derechos y obligaciones, aunque estos posean distintas nacionalidades.

Como consecuencia lógica de la afirmación anterior, se percibe que la exigencia de equiparación está directamente relacionada al principio de no discriminación, tema que será objeto de análisis más adelante. Ahora, al menos, es posible afirmar, en términos generales, que la equiparación entre las personas es una técnica con presunción relativa de legitimidad constitucional (art. 14 de la Constitución española y art. $5^{\circ}$ de la brasileña), mientras la diferenciación (próxima técnica a ser investigada) necesita de la ley expresa ${ }^{122}$ y de una seria justificación, debido a que, en principio, los tratos diferenciados quebrantarían la mencionada equiparación entre todas las personas.

En el contexto mencionado arriba, aunque la equiparación, en principio, pudiera parecer ser la tendencia natural de la ley, conviene subrayar que:

"el verdadero problema para exigir un tratamiento jurídico igual consiste en determinar cuándo dos situaciones reales son equiparables; cuándo sus similitudes deben predominar sobre sus diferencias,

\footnotetext{
${ }^{122}$ Comentando la STC 108, de 26 de noviembre de 1984, la doctrina destaca que: "el tratamiento legal diferenciador debe derivar de la ley de forma "clara, precisa y directa" y no extraerse mediante "hipotéticos juicios" interpretativos de la legalidad ordinaria, que no corresponde realizar al TC en cuanto garante de la Constitución, a cuyo enjuiciamiento restringe su esfera de actuación." (RODRÍGUEZ-PIÑERO, Miguel. y FERNÁNDEZ LÓPEZ, María Fernanda. Op.cit., p. 42.)
} 
proceso que implica un doble juicio de valor, el de la elección de los criterios concretos a tener en cuenta, y el de la evaluación de los hechos en función de estos criterios “ 123

La apreciación individualizada de cada situación es imprescindible para la definición de la técnica a ser utilizada. En general, la violación de la igualdad ocurre cuando en la ley o en su aplicación hay una discriminación no tolerada. Sin embargo, también habrá el quebrantamiento de la igualdad cuando haya una equiparación, cuando hay una circunstancia que exige una diferenciación.

\subsubsection{3 - Diferenciación}

Las dos primeras técnicas ya analizadas, por distintas razones, exigen un mismo trato jurídico, sea entre iguales (generalización), sea entre desiguales (equiparación). No obstante, es evidente que habría de existir una técnica de igualdad que estableciera en las normas jurídicas tratos distintos a las personas. Es lo que se llama diferenciación.

La mencionada técnica exige el discernimiento por el legislador de las diferencias relevantes entre las personas, y supone un trato normativo que tenga en consideración tales distinciones. Es que aunque el Derecho establezca que todos son iguales, "a desigualdade, no entanto, é um fato, um produto da natureza e uma contingência da história do homem. Como criatura singular, o ser humano é plural, diverso, único." 124

La clásica fórmula que afirma que la igualdad consiste en el trato igual a los iguales, y en el trato desigual a los desiguales ya reconocía la necesidad de diferenciación para el cumplimiento de la igualdad.

Respecto a la referida fórmula de la igualdad, se puede añadir que:

"A regra da igualdade não consiste senão em quinhoar desigualmente aos desiguais, na medida em que se desigualam. Nesta desigualdade social, proporcionada à desigualdade natural, é que se acha a verdadeira lei da igualdade. O mais são desvarios da inveja, do

${ }^{123}$ RODRÍGUEZ-PIÑERO, Miguel y FERNÁNDEZ LÓPEZ, María Fernanda. Op.cit., p. 47.

${ }^{124}$ ANTUNES ROCHA, Cármen Lúcia. Op.cit., p. 13. 
orgulho, ou da loucura. Tratar com desigualdade a iguais, ou a desiguais com igualdade, seria desigualdade flagrante, e não igualdade real." 125

La diferenciación considera la igualdad formal en sentido dinámico ${ }^{126}$, lo que provoca que, en determinadas circunstancias especiales, las normas jurídicas establezcan derechos y deberes diferenciados a las personas que, por algún motivo significativo, poseen características particulares que las distinguen.

Entender la igualdad como sinónimo de equiparación es un error, ya que "se subraya a menudo que la equiparación absoluta de todos y todas las situaciones no hace sino conducir a una sucesión de desigualdades reales ${ }^{127}$."

Además, el trato distinto a los desiguales es una exigencia de la democracia, ya que prestigia las diferencias, nada más democrático que eso. En ese sentido, ya se afirmó que:"quien se irrita al ver tratados desigualmente a los iguales, pero no se inmuta al ver tratados igualmente a los desiguales no es demócrata, es plebeyo."128

$\mathrm{Si}$ la equiparación absoluta no es deseable, tampoco se pretende diferenciaciones sin justificación. Además, aunque exista una justificación, esta deberá ser razonable y proporcional, como explica el Tribunal Constitucional español:

"El art. $14 \mathrm{CE}$ contiene en su primer inciso una cláusula general de igualdad de todos los españoles ante la Ley, habiendo sido configurado este principio general de igualdad, por una conocida doctrina constitucional, como un derecho subjetivo de los ciudadanos a obtener un trato igual, que obliga y limita a los poderes públicos a respectarlo y que exige que los supuestos de hecho iguales sean tratados idénticamente en sus consecuencias jurídicas y que, para introducir diferencias entre ellos, tenga que existir una suficiente justificación de tal diferencia, que aparezca al mismo tiempo como fundada y razonable, de acuerdo con criterios y juicios de valor

\footnotetext{
${ }^{125}$ BARBOSA, Rui. Oração aos moços, Ed. Martin Claret, p. 39.

${ }^{126}$ PÉREZ LUÑO, Antonio Enrique. Op.cit., p. 28.

${ }^{127}$ FERNÁNDEZ, Encarnación. Op.cit., p. 72.

128 ORTEGA Y GASSET, J. Democracia morbosa, en Obras completas, Alianza Editorial \& Revista de Occidente, Madrid, 1983, vol. II, p. 138.
} 
generalmente aceptados, y cuyas consecuencias no resulten, en todo caso, desproporcionadas." $" 129$

Así, la elección de los criterios de diferenciación se convierte en una de las tareas más complejas del legislador (y de los que producen normas jurídicas, en general). Sin embargo, aunque el legislador haya elegido un criterio de diferenciación que posee una justificación razonable y no arbitraria, para que la igualdad sea obtenida, es imprescindible que el trato distintivo establecido en la ley sea adecuado, suficiente para el alcance de las finalidades de la diferenciación, y proporcional, evitando excesos que comportarían injusticias.

Conviene destacar que el Tribunal Constitucional español entiende que aunque el art. 14 de la Constitución española establece no ser posible la diferenciación de trato en la ley cuando esta carezca de una justificación objetiva y razonable, "la prohibición de discriminaciones arbitrarias opera también en la aplicación de la Ley, y, en general, de cualquier norma jurídica..."

Sobre las finalidades de la diferenciación, debe ser corroborado que el trato distinto en las normas jurídicas puede buscar la manutención de una desigualdad de hecho, cuando esta es apreciada de una forma positiva. Como ejemplo, se puede destacar la desigualdad de trato jurídico en la ley del menor, cuando la legislación trata de la ejecución de las penalidades. En estos casos, el Derecho busca la preservación de valores, que un trato igual podría no tener en consideración.

No obstante, la desigualdad de trato también puede tener como objetivo la disminución o supresión (lo que es casi imposible) de las diferencias de hecho, cuando estas son aceptadas como algo negativo (es lo que pasa, por ejemplo, cuando el Derecho prevé tratos preferenciales para las mujeres en el acceso al mercado laboral).

Cuando la diferenciación de trato tiene como finalidad la disminución de la igualdad, lo que el Derecho busca es la sustitución de valores (de uno efectivo por uno ideal o deseado), lo que muchas veces impone la adopción de acciones positivas ${ }^{131}$, que,

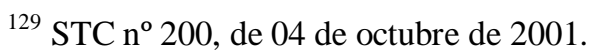

${ }^{130} \mathrm{STC} \mathrm{n}^{\circ} 59$, de 28 de Julio de 1982.

131 Respecto a las referidas medidas, se puede añadir que "após a $2^{a}$ Guerra Mundial os sistemas constitucionais passaram a conferir maior atenção ao princípio da igualdade, formalizando-o como direito fundamental. Ocorre que, a simples proibição de condutas discriminatórias não se fazia suficiente
} 
como ya se ha visto, son medidas de impulso y promoción para eliminación de desigualdades de hecho. ${ }^{132}$

Sobre la cuestión arriba destacada, cabe añadir que:

"el término acción positiva es de una gran ambigüedad. De acuerdo con una interpretación amplia del mismo incluye una gran variedad de medidas destinadas a combatir la discriminación de determinados grupos y a favorecer la igualdad real. Algunas de ellas tienen un carácter meramente promocional y ni siquiera implican un trato desigual. Otras en cambio consisten en un tratamiento diferenciado que favorece a los miembros del grupo desaventajado con la finalidad de conseguir la igualdad (diferenciación igualadora o parificadora)." ${ }^{, 133}$

Como ya he subrayado, es propio del Derecho hacer diferenciaciones. Sin embargo, si la expresión "diferenciación” pasa a ser sustituida por "discriminación”, surgirán muchas voces que destacarán que la mencionada conducta está prohibida por el ordenamiento jurídico. Así, surgen las cuestiones: ¿hay distinciones entres las expresiones "diferenciación” y "discriminación”? Si la respuesta es positiva, ¿cuáles serían las características presentes en la discriminación y cómo es posible diferenciar sin discriminar?

Antes de empezar a contestar las difíciles indagaciones arriba, hay que se tener en cuenta que:

"o princípio jurídico da igualdade é o que a sociedade quer que ele seja. Não é obra de Deuses, nem de formas heterônomas, nem de forças exógenas que se impõem a uma sociedade com explicações místicas e mistificadas. $\mathrm{O}$ ser humano iguala-se ao outro quanto à sua natureza e à sua essência e desiguala-se em sua contingência humana e em sua continência social. O Direito é o que a sociedade - ou, muita

para garantir a igualdade jurídica no âmbito social. Com efeito, em 1965, através da Executive Order 11.246, do Presidente Lyndon Johnson, consolidou-se a expressão ação afirmativa (affirmative action) na ordem jurídica federal norte-americana, significando a exigência de benefícios a algumas minorias socialmente inferiorizada, vítimas de preconceitos que precisavam ser superados com o propósito de se atingir a igualdade garantida constitucionalmente." (TOURINHO, Rita. Op.cit., p. 127)

132 PICÓ LORENZO, Celsa. La discriminación positiva en la función pública, en el libro La discriminación positiva, Consejo General del Poder Judicial, Centro de Documentación Judicial, Directora María Eugenia Alegret Burgués, Madrid, 2006, p. 25.

${ }^{133}$ FERNÁNDEZ, Encarnación., Op.cit., p. 95. 
vez, o eventual detentor da capacidade de ditar as normas - diz que ele é."134

Lo que impone ahora investigar es el significado de discriminación en el Derecho (especialmente en los contextos español y brasileño), y sus relaciones (de identidad o no) con la técnica de la diferenciación de trato.

\subsection{4 - Igualdad y no discriminación}

Como ya se ha analizado anteriormente, el art. 14 de la CE no sólo trata de la igualdad entre todos los españoles, sino también hace expresa referencia a la prohibición de discriminación “...por razón de nacimiento, raza, sexo, religión, opinión o cualquier otra condición o circunstancia personal o social."

Algo semejante sucede en el texto de la Constitución brasileña, cuando determina en el art. $3^{\circ}$, IV, que "constituem objetivos fundamentais da República Federativa do Brasil: (...) promover o bem de todos, sem preconceitos de origem, raça, sexo, cor, idade e quaisquer outras formas de discriminação".

Hoy en día, sólo a través de una atropellada y superficial interpretación del segundo precepto del art. 14 de la CE y del apartado IV del art. $3^{\circ}$ de la CB se podría llegar a la conclusión de que las mencionadas Constituciones no permitirían que las leyes y la Administración Pública establecieran tratos distintos entre las personas.

Sin embargo, era exactamente esta la interpretación (esto es, sin admitir distinciones) que imperaba en el período histórico en que fueron formuladas por primera vez las normas de igualdad ante la Ley (Estado Liberal). No obstante, desde hace un siglo se comprende que la igualdad, para ser efectiva, necesita leyes que establezcan diferenciaciones, con las correspondientes actuaciones de la Administración Pública.

La doctrina indaga lo que ha sucedido para que el principio de igualdad haya experimentado una variación en su contenido y afirma que la respuesta está en que fueron constitucionalizados intereses jurídicos que antes no lo estaban, como la progresividad del sistema tributario, el derecho a la seguridad social, a la salud, a una

${ }^{134}$ ANTUNES ROCHA, Cármen Lúcia. Op.cit., p. 28. 
vivienda digna y todo lo que es el capítulo $3^{\circ}$ del Título I de la Constitución española y en el capítulo II del Título II de la Constitución brasileña (derechos sociales).

En estos términos, sobre la Constitución de España, se ha dicho que "el artículo 14 ha sido puesto en relación con los artículos que recogen esos intereses, y de esa combinación ha nacido el actual sentido del principio". ${ }^{135}$

Según entendimiento doctrinario español, muchos autores suelen separar radicalmente los principios de igualdad (art. 14.I) y de no discriminación (art. 14.II). Sin embargo, afirma que "la igualdad del art. $14 \mathrm{CE}$ es la igualdad del Estado Social y democrático de Derecho; tiene también el significado de prohibición de discriminación ante ciertos criterios de diferenciación."136

Así, si la diferenciación es aceptada como necesaria a la igualdad, ¿cuál es la justificación del art. 14.II de la Constitución española que prevé el principio de no discriminación? La respuesta ciertamente depende de la apreciación de las distinciones entre diferenciación y discriminación, pues como será demostrado posteriormente, no es adecuado utilizar las referidas expresiones como si fueran sinónimas, ya que en la terminología del Derecho, una de las locuciones es el género (diferenciación), mientras la otra (discriminación) es una de sus especies. Por consiguiente, la próxima tarea exige el análisis de la necesaria división entre las mencionadas situaciones jurídicas.

\subsubsection{1 -Diferenciación y discriminación}

El vocablo 'diferenciación' traduce una situación de trato distinto que, en un primer momento, es neutral, ya que, al depender del caso concreto, tanto puede ser jurídicamente admitida, como transgresora del ordenamiento normativo. A su vez, a pesar de que el término "discriminación" puede ser utilizado en más de un sentido ${ }^{137}$,

\footnotetext{
135 SUAY RINCÓN, José. Op.cit., p. 146.

${ }^{136}$ REY MARTÍNEZ, Fernando. Op.cit., p. 59 (nota a pié de página ${ }^{\circ}{ }^{\circ} 5$ )

137 Algunas veces, en el contexto del derecho brasileño, el término discriminación es utilizado como sinónimo de diferenciación. Así, para tales juristas, la discriminación puede ser positiva o negativa. A continuación, se verá opinión doctrinaria que expresa hipotesis de discriminación positiva “A igualdade, então, foi pensada em termos de igualdade de chances ou de oportunidades, ou, ainda, de pontos de partida, a partir da consideração de que "toda a vida social é considerada como uma grande competição para a obtenção de bens escassos." Com o objetivo de colocar todos os membros da sociedade em condições iguais de competição pelos bens da vida considerados essenciais, muitas vezes é necessário favorecer uns em detrimento de outros. Introduzem-se, assim, artificialmente, ou imperativamente, discriminações que de outro modo não existiam" (GUIMARAES TABORDA, Maren. Op.cit., p. 257)
} 
para el Derecho (en especial, en los contextos español y brasileño), en general, significa un trato transgresor de derechos, $\mathrm{y}$, por tanto, no admitido.

También se puede adoptar la distinción entre la discriminación positiva, que teniendo en consideración las diferencias entre los grupos de individuos, ofrece alternativas a fin de que el grupo desfavorecido pueda ser igualado a los demás, y la discriminación negativa, que es una acción perjudicial hacia un grupo, que traduce una distinción, exclusión, restricción o preferencia basada en un prejuicio. ${ }^{138}$

Para la doctrina española, "lo decisivo desde un punto de vista del principio de igualdad es distinguir entre las diferencias de trato justificadas y aquellas otras que son arbitrarias, injustificadas o irrazonables. Para designar estas últimas se emplea a menudo el término discriminación.",139

La doctrina destaca que el término "discriminación" ha sufrido un cambio semántico, puesto que su otro sentido genérico (de origen latino), que significaba ‘diferenciación`, fue siendo sustituido por un sentido más estricto (proveniente del mundo anglosajón) y con una connotación negativa, que pasó a representar las diferenciaciones arbitrarias y transgresoras de los derechos fundamentales ${ }^{140}$.

Así, es relevante destacar el sentido peyorativo que la Constitución española adopta cuando utiliza el término discriminación:

\footnotetext{
"La utilización del término discriminación por el artículo 14.II CE no ha sido caprichosa, y es además muy clarificadora, en la medida en que con este término se ha venido calificando en el contexto internacional una serie de situaciones y actos cuya existencia en sí misma se ha considerado que estaba en contra la propia dignidad humana, que significaban una violación de los derechos del hombre, habiéndose elaborado, sobre todo tras la Segunda Guerra Mundial,

${ }^{138}$ Este concepto de discriminación negativa ha sido formulado teniéndose en consideración el artículo $1^{\circ}$ de la Convención Internacional sobre la Eliminación de todas las formas de Discriminación Racial, que define la discriminación como "La distinción, exclusión, restricción o preferencia basada en motivos varios (sexo, raza, religión, condición social...) cuyo propósito o resultado sea anular o disminuir el reconocimiento, preferencia o ejercicio, en iguales condiciones, de los derechos humanos y libertades fundamentales en la política, la economía, la sociedad, la cultura o cualquier otra esfera de la vida pública."

${ }_{139}$ FERNÁNDEZ, Encarnación. Op.cit., p. 72

${ }^{140}$ RODRÍGUEZ-PIÑERO, Miguel y FERNÁNDEZ LÓPEZ, María Fernanda. Op.cit., pp. 84-85.
} 
una serie importante de instrumentos internacionales de lucha contra la discriminación, de los que puede considerarse herencia directa nuestro artículo 14.II CE."

El sentido peyorativo de la expresión "discriminación" también ha sido adoptado por la Constitución brasileña, en la medida que se verifica la redacción del art. $3^{\mathrm{o}}, \mathrm{IV}$, que determina como objetivo del Estado la promoción del bien estar de todos, “... sem preconceitos de origem, raça, sexo, cor, idade e quaisquer outras formas de discriminação”.

Respecto a la fórmula adoptada en la Constitución brasileña, la doctrina ha enfatizado que:

\begin{abstract}
"A expressão atual "sem distinção de qualquer natureza" é meramente reforçativa da parte inicial do artigo. Não é que a lei não possa comportar distinções. O papel da lei na verdade não é outro senão o de implantar diferenciações. O que não se quer é que, uma vez fixado o critério de discriminação (p. ex.: ser portador de título universitário para exercer determinada profissão), um outro elemento venha interferir na abrangência desta mesma discriminação. Aí por exemplo se diria: as pessoas com mais de quarenta anos de idade ficam dispensadas do referido título. Nisto, portanto, reside a essência do princípio igualizador. É o impedir que critérios o mais das vezes subalternos, portadores de preconceitos ou mesmo voltados à estatuição de benefícios e privilégios, possam vir a interferir em uma discriminação justa e razoável feita pela lei."142
\end{abstract}

A través de una sencilla interpretación gramatical, se puede percibir fácilmente que la Constitución brasileña ha equiparado la expresión "discriminação" con el término "preconceito" (prejuicio, en español).

Conviene resaltar que el Tribunal Constitucional español también hace una clara distinción entre diferenciación de trato, comprendida esta como género, que

\footnotetext{
${ }^{141}$ RODRÍGUEZ-PIÑERO, Miguel y FERNÁNDEZ LÓPEZ, María Fernanda. Op.cit., p. 82.

${ }^{142}$ RIBEIRO BASTOS, Celso. Curso de Direito Constitucional,. 13ª ed., Editora Saraiva, São Paulo,. 1990, pp.168-169
} 
dependerá del análisis de las circunstancias concretas para que pueda o no ser aceptada, y discriminación, una especie prohibida de aquella:

"el principio de igualdad jurídica consagrado en el art. 14 hace referencia, inicialmente, a la universalidad de la Ley, pero no prohíbe que el legislador contemple la necesidad o conveniencia de diferenciar situaciones distintas y darles un tratamiento diverso, que puede incluso venir exigido, en un Estado social y democrático de derecho, para le efectividad de los valores que la Constitución consagra con el carácter de superiores del Ordenamiento como son la justicia y la igualdad (art. 1), a cuyo efecto atribuye, además, a los Poderes Públicos el que promuevan las condiciones para que la igualdad sea real y efectiva (art. 9.3). Lo que prohíbe el principio de igualdad jurídica es la discriminación, como declara de forma expresa el art. 14 de la CE; es decir, que la desigualdad de tratamiento legal sea injustificada por no ser razonable."143

Además, el Tribunal Constitucional de España reconoce el principio de igualdad como un "derecho fundamental de la persona a no sufrir discriminación jurídica alguna, esto es, a no ser tratada jurídicamente de manera diferente a quienes se encuentran en una misma situación, sin que exista una justificación objetiva y razonable de esa desigualdad de trato."

Sin embargo, cabe añadir que aunque uno utilice el término "discriminación" con el sentido arriba destacado, o sea, en tono peyorativo, que es el sentido aceptado en los Derechos español y brasileño, también se debe destacar que, utilizando el mencionado significado para discriminación, hay aquellos que reconocen que esta "tiene un significado amplio, como equivalente a toda infracción de la igualdad, y un significado estricto, relativo a la violación de la igualdad cuando concurren algunos de los criterios de diferenciación prohibidos por el art. 14 CE."

Es importante destacar que el Estado Social y Democrático de Derecho, modelo adoptado por las Constituciones española de 1978 y por la brasileña de 1988, es decisivamente un Estado que se propone incluir a los que están alejados de los derechos

${ }^{143} \mathrm{STC}^{\circ} 34$, de 10 de noviembre de 1981.

${ }^{144} \mathrm{STC} \mathrm{n}^{\circ} 8,16$ de mayo de 1986.

${ }^{145}$ REY MARTÍNEZ, Fernando. Op.cit., p. 56. 
sociales, a aproximar estos ciudadanos a aquellos que ya se benefician de tales derechos y a fortalecer a los más débiles, en sentido social y económico.

En estos términos, la discriminación, por su carácter destacadamente excluyente, vulnera el Estado Social y Democrático de Derecho, bien sea porque no acerca las personas en derechos y beneficios sociales, bien porque no favorece las minorías.

También merece especial consideración que las discriminaciones pueden ocurrir de forma directa o disimuladas. Esta última, "llamada discriminación indirecta, camuflada, disimulada o no ostensible, en la que sobre la base de elección caprichosa de otros criterios de distinción aparentemente neutros se llega, de hecho, a un resultado discriminatorio."

Sobre la discriminación disimulada, se puede destacar que esta no se manifiesta en los criterios arbitrarios elegidos de diferenciación (lo que caracteriza la discriminación directa), sino en la aplicación de los mencionados criterios.

Según la doctrina, la discriminación directa "rompe con la igualdad de trato efectuando diferenciaciones basadas en características definitorias de las personas pertenecientes a una cierta categoría”, mientras que la discriminación indirecta se considera "que la ruptura de la igualdad de trato no se da a través de una disposición normativa, sino a resultas de los efectos o consecuencias de las mismas."147

Como ya he destacado, la discriminación disimulada proviene de un criterio aparentemente neutral, pero que provoca (independientemente de la intención) unos efectos desproporcionadamente perjudiciales para un grupo ${ }^{148}$. En general, son las mujeres las víctimas de las discriminaciones disimuladas.

\footnotetext{
${ }^{146}$ RODRÍGUEZ-PIÑERO, Miguel y FERNÁNDEZ LÓPEZ, María Fernanda. Op.cit., pp 163-164.

147 GONZÁLEZ BUSTOS, María Ángeles. La mujer ante el siglo XXI. Una perspectiva desde el ordenamiento jurídico-administrativo, Editorial @ becedario, Badajoz, 2006, p. 5. En la referida obra (y página), la citada autora ofrece dos ejemplos interesantes: la discriminación directa "sería el caso de que una norma prohibiera la entrada al teatro de personas que midan más un metro ochenta centímetros" y la discriminación indirecta "el supuesto de que la disposición señalase únicamente que quien entre en un determinado espectáculo ha de permanecer sentado, y el tamaño de los asientos no permitiese que quepan en ellos personas que superen los 100 kilos."

${ }^{148}$ FERNÁNDEZ, Encarnación. Op.cit., p. 86.
} 
La tesis de la discriminación disimulada o indirecta fue utilizada por primera vez por el Tribunal Constitucional de España en la Sentencia 145/1991, que trató de desigualdades salariales entre hombres y mujeres. En la mencionada sentencia, el Tribunal Constitucional conceptuó las discriminaciones indirectas como los:

"tratamientos formalmente no discriminatorios de los que derivan, por las diferencias fácticas que tienen lugar entre trabajadores de diverso sexo, consecuencias desiguales perjudiciales por el impacto diferenciador y desfavorable que tratamientos formalmente iguales o razonablemente desiguales tienen sobre los trabajadores de uno y otro sexo a causa de la diferencia sexual." 149

En la sentencia arriba destacada, el Tribunal Constitucional español no quedó satisfecho con la justificación de razonabilidad de la diferenciación de los sueldos de las categorías de peones (sueldos más elevados) y limpiadoras (sueldos más bajos) en un hospital público. Por consiguiente, rechazó la posibilidad de discriminación indirecta de las trabajadoras, ya que estas, en general, solían actuar como limpiadoras, mientras los hombres, como peones.

Además, según el Tribunal Constitucional, la denominación "limpiadoras" es discriminatoria, y el argumento sostiene que la mayor penosidad y esfuerzo físico que caracteriza a la categoría de peón no puede ser admitido, pues “...es una premisa no demostrada...que otorga mayor valor injustificadamente a una cualidad predominantemente masculina, desconociendo otras características del trabajo (atención, cuidado, responsabilidad, etc.) más neutras en cuanto a su impacto en cada uno de los sexos."

En otra manifestación del Tribunal Constitucional, fue analizada la siguiente situación: en una empresa que se dedicaba a fabricación de galletas, los hombres trabajaban en la producción (y por tanto recibían sueldos más elevados), mientras que las mujeres solían estar presentes en el departamento de envasado, empaquetado y acabado (consecuentemente, les tocaba una remuneración más baja).

Sin embargo, como también existían poquísimas mujeres que trabajaban en el sector de producción y aún en esta condición, continuaban recibiendo un sueldo ${ }^{149} \mathrm{STC}^{\mathrm{o}} 145$, de 1 de Julio de 1991. 
inferior al de los hombres, el Tribunal Constitucional fundamentó su sentencia en la discriminación directa, ya que la diferenciación de sueldos se basaba en “...la idea preconcebida de la menor fortaleza física y de cierta debilidad de la mujer en relación con el varón." 150

La no utilización de la tesis de la discriminación indirecta en la sentencia arriba analizada no provoca que el fallo del Tribunal Constitucional no sea una importante referencia para el presente trabajo: aunque se pueda aceptar la diferenciación entre las funciones de producción y envasado para efectos remuneratorios, debido a los distintos valores de los trabajos (criterio aparentemente neutral de diferenciación), por supuesto, la aplicación en concreto del citado criterio condujo a una división sexista de tareas, discriminado de forma indirecta a las mujeres.

Así, se puede afirmar que la gran contribución de la tesis de la discriminación indirecta para la protección de la igualdad es el hecho de que la evaluación de una posible desigualdad debe ocurrir no sólo en el análisis hipotético de los criterios de diferenciación, sino también en la aplicación de estos.

Por esta razón, el control ejercido por el Poder judicial "no puede limitarse a valorar si la diferencia de trato tiene, en abstracto, un justificación objetiva y razonable, sino que debe entrar y analizar, en concreto, si lo que aparece como una diferencia formalmente razonable no encubre o permite encubrir una discriminación contraria al art. $14 \mathrm{CE} . . . " 151$

Sobre el contenido del art. 14.II de la Constitución española, también cabe añadir que los criterios de no discriminación previstos en la citada norma (nacimiento, raza, sexo, religión, opinión o cualquier otra condición o circunstancia personal o social) no son numerus clausus, lo que se puede percibir a partir de la propia redacción de la norma. Sobre esta cuestión, el Tribunal Constitucional ha identificado como criterios discriminatorios: la edad, la legua, la pertenencia a un sindicato o la minusvalía física o psíquica. ${ }^{152}$

\footnotetext{
${ }^{150} \mathrm{STC} \mathrm{n}^{\mathrm{o}} 286$, de 27 de octubre de 1997.

${ }^{151}$ REY MARTÍNEZ, Fernando. Op.cit., p. 15

${ }^{152}$ REY MARTÍNEZ, Fernando. Op.cit., p. 61
} 
Para ejemplificar la situación arriba descrita, se puede destacar que el Tribunal Constitucional decidió, inclusive para el acceso a la función pública, que:

\begin{abstract}
"La edad no es una de las circunstancias enunciadas normativamente en el art. 14, pero no ha que verse aquí una intención tipificadora cerrada que excluya cualquiera otra de las precisadas en el texto legal, pues en la fórmula del indicado precepto se alude a cualquier otro condición o circunstancia personal o social, carácter de circunstancia personal que debe predicarse a la edad; de modo que la edad dentro de los límites que la Ley establece para el acceso y la permanencia en la función pública es una de las circunstancias comprendidas en el art. 14 $\mathrm{y}$ en el art. 23.2, desde la perspectiva excluyente de tratos discriminatorios." 153
\end{abstract}

En la Constitución brasileña de 1988, tal cual sucede con la española, la previsión de los factores prohibitivos de discriminación ha sido realizada de forma ejemplificativa (art. $3^{\circ}$, IV) lo que es confirmado por la doctrina brasileña: "A Constituição vigente (...) confere igualdade perante a lei, sem distinções de qualquer natureza, de sorte que as hipóteses que indicaremos a seguir são simplesmente exemplificativas, tanto quanto o são na própria Constituição."154

Así también, los mencionados criterios del art. 14.II de la Constitución española y del art. $3^{\circ}$, IV de la brasileña no traducen prohibiciones absolutas, ya que, de forma excepcional, pueden existir situaciones específicas donde sea posible establecer una diferenciación basada en uno de los mencionados criterios, sin que esto conduzca a una discriminación.

Respecto a la mencionada circunstancia, merece la pena destacar que lo que dice la doctrina brasileña: "não há critério que possa ser, abstrata e definitivamente, tido como impossível de se erigir como diferenciador, nem há qualquer um que possa ser considerado, também aprioristicamente e em caráter terminativo, como sempre justo para ser aproveitado como diferenciador.","155

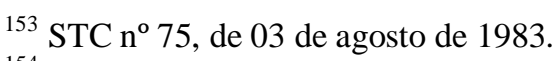

${ }^{154}$ SILVA, José Afonso da. Op.cit., p. 222.

155 ANTUNES ROCHA, Cármen Lúcia. Op.cit., p. 45.
} 
Es lo que pasa con los tratos diferenciados dirigidos a eliminar situaciones discriminatorias de las mujeres o de las personas con edad avanzada. Por ello, no es toda diferenciación cuyo criterio diferenciador esté previsto los mencionados artículos de las Constituciones española y brasileña que significan la vulneración de la mencionada norma ${ }^{156}$

La afirmación de arriba plantea una cuestión imprescindible para el análisis del tema central de la investigación, y que será averiguada a continuación: ¿cómo se puede caracterizar una diferenciación como jurídicamente aceptable o como discriminatoria?

En otras palabras, deben ser analizadas las exigencias de que toda diferenciación considerada autorizada por el Derecho debe tomar en consideración. Por consiguiente, es plenamente posible afirmar que el incumplimiento de una o más de las citadas exigencias jurídicas hará que la diferenciación de trato sea considerada discriminatoria.

Antes de empezar esta tarea, cabe añadir que sobre este tema, el análisis de las decisiones del Tribunal Constitucional español y de los tribunales superiores brasileños es imprescindible, puesto que el entendimiento establecido por los mencionados Tribunales es muy relevante para armonizar las distintas opiniones que la cuestión ciertamente plantea.

\subsubsection{2 - ¿Cuándo se puede aceptar una diferenciación?}

Si la diferenciación puede o no ser legítima para el ordenamiento jurídico, esto va a depender del cumplimiento de diversos requisitos, los cuales, en muchos aspectos, como demostración inequívoca del intercambio de experiencias existente entre los distintos sistemas jurídicos, coinciden en los derechos español y brasileño.

Preliminarmente, como ya ha destacado la doctrina brasileña, la gran cuestión es:

“qual o critério legitimamente manipulável - sem agravos à isonomia - que autoriza distinguir pessoas e situações em grupos apartados para

${ }^{156}$ FERNÁNDEZ, Encarnación. Op.cit., p. 81 
fins de tratamentos jurídicos diversos? Afinal, que espécie de igualdade veda e que tipo de desigualdade faculta a discriminação de situações e pessoas, sem quebra e agressão aos objetivos transfundidos no princípio constitucional da isonomia?"157

De forma general, prevalece la asertiva que establece, de forma paradigmática, "temos o direito de ser iguais sempre que as diferenças nos inferiorizam; temos o direito de ser diferentes sempre que a igualdade nos descaracteriza." ${ }^{, 158}$ En outro momento, ya se dijo con adecuación que "exige-se igualdade na repartição de direitos e deveres básicos, e mantêm-se as desigualdades sociais e econômicas, como por exemplo, de riqueza e de autoridade, se são justas, isto é, se produzem benefícios compensadores para todos." ${ }^{159}$ Pese a la sabiduría de las mencionadas palabras, hay que ser más específico.

Antes de todo, hay que subrayar que la definición de las situaciones pasibles de diferenciación es condicionada por razones históricas, ya que los valores que prevalecen en la sociedad cambian continuamente. En esto sentido:

\footnotetext{
“A regra da igualdade, assim concebida, prescreve a exclusão de qualquer discriminação arbitrária, entenda-se esta a que não é plenamente justificada. Mas o que justifica a discriminação? A natureza das coisas ou critérios subjetivos? A única resposta possível é a de que existem diferenças relevantes e irrelevantes entre os homens e a inserção em uma ou outra categoria depende de um juízo de valor prévio, que é, sempre, historicamente condicionado." 160
}

Primeramente, se debe ratificar que el trazo distintivo no puede ser definido apriorísticamente como discriminatório, ya que "qualquer elemento residente nas coisas, pessoas ou situações, pode ser escolhido pela lei como fator discriminatório, donde se segue que, de regra, não é no traço de diferenciação escolhido que se deve buscar algum

\footnotetext{
${ }^{157}$ BANDEIRA DE MELLO, Op.cit., p. 11.

158 BOAVENTURA DE SOUZA SANTOS. Apud ANTUNES ROCHA, Cármen Lúcia. Princípios constitucionais dos servidores públicos. Editora Saraiva, São Paulo, 1999, p. 149.

${ }^{159}$ GUIMARAES TABORDA, Maren. Op.cit., p. 258.

${ }^{160}$ GUIMARAES TABORDA, Maren. Idem, p. 262.
} 
desacato ao princípio isonômico."161 Así, hay que se definir, de forma general, criterios seguros para el análisis de validez jurídica de las hipótesis de diferenciación, lo que se hará a continuación.

En el derecho español, la interpretación llevada a cabo por el Tribunal Constitucional, que considera la discriminación como una especie prohibida de diferenciación, también permite la estipulación de los requisitos esenciales a las diferenciaciones aceptadas por el ordenamiento jurídico.

De forma sencilla, se puede subrayar las siguientes exigencias para una válida diferenciación de trato jurídico: a) justificación objetiva y razonable del trato distintivo; b) la finalidad perseguida por la diferenciación debe ser legítima, y se da cuando hay conexión entre la finalidad buscada y un interés constitucionalmente relevante; c) los medios empleados en la distinción de tratamiento deben guardar respeto a la proporcionalidad.

A su vez, en el derecho brasileño, se puede destacar la siguiente opinión:

"Para que um discrímen legal seja convivente com a isonomia....impende que concorram quatro elementos: a) que a desequiparação não atinja de modo atual e absoluto, um só indivíduo; b) que as situações ou pessoas desequiparadas pela regra de direito sejam efetivamente distintas entre si, vale dizer, possuam características, traços, nelas residentes, diferenciados; c) que exista, em abstrato, uma correlação lógica entre os fatores diferenciais existentes e a distinção de regime jurídico em função deles, estabelecida pela norma jurídica; d) que, in concreto, o vínculo de correlação supra-referido seja pertinente em função dos interesses constitucionalmente protegidos, isto é, resulte em diferenciação de tratamento jurídico fundada em razão valiosa - ao lume do texto constitucional - para o bem público. ${ }^{162}$

${ }^{161}$ BANDEIRA DE MELLO, Celso Antônio. Op.cit., p. 17.

162 BANDEIRA DE MELLO, Celso Antônio. Idem, p. 41 
Cabe añadir que esto, como muchos otros temas de carácter jurídico, en Brasil, es usualmente más desarrollado por la doctrina que por la jurisprudencia ${ }^{163}$. A su vez, en España, la jurisprudencia, en especial del Tribunal Constitucional (y quizá por la existencia de un tribunal de esta naturaleza), ha aportado relevantes contribuciones a presente cuestión.

Son diversas las sentencias del Tribunal Constitucional español que mencionan los citados requisitos de la diferenciación. Sin embargo, la que mejor resume el entendimiento del mencionado Tribunal es la que establece que:

"resulta indispensable que exista una justificación objetiva y razonable, de acuerdo con criterios y juicios de valor generalmente aceptados, cuya exigencia deba aplicarse en relación con la finalidad y efectos de la medida considerada, debiendo estar presente, por ello, una razonable relación de proporcionalidad entre los medios empleados y la finalidad perseguida, y dejando en definitiva al legislador, con carácter general, la apreciación de situaciones distintas que sea procedente diferenciar y tratar desigualmente." 164

A su vez, la doctrina brasileña resume los citados requisitos en los siguientes términos:

"Quanto ao direito brasileiro, a fim de que as leis, pelo seu conteúdo, não firam a igualdade constitucionalmente garantida, é necessário existir um vínculo lógico entre a discriminação estabelecida e a finalidade a que a lei se destina (...) De outra parte, o critério discriminador tem de estar em consonância com os interesses absorvidos no sistema constitucional e destarte juridicizados. (...) Por fim, um terceiro parâmetro, complementar aos demais, é o fato de que as discriminações devem manter a generalidade e a abstração própria dos atos legislativos ou seja, se a norma singularizar atual e definitivamente um destinatário determinado, ao invés de abranger

${ }^{163}$ La referida afirmación dice respecto al tema bajo análisis, lo que no significa que los Tribunales brasileños, especialmente el Supremo Tribunal Federal (STF), no hayan contribuido con el avance de la igualdad en Brasil. En este sentido, cabe destacar los intensos debates que están ocurriendo en el referido Tribunal respecto a las cotas raciales en las universidades públicas.

${ }^{164}$ STC 75, de 1983. 
uma categoria de pessoas, ou uma pessoa futura e determinada, haverá ofensa ao princípio constitucional da igualdade." 165

Se uno compara los requisitos de diferenciación válida expresados por la jurisprudencia española con los consagrados en la doctrina brasileña, verá la casi identidad absoluta entre ellos. Los requisitos justificación objetiva y razonable del trato distintivo; legitimidad de la finalidad perseguida por la diferenciación debe ser legítima (protección a un interés constitucionalmente relevante) y proporcionalidad de los medios empleados en la distinción de tratamiento, son utilizados en los sistemas jurídicos español y brasileño ${ }^{166}$.

Para facilitar la identificación de las normas que establezcan diferenciaciones de trato no admitidas, fue creada la doctrina de clasificación sospechosa (de origen estadounidense: suspect classification), que considera como presuntamente inconstitucionales las normas que utilizan como criterios distintivos los prohibidos expresamente en la Constitución. ${ }^{167}$, entendimiento más sensato que el que considera nula toda clasificación que emplee los rasgos definitorios mencioados (doctrina de las clasificaciones prohibidas).

En la doctrina brasileña, se ha dicho de forma muy semejante que "o próprio ditame constitucional que embarga a discriminação por motivo de raça, sexo, trabalho, credo religioso e convicções políticas, nada mais faz que colocar em evidência certos

\footnotetext{
${ }^{165}$ GUIMARAES TABORDA, Maren. Op.cit., p. 263.

${ }^{166}$ Debido a la influencia del jurista Celso Antônio Bandeira de Mello, en Brasil también prevalece el entendimiento que "a lei não pode erigir em critério diferencial um traço tão específico que singularize no presente e definitivamente, de modo absoluto, um sujeito a ser colhido pelo regime peculiar." Esto pasaría si “a norma é enunciada em termos que prefiguram situação atual única, logicamente insuscetível de se reproduzir ou materialmente inviável (pelo que singulariza agora e para sempre o destinatário), denuncia-se sua função individualizadora" El citado administrativista brasileño conclui que "Haverá inviabilidade lógica se a norma singularizadora figurar situação atual irreproduzível por força da própria abrangência racional do enunciado(...).Haverá inviabilidade apenas material, quando, sem empeço lógico à reprodução da hipótese, haja todavia, no enunciado da lei, descrição de situação cujo particularismo revela uma tão extrema improbabilidade de recorrência que valha como denúncia do propósito, fraudulento, de singularizarão atual absoluta do destinatário." (BANDEIRA DE MELLO, Celso Antônio. Op.cit., pp. 23-25). De todas las formas, en la situación definida por el mencionado jurista, la ley individualizadora no estaría guardando respeto a la razonabilidad y proporcionalidad, no que hace con que la citada doctrina sea considerada una especificación de los criterios antes mencionados como justificadores de una diferenciación válida.
}

${ }^{167}$ REY MARTÍNEZ, Fernando. Op.cit., pp. 51-52. 
traços que não podem, por razoes preconceituosas mais comuns em certa época e meio, ser tomadas gratuitamente como ratio fundamentadora de discrímen." 168

Para una mejor comprensión de los requisitos jurídicos de la diferenciación legítima, será utilizado en esta investigación el método que suele ser emprendido por los Tribunales cuando tienen que analizar la existencia o no de infracción, por una norma jurídica, del principio de igualdad ${ }^{169}$.

El procedimiento mencionado se realiza a través de tres pasos: la búsqueda de la finalidad de la norma diferenciadora, la demostración de la conexión de finalidad de la norma distintiva con un interés constitucionalmente relevante, y el análisis de la proporcionalidad de la norma.

Fácilmente se puede percibir la aproximación entre los pasos arriba mencionados y los requisitos para que la diferenciación pueda ser aceptada. Así, el procedimiento en cuestión deberá verificar si la justificación del trato distinto es objetiva y razonable, si la finalidad perseguida por la diferenciación es legítima, y si los medios empleados en la distinción de tratamiento guardan respeto a la proporcionalidad.

\subsubsection{3 - ¿Cómo se debe diferenciar?}

\subsubsection{1 - La búsqueda de la finalidad de la norma diferenciadora}

La primera exigencia para que se pueda aceptar una norma que establezca una diferenciación de trato jurídico es la presencia de razonabilidad. Como ya fue destacado, puesto que los hombres son iguales ante la ley, para que puedan surgir normas jurídicas que establezcan diferenciaciones de trato, es imprescindible que exista una justificación de carácter racional y objetivo.

\footnotetext{
168 BANDEIRA DE MELLO, Celso Antônio. Op.cit., pp.17-18.

169 Según José Suay Rincón, "el principio de igualdad obliga a tratar igual lo que es igual y desigualmente lo que es desigual: de ese modo la función del TC será determinar cuándo las situaciones son iguales y cuándo diversas. Para determinar cuándo unas situaciones son iguales o diversas, los Tribunales gozan de un amplio margen de apreciación. Por lo general, se valen de un procedimiento que, aun no siendo especifico de las cuestiones de igualdad, es en este campo donde mayor consistencia y desarrollo ha adquirido...Cuando una ley se impugna ante el TC por infracción del principio de igualdad, el TC ha dde determinar si las situaciones que esa norma regula son iguales o diversas de las reguladas por otra norma ("el término de comparación"). Para ello, busca la "ratio" de la norma impugnada y si ella justifica la desigualdad de trato, la norma no infringirá el principio de igualdad. Para tanto, será la finalidad perseguida por la norma que servirá de parámetro para determinar si la desigualdad de trato está justificada o no." (SUAY RINCÓN, José. , Op.cit., p. 54)
} 
La primera consecuencia de la mencionada exigencia es el rechazo de los criterios de trato distinto caracterizados por la arbitrariedad, que traducen discriminaciones. Obviamente, también configura situación de arbitrariedad de la ley cuando esta trata igualmente situaciones objetivas desiguales, lo que perjudica la parte que debería haber recibido un trato favorecido. ${ }^{170}$

En este sentido, puede ser ofrecido un aclarador ejemplo: se elabora una ley que exige que todos los aspirantes (sin excepciones) a plazas de funcionarios deban demostrar que poseen una excelente forma física y tengan que realizar diversas pruebas físicas durante las oposiciones, incluso una que corresponde a correr 100 (cien) metros, en un tiempo máximo de 12 (doce) segundos.

Obviamente, los aspirantes del sexo femenino, por ejemplo, no conseguirán obtener éxito en la mencionada prueba, ya estando previamente excluidos de la disputa por las plazas. Así, se puede afirmar que el mencionado trato igualitario es arbitrario (salvo se existiera una razón suficiente para el establecimiento de una exigencia idéntica tan dura para todos los aspirantes), ya que no ha tenido en consideración las diferencias anatómicas y fisiológicas de hombres y mujeres.

Sin embargo, la especie de ley arbitraria que más llama la atención (y la que más interesa en el presente momento del trabajo, es la que analiza la racionalidad de las diferenciaciones) es la que contempla una autentica discriminación, cuando "trata desigualmente situaciones iguales, sin fundamentarse...en una razón suficiente que permita justificar la diferencia....de tratamiento."171

Según la doctrina, las diferenciaciones deben alejarse de la arbitrariedad, lo que ocurre cuando es elegido un criterio racional para distinguir el trato concedido a las personas. En las exactas palabras:

\footnotetext{
${ }^{170}$ El Tribunal Constitucional ya ha decidido que: "Implícita, pero inequívocamente, pues se viene a afirmar que este precepto constitucional encierran no ya sólo una prohibición del trato desigual ante situaciones subjetivas análogas, sino, más simplemente, la interdicción de la identidad de régimen jurídico entre sujetos en posiciones fácticas diferentes. Expuesta en tales términos, tal normativa impeditiva de lo que habría de llamar "discriminación por indiferenciación" (STC no 86, de 10 de julio de 1985). Sin embargo, cabe añadir que el Tribunal Constitucional, cuando trata de analizar una posible violación del art. 14 de la Constitución española, rechaza la existencia de un "derecho fundamental a la singularización normativa”. Según el Tribunal Constitucional, "el artículo 14 de la Constitución reconoce el derecho a no sufrir discriminaciones, pero no el hipotético derecho a imponer o exigir diferencias de trato." (STC n 52/1987). No obstante, parece evidente que la ley que establezca identidad de trato, cuando debería prever distinciones, es arbitraria, y, por tanto, no válida.

${ }^{171}$ VILACORTA MANCEBO, Luis. Op.cit., p. 21.
} 
"o critério especificador escolhido pela lei, a fim de circunscrever os atingidos por uma situação jurídica - a dizer: o fator de discriminação - pode ser qualquer elemento radicado neles; todavia, necessita, inarredavelmente, guardar relação de pertinência lógica com a diferenciação que dele resulta. Em outras palavras: a discriminação não pode ser gratuita ou fortuita. Impende que exista uma adequação racional entre o tratamento diferenciado construído e a razão diferencial que lhe serviu de supedâneo. Segue-se que, se o fator diferencial não guardar conexão lógica com a disparidade de tratamentos jurídicos dispensados, a distinção estabelecida afronta o princípio da isonomia."

Como toda diferenciación ocurre a fin de que sea eliminada (o reducida) una situación de desigualdad verificada en la vida social (cuando tal desigualdad no es bien vista $^{173}$ ) o con el objetivo de mantener una hipótesis de desigualdad (siempre que la citada desigualdad sea apreciada por la sociedad ${ }^{174}$ ), el criterio utilizado por la ley para la concesión de tratos diferenciados debe ser adecuado y suficiente para el alcance del objetivo deseado por el legislador, sea este de cambio o de manutención de una determinada realidad fáctica.

La doctrina esclarece que hay dos especies de criterios diferenciadores de trato que son considerados discriminatorios: los que corresponden a características inmanentes "heredadas" del ser humano, "con las que éste nace, que responden a su biológico: así, el nacimiento, la raza, el sexo, la condición o circunstancia personal”, y las causas que son productos de "decisiones o elecciones del ser humano; así, la religión, la opinión y algún tipo de condición o circunstancia social." 175

Para la referida doctrina, los criterios discriminatorios derivados de las causas biológicas niegan la idea de igualdad entre los seres humanos y perjudican al que ha "nacido" con ellas (por ejemplo, las mujeres, los negros, etc.), mientras que los criterios de discriminación emanados de las decisiones o elecciones de los seres

\footnotetext{
172 BANDEIRA DE MELLO, Celso Antônio. Op.cit., pp. 38-39.

${ }^{173}$ Sería el caso del trato distintivo concedido a las personas con discapacidad, para permitirles el acceso a la función pública, lo que, en general, es dificultado por una serie de circunstancias sociales y orgánicas.

${ }^{174}$ En esta situación, se puede citar el caso del trato distinto concedido a las mujeres en las leyes laborales, a fin de que tengan, por ejemplo, un periodo más largo de licencia tras el parto.

${ }^{175}$ RODRÍGUEZ-PIÑERO, Miguel y FERNÁNDEZ LÓPEZ, María Fernanda. Op.cit., p. 178.
} 
humanos también afectan a la igualdad, pero, además de eso, obstaculizan el ejercicio de ciertas libertades y derechos ${ }^{176}$ (libertad de opinión, de religión, etc.)

Es crucial, por tanto, que los criterios de diferenciación elegidos por la norma jurídica no sean la causa de un trato injusto para la parte de la relación que no recibió un tratamiento favorecido. Para eso, es necesaria la búsqueda de la finalidad de la norma, para que se pueda verificar si el fin objetivo perseguido es o no legitimo.

La finalidad de la norma es su objetivo, es lo que ella busca innovar o preservar en la realidad, en beneficio del interés general. En otras palabras, es la razón justificativa de la norma, que debe ser aceptable en relación a los más distintos aspectos, como la coherencia (diferenciar los desiguales, y no los iguales), la fundamentación (utilidad de la diferenciación para la igualdad), y la lógica (correlación entre el criterio diferenciador y la propia diferenciación).

En primer lugar, la finalidad de la distinción debe ser la diferenciación de trato entre personas o situaciones que sean efectivamente desiguales, que posean características diferentes unas en relación a las otras (coherencia). Por ejemplo: en un concurso para una plaza de funcionario, es razonable establecer una mejor evaluación de merito de los aspirantes que poseen posgrado que de los que no lo poseen (obviamente, siempre que demostrada la relevancia de la realización de los mencionados cursos para el ejercicio de la función pública que será cubierta).

Otras exigencias de la finalidad de la norma diferenciadora son su utilidad para la realización de la igualdad y/o de otros valores (comprobado provecho de la distinción) y la conexión entre el criterio distintivo elegido y la finalidad que se pretende alcanzar con la norma (correlación lógica entre el criterio distintivo y la propia diferenciación de trato) ${ }^{177}$.

Por supuesto, no sería razonable una norma que estableciera un trato distinto entre personas, cuando el criterio distintivo elegido no sea útil a la igualdad, o sea, cuando no hay la necesidad de supresión de una desigualdad, cuando esta es

${ }^{176}$ RODRÍGUEZ-PIÑERO, Miguel y FERNÁNDEZ LÓPEZ, María Fernanda. Op.cit., p. 179.

177 Respecto a esta circunstancia, la doctrina sostiene que "as discriminações são recebidas como compatíveis com a cláusula igualitária apenas e tão-somente quando existe um vínculo de correlação lógica entre a peculiaridade diferencial acolhido por residente no objeto, e a desigualdade de tratamento em função dela conferida, desde que tal correlação não seja incompatível com interesses prestigiados na Constituição." (BANDEIRA DE MELLO, Celso Antônio. Op.cit., p. 17). 
jurídicamente indiferente. En este sentido, no sería razonable la diferenciación entre aspirantes que escriben con la mano derecha o con la izquierda en una oposición para plazas de Juez, ya que no hay la necesidad de superación de tal distinción.

A su vez, puede ser considerado razonable (ya que sería útil a la eficacia administrativa, así como a la propia igualdad, en la medida en que se debe tratar desigualmente a los desiguales) el trato diferenciado para aspirantes a plazas de policía que actúan en la frontera, a partir de la exigencia de que estos tengan conocimientos de lenguas extranjeras.

En relación a la correlación lógica entre el criterio distintivo y la propia diferenciación de trato, es imprescindible que haya una justificación racional para que sea utilizado determinado criterio diferenciador y que este posea una relación de pertinencia lógica con la finalidad que se pretende alcanzar. ${ }^{178}$

Sobre la exigencia destacada, se ha dicho que "qualquer fator diferenciador que não possa ser vinculado, objetiva e logicamente, ao fim pretendido pela norma jurídica e que será, insuperavelmente, o de conferir tratamento igual para a justiça da situação protegida, considera-se como inválido." 179

Este tercer requisito impone una apreciación de los criterios distintivos en cada diferenciación de trato, ya que es posible que un criterio determinado pueda ser utilizado en algunas situaciones, mientras que en otras, no. Por eso, a priori, no se puede afirmar que determinado criterio distintivo sea válido o invalido, sin que uno conozca las circunstancias concretas en las cuales aquel será utilizado.

Sobre la cuestión arriba planteada, cabe destacar que muchos requisitos para el acceso a la función pública, como edad, altura, peso, sexo, experiencia profesional, conocimientos lingüísticos, etc., en que pesen ser discriminatorios en la mayoría de las veces, pueden ser aceptados en determinadas circunstancias, exactamente cuando estén

\footnotetext{
${ }^{178}$ Para Celso Antônio Bandeira de Mello, "tem-se que investigar, de um lado, aquilo que é erigido em critério discriminatório e, de outro lado, se há justificativa racional para, à vista do traço desigualador adotado, atribuir o específico tratamento jurídico construído em função da desigualdade afirmada....É agredida a igualdade quando o fator diferencial adotado para qualificar os atingidos pela regra não guardam relação de pertinência lógica com a inclusão ou exclusão no benefício deferido ou com a inserçao ou arrendamento do gravame imposto." (BANDEIRA DE MELLO, Celso Antônio. Op.cit., p. 38)

${ }^{179}$ ANTUNES ROCHA, Cármen Lúcia. Op.cit., p. 46.
} 
demostradas la necesidad de la diferenciación y la correlación entre el criterio diferenciador y la propia diferenciación.

A su vez, si la finalidad de la diferenciación no es razonable, la norma debe ser rechazada. Debido a ello, "si la finalidad es el parámetro exclusivo para determinar si la desigualdad de trato está justificada o no, en el caso de que la Corte no encuentre una finalidad específica para la norma impugnada, no habrá razón alguna que pueda justificar su existencia en el ordenamiento jurídico."180

\subsubsection{2 - La conexión entre la finalidad de la norma diferenciadora con un interés jurídicamente relevante}

Superada la primera cuestión (la búsqueda de la finalidad de la norma diferenciadora), conviene resaltar que no es cualquier finalidad que pueda ser aceptada, ya que en la Constitución fueron elegidos valores que deben estar presentes en las leyes y demás normas jurídicas. En algunas situaciones, hay diferenciaciones de trato que son lógicamente explicables, pero si no son constitucionalmente legitimadas, no pueden ser aceptadas.

Confirmando la línea de pensamiento anteriormente expuesta, se puede destacar que "o que se deve, pois, considerar para a aferição da validade do critério tomado como desigualador de pessoas e situações é a sua natureza intrínseca e a estreita correspondência havida entre ele e o interesse legítimo que se pretenda proteger no sistema jurídico."

Por consiguiente, no es cualquier distinción la que autoriza una diferenciación de trato, sino solamente las que buscan la realización de un bien absorbido en el sistema normativo constitucional ${ }^{182}$.

Así, la desigualdad de trato debe ser una valiosa herramienta para que los legisladores y demás creadores del Derecho puedan elaborar normas que alcancen la igualdad, comprendida en su amplia complejidad, lo que sólo se puede vislumbrar a través de una interpretación sistemática de los valores constitucionales.

\footnotetext{
${ }^{180}$ SUAY RINCÓN, José. Op.cit., p.33.

${ }^{181}$ ANTUNES ROCHA, Cármen Lúcia. Op.cit., p. 46

${ }^{182}$ BANDEIRA DE MELLO, Celso Antônio. Op.cit., p. 42.
} 
Sobre esta cuestión, conviene transcribir la siguiente opinión extraída de la doctrina española:

"es fácil comprender que la desigualdad de trato que una norma establezca no puede ser justificada (y, por tanto, quedar inmune a su inconstitucionalidad ex artículo $3 \mathrm{CI}$ ) por una finalidad cualquiera. Lo primero que a tal finalidad se exige es que proteja (a través de la diferencia de tratamiento) un interés constitucionalmente relevante, entendiendo tal, precisamente, aquél (y sólo aquél) que se encuentra amparado por la propia Constitución." 183

A su vez, sobre la mismísima exigencia de protección de interés jurídicamente consagrado en el sistema jurídico, la doctrina brasileña destaca que:

"não é qualquer diferença, conquanto real e logicamente explicável, que possui suficiência para discriminações legais. Não basta, pois, poder-se estabelecer racionalmente um nexo entre a diferença e um conseqüente tratamento diferençado. Requer-se, demais disso, que o vínculo demonstrável seja constitucionalmente pertinente. É dizer: as vantagens calçadas em alguma particularidade distintiva hão de ser conferidas prestigiando situações conotadas positivamente ou, quando menos, compatíveis com os interesses acolhidos no sistema constitucional." 184

En el contexto del acceso a la función pública, a titulo de ilustración, vale destacar que un interés constitucionalmente relevante es la selección de los funcionarios a través de los criterios de mérito y capacidad (art. 103.III, Constitución española, cuando consagra expresamente los mencionados criterios de selección, y art. 37 de la brasileña, cuando consagra la eficiencia como principio que debe ser observado por la Administración Pública).

Así, los citados valores (mérito y eficiencia) deben convivir de forma armoniosa con lo que está presente en el art. 23.II de la Constitución española y art. 37, I y II, de la brasileña, que establecen el derecho del ciudadano a acceder a las funciones públicas en condiciones de igualdad.

${ }^{183}$ SUAY RINCÓN, José. Op.cit., p. 60.

${ }^{184}$ BANDEIRA DE MELLO, Celso Antônio. Op.cit., pp. 41-42. 
Por consiguiente, toda diferenciación de trato entre los ciudadanos debe tener en consideración la exigencia de selección meritoria, y se debe tener en cuenta si la finalidad de las distinciones de trato tiene conexión con los mencionados valores constitucionales.

Cabe añadir que en el establecimiento de una norma diferenciadora en materia de acceso a la función pública, además de las imposiciones constitucionales de mérito y capacidad, también hay que respetar la razonabilidad, como ya se ha analizado, y la proporcionalidad. ${ }^{185}$ Mientras la primera exige la eliminación de toda arbitrariedad, traducida en la incongruencia entre las condiciones de acceso y el sistema de selección y la función a desempeñar, la segunda reclama, entre otras situaciones, una ponderación adecuada de cada requisito en el contexto general de estos, relacionándole con la función a ser ejercida. ${ }^{186}$

Por su relevancia, a continuación, será analizada la proporcionalidad en la definición de normas diferenciadoras, con énfasis en el acceso a la función pública.

\subsubsection{3 - El uso de criterios diferenciadores con proporcionalidad}

El último paso para la verificación de la posibilidad de aceptación de la norma que establece trato distinto depende del análisis de los criterios diferenciadores y de su respeto a la proporcionalidad. ${ }^{187}$

Este principio, desarrollado inicialmente por la doctrina alemana, está cada vez más presente en los debates jurídicos que tratan de los derechos fundamentales en los más distinto países, y frecuentemente referido en las sentencias del Tribunal

\footnotetext{
${ }^{185}$ MAURI BAJÓS, Joan. Capítulo Cuarto "El acceso al empleo público", del libro Manual de Empleo Público, Federico A. Castillo Blanco (Director), Javier E. Quesada Lumbreras (Coordinador), primera edición, Ilustel, Madrid, 2009., p. 257.

${ }^{186}$ MAURI BAJÓS, Joan. Op.cit., p. 257.

${ }^{187}$ Es relevante subrayar que todas las exigencias para que las diferenciaciones puedan ser aceptadas deben ser analizadas de forma enlazada. En los primeros años tras la Constitución española de 1978, el Tribunal Constitucional ya subrayaba que: "la igualdad es sólo violada si la desigualdad está desprovista de una justificación objetiva y razonable, y la existencia de dicha justificación debe apreciarse en relación a la finalidad y efectos de la medida considerada, debiendo darse una relación razonable de proporcionalidad entre los medios empleados y la finalidad perseguida." (STC no 22, de 1981) En una oportunidad ulterior, el mencionado Tribunal destacó que:"El principio de igualdad no sólo exige que la diferencia de trato resulte objetivamente justificada, sino también que supere un juicio de proporcionalidad en sede constitucional sobre la relación existente entre la medida adoptada, el resultado producido y la finalidad pretendida por el legislador."( STC nº 110, de 25 de marzo de 1993)
} 
Constitucional español y del Supremo Tribunal Federal brasileño, tiene tres grandes subdivisiones: idoneidad, necesidad y proporcionalidad en sentido estricto.

Respecto a las tres mencionadas subdivisiones, la doctrina brasileña reconoce el origen alemán del estudio del principio de proporcionalidad, y destaca que:

\begin{abstract}
"para que a conduta estatal observe o princípio da proporcionalidade, há de revestir-se de tríplice fundamento: 1) adequação, significando que o meio empregado na atuação deve ser compatível com o fim colimado; 2) exigibilidade, porque a conduta deve ter-se por necessária, não havendo outro meio menos gravoso ou oneroso para alcançar o fim público, ou seja, o meio escolhido é o que causa o menor prejuízo possível para os indivíduos; 3) proporcionalidade em sentido estrito, quando as vantagens a serem conquistadas superarem as desvantagens." 188
\end{abstract}

De forma resumida, también se puede afirmar que la idoneidad exige que toda intervención en los derechos fundamentales (en el caso aquí analizado, toda diferenciación) debe ser adecuada para contribuir a la obtención de un fin constitucionalmente legítimo. ${ }^{189}$ Como se puede percibir, la idoneidad guarda una gran relación con exigencia ya analizada de conexión entre la finalidad de la norma diferenciadora con un interés jurídicamente relevante.

A su vez, la necesidad significa que la intervención, superado de forma positiva el análisis de su idoneidad, debe ser la más benigna con el derecho intervenido. Así, lo que se busca en esta dimensión de la proporcionalidad es la interdicción del exceso. La idea es que si uno tiene que sufrir un sacrificio, que sea lo menor posible.

En las palabras del Tribunal Constitucional español, que "no existan otras medidas menos gravosas que, sin imponer sacrificio alguno de los derechos fundamentales....sean igualmente aptas a conseguir dicho fin." 190

\footnotetext{
${ }^{188}$ DOS SANTOS CARVALHO FILHO, José. Op.cit., p. 33.

189 BERNAL PULIDO, Carlos. El principio de proporcionalidad y los derechos fundamentales, Centro de Estudios Políticos y Constitucionales, Madrid, 2003, p. 36. ${ }^{190}$ STC no 207/1996.
} 
En relación a la proporcionalidad en sentido estricto, conviene que las ventajas que se alcanzan mediante la intervención deban compensar los sacrificios causados a sus titulares y para la sociedad en general. ${ }^{191}$

Para el Tribunal Constitucional español, la proporcionalidad en sentido estricto sería el último filtro para la admisión de una medida que interviene en los derechos fundamentales (como es el caso de las diferenciaciones de trato), ya que la intervención no debe prevalecer, aún siendo idónea y necesaria, si causa un sacrificio a derechos desmedido, en comparación con sus ventajas. ${ }^{192}$

Sobre las tres medidas para la realización del juicio de proporcionalidad, el Tribunal Constitucional de España ya estableció con claridad que:

\begin{abstract}
"Para comprobar si la medida....supera el juicio de proporcionalidad, es necesario constatar si cumple los siguientes tres requisitos o condiciones: si tal medida era susceptible de conseguir el objetivo propuesto....; si, además, era necesaria en el sentido que no existía otra medida más moderada para la consecución de tal propósito con igual eficacia; $y$, finalmente, si la misma era proporcionada, en sentido estricto, es decir, ponderada o equilibrada por derivarse de ella más beneficios o ventajas para el interés general que perjuicios sobre otros bienes o valores en conflicto." 193
\end{abstract}

Se puede afirmar que en el procedimiento de análisis de la norma diferenciadora, la verificación de la proporcionalidad de la distinción de trato es una medida muy valiosa, ya que permite la percepción de distinciones de trato que, aunque bien intencionadas, no producen los resultados esperados (igualdad material), y muchas veces causa diversos trastornos.

Sobre la situación arriba descrita, merece la pena destacar, con el fin de que se pueda acercar esta cuestión al tema objeto de esta investigación, que una de las ofensas más frecuentes al principio de proporcionalidad en las oposiciones y concursos ocurre cuando son elaboradas las bases de la convocatoria.

\footnotetext{
${ }^{191}$ BERNAL PULIDO, Carlos. Op.cit., p. 36.

192 STC n²07/1996.

${ }^{193}$ STC nº6/1995.
} 
Para una mejor comprensión, puede ser citado el siguiente ejemplo: buscando seleccionar los aspirantes más capacitados para plazas de guardias de tráfico, en una oposición es exigida la superación de pruebas físicas, además de las de carácter intelectual (pruebas escritas y orales). Nada más razonable, ya que se supone que un guardia de tráfico debe ostentar una buena condición física para que pueda, por ejemplo, quedarse durante horas sucesivas controlando el tráfico de una ciudad.

También se puede afirmar que la finalidad de la exigencia tiene conexión con un interés jurídicamente relevante, que es la garantía de eficacia de la Administración Pública. Sin embargo, en la convocatoria, se exige a los aspirantes someterse a una prueba física de levantamiento de peso (cien quilos, por ejemplo).

Así, surgen algunas preguntas: ¿La medida (exigir la superación de un ejercicio de levantamiento de peso) era susceptible de conseguir el objetivo propuesto (selección de aspirantes aptos a la función de guardia de tráfico)?; ¿Existía otra medida (test físico) más moderada para la selección de los más capacitados para la función de guardia de tráfico? ¿La exigencia era efectivamente proporcional, ponderada $y$ equilibrada por derivarse de ella más beneficios o ventajas para el interés general que perjuicios sobre otros bienes o valores en conflicto?

Ciertamente, la medida no atendería a las tres exigencias de la proporcionalidad (idoneidad, necesidad y proporcionalidad en sentido estricto), ya que la realización del mencionado ejercicio no contribuiría a la selección de los aspirantes más aptos a la función de guardia de tráfico, pues no ayudaría a encontrar a las personas con el perfil más indicado para ejercer las respectivas funciones.

También se constata que la medida adoptada no era la más moderada para la selección de los aspirantes con mejores condiciones físicas, ya que podrían ser exigidas otras pruebas físicas menos rigurosas y con mucha más pertinencia en la función que se pretendía ocupar.

Por fin, se constata que la exigencia del test físico mencionado no era ni ponderada, ni equilibrada, ya que causaría más perjuicios (solamente poquísimos aspirantes lograrían éxito en la citada prueba, y no necesariamente los más aptos) que ventajas al interés público. 
La medida analizada probablemente impediría que los más capacitados para la función de policía local encargado del tráfico urbano (por ejemplo, personas que conocen la legislación del tráfico, que poseen tolerancia a situaciones estresantes, que tienen características físicas imprescindibles al ejercicio de la función, como capacidad de resistencia, buenos reflejos, etc.) se inscribieran en la oposición, ya que sabrían con antelación que no conseguirían superar el mencionado ejercicio.

Así, se puede concluir que la exigencia comentada debe ser rechazada porque instituyó una transgresión sin justificación razonable y sin respeto a la proporcionalidad, lo cual viola el derecho de los ciudadanos a acceder a las funciones públicas en condiciones de igualdad.

Analizados los principales aspectos de la igualdad, a continuación será investigado el alcance del mencionado derecho de acceso a la función pública en los sistemas jurídicos brasileño y español, que, como ya se ha señalado, es una consecuencia directa de la igualdad entre los ciudadanos. 
CAPÍTULO 2 - EL PRINCIPIO DE IGUALDAD EN EL ACCESO A LA FUNCIÓN PÚBLICA ESPAÑOLA Y BRASILEÑA 


\section{1 - El acceso a la función pública}

\subsection{1 - El acceso a la funció pública en condiciones de igualdad: aspectos históricos, políticos y sociológicos}

El derecho de igualdad ante la ley produce múltiples efectos jurídicos. Uno de los más relevantes, que ya estaba previsto en la Declaración de los Derechos del Hombre y del Ciudadano de $1789^{194}$, es el derecho de acceder a las funciones y cargos públicos en condiciones de igualdad ${ }^{195}$.

En estos términos, la Constitución española de 1978 previó el citado derecho en su art. 23.2:

"Art. 23. 1. Los ciudadanos tienen el derecho de participar en los asuntos públicos, directamente o por medio de representantes, libremente elegidos en elecciones periódicas por sufragio universal.

2. Asimismo, tienen derecho a acceder en condiciones de igualdad a las funciones y cargos públicos, con los requisitos que señalen las leyes.”

A su vez, la Carta Magna brasileña de 1988 consagró el derecho al acceso igualitario a la función pública en el art. 37, I y II:

“Art. 37. I - os cargos, empregos e funções públicas são acessíveis aos brasileiros que preencham os requisitos estabelecidos em lei, assim como aos estrangeiros, na forma da lei;

II - a investidura em cargo ou emprego público depende de aprovação prévia em concurso público de provas ou de provas e títulos, de

\footnotetext{
${ }^{194}$ El artículo 1 de la Declaración de los Derechos del Hombre y del Ciudadano de 1789 reconoce que "todos los hombres nacen y permanecen libres e iguales en derechos..." y el artículo 6 establece que “...todos los ciudadanos...son igualmente admisibles a todas las dignidades, puestos y empleos públicos, según su capacidad y sin otra distinción que las de sus virtudes y talentos."

${ }_{195}$ Según la doctrina española, el derecho previsto en el art. 23.2 CE concreta el principio general de igualdad en el ámbito de la función pública. (XAVIER FERREIRA FERNANDES, A. La provisión de puestos de trabajo en la Administración General del Estado, Ministerio de las Administraciones Pública, INAP, Madrid, 2002, p. 56).
} 
acordo com a natureza e a complexidade do cargo ou emprego, na forma prevista em lei, ressalvadas as nomeações para cargo em comissão declarado em lei de livre nomeação e exoneração"

Aunque la realidad social no siempre haya sido favorable a la instalación de una Administración Pública objetiva e imparcial ${ }^{196}$, de acuerdo con las exigencias burocráticas, la verdad es que la exigencia de utilización de procesos selectivos basados en los principios de igualdad, mérito y capacidad estuvo presente en la mayoría de las Constituciones españolas y en las brasileñas.

En el contexto arriba destacado, la Constitución Española de 1837 establecía en el art. 5 que: “Todos los españoles son admisibles a los empleos y cargos públicos, según merito y capacidad." Las Constituciones de 1837 (en el art. 27) y la de 1869 (en el art. 15), utilizaban la misma regla. Por su vez, la Constitución española de 1931 previa en el art. 40 que: "Todos los españoles sin distinción de sexo, son admisibles a los empleos y cargos públicos según su merito y capacidad, salvo las incompatibilidades que las leyes señalen."

Respecto el constitucionalismo brasileño, se puede destacar que la Constitución del Imperio de 1824 establecía en su art. 179, XIV, que "todo o cidadão pode ser admittido aos Cargos Publicos Civis, Politicos ou Militares, sem outra differença, que não seja a dos seus talentos, e virtudes.” A su vez, la primera Constitución republicana (1891) previó en su art. 73 que "os cargos publicos, civis ou militares, são accessiveis a todos os brazileiros, observadas as condições de capacidade especial, que a lei estatuir, sendo, porém, vedadas as accumulações remuneradas."

\footnotetext{
${ }^{196}$ Para Sánchez Morón, comentando el caso español, la exigencia de acceso igualitario y meritorio a las funciones públicas se fue: “...consolidando durante los siglos XIX y XX en la letra de la ley frente a numerosas reminiscencias clasistas, a tentaciones corporativas y endogámicas y a variados tipos de spoils system. Como tal figuran en la mayoría de las Constituciones vigentes y en los textos internacionales de derecho fundamentales. No obstante lo cual, la experiencia demuestra la facilidad con que el favoritismo, el amiguismo y otras prácticas permiten desvirtúalo. En realidad, el grado de vigencia práctica y el de vulneración de estos principios - difícil de medir, pero fácil de intuir constituyen un test importante acerca del respecto que una sociedad y una Administración tienen por el Estado de derecho. También constituyen un condicionante del buen funcionamiento de la Administración, pues raramente será eficaz a que no sea capaz de seleccionar para su servicio a los mejores aspirantes. Por eso, la lucha contra la arbitrariedad administrativa y a favor del derecho, de la igualdad y del interés general encuentran en este capítulo uno de sus más relevantes retos." (SÁNCHEZ MORÓN, Miguel. Derecho de la función pública, 3 ed., Editorial Tecnos, Madrid, 2002, pp.123-124).
} 
A continuación, surgió la Constitución de 1934, que introduzco el concurso público en el ordenamiento jurídico brasileño ("Art. 170. $2^{\circ}$. A primeira investidura nos postos de carreira das repartições administrativas, e nos demais que a lei determinar, effectuar-se-á depois de exame de sanidade e concurso de provas ou títulos.”).

Pródigo en el número de Cartas Constitucionales ${ }^{197}$, Brasil tuvo aun las Constituciones de 1937, que mantuvo la fórmula anterior ("Art. 156.b) a primeira investidura nos cargos de carreira far-se-á mediante concurso de provas ou de títulos;"); otra em 1946, que tampoco inovó ("Art. 186. A primeira investidura em cargo de carreira e em outros que a lei determinar efetuar-se-á mediante concurso, precedendo inspeção de saúde.”).

La Constitución de 1967 estableció la obligatoriedad del concurso público para el ingreso en todos los cargos públicos, a excepción de los cargos de libre designación (“Art. 95. Os cargos públicos são acessíveis a todos os brasileiros, preenchidos os requisitos que a lei estabelecer. $\$ 1^{\circ}$ A nomeação para cargo público exige aprovação prévia em concurso público de provas ou de provas e títulos. $2^{\circ}$ Prescinde de concurso a nomeação para cargos em comissão, declarados em lei, de livre nomeação e exoneração.”).

En 1969, la Constitución entonces vigoraba con la siguiente redacción respecto al tema analizado: “Art. 97. Os cargos públicos serão acessíveis a todos os brasileiros que preencham os requisitos estabelecidos em Lei. $1^{o}$. A primeira investidura em cargo público dependerá de aprovação prévia, em concurso público de provas ou de provas e títulos, salvo os casos indicados em lei.\$2 $2^{o}$ Prescindirá de concurso público a nomeação para cargos em comissão, declarados em lei, de livre nomeação e exoneração."

\footnotetext{
${ }^{197}$ Brasil ya ha tenido las siete constituciones (1824, 1891, 1934, 1937, 1946, 1967 y 1988). Sin embargo, en 1969, una Emienda Constitucional a la Carta de 1967 es por muchos considerada con otra Constitución, debido a los grandes cambios introducidos.
} 
Es relevante destacar que tanto España como Brasil han seguido la tendencia del derecho constitucional universal ${ }^{198}$, respecto a la consagración del derecho de acceso de los ciudadanos a la función pública en condiciones de igualdad ${ }^{199}$.

Lo que se ha reconocido en los textos constitucionales es que si todos los ciudadanos son iguales ante la ley, también lo son delante de la Administración Pública $^{200}$, que está constitucionalmente encargada de aplicar las leyes (igualdad en la aplicación de la ley).

Así, la Administración Pública, cuando necesite cubrir una plaza, tendrá que garantizar el amplio derecho de participación, en condiciones de igualdad, a todos los candidatos que cumplan los requisitos legales, en un proceso selectivo resuelto por criterios objetivos y que tengan en consideración el mérito y la capacidad de los postulantes.

El acceso a la función pública es un tema de gran relevancia para la sociedad, y, con sagacidad ya se dijo desde hace medio siglo que, "quizá sea ésta una de las materias en que la coincidencia del interés general y el de los administrados se manifiesta con rara unanimidad. ${ }^{201}$ Un procedimiento de selección que permita el acceso de personas técnicamente calificadas para el desempeño de las tareas estatales es lo que exige toda la sociedad.

Al mismo tiempo, una selección que otorga un trato igualitario a todos los candidatos es lo que reclama cada uno de los ciudadanos que pretende ejercer una función pública, sea por motivos personales, profesionales o incluso cívicos.

\footnotetext{
${ }^{198}$ Es que el mencionado reconocimiento proviene del hecho de que "num Estado de Direito, todo cidadão tem direito de acesso aos cargos e empregos públicos, pelos quais competirá em igualdade de condições com os demais cidadãos interessados” (LOBELLO DE OLIVEIRA ROCHA, Francisco. Regime jurídico dos concursos públicos, Editora Dialética, São Paulo, 2006, p. 52).

${ }^{199}$ Como ejemplos, la Constitución italiana de 1947 establece: "Art. 97.... a los puestos de la Administración Pública se accede mediante concurso, salvo las excepciones establecidas por ley.". A su vez, la Constitución de 1949 de la República Federativa Alemana prevé en el art. 3 que: “...todos los alemanes tienen igual derecho de acceso a la función pública, según sus calificaciones, capacidades y aptitudes especiales..."

${ }^{200}$ El Tribunal Constitucional, a través de las SSTCo 84/1987, 50/1986, 19/1989, 67/1989, 60/1994 y 73/1994, ha definido que la igualdad del art. 23.2 es una especificación de la contenida en el art. 14 de la Constitución Española (CAVAS MARTINÉZ, Faustino. El Estatuto Básico del Empleado Público. Comentario Sistemático de la Ley 7/2007, de 12 de abril de 2008, José Luis Monareo Perez y otros (dirección y coordinación), Editorial Comares, Granada, 2008, p. 586).

${ }^{201}$ SERRANO GUIRADO, Enrique. El régimen de oposiciones y concursos de funcionarios, Instituto de Estudios Politicos, Madrid, 1956, p. 11.
} 
La mencionada cuestión es fundamental, pues las Constituciones española y brasileña tanto garantizan que todos deben ser tratados igualmente por los Poderes Públicos (lo que implica en el acceso a la función pública en condiciones de igualdad), como también el ordenamiento jurídico exige que la Administración Pública desarrolle sus actividades con eficacia (art. 103, Constitución española y art. 37, de la Constitución brasileña).

Así, los ciudadanos, aunque posean el derecho de acceder a las funciones públicas en condiciones de igualdad, también tienen derecho a la buena administración, lo que exige que la Administración Pública seleccione rigurosamente a sus funcionarios y que estos reúnan las habilidades necesarias para desempeñar sus actividades.

Dada su relevancia, es imprescindible destacar que, en España, el derecho arriba mencionado fue considerado por los creadores de la Constitución como un derecho fundamental del ciudadano, y que debían recibir de los Poderes Públicos una especial protección, conforme con el art. 53.2 CE.

Lo que ocurre, desgraciadamente, es que el tema del acceso a las funciones públicas, especialmente en tiempos de crisis ${ }^{202}$, no es objeto de debate en la sociedad y

\footnotetext{
${ }^{202}$ Sobre este tema, merece la pena transcribir la noticia que relaciona la crisis con el aumento del número de opositores en España. "El número de personas que han decidido preparar una oposición se ha visto incrementado en el último año, desde el inicio de la crisis, en más de un 10\%. Según diversos centros de estudios y academias de oposiciones consultados por Servimedia, en 2008 y en lo que va de 2009 ha crecido sensiblemente el número de alumnos matriculados para sacarse una oposición. Algunos de ellos recurren a esta opción al haberse quedado en el paro, otros estudian a la vez que trabajan a media jornada y todos buscan "un empleo más estable y seguro, con posibilidad de promoción, con igualdad en el acceso y con horarios que permiten conciliar el trabajo con la vida familiar y personal", indicó una de las fuentes consultadas. El perfil medio del opositor español se corresponde con el de una mujer (70\%), de entre 21 y 40 años (84\%) y que compatibiliza la preparación del examen con otro trabajo (64\%). La mayoría de los centros consultados cifra el aumento registrado en los últimos 12 meses en torno al 10\%. Sin embargo, el centro "Máster D" (que cuenta con 50 delegaciones por toda España) sitúa el aumento en el 25\%. El incremento es mayor en el caso de las oposiciones de carácter local y autonómico, y menor en las que son para la Administración central del Estado. Las oposiciones más demandadas son las más fáciles de preparar, a las que se puede acceder en menos de un año (personal subalterno, personal administrativo, etcétera). "Máster D" también ha constatado un crecimiento en el número de opositores a la Sanidad y a la Educación. Por su parte, una fuente del Centro de Estudios Financieros (CEF) indicó que, además del aumento de matriculados, "hay mucha gente que viene a informarse" sobre las oposiciones, incluso a pesar de la disminución del número de plazas ofertadas para este año. Además, el citado centro auguró que "cuando más vamos a notar el aumento de opositores va a ser al término de este curso, cuando muchos estudiantes, en lugar de buscar empleo, se pongan directamente a opositar". El centro de estudios Adams cifra el aumento del número de opositores en el 9,4\%, ya que, "como consecuencia de despidos masivos y del aumento exponencial de la tasa de desempleo, la gente busca empleo seguro, y en la Administración lo van a tener". No obstante, este centro insiste en que, antes de plantearse opositar, es importante "estar motivado", sobre todo cuanto más difícil es el examen que se prepara, ya que "esto es una carrera de fondo" y no todo el mundo consigue una plaza ni todos los
} 
solamente se destaca por las posibilidades de empleo que los procesos selectivos pueden ofrecer: buenos sueldos, estabilidad, etc.

Según la doctrina española, la intensa demanda por las plazas ofertadas por las Administraciones Públicas es un fenómeno sociológico muy relevante en la sociedad española contemporánea, circunstancia que se ha agravado en los últimos años, especialmente debido a crisis que ha asolado este país europeo con un muy alto número de personas en situación de paro. Sobre estos hechos, cabe subrayar que:

"para muchos, trabajar en la administración pública es como encontrar "El Dorado". Hay personas muy capacitadas que están años y años estudiando y formándose para alcanzar el puesto de funcionario. Lo logran opositando - es decir, competiendo a través de exámenes - con miles de personas como ellos. En estos casos, los que consiguen "el sueño", ya sea a la primera o la segunda, encuentran su propósito de vida: disponen de un trabajo para siempre, un buen sueldo, una buena posición y un despacho donde pasar las jornadas laborales, normalmente de 8 a 3, excluyendo sábados y domingos. En muchas ocasiones, los estudios y la formación cursada por estos nuevos funcionarios no estaban enfocados inicialmente para formar parte de la administración pública - han estudiado para ser abogados, gestores, licenciados en químicas o biología, periodistas...- pero los condicionantes del puesto y la situación actual del mercado de trabajo provocan e inducen a estas personas a estudiar, y mucho, para poder conseguir una plaza pública." 203

En Brasil, la situación es a lo mejor aún más compleja, ya que los procesos selectivos suelen atraer miles de candidatos, como se puede verificar:
"Hoje, qualquer concurso público no Brasil atrai milhares de candidatos em ferrenha disputa por poucas vagas, o que torna ainda mais difícil a avaliação de competências. Em tal situação, a necessidade de um verdadeiro "desbaste" torna o concurso mais eliminatório do que seletivo. E como o número de vagas oferecidas é

opositores que aprueban y sacan plaza tardan el mismo tiempo." (Texto extraído del sitio electrónico http://ecodiario.eleconomista.es/espana/noticias/1078366/03/09/El-numero-de-opositores-aumenta-masde-un-10-por-la-crisis.html, com acceso en 01 de octubre de 2009)

${ }^{203}$ MARTÍNEZ VERGEL, Joan. De 8 a 3, anécdotas de funcionarios, Styria, Barcelona, 2008, p. 9. 
geralmente muito menor do que o de candidatos, freqüentemente não chegando a 2 ou $5 \%$, sabe-se de antemão que a grande maioria dos candidatos ficará fora da lista dos selecionados. Haverá sempre, então, uma grande maioria insatisfeita." 204

No hay duda que la gran demanda por el empleo público, sea en Brasil como en España, es motivada por distintos factores, entre los cuales sería interesante destacar en este momento la ausencia de alternativas ventajosas en el sector privado.

Esta visión incompleta (para no decir solamente económica) del significado del acceso a la función pública, y de su relevancia para la vida social, conlleva intrínsecamente dos graves riesgos. El primero es que muchos de los candidatos que se inscriben en los procesos selectivos no tengan el perfil exigido para desempeñar la función pública a la que optan, lo cual, ciertamente, podrá comprometer su desempeño.

Para aquellos candidatos, lo único importante sería adquirir un empleo para toda la vida, aunque esto no les sea particularmente interesante bajo un punto de vista profesional o personal. Lo que se critica no es propiamente la posición del aspirante, que, lógicamente, tiene el derecho de buscar la concreción de sus proyectos (aunque forzado por circunstancias económicas), por motivos personales.

El problema es que la contribución social de un funcionario que ha ingresado (y se mantiene) en la Administración sin la adecuada propensión, motivación y capacitación será probablemente mucho más baja que la de alguien que hubiera encontrado en el servicio público su natural vocación profesional.

El otro riesgo de una visión esencialmente mercantilizada del acceso a la función pública es la incapacidad de la Administración de seleccionar a los candidatos que efectivamente disponen de las aptitudes necesarias para el desempeño de las tareas $\operatorname{administrativas}^{205}$. Así, conviene que las políticas de selección se caractericen por la

\footnotetext{
${ }^{204}$ MORHY, Lauro. A realidade dos concursos públicos. Texto extraído del sitio de la Universidade de Brasilia - UnB (http://www.unb.br/administracao/reitoria/artigos/20050616.php), con acceso en 10 de mayo de 2010.

${ }^{205}$ En procesos selectivos donde miles de personas están competiendo por pocas plazas, se puede afirmar que "é difícil julgar, é difícil avaliar. Julgar em concurso público é ainda mais difícil, dada a exigüidade do tempo e as limitações dos instrumentos de avaliação" (MORHY, Lauro. A realidade dos concursos públicos. Texto extraído del sitio de la Universidade de Brasilia - UnB (http://www.unb.br/administracao/reitoria/artigos/20050616.php).
} 
planificación, por la organización, por la utilización de técnicas científicamente desarrolladas, entre otros factores.

En el ambiente de discusión académico, otra circunstancia que causa gran preocupación es la poca atención dispensada a la investigación del tema del acceso a la función pública. En el contexto destacado, tanto se resiente la falta de estudios científicos relativos a las técnicas de selección específicas para el reclutamiento de funcionarios públicos (que por supuesto, deberán ser, en diversos aspectos, distintas de las utilizadas para el sector privado), así como investigaciones respecto a los aspectos jurídicos respecto a las consecuencias de la selección.

Todo este contexto compromete la idoneidad y la eficacia de los procesos selectivos. En Brasil, ya se ha dicho que:

"Hoje, em boa parte dos concursos, predominam a falta de técnica, a parcialidade, os abusos de poder e arbitrariedades de agentes públicos que tratam a coisa pública como se dela fossem donos. Este cenário dá origem a uma infinidade de lides que nascem diariamente em nossas cortes, que, sem uma doutrina consistente para basear suas decisões, tomam posições desencontradas e, por vezes, equivocadas. Assim, apesar de tantos anos de história e de incorporação ao sistema jurídico pátrio, constatamos que a matéria ainda carece de sistematização e estudo, pois, apesar de juristas de renome já se terem dedicado ao tema, o fizeram quase sempre como pequenos capítulos de livros ou artigos de revista." 206

\subsubsection{2 -El acceso a la función pública en los modelos patrimonialista, burocrático y gerencial}

En la historia de la humanidad, desde que la sociedad empezó a organizarse políticamente como Estado, siempre ha habido la necesidad de seleccionar a aquellos que van a hacer parte de la función pública.

A lo largo de los siglos, los más distintos métodos de acceso fueron variando y sucediéndose, de forma general, cuando había un cambio profundo de los

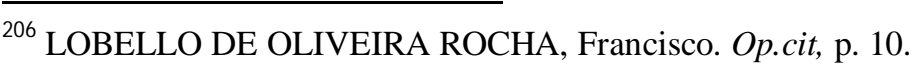


principios políticos y organizativos del Estado ${ }^{207}$ y de la propia Administración Pública, y de forma específica, cuando el cambio producido fue del perfil del funcionario. En verdad, "o regime jurídico formulado para o servidor público revela e traduz o modelo de Estado adotado, sua ideologia e suas opções, inclusive sociais."208

En el primer contexto, se puede destacar los distintos modelos de Estado, (antiguo, absolutista, liberal, social, neoliberal, etc.), en la medida que significaron distintas visiones políticas de la vocación estatal, hicieron que el papel del Estado cambiara, lo que exigió en algunos momentos muchos funcionarios, en otros pocos; en algunas oportunidades, funcionarios de perfil profesional, y en otras, de perfil político. $\mathrm{Y}$, consecuentemente, parece más que evidente que si el Estado, por ejemplo, en la actualidad, necesita funcionarios que deben de tener características que permitan una actuación más técnica, más imparcial (de esta forma, menos sujeta a presiones políticas), es imprescindible que el sistema de acceso sea el de carácter meritorio, lo que no sucedió en el Estado absolutista.

Sobre el perfil del funcionario, este elemento es fundamental para la definición de las técnicas de selección, ya que esta contribuye efectivamente al acceso y consecuente actuación de los servidores públicos.

Acerca de esta cuestión, es valioso utilizar un ejemplo: los jueces, quizás todos estén de acuerdo, son profesionales que tienen un papel muy decisivo en la vida de la sociedad y su perfil debe corresponder a las expectativas sociales, lo que, a su vez, no es de fácil percepción, ya que no existe un consenso general.

\footnotetext{
${ }^{207}$ Distintos factores ejercen una gran influencia en la función pública, ya que esta "no es más que una respuesta a una determinada necesidad social y política en un momento histórico determinado. En la misma influyen las consideraciones políticas, filosóficas, religiosas y sociales de cada época- E incluso, en el mismo período, Estados que pueden haber sido vecinos territorialmente, presentan diferencias más o menos acentuadas sobre la consideración que debe tener la Función Pública en la vida estatal. Lo que a lo largo de la historia de la humanidad aparece como algo verdaderamente indudable es que siempre ha sido necesaria la existencia del funcionario para que el Estado haya podido cumplir sus distintas funciones. De nada serviría el poder del príncipe si éste no contara con sus más inmediatos servidores encargados de gestionar y desarrollar las funciones de gobierno de la comunidad." (BARRACHINA JUAN, Eduardo. La función pública: su ordenamiento jurídico, Parte General I, Promociones y publicaciones Universitarias, Barcelona, 1991, p. 26).

208 ANTUNES ROCHA, Cármen Lúcia. Princípios constitucionais dos servidores públicos, Editora Saraiva, São Paulo, 1999, p. 80.
} 
Sobre este punto, merece la pena subrayar que existen en la sociedad "diferentes concepciones que se tienen acerca de cuál es la figura del juez y de cuál es su papel dentro de la sociedad. No es lo mismo el juez que cumplía su profesión en el Estado-gendarme de finales del siglo XIX, que el juez que desarrolla sus quehaceres en un Estado social a comienzos del siglo XXI."209

En el contexto arriba citado, es imprescindible que las Administraciones Públicas tengan una preocupación más intensa en la definición del perfil de los funcionarios públicos, lo que, evidentemente, debe influenciar no solo a las políticas de selección ${ }^{210}$, sino al control de desempeño, la evaluación de los servidores, para que aquellos que no se ajustan al perfil determinado puedan incluso ser separados de sus funciones.

De la misma forma, los distintos modelos de Administración Pública también influyeron en la definición de los criterios y del propio procedimiento de acceso a la función pública. En este sentido, los modelos patrimonialista, burocrático y gerencial ofrecieron sus principios, finalidades y características para la determinación de quiénes habrían de ser seleccionados y de qué forma esto debería suceder.

En el contexto anteriormente mencionado, es relevante destacar que: "trabalhando com a evolução do pensamento e da história, é possível lapidar três modelos básicos ou paradigmas de administração pública - patrimonialista, burocrática e sistêmica (gerencial, na linguagem do neoliberalismo) -, em que um dos aspectos mais característicos é a respectiva forma de provimento dos cargos públicos"211

\footnotetext{
${ }^{209}$ MALEM SEÑA, Jorge F. El error judicial y la formación de los jueces, Editorial Gedisa, Barcelona, 2008, p. 207.

${ }^{210}$ La definición del perfil de los funcionarios debe llevar en consideración las tareas propias de la función pública a desempeñar, como el grado de exigencia y responsabilidad, la necesidad de conocimientos específicos, o, al revés, el dominio de distintas habilidades, la mayor o menor sujeción a situaciones de estrés (e.g., atención al público), o a posibilidades de soborno y otras formas de corrupción (e.g., fiscales), necesidad de experiencia en la función (e.g., para los cuadros directivos), entre otras situaciones. Todos estos factores son muy relevantes en la definición del contenido de los programas de los procesos selectivos (e.g., exigencia de conocimientos lingüísticos, de legislaciones, de asignaturas que llevan en cuenta el raciocinio lógico, etc.), así como en el desarrollo de sus fases (e.g., realización de pruebas físicas, orales, entrevistas, tests psicotécnicos, etc.). También cabe añadir que la definición del perfil del funcionario es relevante para designación de los miembros de los Tribunales calificadores y para la propia evaluación que estos realizaran.

211 BATISTA GOMES MOREIRA, João. Princípios constitucionais da legalidade e da eficiência nos concursos públicos, en Concurso público e Constituição, Fabrício Motta (Cordinador), Editora Fórum, Belo Horizonte, 2005, p. 122-123.
} 
Si es posible afirmar que la preocupación relacionada a la selección de los funcionarios públicos siempre ha estado presente en la historia de la humanidad, desde que la idea de Estado surgió, no se puede decir que en todos los momentos el sistema de acceso meritorio fuera empleado ${ }^{212}$.

Por el contrario, se puede aseverar que en la historia del Estado, la utilización del mérito como criterio definidor del acceso a las funciones públicas ha sido una excepción.

Durante la fase en que la Administración Pública se basaba en un modelo patrimonialista $^{213}$, la forma de ingreso más usual era el nombramiento real. En ese momento histórico, el monarca tenía en sus manos el poder de elegir aquellos que ocuparían las funciones públicas, y, consecuentemente, era el responsable por definición de los criterios de selección, que solían no tener ninguna relación con la capacidad de los elegidos. Al revés, el monarca otorgaba los cargos como si fueran favores a aquellos afortunados y dóciles súbditos que le rodeaban.

Junto al libre nombramiento, que podía darse de forma absoluta (la voluntad real era simplemente la única fuente de la elección) o relativa (en escasas situaciones, el rey consultaba a las asambleas o a su consejo sobre el nombramiento), existieron otras formas de acceso que caracterizaron el modelo patrimonialista. Sobre estas hipótesis,

\footnotetext{
${ }^{212}$ Destaca la doctrina que "os concursos públicos são utilizados desde a antiguidade como forma de seleção dos ocupantes de cargos públicos. As primeiras referências tradicionais que identificam a realização de escolha de candidatos pelo sistema de mérito datam de períodos de 2200 a.C. a 150 a.C., na China. Há relatos de que, por volta de 2200 a.C., oficiais do Império chinês eram submetidos a avaliações a cada três anos para verificar seu preparo físico. Após cada três testagens eram promovidos ou demitidos. Há referência a estas avaliações físicas trienais também durante a dinastia Zhou, em 1115 a.C. Foi durante a dinastia Han (202 a.C.-200 d.C.), provavelmente no ano 165 a.C., que as avaliações escritas foram inseridas. Na evolução da dinastia Ming (1368 d.C. a 1644 d.C.), os exames tornaram-se uma instituição social formalizada e elaborada. Incluíam diferentes níveis de exames, em que os candidatos bem sucedidos recebiam títulos, parecidos com os títulos universitários. A cada nível superado, adquiria-se mais títulos que davam acesso a cargos de maior poder na Administração. Como ocorre em qualquer sistema que dure centenas de anos, houve épocas em que a corrupção e a má administração causaram distorções no recrutamento. Apesar dos problemas e críticas, porém, e após algumas reformas, o sistema Ming foi responsável por uma unidade de valores e uma padronização da escolaridade que funcionou sem maiores incidentes por mais de 500 anos. Tudo indica que os europeus que tiveram contato com a cultura chinesa na época das cruzadas ficaram impressionados com sua objetividade, trazendo-os para o mundo ocidental. Países com o Reino Unido, e posteriormente, Estados Unidos e Canadá passaram a adotar esses métodos para funções civis elevadas" (LOBELLO DE OLIVEIRA ROCHA, Francisco. Op.cit, p. 49).

${ }^{213}$ En otro momento, indiqué como características patrimonialistas: individualismo, mesianismo, idolatría, inmediatismo, sentimentalismo, favoritismo, clientelismo, fisiologismo, nepotismo, corporativismo, partidarismo, revanchismo, estrellismo, entre otras. Sobre este tema: CARVALHO, Fábio Lins de Lessa. Op.cit, p. 41-42.
} 
"al considerar la relación funcionarial en base a principios propios del Derecho privado, el cargo público se reveló, en algunas ocasiones, como portador de ciertos elementos patrimoniales, y por ello, no era extraño que se enajenasen los oficios públicos por una determinada cantidad de dinero." 214

Otras formas de acceso utilizadas en el mencionado modelo fueron: por medio de la institución hereditaria ${ }^{215}$, lo que solía suceder en los altos cargos, la compra y venta, que consistía en un sistema que privilegiaba a los más ricos ${ }^{216}$, el arrendamiento, donde los cargos públicos eran cedidos por el Estado a los particulares por determinado plazo y mediante el pago de determinada cuantía.

Es curioso señalar que también existieron otros métodos de acceso que aunque no sean propiamente patrimonialistas, en el sentido de modelo de administración donde el gobernante utiliza sus poderes para su propio beneficio o de otros (favoritismo) en perjuicio de la sociedad, tampoco pueden ser considerados meritorios, en el sentido actual del término, que toma en consideración la capacidad para el desempeño del cargo. Es lo que pasaba con el sorteo y con la elección ${ }^{217}$ de determinadas funciones públicas.

${ }^{214}$ BARRACHINA JUAN, Eduardo. La función pública: su ordenamiento jurídico, Parte General I, Promociones y publicaciones Universitarias, Barcelona, 1991, p. 74.

${ }^{215}$ Sobre esta forma de acesso, "também instituído na Idade Média, o sistema de ingresso nos cargos por meio de hereditariedade apresentou desde logo inúmeros inconvenientes, pois é fácil compreender-se que os herdeiros daquele que recebeu inicialmente o cargo público nem sempre tinham estado à altura do antepassado, tendo-se visto postos de alta responsabilidade civil e mesmo militar, passarem às mãos de sucessores indignos ou incapazes que, diante de dificuldades que não sabiam resolver, delegavam motu proprio seus ofícios a substitutos ou representantes, sem garantia alguma para o decoro do emprego." (CRETELLA JÚNIOR, José. Tratado de Direito Administrativo, volume IV, Editora Forense, Rio de Janeiro, 1967, p. 271.).

${ }^{216}$ Sobre la compra y venta como sistema de acceso a la función pública, cabe subrayar que " a situaçao econômica dos diversos países europeus, agravada pelos desmandos da realeza, pelas guerras religiosas e pelos empreendimentos da época de Luis XIV, contribuiu sobremaneira para incrementar o sistema de venalidade dos cargos públicos, chegando a constituir excelente fonte de renda momentânea para os Estados. Da França o sistema irradiou-se para a Alemanha, Espanha e Itália com todos os inconvenientes dele advindos, pois os empregos comprados equivaliam a objetos, a mercadorias, suscetiveis até de transmissão hereditária. Tal sistema que assegurava os lugares aos mais ricos, não aos mais capazes, comprometia a segurança da realeza, manietada por um sistema deficiente de serviços públicos confiados a incompetentes." (CRETELLA JÚNIOR, José. Op.cit, p. 271.)

${ }^{217}$ Esa forma de acceso a la función pública, adoptada en algunos países, entre ellos los Estados Unidos de Norteamérica, presenta diversos inconvenientes, ya que posibilita que la manipulación del electorado pueda permitir la selección de personas que no reúnen las condiciones técnicas indispensables para el ejercicio de funciones públicas profesionales (y no políticas o representativas). Este sistema trata la administración como un ambiente similar a la política. Sin embargo, el sistema sobredicho no se confunde con aquel donde los "electores" son entidades colectivas, comisiones, tribunales, consejos profesionales, etc., donde, aunque haya un componente político en la decisión, prevalece el componente técnico. Ya se 
Los cambios introducidos por los modelos que sucedieron al patrimonialismo no lograran superar totalmente sus características, que todavía permanecen (en mayor o menor escala) en la Administración Pública de los más distintos países. Así:

\begin{abstract}
"Não se pode dizer, assim, que o ciclo patrimonialista da Administração Pública tenha sido superado com uma revolução democrática instantânea. Persistem formas autoritárias e privilégios institucionalizados e, além disso, é freqüente ainda hoje o direcionamento da administração, ostensiva ou disfarçadamente, para atender a interesses pessoais, privados (ex.: eleitoreiros), como se o administrador dele (patrimônio) proprietário fora, o que transparece em grande medida no provimento de cargos públicos"218
\end{abstract}

A su vez, en el modelo burocrático, movido por las concepciones de la burguesía, surgen las ideas que van a inspirar la creación y adopción del sistema de mérito como definidora del acceso a las funciones públicas ${ }^{219}$.

En primer lugar, el racionalismo como principio de organización administrativa impone la especialización y la profesionalización del funcionario, circunstancias que exigirán la sustitución del modelo antiguo de acceso.

Lo que se exige ahora es un funcionario que sea capaz de responder de forma satisfactoria a las demandas de un servicio público recién creado en cuanto conjunto de órganos administrativos especializados y jerarquizados.

Estas circunstancias hicieron que la organización burocrática impusiera servidores permanentes (en ese momento surge la figura de la estabilidad ${ }^{220}$ ),

dijo que el acceso a través de elecciones hace que el funcionario, aunque se emancipe de su jefe, permanezca esclavizado por su electorado, sin que tenga su individualidad, garantía de imparcialidad. (BRANDAO CAVALCANTI, Themistocles. Tratado de Direito Administrativo, vol. IV, 3 ed., Livraria Freitas Bastos, Rio de Janeiro, 1956, p. 175).

${ }^{218}$ BATISTA GOMES MOREIRA, João. Op.cit, p. 124.

${ }^{219}$ En este sentido, "desde el momento en que los intereses económicos de la burguesía capitalista acaban destruyendo el esquema de Estado feudal y patrimonial, imponiendo el modelo de Estado moderno, se hace indispensable la gestión del poder a través del mecanismo burocrático...implica.....una mayor especialización de conocimientos por parte de los agentes públicos en función de las crecientes tareas del Estado con relación a la cambiante realidad económica y social que es propia de todo el siglo XIX.”(PAREJO ALFONSO, Luciano, JIMÉNEZ-BLANCO, A., ORTEGA ÁLVAREZ, L. Manual de Derecho Administrativo, vol. 2, 5 ed., Editorial Ariel, Barcelona, 1998, p. 1). 
distribuidos en carreras, lo que garantizó la necesidad de continuidad de las actividades administrativas, hasta entonces sujeta a las inestabilidades del gobierno.

Así, la única forma de apoyar que los órganos públicos estuvieran preparados para atender a las nuevas exigencias era garantizar el acceso de personas técnicamente capaces de cumplir las tareas administrativas, lo que hizo destacar la figura del sistema de mérito.

Para dejar claro la opción por una estructura burocrática de administración pública, distintos países pasaron a establecer en sus Constituciones el principio de mérito y capacidad para dejar clara la opción elegida para el acceso a las funciones públicas. $^{221}$ Así, como ejemplo, se puede destacar que en el Derecho Constitucional español, el mencionado principio no se previó en la primera Constitución liberal (de 1812), sin embargo, fue adoptado en la siguiente (1837) y en todas las demás ${ }^{222}$.

Otra característica del modelo burocrático presente en el sistema de acceso meritorio es el establecimiento de procedimientos detallados, que van a definir con pormenores las reglas de la competición, lo que servirá para alejar la arbitrariedad de la decisión, en la medida que garantiza un juicio imparcial, basado en criterios objetivos previamente definidos.

En este camino, ya se ha subrayado que:

\footnotetext{
${ }^{220}$ Con mucha pertinencia, se dijo que "frente a la estabilidad en los empleos, base fundamental de toda organización burocrática, el purismo liberal aducía en contra el argumento democrático del riesgo de apropiación del poder por un funcionariado inamovible. Además, en una época en que no hay financiación pública para la actividad política ni apenas partidos políticos, los empleos públicos son la única moneda con la que se puede recompensar a los que apoyan a los ganadores de las elecciones, lo que también era incompatible con empleos permanentes." En los Estados Unidos de Norteamérica, el rechazo por el sistema de funcionariado inamovible hizo que el Presidente Jackson, para justificar el sistema de botín (spoil system) dijera que "los trabajos confiados a los agentes del Estado son tan fáciles que todo hombre inteligente puede adaptarse a ellos sin demora." (PARADA, Ramón. Derecho administrativo II, organización y empleo público, 20 ed., Marcial Pons, Madrid, 2008, p. 360).

${ }^{221}$ Mientras los países europeos establecían el sistema de mérito en sus Constituciones, y en la propia Declaración de Derechos del Hombre y del Ciudadano de 1789, de forma distinta, según destaca Ramón Parada, los Estados Unidos de Norteamérica consagraron en la Constitución de 1787 el sistema de libre designación presidencial de los cargos no representativos (art. II, sección 2). (PARADA, Ramón. Op.cit, p. 361).

${ }^{222}$ En el panorama constitucional español, el principio de merito y capacidad en el acceso a la función pública fue previsto en las Constituciones de 1837 (art. 5), 1869 (art. 27), 1876 (art. 15), 1931 (art. 40) y 1978 (art. 23.2 y 103.3).
} 
"O objetivo de preservar a impessoalidade do administrador e de prevenir o desvio de finalidade fez aflorar o modelo de administração racional-burocrática, a partir da segunda metade do século XIX, portanto, na vigência do Estado Liberal. (...) A vinculação da administração a regulamentos genéricos, abstratos, evita decisões casuísticas, impedindo os favores e privilégios individuais, que dominam no patrimonialismo",223

Como se ha analizado anteriormente, en el modelo patrimonialista, la decisión sobre aquellos que van a desempeñar las funciones públicas es de carácter subjetivo, pues depende solamente de la voluntad del gobernante.

De este modo, se percibe que la burocracia es un sistema que permitió el acceso a las funciones públicas en condiciones de igualdad, ya que todos los interesados van a ser sometidos a los mismos procedimientos y a iguales criterios de decisión ${ }^{224}$. Esta, a su vez, en teoría, no dependerá de consideraciones personales de órganos juzgadores, que solamente deben aplicar las reglas ya definidas.

Sin embargo, aunque la utilización de criterios objetivos conduzca a la igualdad de trato entre los candidatos, esta no necesariamente conduciría a la selección de los más aptos. Por ejemplo, si el criterio de selección adoptado fuera la edad, nadie podría contestar a su carácter objetivo. No obstante, el mencionado criterio no tendría en consideración la exigencia de acceso de los más calificados para el desempeño de la función pública.

La burocracia también tuvo en cuenta la situación arriba descrita, ya que uno de los pilares del modelo analizado es la racionalidad, que conduce a la necesidad de profesionalidad de las corporaciones, especialmente, los órganos públicos. La sobredicha característica supone la utilización de personal capacitado para la realización

\footnotetext{
${ }^{223}$ BATISTA GOMES MOREIRA, João. Op.cit, p. 125.

${ }^{224}$ La sumisión a reglas previamente establecidas, sea en los procesos selectivos de acceso a la función pública, sea en cualquier procedimiento administrativo, ha garantizado la previsibilidad de comportamientos, lo que fue esencial para que hubiera un control de los actos administrativos por el ciudadano, que pasó a tener la posibilidad de exigir de la Administración pública que actuara según los modelos estipulados en los reglamentos. Es el clásico principio de legalidad, analizado a través de la óptica del ciudadano.
} 
de las distintas tareas y, como ya se ha visto, solamente el acceso meritorio conduce a la selección de los más competentes.

En estos términos, "la burocracia profesional adquiere de esta manera un nuevo estatuto jurídico sobre bases objetivas, de mérito y capacidad, las mismas que siguen proclamando las Constituciones democráticas de nuestros días."225

Si la burocracia ha traído muchas ventajas, tales como la imparcialidad, la objetividad, la previsibilidad de los comportamientos, la racionalidad, profesionalidad, etc., con reflejos muy positivos en el acceso a la función pública, que pasó a ser igualitario y meritorio, también es correcto afirmar que el mencionado modelo ha tenido sus inconvenientes, para la gestión pública en general, y para el acceso a la función pública, de forma particular.

En el contexto general, la burocracia ha producido una máquina administrativa lenta, que no ha conseguido transitar con éxito por los tortuosos e inevitables trámites establecidos en una reglamentación excesivamente detallista ${ }^{226}$.

Sobre la cuestión arriba mencionada, hay que subrayar que la paradoja es que la necesidad del detallismo reglamentario fue una de las grandes virtudes de la burocracia, pues sirvió para frenar la arbitrariedad de los gobernantes, garantizando los derechos de los ciudadanos, y también ha sido uno de sus principales inconvenientes, ya que ha saturado la Administración, que no ha conseguido conciliar el cumplimiento de procedimientos rígidos y la necesaria eficacia de sus actuaciones.

\footnotetext{
${ }^{225}$ SÁNCHEZ MORÓN, Miguel. Op.cit, p. 25.

${ }^{226}$ Respecto a esta constatación, la doctrina enfatiza que "praticamente todos os pilares do modelo weberiano de organização da Administração Pública ruíram durante os anos em que se positivou o chamado Estado de Bem-Estar: (1) as vicissitudes da burocracia a tornaram, ao contrário do que previra Weber, um grande obstáculo à eficiência das ações estatais; (2) a quantidade e a complexidade das novas atividades desempenhadas pela Administração Pública fizeram com que fosse necessário dotar a Administração de amplo poderes regulatórios, emasculando o princípio da estrita legalidade e, conseqüentemente, diminuindo a segurança jurídica dos administrados em função da atuação estatal; (3) a hierarquização, aliada ao crescimento dos quadros funcionais da Administração, conduziu não ao estrito controle da máquina administrativa, mas à irresponsabilidade dos funcionários subalternos, descompromissados com os objetivos maiores do serviço público; (4) a vinculação à forma deu lugar ao "formalismo", chaga que conduziu invariavelmente a Administração a esquecer os seus objetivos primordiais em prol de um estéril apego às formalidades procedimentais; (5) o distanciamento da Administração em relação à sociedade, por fim, não a tornou impessoal, racional ou técnica, mas dominada por interesses políticos desligados dos objetivos maiores dos cidadãos e, conseqüentemente, ineficiente e ilegítima" (PEREZ, Marcos Augusto. A Administração Pública Democrática: Institutos de participação popular na Administração Pública, Editora Fórum, Belo Horizonte, 2004, p. 47-48)
} 
El modelo burocrático ha sido criticado por no tener en consideración exigencias que, tradicionalmente, solamente solían ser destacadas en el sector privado, como eficacia, eficiencia, productividad, flexibilidad, rapidez, entre otras, y que pasaron a formar parte de los debates que envuelven la gestión pública.

Así, ocupa un espacio importante el modelo gerencial de administración pública, que pasa ser planteado por influencia del neoliberalismo y que pasa a atacar el modelo burocrático, no necesariamente con el objetivo de que este sea eliminado, sino reformado, perfeccionado, y, para sus críticos, adaptado a las nuevas exigencias del mercado.

Consecuentemente, cabe subrayar que:

"la necesidad de gestionar también lo público con principios de eficacia $\mathrm{y}$ eficiencia económica $\mathrm{y}$, por tanto, de aumentar la productividad de las Administraciones Públicas, ha llevado a postular una modernización de los sistemas de organización y funcionamientos públicos y, muy especialmente, de la gestión de personal, sobre la base de principios y técnicas implantados con éxito en las grandes corporaciones privadas. El conjunto de estas aportaciones suele conocerse bajo el nombre de Nueva Gestión Pública...La finalidad de todas ellas es conseguir una función pública menos rutinaria y pasiva, más dinámica, eficiente y motivada." 227

El nuevo modelo de gestión pública propone una mayor flexibilización ${ }^{228} \mathrm{de}$ la función pública, con influencia en los regímenes jurídicos del empleo público (coexistencia de los regímenes laboral y estatutario), en los sistemas de acceso y promoción, en la descentralización, en el control y evaluación de desempeño de los

\footnotetext{
${ }^{227}$ SÁNCHEZ MORÓN, Miguel. Op.cit, pp. 36-36.

${ }^{228}$ Cabe destacar la seguiente opinión doctrinaria:" O fato de a administração burocrática ser propensa a tornar-se um fim em si mesma, em vez de instrumento de realização do interesse verdadeiramente público, levou à busca de alternativas para reorientação da Administração Pública, com ênfase nas características de flexibilidade e eficiência. (...) Pode-se dizer, assim, que o surgimento do princípio da legalidade coincide com o do modelo de administração burocrática, no qual se insere o instituto do concurso para provimento de cargos públicos, objetivando cumprir exigências de objetividade e impessoalidade. Não é menor a coincidência entre o novo modelo de administração, orientada pela eficiência (finalidade), e a nova orientação que se imprime ao princípio da legalidade, o qual, também sob o influxo da finalidade, assume contornos flexíveis e divide prestígio com outros princípios constitucionais. Diante dessa mudança de paradigma, é de se questionar sobre o futuro do instituto do concurso público" (BATISTA GOMES MOREIRA, João. Op.cit, p. 128).
} 
funcionarios $^{229}$, en la retribución, en la movilidad del funcionario, en la manutención del vínculo, en la jubilación, en la creación de la clase de directivos, entre otros sectores.

Por supuesto, la necesidad de introducir cambios estructurales en la función pública era evidente, lo que exigía el reconocimiento de las deficiencias que hacían (y todavía hacen) que la imagen de los funcionarios ${ }^{230}$ y de la propia Administración pública fuera (y todavía sea), para muchos ciudadanos, tan negativa. ${ }^{231}$

Parece indiscutible que el funcionario no puede ser culpado por todos los problemas atribuidos a la Administración pública, que suele no estar estructurada de forma adecuada para atender las demandas sociales. En realidad, muchas veces los funcionarios se enfrentan a una realidad muy dura, muy próxima al caos administrativo y poco conocida por la sociedad. Y son ellos los que garantizan, con su trabajo (aunque varias veces discapacitados y mal remunerados), el mínimo de derechos al ciudadano.

Sin embargo, también hay que destacar que la baja motivación de los funcionarios, el ineficaz sistema de control de su desempeño y la poca preocupación administrativa por la formación continua, al lado del corporativismo cada vez más presente, fueron (y todavía son) las grandes dificultades para la institución de una función pública calificada, lo cual afecta toda la eficacia en la actuación de la administración pública.

\footnotetext{
${ }^{229}$ La doctrina española ha acentuado que la evaluación de desempeño, "aun cuando no lo estableciera el $E B E P$, se trataría de un criterio impuesto por un elemental principio de eficiencia en la gestión pública"(FERNÁNDEZ RAMOS, Severiano. Proposiciones para la articulación de la carrera horizontal de los funcionarios, Justicia Administrativa, Revista de Derecho Administrativo, n. 47, 2010, p. 19).

${ }^{230}$ Para cambiar la situación mencionada, se sostiene la necesidad de cambio del perfil del funcionário público:"O modelo de "Estado gerencial” seria um "Estado mínimo", no qual os servidores públicos fossem cuidados sob a forma de profissionais com os mesmos contornos jurídicos ostentados pelo empregado da empresa privada. Nesse modelo de Estado liberal ou voltado ao cometimento de práticas segundo o figurino liberal, o servidor público torna-se cada vez menos servidor, atuando cada vez menos como cidadão que serve aos demais na investidura que lhe é conferida no cargo público, e cada vez poese como um profissional com a configuração profissional de um trabalhador do "mercado de trabalho" $e$ nada mais" (ANTUNES ROCHA, Cármen Lúcia. Princípios constitucionais dos servidores públicos, Editora Saraiva, São Paulo, 1999, p. 81).

${ }^{231}$ Sobre esta situación, "para muchos, hoy por hoy, tener que realizar una gestión ante la administración pública es casi como ir al dentista. Incluso padeces los mismos síntomas. De noche, no puedes dormir, no paras de dar vueltas a esa visita: “¿Me atenderán bien? ¿Me solucionarán el problema? ¿Será sólo esta vez, o tendré que regresar de nuevo? Me cobrarán mucho?". La única diferencia es que en esta administración - a diferencia del dentista - no tienes que pagar al contado." (MARTÍNEZ VERGEL, Joan., Op.cit, p. 13).
} 
En el contexto arriba mencionado, el sistema de acceso ha asumido un papel de gran relevancia, ya que sus frutos repercuten de manera muy intensa en las actividades estatales.

Una primera cuestión abordada por aquellos que exigían cambios en la función pública tenía conexión con la necesidad de flexibilización de las categorías de personas que deberían tener acceso a los cuadros de la Administración pública ${ }^{232}$. Así, contra el fuerte corporativismo de los funcionarios de carrera, se propulsó el ingreso de otras categorías, cuyas relaciones con la Administración fueran más precarias.

La idea era que, como el proceso de laboralización del personal de las entidades públicas permitía el acceso de empleados sometidos a régimen jurídico contractual, eso contribuía al reclutamiento de personas en situaciones donde la naturaleza de las tareas no exigiera la utilización de funcionarios de carrera, cuya estabilidad sería perjudicial a la actuación administrativa.

Sin embargo, las nuevas políticas de selección (y su búsqueda de flexibilización) han acarreado muchos inconvenientes, como denuncia la doctrina, cuando afirma que durante muchos años no se ha producido un sistema de acceso conforme a los procedimientos ordinarios, "sino que lo habitual ha sido la contratación laboral irregular y temporal, el personal interino y los posteriores procesos de consolidación", lo que, según destaca, excluyeron la posibilidad de competencia en los procedimientos selectivos. ${ }^{233}$

Respecto al incremento de la temporalidad en el empleo público, la Comisión para estudio y preparación del Estatuto Básico del Empleado Público reconoció que:

\footnotetext{
${ }^{232}$ Muchos críticos del modelo burocrático empezaron a echar la culpa de los males de la Administración Pública en el regime jurídico establecido por el Derecho Administrativo, lo que en general lo hacían de forma indebida. Así, "para esses autores, o Direito Administrativo é considerado um conjunto de normas excessivamente rígido, que atrasa, incomoda ou impede constantemente as mudanças de rumo necessárias para uma atuação eficaz da Administração Pública. Para os teóricos defensores dessa abordagem, geralmente ligados à ciência da administração, não é concebível qualquer eficiência administrativa sem o afrouxamento dos constrangimentos que o Direito Administrativo impõe. Convidase, portanto, a Administração a se inspirar no Direito Privado e em princípios de gestão em voga nas empresas privadas, pressupondo-se que haveria identidade entre os problemas que as organizações públicas e privadas teriam que enfrentar" (PEREZ, Marcos Augusto. Op.cit, pp. 49-50).

${ }^{233}$ FONDEVILA ANTOLÍN, Jorge. La selección y pérdida de la condición de empleado público. Especial referencia a su aplicación en la Administración Local, Atelier Libros Jurídicos, Barcelona, 2008, p. 24.
} 
"el reclutamiento de empleados temporales no exige las mismas garantías, sea en virtud de los procesos consiguientes de consolidación o estabilización del empleo público, que suponen en la práctica integrar, mediante cursos breves o pruebas muy simples, como personal fijo, en su mayor parte funcionario, a empleados que en su día fueron nombrados o contratados sin un verificación rigurosa de sus méritos y capacidades o sin ningún tipo de selección abierta."234

Sobre los mencionados procesos de consolidación, una medida adoptada frecuentemente fue la realización de pruebas restringidas (concursos cerrados), donde no había la posibilidad de participación libre de los ciudadanos, ya que era un procedimiento restrictivo para aquellos que ya prestaron servicios a la Administración Pública.

Debido a su relevancia en el contexto de este trabajo, la cuestión planteada será analizada con mayor intensidad en otro momento, pero ahora ya se puede percibir como un intento de seleccionar personas supuestamente más aptas (ya que ya habían demostrado su capacidad en labores anteriores) disminuía el derecho del ciudadano de acceso a la función pública en condiciones de igualdad.

Otra práctica usual pasó a ser la realización de concursos cuyos baremos de méritos abstractos, inespecíficos o ambiguos conferían "una discrecionalidad prácticamente ilimitada a la Administración." 235

Puesto que el modelo de gestión privada pasó a ser copiado por el sector público $^{236}$, en el procedimiento de selección de los empleados públicos pasaron a ser utilizados métodos propios del mencionado ámbito, como entrevistas, test psicotécnico, y otras técnicas donde el subjetivismo del juzgador es un componente siempre presente,

\footnotetext{
${ }^{234}$ Informe de la Comisión para estudio y preparación del Estatuto Básico del Empleado Público, INAP, Madrid, Miguel Sánchez Morón (Presidente), abril 2005, p.89-90.

${ }^{235}$ FERNÁNDEZ DOMÍNGUEZ, Juan J. y RODRÍGUEZ ESCANCIANO, Susana. Op.cit, p. 34.

${ }^{236}$ En verdad, se debe destacar que "é certo que se pretende que o servidor público tenha cada vez mais reforçada a sua condição de profissional, porque é no desenvolvimento de um trabalho público que ele cumpre o seu papel social. Porém, não se busca um servidor público dotado das mesmas e únicas qualificações técnicas e sem qualquer vinculação, inclusive ética, política (no sentido helênico) e social, com a pessoa jurídica pública, cujos quadros integra. Se assim for, ele terá um total desapego não apenas ao público, ao qual se volta o seu desempenho, mas ao próprio serviço público, cujo desenho jurídico tem uma natureza diferenciada da atividade desenvolvida pelo trabalhador na empresa privada.” (ANTUNES ROCHA, Cármen Lúcia. Op.cit., p. 81).
} 
lo que, como se verá en el capítulo sobre el procedimiento de selección, puede ofrecer un gran riesgo a la igualdad de trato entre los candidatos.

Respecto a la introducción de nuevos paradigmas de selección de los funcionarios públicos tras el surgimiento del modelo gerencial, se pude resaltar que:

"O objetivo de segurança e isonomia, que conduz a uma perspectiva voltada para os meios (causalista e legalista; a norma vista como fim em si mesma), própria do modelo burocrático, é temperado com a noção de que ao lado dos interesses individuais dos candidatos em concurso está o interesse da sociedade por uma administração eficiente. (...) Esta mudança de perspectiva conduz à inovação de critérios.(...) Esta constatação leva à necessidade de encontrar critérios de seleção consistentes em avaliações multiformes e prolongadas, talvez a sobrevalorização do currículo em lugar de provas isoladas e a realização de cursos de formação e estágios, que vêm se tornando freqüentes, como etapas dos concursos",237

Se percibe que la iniciativa citada fue (y todavía es) un intento de cambiar la configuración de las oposiciones, que solían (y todavía suelen) ser exámenes "donde se valoran esencialmente conocimientos adquiridos memorísticamente, y muchas veces poco vinculados con las funciones a desarrollar después del ingreso." 238

Algunas de las medidas recién adoptadas fueron necesarias, mientras otras desastrosas, ya que comprometieron principios constitucionales. En verdad, lo que se debe garantizar es que la sustitución de un modelo de Administración Pública por otro no haga desaparecer las calidades del modelo inicial. En eso sentido, lo que debería ocurrir sería una complementación, un perfeccionamiento, conforme se ve:

"os modelos de administração não constituem, entre si, oposições radicais, como se poderia entender numa visão racionalista, mais complementos (princípio da complementaridade), definindo um modelo, em vez de exclusividade, a predominância de caracteres. A passagem para o modelo sistêmico não significa abandono, mas

\footnotetext{
${ }^{237}$ BATISTA GOMES MOREIRA, João. Op.cit., p. 130.

${ }^{238}$ FERNÁNDEZ DOMÍNGUEZ, Juan J. y RODRÍGUEZ ESCANCIANO, Susana. Op.cit., p. 36.
} 
aperfeiçoamento dos métodos até então vigentes, com acréscimo de novos parâmetros." 239

La supresión de las muchas ventajas introducidas por el modelo burocrático es preocupante, pues puede comprometer la observancia de valores (hoy, principios constitucionales) muy relevantes, como la objetividad y la imparcialidad. Además, se puede afirmar que "a persistência de caracteres burocráticos de administração pública mais se justifica em situações históricas como a do Brasil, que, na observação dos sociólogos, ainda busca superar o estágio patrimonialista., 240

En conclusión, como resume Sánchez Morón, lo que se debe buscar es "conseguir un equilibrio entre la eficacia de la organización y los derechos y expectativas legítimas del funcionario, salvaguardando al mismo tiempo los principios de merito y capacidad y de imparcialidad es el reto del presente y del futuro."241

\subsubsection{2 - El acceso meritorio a la función pública y la exigencia de actuación objetiva y eficaz de la Administración Pública}

La actuación de la Administración Pública es regida por distintos principios que tienen como principales objetivos delimitar el espacio de actuación de los gestores públicos, impidiendo que estos se comporten de forma arbitraria y contraria al interés general, así como también imponer directrices de conducta administrativa, para que esta sea suficientemente eficaz y justa, exigencias de un Estado que, al mismo tiempo, debe atender las complejas demandas sociales, pero sin sacrificar los derechos fundamentales del individuo.

Para establecer los paradigmas de actuación de la Administración Pública española, la Constitución de 1978 propulsó determinados principios, que están previstos en el art. 103.1. ${ }^{242}$ Lo que la Constitución exige es que la actividad administrativa sea

\footnotetext{
${ }^{239}$ BATISTA GOMES MOREIRA, João. Idem, p. 128.

${ }^{240}$ BATISTA GOMES MOREIRA, João. Idem, p. 129.

${ }^{241}$ SÁNCHEZ MORÓN, Miguel. Op.cit., p. 38.

242 "Artículo 103.1. La Administración Pública sirve con objetividad los intereses generales y actúa de acuerdo con los principios de eficacia, jerarquía, descentralización, desconcentración y coordinación, con sometimiento pleno a ley y al Derecho."
} 
destinada a la sociedad, y que esto ocurra a través de determinados parámetros, entre los cuales se acentúan la objetividad y la eficacia.

A su vez, la Constitución brasileña de 1988 ha dedicado un capítulo a la Administración Pública (capítulo sétimo del título III), donde ha empezado consagrando determinados principios ${ }^{243}$. Entre los citados principios, cabe destacar en este momento la impersonalidad (impessoalidade, en portugués) y la eficiencia. Como ya se ha subrayado en el primer capítulo, la impersonalidad prevista en la Constitución brasileña exige que la actividad administrativa no establezca privilegios, ni tampoco perjuicios en detrimento de los ciudadanos, pues deberá atender exclusivamente el interés general. En otras palabras, que se actué con objetividad.

Como se puede claramente percibir, en los contextos del constitucionalismo español y brasileño, indudablemente, la objetividad y la eficacia ocupan un espacio muy relevante, pues mientras que la primera busca la eliminación de todas las consideraciones personales en la toma de decisiones y la opción por la racionalidad en la organización y actuación administrativa, la última se preocupa por el alcance de los mejores resultados, con la perfección del rendimiento de la actividad de la Administración Pública.

Evidentemente, la actividad de la Administración Pública, en todos sus momentos, es sometida a las exigencias de objetividad y eficacia. Sin embargo, según el modelo arriba mencionado, la objetividad tendría una relación directa con los procedimientos administrativos necesarios a la formación de la voluntad administrativa (medio), mientras la eficacia con el producto final de estos puede ser constatada por el grado de satisfacción de las necesidades de la población (fin).

Como los fines dependen de los medios, también se puede añadir que la eficacia de la actividad administrativa depende de la presencia o no de la objetividad en su organización y actuación, ya que si el destino de la Administración Pública es

\footnotetext{
${ }^{243}$ Art. 37. A administração pública direta e indireta de qualquer dos Poderes da União, dos Estados, do Distrito Federal e dos Municípios obedecerá aos princípios de legalidade, impessoalidade, moralidade, publicidade e eficiência..."
} 
conducido en olvido hacia el referido valor, ciertamente los resultados serán catastróficos. ${ }^{244}$

La objetividad de la Administración Pública impone distintas reivindicaciones. Seguramente, la más importante es que la actividad administrativa sea destinada a fines de interés general, lo que excluye diversas conductas desgraciadamente usuales, se den en países económicamente desarrollados o no. Las prácticas de favoritismo o las de revanchismo (y sus distintas variaciones) estuvieron, están y ciertamente estarán presentes en todas las sociedades ${ }^{245}$, lo cual exige una permanente atención de los ordenamientos jurídicos.

En otras palabras, el fenómeno de la mala utilización del poder es inherente a la existencia de una sociedad que, al organizarse, tiene que atribuir a determinadas personas o grupos potestades que no siempre son utilizadas de forma adecuada. Así, lo que Montesquieu ya decía hace más de dos siglos en su L'espirit de loi continúa siendo vigente.

En suma, tras la comprensión de la inevitable presencia de corrupción, toma de consciencia imprescindible, esta debe ser acompañada por dos actitudes: la intolerancia por parte de la sociedad delante de los más distintos niveles de corrupción, aunque delante de los llamados "niveles aceptables" y el rechazo incesante a las prácticas corruptas, lo que depende de medidas variadas, que se basan en la educación a la previsión de sanciones rigurosas. ${ }^{246}$

Otra importante constatación es que el quebrantamiento de la objetividad administrativa también es una seria amenaza a la igualdad de todos, ya que cuando la

\footnotetext{
${ }^{244}$ Según Alejandro Nieto, "las deficiencias del aparato administrativo son la mejor prueba de que los gobernantes no están realmente interesados en la consecución de los objetivos formales del Estado. Porque si realmente lo estuvieran se apresurarían a organizar una Administración idónea." (NIETO, Alejandro. El desgobierno de lo público, Ariel, Barcelona, 2007, p. 246).

245 En el preámbulo de la Convención de Naciones Unidas contra la Corrupción, se reconoce que "la corrupción ha dejado de ser un problema local para convertirse en un fenómeno transnacional que afecta a todas las sociedades y economías, lo que hace esencial la cooperación internacional para prevenir y luchar contra ella."

${ }^{246}$ Para Fernando Rodríguez López, a pesar de las distintas medidas que pueden ser desarrolladas para combatir la corrupción, "debe reconocerse la incapacidad de las medidas del Derecho sancionador para frenar por sí solas el fenómeno de la corrupción”. (RODRÍGUEZ LÓPEZ, Fernando. ¿Puede el Derecho sancionador frenar la corrupción? Reflexiones desde el análisis económico del Derecho, en La corrupción en un mundo globalizado: análisis interdisciplinar, Nicolás Rodríguez García y Eduardo A. Fabián Caparrós (Coordinadores), Ratio Legis, Salamanca, 2004, p. 26).
} 
Administración Pública utiliza criterios personales para tomar una decisión, eso supone la violación de normas jurídicas que son garantizadoras de un trato igualitario.

Las reglas para la distribución de bienes y derechos, que fueron previa y democráticamente definidas y que establecen condiciones equivalentes a todos los ciudadanos, pasan a ser suplantadas por la voluntad del administrador, que consiste en la patrimonialización el espacio público.

Si la igualdad de todos los ciudadanos ante la Ley supone que todos se sometan a las mismas reglas, sin consideración de factores discriminatorios como religión, nacimiento, edad, sexo, raza, condición física, etc., a su vez, la igualdad en la aplicación de la Ley debe eliminar las consideraciones de orden personal del administrador público (amistad, parentesco, partido, corporación, etc.).

Para que esto suceda, la objetividad se impone y tiene como efecto directo la indispensable exigencia de imparcialidad en el desempeño de los funcionarios públicos (art. 103.3 CE y art. $37 \mathrm{CB}$ ).

La Administración Pública actúa a través de sus funcionarios, que constituyen sus recursos más relevantes. Las constantes exigencias de profesionalización y modernización administrativa siempre deberán partir del reconocimiento del valor de las personas que trabajan en la Administración, y que estos, evidentemente, si no tienen un comportamiento basado en criterios éticos, todas las demás medidas serán de poca utilidad.

Como la objetividad conduce a la eficacia, también se debe añadir que el alcance de los resultados por parte de la Administración Pública, sea respecto a criterios cuantitativos o cualitativos, depende de la actuación imparcial de los funcionarios públicos, que deben dedicarse tan sólo a la satisfacción del interés general. Para esto, la primera providencia consiste en la selección de las personas adecuadas.

Sobre la exigencia arriba citada, se puede destacar que:

"la selección de los funcionarios es una cuestión esencial...Porque si selecciona mal, no habiendo como regla en el caso de los funcionarios 
la posibilidad de "despido" más que en supuestos disciplinarios realmente límite, eso significa que la Administración empleadora ha de "cargar" durante toda la vida con el error de origen que casi nunca remedia en la fase de formación por muchos cursos y sistemas de reciclaje que se prevean y que resultan de más que dudosa utilidad. ${ }^{, 247}$

Así, es posible afirmar que el tema relativo al acceso a la función pública debería recibir una especial atención de los Poderes Públicos (lo que no suele suceder), ya que el éxito (o su fracaso) de la actuación administrativa está en manos de las personas que van a conducir los procedimientos y a tomar las decisiones de la Administración.

Sin embargo, aunque la afirmación arriba planteada sea de corriente aceptación por todos, cabe resaltar que el modelo de selección de los funcionarios debe tener en consideración distintos valores, que tanto prestigian derechos de los ciudadanos (como la igualdad de trato en el acceso a las funciones públicas), como buscan la satisfacción de otras exigencias constitucionales, más relacionadas a la actuación administrativa, como la objetividad y la eficacia.

En estos términos, como se verá a continuación, la selección de los funcionarios públicos a través del mérito y de la capacidad es el factor más importante para garantizar una Administración Pública profesional ${ }^{248}$, que actúa con objetividad en la obtención de los mejores resultados para la sociedad.

Es más: los mencionados criterios son los únicos que pueden ser utilizados de forma legítima para garantizar el acceso a la función pública en condiciones de igualdad, sea en el ordenamiento jurídico brasileño, sea en el español, aunque esto se manifieste a partir de distintos sistemas selectivos, que, por supuesto, intentan prestigiar otros valores presentes en cada uno de los referidos sistemas jurídicos.

\footnotetext{
${ }^{247}$ FONDEVILA ANTOLÍN, Jorge. Op.cit.,p. 12.

${ }^{248}$ La conexión entre el acceso meritório y la profesionalización de la función pública es siempre destacada por la doctrina: "O provimento de cargos por meio de concursos públicos deve ser, portanto, um instrumento para propiciar a profissionalização da burocracia estatal, garantindo que se contratem apenas candidatos que preencham as necessidades da Administração e atendam ao interesse público. Como conseqüência de uma contratação eficiente, aumenta-se a estabilidade da Administração Pública e reduz-se a sensibilidade da máquina pública à alternância de governos e governantes oportunistas." (LOBELLO DE OLIVEIRA ROCHA, Francisco. Op.cit., p. 9).
} 


\subsubsection{3 - Las ventajas del acceso meritorio}

Conforme ya se ha destacado, el acceso a la función pública a través del mérito y de la capacidad presenta distintas ventajas, siendo la sociedad su principal beneficiaria, ya que pasará a contar con funcionarios calificados para servirla.

Las consecuencias directas de la selección meritoria son muchas, lo que hace la enumeración de las más relevantes ostente un carácter meramente ejemplificativo, como se puede percibir a continuación:

a) la valorización de la función pública, ya que los seleccionados, después de un duro procedimiento de selección, caracterizado por una competición muy intensa, pasarán a contar con la admiración social;

b) la estima que el aspirante seleccionado tendrá por su actividad, que suele ser el resultado de muchos años de dedicación y esfuerzo;

c) la posibilidad más amplia de selección de aspirantes aptos, lo que puede ser relativo, si el procedimiento selectivo no observa determinadas condiciones;

d) el mayor estímulo a la participación ciudadana, una vez que aquél que tenga interés de influenciar en los destinos de la sociedad pueda hacerlo en la condición de funcionario público;

e) el respecto a la igualdad de oportunidades para todos, puesto que el principio general es el de la amplia accesibilidad a la función pública;

f) la mayor independencia del funcionario debido a su no vinculación con la clase política; $y$

g) la mayor resistencia a las tentaciones de la corrupción, debido a muchos de los factores anteriores, que pasarán a ser analizados.

En primer lugar, se puede afirmar que, en general, el acceso meritorio concede a la función pública un prestigio social considerable. Quizá porque aún es valorado el esfuerzo que uno debe realizar para que se pueda acceder a la función pública. En realidad, tienen buena reputación todos los procedimientos selectivos de carácter objetivo a través de los cuales cualquiera, siempre que reúna los requisitos 
legales, pueda participar. En las oposiciones y concursos, todos los ciudadanos tienen igual derecho de participación y gozan de los mismos derechos en la competición, y cuando hay una generalización de trato jurídico la sociedad suele estimarla de forma positiva.

En cambio, el hecho de que todos los ciudadanos puedan participar en los procedimientos selectivos no es suficiente para la buena imagen social de las oposiciones. Se agrega un valor positivo a estos procedimientos también porque se aprecia la imparcialidad de la selección ${ }^{249}$, lo que ciertamente no ocurriría si el criterio de elección de los funcionarios fuera subjetivo, como, por ejemplo, en una simple entrevista personal sin cualquier baremo de naturaleza técnica.

Otra circunstancia relevante para el buen prestigio de las oposiciones y de aquellos que llegan a ocupar plazas en la función pública es el elevado grado de dificultad de los procedimientos de selección.

Hoy en día, debido a distintas causas, el número de opositores en España y, especialmente, en Brasil es muy elevado. El incremento de la concurrencia ha hecho surgir un verdadero segmento económico destinado a la preparación de aspirantes a la función pública y cuando un individuo, tras años de dedicación a los estudios, consigue éxito en la oposición, el reconocimiento social es inmediato.

\footnotetext{
${ }^{249}$ Obviamente, los procesos selectivos no siempre han tenido este prestigio. Sobre el imagen (anterior y actual) de los procesos selectivos en Brasil, se puede transcribir la siguiente situación: "Em 1990, estava eu estudando num cursinho para Delegado de Polícia/RJ. Era o primeiro concurso para o cargo em mais de vinte anos. No meio da aula, sala lotada, surge um cidadão anunciando que estavam vendendo as vagas e dizendo o preço, que equivalia a um bom carro zero. Um aluno, que estava ao meu lado, levantou dizendo que iria pegar dinheiro emprestado com o sogro e comprar a vaga dele; saiu em desabalada correria. Nunca mais o vi. Metade da turma saiu do curso nos dias que se seguiram. Não tendo dinheiro e, mesmo que o tivesse, tendo aprendido dos pais que esses atalhos não valem seu custo, pensei o seguinte: havia 139 vagas e como - se estavam sendo vendidas mesmo - eram muito caras, imaginei que apenas conseguiriam vender umas 130, que sobrariam umas 9 vagas para quem chegasse lá sabendo a matéria e acertasse as questões. Decidi que iria lutar por uma dessas 9 vagas honestas. $O$ concurso aconteceu e apenas 23 candidatos foram aprovados. Conheci todos e posso assegurar que não pagaram nada. Aliás, eu fui um dos aprovados - o primeiro colocado. Em suma, era tudo mentira. Posso dizer que naquela época a gente sabia, imaginava ou suspeitava de fraude e se limitava a desistir (alguns) ou a estudar para passar nas que sobrassem. Esse quadro tem melhorado. Hoje se levanta o dedo, se procura as autoridades, hoje as pessoas acreditam mais nas instituições" (DOUGLAS, Willian. Fraude no concurso. Carta aos aprovados honestamente e aos demais interessados. Texto extraído del sitio de la Associação Nacional de Proteção e Apoio aos Concursos - ANPAC (http://www.anpac.org.br/portal/index.php/artigos/70-fraude-no-concurso-da-prf), acceso en 27 de abril de 2010.
} 
Exactamente por las razones arriba citadas (el gran esfuerzo personal y el elevado reconocimiento social), el aspirante seleccionado tendrá por su actividad una gran estima, lo que producirá que este se sienta especialmente afortunado. Esta sensación ciertamente conduce a un mayor grado de satisfacción con el trabajo desempeñado, lo cual, a su vez, contribuirá con la calidad de la actividad administrativa.

Por el contrario, si uno no siente su trabajo valorado (por si mismo y por los demás), la motivación y el nivel de compromiso con las tareas disminuyen, lo que probablemente va a influenciar en el desempeño del funcionario público. Al contrario de lo que muchos suelen afirmar, la retribución no es el único factor primordial de motivación en la función pública.

Quizás por la disminución del grado de motivación en la secuencia de sus carreras, muchos funcionarios pasan a tener un rendimiento que está lejos de lo que de ellos se espera y, delante de esa ineficacia, los funcionarios no siempre gozan de una buena imagen en la sociedad. ${ }^{250}$

Sin embargo, el descenso del nivel de motivación y de comprometimiento del funcionario, y su consecuente diminución de rendimiento, no pueden ser atribuidas al acceso, aunque este, pese a haber sido realizado de forma deficiente, pueda influenciar en las referidas situaciones.

Lo que se subraya aquí es que, superada la fase de acceso, los funcionarios deben ser continuamente estimulados, y eso se consigue a partir de distintas actuaciones administrativas, como, por ejemplo, la previsión de posibilidad de crecimiento, atribución de responsabilidades, capacitación permanente, política remuneratoria atractiva, exigencia de nuevas tareas, entre otras.

Seguramente, una de las ventajas más evidentes de la utilización del mérito y la capacidad para la selección de los funcionarios públicos es el hecho de que tales criterios son los más fiables para la elección de los más aptos.

\footnotetext{
${ }^{250}$ Sobre el funcionamiento de la Administración pública, ya se ha dicho que "la percepción creciente es la de que se trata de un espacio donde los ciudadanos, en vez de ser tratados como clientes, en muchas ocasiones suelen ser considerados como un problema. Un lugar donde parece que nadie sabe muy bien quien manda, ni el trabajo que hace. Un escenario lleno de tópicos y estereotipos, todos ellos muy consolidados entre la cultura popular, aunque algunos sean injustos e irreales. Algunos. Lo menos, pero algunos." (MARTÍNEZ VERGEL, Joan. Op.cit., p. 17).
} 
En realidad, la Administración Pública tiene determinadas necesidades de personal, y para atender tales carencias, debe seleccionar personas que puedan, de forma eficaz, desempeñar las tareas exigidas. Tras muchos siglos de utilización de criterios subjetivos, discriminatorios e inadecuados, la humanidad ha progresado en la forma de elección de los funcionarios públicos, a partir de la utilización del sistema meritorio ${ }^{251}$.

En este sentido, la racionalidad del procedimiento, sometido a reglas generales previamente estipuladas, la objetividad de la decisión, basada en criterios técnicos que se someten a control, y la utilización de los principios de mérito y capacidad para la definición del acceso, son los factores preponderantes que harán posible la admisión de los más aptos.

No obstante, cabe subrayar que:

\begin{abstract}
"Concurso público não se confunde com simulacro de concurso público. Não atende aos requisitos constitucionais o chamamento ou a inscrição de apenas alguns apaniguados que simularão uma disputa apenas para aparentar a realização de um concurso público. Não é concurso público o certame que se desenvolve sem observância do princípio da isonomia. É essencial que todo e qualquer interessado seja tratado com igualdade, para que vençam os melhores." ${ }^{252}$
\end{abstract}

Otro aspecto que debe ser resaltado es que el concepto de "más apto" ha cambiado y todavía se encuentra cuestionado, ya que hay un fuerte debate sobre si es preferible seleccionar un funcionario ampliamente especializado en determinada tarea o alguien con una capacidad más amplia de actuar en distintos sectores.

También es importante que se enfatice que los procesos selectivos deben tener en cuenta que la necesidad de reclutamiento de funcionarios técnicamente

\footnotetext{
${ }^{251}$ Las desventajas de los sistemas no meritorios de acceso son notorias. Sobre esta cuestión, pueden ser destacados los siguientes inconvenientes: "deterioro de la imagen de la Administración pública; ineficacia del aparato administrativo por la falta de profesionalidad de sus servidores; prioridades partidaristas en la toma de decisiones públicas y, sobre todo, una permanente preocupación en las filas de los servidores públicos por los temas electorales." (ILDEFONSO HUERTAS, Rosa María. Tres modelos comparados de función pública y sus procesos de selección, Instituto Andaluz de Administración Pública, Sevilla, 2004, p. 125).

${ }^{252}$ ABREU DALLARI, Adilson. Princípio da isonomia e concurso público, en Concurso público e Constituição, Fabrício Motta (Cordinador), Editora Fórum, Belo Horizonte, 2005, p. 94.
} 
preparados impone la búsqueda de otros factores que, en un primer momento, no serían directamente relacionados con el mérito y la capacidad.

Es que el buen ejercicio de una función pública exige mucho más que conocimientos técnicos; es imprescindible que el funcionario tenga un perfecto discernimiento político del papel que ejerce en la sociedad, lo que impone la selección de personas éticamente calificadas ${ }^{253}$, especialmente cuando los funcionarios, por razones profesionales, son obligadas a convivir en el mismo ambiente con políticos corruptos. En estas oportunidades, el funcionario éticamente preparado puede y debe ser un relevante obstáculo a los variados intentos de la clase política, que se apodera de la Administración Pública con objetivos inescrupulosos.

Sobre la citada realidad, en Brasil, ya se ha afirmado que:

\begin{abstract}
"Se é verdade que ainda assistimos a um quadro estatal cujas estruturas ostentam índices alarmantes de corrupção, vaidade e desmandos, no mais das vezes imputados à cúpula dos Poderes da República, decorrente de um passado histórico marcado por diversos desvios e opções políticas equivocadas, cuja feição remonta a uma estrutura colonial subserviente e patrimonialista, também é certo que presenciamos um movimento paulatino, impessoal e moralizador de novos atores sociais, os quais têm orgulho de ostentar o status de agente público, provenientes, marcadamente, da classe média e das camadas mais pobres da população brasileira, recrutados democraticamente graças ao concurso público"254
\end{abstract}

\footnotetext{
${ }^{253}$ En los procesos selectivos realizados por las Administraciones Públicas brasileña y española, es poco usual la preocupación con el perfil ético de los candidatos. En el caso español, una de las pocas medidas adoptadas es la previsión como requisito de acceso la demostración por el candidato de que este no haya sido separado mediante expediente disciplinario del servicio de cualquiera de las Administraciones Públicas o de los órganos constitucionales o estatutarios de las Comunidades Autónomas; y que no se halla en inhabilitación absoluta o especial para empleos o cargos públicos por resolución judicial, para el acceso al cuerpo o escala de funcionario, o para ejercer funciones similares a las que desempeñaba en el caso del personal laboral, en el que hubiese sido separado o inhabilitado. También pueden ser citadas algunas entrevistas que son realizadas en determinados procesos de selección. En el derecho brasileño, en determinadas oportunidades, es utilizado el mecanismo de la investigación social, para evitar la selección de personas que desarrollaran actividades en el pasado no compatibles con el ejercicio de una función pública. En los dos países, la preocupación con el perfil ético de los aspirantes también se manifiesta en los tests psicotécnicos y en las pruebas orales, aunque, en los dos casos, con muchos problemas de operacionalización.
}

${ }^{254}$ BARBOSA MAIA, Márcio, y PINHEIRO DE QUEIROZ, Ronaldo. Op.cit., pp. 1-2. 
Otro aspecto positivo del acceso meritorio está relacionado con el estímulo generado a la participación ciudadana, pues abre la posibilidad de que cualquiera de los miembros de la comunidad, en la condición de funcionario público, pueda influenciar en los destinos de la sociedad. Así pues, el ciudadano que pasa a poseer la condición de funcionario público no pierde su status de ciudadano. Sucede al revés, pasa a tener una posibilidad más concreta y privilegiada de contribución social.

Comentando la mencionada situación del ciudadano, la doctrina ha destacado con elogiable claridad que:

"Ao mais desavisado poderia parecer que a participação funcional (no funcionamento da máquina administrativa) não conformasse uma atuação de natureza política. De resto, sempre se teve como assentado, pelo menos pela maioria dos doutrinadores, que a Administração Pública seria apolítica. Chegou-se mesmo a afirmar que ela (e até o Estado) seria aética. Nem uma coisa é mais pacífica, nem a outra é mais aceita. Há uma moralidade pública (inclusive compondo a principiologia constitucional da Administração Pública) e um complexo de comportamentos, procedimentos e normas compondo as políticas públicas. A sua execução pela organização administrativa estatal constitui atividade política, e a participação nessa estrutura constitui, assim, uma forma de atuar politicamente, ainda que o conteúdo do desempenho seja primariamente administrativo."255

En otro momento de precisión, la doctrina brasileña ha afirmado que:

"O servidor público participa da relação trabalhista pública na condição de profissional. Mas não apenas. O servidor público cumpre um papel cidadão na condução da coisa pública em cujo desempenho lhe é dado trabalhar. Por isso, diversamente do trabalhador privado ou autônomo, ele detém uma dupla condição jurídica: a de cidadão componente da estrutura orgânica da entidade política estatal (e então ele é parte do Estado, participa do Estado na condição de um dos agentes que o compõem) e a de trabalhador (e então ele é um

255 ANTUNES ROCHA, Cármen Lúcia. Princípios constitucionais dos servidores públicos, Editora Saraiva, São Paulo, 1999, p. 145. 
profissional buscando realizar o seu ofício numa situação de membro da sociedade procurando a sua realização pessoal). ${ }^{, 256}$

Debido a su importancia en el contexto de este trabajo, se dedicará un apartado para analizar con más profundidad el derecho de acceso a la función pública como forma de participación del ciudadano en la actividad estatal.

Como ya se ha destacado, el acceso a la función pública debe garantizar no sólo la selección de los más aptos, sino también generar la igualdad de oportunidades entre todos los ciudadanos. En esta misma línea de pensamiento, la doctrina ya ha subrayado que "se o concurso público não é, segundo pensam alguns, a melhor forma de recrutamento de pessoal para a Administração Pública, representa, seguramente, a melhor opção até agora concebida, possibilitando, seu democrático procedimento, a todos que reúnan as condições exigidas ampla participação na competição."257

Se podría plantear si el mérito sería el único criterio que llevaría al trato igualitario de los ciudadanos. Por supuesto, alguien podría sugerir el sorteo como criterio notablemente objetivo. Sin embargo, este criterio no sería válido, pues estaría concediendo un trato de la más absoluta igualdad sin tener en consideración las diferencias entre las personas, las distintas capacidades y los desiguales méritos. En otros términos, estaría concediendo un trato igual, injusto para los desiguales, que sería solo uno de los muchos inconvenientes de un acceso que no tuviera en cuenta el mérito.

Pero uno podría decir: la competición que se realiza a través de un procedimiento selectivo meritorio también trata de forma igual a los desiguales, ya que las personas tienen distintos niveles intelectuales, circunstancia causada por factores genético o sociales.

El acceso meritorio permite que cada uno de los ciudadanos pueda, a partir de sus propios esfuerzos, prepararse, capacitarse, adquirir los conocimientos exigidos, .gracias a que el mérito del aspirante no depende de factores inmutables., sino que este

\footnotetext{
${ }^{256}$ ANTUNES ROCHA, Cármen Lúcia. Op.cit., p. 79.

${ }^{257}$ BACELLAR FILHO, Romeu Felipe. O concurso público e o processo administrativo, en Concurso público e Constituição, Fabrício Motta (Coordinador), Editora Fórum, Belo Horizonte, 2005, p. 73.
} 
es construido y adquirido a lo largo de una vida. Y para que eso suceda, los factores innatos del ser humano son irrelevantes, o pueden ser compensados por acciones positivas, como suele ocurrir con las mujeres y personas con discapacidad.

En el acceso a la función pública, el principio general es el de amplia accesibilidad, pero la definición de aquellos que van a ocupar las plazas depende de los aspirantes. Es la igualdad de oportunidades.

Las dos últimas ventajas (la mayor independencia del funcionario debido a su no vinculación con la clase política y la mayor resistencia a las tentaciones de la corrupción), pasarán a ser analizadas en el próximo apartado.

\subsubsection{4 - La relación entre formas de acceso y prevención a la corrupción}

La actividad administrativa es conducida por personas que están permanentemente sujetas a distintas situaciones donde la frontera entre el cumplimiento de sus deberes funcionales y la sumisión a las tentaciones del poder es fácilmente superada. Para la doctrina española, la "corrupción acompaña al poder como la sombra al cuerpo" 258 .

Sin embargo, hay circunstancias que favorecen las prácticas indebidas por los funcionarios públicos. ${ }^{259}$ Es notorio que el acceso a la función pública es una de las claves del buen funcionamiento de la Administración Pública. A su vez, si la selección de los funcionarios públicos es conducida por intereses ajenos a los de la sociedad (personales, políticos, partidarios, corporativos, etc.), el precio es el agravamiento de los valores éticos que deben inspirar la actuación administrativa.

También es igualmente notorio que hay aún muchos problemas en la conducción de los procesos selectivos. No obstante, la existencia de inconvenientes (administrativos, jurídicos, sociológicos, políticos, etc. no pueden descalificar la

\footnotetext{
${ }^{258}$ NIETO, Alejandro. Corrupción en la España democrática, Ariel, Barcelona, 1997, p. 7.

259 Sobre esto, "obviamente, que el funcionario disponga de estas posibilidades, entre otras, para comprometerse en un comportamiento corrupto depende en gran medida del esquema institucional que se adopte, de la calidad o de lo engorroso de los trámites administrativos exigidos a los ciudadanos para alcanzar determinados objetivos jurídicos y, naturalmente, de los sistemas de controles y sanciones impuestos a los funcionarios para desincentivar tal comportamiento." (MALEM SEÑA, Jorge F. La corrupción: aspectos éticos, económicos, políticos y jurídicos, Gedisa Editorial, Barcelona, 2002, p. 46).
} 
altísima relevancia del acceso meritorio. Como se ha dicho para el contexto brasileño "registro que ainda prefiro todos os problemas derivados dos concursos e das licitações do que a situação anterior do país, na qual os cargos e contratos relativos à Administração eram reservados para os "amigos do Rei".,260

En el contexto arriba resaltado, una situación que debe ser combatida por la sociedad, a través del ordenamiento jurídico, es la utilización del poder para la distribución de favores políticos, en especial, para el nombramiento de personas que, en realidad, son militantes del partido político que controla el Gobierno ${ }^{261}$. Prácticas como esta violan la igualdad entre los ciudadanos y ponen en riesgo la objetividad, la eficacia y la ética administrativa.

El clientelismo en la actividad administrativa (clientelismo burocrático ${ }^{262}$ ) permite la adjudicación ilícita de contratos, la concesión de subvenciones de forma privilegiada, la facilitación indebida de trámites, la exima de pagos, contribuciones, requisitos contractuales o impuestos, la entrega de informaciones privilegiadas ${ }^{263}$.

Sin embargo, quizá, la designación de funcionarios a través de criterios políticos es la práctica más nefasta, ya que es la fuente de todas las demás, puesto que los afiliados, amigos, familiares y militantes elegidos tendrán una situación de especial protección por sus protectores que les permitirán realizar las conductas ilegales arriba mencionadas sin ningún recelo de eventuales sanciones.

En el ordenamiento jurídico español, no obstante el sistema meritorio sea adoptado por la Constitución como la regla con carácter de absoluta (art. 103.3, CE), hay la posibilidad prevista en la legislación de que una plaza sea calificada como de libre designación, lo que, en teoría, no significaría la ruptura de los mencionados

260 DOUGLAS, Willian. Fraude no concurso. Carta aos aprovados honestamente e aos demais interesados. Texto extraído del sitio de la Associação Nacional de Proteção e Apoio aos Concursos ANPAC (http://www.anpac.org.br/portal/index.php/artigos/70-fraude-no-concurso-da-prf).

${ }^{261}$ Comparando la corrupción en los contratos administrativos y en los nombramientos de funcionarios, Alejandro Nieto afirma que mientras en la primera situación se obtiene una ventaja indebida, eso sucede en una operación única. A su vez, un nombramiento funcionarial realizado de forma indebida (políticamente, por nepotismo, o por corrupción) presupone una renta vitalicia para su beneficiario, y su fidelidad al partido, con la consecuente concesión permanente de favores ilícitos. (NIETO, Alejandro. Op.cit., p. 190).

${ }^{262}$ Respecto este tema, véase: VILLORIA MENDIETA, Manuel. La corrupción política, Editorial Sintesis, Madrid, 2006, p. 191.

${ }^{263}$ Sobre la referida cuestión, "una de las manifestaciones más frecuentes de la corrupción, en los últimos tiempos, se produce con la utilización por el funcionario de la llamada información privilegiada, que constituye una infracción de su deber de secreto profesional." (GARCÍA MACHO, Ricardo. Secreto profesional y libertad de expresión del funcionario. Tirant lo blanch, Valencia, 1994, p. 164.) 
principios. Lo que era una excepción para situaciones que justificarían un nombramiento de confianza, se acabó convirtiendo en una práctica usual y de difícil control, en especial, respecto a la sumisión de la designación a los principios de mérito y capacidad.

Así, respecto a la libre designación, se afirmó que "pese a estos intentos normativos de reducir al máximo su ámbito material-, con el paso del tiempo se ha vuelto a manifestar una tendencia generalizada a incrementar el número de plazas cuya provisión tiene lugar acudiendo a este expediente."264

En el derecho brasileño, la propia Constitución ha consagrado la excepción a la regla del concurso público, cuando permitió la libre designación para determinado cargo de confianza (cargos em comissão), según el art. 37, II. En la realidad, lo que debería ser tratado como situación excepcional (para la Constitución, los citados cargos solamente pueden ser utilizados para el nombramiento de funcionarios para cargos de dirección, asesoramiento y de comando), terminó consolidándose como una práctica usual en todos los niveles federativos (federal, estadual y municipal).

A lo que todo esto conlleva es a que las mencionadas plazas sean de libre designación y también de libre cese, lo que causa dos graves problemas: en primer lugar, la violación de la regla del mérito y la capacidad, lo que constituye una gran apatía hacia la calificación y desempeño de los funcionarios de carrera, ya que estos saben que solamente van a alcanzar los niveles más altos a través de una designación de carácter eminentemente político.

A su vez, debido al libre cese:
"si los cargos públicos son inestables e inseguros; o su titularidad es detentada por poco tiempo aparecen nuevos incentivos para una rápida corrupción de los funcionarios, ya que en sus respectivos cálculos de utilidades tendrán poco que perder, en términos de resignación del cargo y consecuentemente de su salario si son detectados porque sus funciones son temporalmente reducidas, y mucho que ganar si se comprometen en actividades corruptas."265

\footnotetext{
${ }^{264}$ FERNÁNDEZ DOMÍNGUEZ, Juan J. y RODRÍGUEZ ESCANCIANO, Susana. Op.cit., p. 82.

${ }^{265}$ MALEM SEÑA, Jorge F. La corrupción: aspectos éticos, económicos, políticos y jurídicos, Gedisa Editorial, Barcelona, 2002, p. 77.
} 
Parece evidente que la corrupción se encuentra más presente (o al menos, produce más daño) en los altos niveles de la clase política. Respecto a esta cuestión, Alejandro Nieto afirma que:

"hay zonas singularmente corrompidas y otras salobres por milagro en las que a nadie se le ocurre tentar ni caer en la tentación. La corrupción, por otra parte, ama las alturas. Hoy en España los niveles modestos se encuentra aceptablemente limpios; pero conforme se sube en la escala administrativa se va enrareciendo el ambiente y al llegar a los niveles políticos todo está corrompido: o por comisión o por complicidad o por encubrimiento."266

Lo que realmente pasa es que "el sistema de libre designación atribuye a la Administración una discrecionalidad máxima en la provisión de puestos de trabajo, constituyendo una variante excepcional a riesgo de comprometer seriamente los principios de mérito y capacidad. ${ }^{267}$ En estos términos, se percibe fácilmente la relación entre el acceso y provisión de las plazas en la función pública, con su buen o mal funcionamiento.

También se puede añadir que la organización de la función pública es esencial para la conducción adecuada de la actividad administrativa. Eso se verifica cuando hay un exceso en la utilización de personal eventual, en el número de plazas por libre designación, en la deficiencia de la definición normativa de las carreras ${ }^{268}$. En otras palabras, en la ausencia de profesionalidad de la función pública.

Hay estudios que demuestran que la creación de un servicio civil de carrera $^{269}$ es uno de los más importantes factores de la lucha anticorrupción ${ }^{270}$. A su vez,

\footnotetext{
${ }^{266}$ NIETO, Alejandro. Corrupción en la España democrática, Ariel, Barcelona, 1997, p. 136.

${ }^{267}$ FERNÁNDEZ DOMÍNGUEZ, Juan J. y RODRÍGUEZ ESCANCIANO, Susana. Op.cit., p. 80.

268 Así, "La existencia de un servicio civil de carrera y una Administración profesionalizada y con sistemas de controles internos y externos desarrollados es una de las barreras más importantes contra la corrupción. No parece que la existencia de burocracias profesionales fomenten la corrupción, frente a las ideas libertarias que afirman lo contrario, sino que, cuando las burocracias son estables y están socializadas en el servicio público, son uno de los mejores instrumentos de prevención de la corrupción."(VILLORIA MENDIETA, Manuel. La corrupción política, Editorial Sintesis, Madrid, 2006, p. 290)

${ }^{269}$ En el mencionado servicio civil de carrera, la figura de la estabilidad en la función deberá estar presente: "Com efeito, a estabilidade na carreira de Estado, para além das mudanças pontuais no tocante a regras, há de ser vista como rigorosamente intangível, desempenhando valiosa tríplice função. De fato, tal proteção de alçada constitucional colima: (a) garantir a manutenção das políticas públicas, uma vez que são os servidores estáveis que asseguram a permanência das metas do Estado (de longo prazo), sem prejuízo das alterações conjunturais, a cargo dos agentes políticos, transitórios por
} 
cuando esto no sucede y cuando hay una "estructura tan pobremente organizada y con un personal poco calificado y dependiente del poder político no extraña que se faciliten irregularidades de distinto tenor sino también se produzcan en la administración pública comportamientos de corrupción sistemáticos.",271

La utilización sin frenos y sin parámetros más rígidos de la potestad administrativa de definición de los ocupantes de los cargos de libre designación hace con que el interés por la política, la concesión de apoyos en las elecciones a determinados grupos o mismo la presencia del ciudadano en la vida partidaria solo sea motivada por la posibilidad del mismo recibir algún cargo, a cambio (llamado retribución) de su actuación política, que debería ser espontanea y sin cualquier pretensión que no tenga naturaleza cívica. Por esta razón, a muchas personas el concurso público no interesa ${ }^{272}$.

Sobre esta cuestión, hay un relevante examen del panorama del clientelismo en los más distintos países:

"En las democracias de mayor calidad, los miembros del grupo más íntimo aspiraran, si se gobierna, a los cargos políticos existentes, pero los miembros del out group no piensan, normalmente, en obtener beneficios personales, aunque sí colaboran para ver a su líder en el

\footnotetext{
definiçao. A estabilidade oferece, ainda, ao servidor que responde por atividade essencial de Estado: (b) a salvaguarda contra a prepotência dos mandantes de turno, não raro travestida de "discricionariedade". Como acentuado, sem a independência e a segurança oferecidas pela estabilidade, o cidadão logra ter menores chances de uma prestação adequada dos serviços essenciais, mormente por déficit de controle. A terceira função da estabilidade reside na (c) contrapartida que o regime institucional (não-contratual) oferece à vista da periclitante lâmina posta à disposição do Poder Público sob a forma de poderio unilateral (ainda que mitigado) de alteração das regras do regime. No intuito de cumprir a tríplice função, a estabilidade no serviço público deve ser compreendida como proteção de alçada constitucional contra a perda do cargo, conferida ao titular de cargo efetivo, nomeado em razão de concurso público, após o desenrolar do período de estágio probatório" (FREITAS, Juarez. Concurso público e regime institucional: as carreiras de Estado, en Concurso público e Constituição, Fabrício Motta (Cordinador), Editora Fórum, Belo Horizonte, 2005, p. 236-237).

${ }^{270}$ VILLORIA MENDIETA, Manuel. El servicio civil de carrera en Latinoamérica: diagnóstico, causas y propuestas, Instituto Nacional de Administración Pública - INAP, Madrid, 2007, p. 78.

${ }^{271}$ MALEM SEÑA, Jorge F. La corrupción: aspectos éticos, económicos, políticos y jurídicos, Gedisa Editorial, Barcelona, 2002, p. 74.

${ }^{272}$ Respecto a esta afirmación: "O concurso público somente interessa aos fracos, aos desprotegidos, àqueles que não contam com o amparo dos poderosos capazes de conseguir cargos ou empregos sem maiores esforços. A realização de concursos públicos sempre terá uma forte oposição daqueles que dispõem de meios para prover cargos e funções por outros meios. Além disso, sempre existe uma desconfiança dos participantes comuns no tocante à lisura e à legitimidade do procedimento. As autoridades diretamente incumbidas de levar a efeito um concurso público sempre terão de se haver com uma saraivada de impugnações e denúncias de toda ordem." (ABREU DALLARI, Adilson. Princípio da isonomia e concurso público, en Concurso público e Constituição, Fabrício Motta (Cordinador), Editora Fórum, Belo Horizonte, 2005, p. 99).
} 
gobierno y, con ello, llevando adelante las políticas e ideales en los que creen. En los países más clientelares, por el contrario, todos los miembros del out group aspiran a lograr un beneficio personal por su apoyo, su voto y el de su familia. El resultado es que generan unas presiones muy fuertes, cuando se llega al gobierno, para acomodar a todos los miembros de los grupos de apoyo, y la Administración se convierte necesariamente en el objeto y lugar donde repartir el botín. Pero si se bloquea la entrada a la Administración por razones de afinidad partidista, y se crea un ámbito meritocrático, todos los miembros del out group tendrán que reconfigurar su horizonte de expectativas y con ello dejarán de presionar por obtener puestos públicos. El voto y la militancia, entonces, se moralizan, dejan de vincularse al interés personal." ${ }^{273}$

Así, es cada vez más evidente la necesidad de una mejor definición normativa de las políticas de reclutamiento como forma de prevención de la corrupción y todas sus variantes, para que el principio constitucional del mérito y de la capacidad puedan prevalecer en cualquier circunstancia, lo que garantizará la objetividad, la imparcialidad y la eficacia administrativa.

Por supuesto, la preocupación con las prácticas clientelistas no solo debe existir en los países no desarrollados, aunque en estos la situación es agravada. En verdad, lo que puede diferenciar los países en su grado de inquietud respecto a los mencionados problemas y la eficacia de las medidas utilizadas para combatirlos, como advierte la propia doctrina española:

\footnotetext{
"Es preciso reconocer que el clientelismo no es una patología de la acción política cuyo espacio de acción se reduzca a Latinoamérica. El clientelismo existe en todas las democracias. Lo que diferencia cierto tipo de clientelismo débil y difuso de un clientelismo patrimonialista y sistémico es, precisamente, la presencia de un servicio civil de carrera fuertemente asentado como institución del régimen."274
}

\footnotetext{
${ }^{273}$ VILLORIA MENDIETA, Manuel. El servicio civil de carrera en Latinoamérica: diagnóstico, causas y propuestas. Instituto Nacional de Administración Pública - INAP, Madrid, 2007, p.111.

${ }^{274}$ VILLORIA MENDIETA, Manuel. Op.cit., p.110.
} 
Además, se impone que tras la selección, la Administración Pública pueda ofrecer a los funcionarios públicos las debidas condiciones que permitan que en sus actuaciones, predominen la técnica, la objetividad y la imparcialidad. Para tal objetivo:

\begin{abstract}
“os agentes que exercem funções típicas e finalísticas de Estado (funções essenciais), além de terem a garantia de aceso impessoal do concurso público, merecem a proteção de robustos anteparos formais e substanciais contra voluntarismos persecutórios ou enxugamentos fiscais lineares. E merecem tratamento diferenciado também em termos previdenciários, sem que isso configure qualquer privilégio. Tais anteparos não devem servir, está claro, para a acomodação dos agentes públicos, mas para que possuam couraça num mundo de estonteante volatilidade e promovam o "bem de todos", em lugar da obediência acrítica aos chefes ou poderosos da hora"275
\end{abstract}

\title{
2.1.1.5 - Acceso a la función pública en condiciones de igualdad como derecho de participación del ciudadano
}

Es posible afirmar que el derecho de acceso a las funciones públicas es una derivación de la propia democracia, ya que posibilita que los ciudadanos, que así deseen y siempre que cumplan los requisitos señalados en las leyes, puedan tomar parte de las decisiones políticas.

La relación entre las oposiciones y concursos y la democracia es más amplia de lo que muchos puedan suponer. En un Estado que sea efectivamente democrático, todos los ciudadanos deben tener la posibilidad de participar en la vida pública, y el ordenamiento jurídico debe ofrecer oportunidades iguales a todos los interesados.

En el derecho español, el primer apartado del art. $23 \mathrm{CE}$, que establece el derecho de participación del ciudadano en los asuntos públicos, y el segundo apartado del mismo artículo, que trata del acceso a las funciones y cargos públicos, traducen el régimen democrático de la Constitución española de 1978.

\footnotetext{
275 FREITAS, Juarez. Carreiras de Estado e o direito fundamental à boa administração, artículo publicado en Interesse Público - Revista Bimestral de Direito Público, no 53, Editora Forum, São Paulo, 2009, p. 27.
} 
Así, aunque los apartados del art. $23 \mathrm{CE}$ traten de situaciones en cierto aspecto distintas (el primero atribuye al ciudadano, de forma genérica, legitimidad para el ejercicio del poder, directamente o por medio de representantes, y el segundo garantiza la igualdad de acceso a funciones y $\operatorname{cargos}_{\text {públicos }}{ }^{276}$, donde prevalece la naturaleza técnica de las plazas), estos tienen puntos comunes, en especial, la legitimación concedida al ciudadano con el fin de estar preparado para formar parte de la vida del Estado. ${ }^{277}$

En esta dirección, “...los derechos a participar de los asuntos públicos y a acceder en condiciones de igualdad a funciones y cargos, guardan estrecha relación con el sistema democrático.,"278

La doctrina afirma que el sistema de acceso meritorio a las funciones públicas es un principio de justificación democrática tan sólido como el principio electivo: "una competición por los votos frente a una competición sobre la aptitud profesional porque los espacios a ocupar requieren en un caso el mayor apoyo popular y en otro el mayor nivel de excelencia.",279

Como observa la doctrina:

"respecto de las oposiciones se han esgrimido muchos argumentos a favor y en contra. Frente a quienes mantienen que son una pura repetición de conocimientos que en muchos casos no conlleva, siquiera, su correcto aprendizaje y comprensión, hay quien ha dicho

\footnotetext{
${ }^{276}$ Como el tema de esto trabajo se limita al estudio de la incidencia de la igualdad en el acceso a la función pública, conviene hacer mención a la distinción entre cargos y funciones públicas. En este sentido, “...cabe señalar que, de la mano de la jurisprudencia constitucional que, bajo la expresión cargos y funciones públicas, caben dos nociones diversas: cargo representativo y cargo funcionarial o, más ampliamente, no representativo. El primero, - fruto de la intelección de los apartados 1 y 2 del precepto - hace referencia a los cargos que expresan una representación política, lo que se predica de los cargos parlamentarios nacionales, autonómicos, diputados provinciales y Concejales. El segundo contempla los llamados cargos funcionariales." (PULIDO QUECEDO, Manuel. El acceso a los cargos y funciones públicas (Un estudio del articulo 23.2 da la Constitución), Parlamento de Navarra, Editorial Civitas S.A., Madrid, 1992, p. 71).

${ }^{277}$ En este sentido, subraya la doctrina que el derecho de acceso a cargos y funciones públicas pertenece al género de los derechos de participación política, reconocido al hombre en su condición de ciudadano que vive en un Estado, al citoyen. (PULIDO QUECEDO, Manuel. Op.cit., pp. 54-55).

${ }^{278}$ RIVERO ORTEGA, Ricardo. Acceso a la función pública autonómica y doctrina constitucional (Comentario a la STC de 11 d febrero de 1989), Revista de Administración Pública, número 151, eneroabril 2000, Madrid, p. 344.

${ }^{279}$ PARADA, Ramón. Derecho administrativo II, organización y empleo público, 20 ed., Marcial Pons, Madrid, 2008, p. 362.
} 
que es la única institución realmente democrática que conoce nuestro derecho público desde 1812." 280

Otro aspecto poco comentado es la necesidad del Poder Público de promover la participación de todos los ciudadanos, en especial, en la vida política. Sobre esa cuestión, advertida en el art. $9.2^{281}$ de la Constitución española, cabe subrayar que:

“...es necesario que el ciudadano tenga la posibilidad de ejercer un control directo de la toma de decisiones de sus representantes e incluso de tomar decisiones o al menos expresar sus ideas sobre éstas para que los representantes no olviden a su electorado y no se distancien de él en el periodo que dura dita representación."282

Parece evidente, aunque poco comentado por la doctrina española, que los Poderes Públicos deban proporcionar de forma ecuánime a todos los individuos las más distintas oportunidades, incluso en la vida política, y la posibilidad de ejercicio de funciones públicas es una ocasión ciertamente especial, gracias a que permite que el ciudadano desempeñe las más diversas tareas de la Administración Pública.

En el derecho brasileño, se puede percibir claramente que la Constitución de 1988 no fue tan expresa como la española, respecto a la declaración del derecho del ciudadano participar de los asuntos públicos. En este sentido, lo que la Carta Magna brasileña estableció fue que "Todo o poder emana do povo, que o exerce por meio de representantes eleitos ou diretamente, nos termos desta Constituição" (artículo $1^{\circ}$, párrafo único), y que: “A soberania popular será exercida pelo sufrágio universal e pelo voto direto e secreto, com valor igual para todos, e, nos termos da lei, mediante: I - plebiscito; II - referendo; III - iniciativa popular" (art. 14, I, II y III).

\footnotetext{
${ }^{280}$ PALOMAR OLMEDA, Alberto. Derecho de la función pública: régimen jurídico de los funcionarios públicos, 7 ed., Dykinson, Madrid, 2003, p.301.

${ }^{281}$ La última parte de la mencionada norma constitucional es de una clareza asombrosa "Art. $9^{\circ} .2$. Corresponde a los poderes públicos promover las condiciones para que la libertad y la igualdad del individuo y de los grupos en que se integra sean reales y efectivas; remover los obstáculos que impidan o dificulten su plenitud y facilitar la participación de todos los ciudadanos en la vida política, económica, cultural y social."

${ }^{282}$ SÁNCHEZ SÁNCHEZ, Zulima. Estudio práctico de las asociaciones, democracia directa y otras formas de participación ciudadana, doctrina, jurisprudencia y formularios, Editorial Lex Nova, 2004, Valladolid, p. 88.
} 
Si es verdad que la generalidad de la redacción utilizada por la Constitución brasileña decepciona, especialmente cuando comparada con la claridad el art. 23, I, de la Constitución española, también lo es que la referida ausencia de especificidad ha permitido el desarrollo de variadas posibilidades de participación ciudadana, que necesariamente no se limitan a las modalidades previstas en el art. $14 \mathrm{CB}$ (plebiscito, referéndum y iniciativa popular para empezar el proceso legislativo).

En este camino:

“em que pese a não restar previsto como direito essencialmente político no art. 14 da CF/88 (exercício da soberania popular), tem-se que o art. 37, II do mesmo diploma normativo, em uma análise mais ampla, ao instituir o direito de acesso do povo a cargos ou empregos públicos, findou exatamente por dar cumprimento ao parágrafo único do art. $1^{\circ}$ da $\mathrm{CF} / 88$, de forma a permitir que o titular do poder político possa participar diretamente de seu exercício, robustecendo e garantindo o princípio democrático (democracia participativa)." ${ }^{283}$

En el contexto delineado, el acceso a la función pública es considerado por muchos doctrinadores brasileños como un relevante mecanismo de participación del ciudadano en las actividades estatales. Para determinados juristas, "a forma republicana do Estado, consagrada no art. $1^{\circ}$ da Constituição Federal, confere a todos os cidadãos o direito de participar da Administração Pública, seja direta ou indiretamente, o que inclui o exercício de cargos e empregos públicos."284

Se puede percibir que la doctrina brasileña admite una doble posibilidad de participación ciudadana a través del ejercicio de cargos públicos. Así, se puede destacar que "como o poder emana do povo, é indispensável no Estado Democrático (art. $1^{\circ}$ da $\mathrm{CF} / 88$ ), que ele chegue ao exercício do poder político, mediante mandato eletivo ou mediante concurso público. O primeiro traduz a legitimidade e a representatividade popular; o segundo, o mérito do agente (aspecto técnico). ${ }^{285}$ En otra oportunidad, ya se afirmó que "tanto o titular do cargo político quanto o do cargo administrativo integram,

\footnotetext{
${ }^{283}$ MACHADO JÚNIOR, Agapito. Concursos públicos, Editora Atlas, São Paulo, 2008, p. 12. ${ }^{284}$ LOBELLO DE OLIVEIRA ROCHA, Francisco. Op.cit., p. 51.

${ }^{285}$ MACHADO JÚNIOR, Agapito. Op.cit., p. 12.
} 
na condição de agentes, a pessoa política, e o direito a aceder a cada qual deles é o exercício político da cidadania."286

En realidad, muchos doctrinadores, sean constitucionalistas o administrativistas, han destacado las variadas posibilidades de participación del ciudadano en la actividad administrativa. Respecto a la referida modalidad de ejercicio de la ciudadanía, se puede afirmar que:

\begin{abstract}
“A participação administrativa não só por essa apreciável abrangência, mas pela potencialidade, que apresenta, de assumir diversas modalidades, muitas delas sem necessidade de expressa previsão constitucional, desponta como uma solução de especial interesse para o Direito Público contemporâneo, cada vez mais comprometido com a realização da legitimidade." ${ }^{287}$
\end{abstract}

A su vez, en el ámbito de la participación administrativa, el ejercicio de función pública ocupa un relevante espacio de la experiencia democrática, otorgando al ciudadano la posibilidad de intervención en la vida social, la medida en que desarrolla una actividad de la Administración Pública. Por esa razón, se ha afirmado que "talvez seja o concurso público uma das maiores contribuições que o Direito Administrativo prestou à democracia."288

La discusión relativa al ejercicio o no de poder político por el funcionario público existe, aunque la mayoría de los juristas brasileños reconoce su presencia. Así, se entiende que "existe, assim, um verdadeiro direito de acesso aos cargos, empregos e funções públicas, sendo o cidadão e o estrangeiro, na forma da lei, verdadeiros agentes

\footnotetext{
286 ANTUNES ROCHA, Cármen Lúcia. Princípios constitucionais dos servidores públicos, Editora Saraiva, São Paulo, 1999, p. 145.

287 FIGUEIREDO MOREIRA NETO, Diogo de. Direito da participação política: legislativa, administrativa, judicial (fundamentos e técnicas constitucionais da legitimidade), Editora Renovar, Rio de Janeiro, 1992, p. 87.

${ }^{288}$ BRAGA CALHAU, Lélio. Da inconstitucionalidade da decisão irrecorrivel de bancas examinadoras de concurso público. Texto extraído del sitio: http://jus2.uol.com.br/doutrina/texto.asp?id=390.
} 
do poder, no sentido de ampla possibilidade de participação da administração pública."289

También hay aquellos que sostienen que el concurso público "é o veículo constitucional apto a tornar qualquer do povo um servidor público (em sentido amplo). É o titular do poder político (povo) passando a participar diretamente de seu exercício (servidor público), como órgão da Administração Pública (direta ou indireta), prezandose, pois, a democracia participativa",290

Para que no quede duda respecto al reconocimiento del carácter de participación democrática a través del ejercicio de la función pública en la doctrina brasileña, se puede destacar que en todos los momentos de la dinámica administrativa: "o administrado há que estar presente como elemento democrático a fundamentar a atividade estatal. Esta participação igual faz-se, primária e principalmente, pelo princípio da acessibilidade aos cargos públicos por todos os brasileiros dotados de condições legais para o seu provimento"291

El mencionado principio de accesibilidad a los cargos públicos es subrayado por diversos juristas brasileños:

\begin{abstract}
"o princípio da acessibilidade decorre dos princípios democráticos informadores da organização do Poder Público no Estado de Direito como hoje concebido. Tem-se que o princípio democrático como informador da acessibilidade aos cargos públicos porque ele impõe a participação plural e universal dos cidadãos na estrutura do Poder Público. É direito do cidadão participar do Poder Público, inclusive compondo os seus quadros na qualidade jurídica de servidor. ${ }^{292,}$
\end{abstract}

\footnotetext{
${ }^{289}$ MORAES, Alexandre de. Direito constitucional. 21ª ed., Editora Jurídico Atlas, São Paulo, 2007, p. 326.

${ }^{290}$ MACHADO JÚNIOR, Agapito. Op.cit., p. 6.

291 ANTUNES ROCHA, Cármen Lúcia. O principio constitucional da igualdade. Editora Lê, Belo Horizonte, 1990, p. 96.

${ }^{292}$ ANTUNES ROCHA, Cármen Lúcia. Princípios constitucionais dos servidores públicos, Editora Saraiva, São Paulo, 1999, p. 114.
} 
Sin embargo, de la misma forma que el Estado debe preocuparse con la igualdad en las elecciones, a fin de que los candidatos que poseen las mejores condiciones económicas no suplanten a los menos afortunados, también se debe destacar que "no Estado Democrático de Direito, há que se obrigar as entidades políticas a cuidar para que todos os cidadãos se dotem das condições materiais, intelectuais, psicológicas, políticas e sociais mínimas que os habilitem à disputa do cargo, da função e do emprego público."293

\subsection{2 - El derecho de acceso a las funciones públicas en condiciones de igualdad}

Pese a la existencia del referido derecho en los dos ordenamientos jurídicos analizados en este trabajo (y a los diversos puntos comunes), a partir de ahora, serán hechas consideraciones específicas respecto a la incidencia de las normas que garantizan el acceso igualitario en el sistema constitucional español y brasileño.

Como ya se ha destacado, inicialmente, será analizado el contexto español, para que, a continuación, sean expuestas las observaciones relativas a la realidad brasileña, lo que permitirá la comparación entre los dos órdenes constitucionales.

Cabe ratificar que cuando se realiza un estudio comparativo de dos sistemas jurídicos, no sólo serán encontrados puntos de distinción, sino también de conexión entre ellos. En este contexto, las consideraciones que serán acentuadas en relación a cada ordenamiento, en gran medida y con las debidas adaptaciones (jurídicas, sociales, políticas, históricas, etc.), servirán para la aportación de datos y reflexiones muy relevantes para la comprensión del otro, lo que enriquecerá el debate en el mencionado medio jurídico académico.

Es que las experiencias de cada sistema jurídico, sean ellas positivas o negativas, deberán ser conocidas por los hacen parte del otros sistemas, lo que permitirá la adopción de las medidas adecuadas y el rechazo de las infructíferas.

293 ANTUNES ROCHA, Cármen Lúcia. Princípios constitucionais dos servidores públicos, Editora Saraiva, São Paulo, 1999, p. 149. 


\subsubsection{1 - En la Constitución española de 1978}

\subsubsection{1 - El derecho de acceso a las funciones públicas en condiciones de igualdad como derecho de carácter reaccional}

Inicialmente, conviene decir algunas notas sobre el significado del derecho que será analizado a continuación. El derecho de acceso a la función pública en condiciones de igualdad, en el derecho español, seguramente tiene un contenido propio, aunque este no garantice el derecho a la ocupación de puestos de trabajo en la Administración Pública, ni tampoco el derecho de proponerse como aspirante en un procedimiento selectivo para la función pública.

En verdad, tiene un carácter de derecho reaccional de configuración legal ${ }^{294}$, circunstancia que no disminuye la relevancia del sobredicho derecho. En los términos anteriormente expresados:

"El artículo 23.2 CE no confiere derecho alguno a desempeñar funciones determinadas, ni siquiera el derecho a proponerse como candidato a las mismas, sino que garantiza a los ciudadanos una situación jurídica de igualdad en el acceso a las funciones públicas, con la consiguiente imposibilidad de establecer requisitos para acceder a las mismas que tengan carácter discriminatorio, y otorga un derecho de carácter puramente reaccional para impugnar ante la justicia ordinaria, y, en último extremo, ante el Tribunal Constitucional toda norma o aplicación concreta de una norma que quiebre la igualdad..."295

Una observación más sobre el alcance de carácter reaccional del derecho previsto en el art. 23.2 CE debe ser aquí indicada:
"legitima la reacción contra las normas que configuran el procedimiento de selección permitiendo a los ciudadanos impugnar las bases de una convocatoria que puedan considerarse discriminatorias y,

\footnotetext{
${ }^{294}$ MAURI BAJÓS, Joan. Capítulo Cuarto del libro "El acceso al empleo público", Manual de Empleo Público, Federico A. Castillo Blanco (Director), Javier E. Quesada Lumbreras (Coordinador), primera edición, Ilustel, Madrid, 2009., p. 254.

${ }^{295}$ CAVAS MARTINÉZ, Faustino. El Estatuto Básico del Empleado Público. Comentario Sistemático de la Ley 7/2007, de 12 de abril de 2008, José Luis Monareo Perez y otros (dirección y cordinación), Editorial Comares, Granada, 2008, p.586.
} 
en segundo lugar, garantiza la aplicación de esas bases de una forma igual a todos los aspirantes, impidiendo que la Administración pública, mediante una interpretación o una aplicación indebida de la regulación existentes, establezca diferencias no predeterminadas entre los candidatos.(STC 115/67, de 18 de abril, y 37/2004, de 11 de marzo)." 296

Así, el derecho previsto en el art. 23.2 CE permitirá que el aspirante a la función pública utilice los instrumentos de control dispuestos en el ordenamiento jurídico (sean administrativos o jurisdiccionales) para impedir actuaciones ilegítimas, siempre que la Administración Pública establezca las normas del procedimiento selectivo que no respeten las exigencias de igualdad y mérito, y cuando, aunque las bases de la convocatoria hayan sido establecidas de forma legal, la aplicación e interpretación de las mismas no ocurran según la razonabilidad y proporcionalidad.

No son pocas las posibilidades de transgresión del derecho de acceso a la función pública en condiciones de igualdad y que pueden, consecuentemente, ser objeto de cuestionamiento de los candidatos. Partiendo de un análisis simplificador, se halla la hipótesis de transgresión de la igualdad tanto en la definición de las reglas de la selección de los funcionarios, como en la conducción del proceso selectivo llevado a cabo por la Administración Pública.

En el primer caso, las bases de la convocatoria pueden señalar requisitos que no respeten la igualdad, estableciendo exigencias de carácter discriminatorio a los aspirantes. En esa materia, cuestiones que envuelven conocimientos lingüísticos, de edad, de género, de condición física, titulación, religión, nacionalidad, experiencia profesional, entre otras, podrán, en determinadas condiciones, violar el derecho fundamental analizado.

Estas cuestiones, que serán desarrolladas en el segundo capítulo de este trabajo, merecen un estudio anterior al análisis del procedimiento, ya que podrán impedir la inscripción de los interesados, cuando estos no cumplan los requisitos señalados ilegítimamente por la Administración Pública.

${ }^{296}$ MAURI BAJÓS, Joan. Op.cit., p. 254. 
En cambio, aunque los requisitos de participación hayan sido definidos de forma adecuada, cabe añadir que, aun en la elaboración de las reglas del proceso de selección, es posible que ocurra la violación del derecho de acceso a la función pública en condiciones de igualdad a partir de la definición indebida de las normas del procedimiento administrativo de competición.

Sobre esta cuestión, que será el objeto del tercer capítulo de este trabajo, ya se puede adelantar que en cada una de las reglas elaboradas que tratan de las fases del procedimiento, sea en sus actos meramente internos (por ejemplo, la composición y formación del Tribunal de selección) o externos, que cuentan con la participación de los aspirantes (normas sobre solicitudes de inscripción, realización de las pruebas, aportación de documentos, etc.), existen amplias posibilidades de que haya la redacción de reglas procedimentales que se alejan de los vectores constitucionales.

Como antes he subrayado, la violación de la igualdad también se manifiesta en la aplicación de las normas elaboradas por la Administración. Ciertamente, si la norma ya está maculada, su aplicación repetirá el vicio preexistente. Es la primera posibilidad de transgresión.

Sin embargo, es posible, e incluso usual, que en la aplicación de las normas del procedimiento, la transgresión de la igualdad se lleve a término aunque aquellas hayan sido redactadas de forma adecuada. Eso podría suceder de dos maneras: cuando la Administración Pública incumple las bases de la convocatoria, o cuando debido a la omisión, insuficiencia o falta de claridad de las normas administrativas, la Administración es llevada a tomar decisiones que no están plenamente regladas. En este punto, donde la discrecionalidad administrativa es reclamada, hay muchísimos conflictos que corrientemente llegan al Poder Judicial.

En resumen, el carácter meramente reaccional del derecho previsto en el art. 23.2 CE, lo que, en un primer momento podría ser comprendido como una limitación, permite un amplio control de todos los actos de la selección de funcionarios, entendimiento consagrado por el Tribunal Supremo en diversas oportunidades, como se verá a continuación:

"Lo que otorga el art. 23.2 como concreción del principio de igualdad

- STC 23-4-86 (R.T. Const. 50) - es un derecho de carácter 
puramente reaccional para impugnar ante la jurisdicción ordinaria y en último término constitucional, toda norma o toda aplicación concreta de una norma que quiebra la igualdad...,"297

\subsubsection{2 - El derecho de acceso a las funciones públicas en condiciones de igualdad como derecho de configuración legal}

Para que el derecho fundamental del art. 23.2 CE pueda ser ejercido, será necesario que las leyes instituyan las condiciones para la definición de los requisitos de acceso y del procedimiento de selección a la función pública. Así, además de su carácter reaccional, el sobredicho derecho es de configuración legal.

En los términos anteriormente previsto, "la ley se configura como elemento determinante, desde un punto de vista constitucional, para establecer los requisitos que delimiten el derecho de acceso a las funciones públicas."298

A pesar de ello, hay opiniones en la doctrina española que sostienen que los requisitos para el acceso a la función pública pueden ser establecidos mediante leyes, o por medio de normas reglamentarias cuando haya una anterior remisión legislativa que lo autorice. ${ }^{299}$ Así, en la medida que ostenta la condición de derecho de configuración legal, el derecho previsto en el art- 23.2 CE solamente comportaría delimitación al ser realizada por el legislador, o mediante su autorización, por el reglamento.

La exigencia de reserva de ley establecida en el art. 23.2 (...con los requisitos que señalen las leyes), también fue prevista en el art. 103.2 (La ley regulará el estatuto de los funcionarios públicos, el acceso a la función pública de acuerdo con los principios de merito y capacidad...). Lo que la doctrina y los Tribunales admiten es la posibilidad de remisiones normativas, lo que ocurriría cuando la ley, delante de la dificultad del establecimiento completo de reglas casuísticas para cada función pública, autorizara, dentro de ciertos límites, la previsión por reglamento de determinadas cuestiones relativas al acceso a las referidas funciones.

\footnotetext{
${ }^{297}$ STS de 24 de mayo de 1989 (Ar. 3907).

${ }^{298}$ PALOMAR OLMEDA, Alberto. Derecho de la función pública: régimen jurídico de los funcionarios públicos, 7 ed., Dykinson, 2003, Madrid, p. 105.

${ }^{299}$ FÉREZ, Manuel. El sistema de mérito en el empleo público: principales singularidades y analogías respecto del empleo en el sector privado. Documentación Administrativa, n. 241-242, enero-agosto, 1995, Madrid, p. 61-123, p. citada 64.
} 
En el camino arriba citado, el Tribunal Constitucional decidió que:

"no cabe admitir que el último inciso del artículo 23.2 de la Constitución resulte vulnerado por el solo hecho de que los requisitos para acceso a la promoción a un determinado cargo o función dentro de la Administración Pública se establezcan por norma reglamentaria, ya que ello es lícito y posible según la Constitución...sería ilógico exigir del legislador una previsión casuística del contenido de los requisitos para acceder a cualquier cargo o función en el seno de la Administración, pues dichos requisitos "habrán de variar sustancialmente en cada caso.",, 300

Indudablemente, lo que va a definir el carácter lícito o no de las remisiones normativas es la existencia, en la ley autorizadora, de límites ciertos y la naturaleza no incondicionada ${ }^{301}$ de las dichas remisiones. ${ }^{302}$

Una situación concreta que puede ayudar a la comprensión de la función del reglamento en la definición de las normas de acceso a la función pública es el contexto específico del acceso de las personas con discapacidad.

En este caso, aunque sean las leyes las que establecen las cuestiones básicas sobre el trato distinto que las personas con discapacidad deben recibir de la Administración Pública, son los reglamentos los que hacen posible la aplicación de los dispositivos legales.

Así, mientras la Ley 51/2003, del 2 de diciembre, de igualdad de oportunidades, no discriminación y accesibilidad universal de las personas con

\footnotetext{
${ }^{300}$ STC 47, de 20 de marzo de 1990

${ }^{301301}$ De forma muy clara, el Tribunal Constitucional, en la STC 99/1987, decidió que: "En el ámbito de la función pública había de ser sólo la Ley la fuente introductora de las normas reclamadas por la Constitución...no siendo posible el legislador disponer de la reserva misma a través de remisiones incondicionales, o carente s de límites ciertos y estrictos pues ello entrañaría un desapoderamiento del Parlamento a favor de la potestad reglamentaria que sería contrario a la norma constitucional merecedora de reserva. En relación a los ámbitos reservados por la Constitución a la regulación por ley no es, pues, imposible una intervención auxiliar o complementaria del Reglamento, pero siempre - como se señaló en la STC 83/1984, de 24 de julio - que estas remisiones sean tales que restrinjan, efectivamente, el ejercicio de esa potestad reglamentaria a un complemento de la regulación legal, que sea indispensable por motivos técnicos para optimizar el cumplimiento de las finalidades propuestas por la Constitución o por la propia Ley, de tal modo que no se llegue a una total abdicación por parte del Legislador para establecer reglas limitativas, transfiriendo esta facultad al titular de la potestad reglamentaria, sin fijar ni siquiera cuáles son los fines y objetivos que la reglamentación ha de perseguir."

${ }^{302}$ PULIDO QUECEDO, Manuel. Op.cit., p. 88.
} 
discapacidad, determina en su art. $1^{\text {o }} .2$ quiénes son las mencionadas personas, y la Ley 7/2007 (Estatuto Básico del Empleado Público), en su art. 59, garantiza el cupo de plazas en las ofertas de empleo público para dichas personas, el Real Decreto1971/1999 es el instrumento normativo utilizado para establecer cómo se determinan los porcentajes de minusvalía que padecen algunas personas, y, a su vez, el Real Decreto 2271/2004 regula, con la ayuda del Orden Ministerial PRE/1822/2006, de 9 de julio, la cuestión de la concesión de un tiempo adicional para la realización de los ejercicios por los aspirantes con discapacidad, lo que es necesario para hacer efectivo el derecho garantizado por ley.

De la misma forma que hay demarcaciones para la utilización de la remisión normativa, también es evidente que no será cualquier delimitación al derecho de igualdad de trato definida por el legislador la que podrá ser admitida. Sobre esa cuestión, se puede afirmar que en relación a los derechos de configuración legal, el legislador no está autorizado a trasponer el límite del contenido esencial de los $\operatorname{mismos}^{303}$, siendo responsabilidad del Tribunal Constitucional la revisión del mencionado contenido.

La cuestión clave es analizar bajo qué circunstancias es posible delimitar el derecho mencionado. Ciertamente, esa respuesta no es fácil. Sin embargo, la propia Constitución ofrece la solución, cuando establece, en el art. 103.3, que el acceso a la función pública ocurrirá de acuerdo con los principios de mérito y capacidad.

Si la ley puede establecer las condiciones para el acceso a las funciones públicas, respetados los parámetros constitucionales arriba citados, es imprescindible decir que la adecuación de tales condiciones a las actividades que serán desempeñadas por el funcionario y la proporcionalidad de sus disposiciones son esenciales para garantizar la legitimidad de la ley.

Cabe añadir que toda delimitación de una situación jurídica que, en principio, es de igualdad, debe tener en consideración diversas circunstancias, y muchas de ellas solamente estarán presentes en cada caso. Justamente, debe ser aludido que:

\footnotetext{
${ }^{303}$ PULIDO QUECEDO, Manuel. Op.cit., p. 61.
} 
"La igualdad está configurada como un derecho subjetivo de los ciudadanos a obtener un trato igual."- La igualdad no puede valorarse en abstracto, pues ha de entenderse y enjuiciarse siempre en función de las circunstancias que concurren en cada caso concreto. Requiere su aplicación, pues, siempre una operación de comparación, pues se trata de un derecho-principio relativo. - Encierra desde logo la prohibición de discriminación, pero esta prohibición no es absoluta o incondicionada." $" 304$

Así que, cabrá al Tribunal designado por la Administración la conducción de los trámites administrativos que tienen como misión establecer las bases de realización del proceso selectivo, mediante la elaboración de convocatorias, y aplicarlas, con los mismos criterios, a todos los postulantes.

En el establecimiento de las normas reguladores del proceso selectivo (oposición, concurso o concurso-oposición), el Tribunal debe tener en cuenta la adecuación entre las exigencias y las funciones públicas que serán cubiertas (principios de la razonabilidad), no debe utilizarse un grado de exigencia muy superior o muy inferior del necesario para la evaluación de los conocimientos de los aspirantes (principio de la proporcionalidad), debe destinar esfuerzos para la selección de los más aptos (principio de mérito y capacidad), y, por fin, no puede utilizar criterios discriminatorios (principio de igualdad).

Por fin, el Tribunal Constitucional ya destacó que la vulneración del principio de igualdad en el acceso a las funciones públicas sólo ocurre cuando hay una desigualdad que introduce:

“...diferencia entre situaciones que pueden considerarse iguales y que carece de una justificación objetiva y razonable, es decir, el principio de igualdad exige que a iguales supuestos de hecho se apliquen iguales consecuencias jurídicas, debiendo considerarse iguales dos

\footnotetext{
${ }^{304}$ SANTAMARIA PASTOR, Juan Alfonso y PAREJO ALFONSO, Luciano. Derecho Administrativo: la jurisprudencia del Tribunal Supremo, Editorial Centro de Estudios Ramon Areces S.A., 1989, Madrid, p. 169.
} 
supuestos de hecho cuando la utilización o introducción de elementos

diferenciadores sea arbitraria o carezca de fundamento racional." 305

\subsubsection{3 - El alcance del derecho previsto en el art. 23.2 CE}

Sobre el alcance de dicho derecho, aunque el tema de este trabajo se limite al análisis del acceso a la función pública, lo que impone exclusivamente el estudio de la selección de funcionarios ${ }^{306}$, cabe añadir que la norma del art. 23.2 CE alcanza tanto la competición para plazas que serán ocupadas por funcionarios, como también para el acceso del personal laboral, debido a que en las dos situaciones, los principios constitucionales de igualdad (art.14), mérito y capacidad (art. 103.3) serán aplicados.

La afirmación arriba citada la confirman diversos juristas, que enfatizan en que la incidencia de los principios constitucionales de igualdad, mérito y capacidad, como obligatorios a toda la selección de personal realizada por la Administración Pública, lo que derogaría el argumento contrario, que está basado en la libertad de contratación de toda empresa, asegurada por el art. 38 CE. ${ }^{307}$

\footnotetext{
${ }^{305}$ Sentencia del Tribunal Constitucional 86, de 10 de mayo de 2004.

${ }^{306}$ En la nota 114, se ha destacado que el presente trabajo contempla el estudio del acceso a las funciones públicas, y no a los cargos públicos (de naturaleza representativa). También es relevante subrayar que este trabajo científico tiene en consideración la distinción de régimen jurídico de los empleados públicos consagrada en el derecho español, entre funcionarios y personal laboral, división que fue recogida en el Estatuto Básico del Empleado Público. Destaca Sánchez Morón QUE, "El EBEP, como se ha dicho, recoge esta división, pues, conforme a las razones del Informe que lo preparó, no ha entendido oportuno ni realista unificar la naturaleza del régimen jurídico aplicable a todos los empleados públicos. De hecho, en nuestro país el proceso de laboralización generalizada del empleo público que ha tenido lugar en otros no hubiera sido posible, por razones constitucionales expuestas en el capitulo anterior, así como por tradición y otras razones políticas de peso. Pero tampoco resultaba viable la funcionarización del personal, ya que tras el desarrollo de la contratación laboral en el sector público se encuentran razones de conveniencia, ligadas a la búsqueda de una mayor flexibilidad de las relaciones de empleo y de gestión de personal, que están lejos de desaparecer." (SÁNCHEZ MORÓN, Miguel. Op.cit., p. 64).

${ }^{307}$ Así, "la Administración en el momento de proceder a la contratación de personal no tiene la misma libertad que un empresario privado, pues se encuentra sometida a una serie de principios constitucionales que se proyectan sobre la totalidad del empleo público, en concreto, nos referimos a las previsiones de los artículos 14 y 103.1 de la Constitución Española, e igualmente el artículo 23.2, si bien con respecto a este último no existe un consenso al respecto, pero anticipamos que a nuestro entender la totalidad del empleo público se encuentra bajo la proyección del contenido de este precepto..." (FONDEVILA ANTOLÍN, Jorge. Constitución y empleo público. Estudios y propuestas en relación a un régimen jurídico común, Comares, Granada, 2000, p. 202).
} 
La doctrina española ha destacado que "es indudable que aunque sea por la vía genérica del artículo $14 \mathrm{CE}$ los ciudadanos son titulares del derecho fundamental a acceder en condiciones de igualdad al empleo público en régimen laboral". 308

En el camino arriba destacado, que garantiza la objetividad del procedimiento selectivo del personal laboral de la Administración Púbica, el EBEP (Ley 7, de12 de abril de 2007) impone, de forma genérica, el sistema de acceso meritorio en su art. $55.1^{309}$.

En resumen, si todos los españoles son iguales ante la Ley (art. $14 \mathrm{CE}$ ), y si es imprescindible que las decisiones administrativas sean conducidas por criterios objetivos e imparciales (art. 103.1 CE) y que las preferencias personales de los gestores públicos no puedan caracterizar la acción de la Administración, es esencial que haya la exigencia general de que los Poderes Públicos, cuando tengan que seleccionar funcionarios públicos, conduzcan a un procedimiento administrativo que sea, simultáneamente, de carácter abierto al público, para garantizar la participación de los ciudadanos en condiciones de igualdad, pero caracterizado por el rigorismo, para que solamente sean aprobados aquellos aspirantes que indudablemente ostenten efectivas condiciones técnicas de desempeñar con eficacia las actividades de su función.

El postulado arriba citado se aplica para todos los entes de la Administración (estatal, autonómica y local), y envuelve tanto a los funcionarios de carrera como al personal laboral, ya que aunque el régimen jurídico de las sobredichas categorías sea distinto, el fundamento para la exigencia de igualdad, objetividad y sumisión a criterios meritorios se mantiene en los dos casos.

\subsubsection{4 - EI acceso meritorio como mandamiento constitucional.}

Como ya se ha destacado anteriormente, existen algunas características esenciales de la actividad de la Administración Pública que repercuten directamente en la actuación de los funcionarios públicos. En este sentido, se puede afirmar que:

\footnotetext{
308 BAUTISTA VIVERO SERRANO, Juan. El acceso al empleo público en régimen laboral tras el estatuto básico del empleado público: algunas luces y demasiadas sombras, Revista Española de Derecho Administrativo, $n^{\circ} 143$, julio-septiembre 2009, p. 426.

309 "Todos los ciudadanos tienen derecho al acceso al empleo público de acuerdo con los principios constitucionales de igualdad, mérito y capacidad, y de acuerdo con lo previsto en el presente Estatuto y en el resto del ordenamiento jurídico."
} 
"si la Administración pública actúa de acuerdo con el principio de eficacia, con sometimiento pleno a la ley y el Derecho y sirviendo con objetividad los intereses generales, resultaría que a la función pública y a los funcionarios públicos corresponden como notas la objetividad, la eficacia y el conocimiento del ordenamiento jurídico. Las notas anteriores conducen a otra nota que es la de la permanencia..."310

Así, para que los funcionarios públicos puedan actuar de forma eficaz, es imprescindible que estos sean seleccionados a través de criterios que tengan en consideración las habilidades necesarias que deban poseer aquellos que van a desempeñar las funciones públicas.

Se podría afirmar que la mencionada necesidad de "selección de los más aptos" también está presente en las actividades desarrolladas por las empresas privadas. Sin embargo, en el sector público, la selección meritoria no sólo es recomendable para garantizar la eficacia, sino que también es una exigencia prevista en la Constitución. ${ }^{311}$

Además, de forma distinta a lo que pasa en el sector privado, los procedimientos selectivos del sector público no pueden depender de la utilización de criterios personales del seleccionador, que violarían el derecho de todos los ciudadanos de acceder a la función pública en condiciones de igualdad.

Evidentemente, lo que la Constitución española busca es garantizar el acceso a la función pública a través de un procedimiento de selección conducido con objetividad (para respetar la igualdad) y que busque, consecuentemente, la admisión de futuros funcionarios públicos que dispongan de las condiciones técnicas y morales adecuadas para actuar con imparcialidad y para generar eficacia.

Como se puede percibir, una cosa conduce inevitablemente a la otra: la objetividad en la selección proporciona que los elegidos puedan actuar de forma

\footnotetext{
${ }^{310}$ MOREY JUAN, Andrey. La función pública: necesidad de un análisis conceptual y de la revisión del sistema de libre designación, INAP, Madrid, 2004, p. 45.

311 "Art. 103.3. La ley regulará el estatuto de los funcionarios públicos, el acceso a la función pública de acuerdo con los principios de merito y capacidad, las peculiaridades del ejercicio de su derecho a sindicación, el sistema de incompatibilidades y las garantías para la imparcialidad en el ejercicio de sus funciones."
} 
objetiva, ya que no estarán vinculados a través de relaciones políticas, de amistad, familiares o partidarias.

A su vez, la eficacia en el procedimiento selectivo, que se verifica con la elección de los más capaces, conduce a la actuación eficaz de los funcionarios públicos, ya que estos dispondrán de las habilidades necesarias a la consecución de las tareas administrativas.

Conforme ya se ha subrayado, la utilización de los criterios de mérito y capacidad en la selección de los funcionarios públicos es una exigencia directamente relacionada al derecho del ciudadano de acceso a la función pública en condiciones de igualdad (art. 23.2 CE). En este sentido:

\begin{abstract}
"no en vano todos los ciudadanos son iguales ante la ley y, en su aplicación, los poderes públicos no pueden expresar preferencias discriminatorias o fundadas en razones meramente subjetivas de unos sobre otros. Dichas pautas neutras deben asentarse, además, en los parámetros de mérito y de capacidad, verdaderos índices de una gestión eficaz del interés de la comunidad (merits system)." ${ }^{312}$
\end{abstract}

Aunque el art. 23.2 CE no haga expresa referencia a los criterios que deben servir de parámetro para que el acceso a las funciones públicas ocurra en condiciones de igualdad $^{313}$, la doctrina y el propio Tribunal Constitucional, a través de una interpretación sistemática de la Constitución, consideran que el contenido del art. 103.3 está incorporado en el art. 23.2 CE. ${ }^{314}$

Para demostrar la afirmación arriba citada, el Tribunal Constitucional ha decidido que:

"El principio de igualdad en el acceso a las funciones y cargos públicos consagrado en el artículo 23.2 de la Constitución ha de

\footnotetext{
${ }^{312}$ FERNÁNDEZ DOMÍNGUEZ, Juan J. y RODRÍGUEZ ESCANCIANO, Susana. Op.cit., p. 21.

${ }^{313}$ La opción de los constituyentes se justifica, una vez que los criterios de mérito y capacidad garantizan el acceso igualitario a las funciones públicas (art.103.3), y no a los cargos públicos (cargos representatativos). Sin embargo, el derecho previsto en el art. 23.2 alcanza tanto el acceso a las funciones como a los cargos públicos. Así, no hubiera sido propiamente adecuado utilizar, de forma indistinta, los criterios de merito y capacidad para el acceso a las dos situaciones comentadas.

${ }^{314}$ PULIDO QUECEDO, Manuel. Op.cit., p. 405.
} 
ponerse en necesaria conexión con los principios de mérito y capacidad en el acceso a las funciones públicas del artículo 103.3 de la Constitución."’315

Lo que se percibe es que, tras una larga historia en la cual prevalecieron criterios subjetivos que conducían a favoritismos y a revanchismos, actualmente, el ordenamiento jurídico impone a la Administración Pública exclusivamente los criterios de mérito y capacidad para seleccionar a los funcionarios públicos, que, indudablemente, fue una exigencia de la burocracia, que tardó muchísimos años en consolidarse como regla universal. ${ }^{316}$

La legitimación constitucional de los criterios de mérito y capacidad como los únicos válidos para la selección igualitaria de los funcionarios públicos permite también que todos los ciudadanos puedan, por sus esfuerzos propios, acceder a la función pública, circunstancia que estimula la participación y democratiza el acceso.

Así, si uno sabe que la cobertura de una plaza en la Administración Pública no depende de relaciones de cualquier nivel con los gestores públicos y que su mérito y capacidad serán los únicos factores que influenciarán su eventual admisión, el interés en ingresar en el servicio público aumenta, lo que se puede percibir fácilmente a través de los estratosféricos números de aspirantes que participan en las oposiciones en este país.

También es importante mencionar que el mérito y la capacidad son factores que pueden ser desarrollados por cada individuo y que no dependen de circunstancias ajenas a su voluntad y esfuerzo, como la raza, el sexo, la condición física y el

\footnotetext{
${ }^{315}$ STC $67 / 1989$.

${ }^{316}$ Para Alejandro Nieto, la figura del funcionario surgió debido a dos contextos: "en primer lugar, la consolidación de un grupo social, técnicamente cualificado y especializado, capaz de desarrollar una tareas cada vez más complejas que desbordaran las habilidades de los políticos, y en segundo lugar, la consolidación de un régimen jurídico privilegiado que les permitiera distanciarse da clase política y facilitara su identificación con la institución (es Estado) al que servían." No obstante, "en la actualidad ya nada queda de eso, puesto que la cualificación técnica puede conseguirse sin necesidad de una titulación funcionarial y, además, porque los partidos políticos no están dispuestos a aceptar esa relativa independencia de los servidores públicos, antes al contrario, exigen su sumisión más completa y su conversión en un botín patrimonializable a disposición de sus amigos de confianza política. Desde este punto de vista la fórmula ideal sería la del sistema de botín o patronaje (spoils system; en castellano tradicional, de cesantía) con vuelta a los turnos del siglo XIX. Como la Constitución, no obstante, ha cerrado este camino al inclinarse por el sistema funcionarial tradicional, ha habido que aceptarlo oficialmente aunque la práctica se ha encargado de inventarse mil modos de falsearlo, que luego la legislación va convalidando paso a paso." (NIETO, Alejandro. El desgobierno de lo público, Ariel, Barcelona, 2007, p. 188).
} 
nacimiento, lo que convierte a la selección meritoria como la única efectivamente igualitaria. Se puede decir que si uno no es apto hoy para disputar una plaza, es posible que, a través de su dedicación personal, pueda adquirir la condición de apto después de determinado tiempo de estudio y preparación.

Evidentemente, hay la necesidad del Estado de establecer políticas de compensación que permitan que todos tengan las mismas oportunidades de acceso, principalmente cuando existen segmentos de la sociedad que encuentran dificultades más significativas para ejercer determinados derechos. Es lo que pasa con las mujeres, en una proporción menor, y con las personas con discapacidad, en un sentido más intenso.

Es relevante subrayar que los criterios de mérito y capacidad son los únicos que pueden ser utilizados en el establecimiento de exigencias a los aspirantes en las oposiciones y concursos, y por tanto, son los únicos factores legítimos de diferenciaciones entre aquellos que concurren por las plazas ofrecidas por la Administración Pública. ${ }^{317}$

Sin embargo, hay que reconocer que aunque se hable con demasiada obstinación del mérito y la capacidad como únicos factores legitimadores para el acceso a la función pública, el legislador, la Administración y los Tribunales no han abordado la cuestión de fondo relativa a su contenido. ${ }^{318}$

En realidad, estos criterios son conceptos jurídicos indeterminados, que deberán ser desarrollados a través de criterios técnicos ante situaciones concretas, pero siempre pasibles de control. Así, para la comprensión del significado del mérito y la capacidad en determinados contextos, es necesario emprender un proceso intelectivo de valoración de la realidad objetiva de carácter reglado ${ }^{319}$, lo que impone un buen nivel de

\footnotetext{
${ }^{317}$ En este sentido, se puede destacar que "no toda desigualdad en las condiciones de acceso está prohibida, sino sólo aquellas que no se basen en criterios de merito y capacidad; o visto desde el ángulo inverso, no toda concreción de las exigencias de merito y capacidad es discriminatoria, sino sólo aquellas que produzcan un trato desigual entre los que se encuentran en una situación igual (SSTC 75/1983, 50/1986, de 23 de abril, 148/1986, de 25 de noviembre, 18/1987, de 16 de febrero)." (FERREIRA FERNÁNDEZ, A. Xavier. Op.cit., p. 57).

${ }^{318}$ FÉREZ FERNÁNDEZ, Manuel. La capacidad y el mérito en el acceso al empleo público profesional, Información, Documentos y Estudios para la Modernización de la Administración Pública, Número 22, Zaragoza, Julio-agosto 1994, p. 2.

${ }^{319}$ FÉREZ FERNÁNDEZ, Manuel. Op.cit., p. 41
} 
conocimiento del puesto de trabajo que se pretende ocupar, de las actividades desempeñadas y de las habilidades exigidas para ello, además de un buen manejo de los criterios de razonabilidad y proporcionalidad, con el fin de que los requisitos sean adecuados a su propósito de selección de aspirantes aptos y para que no establezcan sacrificios indebidos a derechos fundamentales, especialmente, al de acceso a la función pública en condiciones de igualdad (art. 23.2 CE).

En pocas palabras, el mérito y la capacidad son el parámetro de constitucionalidad del derecho fundamental de acceso a la función pública. Sobre esta cuestión, de forma precisa, ya se destacó que:

"si hubiéramos de calificar jurídicamente el merito y la capacidad desde la perspectiva de cada función, podríamos establecer la siguiente catalogación: para el legislador son los dos principios jurídicos que está incorporados al derecho fundamental del artículo 23.2 CE; para la Administración son los únicos criterios de selección utilizables (salvo previsión normativa en contra) y cuyo contenido debe concretar en cada caso para cumplir con la doble finalidad de seleccionar a los más idóneos y garantizar la igualdad en el proceso de selección; y para los Tribunales son conceptos jurídicos indeterminados cuyo control es obligado para determinar si ha sido lesionado o sacrificado indebidamente un derecho fundamental." ${ }^{320}$.

Utilizado en un sentido amplio, el mérito abarcaría tanto la capacidad como el mérito en sentido estricto. En este sentido más dilatado del término, más usual en otros países (merit system ${ }^{321}$ de los Estados Unidos de Norteamérica), la palabra mérito es utilizada de forma genérica, para referirse al principio que debe servir de norte para determinadas elecciones, que dependerán exclusivamente de la demonstración objetiva del merecimiento del aspirante, en contraposición a las situaciones de arbitrariedad típicas del spoil system.

\footnotetext{
${ }^{320}$ FÉREZ FERNÁNDEZ, Manuel. Op.cit., p. 52.

${ }^{321}$ Según Jorge Fondevila Antolín, en los Estados Unidos de Norteamérica, el concepto de mérito “...se produjo una paulatina pérdida de interés y de uso del término, hasta el año de 1978 fecha en la que la Administración Carter procede a una revisión del sistema del mérito declarando que el contenido del mismo es el configurado por una valoración de conocimientos, aptitudes y habilidades, definición que nos puede servir de punto referencia." (FONDEVILA ANTOLÍN, Jorge. Op.cit., p. 112).
} 
En cuanto a la distinción entre las dos figuras ${ }^{322}$, es necesario subrayar que no hay un concepto legal para estas (aunque las leyes ofrezcan un buen material para la formación de conceptos doctrinales), ni tampoco existe una uniformidad en la doctrina sobre esta cuestión. Hay incluso los que cuestionan la propia existencia de distinción entre los conceptos. En este sentido, “...debemos preguntarnos cuál es la diferencia conceptual entre mérito y capacidad, si es que existe, y más cuándo la práctica y la regulación jurídico positiva de los procedimientos de selección no aportan dato concreto alguno al respecto., 323

Para demostrar esa ausencia de uniformidad doctrinal y jurisprudencial, la doctrina $^{324}$ apunta dos líneas jurisprudenciales, con reflejo en la doctrina. En la primera línea, mientras el mérito estaría relacionado a "la demostración por cada aspirante a empleo público de que es mejor o que está entre los mejores, cuando son varios los seleccionados... al criterio que legitima la opción a favor de un aspirante frente a otro u otros...", , la capacidad estaría conectada a la "aptitud de una persona para un quehacer determinado...la tenencia de los requisitos objetivos que la legislación exige para poder ser aspirante a la función pública y que se subjetivizan en cada aspirante". ${ }^{225}$

Para esta línea de pensamiento, también habría distinción en relación al modo y al momento en que se exigen el mérito y la capacidad. Así, mientras la capacidad, como etapa de cumplimiento de requisitos, se establece en la definición de las normas reguladoras de la función pública, con reflejo en las convocatorias de las pruebas selectivas, y se demuestra en la posesión, el mérito, como criterio comparativo entre los aspirantes, se acredita en la competición entre ellos ante el Tribunal calificador, que evaluará el mérito (conocimientos, capacidades, dominio, etc.) de cada uno. ${ }^{326}$

\footnotetext{
${ }^{322}$ Para Morell Ocaña, "ambas nociones, si no acarrean redundancia, han de albergar un significado diferente." (MORELL OCAÑA, Luis. El sistema de confianza política en la Administración Pública, Ed. Civitas, Madrid, 1994, p. 155).

${ }^{323}$ FONDEVILA ANTOLÍN, Jorge. Op.cit., p. 112.

${ }^{324}$ ERKOREKA GERVASIO, J.I. Exigencia de preceptividad en los perfiles lingüísticos como requisito de capacidad en el ejercicio de funciones públicas, Revista Vasca de Administración Pública, n. 44-II, 1996, p. 266, en FONDEVILA ANTOLÍN, Jorge. La selección y pérdida de la condición de empleado público: especial referencia a su aplicación en la Administración local, Atelier, Barcelona, 2008, p. 113.

${ }_{325}$ PERÉZ LUQUE, Antonio. La selección del personal permanente de las corporaciones locales (en la legislación del Estado), El Consultor de los Ayuntamientos y de los Juzgados, Madrid, 2001, p. 81.

${ }^{326}$ MORELL OCAÑA, Luis. Op.cit., pp. 156-157.
} 
La línea de pensamiento arriba mencionada está repetida en decisiones del Tribunal Supremo (STS de 8 de noviembre de 1991 y la de 23 de mayo de 1992). Sin embargo, el entendimiento más corriente que diferencia mérito y capacidad es otro (STS de 3 de noviembre de 1986) y tiene en consideración las dos distintas maneras para la verificación de la idoneidad de los aspirantes.

La primera forma consiste en la comparación de las vidas profesionales de los candidatos, a través del análisis de sus estudios, formación y experiencias, o, en una palabra, de sus méritos. El aspirante que demostrara que había realizado más, que había tenido más esfuerzo, sería el vencedor de la selección, pues tendría más mérito.

A su vez, la idoneidad podría ser investigada mediante el análisis del rendimiento de los aspirantes en determinadas pruebas realizadas en el propio procedimiento selectivo. El aspirante que desempeñara mejor las pruebas realizadas sería el vencedor, pues tendría más capacidad.

Es esencial destacar que tanto el mérito como la capacidad deben ser analizados en su relación con el puesto de trabajo que será cubierto. Así, en relación al mérito, es imprescindible que los estudios (cursos, seminarios, congresos científicos, etc.), la formación académica (licenciatura, posgrado, etc.) y la experiencia profesional (empleos, prácticas, etc.) del candidato sean suficientemente relevantes para la demonstración de su idoneidad para el ejercicio del puesto de trabajo correspondiente.

De la misma forma, el contenido y el formato de las pruebas deben tener en cuenta la futura actuación de los aspirantes aprobados, en los puestos designados, y la necesidad de que se verifique si los candidatos tendrán condiciones técnicas para realizar las tareas de las funciones públicas que cubrirán.

Por supuesto, el resultado de la selección igualitaria y meritoria no es una garantía absoluta de que los vencedores vayan a desempeñar de forma satisfactoria las tareas que les serán designadas. Sin embargo, hay una presunción legal de que los aprobados son los más aptos, entre aquellos que participaron en la competición, y que, debido a la exigencia de publicidad, a todos fue ofertada la oportunidad de participar en el proceso de selección. 
En este sentido, lo que el procedimiento selectivo va a verificar es la capacidad inicial para el ejercicio de la función pública, ya que se puede considerar que "la capacidad para el desempeño de las funciones del puesto sólo puede medirse genérica y potencialmente, por una implícita presunción legal: se considera que una persona que apruebe una oposición estará en esas condiciones. Una capacitación definitiva y acreditada no se conocerá hasta que se observe el efectivo rendimiento del funcionario en su puesto de trabajo." 327

Por supuesto, basándose en la corriente mayoritaria que diferencia mérito y capacidad, en la actual configuración del ordenamiento jurídico español, los procedimientos selectivos unas veces prefieren valorar la capacidad (oposición), los dos criterios (concurso-oposición), otras veces el mérito (concurso).

En el capítulo quinto de este trabajo, será analizado el procedimiento de acceso a la función pública, sus modalidades, y, consecuentemente, las características y adecuaciones de cada uno de estas.

Aun sobre la mencionada distinción, la doctrina añade que el Tribunal Constitucional no resuelve la cuestión, sino que además introduce nuevas dudas, al confirmar la existencia de una delgada línea que separa ambos conceptos, y que se trata de conceptos jurídicos indeterminados, que por su propia naturaleza resulta muy difícil establecer el deslinde de los mismos ${ }^{328}$, doctrina que se ha adoptado en este trabajo.

Concluyendo, la citada doctrina declara que:

"Quizás debamos afirmar que nos encontramos ante unos conceptos que exigen su consideración de forma conjunta y sin distinción, y más aún, si tenemos en cuenta que tanto el Tribunal Constitucional como la propia legislación vigente hasta estos momentos (LMRFP), siempre los han englobado dentro del mismo principio que es desarrollo a su vez del principio de igualdad predicado de las previsiones del artículo 23.2 de la Constitución Española, y por ello, el acotamiento del sentido de los mismos deba provenir del contenido de la propia

\footnotetext{
${ }^{327}$ VICENTE DOMINGO, Ricardo de. El puesto de trabajo en el derecho de la función pública, Tirant lo Blanch, "Colección administrativo", Valencia, 1997, p. 129.

${ }^{328}$ FONDEVILA ANTOLÍN, Jorge. Op.cit., pp. 113-114.
} 
jurisprudencia del Tribunal Constitucional, con respecto al contenido material del derecho reconocido por el citado artículo",329

\subsubsection{2 - En la Constitución brasileña de 1988}

El acceso meritorio a la función pública también está consagrado en el derecho constitucional brasileño. Se puede afirmar que las normas jurídicas que tratan del ingreso de funcionarios en el servicio público son fuertemente inspiradas en el principio de igualdad en el acceso, aunque en la realidad todavía existan situaciones donde la tradición de una Administración Pública burocrática, pero mezclada con características patrimonialistas, prevalece frente al discurso oficial moralizador.

Sin embargo, se debe resaltar que los avances registrados en las últimas dos décadas son notables, sea el proceso de universalización del concurso público, nombre del proceso de selección realizado en Brasil, sea en la utilización de parámetros efectivamente meritorios en el ingreso en la función pública.

Las circunstancias anteriormente mencionadas son incluso destacadas fuera del país, hasta mismo por la doctrina española ${ }^{330}$. Lo que pasa es que, en realidad, en el contexto latinoamericano, "Brasil ha consolidado un sistema de mérito más riguroso y homogéneo." 331

\footnotetext{
${ }^{329}$ FONDEVILA ANTOLÍN, Jorge. Op.cit., pp.114-115.

${ }^{330}$ En este sentido: "Brasil es el mejor ejemplo de una Administración burocrática consolidada, con rasgos muy avanzados del modelo ideal de servicio civil profesional, que desde ese trampolín se lanza de la implantación de rasgos postburocráticos en su gestión de recursos humanos. Por lo analizado, el modelo brasileño tiene, además, una alta capacidad de automejora. También destaca por la continuidad normativa, continuidad que no impide el nacimiento de nuevas normas - como todo el paquete de reformas de año 1995 - pero que surgen en un contexto coherente y de perfeccionamiento y adaptación constantes. Es importante destacar que en Brasil la formulación e implementación de políticas públicas están constitucionalizadas, y se requiere de enmiendas constitucionales para promover cambios concernientes al SC. En este país, de acuerdo con Longo (2005a) el servicio público federal recluta personal mediante concurso público, incluso para cargos temporales, garantizando la selección por mérito y cualificación. No existe evidencia significativa, en términos generales, de manipulación o clientelismo sobre los concursos federales. Existen, además, mecanismos de discriminación positiva para incorporar a mujeres y personas de color, aunque el número de mujeres en los cargos de Dirección y Asesoría Superior se mantiene bajo" (VILLORIA MENDIETA, Manuel. El servicio civil de carrera en Latinoamérica: diagnóstico, causas y propuestas. Instituto Nacional de Administración Pública - INAP, Madrid, 2007, p. 40).

${ }^{331}$ VILLORIA MENDIETA, Manuel. Op.cit., p. 56.
} 
Las normas que tratan del acceso meritorio a la función pública están directamente previstas en la Constitución brasileña de 1988, y esta ha dedicado una gran cuantidad de normas respecto al tema ${ }^{332}$.

Debido a la gran cuantidad y a la indiscutible relevancia de las normas constitucionales respecto a la función pública, la doctrina brasileña ha destacado que "acima das regras estatutárias contidas na lei respectiva, sobrepairam os mandamentos constitucionais pertinentes aos servidores públicos. Repetimos que é de todo razoável falar-se em estatuto constitucional do servidor público, ao lado dos estatutos legais."333

En el citado estatuto constitucional del funcionario público, a fin de que uno pueda percibir la preocupación que se ha tenido en la Constitución brasileña con el cumplimiento de la regla del acceso igualitario a la función pública, basta resaltar el gran nivel de detalle previsto en el art. $37, \S 2^{\circ}$ :

"O constituinte, visando a garantir a obrigatoriedade da regra do concurso público, prescreveu como causa de nulidade absoluta (de pleno direito) do ato de provimento, com a conseqüente responsabilização do agente público, a inobservância dos incisos II e III do art. 37 da $\mathrm{CF} / 88$ (art. 37, § $2^{\circ}$ ). É um dos poucos casos de

\footnotetext{
${ }^{332}$ Es posible que la Constitución brasileña sea una de las que más normas dedica al acceso a la función pública, característica que sigue el modelo analítico de constitución adoptado en 1988. A lo mejor el recelo del incumplimiento de la regla del concurso público hizo con que la Asamblea Constituyente creara muchos parámetros para la Administración Pública:"Art. 37. I - os cargos, empregos e funções públicas são acessiveis aos brasileiros que preencham os requisitos estabelecidos em lei, assim como aos estrangeiros, na forma da lei; II - a investidura em cargo ou emprego público depende de aprovação prévia em concurso público de provas ou de provas e títulos, de acordo com a natureza e a complexidade do cargo ou emprego, na forma prevista em lei, ressalvadas as nomeações para cargo em comissão declarado em lei de livre nomeação e exoneração; III - o prazo de validade do concurso público será de até dois anos, prorrogável uma vez, por igual período; IV - durante o prazo improrrogável previsto no edital de convocação, aquele aprovado em concurso público de provas ou de provas e títulos será convocado com prioridade sobre novos concursados para assumir cargo ou emprego, na carreira; $V$ - as funções de confiança, exercidas exclusivamente por servidores ocupantes de cargo efetivo, e os cargos em comissão, a serem preenchidos por servidores de carreira nos casos, condições e percentuais mínimos previstos em lei, destinam-se apenas às atribuições de direção, chefia e assessoramento; VI - é garantido ao servidor público civil o direito à livre associação sindical; (...); VIII - a lei reservará percentual dos cargos e empregos públicos para as pessoas portadoras de deficiência e definirá os critérios de sua admissão; IX - a lei estabelecerá os casos de contratação por tempo determinado para atender a necessidade temporária de excepcional interesse público; (...)§ $2^{\circ}$ - A não observância do disposto nos incisos II e III implicará a nulidade do ato e a punição da autoridade responsável, nos termos da lei. Art. $39 \$ 3^{\circ}$ Aplica-se aos servidores ocupantes de cargo público o disposto no art. $7^{\circ}$, IV, VII, VIII, IX, XII, XIII, XV, XVI, XVII, XVIII, XIX, XX, XXII e XXX, podendo a lei estabelecer requisitos diferenciados de admissão quando a natureza do cargo o exigir."

${ }^{333}$ SANTOS CARVALHO FILHO, José dos. Op.cit., p. 540.
} 
nulidade expressa no texto constitucional atual, o que denota a importância da regra do concurso público. Talvez tenha sido assim em virtude da prática de certos governantes no passado, e mesmo após o advento da Constituição Democrática, teimarem, em não respeitar a regra" 334

La doctrina brasileña enfatiza que las reglas que establecen el derecho de acceso del ciudadano a la función pública en condiciones de igualdad son derivadas de los principios constitucionales, especialmente de tres de ellos: el principio republicano, el principio democrático y el principio de igualdad.

También se ha destacado la naturaleza principiológica del concurso público, que estaría albergado en el sistema constitucional brasileño, aunque no existiera una regla expresa que lo previera:

\footnotetext{
"Três, pode-se afirmar, são os fundamentos que legitimam a exigência do concurso de ingresso de pessoal na Administração direta, autárquica, fundacional e empresarial de qualquer nível de governo: principiológico, constitucional e legal. Embora outros possam servir de suporte para a obrigatória realização desse certame, é nos princípios da igualdade e da moralidade administrativa que está o mais relevante dos seus fundamentos. Destarte, mesmo que os fundamentos constitucional e legal não existissem, ainda se poria a obrigatoriedade de sua promoção." 335
}

Respecto a los princípios que han servido de inspiración para la adopción del concurso público en el derecho constitucional brasileño vigente, se puede transcribir que "a exigência de concurso público, destarte, apenas densifica uma série de princípios constitucionais, tais como a garantia de igualdade de condições, o princípio republicano,

\footnotetext{
${ }_{334}^{334}$ MACHADO JÚNIOR, Agapito. Op.cit., p. 13.

${ }^{335}$ GASPARINI, Diógenes. Concurso público - imposição constitucional e sua operacionalização, en Concurso público e Constituição, Fabrício Motta (Coordinador), Editora Fórum, Belo Horizonte, 2005, p. 21.
} 
o direito de participação na gestão pública, a previsibilidade de critérios e justiça desses critérios, a impessoalidade etc. Mais que legítimos são os seus fins." ${ }^{336}$

En los términos antes subrayados, hay muchos doctrinadores que afirman que la norma que impone que todos deban tener las debidas condiciones para acceder a la función pública es una consecuencia directa de la adopción del modelo republicano de Estado, que no admite distinciones entre los ciudadanos. A su vez, otros intentan demostrar como la experiencia democrática exige que todos puedan hacer parte de los órganos estatales, sea el ejercicio de cargos políticos o mismo técnicos.

Pese a la adecuación de los argumentos citados, dos consideraciones deben ser aquí mencionadas: en primer lugar, si es verdad que la adopción del modelo republicano de Estado impone el establecimiento de un estatuto jurídico igualitario para todos los ciudadanos, permitiendo a estos el acceso a las mismas oportunidades, incluso en el ingreso a la función pública, no si puede afirmar que tales derechos también no existan en los modelos monárquicos, especialmente en la monarquías constitucionales y parlamentarias, como es el caso de España.

La segunda consideración es que a pesar de la relevancia de los principios ya mencionados (republicano y democrático) en el acceso a la función pública ${ }^{337}$, la doctrina brasileña siempre ha destacado con mucho más énfasis que el derecho del ciudadano participar de procesos selectivos, ser evaluado por criterios objetivos y llegar a ejercer funciones públicas es una derivación directa del principio de igualdad.

Para confirmar la asertiva anterior, basta exponer algunas opiniones doctrinarias $^{338}$, como la que sostiene que "a realização de concurso público (...) com certeza é uma densificação do direito fundamental a igualdade.”339

\footnotetext{
${ }^{336}$ SCHIER, Paulo Ricardo. Constitucionalização e 20 anos da Constituição. Reflexão sobre a exigência de concurso público (entre a isonomia e a segurança jurídica), Texto extraído del sitio Jus Navigandi, (http://jus2.uol.com.br/doutrina/texto.asp?id=13167), acceso en 20 de junio de 2010.

${ }^{337}$ En este trabajo ya se ha realizado el estudio del derecho del ciudadano de acceso a la función pública como derecho de participación del mismo en los asuntos públicos, lo que demuestra la plena adopción de la teoría que sostiene la estrecha vinculación entre el acceso igualitario y la democracia.

${ }^{338}$ En este sentido: "O direito dos cidadãos de acesso aos cargos públicos (CF, art. 37, I) decorre do princípio fundamental dos regimes democráticos, que é o da igualdade (art. $5^{\circ}$ ) de todos perante a lei, nas mesmas condições. Se todos são iguais perante a lei, também o são perante a Administração, e por isso, nas mesmas condições, o que abrange o atendimento aos requisitos legais, todos os brasileiros
} 
A su vez, para el Ministro Celso de Mello, del Supremo Tribunal Federal brasileño:

"O concurso público representa garantia concretizadora do princípio da igualdade. O respeito efetivo à exigência de prévia aprovação em concurso público qualificase, constitucionalmente, como paradigma de legitimação ético-jurídica da investidura de qualquer cidadão em cargos, funções ou empregos públicos, ressalvadas as hipóteses de nomeação para cargos em comissão (CF, art. 37, II). A razão subjacente ao postulado do concurso público traduz-se na necessidade essencial de o Estado conferir efetividade ao princípio constitucional de que todos são iguais perante a lei, sem distinção de qualquer natureza, vedando-se, desse modo, a prática inaceitável de o Poder Público conceder privilégios a alguns ou de dispensar tratamento discriminatório e arbitrário a outros." 340

Además del reconocimiento doctrinario de la conexión entre igualdad y acceso a la función pública, afortunadamente, ya hay juristas brasileños que exigen que la igualdad tenga su alcance cada vez más dilatado, a fin de que puedan ser extraídas los efectos suficientes a la realización de una igualdad material. En esto sentido, se ha dicho de forma muy ajustada que:

"a formulação mais moderna do princípio da igualdade de acesso a cargos públicos aponta para a idéia de oportunidade eqüitativa; este valor, seja quais forem as posições econômicas dos cidadãos, tem de ser aproximadamente igual, ou, no mínimo, suficientemente igual, para que todos tenham uma oportunidade eqüitativa de ocupar cargos públicos e de influenciar o resultado das decisões políticas." ${ }^{341}$

Aun con más precisión, se ha afirmado que:

possuem o direito de acesso aos cargos públicos" (NETTO DE ARAÚJO, Edmir. Curso de direito administrativo. Editora Saraiva, São Paulo, 2005, p. 266).

${ }^{339}$ SCHIER, Paulo Ricardo. Constitucionalização e 20 anos da Constituição. Reflexão sobre a exigência de concurso público (entre a isonomia e a segurança jurídica), Texto extraído del sitio Jus Navigandi, (http://jus2.uol.com.br/doutrina/texto.asp?id=13167).

340 Supremo Tribunal Federal, Ação Direta de Inconstitucionalidade no 2364-AL, Julgamento: Tribunal Pleno.

341 GONÇALVES CARVALHO, Kildare. Direito constitucional: teoria do estado e da constituição: direito constitucional positivo. 15 a ed. rev. atual. e ampl., Editora Del Rey, Belo Horizonte, 2009, p. 202. 
"Magnamente relevada na democracia e mais ainda na República, a igualdade jurídica demarca o continente e o contingente de um modelo de experiência política, para o qual os cidadãos contam com os mesmos direitos e, especialmente, as mesmas oportunidades para se realizaram em suas vocações e em seus interesses. O princípio da acessibilidade aos cargos, funções e empregos públicos resgata e concretiza a igualdade na dinâmica administrativa pública. É que para a realização do princípio da igualdade jurídica não basta que se confiram direitos, se reconheçam faculdades e se estampem normas expressivas de sua aceitação no sistema de direito. Urge que se instrumentalizem os homens na busca da igualdade materializada pela criação de oportunidades sociais, políticas e econômicas iguais."342

\subsubsection{1 - Análisis de las normas constitucionales relativas al acceso meritorio}

Superada la cuestión respecto a los principios que inspiran el acceso meritorio a la función pública, cabe ahora analizar las normas de la Constitución brasileña que tratan del referido tema.

Para empezar, cabe la advertencia expresada por la doctrina brasileña que espera que "a Administração atue de forma planejada, transparente, contínua, previsível, sem avanços muito acelerados nem retornos bruscos, sempre objetivando salvaguardar o interesse público. Estas idéias devem perpassar, de alto a baixo, o exame dos concursos públicos à luz do ordenamento constitucional brasileiro"343

La doctrina brasileña afirma que los dos primeros ítems del art. 37 de la Constitución establecen dos principios: en el ítem I, estaría consagrado el principio de accesibilidad a los cargos y empleos públicos ${ }^{344}$, y en el ítem II, el principio del concurso público, que sería el instrumento que viabiliza la concreción del primero ${ }^{345}$.

\footnotetext{
342 ANTUNES ROCHA, Cármen Lúcia. Princípios constitucionais dos servidores públicos, Editora Saraiva, São Paulo, 1999, p. 148.

${ }^{343}$ MOTTA, Fabrício. Concurso público e confiança na atuação administrativa: análise dos princípios de motivação, vinculação ao edital e publicidade, en Concurso público e Constituição, Fabrício Motta (Cordinador), Editora Fórum, Belo Horizonte, 2005, p. 141.

${ }^{344}$ Respecto al nuevo panorama del concurso públicos trás la Carta Magna de 1988, cabe destacar que: “Antes da Constituição de 1988, o concurso público era exigido somente para a primeira investidura em cargo público, o que permitia a transposição ou ascensão funcional, ato pelo qual o servidor passava de um cargo a outro de conteúdo ocupacional diverso, mediante concurso interno. Tratava-se de um sistema
} 
En el ítem I del art. 37, la Constitución brasileña declara que tanto los brasileños como los extranjeros pueden acceder a la función pública, aunque este derecho se manifieste de forma distinto para los no nacionales ${ }^{346}$.

Los doctrinadores utilizan el término accesibilidad para designar las condiciones que garantizan el derecho de los ciudadano acceder a la función pública en condiciones de igualdad ${ }^{347}$

La referida accesibilidad deberá permitir que el ingreso en las funciones públicas se extienda a todos los ciudadanos, lo que exige que el concurso sea verdaderamente público. Esto hace con que no más sea admisible el acceso a la función pública a través de pruebas restringidas, que solamente contaban con la participación de

de mérito no serviço público, que premiava os servidores que buscavam o aprimoramento na profissão. Todavia, o Supremo Tribunal Federal, ao interpretar o inc. II, do art. 37 da Constituição, entendeu banida do ordenamento jurídico a ascensão funcional como forma de provimento de cargo público efetivo. Por construção jurisprudencial, acabou-se por eliminar um dos mais importantes institutos de profissionalização do servidor público. O Supremo Tribunal Federal deixou aberta, no entanto, a possibilidade do Legislador criar um sistema de promoção na mesma carreira (...). Contudo, os legisladores não têm se preocupado em implementar um sistema de promoção nas carreiras públicas" (BACELLAR FILHO, Romeu Felipe. Profissionalização da função pública: a experiência brasileira, en La profesionalización de la Función Pública en Iberoamérica, Instituto Nacional de Administración Pública - INAP, Madrid, 2002, p.100). Así, hoy en día, en el derecho brasileño, la figura del concurso interno solamente es reservada a situaciones de provisión a puestos de trabajo (provimento derivado), que no se confunden con el acceso a los cargos públicos. En estos términos, concurso interno es el "processo seletivo realizado exclusivamente dentro do âmbito de pessoas administrativas e órgãos públicos. Deste podem participar tão-somente os ocupantes de cargos escalonados em carreira, portanto já integrantes do quadro de pessoal da Administraçao Pública via concurso público de provas ou provas e títulos. Assim, o concurso interno só é constitucional quando utilizado para elevação de servidores na carreira, conforme exigido em lei. (...) nada obsta que os servidores do quadro permanente melhore suas posições funcionais obtendo êxito em concurso interno, em igualdade de condições com os demais integrantes do referido quadro" (TOURINHO, Rita. Op.cit., p. 41-42).

${ }^{345}$ Así: "O que a Lei Magna visou com os princípios da acessibilidade e do concurso público foi, de um lado, a ensejar a todos iguais oportunidades de disputar cargos ou empregos na Administração direta, indireta ou fundacional. De outro lado, propôs-se a impedir tanto o ingresso sem concurso, ressalvadas as exceções previstas na Constituição, quanto obstar a que o servidor habilitado por concurso para cargo ou emprego de determinada natureza viesse depois a ser agraciado com cargo ou emprego permanente de outra natureza, pois esta seria uma forma de fraudar a razão de ser do concurso público" (BANDEIRA DE MELLO, Celso Antônio. Curso de Direito Administrativo, 13 a ed., Editora Malheiros, São Paulo 1999, p. 256-257)

${ }^{346}$ En el tercer capítulo de este trabajo, que trata de los requisitos de acceso a la función pública, será investigado el tema del acceso de los extranjeros a la Administración Pública brasileña, oportunidade en que se verá las distinciones del ingreso entre estos y los brasileños.

${ }^{347}$ En este camino: "Acessibilidade é o conjunto de normas e princípios que regulam o ingresso de pessoas interessadas no serviço público. Os parâmetros que regem o acesso ao serviço público acarretam vinculação para os órgãos administrativos, de modo que não pode a Administração criar dificuldades maiores nem abrir ensanchas de facilidades fora das regras que compõem o sistema. Cuidase, pois, de verdadeiro direito subjetivo - o direito de acesso aos cargos, empregos e funções públicas, observadas logicamente as normas aplicáveis em cada tipo de provimento" (SANTOS CARVALHO FILHO, José dos. Op.cit., p. 553). 
funcionarios públicos. Por esta razón, tras la Constitución de 1988, el Supremo Tribunal Federal ha editado la Súmula 685, que declara: "É inconstitucional toda modalidade de provimento que propicie ao servidor investir-se, sem prévia aprovação em concurso público destinado ao seu provimento, em cargo que não integra a carreira na qual anteriormente investido."

Como la norma bajo análisis hizo dos referencias a la creación de leyes (os cargos, empregos e funções públicas são acessíveis aos brasileiros que preencham os requisitos estabelecidos em lei, assim como aos estrangeiros, na forma da lei), la doctrina subraya que

"Há aí duas normas e dupla referência à lei. A primeira norma, que reconhece acessibilidade a todos os brasileiros, é de eficácia contida e aplicabilidade imediata, de sorte que a lei a ela referida não cria o direito previsto, antes o restringe ao prever requisitos para seu exercício. Essa lei está limitada pela própria regra constitucional, de forma que os requisitos nela fixados não poderão importar em discriminação de qualquer espécie ou impedir a correta observância do princípio de acessibilidade de todos ao exercício de função administrativa. Mas a EC 19/98 inovou criando a possibilidade de acesso do estrangeiro aos cargos, empregos e funções públicas. É a outra norma, só que esta é de eficácia limitada, pois que o exercício do direito nela estatuído depende de forma a ser estabelecida em lei. Assim também, é o direito à admissão de professores, técnicos e cientistas estrangeiros nas universidades, prevista no art. 207, $1^{\circ}$ (EC11/96). ${ }^{, 348}$

Como esta discusión será realizada en el segundo capítulo, de momento, cabe subrayar que la definición de los requisitos de acceso a la función pública (sea de brasileños o de extranjeros) debe ocurrir a través de ley ${ }^{349}$, lo que es una tradición del constitucionalismo brasileño: "Ressalvada a Carta de 1937 (...), o constitucionalismo

\footnotetext{
${ }^{348}$ SILVA, José Afonso da. Op.cit., p. 660.

349 "Como todo brasileiro tem o direito de aceder ao cargo, emprego ou funçao pública somente a lei pode limitar, condicionar ou restringir o exercício deste direito. Tal condicionamento impõe-se por força do interesse jurídico" (ANTUNES ROCHA, Cármen Lúcia. Princípios constitucionais dos servidores públicos, Editora Saraiva, São Paulo, 1999, p. 160).
} 
brasileiro sempre se marcou pela garantia de que somente a lei formal poderia ser fonte de condicionamento do acesso ao cargo, emprego ou função pública." ${ }^{350}$

A su vez, en el ítem II del art. 37, la Constitución brasileña establece que, como regla general de acceso a la función pública, se impone la realización de concurso público, sea este de pruebas (provas) o de pruebas y méritos (provas e títulos). A continuación, el mencionado ítem prevé la excepción a la regla general: los cargos de libre designación (“... ressalvadas as nomeações para cargo em comissão declarado em lei de livre nomeação e exoneração”).

La Constitución brasileña, siempre en su intención de entrar en detalles, ya llegado a tratar de cuestiones procedimentales del concurso público, como es el caso de los itens III y IV del art. 37, que establecen el plazo de validez del proceso selectivo ${ }^{351}$ (“o prazo de validade do concurso público será de até dois anos, prorrogável uma vez, por igual período"), y la exigencia de convocación de los candidatos aprobados en los procesos selectivos anteriores, para que puedan ser nombrados aquellos relativos a los concursos siguientes (" ...aquele aprovado em concurso público de provas ou de provas e títulos será convocado com prioridade sobre novos concursados para assumir cargo ou emprego, na carreira").

En la Constitución brasileña de 1988, la exigencia de acceso meritorio a través de concursos públicos (régimen administrativo) se impone no solo a los cargos públicos, sino también a los empleos públicos (régimen laboral). Además, todas las personas jurídicas que hacen parte de la Administración Pública (entes de la federación, autarquías, fundaciones públicas o empresas estatales ${ }^{352}$ ) están obligadas a reclutar sus empleados a través del concurso público. ${ }^{353}$

\footnotetext{
${ }^{350}$ ANTUNES ROCHA, Cármen Lúcia. Op.cit., pp. 158-159.

${ }^{351}$ Solamente durante el período de validez del concurso público hay la posibilidad de la Administración Pública realizar de forma válida el acto de nombramiento de los candidatos que aprobaron las pruebas.

352 Sobre la realización de concurso público por las empresas estatales: "Não resta dúvida de que o ingresso em cargos públicos ou empregos públicos nas autarquias e fundações com personalidade jurídica de direito público dependerá de prévia aprovação em concurso público. Quanto às empresas estatais, já se chegou a cogitar a imunidade dessas empresas à regra geral do concurso público. No entanto, hoje, é entendimento pacífico de que inexiste tal imunidade." (TOURINHO, Rita. Op.cit., p. 25).

${ }^{353}$ La doctrina destaca que "O alcance da exigência deve ser o mais amplo possível, de modo que pode se considerar que a exigência da aprovação em concurso se configura como a regra geral. A regra abrange não só o provimento em cargos públicos, como também a contratação de servidores pelo regime trabalhista. O mandamento constitucional, aliás, faz referência à investidura em cargo ou emprego
} 


\subsubsection{2 - El concurso público en la realidad brasileña}

Como ya se ha resaltado en este trabajo, en Brasil hay la convivencia entre un sistema jurídico racional, instituciones modernas y el acceso caracterizado por el mérito y la igualdad; con muchas situaciones de incumplimiento de las normas, aunque este suceda de forma no generalizada.

Respecto a la función pública brasileña, ya se ha dicho que Brasil convive con un sistema civil de carrera muy desarrollado (especialmente en el nivel de la Unión, la administração pública federal) y una corrupción elevada, aunque esta sea esencialmente política, y no administrativa. ${ }^{354}$

El papel del concurso público en la realidad brasileña es mucho mayor que uno puede suponer. El representa el intento de moralizar un sector de la Administración Pública tradicionalmente viciado. En otra oportunidad, hemos dicho que:

“A seleção de agentes públicos a partir de critérios objetivamente aferíveis, além de simbolizar o racionalismo enquanto exigência e característica das sociedades contemporâneas, no contexto, representando a burocracia administrativa, é uma das principais implicações do princípio da impessoalidade na Constituição Federal de 1988. A utilização da máquina administrativa para distribuição de cargos e empregos públicos (empreguismo) representava um dos resquícios mais evidentes do patrimonialismo na Administração Pública brasileira, o que fez com que a adoção do concurso público enquanto mecanismo eficaz que pudesse coibir esta prática tenha se tornado uma bandeira levantada por diversos setores da sociedade civil, dentre elas, os juristas. Enquanto Odete Medauar denunciava que "o tema servidores traz subjacentes várias questões sociopolíticas: o empreguismo, o clientelismo, o nepotismo, o fisiologismo, que traduzem o uso da máquina administrativa para fins eleitorais, pessoais, para barganha com o Legislativo", Hely Lopes Meirelles já

público (art. 37, II). Por outro lado, o concurso deve ser exigido quer para a Administração Direta, quer para as pessoas da Administração Indireta, sejam as públicas, como as autarquias e fundações autárquicas, sejam as pessoas privadas, como as sociedades de economia mista e as empresas públicas." SANTOS CARVALHO FILHO, José dos. Op.cit., p. 542.

${ }^{354}$ VILLORIA MENDIETA, Manuel. El servicio civil de carrera en Latinoamérica: diagnóstico, causas y propuestas. Instituto Nacional de Administración Pública - INAP, Madrid, 2007, p. 80. 
declarava que “... pelo concurso público afastam-se, pois, os ineptos e os apaniguados, que costumam abarrotar as repartições, num espetáculo degradante de protecionismo e falta de escrúpulos de políticos que se alçam e se mantêm no poder leiloando empregos públicos." $", 355$

Aunque todos reconozcan unánimemente la relevancia de los concursos públicos en el contexto de la Administración Pública brasileña, paradoxalmente, la doctrina no ha dedicado tantos estudios relativos al tema como se debería hacerlo. Lo mismo se puede afirmar respecto a la jurisprudencia, que muy poco ha consolidado referente a la materia de los procesos selectivos de acceso a la función pública.

Sobre las constataciones anteriores, se puede añadir al presente trabajo que "É inconteste que por muito tempo o concurso público não teve o tratamento adequado por parte da doutrina e da jurisprudência, provavelmente porque somente com a sua efetivação no ordenamento jurídico as questões conflitivas foram surgindo, necessitando assim de análises mais precisas e posições mais firmes." ${ }^{356}$

Aquí se ratifica la afirmación del descaso de la Administración Pública brasileña con los concursos públicos y que esta se debe a la ausencia de concientización relativa a las dificultades que el proceso selectivo de funcionarios públicos impone. Por esta razón, se ha afirmado que "realizar um concurso público no Brasil, e talvez em qualquer país, é tarefa extremamente difícil. Trata-se de medir competências em tempo restrito, com instrumentos imperfeitos e sob forte pressão de pessoas e setores interessados, muitas vezes inescrupulosos.

A su vez, también cabe subrayar la posición fragilizada de los ciudadanos frente a la Administración Pública, lo que es confirmado por la siguiente línea de pensamiento:“o instituto do concurso público apresenta uma certa complexidade,

\footnotetext{
${ }^{355}$ LINS DE LESSA CARVALHO, Fábio. Op.cit., p. 72.

${ }^{356}$ TOURINHO, Rita. Op.cit., p. 2.

${ }^{357}$ MORHY, Lauro. A realidade dos concursos públicos. Texto extraído del sitio de la Universidade de Brasilia - UnB (http://www.unb.br/administracao/reitoria/artigos/20050616.php), acceso en .07 de julio de 2010.
} 
desprezada pela Administração Pública e desconhecida dos cidadãos, que não sabem ao certo quais os seus efetivos direitos diante da matéria"358

Cuando la poca preocupación de la doctrina y de la jurisprudencia brasileña respecto al concurso público es añadido al bajo interés demostrado por la Administración Pública con tales cuestiones y a la ignorancia del ciudadano respecto a sus derechos, uno llega a la conclusión que los avances introducidos en el sistema jurídico pueden ser comprometidos por el relativo descaso observado en importantes sectores de la sociedad.

Entre los problemas detectados que amenazan la efectividad del acceso igualitario a la función pública brasileña, se puede resaltar la utilización sin los debidos criterios de las situaciones de excepción al concurso público previstas en el sistema jurídico, lo que se verá a continuación.

\subsubsection{3 - La utilización indebida de las excepciones constitucionales del concurso público}

No hay duda que con el adviento de la Constitución brasileña de 1988 la realización de concursos públicos se convirtió en una nueva realidad para las Administraciones Pública de este país, que hasta entonces solamente estaban obligadas a realizar procesos selectivos meritorios en determinadas situaciones.

Todo esto hizo con que 5562 municipios, 26 Estados, el Distrito Federal y la Unión pasaran a adaptar sus estructuras administrativas para el cumplimiento de la regla constitucional, lo que demandó, sobre todo, un cambio de mentalidad de los responsables públicos.

Dos décadas después, es innegable que el acceso a la función pública brasileña ha incorporado los valores del merito y de la capacidad, únicos criterios aptos a la selección igualitaria. La verdad de esta afirmación puede ser confirmada por el gran número de personas (especialmente jóvenes) que han dedicado muchos años de sus vidas a la preparación para los concursos públicos.

\footnotetext{
${ }^{358}$ TOURINHO, Rita. Op.cit., p. 1.
} 
La dura competencia para aprobar un concurso público en Brasil supera la que existe en España para lograr éxito en una oposición. Para que uno pueda darse cuenta, la última oposición para 800 plazas de Mossos d’Esquadra en Cataluña han recibido 11.920 candidaturas, lo que es considerado un récord. Sobre la referida oposición, que ha tenido la competencia de casi 15 aspirantes por cada puesto de trabajo, se ha dicho que "En tiempos de bonanza, la mayoría de los que se apuntan lo hace por vocación. Pero con la crisis, y más si percibe que va para largo, hay gente que lo ve como una buena salida y una vía de estabilidad" ${ }^{\text {"359 }}$.

A su vez, en Brasil ${ }^{360}$, el concurso público para 750 plazas de policial rodoviário federal, realizado en 2009, 103.437 candidatos hicieron sus inscripciones, lo que llega a una competencia de más de 137 aspirantes por cada plaza, lo que es cada 10 veces mayor que la competencia mencionada en el ejemplo español. Y cabe destacar que en el concurso público brasileño citado, se exige el título de licenciado.

Para complementar la comparación, el concurso público para policial rodoviário federal en 2008 ofertó 340 plazas y había 158.681 candidatos, o sea, había menos plazas y más aspirantes que el concurso público de 2009. En 2008, la competencia atingió la cifra de más de 466 candidatos por cada plaza ofertada, lo que es

\footnotetext{
${ }^{359}$ Informaciones extraídas del reportaje Las oposiciones a mosso vuelven a batir récords, publicado en Barcelona, en el periódico 20 minutos en el día 8 de febrero de 2010, p. 7.

360 En Brasil, la alta competencia ya está produciendo efectos negativos, como se puede ver en este reportaje: "O sonho de ingressar na carreira pública pode muitas vezes ser ameaçado pela forte concorrência imposta por alguns concursos. Atualmente, além de ter que se preocupar com os tradicionais números dos problemas matemáticos, boa parte dos candidatos não consegue parar de pensar na infinidade de zeros que compõe o número de inscritos em determinadas provas. Para se ter uma idéia, só na última semana, o Banco do Brasil, os Correios, o Instituto Brasileiro de Geografia e Estatística (IBGE) e a Superintendência de Seguros Privados (Susep), contabilizaram, juntos, mais de 2,1 milhões de inscrições. Para a capital federal, por exemplo, o IBGE abriu 2.820 vagas de recenseador, sendo que, desse total, 2.679 são para ampla concorrência e 141 para pessoas com necessidades especiais. Isso significa que Brasília tem apenas 0,27\% do total de oportunidades oferecidas pelo órgão, o que pode assustar ainda mais os moradores da cidade que sonham em trabalhar no maior instituto de pesquisas do país.(...). Segundo os professores especialistas, só mesmo uma rotina regular de estudos pode fazer com que os candidatos vençam com mais facilidade a concorrência. A grande adesão da sociedade a esses concursos pode ser explicada pelo alto número de vagas disponíveis e pela facilidade nas candidaturas. Praticamente todas as organizadoras inscrevem os interessados pela internet. A estabilidade, privilégio nos dias de hoje, também é responsável por atrair um enorme número de pessoas. (...). Os rumores de que um concurso público terá muitos inscritos já são suficientes para espantar boa parte dos concorrentes. Segundo, deixar de prestar uma prova só pelo alto número de candidatos é um erro grave". (Extraído del reportaje Alta concorrência em concursos faz candidatos desistirem de disputar os cargos, publicado en 25.04.2010 en el sitio electrónico http://www.dnonline.com.br/noticia/tag/concursos/ver_noticia/38880/, con acceso en 17 de mayo de 2010)
} 
31 veces mayor que la competencia de la oposición para Mosso d`Esquadra de Cataluña.

Pese a la gran competencia verificada en los concursos públicos brasileños, lo que avala su credibilidad, todavía son utilizados muchos expedientes para fraudar la exigencia constitucional de acceso igualitario a la función pública.

En el referido camino, se ha afirmado que:

"Na prática, a Administração Pública brasileira até hoje, mesmo após quase vinte anos da edição da Constituição Federal de 1988, que introduziu rigorosamente a exigência de concurso público para admissão de pessoal, continua buscando mecanismos para burlar essa regra, permitindo que certos candidatos tenham acesso aos cargos e empregos públicos por outros meios, não sujeitando-se à escolha meritória." 361

En verdad, antes de todo, es relevante destacar que es la propia Constitución de 1988 que establece algunas situaciones de excepción al concurso público ${ }^{362}$, cuando hay determinadas circunstancias especiales que no recomiendan la realización de un proceso selectivo abierto a todos.

Sin embargo, hay que subrayar que "tais exceções não visam possibilitar o benefício de determinados apadrinhados do gestor público, mas sim resguardar a melhor

\footnotetext{
361 MARINELA DE SANTOS SOUZA, Fernanda. Concursos públicos - acessibilidade e grandes polêmicas, extraído del libro Leituras complementares de Direito Administrativo - Advocacia Pública, Fernanda Marinela e Fabrício Bolzan (organizadores), Editora Podium, Salvador, 2008, p. 185.

${ }^{362}$ La Constitución Federal establece las hipótesis em las cuales el concurso público no es realizado:" Com efeito, o concurso público é dispensado: para o provimento nos cargos em comissão e nas funções de confiança (art. 37, incs. II e V); para a investidura dos integrantes do quinto constitucional dos Tribunais judiciários, compostos por membros do Ministério Público e de advogados (art. 94); para a investidura dos membros dos Tribunais de Contas (art. 73, $1^{o}$ e $2^{\circ}$ ); para a nomeação dos ministros do Supremo Tribunal Federal (art. 101, parágrafo único), do Superior Tribunal de Justiça (art. 104, parágrafo único), do Tribunal Superior do Trabalho (art. 111, $2^{\circ}$ ), do Tribunal Superior Eleitoral (art. 119, II), do Superior Tribunal Militar (art. 123), e dos juízes do Tribunal Regional Eleitoral (art. 120, III); para a contratação de agentes temporários (art. 37, IX); e para o aproveitamento de ex-combatentes da Segunda Guerra Mundial (art. 53, I, do ADCT)." (PINHEIRO MADEIRA, José Maria. Servidor público na atualidade, $3^{\text {a }}$ ed., Editora América Jurídica, Rio de Janeiro, 2006, p. 69-70).
} 
satisfação do interesse público em algumas situações em que a Administração Pública necessita de pessoas determinadas ou de admissões feitas em situações excepcionais." "363

Así, en la realidad de la Administración Pública brasileña, esta consigue manipular los institutos jurídicos para que el concurso público (o sea, la selección meritoria e igualitaria) no suceda:

"O descumprimento da referida exigência vem sendo justificada pelos administradores sob o argumento da necessidade urgente do serviço, falta de "condições" para realização dos concursos com freqüência, desnecessidade de concurso para funções de menor complexidade, entre tantas outras versões juridicamente inservíveis. Mas o que se vê na prática do empreguismo é a colocação de pessoas nos quadros da administração pública, sem concurso, muito mais para fins eleitoreiros e acomodação de correligionários, parentes e amigos das autoridades no poder, do que, propriamente, para trabalhar - embora existam situações em que essa mão de obra arregimentada com afronta à Constituição venha a ser colocada a serviço da população - o que, porém, não ameniza a agressão à Lei Maior.(...) São incontáveis as formas encontradas no dia a dia para burlar-se a regra do concurso público, que vão desde a simples não realização do certame para o ingresso no serviço público, até a criminosa utilização de concursos fraudulentos para dar aparência de legalidade a situações irregulares." 364

La primera situación de excepción prevista en la Constitución brasileña es la posibilidad de libre designación para los cargos em comissão, que serian aquellos reservados, según el art. 37, V CB, para las “...atribuições de direção, chefia e assessoramento".

Se suele decir que el vínculo de confianza que une el funcionario de libre designación y el responsable público impone que la selección ocurra libremente, lo que debe ser entendido dentro del contexto de los principios adoptados en la Constitución,

\footnotetext{
${ }^{363}$ TOURINHO, Rita. Op.cit., p. 23.

364 SOARES, Evanna. Percalços na implementação do concurso público. Texto extraído del sitio Jus Navigandi (http://jus2.uol.com.br/doutrina/texto.asp?id=13424), acceso en 15 de mayo de 2010.
} 
especialmente los que deben ser observados por la Administración Pública. En este sentido, cabe destacar que:

\begin{abstract}
"Sempre que é realizado o prévio concurso público, e, por sua vez, adotado o critério do mérito para escolha do servidor público, têm-se normalmente assegurados os princípios da isonomia, da impessoalidade, da moralidade e da eficiência, entre outros, pois tal consequiência é intrínseca à realização do certame. Por conseguinte, quando se adota o critério da confiança, ainda assim, há que se preservarem tais princípios constitucionais, o que se extrai sem muito esforço do sistema constitucional, até mesmo porque o inciso $\mathrm{V}$, que prevê a assunção de funções de confiança e de cargos comissionados, submete-se ao caput do art. 37, que prevê tais princípios" ${ }^{\text {"365 }}$
\end{abstract}

A lo mejor, el principio de impersonalidad (impessoalidade) es lo que mejor condensa todas las exigencias de la Constitución brasileña para la selección de aquellos que van a ocupar las plazas de libre designación. En este sentido, se puede subrayar que "a relação de confiança entre o nomeado e o nomeante deve ser pautada no princípio da impessoalidade. Ou seja, a confiança revelada na certeza de que aquele agente é capaz de atender às aspirações da coletividade e não à confiança pautada em laços de amor ou de sangue." 366

En la realidad brasileña, en general, los cargos de libre designación son utilizados para satisfacción de intereses personales y partidarios. En este contexto, dos situaciones llaman la atención: la práctica del nepotismo y la utilización de la potestad de nombramiento de cargos de libre designación por el administrador público para cambiar favores políticos y económicos (clientelismo).

El nepotismo, presente desde tiempos inmemoriales en Brasil, significa "uma postura administrativa indevida de privilegiar ou favorecer parentes, nomeando-os para ocupar cargos, empregos ou funções públicas sem qualquer análise de aptidão para

\footnotetext{
${ }^{365}$ MACHADO JÚNIOR, Agapito. Op.cit., p. 105.

366 TOURINHO, Rita. Op.cit., p. 27.
} 
o desempenho de tais atribuições (mérito), o que inevitavelmente atentará contra a isonomia, a impessoalidade, a moralidade e a eficiência administrativa" ${ }^{\text {"367 }}$

Pese a existencia de algunas medidas que intentan cohibir la práctica del nepotismo en Brasil, se puede afirmar que el mismo aun es utilizado de forma intensa, sea abiertamente, lo que ocurre especialmente en los municipios, sea de forma velada, a través de distintos mecanismos fraudulentos, como el nepotismo cruzado, donde determinado responsable público mantiene bajo su autoridad los parientes de otro gestor público, e este, a su vez, hará lo mismo como forma de compensación.

A pesar de la gravedad de la práctica del nepotismo, es posible afirmar que el clientelismo es aun más perjudicial al interés general ${ }^{368}$, ya que los cargos son distribuidos a los que pertenecen al grupo de ocupa el poder y estos los utiliza sin cualquier preocupación, en olvido al hecho de que "o comissionamento em cargo público deve ser pautado na qualificação profissional do comissionado, ou seja, no merecimento que apresenta para o desempenho da função pública"369

Otra situación prevista en la Constitución brasileña que merece comentario es la contratación por tiempo determinado, que debe ser utilizada para “...atender a necessidade temporária de excepcional interesse público" (art. 37, IX, CB).

Lo que fue previsto como algo anómalo, que solamente debería ser utilizado bajo circunstancias excepcionales ${ }^{370}$, en la realidad brasileña, pasó a hacer parte del cotidiano administrativo, en un flagrante atentado a la Constitución.

\footnotetext{
${ }^{367}$ MACHADO JÚNIOR, Agapito. Op.cit., p. 105.

368 En muchos casos, no hay siquiera la preocupación respecto a la relación entre el cargo de libre designación y la exigencia constitucional de que el mismo sea relativo a una atribución de dirección, asesoramiento o jefatura. En estos casos: "o trabalhador é inserido no serviço público, sem concurso público, mediante "nomeação" para cargo ou função demissível "ad nutum" - que, como se sabe, dispensa o certame referenciado. Ocorre que a atividade desenvolvida é incompatível com tais cargos ou funções (a exemplo de motorista da ambulância do hospital municipal, gari, professor, etc.), porque evidentemente ligada ao serviço público permanente e normal. Com outras palavras: as atribuições, inclusive de natureza técnica, do cargo dito de confiança, não se harmonizam com o princípio da livre nomeação e exoneração, como reconhecido pelo STF na ADI n. 3.233, rel. Min. Joaquim Barbosa, e na ADI n. 3.706, rel. Min. Gilmar Mendes. Em outros casos, o "cargo" ou "função" nem sequer está previsto em lei como "de confiança"." (SOARES, Evanna. Percalços na implementação do concurso público. Texto extraído del sitio Jus Navigandi (http://jus2.uol.com.br/doutrina/texto.asp?id=13424).

369 TOURINHO, Rita. Op.cit., p. 28.

${ }^{370}$ Debe ser siempre subrayado el carácter excepcional de la contratación temporária: "Trata-se, aí, de ensejar suprimento de pessoal perante contingências que desgarrem da normalidade das situações e
} 
Una de la formas de transgresión de la exigencia de concurso público es la utilización de la contratación temporaria para funciones permanentes de la Administración Pública, cuando no hay circunstancia especialísimas que impidan el reclutamiento inmediato a través de concurso público.

Parte de la doctrina brasileña admite la contratación temporaria para funciones permanentes, pero exige que esta suceda bajo condiciones excepcionalísimas $^{371}$. En este sentido:

\begin{abstract}
"Pode-se dar que a necessidade do desempenho não seja temporária, que ela até tenha de ser permanente. Mas a necessidade, por ser contínua e até mesmo ser objeto de uma resposta administrativa contida ou expressa num cargo que se encontre, eventualmente, desprovido, é que torna aplicável a hipótese constitucionalmente manifestada pela expressão "necessidade temporária". Quer-se, então, dizer que a necessidade das funções é contínua, mas aquela que determina a forma especial de designação de alguém para
\end{abstract}

presumam admissões apenas provisórias, demandadas em circunstâncias incomuns, cujo atendimento reclama satisfação imediata e temporária (incompatível, portanto, com o regime normal de concursos)" (BANDEIRA DE MELLO, Celso Antônio. Curso de Direito Administrativo, $13^{\mathrm{a}}$ ed., Editora Malheiros, São Paulo, 2008, p. 210 ).

${ }^{371}$ En este trabajo, es adoptada la teoría que sostiene que, en general, la contratación temporaria debe ser utilizada para funciones temporarias. Sin embargo, se entiende que es permitida la contratación temporaria para funciones permanentes siempre que haya circunstancias excepcionalísimas y durante el plazo que dure el concurso público abierto para cubrir las referidas plazas. Este mismo entendimiento es adoptado por Celso Antônio Bandeira de Mello (Curso de Direito Administrativo, 2008, p. 281) y Maria Sylvia Zanella di Pietro e Di Pietro (Direito Administrativo, 2006, p. 492-499). Sin embargo, cabe subrayar que "A jurisprudência recente do Supremo Tribunal Federal já se inclinou no sentido da inconstitucionalidade da contratação temporária para a admissão de servidores para funções burocráticas ordinárias e permanentes. Esse entendimento, com efeito, colocava em primeiro plano a análise da característica da função a ser desempenhada, se transitória ou permanente, e não da necessidade específica a ser atendida mediante o desempenho de tal função. Nessa mesma linha de raciocínio, o STF julgou procedente pedido de ação direta de inconstitucionalidade ajuizada pelo Conselho Federal da Ordem dos Advogados do Brasil contra a Lei 6.094/2000, do Estado do Espírito Santo, que autorizava o Poder Executivo a realizar contratação temporária de Defensores Públicos, em caráter emergencial, de forma a assegurar o cumprimento da Lei Complementar 55/94. Neste caso singular, entendeu a Corte que a Defensoria Pública é instituição permanente, com cargos organizados em carreira específica, que não comporta defensores contratados em caráter precário” (MOTTA, Fabrício. A contratação de pessoal por prazo determinado pela administração pública vista pelo Supremo Tribunal Federal. Texto extraído do sitio eletrônico Jus Navigandi (http://jus2.uol.com.br/doutrina/texto.asp?id=8045), acceso en 22 de mayo de 2010. 
desempenhá-las sem o concurso e mediante contratação é temporária" 372

Lo que pasa es que los organismos públicos no actúan en el momento adecuado (no hay planificación de las acciones administrativas ${ }^{373}$ ), permiten que el problema se instale, y después sostienen que hay la necesidad urgente de contratación de profesionales. En otras palabras, alegan su propia torpeza para no realizar el concurso público. En este sentido:

"Admitir-se a utilização de contratos temporários para o exercício de funções permanente é abrir uma porta para fraudar a regra constitucional de concurso público: porém não se pode ignorar que a sociedade não poderá sofrer prejuízos em virtude da inércia administrativa. Assim, caso haja necessidade urgente de médicos em postos de saúde, por exemplo, admite-se a contratação temporária, devendo-se em contrapartida, providenciar imediatamente a realização de concurso público, apurando-se a responsabilidade pela omissão na realização do certame no tempo devido." 374

También causa preocupación de gran cantidad de leyes que establecen hipótesis de contratación temporaria que no respectan el perfil constitucional del referido instituto ${ }^{375}$.

\footnotetext{
372 ANTUNES ROCHA, Cármem Lúcia Antunes. Princípios constitucionais dos servidores públicos. São Paulo: Saraiva, 1999, p. 242.

${ }^{373}$ Lo que pasa es que es "princípio norteador da Administração o planejamento, estando até mesmo positivado no art. $6^{o}$, inciso I, do Decreto-Lei $n^{\circ} 200 / 1967$, devendo os órgãos e entidades públicas adequar as suas projeções de contratação de pessoal às necessidades do serviço e à disponibilidade orçamentária. Assim, mostra-se irregular a atuação do gestor público que, ao longo de anos, não implementa procedimentos de concurso público e, em dado momento, efetua contratação excepcional temporária, sem concurso, sob o argumento de que, caso não a promova, advirão prejuízos à prestação de serviços públicos." (SEVIDANES DA MATTA, Marco Antonio. Contratação temporária de pessoal na Administração Pública: desvirtuamento do uso da exceção prevista no art. 37, IX, da Constituição Federal. Texto extraído do sitio Jus Navigandi (http://jus2.uol.com.br/doutrina/texto.asp?id=8695), acceso en 22 de mayo de 2010).

${ }^{374}$ TOURINHO, Rita. Op.cit., pp. 31-32.

${ }^{375}$ En este sentido: "o Supremo Tribunal Federal já declarou a inconstitucionalidade de leis que "(...) instituem hipóteses abrangentes e genéricas de contratação temporária, não especificando a contingência fática que evidenciaria a situação de emergência, atribuindo ao chefe do Poder interessado na contratação estabelecer os casos de contratação". Nestes termos, sob pena de incompatibilidade com a Constituição, deve a lei especificar quais são as atividades de necessidade pública para a contratação temporária, demonstrando a real existência de necessidade temporária que autorize a contratação de pessoal" (MOTTA, Fabrício. A contratação de pessoal por prazo determinado pela administração
} 
Otra circunstancia que debe ser mencionada es la utilización de criterios subjetivos de selección en las contrataciones temporarias Así, aunque cuando la Administración Pública está delante de una real situación que demanda el manejo del referido instituto jurídico, lo hace de forma inconstitucional, la medida en que los que serán contemplados con la contratación son elegidos de forma subjetiva.

Pocos representantes de la doctrina brasileña han resaltado el hecho que son “plenamente inconstitucionais as contratações temporárias cujos processos de seleção são lastreados em critérios subjetivos, como o procedimento de avaliação de currículos largamente utilizado pela Administração Pública, em desrespeito à competitividade, à seletividade e ao princípio proibitivo da quebra da ordem de classificação.”376

En realidad, la Administración Pública brasileña, cuando necesita realizar una contratación temporaria, instaura un procedimiento de competición simplificado, ya que, en general, tiene prisa y la contratación va a ser formalizada por un tiempo determinado, lo que dispensaría mayores rigorismos.

Sin embargo, cabe añadir que "concurso simplificado não significa certame sem regras procedimentais, sem segurança jurídica, portanto, absolutamente informal. Um mínimo procedimental deve existir, sob pena de violação do princípio da igualdade e, por que não, da segurança jurídica."377

Otro expediente utilizado con frecuencia en la Administración Pública brasileña es la tercerización de mano de obra ${ }^{378}$, que se traduce en la contratación de una empresa que va a fornecer los trabajadores para los organismos públicos.

pública vista pelo Supremo Tribunal Federal. Texto extraído do sitio eletrônico Jus Navigandi (http://jus2.uol.com.br/doutrina/texto.asp?id=8045). A referida decisão do STF foi a ADI 3210 Relator(a): Min. CARLOS VELLOSO Julgamento: 11/11/2004 Órgão Julgador: Tribunal Pleno Publicação: DJ DATA-03-12-2004.

${ }^{376}$ BARBOSA MAIA, Márcio, y PINHEIRO DE QUEIROZ, Ronaldo. Op.cit., p. 48.

377 GASPARINI, Diógenes. Concurso público - imposição constitucional e sua operacionalização, en Concurso público e Constituição, Fabrício Motta (Coordinador), Editora Fórum, Belo Horizonte, 2005, p. 45.

${ }^{378}$ El Tribunal Superior del Trabajo editó la Súmula 331 respecto al tema de la tercerización de mano de obra "Analisando minudentemente a referida Súmula do TST, têm-se as seguintes conclusões: (a) não se aceita a terceirização da atividade-fim do ente público; (b) no caso de contratação indevida de terceirizados pelo ente público, não há que se reconhecer vínculo empregatício, haja vista a nulidade pela violação da regra do concurso público; (c) admite-se a terceirização de atividade-meio do ente público, desde que precedida de licitação, a exemplo, serviços de limpeza, conservação, vigilância, 
Uno de los problemas detectados en esta especie de contratación es su indebida utilización para la satisfacción de actividades finalisticas de la Administración Pública, que deberían ser realizadas por funcionarios públicos seleccionados a través de concursos públicos. Respecto al tema, en Brasil se ha dicho que:

\begin{abstract}
"Inegável a existência de sérias discussões doutrinárias quanto à terceirização no âmbito da Administração Pública, principalmente quando esta assume a forma de terceirização de mão-de-obra. Aliás, a execução indireta de atividades-meio na seara administrativa é uma realidade, inclusive com a complementaridade entre as tarefas funcionais e as terceirizadas coexistentes na mesma organização.(...) Percebe-se, então, que a terceirização não poderá abranger atividades típicas de cargos ou empregos públicos, nem tampouco atividades que envolvam a prática de ato administrativo, quer dizer, emissão de declaração que produza efeitos jurídicos",379
\end{abstract}

Otra hipótesis prevista en la Constitución Federal que causa perplejidad es la autorización introducida por la Enmienda Constitucional $n^{\circ} 51 / 2006$, que autoriza la contratación de agente sanitarios y de combate a endemias a través de proceso selectivo público.

La referida perplejidad es derivada de la ausencia de clareza del texto constitucional $^{380}$, que no especifica cuál es el contenido del referido proceso de selección (hay dudas si se trata de concurso público o de un proceso selectivo simplificado, lo que es utilizado para la contratación temporaria).

\footnotetext{
telefonia, etc.; (d) nas terceirizações regulares (atividade-meio), ainda assim, o ente público se responsabilizará subsidiariamente pelos encargos trabalhistas do empregado da empresa prestadora de serviço" (MACHADO JÚNIOR, Agapito. Op.cit., p. 114).

379 TOURINHO, Rita. Op.cit., p. 45.

${ }^{380}$ Tras la mencionada enmienda, el $\S 4^{\circ}$ del art. 198, de la Constitución de 1988 pasó a tener la siguiente redación: "Art. 198. $\S 4^{\circ}$ Os gestores locais do sistema único de saúde poderão admitir agentes comunitários de saúde e agentes de combate às endemias por meio de processo seletivo público, de acordo com a natureza e complexidade de suas atribuições e requisitos específicos para sua atuação".
} 
Sin embargo, la doctrina ha interpretado la referida enmienda en el sentido de que el principio de la amplia accesibilidad debe prevalecer, lo que impone la realización de concurso público ${ }^{381}$. Respecto a esta cuestión, se puede concluir que:

\begin{abstract}
"quando a Emenda 51 - tecnicamente lastimável - fala em 'processo seletivo público', ter-se-á de entender que não poderia revogar a igualdade de todos perante a lei (cláusula pétrea, por se alojar entre os direitos e garantias individuais, conforme o art. 60, $\S 4^{\circ}$, IV, da CF) e, a fortiori, perante as possibilidades de ingresso no serviço público. Logo, o tal processo seletivo terá de apresentar características similares às de um concurso público, podendo apenas simplificá-lo naquilo que não interfira com a necessária publicidade, igualdade dos concorrentes e possibilidade de aferirem a lisura do certame. Será obrigatório, ainda, que as provas ou provas e títulos guardem relação com a natureza e a complexidade do emprego." 382
\end{abstract}

\footnotetext{
381 “A Emenda Constitucional n. 51,de 14.2.2006, introduzindo o $\$ 4^{\circ}$ ao art. $198 \mathrm{da}$ CF, consignou que os agentes comunitários de saúde e os agentes de combate às endemias podem ser recrutados pelos gestores locais do sistema único de saúde através de processo seletivo público, de acordo com a natureza e a complexidade de suas atribuições e requisitos para seu desempenho, estendendo-se o alcance da norma à contratação direta por Estados, Distrito Federal e Municípios, ressalvadas leis especiais desses entes. À primeira vista, tal processo seletivo não seria o mesmo que o concurso público de provas e títulos, assim como previsto no art. 37, II, da CF, parecendo ter-se admitido procedimento seletivo simplificado exceção ao princípio concursal. A legislação regulamentadora, porém, aludiu a processo seletivas de provas ou de provas e títulos, o que espelha o concurso público. A expressão empregada no novo texto, além de atécnica, só serviu para suscitar dúvida no intérprete: na verdade, bastaria que o Constituinte se tivesse referido simplesmente ao concurso público - instituto já com definição própria e imune a tais dúvidas." (SANTOS CARVALHO FILHO, José dos. Op.cit., p. 601).

${ }^{382}$ BANDEIRA DE MELLO, Celso Antônio. Op.cit., p. 277.
} 
CAPÍTULO 3 - LA IGUALDAD EN LOS REQUISITOS DE ACCESO A LA FUNCIÓN PÚBLICA ESPAÑOLA Y BRASILEÑA 


\section{1 - Análisis de los requisitos de acceso a la función pública}

El derecho del ciudadano de acceder a la función pública en condiciones de igualdad está asegurado en la Constitución Española de 1978 y en la brasileña de 1988, lo que ha sido visto de forma pormenorizada en el capitulo anterior. En las mencionadas líneas, fue destacado que el derecho previsto en el art. 23.2 CE y el el art. 37, I, CB, tiene como objetivo garantizar que el acceso a la función pública sea solamente dependiente del mérito y de la capacidad de los aspirantes.

Otro aspecto ya estudiado es la circunstancia de que el derecho de acceso en situación de igualdad a la función pública es de configuración legal, lo que provoca que el legislador deba establecer las condiciones para su ejercicio. En esta tarea, el Poder Legislativo es sometido a parámetros constitucionales muy claros, ya que además de la presencia decisiva del principio de igualdad como uno de los valores supremos de los referidos ordenamientos jurídicos, los principios de mérito y de capacidad, en el contexto del acceso a la función pública, son los únicos criterios que pueden inspirar la definición de los límites del susodicho derecho.

La labor del legislador en relación al establecimiento de las condiciones para el ejercicio del derecho de acceso a la función pública en condiciones de igualdad se manifiesta de dos formas: a través de la definición de los requisitos de participación de los aspirantes en los procesos selectivos (lo que se verá en este capítulo), y mediante la previsión de las reglas procedimentales de la competición entre aquellos que superaron las exigencias mencionadas (lo que se investigará en el quinto capítulo de este trabajo)..

Por supuesto, la inexistencia de derechos de carácter absoluto hace que haya la necesidad de que sean señalados los cuadrantes dentro de los cuales cada uno de los ciudadanos puede ejercer sus derechos. Aunque sea la Constitución la fuente de los derechos fundamentales y la norma que delinea su perfil, es innegable el hecho de que las leyes deben posibilitar la realización de los mencionados derechos, a partir de la definición de las condiciones de su concreción. 
Por la razón anteriormente expuesta, se puede añadir que el "direito de acesso ao serviço público não é desprovido de algumas exigências. Por esse motivo, o texto constitucional deixou bem claro que o acesso pressupõe a observância dos requisitos estabelecidos em lei." ${ }^{383}$

En el contexto arriba planteado, la Constitución Española, cuando definió que los ciudadanos tenían el derecho a acceder en condiciones de igualdad a las funciones y cargos públicos (art. 23.2), añadió la inevitable expresión "con los requisitos que señalen las leyes." A su vez, previó en el art. 103.3 que "La ley regulará... el acceso a la función pública de acuerdo con los principios de merito y capacidad".

En el ámbito del derecho brasileño, la Carta Magna de 1988 determina en el apartado I del art. 37 que los cargos y empleos públicos son accesibles a los brasileños que cumplan los requisitos establecidos en ley, así como a los extranjeros, en la forma prevista en ley; en el apartado II del mismo artículo, que el ingreso en la función pública depende de la aprobación en concurso público, que deberá ser reglado por ley.

La generalidad de la redacción de las normas de las Constituciones hace que los derechos fundamentales asegurados en las mismas tengan la configuración de su contenido establecida en las leyes, lo que posibilita su permanente evolución, circunstancia que sería menos viable en el caso de que sus normas fueran redactadas de forma indebidamente analítica, además de permitir su ejecutividad, ya que las normas legales pueden definir con detalle a aquellos que están encargados de cumplir los mandamientos constitucionales.

En el mencionado camino, conviene subrayar que la Administración Pública, sea en contexto brasileño o español, como está sometida al principio de legalidad, respalda sus actuaciones en las prescripciones legales, sin las cuales sería fácticamente imposible que los órganos administrativos actuaran de forma imparcial, ya que les faltarían criterios legítimos y objetivos para garantizar una prestación efectivamente igualitaria de sus servicios.

${ }^{383}$ SANTOS CARVALHO FILHO, José dos. Op.cit., p. 555. 
Así, el acceso de los ciudadanos a la función pública en condiciones de igualdad solamente es viable cuando hay leyes que definen con objetividad los requisitos para la participación en los procedimientos selectivos.

Según lo visto, la existencia de leyes definidoras de los requisitos de los aspirantes es condicio sine qua non para la construcción de un sistema de acceso a la función pública. Sin embargo, es imprescindible también que las mencionadas leyes sean redactadas respecto al principio de igualdad, y, esto, como ya se ha visto, en el contexto específico del acceso a la función pública, tendrá en cuenta necesariamente los principios de mérito y de capacidad para que sea realizado, además de otros, como la razonabilidad y la proporcionalidad.

Se puede añadir que los requisitos de acceso a la función pública están presentes en las leyes para evitar la arbitrariedad administrativa, para impedir las tentaciones del favoritismo y otras formas de desviación de poder.

Puesto que la Administración Pública, si no está sometida a reglas claras y detalladas, actúa según criterios de conveniencia y oportunidad que no siempre suelen adecuarse al interés general. Es más, aunque los gestores públicos quieran satisfacer el interés de la sociedad, si no hay reglas que definan de qué forma esto deba ser llevado a cabo, hay un gran riesgo de violación de la objetividad, ya que delante de la ausencia de criterios previos, los mencionados gestores utilizarán sus propios criterios.

Así, respecto a la selección de los funcionarios, la definición de los requisitos de acceso en las leyes tanto busca reprimir la arbitrariedad (aquí entendida como utilización de criterios patrimonialistas, contrarios al interés general), como cohibir la propia discrecionalidad (aquí relacionada a la utilización de criterios subjetivos, caracterizados por la voluntad del administrador público). ${ }^{384}$

\footnotetext{
${ }^{384}$ Cabe destacar que: "Deve-se ter em vista que o concurso público é um procedimento orientado à discriminação entre indivíduos. Ou seja, trata-se de uma atuação administrativa que busca identificar as diferenças entre os diversos indivíduos para o efeito de atribuir a eles tratamento diferenciado correspondente e proporcional. O que é inadmissível é a discriminação arbitrária e injustificada. $E$ indispensável que os critérios de discriminação dos candidatos sejam estabelecidos em vista do desempenho apresentado, considerando o fim a que se destina o concurso. Ademais, o concurso público é norteado pelo princípio da isonomia, o que significa a aplicação do princípio da proporcionalidade."(JUSTEN FILHO, Marçal. Curso de direito administrativo, $4^{\mathrm{a}}$ ed., Editora Saraiva, São Paulo, 2009, p. 743-749).
} 
La doctrina española advierte que "ninguna autoridad puede invocar su origen democrático para infligir la Ley; esta es la esencia misma del Estado de Derecho." ${ }^{385}$ Sin embargo, hay diversos gestores que hacen poco caso de las leyes, y pasan a administrar los intereses de la comunidad a partir de sus puntos de vista, de sus consideraciones personales, en una evidente violación del deber de objetividad.

Así, debe ser reiterado, en el contexto de la selección de personal, que solamente las leyes (y no la opinión del administrador) deben definir los requisitos que deban cumplir los aspirantes a la función pública.

Y más: cuando se destaca que solamente las leyes (y los reglamentos, cuando autorizados por las leyes) pueden establecer requisitos de acceso, significa que "las bases de la selección no pueden ampliar el contenido del Ordenamiento jurídico. No pueden recoger los que no sean obligatorios, pues estos requisitos no son mínimos, sino exactos, no adicionables." 386

Sin embargo, en la realidad, lo que se percibe en determinadas ocasiones es la indebida invasión de la competencia del legislador por el administrador público, lo que hace con que este defina, para cada proceso de selección, cuales son los requisitos que los candidatos deben cumplir, causando una gran inseguridad jurídica. En este camino, la doctrina brasileña apunta que:

"Uma passada de olhos por esses Editais irá nos revelar algumas
dessas impropriedades levadas a efeito pelo Administrador no
momento de selecionar candidatos para ingresso em carreiras
públicas. Assim é que se verifica, com uma habitualidade
impressionante, o estabelecimento de requisitos para ingresso nessas

385 GARCÍA DE ENTERRÍA, Eduardo. "Un punto de vista sobre la nueva Ley de Régimen Jurídico de las Administraciones Públicas y del Procedimiento Administrativo Común", RAP, $\mathrm{n}^{\circ}$ 130, enero-abril de 1993, p. 212.

${ }^{386}$ PÉREZ LUQUE, Antonio. La selección del personal permanente de las corporaciones locales (en la legislación del Estado), El Consultor de los Ayuntamientos y de los Juzgados, 2001, Madrid, p. 303. 
carreiras por meio de um Edital, o que materializa um grave equívoco por não constituir ele instrumento hábil para este mister." 387

Sobre el tema arriba citada, en el ámbito del derecho español, también se ha dicho ya que la fijación de límites para el acceso a la función pública es uno de los puntos sobre los que el Tribunal Constitucional del referido país ha tenido ocasión de pronunciarse más veces, y que "una premisa básica para abordar la cuestión y no es otra que la necesidad de que el establecimiento de cualquier límite o matización sólo pueda efectuarse por una norma con rango de ley." 388

Cabe subrayar aún que las características personales y profesionales exigidas por las leyes deben considerar las exigencias necesarias para el buen desempeño de las actividades administrativas. $\mathrm{Y}$ eso se verifica en cada una de las distintas funciones y cargos públicos. En el mencionado contexto, ha destacado la doctrina que:

"o Estado deverá identificar as virtudes desejáveis para o futuro ocupante do cargo público. Essa identificação deverá tomar em vista as atribuições do cargo, a responsabilidade daí derivada e outras características que podem alcançar inclusive a capacitação física indispensável. Em vista dessas virtudes, serão estabelecidos requisitos de participação e critérios de julgamento, que devem apresentar cunho instrumental em vista daquelas virtudes. A validade dos requisitos de participação e dos critérios de julgamento depende da adequação e da necessidade em vista das virtudes desejáveis para o futuro servidor público, tal como a compatibilidade da exigência com os valores constitucionais fundamentais" $" 389$

Así, no es suficiente que el requisito de acceso a la función pública esté previsto en una ley, sino que también aquel sea adecuado al desempeño de la actividad administrativa a ser ejercida. En el caso de no observancia de esta última exigencia, la ley será considerada inconstitucional:

${ }^{387}$ SPITZCOVSKY, Celso. Limitações constitucionais aos editais de concursos públicos. Texto extraído del sitio Jus Navigandi (http://jus2.uol.com.br/doutrina/texto.asp?id=5125), acceso en 12 de mayo de 2010.

${ }^{388}$ PALOMAR OLMEDA, Alberto. Derecho de la función pública: régimen jurídico de los funcionarios públicos, 7 ed., Dykinson, Madrid, 2003, p. 109.

${ }^{389}$ JUSTEN FILHO, Marçal. Op.cit., p. 743-749. 
"Os requisitos deverão, também, ser fixados em estreita consideração com as funções a serem exercidas pelos servidores, sob pena de serem considerados discriminatórios e violadores dos princípios da igualdade e da impessoalidade. Se a lei determinar algum dispositivo que institua requisito ofensivo a tais postulados, estará ele inquinado do vício de inconstitucionalidade."

La última afirmación arriba citada induce a que el análisis de la legitimidad de los requisitos de acceso casi siempre dependa de las circunstancias que concurren en cada caso (relatividad de los requisitos). ${ }^{391}$

Lo que los ordenamientos constitucionales suelen hacer es identificar determinados criterios que, a priori, son considerados inválidos (art. $3^{\circ}$, IV, CB, y art. 14, CE). En España, es la llamada doctrina de clasificación sospechosa, que pone bajo sospecha determinados criterios.

En Brasil, se ha dicho que: "apesar dos citados dispositivos, aqui não há proibição absoluta de discriminar mediante tais critérios. O que o constituinte quis foi alertar que a discriminação através de tais critérios é comumente abusiva, devendo ser evitada",392

De la misma forma, se puede afirmar que hay muchos otros criterios que no fueron previstos expresamente en la Constitución, pero que también pueden, caso utilizados, crear discriminaciones odiosas ${ }^{393}$.

\footnotetext{
${ }^{390}$ PINHEIRO MADEIRA, José Maria. Op.cit., p. 76.

${ }^{391}$ De forma conclusiva, se ha afirmado que: "pode-se dizer que as exigências de participação somente são conciliáveis com o sistema jurídico quando corresponderem a uma característica essencial necessária ou inquestionavelmente conveniente para o desempenho das funções correspondentes ao cargo em disputa. Isso significa que somente diante de cada caso concreto, somente em função do conteúdo ocupacional de determinado cargo é que se poderá saber se uma dada exigência, se um dado requisito de participação, é constitucional ou inconstitucional, em razão de sua pertinência ou não com as funções que deverão ser exercidas pelo futuro ocupante do cargo." (ABREU DALLARI, Adilson. Princípio da isonomia e concurso público, en Concurso público e Constituição, Fabrício Motta (Cordinador), Editora Fórum, Belo Horizonte, 2005, p. 97).

392 MACHADO JÚNIOR, Agapito. Op.cit., p. 124.

${ }^{393}$ Respecto a esta cuestión, se ha dicho, comentando la Constitución brasileña, que: "A enumeração de alguns fatores de discriminação no texto do dispositivo não significa que outros sejam tolerados. A relação é meramente exemplificativa pois dela não consta a distinção por motivo de raça (implicitamente contida no inciso XLII, do artigo $5^{\circ}$ ), que, além de ensejar as sanções normais a qualquer ato preconceituoso (sua nulidade, a responsabilidade funcional do agente) constitui crime inafiançável e imprescritível, punido com pena de reclusão. Assim sendo, tanto o estabelecimento de condições referentes à altura, à idade, bem como ao sexo, poderão ser lícitos ou não, caso respeitem ou violem o
} 
Cabe añadir que se ha dicho anteriormente "casi siempre", primeramente, porque se puede afirmar que existen requisitos generales de participación en cualquier proceso de selección ${ }^{394}$ (exigencias mínimas para que un aspirante pueda tomar parte en una competición para el acceso a la función pública, como "poseer la titulación exigida").

En otras oportunidades, casi siempre, porque habrá requisitos que serán siempre ilegítimos, principalmente porque infringen derechos fundamentales. Para ejemplificar esta situación, es posible destacar, la exigencia, para el acceso a una función pública, de afiliación en determinado sindicato, lo que infligiría la norma prevista en el art. 28.1 $\mathrm{CE}^{395}$, y en el art. $8^{\circ} \mathrm{CB}^{396}$.

Sobre los requisitos no exigibles, la doctrina española utiliza una clasificación que los divide en tres apartados: a) los que atentan a los arts. 14 y 23.2 de

princípio da isonomia, isto é, caso sejam ou não pertinentes, o que se verificará em cada caso concreto. Condição pertinente será somente aquela ditada pela natureza da função a ser exercida, ou seja, circunstância, fator ou requisito indispensável para que a função possa ser bem exercida, o que não se confunde com a mera conveniência da administração, nem com preferências pessoais de quem quer que seja." (ABREU DALLARI, Adilson. Regime Constitucional dos Servidores Públicos. 2 ed., São Paulo:Revista dos Tribunais, 1990, p. 32).

${ }^{394}$ El Estatuto Básico del Empleado Público español (Ley 7/2007) define en el art. 56.1 cuáles son los mencionados Requisitos generales en los términos siguientes:

"Para poder participar en los procesos selectivos será necesario reunir los siguientes requisitos:

a) Tener la nacionalidad española, sin perjuicio de lo dispuesto en el artículo siguiente.

b) Poseer la capacidad funcional para el desempeño de las tareas.

c) Tener cumplidos dieciséis años y no exceder, en su caso, de la edad máxima de jubilación forzosa. Sólo por ley podrá establecerse otra edad máxima, distinta de la edad de jubilación forzosa, para el acceso al empleo público.

d) No haber sido separado mediante expediente disciplinario del servicio de cualquiera de las Administraciones Públicas o de los órganos constitucionales o estatutarios de las Comunidades Autónomas, ni hallarse en inhabilitación absoluta o especial para empleos o cargos públicos por resolución judicial, para el acceso al cuerpo o escala de funcionario, o para ejercer funciones similares a las que desempeñaban en el caso del personal laboral, en el que hubiese sido separado o inhabilitado. En el caso de ser nacional de otro Estado, no hallarse inhabilitado o en situación equivalente ni haber sido sometido a sanción disciplinaria o equivalente que impida, en su Estado, en los mismos términos el acceso al empleo público.

e) Poseer la titulación exigida."

En del derecho brasileño, como no hay una ley general que regule el acceso a la función pública, se puede citar la Ley Federal 8112/90, que es el Estatuto del Servidor Público Federal (de la Unión), que establece: "Art. $5^{\circ}$ São requisitos básicos para investidura em cargo público:

I - a nacionalidade brasileira;

II - o gozo dos direitos políticos;

III - a quitação com as obrigações militares e eleitorais;

IV - o nível de escolaridade exigido para o exercício do cargo;

$V$ - a idade mínima de dezoito anos;

VI - aptidão física e mental.

$\S 1^{\circ}$ As atribuições do cargo podem justificar a exigência de outros requisitos estabelecidos em lei."

395 "Artículo 28. 1. Todos tienen derecho a sindicarse libremente.(...)."

396 "Art. $8^{\circ}$ É livre a associação profissional ou sindical (...)", 
la CE; b) los que corresponden a conocimientos a demostrar en los ejercicios y pruebas; y c) los que son propios de fases procedimentales diferentes. ${ }^{397}$

Los del primer grupo tratan sobre los requisitos que violan el principio de igualdad y condicionan la participación de los aspirantes en la selección, como la vecindad y residencia ${ }^{398}$, las condiciones sociales y económicas, ideas políticas, el hecho de ya ser funcionario de una Administración Pública.

La citada doctrina también hace referencia a otros requisitos inexigibles, como género, religión, buena conducta, carecer de antecedentes penales, haber prestado el servicio militar o la prestación social sustitutoria. ${ }^{399}$ Algunos de los requisitos arriba mencionados serán objeto de un análisis más detallado en este trabajo, ya que por poseer determinadas peculiaridades, demandan mayor profundización, como las cuestiones de género y religión (en estos estudios, se verá como hay diferencias considerables entre los sistemas jurídicos español y brasileño).

A su vez, las restricciones del segundo grupo (las que corresponden a conocimientos a demostrar en los ejercicios y pruebas), no serían propiamente requisitos que condicionan la participación de los aspirantes, sino exigencias que pueden dificultar, de forma indebida, el acceso ${ }^{400}$. Es lo que pasa con la previsión injustificada de determinados contenidos en el temario. Sobre este tema, serán dedicadas algunas páginas de este trabajo a la cuestión de exigencia de conocimientos

\footnotetext{
${ }^{397}$ PÉREZ LUQUE, Antonio. Op.cit., p. 304.

398 Sin embargo, en determinadas circunstancias, cuando hay un reparto de plazas por ámbitos territoriales, para garantizar la eficacia, sería posible exigir a los aspirantes conocimientos de las características y condiciones del lugar donde han de desempeñar su función, ya que "indudablemente quien conozca en mayor medida aquellas condiciones, características y circunstancias del lugar en que ha de desplegar su labor estará mejor preparado para desarrollarla y presentará una mejor aptitud para ser seleccionado, tratándose de un presupuesto que a todos los aspirantes se impone por igual, sin privilegios ni discriminaciones, tal como se afirma en la SRSJ de Galicia de 7 de abril de 2004 (RJCA 2004/780)." (MAURI MAJÓS, Joan. Op.cit., p. 293)

${ }^{399}$ PÉREZ LUQUE, Antonio. Op.cit., pp. 304-311.

400 En Brasil, José dos Santos Carvalho Filho diferencia los requisitos de inscripción ("algumas exigências legitimamente reclamadas pela Administração ao momento em que o candidato se inscreve no concurso"), como la exibición del documento de identidad o de apoderamiento, etc., y que debem estar previstos en el edital (ya es suficiente), de los requisitos del cargo ("são aqueles que o candidato deve preencher para a investidura no cargo público"). Sobre tales requisitos, dijo: "Em virtude do princípio de legalidade (art. 37, CF), esses requisitos devem estar contemplados em lei. Nada impede, contudo, que o edital os mencione, reproduzindo o que a lei estabelece. O que não é lícito é que tal exigência seja apenas prevista no edital. Também revela ilegitimidade a exigência de cumprir requisito de cargo ao momento em que o candidato se limita a inscrever-se no concurso. Cuida-se de exigência prematura, desnecessária e inoportuna. Se o requisito é para o cargo, sua exigência deverá dar-se somente quando o candidato, já agora aprovado, estiver em condições de ser nomeado para a conseqüente investidura" (SANTOS CARVALHO FILHO, José dos. Op.cit., p. 557).
} 
lingüísticos, que suele generar un gran y polémico debate en los medios académico y judicial españoles.

Las restricciones del tercer grupo (los que son propios de fases procedimentales diferentes) pueden impedir la toma de posesión, como la previsión del art. 62.1 "c" del Estatuto Básico del Empleado Público español, que estipula para la adquisición de la condición de funcionario de carrera el acatamiento de la Constitución y, en su caso, del Estatuto de Autonomía correspondiente y del resto del Ordenamiento Jurídico.

En cambio, no parece que los ejemplos dados por dicha doctrina (la mencionada exigencia de acatamiento de la Constitución y la declaración del aspirante de que no posee otro empleo público) son condiciones inexigibles, ya que son plenamente justificables. También es relevante destacar que lo que el Estatuto Básico del Empleado Público impone en su art. 62.2.

Así, a partir de la norma arriba transcrita, es posible subrayar dos aspectos importantes: en primer lugar, que el momento propio para la demostración del cumplimiento de los requisitos de acceso a la función pública debe ocurrir tras el proceso selectivo, antes de la toma de posesión.

Así, el Real Decreto 364/1995, de 10 de marzo, por el que se aprueba el Reglamento General de Ingreso del Personal al Servicio de la Administración General del Estado y de Provisión de puestos de trabajo y Promoción Profesional de los Funcionarios Civiles de la Administración General del Estado, trata de la aportación de documentos en el artículo 23.1, y establece el plazo para el referido acto ${ }^{402}$.

Sobre la referida cuestión, cabe destacar que:

"el Ordenamiento jurídico no exige a los aspirantes que con sus solicitudes de participación en el sistema selectivo tengan que aportar

\footnotetext{
401 “A efectos de lo dispuesto en el apartado 1.b) anterior, no podrán ser funcionarios y quedarán sin efecto las actuaciones relativas a quienes no acrediten, una vez superado el proceso selectivo, que reúnen los requisitos y condiciones exigidos en la convocatoria."

402 "Los aspirantes propuestos aportarán ante la Administración, dentro del plazo de veinte días naturales desde que se publiquen en el Boletín Oficial del Estado las relaciones definitivas de aprobados a que se refiere el artículo anterior, los documentos acreditativos de las condiciones de capacidad y requisitos exigidos en la convocatoria."
} 
la justificación documental de las condiciones de capacidad exigidas en las bases de la convocatoria, pero, una vez seleccionados, éstos han de hacerlo, medida que está dentro de los principios de economía, celeridad y eficacia" ${ }^{403}$

No obstante, en el ámbito de la legislación del Estado, conviene destacar lo que el referido Real Decreto determina en el artículo $18.2^{404}$.Esta norma significa que aunque los documentos comprobatorios de los requisitos de acceso previstos en las bases de la convocatoria solamente necesiten ser aportados tras el proceso selectivo (cf. art. 23.1 del Real Decreto 364/1995), "ha de tenerse en cuenta que el efecto de la tenencia de las condiciones exigidas es con referencia al el último día de terminación del plazo de presentación de solicitudes (art. 18.2 RD 364/1995). Lo obtenido o adquirido después ya no es válido." ${ }^{, 405}$

La segunda consecuencia del art. 62.2 del Estatuto Básico del Empleado Público español es que la propia legislación diferencia los requisitos de las condiciones para el acceso a la función pública.

Así, los requisitos serían necesarios para "tomar parte en las pruebas selectivas” ${ }^{\star 406}$, condicionando la participación de los aspirantes en la selección y serían acreditados a partir de la aportación de documentos por los aspirantes aprobados.

A su vez, se puede relacionar las condiciones a los conocimientos a demostrar en los ejercicios y pruebas, lo que estaría asociado al concepto de la capacidad de los aspirantes, comprendida esta como la verificación de la idoneidad mediante el análisis del rendimiento de los aspirantes en determinadas pruebas realizadas en el propio procedimiento selectivo.

En el derecho brasileño, la doctrina suele destacar tres exigencias para la definición de los requisitos de acceso a la función pública ${ }^{407}$ : la previsión en ley, la

\footnotetext{
${ }^{403}$ PÉREZ LUQUE, Antonio. Op.cit., p. 565.

404 "Para ser admitido y, en su caso, tomar parte en las pruebas selectivas correspondientes, bastará con que los aspirantes manifiesten en sus solicitudes de participación que reúnen todas y cada una de las condiciones exigidas, referidas siempre a la fecha de expiración del plazo de presentación.”

405 PÉREZ LUQUE, Antonio. Op.cit., p. 567.

406 SÁNCHEZ MORÓN, Miguel. Op.cit., p.116.

${ }^{407}$ La siguiente asertiva resume las tres exigências: "As regras a serem observadas pelos candidatos no momento da inscrição para o certame devem estar previstas no edital, não podendo a Administração
} 
relación entre la exigencia y las actividades o tareas que serán desarrolladas ${ }^{408}$, y la observancia de los diversos principios constitucionales ${ }^{409}$, especialmente aquellos que regulan la actividad administrativa ${ }^{410}$.

Así, se puede afirmar que en el ámbito del derecho brasileño, para la válida definición de los requisitos de acceso a la función pública se impone estos estén presentes en ley (exigencia formal ${ }^{411}$ ) y que esta norma observe las condiciones previstas en la Constitución (exigencia material ${ }^{412}$ ).

extrapolar as suas exigências. Essas condições devem ser razoáveis, guardar compatibilidade com as atribuições do cargo e devem estar previstas na lei que disciplina a carreira." (MARINELA DE SANTOS SOUZA, Fernanda. Concursos públicos - acessibilidade e grandes polêmicas, extraído del libro Leituras complementares de Direito Administrativo - Advocacia Pública, Fernanda Marinela e Fabrício Bolzan (organizadores), Editora Podium, Salvador, 2008, p. 196).

${ }^{408}$ Así, se há dicho que: "Cabe ao legislador, portanto, estabelecer critérios para admissão com obediência ao princípio da isonomia, só estabelecendo exigências específicas quando necessária em razão das atribuições a serem exercidas." (ZANELLA DI PIETRO, Maria Sylvia. Direito Administrativo, $21^{\mathrm{a}}$ ed., Editora Atlas, São Paulo, 2008, p. 500). La doctrina brasileña también há subrayado que "não só o legislador como o administrador púbico estão impedidos de criar requisitos objetivos ou subjetivos de caráter discriminatório. E o que é mais grave: sem qualquer relação direta com as funções atribuídas ao cargo. Na verdade, requisitos de acesso só se legitimam se estiver rigorosamente comprovado que foram fixados levando em conta as funções a serem exercidas, vale dizer, a missão destinada ao servidor dentro do cenário da Administração Pública." (SANTOS CARVALHO FILHO, José dos. Op.cit., p. 556)

${ }^{409}$ En este sentido: "Deve-se ainda anotar que o princípio da ampla acessibilidade aos cargos $e$ empregos públicos, reconhecido no sistema constitucional brasileiro, é também conseqüência do trinômio democracia-isonomia-eficiência. As eventuais restrições à participação em concursos, por tais motivos, devem possuir justificação nos valores consagrados pela Constituição e consagradas em lei formal" (MOTTA, Fabrício. Concursos públicos e o princípio da vinculação ao edital. Texto extraído del sitio Jus Navigandi (http://jus2.uol.com.br/doutrina/texto.asp?id=8035, elaborado em 03.2005, con acceso en 16 de mayo de 2010.)

${ }^{410}$ En este contexto: "o mesmo art. 37, I, condiciona a acessibilidade aos cargos públicos ao preenchimento dos requisitos estabelecidos em lei. Com isso, ficam as Administrações autorizadas a prescrever exigências quanto à capacidade física, moral, técnica, científica e profissional, que entender convenientes, como condiçôes de eficiência, moralidade e aperfeiçoamento do serviço público" ${ }^{410}$ LOPES MEIRELLES, Hely. Direito Administrativo Brasileiro. $15^{a}$ ed., Ed. Revista dos Tribunais, São Paulo, 1990, p. 368-369).

${ }^{411}$ Respecto a las exigencias formales, se ha dicho que: "Para o acesso a cargo, emprego ou função não basta ser brasileiro. $O$ interessado há, ainda, que satisfazer aos requisitos estabelecidos em lei, consoante reza a parte final do referido inciso. A lei responsável pela instituição desses requisitos é a de entidade política titular do cargo, emprego ou função pública que se deseja preencher, dada a autonomia que se lhes assegura nessa matéria. Um dos requisitos é sem dúvida, lograr aprovação e classificação em concurso público de provas ou de provas e títulos. A lei em apreço é da iniciativa do Chefe do Poder Executivo (art. 61, § $1^{o}$, II, c, da CF), em relação aos cargos, empregos e funções desse Poder. Será, no entanto, resolução quando tratar-se de criação de cargo do serviço administrativo do Legislativo. De fato, não seria lógico, nem prático, que esse Poder pudesse criar cargo sem que se lhe reservasse a competência para estabelecer os requisitos de provimento, por exemplo. O quorum e os turnos de votação são os constantes no Regimento Interno da Casa de Leis competente." (GASPARINI, Diógenes. Direito Administrativo. $4^{\text {a }}$ ed., Editoria Saraiva, São Paulo, 1995, p.119).

${ }^{412}$ Respecto a las exigencias materiales, se ha subrayado que: "Sabe-se que o legislador tem amplo poder de escolha dos requisitos necessários para provimento de determinado cargo ou emprego público 
También se puede destacar que, según la doctrina y la jurisprudencia brasileñas, tan solo por ocasión de la toma de posesión del funcionario es que debe ser realizada la exigencia de los requisitos de acceso a la función pública. ${ }^{413}$

Es que "por determinação do inc. I do art. 37 da Carta Constitucional brasileira, os requisitos previstos em lei são para acesso ao cargo, não para inscrição no concurso. Isso quer dizer que os requisitos de habilitação só poderão ser exigidos no momento da posse." 414

En el ámbito de la jurisprudencia brasileña ${ }^{415}$, la Súmula 266, del Superior Tribunal de Justicia ha definido que "o diploma de habilitação legal para o exercício do cargo deve ser exigido na posse, e não na inscrição para o concurso público."

quando da confecção da lei (discricionariedade inerente ao agente público); entretanto, qualquer escolha deverá ter coerência com a Constituição Federal, sob pena de nulidade pelo Poder Judiciário, que reconhecerá a inconstitucionalidade da norma. É certo que a própria Constituição sugere certos limites quanto aos critérios de seleção e de admissão de pessoal, a começar pelo objetivo do Estado em promover o bem de todos sem qualquer tipo de discriminação (art. $3^{\circ}$, IV, da CF/88). Em especial, é de registra o $\$ 3^{\circ}$ do art. 39, que manda aplicar ao servidor público o inciso XXX do art. $7^{\circ}$, que estabelece, por sua vez, "a proibição de diferença de salários, de exercício de funções e de critério de admissão por motivo de sexo, idade, cor ou estado civil" (MACHADO JÚNIOR, Agapito. Op.cit., p. 124).

${ }^{413}$ Así, cabe destacar que "Ao exigir-se certos critérios, ou habilitações, a Administração Pública não pretende que sejam estes supridos ao momento da prova, mas para que os candidatos tenham conhecimentos necessários ao melhor exercício das atribuições do cargo, portanto, ao momento da investidura. Quando se estabelece uma determinada experiência para exercício da função, é porque se acredita que aquele tempo trará maturidade ao candidato, não para fazer o concurso, mas para entrar no exercício da função do cargo. Da mesma forma, quando se exige um diploma de curso superior, não é para o candidato realizar as provas, pois pode estar concluindo o curso, mas é para que ele tenha legitimidade, tenha conhecimentos necessários para melhor exercer as atribuições do cargo. Não é necessário muito esforço interpretativo para se chegar a essa conclusão. A melhor exegese aplicada à questão é a de que a existência da habilitação plena somente deve se dar ao momento da posse, não quando da inscrição no concurso ou no interstício temporal de sua realização. Atende-se, com isto, a finalidade da Constituição, o objetivo desta. Cumpri-la, como sabemos, não é aferrar-se servilmente à sua letra, mas realizar os objetivos desta. Ora, não tem nenhuma significação a inexistência, no ato da inscrição, do documento, da habilitação para o exercício da profissão. No momento em que esse exercício vai ocorrer é que a habilitação é necessária (...)También se ha subrayado que: "Não há equidade em exigir-se dos candidatos a habilitação no momento da inscrição no concurso, quando terão totais condições de exercer o cargo no momento da investidura. Tratar o administrado dessa forma é, em última análise, uma forma de discriminação. Entenda-se: o candidato possuirá todas habilitações necessárias para o correto exercício da função pública, contudo é impedido de realizar o concurso para ingresso porquanto o administrador antecipou a demonstração dessas habilitações para o momento da inscrição no certame. Total absurdo".(SOARES DA COSTA, Wagner. Concurso público: inconstitucionalidade da exigência dos requisitos ao momento da inscrição, texto extraído del sitio Jus Navigandi (http://jus2.uol.com.br/doutrina/texto.asp?id=3596), publicado en 01.2003, acceso en 16.02.2010).

${ }^{414}$ LOBELLO DE OLIVEIRA ROCHA, Francisco. Op.cit., p. 76.

${ }^{415}$ Sin embargo, el Supremo Tribunal Federal admitió que la exigencia de la comprobación de la actividad jurídica por tres años sea hecha cuando de la inscripción en el concurso. (ADI 3.460, Rel. Min. Carlos Britto, en 31.08.2006, Informativo STF $\mathrm{n}^{\circ} 438$ set/2006, cuando tuvo que analizar la Resolución 
Analizando algunos requisitos que violan frontalmente los principios del ordenamiento jurídico, cabe añadir que, en la mayor parte de las ocasiones, no es seguro afirmar apriorísticamente que determinados requisitos son o no jurídicamente aceptables, sin que se conozcan las circunstancias que giran en torno a las mencionas exigencias de los aspirantes.

Por esta razón, se resaltó anteriormente en este trabajo el carácter relativo de los requisitos, ya que la verificación de la posibilidad de su aceptación depende de diversos factores, siempre relacionados con la función a ser desempeñada (respetando los factores de mérito y capacidad). ${ }^{416}$

El establecimiento de requisitos específicos para cada situación está autorizado por la Constitución brasileña, en el art. $39, \S 3^{\circ 417}$, y por el Estatuto Básico del Empleado Público español (Ley 7/2007), en el apartado 3 del art. $56^{418}$.

Respecto a la referida ley prevista en la Constitución brasileña, se ha destacado que:

\begin{abstract}
"Mas à lei específica, de caráter local, é vedado dispensar condições estabelecidas em lei nacional para a investidura em cargos públicos, como as exigidas pelas leis eleitoral e do serviço militar, ou para o exercício de determinadas profissões (Constituição da República, art. 22, XVI). E tanto uma como outra deverá respeitar as garantias asseguradas do art. $5^{\circ}$, da Constituição da República, que veda distinções baseadas em sexo, raça, trabalho, credo religioso e
\end{abstract}

\footnotetext{
35/2002 con la redacción de la Resoluccón 55/2004, del Conselho Superior del Ministerio Público del Distrito Federal y de los Territorios).

${ }^{416}$ La doctrina brasileña comenta que "Embora o objetivo do constituinte seja o de proibir o limite de idade e outros tipos de discriminação, a proibição não pode ser interpretada de modo absoluto; primeiro, porque o artigo 37, I, deixa para a lei ordinária a fixação dos requisitos de acesso aos cargos, empregos e funções; segundo, porque, para determinados tipos de cargo, seria inconcebivel a inexistência de uma limitação, quer em relação a sexo, que em relação à idade. Não se poderia conceber que, para o cargo de guarda de presídio masculino, fossem admitidas candidatas do sexo feminino, ou que para certos cargos policiais fossem aceitas pessoas de idade mais avançada." (ZANELLA DI PIETRO, Maria Sylvia. Op.cit., p. 500).

417 “Art. 39. $\S 3^{\circ}$ Aplica-se aos servidores ocupantes de cargo público o disposto no art. $7^{\circ}, I V, V I I, V I I I$, $I X, X I I, X I I I, X V, X V I, X V I I, X V I I I, X I X, X X, X X I I$ e XXX, podendo a lei estabelecer requisitos diferenciados de admissão quando a natureza do cargo o exigir".

418 "Art.56.3. Podrá exigirse el cumplimiento de otros requisitos específicos que guarden relación objetiva y proporcionada con las funciones asumidas y las tareas a desempeñar. En todo caso, habrán de establecerse de manera abstracta y general.”
} 
convicções políticas. Quanto ao princípio da isonomia (Constituição da República, art. $5^{\circ}$ ), é preciso ver que, além das distinções acima referidas a igualdade de todos os brasileiros perante a lei veda as exigências meramente discriminatórias, como as relativas ao local de nascimento, condições pessoais de fortuna, família, privilégios de classe ou qualquer outra qualificação social. E assim é porque os requisitos a que se refere o texto constitucional hão de ser apenas os que, objetivamente considerados, se mostrem necessários ao cabal desempenho da função pública." 419

A su vez, se puede afirmar que debido a la claridad de la mencionada regla contemplada en la legislación española, es posible llegar a dos exigencias para que los requisitos específicos puedan ser exigidos: a) que guarden relación objetiva y proporcionada con las funciones asumidas y las tareas a desempeñar, y b) que sean establecidos de manera abstracta y general.

La primera exigencia prohíbe la previsión de requisitos específicos que no respeten la razonabilidad, lo que ocurriría si la restricción al acceso general no guardara relación con las actividades inherentes a la función pública que será desempeñada. De forma caricaturesca, se puede imaginar el ejemplo de la previsión de altura mínima o máxima para el ejercicio de la función de telefonista, o de conocimientos de la lengua griega para el desempeño de la función de vigilante.

Sin embargo, en el día a día de las Administraciones Públicas, las situaciones no son tan grotescas como las que fueron ejemplificadas arriba. Lo que suele suceder es que muchas exigencias para con los aspirantes tienen una cierta justificación, ora más, ora menos plausibles, lo que puede causar muchas dudas y polémicas.

En estos casos, es muy relevante tomar en consideración lo que ya ha sido analizado en el capítulo primero, cuando fueron dedicadas algunas páginas al estudio de ¿Cómo se debe discriminar? Con la previsión de requisitos para el acceso a la función pública, a través del establecimiento de límites al ejercicio del derecho previsto en los art. 23.2 CE y 37, I CB, habrá una efectiva necesidad de discriminar, en el sentido de diferenciar situaciones, afectando a las personas.

${ }^{419}$ LOPES MEIRELLES, Hely. Op.cit., pp. 368-369. 
En el mencionado estudio, se verificó que en los procesos de elaboración e interpretación de la norma diferenciadora, debe haber la búsqueda de la finalidad de la norma discriminante, hay que buscar la conexión entre la finalidad de la norma discriminante con un interés jurídicamente relevante, y hay que tener en cuenta la necesidad de utilización de criterios discriminantes con proporcionalidad.

La doctrina española destaca que:
"La introducción de algún requisito discriminatorio, es decir, que comporte desigualdades de trato no objetivas ni razonables, constituye una infracción del artículo 23.2 CE (aparte la eventual infracción de disposiciones legales o reglamentarias en que incurriere). Por tanto, contra ella podrá interponerse recurso de amparo judicial (además del recurso ordinario) $\mathrm{y}$, subsidiariamente, recurso de amparo constitucional. ${ }^{, 420}$

Como ya hay un extenso rol de intentos relativos al establecimiento de requisitos específicos para el acceso a la función pública por las distintas administraciones públicas españolas, muchas situaciones ya han sido analizadas por los Tribunales, que no siempre han tomado las decisiones más adecuadas. ${ }^{421}$

Seguramente en Brasil, debido a la ausencia de una norma general de función pública para todos los niveles de la federación, y hasta mismo delante de la inexistencia de leyes de cada ente federal (especialmente, en los más de cinco mil municipios) que establezcan los requisitos de acceso a la función pública ${ }^{422}$, los problemas son aun más graves.

Respecto a la segunda exigencia del derecho español (art. 56.3 del EBEP) para la aceptación de los requisitos específicos para el acceso a la función pública, cabe

\footnotetext{
${ }^{420}$ SÁNCHEZ MORÓN, Miguel. Op.cit., p. 124,

421 Sobre esta cuestión, la doctrina indica decisiones judiciales sobre requisitos de: "vivir o estar empadronado en un municipio o territorio concreto (STSJ de Cataluña de 26 de septiembre de 2006, RJCA 2006/2007), tener edad superior a cuarenta años (STS de 13 de diciembre de 1995m Ref. Ilustel: 286406), haber realizado el servicio militar obligatorio (STS de 4 de diciembre de 1990, RJ 1990/10127), tener la condición de parado y estar inscrito en las oficinas de empleo (STS de 8 de julio de 1998) o poseer una determinada experiencia profesional (STSJ de Asturias de 22 de marzo de 2007, JUR 2007/214167)." (MAURI MAJÓS, Joan. Op.cit., p. 293).

${ }^{422}$ Es relevante que se tenga en consideración que em Brasil: "A lei responsável pela instituição dos requisitos necessários para o acesso a cargos, empregos e funções públicas (...) é de cada um dos entes da federação que desejem preencher os mesmos" (PINHEIRO MADEIRA, José Maria. Op.cit.,.p. 75).
} 
subrayar la reivindicación de que estos sean establecidos de manera abstracta y general, lo que es una exigencia del carácter imparcial de la actuación administrativa.

Por supuesto, los procesos selectivos no deben servir como legitimación formal de maniobras ilícitas realizadas por gestores públicos que quieren distribuir funciones públicas a sus agraciados. En muchas oportunidades, la Administración Pública encubre sus favoritismos a partir de la realización de un procedimiento formalmente regular. En realidad, lo que ocurre es una competición simulada, que enmascara las preferencias de aquellos que están en el ejercicio del poder.

Las oposiciones "sospechosas" son denunciadas con gran frecuencia en la prensa, y pueden comprometer la actuación administrativa, ya que los favorecidos no suelen tener la capacitación necesaria para el desempeño de la función pública ${ }^{423}$.

Sin embargo, aún más grave es la quebrancía del derecho de acceso del ciudadano en condiciones de igualdad, y esto sucede cuando hay favoritismos o vetos a determinadas personas en los procesos selectivos. Por esta razón, "os concursos públicos devem dispensar tratamento impessoal e igualitário aos interessados. Sem isto ficariam fraudadas suas finalidades. Logo, são inválidas distinções capazes de desvirtuar a objetividade ou o controle destes certames." 424

Tras analizar las principales exigencias que deberán ser contempladas en las leyes que establezcan los requisitos de acceso a la función pública, cabe añadir que aunque aquellas sean elaboradas de forma adecuada, aun permanece el riesgo de su mala aplicación. Por este motivo, hay que se destacar también la necesidad de que las referidas leyes sean interpretadas según los principios propios de los procesos selectivos, entre los cuales se destaca la amplia accesibilidad. En este contexto, respecto a la incidencia de la presente orientación en el derecho brasileño, se ha dicho que:

\footnotetext{
${ }^{423}$ En España fue creada la Asociación para la transparencia en las oposiciones. En su blog, se puede percibir la razón de su creación: "Creo que ya es hora de que empecemos a luchar por lo nuestro. Somos personas que hemos visto como la corrupción no solo se extiende al Urbanismo sino que el codiciado "puesto de trabajo de funcionario" también es moneda de cambio de múltiples favores de amigos, compañeros de trabajo y como no, de familiares de: políticos, jefecillos de sección y sindicalistas, es decir, de todo aquel que está en un buen puesto en la Administración pública o que simplemente forma parte de los tribunales en las oposiciones. Es por eso que nos proponemos denunciarlo públicamente y luchar para que esta impunidad acabe. Así que animamos a todos a que con vuestras aportaciones vayamos descubriendo a todos estos y cortándoles las alas." (http://asociac-transparenciaoposiciones.blogspot.com/2006/12/ya-era-hora.html).

${ }^{424}$ BANDEIRA DE MELLO, Celso Antônio. Op.cit., p. 257-258.
} 
"Quanto mais extensiva e ampliativa a interpretação oferecida a toda norma prescritiva de requisitos a serem preenchidos pelos candidatos aos cargos, empregos e funções pública, mais adequada ela é à Constituição, pois o princípio é da acessibilidade e não da negativa do acesso, pelo que, quanto mais se estender a possibilidade de os brasileiros acederem ao serviço público, mais cumprida a norma fundamental estará sendo." 425

A continuación, serán analizadas las principales cuestiones relativas a los requisitos de acceso a la función pública en el derecho español y brasileño. A fin de que sea posible una mejor exposición y análisis de los requisitos de acceso a la función pública, en este trabajo, se ha adoptado una clasificación que divide los mencionados requisitos en dos grupos: los positivos y los negativos.

Los requisitos positivos son los que exigen que los aspirantes a la función pública posean determinadas características, consideradas por la legislación como imprescindibles para el ejercicio de las tareas de determinados puestos.

A su vez, los requisitos negativos estarían relacionados a la inexistencia de determinadas situaciones que son consideradas por la legislación como inapropiadas para el ejercicio de las funciones públicas. En este contexto, puede ser citada la inexistencia de separación definitiva del servicio y de inhabilitación para el desempeño de empleo público, previstas en el art. 56.1 d) del Estatuto Básico del Empleado Público en España.

\section{2 - Requisitos positivos}

En este trabajo, serán estudiados los requisitos positivos contemplados en los ordenamientos jurídicos español y brasileño, algunos de ellos generales, siempre presentes en los procesos selectivos de los referidos países, como la nacionalidad, la edad, la capacidad funcional y la titulación, y otros específicos, ya que solamente inciden en determinados contextos, como es el caso de la exigencia de conocimientos lingüísticos en los procesos selectivos las Comunidades Autónomas españolas bilingües

425 ANTUNES ROCHA, Cármen Lúcia. Princípios constitucionais dos servidores públicos, Editora Saraiva, São Paulo, 1999, p. 168. 
(por ejemplo, Cataluña y País Vasco), o el requisito de tres años de experiencia profesional (actividad jurídica) para las oposiciones de la Magistratura y de la Fiscalía en Brasil.

Es que, como ya se ha visto, la legislación tanto puede establecer requisitos generales para el acceso a la función pública, lo que se exige para todas las plazas (por ejemplo, el requisito de "poseer la capacidad funcional para el desempeño de las tareas" previsto en el derecho español, y la exigencia de "aptidão física e mental" establecida en el derecho brasileño.), como también puede autorizar, bajo determinadas condiciones, la previsión legal de requisitos específicos para cada especie de plaza (es lo que está previsto en el art. 56.3 del Estatuto Básico del Empleado Público español y en el art. 39, § $3^{\circ}$ de la Constitución brasileña).

Por su relevancia transcendente, también serán analizadas las cuestiones relativas al acceso a la función pública de las mujeres y de las personas con discapacidad. Estas dos situaciones merecerán un análisis más profundizado, ya que representan relevantes áreas en las cuales pueden ser realizadas acciones positivas por los poderes públicos.

En la parte final de este capítulo, también serán investigados temas polémicos relacionados a las exigencias para el acceso a la función pública, aunque no sean muchas veces tenidas en consideración por la legislación, como sucede con la religión, la raza, la orientación sexual y la experiencia de los aspirantes.

Cabe resaltar que el análisis de todos los requisitos de acceso a la función pública será realizado a través del paradigma del principio de igualdad, ya que este es el principal objeto del presente trabajo.

\subsection{1- Nacionalidad}

Durante muchos años, las legislaciones de los más distintos países solían establecer que el ejercicio de las funciones públicas solamente podría ocurrir a través de personas que tuviesen la nacionalidad del referido Estado. Esta concepción más estricta rechazaba el ingreso de extranjeros en la función pública, estaba basada en argumentos como el riesgo de que la soberanía nacional pudiera ser amenazada o que los extranjeros 
solo podrían ejercer derechos civiles, lo que excluiría la participación en procesos selectivos para acceso a la función pública.

Afortunadamente, este panorama ha cambiado en las últimas décadas, lo que se puede fácilmente percibir a través del innegable proceso de ampliación de la posibilidad del extranjero ejercer cargos y empleos públicos. La referida alteración ha permitido que las Administraciones Públicas de los más distintos países pudiesen contratar personas con alta capacidad técnica, especialmente en sectores en los cuales la mano de obra nacional no satisfacía la demanda existente.

Además, es incuestionable que el ingreso del extranjero a la función pública es una exigencia del derecho de acceso en el referido ámbito, especialmente cuando se prevé que tal derecho será ejercido en condiciones de igualdad.

No obstante, como se verá a continuación, aunque la Constitución brasileña establezca de forma más clara y contundente que la española, que el extranjero debe recibir un trato equivalente aquel ofrecido al nacional ${ }^{426}$, el acceso del extranjero a la función pública en España es una realidad más visible que en Brasil.

Seguramente, la afirmación anterior se debe al hecho de que la integración de España en la Unión Europea ha producido diversos efectos, entre los cuales se destaca la exigencia de libre circulación de trabajadores, incluso en el sector público, circunstancia que no ha sucedido con la misma intensidad en el contexto brasileño y su integración al Mercosur.

En España, el Estatuto Básico del Empleo Público (Ley 7/2007) impone la nacionalidad española como requisito general de acceso a la función pública, según prevé el art. 56.1 a) ${ }^{427}$. Sin embargo, abre la posibilidad de acceso de extranjeros a la

\footnotetext{
${ }^{426}$ En este sentido, cabe subrayar que la Constitución brasileña determina que "Art. $5^{\circ}$ Todos são iguais perante a lei, sem distinção de qualquer natureza, garantindo-se aos brasileiros e aos estrangeiros residentes no País a inviolabilidade do direito à vida, à liberdade, à igualdade, à segurança e à propriedade (...)". A su vez, la Constitución española impone que: "Art. 13. 1. Los extranjeros gozarán en España de las libertades públicas que garantiza el presente Título en los términos que establezcan los Tratados y la Ley" Además, en el art. 14, al tratar de la igualdad, prevé que "Art. 14. Los españoles son iguales ante la Ley, sin que pueda prevalecer discriminación (...)”.

427 "Artículo 56. Requisitos generales.

1. Para poder participar en los procesos selectivos será necesario reunir los siguientes requisitos:

a) Tener la nacionalidad española, sin perjuicio de lo dispuesto en el artículo siguiente."
} 
función pública bajo determinadas circunstancias previstas en el art. $57^{428}$ de la referida ley.

La cuestión que se analiza ya estaba prevista en la Ley 17/1993, del 23 de diciembre, norma derogada expresamente por el Estatuto Básico, en su Disposición derogatoria única apartado d). A partir del análisis de las disposiciones normativas arriba mencionadas, se percibe que:

"la regla general para acceder a la función pública ya no es ser español sino nacional de uno de los Estados miembros de la Unión Europea, o bien cónyuge no separado en derecho de aquél o descendiente de uno u otro que sea menor de edad o dependiente, o incluso persona de otra nacionalidad a la que se apliquen los Tratados celebrados por la Unión Europea y ratificados por España para la aplicación de la libre circulación de trabajadores (artículo 57, 2 y 3). ${ }^{429}$

428 “Artículo 57. Acceso al empleo público de nacionales de otros Estados.

1. Los nacionales de alguno de los Estados miembros de la Unión Europea podrán acceder, como personal funcionario, en igualdad de condiciones que los españoles, a los empleos públicos, con excepción de aquellos que directa o indirectamente impliquen una participación en el ejercicio del poder público o en las funciones que tienen por objeto la salvaguardia de los intereses del Estado o de las Administraciones Públicas.

A tal efecto, los órganos de Gobierno de las Administraciones Públicas determinarán las agrupaciones de funcionarios contempladas en el artículo 76 a las que no puedan acceder los nacionales de otros Estados.

2. Las previsiones del apartado anterior serán de aplicación, cualquiera que sea su nacionalidad, al cónyuge de los españoles y de los nacionales de otros Estados miembros de la Unión Europea, siempre que no estén separados de derecho y a sus descendientes y a los de su cónyuge siempre que no estén separados de derecho, sean menores de veintiún años o mayores de dicha edad dependientes.

3. El acceso al empleo público como personal funcionario, se extenderá igualmente a las personas incluidas en el ámbito de aplicación de los Tratados Internaciones celebrados por la Unión Europea y ratificados por España en los que sea de aplicación la libre circulación de trabajadores, en los términos establecidos en el apartado 1 de este artículo.

4. Los extranjeros a los que se refieren los apartados anteriores, así como los extranjeros con residencia legal en España podrán acceder a las Administraciones Públicas, como personal laboral, en igualdad de condiciones que los españoles.

5. Sólo por ley de las Cortes Generales o de las Asambleas Legislativas de las Comunidades Autónomas podrá eximirse del requisito de la nacionalidad por razones de interés general para el acceso a la condición de personal funcionario.

Artículo 58. Acceso al empleo público de funcionarios españoles de Organismos Internacionales.

Las Administraciones Públicas establecerán los requisitos y condiciones para el acceso a las mismas de funcionarios de nacionalidad española de Organismos Internacionales, siempre que posean la titulación requerida y superen los correspondientes procesos selectivos. Podrán quedar exentos de la realización de aquellas pruebas que tengan por objeto acreditar conocimientos ya exigidos para el desempeño de su puesto en el organismo internacional correspondiente."

${ }^{429}$ SÁNCHEZ MORÓN, Miguel. Autor del capítulo décimo del libro Comentarios a la Ley del Estatuto Básico del Empleado Público, Miguel Sánchez Morón (Director); Federico A. Castillo Blanco, Alberto 
Cabe añadir que, tratándose del acceso a la condición de funcionario, lo que vale son las reglas arriba comentadas. Sin embargo, para la condición de empleado público laboral, también tienen derecho al acceso en condiciones de igualdad con los españoles otros extranjeros, desde que tengan residencia legal en España, según determina el art. 57.4 del Estatuto Básico del Empleado Público.

También conviene destacar que los empleos públicos que directa o indirectamente impliquen una participación en el ejercicio del poder público o en las funciones que tienen por objeto la salvaguardia de los intereses del Estado o de las Administraciones Públicas deben ser reservados a los españoles, conforme el art. 57.1 del mencionado Estatuto básico.

Es curioso enfatizar que las mencionadas hipótesis de reserva de funciones públicas a los españoles coinciden con los casos del art. $9.2^{430}$ del Estatuto, que establece la reserva de funciones, conforme advierte la doctrina. ${ }^{431}$

Para definición de las hipótesis de reserva de funciones a los españoles, el Estatuto Básico atribuye tal competencia a los órganos de Gobierno de las Administraciones Públicas, que deberán determinar las agrupaciones de funcionarios contempladas en el artículo 76 a las que no puedan acceder los nacionales de otros Estados.

Sin embargo, la determinación destacada debe estar sometida al Derecho Comunitario, y este "ha establecido una obligación a sus Estados miembros y, lógicamente también al Reino de España, de garantizar el acceso a los empleos públicos en condiciones de igualdad a los no nacionales comunitarios, es decir, por ciudadanos comunitarios pero que no tengan la nacionalidad española." ${ }^{432}$

También merece registro que hay límites materiales para la definición de las funciones públicas reservadas a los españoles. La presencia del ejercicio de autoridad

Palomar Olmeda, Tomás Sala Franco y Miguel Sánchez Morón (Autores) 2 $2^{\mathrm{a}}$ ed., Editorial Lex Nova, Valladolid, 2008, p. 405.

430 "Artículo 9. Funcionarios de carrera. 2. En todo caso, el ejercicio de las funciones que impliquen la participación directa o indirecta en el ejercicio de las potestades públicas o en la salvaguardia de los intereses generales del Estado y de las Administraciones Públicas corresponden exclusivamente a los funcionarios públicos, en los términos que en la ley de desarrollo de cada Administración Pública se establezca.”

${ }^{431}$ SÁNCHEZ MORÓN, Miguel. Op.cit., p. 405.

${ }^{432}$ FONDEVILA ANTOLÍN, Jorge. Op.cit., p. 54. 
pública en la configuración de las actividades desempeñadas por el funcionario es el elemento fundamental para la reserva de una función pública a los españoles y, consecuentemente, para la exclusión del acceso de los extranjeros. En este sentido:

"lo decisivo para poder justificar la exclusividad de los nacionales para el ejercicio de determinados cargos en la Administración pública es participar en el ejercicio de autoridad pública y, en este sentido, según ha manifestado el Tribunal de Justicia europeo, sólo existe cuando se origina en la soberanía del Estado, en su imperium, e implicando, en consecuencia, poderes de coacción que se imponen a los ciudadanos."

Según la jurisprudencia del Tribunal de Justicia de la Comunidad Europea, las mencionadas funciones estarían relacionadas a sectores como las fuerzas armadas, la policía y las de otras fuerzas de orden público, la magistratura, la administración fiscal y la diplomacia, los empleos en los ministerios del Estado, de los gobiernos regionales, de las colectividades territoriales y de otros organismos asimilados y de los Bancos Centrales. No obstante, también ya reconoció el mencionado Tribunal como de libre circulación ${ }^{434}$ sectores relacionados a la gestión de un servicio comercial (transportes públicos, distribución de electricidad y gas, compañías de navegación aérea o marítima, correos y telecomunicaciones y organismos de radiodifusión), así como sectores como la sanidad pública, la enseñanza en los centros públicos o la investigación civil en los establecimientos públicos. ${ }^{435}$

Otra novedad, que puede atenuar la prohibición del acceso a determinadas funciones públicas, es la posibilidad otorgada a las Cortes Generales o a las Asambleas Generales de las Comunidades Autónomas, a través de ley, de suprimir la exigencia de nacionalidad por razones de interés general para el acceso a la condición de personal funcionario, conforme previsión del art. 57.5 del Estatuto. ${ }^{436}$

\footnotetext{
${ }^{433}$ CAVAS MARTÍNEZ, Faustino. Op.cit., p. 601.

${ }^{434}$ Respecto este asunto, conviene destacar la recién aprobada Ley 17/2009, de 23 de noviembre, sobre el libre acceso a las actividades de servicios y su ejercicio.

${ }^{435}$.Cf. FERNÁNDEZ DOMÍNGUEZ, Juan J. y RODRÍGUEZ ESCANCIANO, Susana. Op.cit., p.42.

436 Sobre la citada regla, la doctrina esclarece que: "esta novedad debe vincularse a la evolución demográfica de nuestro país y al fenómeno de la inmigración. No es difícil conjeturar que determinados empleos reservados a funcionarios públicos quizá no puedan ser cubiertos en el futuro con personas de nacionalidad española exclusivamente o con otros ciudadanos europeos, por falta de demanda suficiente. De hecho es lo que ha sucedido ya en el caso de las clases de tropa y marinería del Ejército y por eso la
} 
Como se ha destacado anteriormente, la evolución del trato jurídico conferido al tema en España es resultado de una reciente tendencia histórica (últimos dos decenios) y cada vez mayor exigencia presente en el Derecho Comunitario Europeo de garantizar la libre circulación de trabajadores, no solo en el sector privado, sino también en la Administración Pública. ${ }^{437}$

La sobredicha evolución legislativa ha producido distintas normas en el Derecho español, empezando por la ya mencionada Ley 17/1993, que concedió una apertura limitada, ya que solamente autorizó el acceso a sectores sobre los cuáles ya había manifestación del Derecho Comunitario, como en las áreas de enseñanza, salud pública, correos, entre otros.

Sin embargo, según destaca la doctrina, "este mínimo indispensable no fue considerado suficiente por la Comisión Europea, la cual amenazó a España con otra demanda por incumplimiento ante el Tribunal de Justicia, razón por la cual la Ley 55/1999, de 29 de diciembre, modificó la Ley 17/1993, optando por una apertura total" ${ }^{438}$, con excepción de aquellos que directa o indirectamente impliquen una participación en el ejercicio del poder público o en las funciones que tienen por objeto la salvaguardia de los intereses del Estado o de las Administraciones Públicas.

Así, se puede percibir que el movimiento de apertura del acceso de los extranjeros a la función pública española parece seguir un camino sin retorno, aunque la velocidad de este avance pueda variar, ya que depende de diversos factores (entre ellos, la crisis económica y los movimientos nacionalistas).

En Brasil, la cuestión bajo estudio puede ser investigada a partir del análisis de los cambios introducidos en la redacción de la Constitución actualmente vigente, lo

Ley 32/2002, de 5 de julio, abrió la puerta de estos empleos a personas de otras nacionalidades, ni siquiera necesariamente europeas. Lo mismo podría suceder en los Cuerpos de Policía, por ejemplo, o, como ya ocurre de hecho, en la sanidad pública, en el ámbito docente u otros. También puede resultar conveniente reclutar ciudadanos de otros países para el ejercicio de ciertas funciones públicas en las que convenga aprovechar el conocimiento de lenguas extranjeras o las relacionadas con colectivos extranjeros asentados en España." (SÁNCHEZ MORÓN, Miguel. Op.cit., p. 406).

437 DOMÍNGUEZ-BERRUETA DE JUAN, Miguel y NEVADO MORENO, Pedro T., "La libre circulación de servidores públicos. Un estudio sobre el acceso de ciudadanos comunitarios a la función pública de los Estados miembros”, Noticias de la Unión Europea, núm. 145, 1997, p. 9 y ss.

${ }^{438}$ FERNÁNDEZ DOMÍNGUEZ, Juan J. y RODRÍGUEZ ESCANCIANO, Susana. Op.cit., p. 42. 
que cambió el panorama del tema del acceso del extranjero a la función pública en el mencionado país.

Es que, según los términos entonces vigentes del art. 37, I, de la Carta Magna, en 1988, solamente los brasileños podrían acceder a los cargos y empleos públicos. Sin embargo, aunque bajo tal normativa constitucional restrictiva, era admisible la contratación temporaria de extranjeros en determinadas áreas, como se puede percibir a partir del resumen abajo citado:

"O inciso I do artigo 37, na redação original, assegurava o direito de acesso aos cargos, empregos e funções públicas apenas aos brasileiros que preenchessem os requisitos estabelecidos em lei, o que abrangia os natos e naturalizados, já que a Constituição não faz qualquer distinção. Sempre se entendeu que a contratação de estrangeiro era possível na hipótese do artigo 37, inciso IX, para "atender a necessidade temporária de excepcional interesse público". Tanto assim que a Lei $n^{\circ} 8.745$, de 9-12-93, que dispõe sobre a contratação de servidor temporário e que foi alterada pela Lei $\mathrm{n}^{\circ}$ 9.849, de 26-1099, inclui, entre os casos que admitem a contratação com base no referido dispositivo constitucional, o de professor estrangeiro e pesquisador visitante estrangeiro (art. $\left.2^{\circ}, \mathrm{V}\right) .,{ }^{, 439}$

Debido a la redacción inicial del art. 37, I, de la Constitución brasileña, en aquel momento histórico, muchas dudas surgieron en la doctrina que, en general, debido a la ausencia de referencia a los extranjeros en el texto, interpretaban en sentido prohibitivo $^{440}$ el acceso de los mismos a la función pública. En este sentido:

"Nos termos do art. 37, I, da CF os cargos, empregos e funções públicas são acessíveis aos brasileiros que preencham os requisitos

\footnotetext{
${ }^{439}$ ZANELLA DI PIETRO, Maria Sylvia. Op.cit., pp. 496-497.

${ }^{440}$ Así, se entendía que: "Em todas as Constituições, a primeira condição que se exige de quem vai ocupar um cargo público é a que seja nacional. Compreende-se, perfeitamente, o fundamento dessa exigência. O funcionário tem o dever de ser fiel para com o Estado que o recebe em seus quadros. Como exigir de um estrangeiro o dever de fidelidade para com Estado que não é o seu? Tratando-se do Brasil, a primeira condição que se exige para certos cargos é a de cidadão brasileiro, condição erigida em preceito constitucional desde o nosso primeiro diploma republicano e sempre mantido pelos diplomas subseqüentes" (CRETELLA JÚNIOR, José. Comentários à Constituição Brasileira de 1988, $2^{\mathrm{a}}$ edição, volume 4, 1992).
} 
estabelecidos em lei. $\mathrm{O}$ dispositivo suscitou dúvidas quanto à possibilidade de estrangeiros exercerem tais postos; parece claro que o preceito somente admite o acesso de brasileiros, inclusive em Universidades públicas" 441 .

El primer cambio introducido en la Constitución brasileña ocurrió a través de la Enmienda Constitucional 11/1996, que autorizó a las universidades e instituciones de investigación científica y tecnológica la contratación de profesores, técnicos y científicos extranjeros $^{442}$, en la forma de la ley ${ }^{443}$.

Se percibe claramente que el objetivo de este primer cambio constitucional era permitir el desarrollo de la investigación científica brasileña, que pasó a acomodar profesionales capacitados de otros países en sus universidades e instituciones.

El segundo (y más relevante) cambio constitucional sucedió con la Enmienda Constitucional 19/1998, que alteró la redacción del art. 37, I, de la Constitución brasileña, para que permitiera la admisión de extranjeros a los cargos y empleos públicos. A partir de nueva redacción, “os cargos, empregos e funções públicas são acessíveis aos brasileiros que preencham os requisitos estabelecidos em lei, assim como aos estrangeiros, na forma da lei”.

Así, en el derecho brasileño actualmente vigente, el acceso de los extranjeros a la función pública ocurre "na forma da lei”, lo que significa que depende de los términos establecidos en la legislación.

Tras la Enmienda Constitucional 19/98, en regla general, la doctrina brasileña aplaudió los cambios introducidos, destacando que el derecho de acceso del

\footnotetext{
${ }^{441}$ MEDAUR, Odete. Direito Administrativo Moderno, Editora Revista dos Tribunais, 1996, pp. 298-299. ${ }_{442}$ "Art. $1^{\circ}$ São acrescentados ao art. 207 da Constituição Federal dois parágrafos com a seguinte redação: Art. 207.

$\S 1^{\circ}$ É facultado às universidades admitir professores, técnicos e cientistas estrangeiros, na forma da lei. $\S 2^{\circ} \mathrm{O}$ disposto neste artigo aplica-se às instituições de pesquisa científica e tecnológica"

${ }^{443}$ La mencionada ley, en el ámbito federal, es la Ley 9.515/97, que trata de la admisión de profesores, técnicos y científicos extranjeros por las universidades e instituciones federales de investigación científica y tecnológica.
} 
extranjero pasa a depende de la edición de ley por cada ente federal, que venga a establecer las hipótesis de ingreso.

En este sentido, la doctrina subraya que tras la citada Enmieda, el derecho de acceso a la función pública "estende-se também aos estrangeiros, "na forma da lei"; entende-se que se trata de lei de cada entidade da federação, já que a matéria de servidor público não é reservada á competência privativa da União. O dispositivo não é autoaplicável, dependendo de lei que estabeleça as condições de ingresso do estrangeiro." ${ }^{, 44}$

En el ámbito de la jurisprudencia, el Supremo Tribunal Federal ha confirmado el entendimiento doctrinario anteriormente expresado, respecto a la no auto aplicabilidad del derecho de acceso de los extranjeros a la función pública, lo que ha hecho en los siguientes términos:

"Estrangeiro. Acesso ao serviço público. Artigo 37, I, da CF/88. O Supremo Tribunal Federal fixou entendimento no sentido de que o artigo 37, I, da Constituição do Brasil [redação após a EC 19/98], consubstancia, relativamente ao acesso aos cargos públicos por estrangeiros, preceito constitucional dotado de eficácia limitada, dependendo de regulamentação para produzir efeitos, sendo assim, não auto-aplicável." ${ }^{445}$

Como se puede percibir, la situación de los extranjeros no fue equiparada a la de los brasileños, ya que mientras estos últimos "dispõem do direito constitucional para aceder aos cargos, empregos e funções pública, somente encontrando o conteúdo limitador do exercício desse direito em lei", aquellos primeros "não dispõem desse mesmo direito constitucional de aceder às funções administrativas, mas sim, da possibilidade de vir a ter esse direito, quando e da forma que for estabelecido na norma infraconstitucional." ${ }^{, 46}$

\footnotetext{
${ }^{444}$ ZANELLA DI PIETRO, Maria Sylvia. Op.cit., pp. 496-497.

${ }^{445}$ STF, Recurso Extraordinario 544.655-AgR, Rel. Min. Eros Grau, julgamento en 9-9-08, $2^{\text {a }}$ Turma, DJE de 10-10-08.

${ }^{446}$ PINHEIRO MADEIRA, José Maria. Op.cit., p. 74.
} 
Respecto a los efectos producidos por la Enmienda Constitucional 19/98 en el acceso de los extranjeros a la función pública, es posible afirmar que la citada alteración del texto constitucional no ha generado muchas situaciones favorables al acceso de los nacionales de otros países, además de las que ya estaban contempladas en la Enmienda Constitucional 11/1996.

En realidad, la doctrina ha afirmado que:

\begin{abstract}
"Reconheceu o constituinte que a rigidez do texto anterior, limitando o acesso aos cargos e funções públicas aos brasileiros, criou inúmeras dificuldades naquelas situações específicas em que se tornava necessário o recrutamento de professores, técnicos e profissionais estrangeiros. É claro que, mesmo não podendo esse recrutamento caracterizar-se como regra geral, é possível agora ao legislador ordinário, regulamentando o dispositivo, estabelecer os casos e as condições nos quais será legítimo o acesso de estrangeiros às funções públicas." 447
\end{abstract}

Así, se puede decir que el número de situaciones en las cuales el acceso de los no nacionales a la función pública brasileña es permitido no ha aumentado considerablemente. Sin embargo, la referida alteración constitucional ha permitido que, en el futuro, pueda el legislador establecer nuevas posibilidades de acceso de los extranjeros a la función pública brasileña, cuando considere que estos pueden aportar relevantes contribuciones al país.

No obstante, conviene destacar que cuando admitida la participación de extranjeros en los procesos selectivos de acceso a la función pública, no es posible que la ley establezca diferenciaciones ilegítimas entre estos (por ejemplo, discriminación de los nacidos en determinados países o mismo preferencia por aquellos que tienen determinada nacionalidad), ni mismo entre los extranjeros y los brasileños.

${ }^{447}$ SANTOS CARVALHO FILHO, José dos. Op.cit., p. 554. 
En definitiva, la experiencia española (aunque en fase no tan avanzada como otros países europeos y si bien que debido a las presiones de la Unión Europea) relativa a la contribución que el acceso de los extranjeros a la función pública puede ofrecer debe ser llevada en consideración por los más distinto países, especialmente en Brasil, que fue y es formado por personas de distintas nacionalidades.

\subsection{2 - Conocimiento lingüístico}

El presente análisis es un ejemplo de exigencia para el acceso a la función pública que solamente repercute en determinados procesos selectivos, especialmente en España, que hace mucho intenta resolver sus problemas lingüísticos de forma satisfactoria, ya que algunas Comunidades Autónomas poseen dos lenguas oficiales.

Antes de todo, para analizar la cuestión de la exigencia de conocimientos de idiomas en los procesos selectivos de acceso a la función pública, conviene resaltar que la propia Constitución española trata de la cuestión lingüística. ${ }^{448}$

Una vez que la Constitución estableció, en el art. 3.2, que las demás lenguas españolas serán también oficiales en las respectivas Comunidades Autónomas de acuerdo con sus Estatutos, estos (y las legislaciones autonómicas) han impuesto la obligación de conocer la lengua cooficial propia: a) para acceder a la función pública en general (Cataluña y Baleares); y b) para acceder a determinados puestos (País Vasco, de acuerdo con el perfil lingüístico de la plaza, y Galicia). ${ }^{449}$

Comentando el alcance de la cooficialidad lingüística en las Comunidades Autónomas, la doctrina afirma que: “...las pruebas selectivas se han de adecuar a las características de los puestos de trabajo a que optan los aspirantes. Lo que permitiría colocar en cada caso, a la vista de tareas a realizar, como un mérito o una exigencia, el conocimiento del idioma del territorio. “450

\footnotetext{
448 “Art. $3^{\circ}$. El castellano es la lengua española oficial del Estado. Todos los españoles tienen el deber de conocerla y el derecho de usarla.

2. Las demás lenguas españolas serán también oficiales en las respectivas Comunidades Autónomas de acuerdo con sus Estatutos.

3. La riqueza de las distintas modalidades lingüísticas de España es un patrimonio cultural que será objeto de especial respecto y protección."

${ }^{449}$ SÁNCHEZ MORÓN, Miguel. Op.cit., p. 122.

${ }^{450}$ MORELL OCAÑNA, Luis. Op.cit., p. 414.
} 
Otro entendimiento de la doctrina, que se basa en la STC del 26 de febrero de 1986, destaca que:

"Larga polémica ha generado (y todavía hoy lo hace) la cuestión de si el conocimiento de una lengua cooficial distinta del castellano puede constituir, en aquella Comunidades Autónomas o zonas donde existe tal cooficialidad, un requisito para acceder a la función pública autonómica o local. Tras algunos titubeos iníciales de la jurisprudencia del Tribunal Supremo....el Tribunal Constitucional declaró en SSTC 82, 83 y 84\1986, de 26 de junio, que las Comunidades Autónomas donde existan dos lenguas oficiales pueden prescribir en el ámbito de sus respectivas competencias el conocimiento de ambas lenguas para acceder a determinadas plazas de funcionarios $\mathrm{y}$, en general, considerar como mérito el nivel de conocimiento de las mismas...En posterior STC 46\1991, de 28 de febrero, el Tribunal Constitucional ha entendido que puede no sólo evaluarse como mérito sino imponerse como requisito de capacidad para el acceso a la Administración de la Generalidad de Cataluña el conocimiento de la lengua catalana (art. 34 de la Ley de Función Pública de la Generalidad), si bien de manera matizada y por relación con la función a desempeñar, pues "sería contrario al derecho de la igualdad en el acceso a la función pública exigir un conocimiento del catalán sin relación alguna con la capacidad requerida para desempeñar la función de que se trate"., 451

La doctrina también expone que el País Vasco estableció la más completa previsión de ordenación del acceso a la función pública en las Comunidades Autónomas de cooficialidad lingüística, regulando, así, el sistema de individualización de los puestos de trabajo, y determinando el perfil lingüístico asignable a cada uno, según el nivel de conocimiento del euskera que exija su desempeño. ${ }^{452}$

Por tanto, el Tribunal Constitucional, a través de distintas sentencias, admite la posibilidad de exigencia de conocimiento de la lengua cooficial en los procesos

${ }^{451}$ SÁNCHEZ MORÓN, Miguel. Op.cit., p. 122.

${ }^{452}$ MORELL OCAÑNA, Luis. Op.cit., p. 415. 
selectivos realizados por las Comunidades Autónomas que tengan dos lenguas oficiales $^{453}$.

También es verdad que el Tribunal Supremo hace tiempo que modificó su entendimiento (SSTS de 22 de julio de 1996, 20 de marzo y 10 de octubre de 1998, 24 de mayo y 6 de junio de 1999 y 26 de enero de 2000), pasando a admitir que el conocimiento de lenguas cooficiales pueda ser un elemento eliminatorio del acceso a puestos de trabajo en zonas en que exista predominio de la población que utilice esas lenguas cooficiales en sus relaciones con la Administración Pública. ${ }^{454}$

Sin embargo, el entendimiento arriba descrito (admisión del carácter eliminatorio de la exigencia de conocimientos de otras lenguas) debe ser visto como una situación de excepción en el ámbito del Tribunal Supremo, pues, de acuerdo con las SSTS de 19 de febrero, 22 de julio de 1996 y 20 de marzo de 1998:

"el principio general sigue siendo el que pueda valorarse como mérito no eliminatorio el conocimiento de lenguas españolas diferentes del castellano; segundo, que para concretas y determinadas plazas, los poderes públicos competentes puedan darle el dicho carácter a la prueba de conocimiento del idioma cooficial de la respectiva Comunidad Autónoma; tercero, que la finalidad de esta excepción al principio general es la de proveer a la presencia en la Administración de personal de habla de lengua vernácula como modo de garantizar el derecho de usarla por parte de los ciudadanos de la respectiva Comunidad (STC de 26 de junio de 1986); cuarto, que la apreciación del cumplimiento de esta concreta finalidad obliga a considerar discriminatoria la mencionada exigencia cuando se imponga para cubrir plazas que no estén directamente vinculadas por los administrados de las lenguas de su Comunidad Autónoma..."

En el ámbito de la legislación, la Ley 30/1992, del 26 de noviembre, que establece el Régimen Jurídico de las Administraciones Públicas y del Procedimiento

\footnotetext{
${ }^{453}$ Sin embargo, merece registro que en 2010, en la polémica sentencia del Tribunal Constitucional respecto al Estatuto catalá, el citado Tribunal ha reconocido que el art. 6.2 de la mencionada norma es inconstitucional y nulo "en su pretensión de imponer un deber de conocimiento del catalán equivalente en su sentido al que se desprende del deber constitucional de conocimiento del castellano". (STC 031/2010, de 28 de junio de 2010).

${ }^{454}$ SÁNCHEZ MORÓN, Miguel. Op.cit., p. 123.
} 
Administrativo Común, se establece el derecho del ciudadano a dirigirse a la Administración Pública en la lengua oficial que elija. ${ }^{455}$

Sobre las implicaciones de la cuestión lingüística española, en especial, relativa a las relaciones de los ciudadanos con la Administración Pública se puede afirmar que:

“...además de ser un mecanismo funcional, la lengua representa otros valores que sin duda, y legítimamente, por cierto, otorgan a la regulación de su régimen jurídico una trascendencia y un significado distintos a los de otros instrumentos de comunicación. Prever que los ciudadanos puedan relacionarse con la Administración en lengua vasca, catalana o galega no es lo mismo que prever que se dirijan a ella por telefax." ${ }^{, 456}$

Las normas transcritas demuestran que, en varias situaciones, podrán haber ciudadanos que exijan relacionarse con la Administración Pública en la lengua cooficial al castellano. En este caso, el derecho del ciudadano a una buena prestación de los servicios públicos solamente podrá ser respetado si la Administración Pública dispone de funcionarios que hablen la lengua solicitada por el ciudadano.

\footnotetext{
455 “Art. 35. Derechos de los ciudadanos. - Los ciudadanos, en sus relaciones con las Administraciones Públicas, tienen los siguientes derechos:(...)

d) A utilizar las lenguas oficiales en el territorio de su Comunidad Autónoma, de acuerdo con lo previsto en esta Ley y en resto del Ordenamiento Jurídico. (...)

Art. 36. Lengua de los procedimientos. -1 - La lengua de los procedimientos tramitados por la Administración General del Estado será el castellano. No obstante lo anterior, los interesados que se dirijan a los órganos de la Administración General del Estado con sede en el territorio de una Comunidad Autónoma podrán utilizar también la lengua que sea cooficial en ella.

En este caso, el procedimiento se tramitará en la lengua elegida por el interesado. Si concurrieran varios interesados en el procedimiento, y existiera discrepancia en cuanto a la lengua, el procedimiento se tramitará en castellano, si bien los documentos o testimonios que requieran los interesados se expedirán en la lengua elegida por los mismos.

2 - En los procedimientos tramitados por las Administraciones de las Comunidades Autónomas y de las Entidades Locales, el uso de la lengua se ajustará a lo previsto en la legislación autonómica correspondiente.

3 - La Administración Pública instructora deberá traducir al castellano los documentos, expedientes o partes de los mismos que deban surtir efecto fuera del territorio de la Comunidad Autónoma y los documentos dirigidos a los interesados que así lo soliciten expresamente. Si debieran surtir efectos en el territorio de una Comunidad Autónoma donde sea cooficial esa misma lengua distinta del castellano, no será precisa su traducción.”

${ }^{456}$ PENDÁS GARCÍA, B. (coordinación), Administraciones Públicas y Ciudadanos (Estudio sistemático de la Ley 301992, de 26 de noviembre, de Régimen Jurídico de las Administraciones Públicas y del Procedimiento Administrativo Común), Praxis, p. 312
} 
Así, el alcance arriba comentado lleva a la conclusión de que existiría tanto un derecho al uso lingüístico activo de la lengua elegida por el ciudadano (en la condición de emisor de la comunicación), como también al derecho pasivo de ser atendido en dicha lengua (el ciudadano como receptor o destinatario de la comunicación).

Relativo a este punto, la doctrina enfatiza que el art. 35 i), de la Ley del Régimen Jurídico y Procedimiento Administrativo Común establece el derecho del ciudadano a ser tratado con respeto y deferencia por las autoridades y funcionarios, que habrán de facilitarles el ejercicio de sus derechos. Así, "el uso por la Administración de la lengua elegida por el ciudadano constituye un deber, allí donde la organización del servicio haga posible su cumplimiento"

No son pocos los que ya han escrito y aún van a escribir sobre este tema. Para destacar la preeminencia de esta cuestión en España, conviene transcribir que “...las dificultades que conlleva la cooficialidad de una lengua son el resultado de una decisión constitucional y, por lo tanto, los poderes públicos deben poner los medios para que no deje de cumplirse." 458

Los derechos establecidos en el ordenamiento jurídico deben tener la compañía inmediata de sus garantías. Así, el derecho de uso de la lengua cooficial por el ciudadano debe ser atendido por la Administración Pública, a través de una infraestructura adecuada.

Analizando la situación del uso del euskera, ya se ha escrito anteriormente que:

"Si todos los particulares tienen el derecho a utilizar el euskara en cualquier lugar u los poderes públicos en la Comunidad Autónoma Vasca tienen la obligación de atender a los ciudadanos vascos en su lengua propia si éstos así lo desean, ello acarrea ineludiblemente la

\footnotetext{
${ }^{457}$ VAQUER CABELLERÍA, M. "Derechos de los ciudadanos: lengua de los procedimientos, registros administrativos y subsanación de solicitudes", Documentación Administrativa n 254-255 (mayodiciembre 1999), Madrid, p.95.

${ }^{458}$ FERNANDÉZ-ESPINAR, L.C. "El alcance de la cooficialidad lingüística en el procedimiento administrativo y la administración de justicia", Revista Española de Derecho Administrativo, 58 abriljunio de 1988, Civitas, Madrid, p. 297.
} 
necesidad de adaptación del aparato administrativo a esta nueva situación." 459

En otro tiempo, dijo la mencionada doctrina, para justificar la exigencia del euskera en determinadas oposiciones:

“...no permitir la valoración de una capacitación técnica que posibilite la práctica efectiva de la cooficialidad del euskara en una Administración Pública, en razón precisamente de la previa declaración de cooficialidad, es comparable - a efectos de mera comprensión, exclusivamente -, con que se declarase inadmisible cualquier medida o requisito destinados a una mayor objetividad en el funcionamiento de la Administración o a una mayor eficacia de sus servicios porque la Constitución ya ha señalado que la Administración sirve con objetividad los intereses generales y actúa de acuerdo con el principio de eficacia (art.103.1)..."460

Además, parece evidente que si la Administración debe prestar sus servicios al ciudadano con eficacia, conviene que sus funcionarios estén capacitados para esa misión. Y los procesos selectivos para el acceso a la función pública deben tener en cuenta esa circunstancia. En ese camino, está el Estatuto Básico del Empleado Público (Ley 7/2008, de 12 de abril de 2008). ${ }^{461}$

Así, la cuestión ahora analizada en este trabajo destaca distintos derechos ubicados en la Constitución: el derecho a la igualdad para acceder a las funciones públicas, el derecho al uso de la lengua cooficial y el derecho a una Administración que desarrolle sus actividades con eficacia.

Así, es evidente la necesidad de armonización de dichos derechos. La declaración de cooficialidad de otras lenguas diferentes del castellano debe ser compatibilizada con el derecho de igualdad para acceder a la función pública.

\footnotetext{
459 COBREROS MENDAZONA, E., "Cooficialidad lingüística y discriminación por razón de la lengua”, Revista Española de Derecho Administrativo, Civitas, 42, abril-junho de 1984, Madrid, p. 473. 460 Idem, p.467.

461 “Art. 56. 2. Las Administraciones Públicas, en el ámbito de sus competencias, deberán prever la selección de empleados públicos debidamente capacitados para cubrir los puestos de trabajo en las Comunidades Autónomas que gocen de dos lenguas oficiales.”
} 
Aun siendo razonable, como regla general, la exigencia de conocimientos de otras lenguas cooficiales para la apreciación del mérito de los postulantes en determinadas Comunidades Autónomas que posean tales lenguas, no puede ser un criterio eliminatorio, ya que viola el derecho a la igualdad en el acceso a las funciones públicas.

Como excepción, hay la hipótesis donde la utilización de la lengua cooficial por el funcionario sea imprescindible. Exclusivamente, ante esta circunstancia especialísima, el conocimiento de la lengua cooficial podría ser un criterio eliminatorio en el proceso selectivo de acceso a la función pública.

Así, a partir de todo lo que se ha analizado, algunas conclusiones pueden ser enunciadas:

1- Respecto al principio de la igualdad, solamente es admisible la exigencia de conocimiento de las lenguas cooficiales para el acceso a las funciones públicas si la índole del puesto de trabajo impone la necesidad del conocimiento de dicho idioma ${ }^{462}$ (principio de la necesidad) $^{463}$;

2- En caso el de que el uso de la lengua cooficial por el funcionario sea justificadamente fundamental para el buen desempeño de sus actividades, la exigencia en las oposiciones no debe ser un factor eliminatorio de los aspirantes que no tengan dichos conocimientos lingüísticos (principio de la amplia participación de los aspirantes);

3- En caso el de que la exigencia de conocimiento del idioma cooficial en situaciones especiales no sea un factor eliminatorio, tampoco puede tener una relevancia muy intensa en la definición de los aprobados (principio de la utilización del medio

\footnotetext{
${ }^{462}$ El Tribunal Supremo, en la STS de 18 de enero de 2000, reconoció que es discriminatoria la exigencia del conocimiento del euskera como requisito que deben reunir los aspirantes para las plazas que envuelven tareas de fontanería, de pintura y de albañilería, puesto que dicho conocimiento no está vinculado al desempeño de dichas funciones.

${ }^{463}$ En este camino, "el derecho a la igualdad en el acceso a la función pública, por sus secuelas para la efectividad de otros derechos fundamentales (por ejemplo, la libertad de circulación), por su relevancia nacional y carácter fundamental tiene de ser garantizado hasta donde sea incompatible con una efectiva protección lingüística. Para restringir la libertad de "todos" de acceder a la función pública no basta con alegar que se persigue el fin (razonable) de que los funcionarios públicos dominen las lenguas oficiales en la comunidad; es preciso que ese fin no puede ser satisfecho sin una restricción menor del derecho fundamental, se requiere utilizar el medio menos dañoso para conseguir dicho resultado."(BAÑO LEÓN, J.M., "El ejercicio del pluralismo lingüístico en la Administración Pública", Revista Española de Derecho Administrativo, Civitas, 54 abril-junio 1987, Madrid, p. 238).
} 
menos dañoso), lo cual no conformaría una discriminación (imposibilidad o extrema dificultad de acceso), sino una simple desventaja para los aspirantes que solamente hablen castellano;

4- Únicamente en situaciones anómalas, podría la exigencia de conocimiento de la lengua cooficial tener carácter eliminatorio, y eso ocurriría cuando no fuera posible el desempeño de la función pública sin dicha habilidad lingüística. Aun así, el nivel de exigencia en las pruebas debe guardar relación de proporcionalidad con el grado de exigencia de conocimiento lingüístico para cada plaza ${ }^{464}$;

5- Aunque el conocimiento del idioma sea fundamental para el desempeño de la función pública, las Comunidades Autónomas deberían establecer en sus legislaciones sobre función pública la obligatoriedad de la enseñanza de la lengua cooficial en los cursos de formación de los funcionarios, después de sus nombramientos, lo que resolvería la cuestión relativa a la necesidad de existencia de funcionarios que hablen las lenguas cooficiales, sin que hubiera la violación del derecho de igualdad en el acceso a la función pública.

Además, conviene destacar que ese procedimiento de permitir que los conocimientos de la lengua cooficial sean adquiridos en un curso de formación, según doctrina, ya estaba previsto en las leyes de función pública de la Comunidad Valenciana (Ley 4\1983, de 23 de noviembre) y de las Baleares (Ley 3\1986, de 29 de abril). ${ }^{465}$ En este camino, se puede apuntar el Decreto Legislativo del 24 de octubre de 1995, que aprueba el texto refundido de la ley de función pública de la Comunidad Valenciana. ${ }^{466}$

6- En definitiva, las Administraciones Públicas, en especial de las Comunidades Autónomas donde haya lenguas cooficiales, a través de sus leyes y demás reglamentos, y no los Tribunales de Oposiciones, en las convocatorias, deben establecer, con criterio, cuáles son las funciones públicas (y, consecuentemente, las

\footnotetext{
${ }^{464}$ El Tribunal Superior de Justicia de Cataluña, en la STSJ del 18 de diciembre de 2001, entendió que la exigencia del certificado oficial de nivel B de catalán es adecuada y proporcional al Cuerpo de Oficiales y Auxiliares, pero no es para el de Agentes, ya que estos no desarrollarían en la práctica actividad alguna por escrito y sí solamente de forma oral.

${ }_{465}$ MORELL OCAÑNA, Luis. Op.cit., p.415.

${ }^{466}$ Art.9.4. Quienes superen las pruebas selectivas, acreditarán sus conocimientos de valenciano mediante la presentación de los certificados, diplomas o títulos que hayan homologados por la Generalitat Valenciana, o mediante la realización de un ejercicio específico al efecto. El personal que no pueda acreditar dichos conocimientos quedará comprometido a la realización de los cursos de perfeccionamiento que a este fin organice la Generalitat Valenciana."
} 
oposiciones) que no exigen que el funcionario tenga conocimiento de la lengua cooficial (situación más usual), que tenga un cierto conocimiento (situación poco usual) o que posea un amplio conocimiento (situación más extrema), todo eso en atención a los principios de igualdad, razonabilidad, proporcionalidad, mérito y capacidad.

En Brasil, la cuestión lingüística no es problemática, ya que la integralidad de la población brasileña habla el mismo idioma, el portugués, que está previsto en la Constitución brasileña como el único idioma oficial del país (art. 13).

En los procesos selectivos brasileños, como regla general, se puede afirmar que solamente son exigidos de los candidatos conocimientos de la lengua portuguesa, lo que no suele causar trastornos al trámite de la competición.

Sin embargo, también se puede destacar que, de forma excepcional, la Administración Pública brasileña puede exigir conocimientos de lengua extranjera en determinados concursos públicos, cuando hay la demostración de que el ejercicio del cargo o empleo público impone el dominio de otro idioma, además del portugués.

En este contexto, se puede citar los procesos selectivos para la carrera diplomática (admisión en el Instituto Rio Branco) ${ }^{467}$; los concursos para profesor de lenguas extranjeras, sea en los institutos o en las universidades públicas; y los concursos para traductor público ${ }^{468}$.

No son muchas las situaciones que traen polémicas, cuando es exigido el conocimiento de lengua extranjera en los concursos públicos brasileños. De forma resumida, se puede afirmar que la ausencia de necesidad del citado idioma para el

\footnotetext{
${ }^{467}$ Según la Portaria 768, de 23 de noviembre de 2007, que trata del concurso para la carrera diplomática en Brasil: "Art. $5^{\circ}$ - A Quarta Fase constará de prova escrita, de caráter exclusivamente classificatório, de uma segunda língua estrangeira, que poderá ser, conforme a opção do candidato, Alemão, Árabe, Chinês (Mandarim), Espanhol, Francês, Japonês ou Russo. Parágrafo único. Para efeitos de classificação, a prova da Quarta Fase terá peso equivalente à metade do peso de cada uma das provas da Terceira Fase."

${ }_{468}$ El Decreto ${ }^{\circ} 13.609$, de 21 de octubre de 1943, que trata del reglamento para el ofício de tradutor público e intérprete comercial, determina que. "Art. $5^{\circ}$ O concurso compreenderá: a) prova escrita constando de versão, para o idioma estrangeiro, de um trecho de 30 (trinta) ou mais linhas, sorteado no momento, de prosa em vernáculo de bom autor; e tradução para o vernáculo de um trecho igual, preferencialmente de cartas rogatórias, procurações, cartas partidas, passaportes, escrituras notariais, testamentos, certificados de incorporação de sociedades anônimas e seus estatutos; b) prova oral, constituindo em leitura, tradução e versão, bem como em palestra, com argüição no idioma estrangeiro $e$ no vernáculo que permita verificar se o candidato possui o necessário conhecimento e compreensão das sutilezas e dificuldades de cada uma das línguas."
} 
ejercicio del cargo o empleo público, y el alto nivel de exigencia en las pruebas son los principales problemas detectados.

En el ámbito jurisprudencial, el tema de la exigencia de conocimientos de lengua extranjero en los procesos selectivos es más debatido cuando se impone tales discernimientos para el acceso a los cursos universitarios (licenciatura, maestría, doctorado, etc.), que propiamente para el ingreso en la función pública ${ }^{469}$.

Pese a poca discusión del tema en Brasil, las mismas observaciones hechas para los procesos selectivos españoles pueden ser aquí ratificadas: la exigencia de conocimientos de lenguas extranjeros solamente debe ocurrir cuando hay circunstancias que demuestren la necesidad de utilización de los referidos conocimientos en el ejercicio del cargo o empleo público. Aun así, el nivel de exigencia de la lengua extranjera en las pruebas debe ser proporcional al grado de utilización de tal idioma en las actividades administrativas, debiendo las pruebas tener un carácter no eliminatorio, que sería permitido solamente en situaciones extremas.

\subsection{3 - Edad}

Uno de los requisitos exigidos a los aspirantes a la función pública que más polémicas ofrece es la edad. Respecto a esa exigencia, en teoría, lo que todos los ordenamientos jurídicos deben regular es la posibilidad de establecer una edad mínima para el ejercicio de una función pública, así como también la exigencia de una edad máxima para que alguien sea admitido en los cuadros de la Administración Pública.

El tema bajo análisis suscita distintas cuestiones que pueden afectar a la igualdad entre los ciudadanos, entre las cuales se puede destacar la necesidad de madurez personal y profesional para el desempeño de determinadas funciones públicas, la posibilidad de exclusión de personas de edad avanzada para la realización de ciertas tareas o a su vez la conveniencia de que los funcionarios permanecieren en el servicio público por muchos años, lo que podría exigir la anticipación de su ingreso.

\footnotetext{
${ }^{469}$ No son muchas las decisiones judiciales que analizan la exigencia de conocimiento lingüístico en los concursos públicos brasileños. Como ejemplo, se puede citar: "MANDADO DE SEGURANÇA CONCURSO PÚBLICO - PROVA DE LÍNGUA ESTRANGEIRA - ALEGAÇÃO DE VIOLAÇÃO DO PRINCÍPIO DA ISONOMIA - INOCORRENNCIA - PRETENSÃO DO IMPETRANTE PARA QUE O PODER JUDICIÁRIO EXAMINE OS CRITÉRIOS DE ELABORAÇÃO E CORREÇÃO DAS PROVAS IMPOSSIBILIDADE - SEGURANÇA DENEGADA". (Tribunal de Justicia de Mato Grosso do SulMandado de Segurança: MS 15502 MS 2006.015502-8)
} 
En el Derecho español, durante muchos años, la edad mínima exigida para el acceso a la función pública era de 18 años. Sobre la mencionada edad, cabe destacar que determina la Constitución española de 1978 en su art. 12 que "Los españoles son mayores de edad a los 18 años", lo que se repite en la edad establecida en el Código Civil del referido país para adquisición de la mayoría de edad (art. 315: "La mayor edad empieza a los dieciochos años cumplidos”).

Sin embargo, desde la vigencia del nuevo Estatuto Básico del Empleado Público español (Ley 7/2007), el legislador redujo la mencionada edad a 16 años $^{470}$, lo que fue considerado como la gran novedad del Estatuto en materia de establecimiento de requisitos para el acceso a la función pública ${ }^{471}$.

Según la doctrina, la previsión de la edad mínima de 16 años para acceder a los empleos públicos es concordante con la prevista por la legislación laboral común ${ }^{472}$, lo que permitiría unificar la edad de acceso a un empleo en la Administración como personal funcionario o laboral. ${ }^{473}$

En realidad, el Estatuto atendió la recomendación de la Comisión para el estudio y Preparación del EBEP que incluyó la siguiente sugerencia:

"por lo que se refiere a la edad, parece necesario en un Estatuto Básico que se refiere a todos los empleados públicos, establecer la edad mínima de dieciséis años, conforme la legislación laboral, sin que adviertan hoy en día razones para mantener una diferencia de régimen para los funcionarios públicos."

\footnotetext{
470 “Artículo 56. Requisitos generales.

1. Para poder participar en los procesos selectivos será necesario reunir los siguientes requisitos:

(...)

c) Tener cumplidos dieciséis años y no exceder, en su caso, de la edad máxima de jubilación forzosa. Sólo por ley podrá establecerse otra edad máxima, distinta de la edad de jubilación forzosa, para el acceso al empleo público."

${ }^{471}$ Sin embargo, la Orden APU/3416/2007, del 14 de noviembre, por la que se establecen las bases comunes que regirán los procesos selectivos para el ingreso o el acceso en cuerpos o escalas de la Administración General del Estado, admitió que: "Las bases específicas podrán exigir la edad mínima de dieciocho años para el acceso a los Cuerpos y Escalas que impliquen el ejercicio de autoridad o cuyas funciones supongan riesgo para la salud."

${ }^{472}$ El artículo 6 del Estatuto de Trabajadores prohíbe la admisión al trabajo a menores de 16 años de edad, lo que significa que a partir de la mencionada edad ya se pueda trabajar.

473 MAURI MAJÓS, Joan. Op.cit., p. 285.

${ }^{474}$ Informe de la Comisión para el estudio y preparación del Estatuto Básico del Empleado Público , INAP, Miguel Sánchez Morón (Presidente), Abril 2005, p. 93
} 
Además, también es posible justificar la reducción de la edad mínima, de 18 a 16 años, para el acceso a la función pública utilizando el argumento barajado por la doctrina, que destaca que la fijación de la edad de 16 años por el Estatuto corresponde con las etapas escolares obligatorias que, de acuerdo con la Ley Orgánica 2/2006, de Educación, está formada por la educación primaria y la educación secundaria obligatoria, cuyo desarrollo regular comprende diez años de escolaridad, desde los seis hasta los dieciséis años. ${ }^{475}$

El argumento arriba citado busca destacar la conveniencia de la modificación legislativa, ya que permite el ingreso del estudiante que termine su educación secundaria en el mercado laboral, inclusive en el sector público.

Además, como destacan otros representantes de la doctrina española ${ }^{476}$, la correspondencia entre formación y edad laboral se ajusta a lo dispuesto en el Convenio 138 de la Organización Internacional del Trabajo ${ }^{477}$ (ratificado por España en 1977), y al contenido de la Directiva 94/33/CE ${ }^{478}$,

Así, sea por razones de unificación de la edad para el acceso al empleo público, o bien sea para que haya una correspondencia entre las edades de conclusión de la educación secundaria, la cual permite el acceso a la función pública, es relevante destacar que los grandes debates relativos al requisito "edad" en España no están centrados en la discusión de la edad mínima.

\footnotetext{
${ }^{475}$ CAVAS MARTÍNEZ, Faustino. Op.cit., p.593.

${ }^{476}$ LÁZARO, José Luis. Capitulo intitulado "Acceso al empleo público y adquisición de la relación de servicio" del libro Comentarios al Estatuto Básico del Empleado Público, Salvador del Rey Guanter (Dirección), Manuel Férez Fernández y Esther Sánchez Torres (Coordinación), La Ley, Madrid, 2008, p. 679

${ }^{477}$ Tras determinar que en el art. $1^{\circ}$ que: "Todo Miembro para el cual esté en vigor el presente Convenio se compromete a seguir una política nacional que asegure la abolición efectiva del trabajo de los niños y eleve progresivamente la edad mínima de admisión al empleo o al trabajo a un nivel que haga posible el más completo desarrollo físico y mental de los menores", el art. 2.3 del mencionado Convenio impone que: "La edad mínima fijada en cumplimiento de lo dispuesto en el párrafo 1 del presente artículo no deberá ser inferior a la edad en que cesa la obligación escolar, o en todo caso, a quince años “

${ }^{478}$ La referida Directiva de la Unión Europea, de 22 de junio de 1994, establece en su art. $1^{\circ}$ que "los Estados miembros adoptarán las medidas necesarias para prohibir el trabajo de los niños. En las condiciones previstas en la presente Directiva, velarán por que la edad mínima de admisión al empleo o al trabajo no sea inferior a la edad en la cual cesa la obligación de escolaridad a tiempo completo impuesta por la legislación nacional, ni, en todo caso, a 15 años."
} 
En el contexto arriba mencionado, cabe subrayar que la gran discusión doctrinaria y jurisprudencial en el citado país se relaciona a la exigencia de una edad máxima como límite para la participación de los procesos selectivos.

Como ya he destacado, el EBEP estipula como requisito para que los aspirantes puedan participar en los procesos selectivos "no exceder, en su caso, de la edad máxima de jubilación forzosa." Así, como regla general, no será admitida la inscripción del aspirante que, en el momento de su inscripción en el proceso selectivo, ya posea la edad que excede la edad máxima para la jubilación forzosa ${ }^{479}$ relativa a la función que será objeto de la competición.

Sin embargo, cabe añadir que si el aspirante, cuando es convocado para tomar posesión, ya posee la edad máxima de jubilación forzosa, es evidente que no podrá ser admitido, pues esto estaría en una evidente contradicción con la norma que impone la exclusión de aquellos que ya han alcanzado la referida edad.

Así, como justificativa de la regla general de edad máxima, se puede utilizar el argumento de que no sería aceptable permitir la admisión de alguién que posea situación que ya estaría catalogada, desde el primer momento de su carrera funcional, en una de las situaciones legales previstas como causa de pérdida de la referida condición (cf. art. 63, c, del Estatuto Básico del Empleado Público español).

La mencionada regla general del requisito "edad máxima” es exceptuada por la norma que determina que "Sólo por ley podrá establecerse otra edad máxima, distinta de la edad de jubilación forzosa, para el acceso al empleo público.”

Sobre esta excepción, algunos aspectos merecen ser destacados: en primer lugar, solamente las leyes podrían establecer una edad máxima para el acceso a la función pública inferior a la de la jubilación forzosa. Sobre esta cuestión, se puede subrayar que:

"la razón de esta imposición legal hay que encontrarla en la doctrina constitucional en la que se mantiene que toda limitación del derecho al

\footnotetext{
${ }^{479}$ Según el art. 67.3 del Estatuto Básico del Empleado Público, "La jubilación forzosa se declarará de oficio al cumplir el funcionario los sesenta y cinco años de edad."
} 
trabajo pertenece al ámbito de la reserva de ley (STC 58/1985, de 30 de abril), ya que toda limitación por razón de edad, desconectada del principio de mérito y capacidad, puede actuar como una condición o circunstancia personal susceptible de provocar efectos discriminatorios. $" 480$

En segundo lugar, que para que las leyes puedan establecer otra "edad máxima", distinta de la de jubilación forzosa, debe haber una justificación razonable, que pueda demostrar que hay motivos legítimos para que el acceso a la función pública pueda ser negado a aquellos que exceden determinada edad.

Sobre la posibilidad de estipulación del requisito "edad máxima", hay que subrayar lo que el Estatuto Básico español atribuye a los empleados públicos, en el art. 14 i) ${ }^{481}$, el derecho a no discriminación por razón de edad.

Como se puede observar, el ordenamiento jurídico español entiende que es contrario al derecho "no permitir la participación en un proceso selectivo por razón de edad." ${ }^{482}$, lo que hace que la estipulación de otras edades máximas para el acceso a la función pública solamente sea legítima cuando está basada en argumentos muy sólidos.

Sobre esta cuestión, cabe destacar que fue derogada por la Ley 60/2003, del 30 de diciembre, la previsión contenida en el artículo 135 b) de la Ley de Bases del Régimen Local, que establecía que para la participación en los procesos selectivos a la función pública local, el aspirante no podía acceder al puesto si tenía menos de diez años para la jubilación forzosa.

Respecto a los argumentos que suelen ser ofrecidos para legitimación de la estipulación de otras "edades máximas" 483 , se puede destacar: a) necesidad de una

\footnotetext{
${ }^{480}$ MAURI MAJÓS, Joan. Op.cit., pp. 284-285.

481 "A la no discriminación por razón de nacimiento, origen racial o étnico, género, sexo u orientación sexual, religión o convicciones, opinión, discapacidad, edad o cualquier otra condición o circunstancia personal o social."

${ }^{482}$ LÁZARO, José Luis. Op.cit., p. 681.

${ }^{483}$ A su vez, la eventual exigencia de la edad mínima se justificaría por la necesidad del aspirante de tener una elevada madurez personal y profesional para ejercer determinadas funciones. Sin embargo, estas exigencias, siendo necesarias, pueden ser demostradas, respectivamente, a partir de la realización de testes psicotécnicos, entrevistas y otros medios de verificación de madurez personal, y por la presentación de documentos que demuestren que el aspirante ha ejercido con anterioridad determinadas actividades profesionales, siempre relacionadas con aquellas que serán desempeñadas por los funcionarios.
} 
capacidad física y mental determinada (plenitud de aptitudes); y b) conveniencia de la permanencia del funcionario en el servicio por muchos años.

Así, la estipulación de una edad máxima inferior a la de la jubilación forzosa para acceder a determinadas funciones públicas puede ocurrir cuando se demuestre que las exigencias del puesto ofertado necesitan una plenitud de aptitudes, en general físicas, que supuestamente, aquellos que ya alcanzaron determinada edad no las pueden poseer.

En este contexto, las funciones que exigen una mejor condición física (sea por el predominio de trabajos manuales exhaustivos o por la necesidad de utilización de fuerza física para determinadas tareas) podrían ser utilizadas como ejemplos de situaciones donde sería posible, en teoría, la previsión legal de edad máxima inferior a la de la jubilación forzosa. Uno de los casos respecto a esta exigencia ocurre en el acceso al Cuerpo Nacional de Policía, ya que el Real Decreto 614/1995, exige que los aspirantes no hayan cumplido 30 años.

La cuestión arriba destacada será objeto de uno de los estudios de este capítulo acerca de los requisitos de acceso a la función pública, la capacidad funcional, lo que hace que su análisis deba ser postergado.

Sin embargo, ahora se puede transcribir la advertencia de la doctrina: "los avances médicos, una mejor calidad de vida $\mathrm{y}$ otros factores, pueden incidir negativamente en esa tesis o, en todo caso, retrasar la edad considerablemente o al menos de forma distinta a como se ha venido haciendo hasta ahora." ${ }^{484}$

Sobre el otro fundamento utilizado para el establecimiento de un límite de edad para el acceso a la función pública inferior al de la edad para la jubilación forzosa es para "asegurar la más completa actuación a través de un dilatado ejercicio de la función encomendada que mejore el rendimiento del funcionario y del servicio."

Sobre la situación arriba descrita, cabe destacar que el argumento que sostiene la legitimidad de la exigencia de determinada edad máxima (distinta de la de la

\footnotetext{
484 LORENZO DE MEMBIELA, Juan B. El acceso y provisión de puestos de trabajo en la Administración Pública, Manual Práctico de Función Pública, vol. III, Thomson, Aranzadi, Cizur Menor (Navarra), 2009, p. 139.

${ }^{485}$ LORENZO DE MEMBIELA, Juan B. Op.cit., p. 140.
} 
jubilación forzosa) para atender las conveniencias del servicio público solamente puede ser jurídicamente aceptado como un requisito de acceso a la función pública si guarda relación con los principios de mérito y capacidad. ${ }^{486}$

Respecto al entendimiento del Tribunal Constitucional español, esto ya ha tenido la posibilidad de manifestarse sobre la cuestión del establecimiento de límite de edad para el acceso a la función pública en distintas oportunidades. Sin embargo, la exigencia de edad máxima inferior a la de la jubilación forzosa, la STS nº 75, del 3 de agosto de 1983, suele ser la más citada para definir la visión del mencionado Tribunal.

En la referida sentencia, el Tribunal Constitucional consideró legítima la exigencia de edad máxima inferior a la de la jubilación forzosa (en el caso, se exigía 60 años) delante de las particulares circunstancias que rodeaban a la función de Interventor de Fondos de un ayuntamiento complejo e importante (Barcelona).

Según el Tribunal Constitucional, las circunstancias especiales relativas al trabajo mencionado justificaban que aquel que fuera a ocupar la plaza lo hiciera por un tiempo suficiente, lo que no ocurriría si fuera ocupada por personas mayores de 60 años, que estuvieran cerca de la jubilación.

No obstante, más recientemente, la doctrina subraya que el propio Tribunal Constitucional, en la STC 37/2004, del 11 de marzo, rechazó argumentos relacionados con el susodicho:

"con el establecimiento de carreras administrativas que tengan una duración razonable y con la necesidad y con la necesidad de que los empleados ejerzan su actividad durante un período mínimo habida cuenta del interés del servicio y del necesario equilibrio financiero del régimen de pensiones, que en otras sedes se han considerado objetivos y razonables". ${ }^{487}$

De todas formas, en la Sentencia $n^{\circ} 75 / 1983$, fueron fijadas las raíces que pasaron a basar los futuros entendimientos del Tribunal Constitucional sobre el requisito “edad" para el acceso a la función pública, hecho que hace que merezca la pena la transcripción de parte de su contenido:

${ }^{486}$ CAVAS MARTÍNEZ, Faustino. Op.cit., p. 594.

${ }^{487}$ MAURI MAJÓS, Joan. Op.cit., p. 284. 
“...la edad, dentro de los límites que la Ley establece para el acceso y la permanencia en la función pública, es una de las circunstancias comprendidas en el artículo 14 y en el artículo 23.2 desde la perspectiva excluyente de tratos discriminatorios. Pero sería equivocado inferir de aquí que todo funcionario, desde el momento del acceso a la función pública y en tanto no se haya operado la extinción conectada a la edad de jubilación, tiene abiertas, cualquiera que sea su edad, las posibilidades de ocupar cualquier puesto en la organización pública, pues, por el contrario, en cuanto la edad es en sí un elemento diferenciador, será legítima una decisión legislativa que, atendiendo a ese elemento diferenciador y a las características del puesto de que se trate, fije objetivamente límites de edad que suponga, para los que la hayan rebasado, la imposibilidad de acceder a estos puestos ..."

En Brasil, como no podría ser de forma distinta, los procesos selectivos de acceso a la función pública, los concursos públicos, también imponen a los candidatos requisitos relativos a la edad, sea ella mínima o máxima. Esto ha hecho con que la doctrina y la jurisprudencia desde hace mucho busque definir los parámetros que deben ser observados por el legislador y por la Administración Pública. ${ }^{488}$

Así, como en España, las situaciones que dicen respecto a la exigencia de edad máxima también suelen ofrecer muchas dificultades a la Administración Pública. Sin embargo, diferentemente de lo que pasa en el citado país europeo, el tema del requisito edad mínima también es problemático, especialmente cuando se busca imponer la exigencia de experiencia profesional a los candidatos.

El principio general aplicado al tema es el de igualdad, aquí identificado en la idea de no discriminación. En estos términos: "o acesso aos cargos e empregos

\footnotetext{
${ }^{488}$ Respecto a esta preocupación en el ambiente jurídico brasileño, se puede decir que: "O limite de idade em concurso público também já foi objeto de muita discussão no Brasil. Inclusive em 1963, com fundamento no texto constitucional de 1946, o Supremo Tribunal Constitucional, preocupado com o assunto, editou a Súmula $n^{\circ} 14$, que define: "Não é admissível por ato administrativo, restringir, por razão de idade, inscrição em concurso para cargo público" (MARINELA DE SANTOS SOUZA, Fernanda. Op.cit., p. 197).
} 
públicos é limitado àqueles que tiverem entre 18 e 70 anos. Dentro destes limites, a regra geral é que não haverá discriminação por motivos de idade."

En este contexto general, la Constitución brasileña es explicita al determinar que entre los derechos sociales, aplicables a todos los trabajadores, incluso a los funcionarios públicos ${ }^{490}$, encontrase, en el art. $7^{\circ}, \mathrm{XXX}$, la "proibição de diferença de salários, de exercício de funções e de critério de admissão por motivo de sexo, idade, cor ou estado civil."

Actualmente, en regla general, la edad mínima exigida de los candidatos en los concursos públicos brasileños es de 18 años, edad que coincide con la establecida en el Código Civil brasileño como la de mayoridad civil y en el Código Penal como la mínima para que pueda haber la imputabilidad penal ${ }^{491}$.

Así, los diversos Estatutos de los Funcionarios Públicos existentes en Brasil (cada ente federativo tiene uno) suelen definir la referida edad como la mínima para que se pueda acceder a la función pública, lo que hizo, por ejemplo, el Estatuto de la Unión (Ley Federal 8112/90), en su art. 5º V.

Aunque la regla general es que la edad mínima para acceso a la función pública es de 18 años, es posible la estipulación de otra (arriba de $18^{492}$ ), siempre que presentes circunstancias especiales que exijan la previsión de una edad más avanzada

\footnotetext{
${ }^{489}$ LOBELLO DE OLIVEIRA ROCHA, Francisco. Op.cit., p. 78.

${ }^{490}$ La Constitución brasileña determina que: "Art. 39.(...) $\& 3^{\circ}$. Aplica-se aos servidores ocupantes de cargo público o disposto no Art. $7^{\circ}$, IV, VII, VIII, IX, XII, XIII, XV, XVI, XVII, XVIII, XIX, XX, XXII e $X X X$, podendo a lei estabelecer requisitos diferenciados de admissão quando a natureza do cargo o exigir" Comentando las referidas normas constitucionales, la doctrina afirma que "os dispositivos apresentam-se como corolário do principio da igualdade, coibindo, portanto, a discriminação " (FERREIA DE ALMEIDA, Péricles. Discriminação em concurso público por motivo de idade. Extraído del sitio Jus Navigandi (http://jus2.uol.com.br/doutrina/texto.asp?id=5364), acceso en 02.02.2010).

491 "a exigência de idade mínima de dezoito anos, constante da lei, decorre do previsto no art. 27 do Código Penal, que estabelece a imputabilidade penal a partir daquela idade. Atualmente também é a partir desta idade que se adquire a maioridade civil, conforme consta do art. $5^{\circ}$ do Código Civil." (TOURINHO, Rita. Op.cit., p. 68).

492 De la misma forma que ha pasado en España, y delante de los argumentos ya apuntados en este trabajo, no sería totalmente despropositada la reducción de la edad mínima para acceso a la función pública brasileña. Al menos, sería recomendable que existiera este debate en el ámbito de la doctrina brasileña, circunstancia que hasta hoy no sucede.
} 
para el ejercicio de un cargo o empleo público y que haya una norma de rango de ley ${ }^{493}$ que establezca esta exigencia.

Respecto a las circunstancias anteriormente referidas, que pueden justificar la previsión de una edad mínima para acceso a la función pública distinta (superior) a la de 18 años, la doctrina destaca las exigencias de razonabilidad ${ }^{494}$ (necesidad de la diferenciación) y de proporcionalidad (prohibición del exceso).

Acerca de la cuestión bajo estudio, la doctrina ha destacado que:

"Se a Administração institui limite mínimo ofendendo o princípio da razoabilidade, o requisito é inconstitucional. Caso demonstre, de forma fundamentada, a razão por que é fixada a idade mínima, a

\footnotetext{
${ }^{493}$ Evidentemente, la Constitución, norma de rango superior a la ley, también puede establecer una edad mínima para ejercicio de determinados cargos públicos. La brasileña lo hizo en el art. 14, § 3: "São condições de elegibilidade, na forma da lei: (...) VI - a idade mínima de: a) trinta e cinco anos para Presidente e Vice-Presidente da República e Senador; b) trinta anos para Governador e ViceGovernador de Estado e do Distrito Federal; c) vinte e um anos para Deputado Federal, Deputado Estadual ou Distrital, Prefeito, Vice-Prefeito e juiz de paz; d) dezoito anos para Vereador"; en el art. 87:. "Os Ministros de Estado serão escolhidos dentre brasileiros maiores de vinte e um anos e no exercício dos direitos políticos"; en el art. 101: "O Supremo Tribunal Federal compõe-se de onze Ministros, escolhidos dentre cidadãos com mais de trinta e cinco e menos de sessenta e cinco anos de idade, de notável saber jurídico e reputação ilibada", y en otras normas.

${ }^{494}$ Respecto a la razonabilidad en la definición de la edad de ingreso en la función pública, la doctrina brasileña ha aportado las siguientes líneas: "Resta-nos indagar: Quando é razoável a exigência de idade mínima ou máxima para o provimento do cargo ou emprego público? Ante ao já exposto, temos que a razoabilidade deve ser auferida pela natureza e atribuições do cargo, isto é, por peculiaridade especial deste, de sorte que a discriminação é imprescindivel e tem por único escopo a melhor seleção de profissionais a integrar os quadros do Poder Público. Deve-se, destarte, afastar o preconceito puro que a todos contamina, presente em nossa sociedade como em tantas, senão todas as outras, por força da comum pobre cultura e por vezes vergonhosa história. Afirmações da estirpe de que a maturidade e seriedade para determinado mister são próprias de cada idade, sem esteio em bases lógicas, refletem, por seus interlocutores, a ignorância de toda a sociedade, que almeja selecionar os candidatos inscritos em certame sem lhes permitir a avaliação. Busca-se, erroneamente, selecionar por conceitos já formados. Não parece ser razoável nenhuma espécie de discriminação. Se é discriminação, não pode ter os atributos da equidade e razoabilidade. A maturidade, seriedade e experiência do candidato são avaliadas pelos exames, tanto ou mais que seus conhecimentos. Como todos sabem, o saber é adquirido pelo estudo, trabalho e reflexão no decorrer da vida estudantil e profissional. Nessa também, ousamos dizes, em igual tempo, são adquiridas as qualidades anteriormente mencionadas. Portanto, a avaliação do preparo técnico do candidato é suficiente para que, por via reflexa, sejam também avaliados todos os outros requisitos para o exercício da profissão, mormente tendo em vista a necessária rigorosidade dos concursos de provas e provas e títulos. Não nos parece, em verdade, que exista caso em que a exigência de idade para a inscrição em certame ou para a posse em cargo ou emprego público se justifique. Por derradeiro, com relação à apreciação do caso concreto pelo Poder Judiciário, devem os julgadores levar em conta também a situação do candidato e sua faixa etária, o que evita que a aplicação fria do texto legal guie a injustiças." (FERREIA DE ALMEIDA, Péricles. Discriminação em concurso público por motivo de idade. Extraído del sitio Jus Navigandi (http://jus2.uol.com.br/doutrina/texto.asp?id=5364), acceso en 02.02.2010).
} 
restrição é legítima e não merece qualquer impugnação. Analisando edital de concurso para ingresso na Polícia Militar do DF, o Pretório Excelso deu foros de legalidade à fixação de idade máxima e de idade mínima para a investidura na corporação. Para o cargo de Magistrado, por exemplo, tem sido admitida a exigência de idade mínima superior à fixada para outros cargos (v.g.: vinte e cinco anos), com a justificativa de que as relevantes funções do cargo exigem maior maturidade para serem devidamente exercidas." ${ }^{495}$

Cabe añadir que, hoy en día, hay la Súmula $n^{\circ}$ 683, del Supremo Tribunal Federal, que establece que: "o limite de idade para inscrição em concurso público só se legitima em face do art. $7^{\circ}, X X X$, da Constituição, quando possa ser justificado pela natureza das atribuições do cargo a ser preenchido."

Así, en los términos de la Súmula arriba mencionada, la doctrina ha subrayado que "o Supremo Tribunal Federal manifestou-se favoravelmente à limitação de idade mínima e máxima para o cargo de agente penitenciário, dada a natureza das atribuições do cargo",496

El tema de la edad máxima en los procesos selectivos en Brasil ha producido mucho debate en los medios académicos y judiciales, lo que ha aportado importantes contribuciones a la solución de la cuestión.

Una primera observación, que puede incluso ser utilizada como punto de partida, dice respecto a la previsión en la Ley 10.741/2003, llamada de Estatuto de las Personas Mayores (Estatuto do Idoso). En su art. 27, la referida ley determina que: "Na admissão do idoso em qualquer trabalho ou emprego, é vedada a discriminação e a fixação de limite máximo de idade, inclusive para concursos, ressalvados os casos em que a natureza do cargo o exigir" ${ }^{, 497}$.

\footnotetext{
${ }^{495}$ SANTOS CARVALHO FILHO, José dos. Op.cit., p. 561.

${ }^{496}$ TOURINHO, Rita. Op.cit., p. 71.

${ }^{497}$ Para la doctrina: "o citado diploma legal, nessa parte, não traz novidade ao mundo jurídico. Apenas repete o que encontra-se, ousamos dizer, de modo mais claro, em nossa Carta Política. Nessa linha de idéias, somente quando a natureza do cargo exigir, pode o legislador estabelecer a discriminação. É que, nesse caso, não há violação do principio constitucional da igualdade." (FERREIA DE ALMEIDA, Péricles. Discriminação em concurso público por motivo de idade. Extraído del sitio Jus Navigandi (http://jus2.uol.com.br/doutrina/texto.asp?id=5364), acceso en 02.02.20010).
} 
En su labor de interpretación de las normas jurídicas, la doctrina ha expresado su opinión respecto a la aplicación del art. 27 del Estatuto de las Personas Mayores en los siguientes términos:

"Como a definição legal do idoso atinge aqueles que têm idade superior a sessenta anos, é preciso adequar tais disposições legais às condições para investidura no serviço público. Primeiramente, o limite de idade para investidura do idoso não poderá ser superior a setenta anos, já que com essa idade ocorre a aposentadoria compulsória, como estabelece o art. 40, $1^{\circ}$, II, da Constituição. Portanto, a proibição de discriminar idade do idoso deve aplicar-se entre sessenta e setenta anos de idade, para adequar-se a disposição legal ao mandamento constitucional. Depois, será necessário considerar, como, aliás, ressalvou a lei, as funções do cargo. Algumas funções serão incompatíveis com o exercício por servidor de idade mais avançada; nesses casos, legítima será a exclusão do idoso. Contudo, se as funções forem suscetíveis de ser exercidas por servidor naquela faixa etária, ilegal será a discriminação do interessado por força de sua idade." 498

Según el entendimiento destacado, la posibilidad de la previsión de edad máxima en los concursos públicos dependerá de la naturaleza del cargo o empleo público que será ejercido, y de la imposibilidad de que el mismo sea desempeñado de forma eficaz por personas que ya hayan superado determinada edad.

Por esta razón, se entiende que la norma constitucional (art. $7^{\circ}, \mathrm{XXX}$ ) no establece una prohibición absoluta, ya que es autorizada la definición de edad máxima para admisión a determinadas funciones, cuando demostrada la razonabilidad de la exigencia. Al menos, este es el entendimiento del principal órgano jurisdiccional brasileño, el Supremo Tribunal Federal:

"Questão muito debatida na jurisprudência do STF diz respeito ao princípio de igualdade e a limitação de idade em concurso público. Em princípio, a exigência de igualdade impede a mencionada ${ }^{498}$ SANTOS CARVALHO FILHO, José dos. Op.cit., p. 564. 
limitação de idade, salvo diante de situações excepcionais justificadas em razão da natureza e das atribuições do cargo a ser provido. Assim, a jurisprudência do Supremo Tribunal Federal firmou-se no sentido de que a norma constitucional que pró́be tratamento normativo discriminatório, em razão da idade, para efeito de ingresso no serviço público, não se reveste de caráter absoluto, sendo legítima, em conseqüência, a estipulação de exigência de ordem etária, quando esta decorrer da natureza e do conteúdo ocupacional do cargo público a ser provido." 499

En el ámbito del Superior Tribunal de Justicia, ya ha sido analizada y rechazada la posibilidad de definición de edad máxima de 45 años para la función de profesor, como se puede ver abajo:

"Constitucional e administrativo. Concurso público. Requisitos. Limite de idade. CF/1988, art. $7^{\circ}$, XXX.

- A CF/1988, em seu art. $7^{\circ}, \mathrm{XXX}$, aplicável aos servidores públicos por força do art. $39, \S 2^{\circ}$, proíbe a infundada diferenciação na admissão para o serviço público por motivo de sexo, idade, cor ou estado civil.

- Hipótese em que o limite de idade de 45 anos fixado para o concurso público é ilegal por falta de razoável amparo jurídico Tal exigência não se justifica por não ser indispensável para o bom cumprimento da função a ser exercida.

- Recurso provido." 500

Para la función de agente de tributos estaduales, el Superior Tribunal de Justiça también entendió que no sería posible establecer una edad máxima (35 años) en el respectivo proceso selectivo, como se puede verificar:

"Constitucional e administrativo. Concurso público. Limite de idade. Princípio da razoabilidade. CF/1988, art. $7^{\circ}$, XXX.

\footnotetext{
${ }^{499}$ CUNHA JÚNIOR, Dirley da. Curso de Direito Constitucional, $2^{\mathrm{a}}$ ed., Editora Podium, Salvador, 2008 , p. 645.

${ }^{500}$ Superior Tribunal de Justiça, RMS 5.009/RS, $5^{\text {a }}$ Turma, Rel. Min. Felix Fisher, v.u., DJU 1 de 24.11.1997, p. 61.250.
} 
- O preceito inscrito no art. $7^{\circ}, \mathrm{XXX}$, da Carta Magna, que veda a adoção de critério discriminatório para acesso aos cargos públicos, inclusive por motivo de idade, deve ser concebido com razoabilidade, sem rigor absoluto, devendo ser considerada a natureza das funções, se exigem ou não vigor físico dos seus titulares, bem como a situação do candidato em face do serviço público.

- Afronta o mencionado princípio constitucional a fixação do limite de idade em 35 anos para inscrição no concurso para provimento do cargo de agente fiscal de tributos estaduais.

- Recurso ordinário provido. Segurança concedida. ${ }^{.501}$

A partir del análisis de los fallos emitidos por los tribunales brasileños, se percibe que estos reconocen la inconstitucionalidad de las leyes que establecen "a limitação de idade para cargos que demandem apenas atividade intelectual e não força física. Isso porque o esplendor da atividade intelectual atinge-se quando ela é aliada à experiência de vida, o que, convenhamos, independe de idade" 502

En el camino arriba apuntado, se puede afirmar que los procesos selectivos para cubertura de los cargos y empleos públicos que demandan actividades puramente intelectuales no pueden exigir edad máxima de los aspirantes ${ }^{503}$, excepto cuando presentes determinadas circunstancias propias del sistema de jubilación.

Otra situación que sucede en determinados concursos públicos es la dispensa de la exigencia de edad máxima para aquellos que ya son funcionarios públicos. Respecto a esta circunstancia, la doctrina es inflexible en la condenación a tal

${ }^{501}$ Superior Tribunal de Justiça, RMS 5.793/RS, 6 6 Turma, Rel. Min. Vicente Leal, v.u., DJU 1 de 03.02.1997, p. 784.

${ }^{502}$ SPITZCOVSKY, Celso. Limitações constitucionais aos editais de concursos públicos. Texto extraído del sitio Jus Navigandi (http://jus2.uol.com.br/doutrina/texto.asp?id=5125), acceso en 02.02.2010.

${ }^{503}$ Por esta razón, "é de simples aferição que os concursos da área jurídica, por envolver, de forma prevalente, atividade intelectiva, não deveriam conter limite máximo de idade, a não ser naquelas raras hipóteses em que o conhecimento jurídico deve estar aliado ao vigor físico, como para agentes policiais ou de fiscalização, que necessitam de força física para a realização de diligências, além do conhecimento jurídico. Nesses concursos, aliás, muitas vezes, exige-se a realização de atividade física como uma das etapas das provas." (KÜMPEL, Vitor Frederico. Limite de idade para concurso público. Texto extraído del sitio Jus Navigandi (http://jus2.uol.com.br/doutrina/texto.asp?id=4725), acceso en 02.02.2010). 
posibilidad $^{504}$, afirmando su ilegitimidad flagrante, ya que la discriminación por edad no "teria suporte na natureza das funções, como seria aceitável, mas sim na qualificação jurídica pessoal do candidato. Há, portanto, inegável ofensa aos princípios da impessoalidade e da acessibilidade funcional, sendo plenamente cabível ao Judiciário reprimir essa distorção., ${ }^{505}$

En definitiva, a partir del análisis de los ordenamientos jurídicos español y brasileño, se puede verificar que ambos tienen la misma preocupación de solamente admitir la posibilidad de exigencia de edad mínima y máxima distinta de aquellas previstas usualmente cuando hay una fuerte (o sea, razonable) justificación. Tal cautela es muy relevante para asegurar la efectiva igualdad de oportunidades en el ingreso de los más jóvenes y de las personas mayores en el sector público.

\subsection{4 - Género}

Aunque hoy en día sea poco usual encontrar en un proceso selectivo reglas que impongan el requisito de género para acceder a la función pública, hay una indiscutible necesidad de analizar los aspectos jurídicos que tienen relación con el ingreso de las mujeres en las plantillas de la Administración Pública.

En este contexto, si es posible afirmar que tanto la Constitución española, como la brasileña establecen que todos son iguales ante la ley, sin que pueda prevalecer discriminación alguna en razón de sexo (art. $14 \mathrm{CE}$; art. $3^{\circ}$, III y 5º, I, $\mathrm{CB}^{506}$ ), también

\footnotetext{
${ }^{504}$ En esto camino, ya se ha afirmado que: "Não cabe a Administração Pública definir no edital do concurso público, mesmo com previsão legal, limite de idade em decorrência das atribuições do cargo somente para quem ainda não é servidor público, dispensando essa exigência para aquele candidato que já é servidor e deseja mudar de cargo. Nesse caso, fica demonstrado que essa discriminação visa beneficiar o candidato já servidor em detrimento daquele que não é, não sendo realmente verificada essa necessidade em decorrência das atribuições dos cargos. Tal lei e edital são flagrantemente inconstitucionais em decorrência do princípio da isonomia (art. $5^{\circ}$, caput da CR/88)." (BRANDAO COSTA, Bernardo. Idade no concurso público. Texto extraído del sitio http://www.pciconcursos.com.br/consultoria/idade-em-concurso-publico, acceso en 02.02.2010). 505 SANTOS CARVALHO FILHO, José dos. Op.cit., p. 560.

${ }^{506}$ La Constitución brasileña no solo establece la igualdad de género, como también impone algunas medidas de diferenciación: "A igualdade de homens e mulheres em direitos e obrigações é prescrita pela própria Carta Constitucional, que, em alguns dispositivos, cuida de conferir tratamento diferenciado àqueles para acertar, na diferença de cuidado jurídico, a igualação do direito à dignidade na vida. Assim, os prazos para a aposentadoria dos trabalhadores de um e outro sexo foram diferenciados (arts. 40, III, e 202), como o foram para o gozo de licença pelo nascimento de filho (arts. $7^{\circ}$, XVIII, e 10, $1^{\circ}$ ). Entretanto, a decisão do constituinte fez-se segundo a razão aceita por ele como justa e motivada, deixando de prevalecer distinção, por exemplo, no prazo de aposentadoria dos magistrados, categoria de
} 
debe ser mencionado que, en la realidad, en diversas situaciones, las mujeres continúan recibiendo un trato desfavorable en los lados del Atlántico.

Sobre la constatación arriba citada, cabe subrayar que:

"En España, el principio de igualdad se encuentra reconocido tanto en la Constitución como en numerosas disposiciones aprobadas por el Gobierno que han ido evolucionando en los últimos años de una manera muy positiva, sin embargo, el reconocimiento de las leyes no ha tenido un reflejo en la evolución de la sociedad por lo que sigue existiendo discriminación y desigualdad." ${ }^{, 507}$

Lo que pasa es que aunque las reglas aplicadas al sector público sean distintas de las destinadas al sector privado (donde la discriminación es más difícil de evitar $^{508}$ ), en España, no se puede olvidar que las mujeres todavía no han alcanzado la efectiva igualdad en el plano material, si comparadas a los hombres ${ }^{509}$.

profissionais aos quais não se estendeu qualquer diferenciação para aquele efeito entre homens e mulheres (art. 93, VI).” (ANTUNES ROCHA, Cármen Lúcia. O principio constitucional da igualdade. Editora Lê, Belo Horizonte, 1990, p. 75).

${ }^{507}$ GONZÁLEZ BUSTOS, María Ángeles. El trato de la igualdad en el ordenamiento jurídico administrativo español. Especial incidencia en la Comunidad Autónoma de Castilla y León. Capítulo 3 de la obra La mujer ante el ordenamiento jurídico: soluciones a realidades de género, María Ángeles González Bustos (Coordinación), diversos autores, Atelier Libros Jurídicos, Barcelona, 2009, p. 84.

508 Respecto a la adopción de medidas de acción positiva para que sean garantizadas las debidas oportunidades laborales a las mujeres, véase: RODRÍGUEZ ESCANCIANO, Suzana. La familia en el ámbito jurídico-laboral. Editorial Tirant lo Blanch, Valencia, 2008.

${ }^{509}$ En este contexto:" Que el número de mujeres supera al de hombres en la Administración pública ya se constató por primera vez en el informe del Registro Central del Personal del Ministerio de Administraciones Públicas presentado durante el pasado año. En concreto, este informe señalaba un porcentaje del $51 \%$ de féminas entre el total de empleados públicos. Traducido en cifras, esto supone la existencia de 118.530 funcionarias frente a 114.079 homólogos varones. A pesar de ello, la presencia femenina se concreta en los escalafones inferiores, dándose escasa presencia de mujeres entre los altos cargos de la Administración del Estado, donde apenas llegan a ocupar un tercio.(...) Una de las causas del menor desarrollo profesional de la mujer señalada en el informe realizado sobre la materia por la Unión Europea, como es la dedicación a profesiones "femeninas", parece cumplirse también en el caso de la Administración Pública española. O es que quizá, dicho de otra manera, lo que se constata es su ausencia en actividades tradicionalmente masculinas, ya que la presencia de mujeres en cuerpos como la Guardia Civil, Policía Nacional o Fuerzas Armadas sigue siendo mínima. Por el contrario, ellas son más numerosas que los hombres en ámbitos como el sanitario o la enseñanza pública, presentando fuerte similitudes con lo que sucede en el sector privado. El número de mujeres, además, se va reduciendo a medida que sube la escala profesional, encontrándose cada vez menos cuanto más alto es el puesto. Es lo que sucede, por ejemplo, en la enseñanza pública, donde hallamos un gran número de mujeres, en torno al 75,87\% del total, según datos de un informe del Ministerio de Trabajo elaborado en 2005, y sin embargo, un escaso $15,11 \%$ de catedráticas. Existe, a pesar de todo, un ámbito ancestralmente masculino en el que la mujer no sólo tiene fuerte presencia, sino que es mayoría. Tal es el caso de la Administración de Justicia, ámbito en el que en lugares como el País Vasco, el 55,25\% de los jueces son mujeres. Otro tanto sucede en la Comunidad Valenciana o Andalucía, comunidades en las que la proporción es de 50,96 y 43,61 puntos porcentuales, respectivamente. En Madrid, el porcentaje asciende 
Sobre esta afirmación, es suficiente resaltar el ínfimo número de puestos de trabajo de alta dirección ocupado por mujeres, aunque estas sean, en general, mayoría en las Administraciones Públicas españolas. ${ }^{510}$

En Brasil, hoy en día, la representatividad de las mujeres en el sector público ya es alta, especialmente en los puestos de trabajo que no dependen de indicación política. A su vez, cuando hay la posibilidad de libre designación para cubertura de los puestos de decisión, la presencia de las mujeres disminuye considerablemente.

En este sentido, la Secretaria Especial de Políticas de Promoción de la Igualdade Racial (Seppir) ha constatado lo que muchos ya sospechaban: que los nombramientos para "os cargos de Direção de Assessoramento Superior (DAS) ainda privilegiam os homens, especialmente os de maior remuneração. (...) 56,14\% dos DAS 3 estão nas mãos dos homens e 43\% nas mãos de mulheres; já nos DAS 4, as mulheres são $37 \%$ do total; nos DAS 5, são 23\%; e nos DAS 6, somam 18\%" "511

La cuestión del acceso de las mujeres a la función pública (y su presencia en los cargos de más alto poder decisorio) no representa solamente una búsqueda de paridad entre los sexos en más de uno de los sectores de la vida social, sino una exigencia de la democracia, ya que la Administración Pública, en la medida que representa uno de los más relevantes espacios de decisión y ejecución de políticas

al 50,49\%. Todo un hito si consideramos que hasta el año 1966 la mujer tuvo vetado el acceso a la carrera judicial. No obstante, al igual que ocurre en otros ámbitos, la representación femenina disminuye a medida que aumenta el escalafón. Los juzgados, primera estación en la escala de la carrera judicial, son los únicos lugares en los que las mujeres superan en número a los varones. A partir de ahí el número cae en picado. Buen ejemplo de ello es que las presidencias de las audiencias provinciales estén ocupadas por 45 hombres y tan sólo 5 mujeres. La carrera fiscal es otra de las profesiones dentro del ámbito de justicia que acoge a un mayor número de mujeres que de hombres. Valga como muestra que en la 47 promoción de fiscales que recibieron sus despachos en enero de este mismo año, de un total de 111 nuevos fiscales, 86 eran mujeres y tan sólo 25 hombres" (RIOBÓ, Esther. Extraído del reportaje Mujeres en la Administración Pública: muchas y cada vez más, publicado en el sitio electrónico (http://www.aprendemas.com/Reportajes/EspecialMujeres/P6.asp), acceso en 24 de Febrero de 2010

${ }^{510} \mathrm{La}$ presencia de las mujeres en las distintas plazas de las Administraciones Públicas disminuye de forma progresiva a medida que "asciende la esfera de poder, prestigio y/o remuneración de los cargos..." Así mismo, también se puede constatar que "en aquellos casos en los que el acceso a los cargos se produce por libre cooptación o libre elección, el número de mujeres es muy inferior a aquellos otros en los que existen mecanismos formales y objetivos de acceso (oposiciones o concursos)." (IV Plan para la Igualdad de Oportunidades entre Mujeres y Hombres 2003-2006, en PICÓ LORENZO, Celsa. La discriminación positiva en la función pública, capítulo del libro La discriminación positiva, Consejo General del Poder Judicial, Madrid, 2006, p. 57).

${ }^{511}$ Texto extraído del reportaje Mulheres debatem liderança na Administraçao Pública, publicado en el sitio electrónico de la Escola Nacional de Administraçao Pública - ENAP, http://www.enap.gov.br/index.php?option=com_content\&task=view\&id=665\&Itemid=158, acceso en 01 de junio de 2010. 
públicas, para que pueda actuar de forma legítima, debe tener sus puestos de trabajo ocupados por todos aquellos que forman parte de la sociedad civil.

La doctrina española ha destacado con claridad que:

"la aplicación del principio de igualdad de trato supone la ausencia de toda discriminación directa o indirecta por razón de sexo en los sectores público y privado en relación con las condiciones de acceso al empleo, al trabajo por cuenta propia o la ocupación, incluidos los criterios de selección y las condiciones de contratación"

Sin embargo, la preocupación por la participación de las mujeres en la Administración Pública debe ser analizada en el contexto específico de las exigencias constitucionales de selección a través de los criterios de igualdad, mérito y capacidad (art. 23.2 y 103.3, CE; art. 37, I y II, CB).

En estos términos, lo que se impone es la armonización entre el derecho de todos los ciudadanos de participar de los procedimientos de selección en condición de igualdad, lo que incluye el derecho de las mujeres a no ser discriminadas (y en algunas pocas situaciones, el derecho de recibir un trato más favorable), con el deber del Estado de seleccionar a los más aptos, exigencia de la eficacia administrativa.

La idea de no discriminación y la técnica de la igualdad de oportunidades son temas muy relevantes en el presente estudio, que empieza por el reconocimiento de los esfuerzos (no siempre productivos) realizados en las últimas décadas en España y en Brasil para una aproximación efectiva entre la situación de los hombres y las mujeres, en los términos que imponen sus Constituciones. Los mencionados esfuerzos son medidas relevantes, pero todavía insuficientes ${ }^{513}$ para la realización de una efectiva igualdad de género.

${ }^{512}$ FERNÁNDEZ DE GATTA SÁNCHEZ, Dionisio. El principio de igualdad de género en la Unión Europea, capítulo del libro Igualdad ¿Para qué ?, A propósito de la Ley Orgánica para la igualdad efectiva de mujeres y hombres, Ángela Figueruelo Burrieza, María Luisa Ibañez Martínez y Rosa María Merino Hernández (Editoras), Editorial Comares, Granada, 2007, p. 149.

513 Cabe destacar que "el reconocimiento constitucional o legal no es suficiente para producir la necesaria transformación de las estructuras creadas por una sociedad patriarcal y sostenidas por unos textos legales que consideraban compatible la proclamación de la igualdad, como derecho de todos, con la situación de desigualdad de las mujeres. Por eso no es extraño que el derecho de acceder en condiciones de igualdad a las funciones y cargos públicos se redujese en la práctica a una presencia testimonial de las mujeres en los puestos de representación merced a la buena voluntad de los dirigentes 
Cabe añadir que el presente estudio se limita al análisis del acceso de las mujeres a la Administración Pública a través de los procedimientos selectivos tradicionales (oposición, concurso y concurso-oposición, en España; y concurso público, en Brasil), lo que excluye la investigación sobre los casos de provisión de puestos de trabajo, o también el ingreso a través de otros mecanismos, como la libre designación. ${ }^{514}$

No obstante, no se puede olvidar la existencia de distintas situaciones en que el acceso de las mujeres a la función pública presenta ciertas peculiaridades, que si no son analizadas con el necesario cuidado, podrán impedir o dificultar la efectiva igualdad de género en el acceso a la función pública. ${ }^{515}$

\subsubsection{1 - El acceso de la mujer a la función pública}

En el Derecho español, antes de todo, cabe acentuar que además de la presencia de las normas producidas en su propio territorio, hay la influencia del Derecho

(hombres) de los partidos políticos que tenían el poder de nombrar a los candidatos." (SEVILLA MERINO, Julia. Igualdad, paridad y democracia, p. 381-419, del libro El reto de la efectiva igualdad de oportunidades, editoras Ángela Figueruelo Burrieza y María Luisa Ibáñez Martínez, Universidad de Salamanca, Comares Editorial, Granada, 2006, p. 381.)

${ }^{514}$ En la perspectiva arriba destacada, el Estado español reconoció oficialmente que: "eliminados los obstáculos jurídicos que impedían a las mujeres desempeñar un empleo público en condiciones de igualdad, todavía perviven, sin embargo, dificultades para erradicar por completo la discriminación de las mujeres en las Administraciones públicas, sobre todo, en lo que se refiere a su promoción profesional a puestos de decisión." (Texto del Orden APU/526/2005, de 7 de marzo, por la que se dispone la publicación del Acuerdo de Consejo de Ministros de 4 de marzo de 2005, por el que se aprueba el Plan para la igualdad de género en la Administración General del Estado).

${ }^{515}$ En este contexto, la Orden APU/526/2005, del 7 de marzo, al establecer el Plan para la igualdad de género en la Administración General del Estado, determina tres medidas para promover la referida igualdad en el acceso a la función pública: "Con el objetivo de promover el acceso de las mujeres al empleo público en condiciones de igualdad, mérito y capacidad, especialmente en los cuerpos o categorías en los que estas se encuentran infrarrepresentadas, se adoptan las siguientes medidas: 1.1. En el Centro de Información Administrativa del Ministerio de Administraciones Públicas se dispondrá de una unidad de información, asesoramiento y asistencia a través de la cual se facilitará a quienes estén interesadas en acceder a un empleo público información acerca de los requisitos exigidos en las correspondientes convocatorias, formación o ayudas y becas disponibles para facilitar el acceso de las mujeres al empleo público. 1.2. Todas las convocatorias de procesos selectivos que realice la Administración General del Estado para el acceso al empleo público, tanto en cuerpos generales como especiales, incluirán un párrafo que señale si existe en el correspondiente cuerpo infrarrepresentación de personas de alguno de los dos sexos. Asimismo, las respectivas bases recogerán una referencia al deber de los tribunales o comisiones de selección de velar, de acuerdo con el artículo 14 de la Constitución Española, por el estricto cumplimiento del principio de igualdad de oportunidades entre ambos sexos. 1.3. La composición de los tribunales y de las comisiones permanentes de selección para el acceso de las personas al empleo público se ajustarán al criterio de paridad entre ambos sexos. Para el presente año, dicha previsión se encuentra en el artículo 4.f) del Real Decreto 121/2005, de 4 de febrero, por el que se aprueba la oferta de empleo público para el año 2005." 
Comunitario, que hace mucho que ya impone reglas respecto a la igualdad de género. En este contexto, se ha subrayado que:

\begin{abstract}
“desde los años 90 del siglo pasado han sido numerosas las iniciativas adoptadas en el nivel internacional que han tenido proyección en el ámbito Comunitario mediante la aprobación de programas de igualdad y distintas normas reguladoras de la posición de la mujer en ámbitos diversos, con la consecuencia fundamental de incidir en Nuestro Ordenamiento, tanto en el nivel estatal, como en el autonomico, y al más alto nivel normativo, creando todo un corpus normativo de la igualdad de mujeres y hombres que, cuanto menos, evidencia la idoneidad del Derecho como herramienta de cambio en relación con la posición de la mujer en tanto que titular de derechos individuales y de carácter social" ${ }^{, 516}$
\end{abstract}

En e citado país, la cuestión referente al acceso de las mujeres a las funciones públicas tiene como principal antecedente legislativo la Ley de Funcionarios Civiles del Estado (Ley 109/1963), que consagró, en su art. 30.2 $2^{517}$, como regla general, el principio de no discriminación por razón de sexo.

La mencionada regla parecía en principio la plena realización de la igualdad de género en materia de acceso a la función pública. Sin embargo:

"a pesar de este principio general contenido en la legislación, existía
una clara tendencia discriminatoria, como se puede observar en el
preámbulo de dicha ley al señalar que las limitaciones que se
establecen al principio general de no discriminación están basadas en
"hechos o circunstancias naturales de tan fácil y obvia comprensión
que resulta redundante o inútil su justificación en detalle (...) sin otra
cortapisa que la derivada de la existencia de trabajos que exigen
esfuerzos desmensurados..." (esta ley exceptuaba, conforme a dicho

516 MORA RUIZ, Manuela. Informe de impacto de gênero em las disposiciones administrativas de carácter general: ¿Uma garantia efectiva de la igualdad desde el derecho administrativo?, capítulo del libro Formación y objeto del Derecho antidiscriminatorio de género: perspectiva sistemática de la igualdad desde el Derecho público, Manuela Mora Ruiz (Directora), Atelier Libros Jurídicos, Barcelona, 2010, p. 208-209.

517 "La mujer puede participar en las pruebas selectivas para el ingreso en la Administración Pública, conforme a la Ley 56/1961, de 22 de julio, de derechos políticos, profesionales y de trabajo". 
criterio, las Fuerzas Armadas, Los Institutos Armados, La Judicatura y la Marina Mercante). ${ }^{.518}$

También debe ser mencionado que, en el citado periodo, las relaciones de familia estaban centradas en la potestad de dirección ejercida por el marido. Así, prevalecía la exigencia, prevista en el Código Civil, de autorización marital para el ingreso de la mujer en una función pública. ${ }^{519}$

Los mencionados tratos discriminatorios son resultado de una cultura que reservaba a las mujeres una posición subalterna, siendo aquellas consideradas débiles e incapaces de ejercer una actividad que envolviera conocimientos intelectuales, como las funciones públicas. ${ }^{520}$

En el derecho brasileño, la Constitución de 1988 inauguró nuevos tiempos en el tema de la igualdad de género. Son muchas las normas constitucionales en este sentido, como las que establecen la igualdad entre hombres y mujeres (art. $5^{\circ}$, I), la que determina la prohibición genérica de discriminación en razón del sexo (art. $3^{\circ}$, III), o la de prohibición de la diferenciación de sexo en los criterios de admisión (art. $7^{\circ}, \mathrm{XXX}$ ).

A su vez, la doctrina ha aportado considerables contribuciones al presente estudio, aunque no se perciba en Brasil la existencia de un verdadero segmento de juristas que tratan de las cuestiones de género, como sucede en España con tanta intensidad en los días de hoy.

Debido a los cambios introducidos por la Constitución brasileña de 1988 y la nueva mentalidad de la doctrina, aunque de forma más tímida que lo esperado, es posible afirmar que:

\footnotetext{
"Também a jurisprudência teve de adequar-se a esta nova ordem social. Antes da Constituição de 1988, era comum encontrarem-se julgados que entendiam razoável a proibição do ingresso feminino em cargos como auxiliar de fiscal de rendas, policial, escrivão de polícia e
}

\footnotetext{
518 GONZÁLES BUSTOS, María Ángeles. La mujer ante el siglo XXI: una perspectiva desde el ordenamiento jurídico-administrativo, Editorial @ becedario, Badajoz, 2006, p. 10.

${ }^{519}$ GONZÁLES BUSTOS, María Ángeles. Op.cit., p. 10.

${ }^{520}$ Para demostrar que la concepción de la inferioridad femenina no era corriente tan sólo en las clases menos instruidas, Fernando Rey Martínez cita Kant, Rosseau y Hegel como defensores de la incapacidad de las mujeres para ejercer funciones que exigen responsabilidad, objetividad y poder de decisión, reduciendo su papel al ámbito familiar.(REYS MARTÍNEZ, Fernando. Op.cit., p. 3-4).
} 
delegado de polícia, entre outros; e a vedação ao ingresso de homens no cargo de parteira prática, por exemplo." 521

\subsubsection{2 - La participación de la mujer en los procesos selectivos}

Seguramente, el acceso a la función pública no consiste en uno de los principales problemas que afecta a las mujeres, ya que el sistema del mérito es indiferente al hecho de que el aspirante pertenezca a uno u otro género. Evidentemente, esta misma situación de equivalencia no ocurre en el mercado laboral, donde ser mujer muchas veces puede ser un gran obstáculo para conseguir un empleo.

Sin embargo, hay algunas cuestiones que merecen una atención especial, cuando se analiza el proceso selectivo de acceso a la función pública y cuestiones de género. En este contexto, es posible destacar tres grandes sectores: composición de los órganos de selección, admisión a determinadas funciones y realización de las pruebas

Según normativa del derecho español, los órganos de selección, que actúan en las oposiciones y concursos para acceso a la función pública, deberán ser constituidos de forma paritaria, entre hombres y mujeres, conforme determina el Estatuto básico del empleado público (Ley 7/2007). ${ }^{522}$

La exigencia arriba mencionada tiene dos propósitos: en primer lugar, garantizar la presencia de mujeres en los órganos de selección de funcionarios públicos, con el propósito de que aquellas puedan formar parte de un relevante espacio de poder dentro de las Administraciones Públicas.

En realidad, los órganos colectivos deben ser un lugar de discusión democrática, y, por tanto, deben estar constituidos de forma equilibrada, con representación de distintos segmentos. En relación a los órganos de selección, estos son considerados como una de las claves fundamentales de la credibilidad de todo proceso

\footnotetext{
${ }^{521}$ LOBELLO DE OLIVEIRA ROCHA, Francisco. Op.cit., p. 80.

522 “Artículo 60. Órganos de selección.1. Los órganos de selección serán colegiados y su composición deberá ajustarse a los principios de imparcialidad y profesionalidad de sus miembros, y se tenderá, asimismo, a la paridad entre mujer y hombre."
} 
de selección para el acceso al empleo público, principalmente por su imparcialidad y objetividad. $^{523}$

Así, cuando se exige la presencia equilibrada entre hombres y mujeres, lo que se busca en primera instancia es impedir la infrarepresentación de las mujeres, lo que suele ocurrir cuando no existe norma que determine la paridad. Como ha destacado la doctrina española que:

"A principios de la segunda década del siglo XXI puede afirmarse sin temor a equivocarse que la participación equilibrado de mujeres y hombres en la toma de decisiones forma parte de los derechos humanos fundamentales y del acervo jurídico internacional, al contribuir a la superación del déficit democrático que afecta a todos los Estados y a la consecución de la igualdad efectiva de mujeres y hombres en todos los ámbitos",524

La mencionada presencia equilibrada proviene de la directriz prevista en el art. 51 de la Ley Orgánica 3/2007, del 22 de marzo, para la igualdad efectiva entre mujeres y hombres. El mencionado precepto determina que las Administraciones Públicas deberán: “d) promover la presencia equilibrada de mujeres y hombres en los órganos de selección y valoración". 525

El citado precepto es una de las muchas imposiciones de la Ley Orgánica 3/2007, que, según la doctrina, ha convertido España en un referente internacional en el

${ }^{523}$ La idea está presente en el Informe de la Comisión para el estudio y preparación del Estatuto Básico del Empleado Público, que actuó sobre la Presidencia del Profesor Miguel Sánchez Morón, INAP, abril de 2005, Madrid, p. 98.

${ }^{524}$ NIEVES SALDAÑA DÍAS, María. La participación equilibrada de género en el ámbito autonómico: balance y perspectivas, capítulo del libro Formación y objeto del Derecho antidiscriminatorio de género: perspectiva sistemática de la igualdad desde el Derecho público, Manuela Mora Ruiz (Directora), Atelier Libros Jurídicos, Barcelona, 2010, p. 111.

${ }^{525}$ En el ámbito de la Administración General del Estado, la Ley Orgánica no 3/2007 establece que: "Art. 53. Todos los tribunales y órganos de selección del personal de la Administración General del Estado y organismos públicos vinculados o dependientes de ella, responderán al principio de presencia equilibrada de mujeres y hombres, salvo por razones fundadas y objetivas, debidamente motivadas." A su vez, el artículo 54, al tratar de la designación de representantes de la Administración General del Estado, impone que "La Administración General del Estado y los organismos públicos vinculados o dependientes de ella designarán a sus representantes en órganos colegiados, comités de personas expertas o comités consultivos, nacionales o internacionales, de acuerdo con el principio de presencia equilibrada de mujeres y hombres, salvo por razones fundadas y objetivas, debidamente motivadas. Asimismo, la Administración General del Estado y los organismos públicos vinculados o dependientes de ella observarán el principio de presencia equilibrada en los nombramientos que le corresponda efectuar en los consejos de administración de las empresas en cuyo capital participe." 
tema de la igualdad de género, que pese a sua importancia, cuesta demasiado esfuerzo avanzar. Añade que "las distintas inercias, la falta de sensibilidad y la escasa volutad política se unen a la mayor parte de las veces para cerra el paso a las mujeres, eludiendo los principios e mérito y capacidad proclamados a nivel constitucional" ${ }^{, 526}$.

No obstante, aunque sea relevante la eliminación de los obstáculos que impiden la amplia participación y la debida representación de las mujeres en los órganos colectivos, la exigencia prevista en el art. 60.1 del Estatuto básico del Empleado Público tiene otra finalidad, seguramente más específica para el presente estudio, aunque generalmente olvidada por la doctrina: garantizar una evaluación más equilibrada de los aspirantes, que pasarán a tener sus actuaciones valoradas tanto por hombres, como por mujeres.

La afirmación anterior podría causar una cierta perplejidad, debido a que uno podría decir que todos los miembros de los órganos de selección deben actuar con imparcialidad, sean hombres o mujeres, lo que es la más absoluta verdad. Sin embargo, aunque los miembros de los órganos de selección actúan de forma técnica, siempre estará presente una pequeña parcela de apreciación subjetiva.

Sobre el tema arriba, un ejemplo puede ser utilizado: en un concurso para el ingreso a una universidad, hay diez aspirantes a la función de profesor: nueve hombres y una mujer. Supóngase que los cinco miembros del órgano de selección sean hombres (o, al revés, mujeres). Es este caso, no será posible desconsiderar totalmente una posible influencia del género del evaluador en las calificaciones atribuidas a los aspirantes.

Ciertamente, la presencia paritaria entre hombres y mujeres en los órganos de selección proporcionaría una visión más equilibrada de la realidad a ser evaluada, lo cual contribuiría al cumplimiento de la imparcialidad. La muestra de la existencia de esta preocupación por el legislador está señalada en el contenido del art. 61 del mismo

\footnotetext{
${ }^{526}$ FIGUERUELO BURRIEZA, Ángela. Políticas públicas previstas para la igualdad real y efectiva, capítulo del libro Igualdad ¿Para qué ?, A propósito de la Ley Orgánica para la igualdad efectiva de mujeres y hombres, Ángela Figueruelo Burrieza, María Luisa Ibañez Martínez y Rosa María Merino Hernández (Editoras), Editorial Comares, Granada, 2007, p. 193.
} 
Estatuto básico del empleado público, cuando exige que los órganos de selección velen por la observancia del principio de igualdad de oportunidades entre sexos. ${ }^{527}$

Todo eso para asegurar "el criterio favorable a la paridad de género, en coherencia con la mayor preocupación actual de nuestro ordenamiento por garantizar la igualdad real entre hombres y mujeres." 528

Otro aspecto relevante del acceso de las mujeres a la función pública trata sobre el tema de la admisión a determinadas funciones. Como ya se ha destacado, en la legislación española anterior a la Constitución de 1978, el acceso de las mujeres a algunas funciones públicas (en las Fuerzas Armadas, en los Institutos Armados, en la Judicatura y en la Marina Mercante) estaba vedado, ciertamente por una concepción largamente aceptada de debilidad física y mental o incapacidad de las mujeres para desempeñar tales funciones.

Tras la Constitución de 1978, diversas leyes fueron elaboradas para eliminar la discriminación de género. En este contexto, para ejemplificar el tema, fueron creadas la Ley Orgánica 1/2004, estableciendo medidas de protección integral contra la violencia de género, y la Ley Orgánica 3/2007, para la igualdad efectiva de mujeres y hombres. Esta última ley posee varios dispositivos que merecen ser destacados, como el artículo $52^{529}$, que determina la presencia equilibrada entre hombres y mujeres en el nombramiento de las personas titulares de los órganos directivos de la Administración General del Estado.

Sin embargo, como este trabajo tiene como objeto los procedimientos selectivos basados en el mérito (oposiciones, concursos, concursos-oposición) y como lo que ahora se analiza es el acceso de las mujeres a determinadas funciones públicas,

527 “Artículo 60. 1. Los procesos selectivos tendrán carácter abierto y garantizarán la libre concurrencia, sin perjuicio de lo establecido para la promoción interna y de las medidas de discriminación positiva previstas en este Estatuto.

Los órganos de selección velarán por el cumplimiento del principio de igualdad de oportunidades entre sexos."

${ }_{528}$ Retirado de la exposición de motivos del Estatuto Básico del Empleado Público (Ley 7/2007), de 12 de abril.

529 “Art. 52. El Gobierno atenderá al principio de presencia equilibrada de mujeres y hombres en el nombramiento de las personas titulares de los órganos directivos de la Administración General del Estado y de los organismos públicos vinculados o dependientes de ella, considerados en su conjunto, cuya designación le corresponda.” 
debe ser destacado el art. 65, que trata del acceso a las Fuerzas Armadas ${ }^{530}$ y art. 67, que versa sobre el acceso a las Fuerzas y Cuerpos de Seguridad del Estado ${ }^{531}$.

Sobre el acceso de las mujeres a las Fuerzas Armadas, es imprescindible mencionar la Sentencia no 216/1991, del 14 de noviembre, del Tribunal Constitucional español, que consideró inconstitucional, por ser discriminatoria, la prohibición de acceso de las mujeres a las Academias Militares. ${ }^{532}$

En la citada sentencia, el Tribunal Constitucional hace mención a otros fallos, que entendieron que "el sexo en sí mismo no puede ser motivo de trato desigual, ya que la igualdad entre ambos sexos está reconocida expresamente por el art. 14 de la CE" ${ }^{, 533}$ y que el mencionado precepto prohíbe de manera explícita

“...el mantenimiento de determinadas diferenciaciones históricamente muy arraigadas y que han situado, tanto por la acción de los poderes públicos, como por la práctica social, a sectores de la población en posiciones no sólo desventajosas, sino abiertamente contrarias a la dignidad de la persona que reconoce el art. 10 de la CE. En este sentido no debe ciertamente olvidarse que la expresa exclusión de la discriminación por razón de sexo halla su razón concreta, como resulta de los mismos antecedentes parlamentarios del art. $14 \mathrm{CE} \mathrm{u}$ es unánimemente admitido por la doctrina científica, en la voluntad de terminar con la histórica situación de inferioridad que, en la vida social y jurídica, se había colocado la población femenina..."

En el caso citado, el Tribunal Supremo de España había entendido que la negación de acceso de las mujeres al Ejército del Aire no lesionaba el núcleo esencial del derecho de igualdad, ya que había sido producida en armonía con la realidad social,

\footnotetext{
530 “Artículo 65. Respecto al principio de igualdad. Las normas sobre personal de las Fuerzas Armadas procurarán la efectividad del principio de igualdad entre mujeres y hombres, en especial en lo que se refiere al régimen de acceso, formación, ascensos, destinos y situaciones administrativas."

531 "Artículo 67. Respecto al principio de igualdad. Las normas reguladoras de las Fuerzas y Cuerpos de Seguridad del Estado promoverán la igualdad efectiva entre mujeres y hombres, impidiendo cualquier situación de discriminación profesional, especialmente, en el sistema de acceso, formación, ascensos, destinos y situaciones administrativas."

${ }^{532} \mathrm{La}$ mencionada sentencia es considerada decisiva en la lucha de las mujeres para acceder a la función pública. En la sentencia citada, el Tribunal Constitucional analizó el caso Ana Moreno, que, en 1987, no tuvo acceso a las pruebas de admisión en la Academia General del Aire.

${ }^{533} \mathrm{STC} \mathrm{n}^{\circ} 207 / 1987$

${ }^{534} \mathrm{STC}^{\circ}{ }^{\circ} 128 / 1987$.
} 
con las diferencias existentes de orden fisiológico, con las especiales características del Arma aérea en sus actividades operativas y de combate y con la estructura entonces actual de los Ejércitos.

Sin embargo, el Tribunal Constitucional lo entendió de forma distinta:

\begin{abstract}
"Pero estos argumentos, a la luz de la doctrina constitucional, no pueden ser aceptados. Es verdad que no todo trato diferenciador resulta desde la perspectiva del art. 14 de la CE discriminatorio, pues cabe que el legislador lo haya establecido con arreglo a criterios fundados y razonables, de acuerdo con juicios de valor generalmente admitidos. No es éste el supuesto, sin embargo." 535
\end{abstract}

Por todo ello, en el contexto español (e igualmente en el brasileño), las mujeres (y los hombres, obviamente) pueden acceder a todas las funciones públicas, puesto que el criterio del sexo es en sí mismo indiferente para el ejercicio de las actividades en la Administración Pública. Una eventual excepción a esta regla tendría que estar muy bien fundamentada.

Respecto a esta cuestión la doctrina brasileña ha admitido la exigencia de género para ingreso en determinadas funciones:

"Em principio, o sexo não pode ser fixado como requisito de acesso. Ressalvadas estarão, no entanto, as situações funcionais que justificarem a escolha de um ou outro dos sexos. Em concurso para prover cargos de Monitora em estabelecimento de abrigo para meninas adolescentes, seria válido limitar-se o acesso ao sexo feminino. Vedado, será, entretanto, instituir esse requisito em cargos que não tenham qualquer justificativa e em que as funções do cargo possam ser normalmente executadas por pessoas de qualquer dos sexos." 536

Otro representante de la doctrina brasileña ha expresado que:

\footnotetext{
${ }^{535}$ STC n $^{\circ} 216 / 1991$.

${ }^{536}$ SANTOS CARVALHO FILHO, José dos. Op.cit., p. 561.
} 
"Somente por meio de lei, em sentido estrito, certos cargos ou empregos públicos podem ser de preenchimento exclusivo por pessoas de determinado sexo, mas desde que haja uma relação de pertinência entre o sexo do servidor (ou servidora) e o específico trabalho a ser por ele (ou ela) desenvolvido. A discricionariedade desarrazoada de sexo configura inconstitucionalidade. (...) Na dúvida, a solução sempre deverá ser no sentido da não-discriminação, pois a igualdade de direitos entre os sexos, não só, mas também com relação ao ingresso no serviço público, é um valor constitucionalmente afirmado e reafirmado"

Sin embargo, aunque sea una hipótesis teóricamente posible, en la práctica administrativa, no se suele encontrar con mucha frecuencia concursos públicos que excluyen la participación de determinado sexo, ya que, cada vez más, la idea de que hay profesiones típicamente masculinas o femeninas no más es aceptada. ${ }^{538}$

Por ser teóricamente posible (lo que impone el estudio del caso), para ejemplificar una situación donde sería legítima la diferenciación, supóngase que la necesidad de admisión de guardias para los centros penitenciarios femeninos podría demandar la selección exclusiva de mujeres, si efectivamente quedara demostrada la inconveniencia de la utilización de guardias del sexo masculino (por ejemplo, delante del constreñimiento que podría ser causado en las inspecciones realizadas en los cuerpos de las mujeres presidiarias).

La última cuestión referente al acceso de las mujeres a la función pública está relacionada con la realización de las pruebas, ya que el simple reconocimiento del amplio acceso a todas las actividades administrativas sería insuficiente si el

\footnotetext{
537 ABREU DALLARI, Adilson. Princípio da isonomia e concurso público, en Concurso público e Constituição, Fabrício Motta (Cordinador), Editora Fórum, Belo Horizonte, 2005, p. 103-104.

538 "Hoje, as mudanças sociais incorporaram-se na jurisprudência que reconhece, assim como acontece com os critérios de idade, que a discriminação por razão de sexo só se viabiliza por determinação legal e se a natureza do cargo ou emprego exigir. Ainda assim, é raro encontrar situações em que tal discriminação se justifique. O exemplo clássico é a contratação de carcereiras para presídios femininos e de carcereiros para presídios masculinos. O fato de uma profissão ser tradicionalmente exercida por homens ou mulheres não é suficiente para justificar a discriminação de sexo. Para ser possível, tal discriminação deve ser necessária e proporcional." (LOBELLO DE OLIVEIRA ROCHA, Francisco. Op.cit., pp. 80-81).
} 
procedimiento de selección no tuviera en consideración las diferencias reales entre hombres y mujeres.

Lo que aquí se plantea no es alcanzado simplemente con medidas de planificación del proceso selectivo, como la exigencia prevista en el derecho español de realización de informe de impacto de género en las pruebas de acceso al empleo público (exigencia del art. 60 de la Ley Orgánica 3/2007) ${ }^{539}$, sino una preocupación por la compatibilidad de las pruebas con las peculiaridades de las mujeres.

En el sentido arriba descrito, pueden ser destacadas las pruebas de naturaleza física, que, en general, son exigidas para el acceso a los Cuerpos de Policía. Parece evidente que el nivel de exigencia física previsto para los hombres no puede ser el mismo para las mujeres. Si hombres y mujeres pueden disputar una plaza en iguales condiciones intelectuales, lo mismo no pasa con las condiciones físicas, ya que la anatomía y fisiología de los sexos son distintas.

Así, hay dos cuestiones que deben ser analizadas: en primer lugar, de naturaleza anatómica, ya que los requisitos de carácter físico para la participación en el proceso selectivo, como altura mínima, peso mínimo y máximo, masa muscular, etc., deben ser diferenciados entre hombres y mujeres.

Como ejemplo, la doctrina española hace referencia a la exigencia de altura mínima de 170 centímetros para hombres y 160 centímetros para mujeres, en el acceso a los Cuerpos de Policía. ${ }^{540}$

Otro aspecto, de carácter fisiológico, trata sobre la realización de las pruebas físicas, como carreras, salto de altura vertical, salto de longitud con carrera previa, nadar estilo libre 50 (cincuenta) metros, levantamiento de peso, trepar por una cuerda lisa, etc. Son manifiestas las distintas capacidades de rendimiento físico del cuerpo del hombre,

\footnotetext{
539 "La aprobación de convocatorias de pruebas selectivas para el acceso al empleo público deberá acompañarse de un informe de impacto de género, salvo en casos de urgencia y siempre sin perjuicio de la prohibición de discriminación por razón de sexo."

${ }^{540}$ Previsión del Real Decreto 249/2006, de 03 de marzo, por el cual se modifica el Reglamento de procesos selectivos y de formación en el Cuerpo Nacional de Policía. Vid GONZÁLEZ BUSTOS, María Ángeles. La mujer ante el siglo XXI. Una perspectiva desde el ordenamiento jurídico-administrativo, Editorial @ becedeario, Badajoz, 2006,p. 34.
} 
al compararlo al cuerpo de la mujer, lo cual puede ser fácilmente percibido a través del análisis de los records mundiales de atletismo, natación y levantamiento de peso.

Así, parece indudable que hay desigualdades fisiológicas entre los sexos, y que eso influye en una disputa que se realiza a través de pruebas físicas, afectando, así, todo el proceso selectivo. Por consiguiente, tales desigualdades violan el principio de igualdad de trato en el acceso a la función pública.

Así, la doctrina brasileña ha sustentado que el embarazo de la mujer debe ser llevado em consideración durante la realización de la prueba física. Por eso, "é inconstitucional impedir que a mulher grávida prossiga no certame em razão desta condição a impossibilitar de prestar o teste de capacidade física. Considerar a gravidez como fator incapacitante é discriminar por sua condição de mulher."

Lo que debe destacar es que el hecho de que la mujer se encuentre embarazada no debe ser motivo para su exclusión del proceso selectivo, aunque tal circunstancia la impida temporariamente de realizar las pruebas físicas.

En este sentido, se puede subrayar la siguiente opinión:

"Outro ponto polêmico diz respeito à situação jurídica das candidatas que engravidam no curso das provas de capacidade física e que venham a apresentar, em função disso, determinadas complicações que inviabilizam a realização dos testes. Em linha de princípio, as alterações fisiológicas decorrentes da gravidez são circunstanciais e não autorizam a exclusão sumária das candidatas grávidas do certame por ocasião da realização das provas de capacidade física. Entendimento contrário conduziria a uma flagrante injustiça, à medida que a condição de grávida funcionaria como uma espécie de punição, comprometendo a efetividade do princípio da paridade que deve existir entre homens e mulheres no tocante a direitos e obrigações." ${ }^{542}$

${ }^{541}$ PINHEIRO MADEIRA, José Maria. Op.cit., p. 96.
${ }^{542}$ BARBOSA MAIA, Márcio, y PINHEIRO DE QUEIROZ, Ronaldo. Op.cit., p. 122. 
El tema bajo estudio será más una vez objeto de investigación en el capítulo quinto del presente trabajo, cuando serán analizadas las condiciones para la efectividad de la igualdad en la realización de las pruebas físicas.

\subsection{5 - Capacidad funcional}

El requisito que ahora será analizado impone que el aspirante a la función pública reúna la debida condición física y mental a fin de que pueda ejercer las actividades específicas de la plaza por la cual competirá.

Como ya se ha visto, todos los requisitos de acceso a la función pública deben relacionarse directamente con la necesidad de selección de personas aptas a la realización eficaz de las tareas propias de cada puesto de trabajo. En este sentido, la doctrina española ha apuntado que

"el requisito de capacidad, física y psíquica, viene establecido hoy por
el artículo 56.1.b) EBEP, en términos más precisos que en la
legislación anterior, pues queda claro que debe interpretarse en
función de las tareas a desempeñar. Por eso es posible exigir
particulares condiciones físicas (una altura mínima, por ejemplo) o de
salud, siempre que así lo justifique la naturaleza de dichas
funciones" "543

Por supuesto, la exigencia que los candidatos participantes de los procesos selectivos satisfagan las condiciones físicas y psíquicas necesarias al ejercicio de la función pública que será cubierta no sólo es recomendable, como obligatoria.

Cabe subrayar que la idea de capacidad funcional, asociada a las condiciones físicas y psíquicas, está inserida dentro del contexto más amplio de la capacidad, que es, además del mérito, uno de los criterios validos de selección de los funcionarios públicos.

Pese al carácter obligatorio de la imposición del referido requisito, se impone que las citadas condiciones sean exigidas de forma razonable y proporcional, a

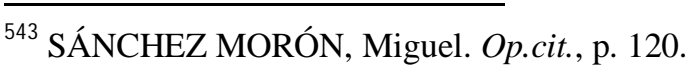


fin de que el derecho del ciudadano acceder a la función pública no sea obstaculizado por exigencias impertinentes o prejuiciosas.

La advertencia anteriormente afirmada también es realizada por la doctrina española:"empleado por diversos cuerpos para imponer requisitos positivos de aptitud física, esta previsión legislativa debe ser examinada cuidadosamente para evitar usos y abusos injustificados y en todo caso, ser objeto de una interpretación restrictiva dada la incidencia de los arts. $23.2^{\circ}$ y 103 de la CE",544.

En el derecho español, la exigencia de capacidad funcional está prevista en el Estatuto Básico del Empleado Público, en el art. 56.1.b), cuando se requiere que el candidato deba "poseer la capacidad funcional para el desempeño de las tareas", y se impone de forma genérica a todos los procesos selectivos realizados por las Administraciones Públicas española.

Pese a la utilización de la fórmula genérica del Estatuto, hay además la posibilidad de que ordenaciones particulares de algunos cuerpos también establezcan "requisitos lógicos de aptitud fisiológica, de acuerdo con las exigencias impuestas por la función a cumplir"

Dentro del concepto de capacidad funcional, se puede verificar la presencia de algunas exigencias relacionadas a la salud, sea física o psíquica, del candidato, y otras referidas a circunstancias fisiológicas del mismo. En las dos situaciones, el nexo con las actividades que serán desempeñadas debe estar presente.

En el derecho brasileño, el requisito de la capacidad funcional es lo que la legislación llama de "aptidão física e mental" (art. 5, VI, Ley Federal 8112/90), previsto como requisito básico para que se pueda ejercer un cargo público.

En la realidad de los concursos públicos brasileños, muchos problemas han surgido debido a exigencias impertinentes relacionadas a la capacidad funcional, ya que no poseen una justificación razonable. Se puede afirmar que muchas de las mencionadas

\footnotetext{
${ }^{544}$ LORENZO DE MEMBIELA, Juan B. Op.cit., p. 151.

${ }^{545}$ FERNÁNDEZ DOMÍNGUEZ, Juan J. y RODRÍGUEZ ESCANCIANO, Susana. Op.cit., p. 44.
} 
imposiciones son difíciles de creer $^{546}$, especialmente por su carácter inusitado, que llegan cerca del absurdo, como la exigencia que el candidato para la función de guardia municipal tuviera al menos 20 dientes $^{547}$, o la exclusión de una candidata que, por razones estéticas, tenía silicona en los $\operatorname{senos}^{548}$, o mismo la imposibilidad de un aspirante que posee tatuaje ser admitido ${ }^{549}$.

${ }^{546}$ Tales exigencias raras también son impuestas en otros países. En este contexto, "um homem de Montevidéu se acorrentou ontem às portas da Prefeitura da capital uruguaia para reinvidicar emprego público que ganhou por concurso e que the foi negado por ser obeso. (...) Méndez e outras quatro pessoas obesas foram selecionadas para esse posto (motorista) entre 16 mil participantes, mas a Prefeitura se negou a conceder os empregos até que emagrecessem (...) Eles ficaram entre as 30 melhores pontuaçoes e, quando se apresentaram para trabalhar, a Prefeitura os discriminou (...) Méndez, que deveria passar de 120 quilos para 92, conseguiu emagrecer 20 quilos em um mês, o que "fez com que desmaiasse várias vezes e, mesmo assim, não chegou ao índice de massa corporal exigido (...) Este episódio demonstra a discriminação à qual estão submetidos os obesos no Uruguai, país onde segundo ele, $60 \%$ dos cidadãos têm problemas de sobrepeso" (Extraído del reportaje Obeso se acorrenta e recupera emprego, publicado en el periódico Diário de Pernambuco, 11 de septiembre de 2009, p. A16). ${ }^{547}$ El ítem 3.5 do título X del edital del concurso para admisión al empleo de Guardia Municipal de la Empresa Municipal de Vigilância S.A, de la ciudad del Rio de Janeiro, de 29 de agosto de 2007, tenía la siguiente redacción: "Será considerado inapto o candidato que possuir menos de 20 (vinte) dentes, sendo 10 (dez) em cada arcada." Respecto a tal exigencia, se ha hecho el siguiente análisis: "Consideremos o universo dentário composto por 32 (trinta e dois) dentes. Desde já, saliente-se que os terceiros molares estão em crescente processo de agenesia. Com a mudança dos hábitos alimentares através dos tempos, principalmente com o cozimento dos alimentos, os dentes "do juízo" estão deixando de existir. Quando muito, restam impactados e impossibilitados de romper o periodonto. Assim, imperioso reduzir a contagem inicial para 28 (vinte e oito) dentes. Ademais, importante aduzir que grande parte da população tem ausência dos $1^{\text {as }}$ molares permanentes, primeiros a serem atingidos pelas cáries, porquanto não possuem antecessores decíduos, vindo à tona em meio a dentição mista, quando os "dentes de leite" ainda estão na arcada, fazendo surgir nas pessoas a crença que também serão substituídos, o que, na verdade, não ocorre. Reduzido, mais uma vez, o quantitativo inicial. Agora restando cerca de 24 dentes. Dados de 2003, do IBGE, em pesquisa realizada por Amostra de Domicílios - PNAD em convênio com o Ministério da Saúde, concernente ao acesso e utilização de serviços de saúde na cidade do Rio de Janeiro, concluíram que para uma população de 15 milhões de pessoas, 1,7 milhão nunca fizeram uma consulta ao dentista. Pergunta-se, em face do cenário traçado e da sabida carência dos serviços públicos de saúde oferecidos a toda a população brasileira, seria razoável exigir-se de um candidato ao emprego de guarda municipal a presença de 20 dentes, sendo 10 em cada arcada?" (DE OLIVEIRA GÓIS, Ewerton Marcus. O concurso público, da razoabilidade e dos vinte dentes. Texto extraído del sitio Jus Navigandi (http://jus2.uol.com.br/doutrina/texto.asp?id=10497), publicado en 09.2007, acceso en 17.02.2010).

548 Respecto a esta situación: "Hipótese interessante foi a da candidata, em Minas Gerais, que se inscreveu no concurso, sendo aprovada na $1^{a}$ fase - prova de conhecimentos - mas excluída nos exames preliminares de saúde, em razão de possuir prótese de silicone nos seios. Essa reprovação não passa pelo crivo do critério da razoabilidade, visto que a prótese implantada operacionalizou-se apenas por motivos estéticos e não para a substituição de órgão perdido total ou parcialmente em razão de "doenças ou deformidades congênitas adquiridas", o que não a torna inapta, no caso, para a atividade policial. $O$ ato que a exclui do processo seletivo é ilegal e discriminatório, uma vez que a candidata não é portadora de qualquer distúrbio que a impeça para o exercício das funções do cargo." (PINHEIRO MADEIRA, José Maria. Op.cit., p. 99).

549 "Concurso Público. Exclusão de candidato portador de tatuagem, decorrente de vedação expressa no edital do concurso. Limites do poder discricionário da administração pública. Contrariedade aos princípios da igualdade, legalidade, impessoalidade, razoabilidade e dignidade da pessoa humana. Preceito administrativo com elevado grau de subjetividade. Segurança concedida. Negado provimento ao recurso voluntário" (Mandado de Segurança $\mathrm{n}^{\circ}$ 2004.001.21523, Rel. Antonio Saldanha Palheiro, 5 
A partir de un análisis de las normas de los concursos públicos brasileños, así como de la jurisprudencia respecto a este tema, se puede constatar que muchas de las exigencias impuestas por la Administración (y cuestionadas por los candidatos) están relacionadas con la altura mínima para el ejercicio de determinados cargos y la necesidad del aspirante demostrar que no padece de determinadas enfermedades.

Respecto a la exigencia de altura mínima, llama la atención la gran cuantidad de procesos judiciales que discuten la posibilidad de la imposición de tal requisito para acceso a determinadas funciones públicas ${ }^{550}$.

De forma pedagógica, la doctrina ha definido el panorama y las condiciones jurídicas respecto a la citada exigencia:

\begin{abstract}
"A exigência de um limite de altura, seja mínimo ou máximo, segue o modelo dos demais requisitos de habilitação: deve ser prevista em lei formal e ser compatível com as funções do cargo ou emprego a ser provido. Tal característica é geralmente exigida nas carreiras policiais e das Forças Armadas. Justifica-se diante da necessidade de porte físico e robustez que se impõe a estes profissionais. A relevância da exigência, no entanto, não exclui a necessidade de previsão legal, nos termos do inc. I do art. 37 da Constituição Federal. Por outro lado, mesmo que prevista em lei, a exigência deve adequar-se às funções que serão exercidas pelo candidato, caso aprovado. Certas funções, apesar de comporem o quadro de carreiras destas instituições, não se amoldam a esta exigência. É o caso, por exemplo, de escrivães e delegados de polícia, membros do corpo médico (médicos, dentistas,
\end{abstract}

Câmara Cível do Tribunal de Justiça do Rio de Janeiro). Comentando tal exigencia, la doctrina ha afirmado que: "Trata-se de ilegalidade, a criação de norma editalícia impedindo que candidatos com tatuagens participem de concursos públicos, a não ser que a Administração Pública demonstre, de forma esmagadora, que tal restrição impediria o dificultaria o concursando em exercer funções próprias do cargo." (PINHEIRO MADEIRA, José Maria. Op.cit., p. 100).

${ }^{550}$ En los tribunales brasileños: "foi considerada inconstitucional e irrazoável lei que fixou estatura mínima para o cargo de Oficial de Saúde da Polícia Militar do Estado de Minas Gerais. Em outra hipótese, o STF, confirmando acórdão do Tribunal de Justiça local, manteve a mesma posição quando foi fixada a altura mínima de 1,60m para preenchimento do cargo de escrivão de polícia do Estado do Mato Grosso do Sul, garantindo a uma candidata que tinha $1,57 \mathrm{~m}$ o direito de participar do certame." (SANTOS CARVALHO FILHO, José dos. Op.cit., p. 556). Sin embargo, respecto al acceso para cargos como agente de policía, el Supremo Tribunal Federal consideró razonable la altura mínima de 1,60m (RE n ${ }^{\circ}$ 148095-5, $2^{\text {a }}$ Turma, Rel. Min. Marco Aurélio, publ. DJ de 3/4/1998) 
enfermeiros, técnicos de enfermagem e outros auxiliares) da Forças Armadas." 551

Como ya se ha destacado, sobre la capacidad funcional, la otra cuestión que suele causar gran debate en los medios jurídicos dice respecto a la prohibición de admisión de los candidatos que padezcan de determinadas enfermedades.

Es razonable que en los procesos selectivos, los candidatos, antes de sus nombramientos, sean sometidos a exámenes de sanidad. Sobre tal procedimiento, la doctrina advierte que:

\begin{abstract}
"Os exames médicos têm como objetivo o diagnóstico de doenças físicas e/ou mentais que impossibilitem o exercício das funções do cargo ou emprego pelo candidato. Têm por finalidade garantir que apenas serão contratados candidatos que tenham higidez física e mental suficientes para o exercício do cargo e impedir a contratação daqueles que, em razão de doenças ou deformidades, não conseguiriam realizar as tarefas que lhes caberiam." ${ }^{552}$
\end{abstract}

Pese a la relevancia de los exámenes médicos, en el derecho brasileño, no hay parámetros claros que diferencien las enfermedades que pueden excluir el candidato del proceso selectivo de las molestias que admiten la admisión del mismo. Una de las pocas referencias respecto a esta situación está contemplada en la Ley Federal 8112/90 (art. 13, párrafo $2^{\circ}$ ), que establece que el plazo para toma de posesión queda suspendido cuando el candidato está enfermo.

$\mathrm{Al}$ admitir que el candidato pueda estar acometida temporariamente de una molestia (y que esta pueda ser prontamente curada), la citada norma admite la existencia de una clara distinción entre enfermedades crónicas y agudas: mientras la enfermedad crónica es una "moléstia de longa duração, evolução lenta e nunca curada de todo, como

${ }^{551}$ LOBELLO DE OLIVEIRA ROCHA, Francisco. Op.cit., p. 82.
${ }^{552}$ LOBELLO DE OLIVEIRA ROCHA, Francisco. Op.cit., p. 87. 
a artrite e a bronquite crônicas", la enfermidad aguda es "a que tem uma rápida evolução, atingido logo sua crise, mas de duração limitada."

Así, se puede afirmar que:

"A eliminação de candidatos nos concursos públicos, portanto, só pode ocorrer em função do diagnóstico de doenças crônicas. Não é qualquer doença crônica, entretanto, que pode levar à eliminação do candidato. É necessário que as consequiências das doenças possam interferir no exercício das funções inerentes ao cargo. $\mathrm{Na}$ determinação de que doenças podem levar à eliminação do candidato, devem ser observados os princípios de igualdade e da razoabilidade. Para evitar sua utilização arbitrária em benefício ou, principalmente, prejuízo de determinados candidatos, em afronta ao princípio da igualdade, os exames médicos deverão ser realizados de acordo com critérios objetivos, sendo permitida a eliminação de candidatos apenas por motivos relevantes." 554

En el contexto destacado en las palabras de la doctrina brasileña, es posible citar la AIDS (SIDA), que es una enfermedad crónica, que podrá o no comprometer el ejercicio de la función pública ${ }^{555}$, lo que dependerá del avance de sus síntomas. Sin embargo, se puede afirmar que en Brasil, la tendencia es la de no permitir la exigencia

553 DINIZ, Maria Helena. Dicionário Jurídico, vol. 2, Ed. Saraiva, São Paulo, 1998, p. 227, en LOBELLO DE OLIVEIRA ROCHA, Francisco. Op.cit., p. 88.

${ }^{554}$ LOBELLO DE OLIVEIRA ROCHA, Francisco. Op.cit., p. 88.

555 Sobre este tema: "Nos últimos anos, em decorrência do aumento de portadores de doenças sexualmente transmissíveis, como a AIDS, por exemplo, passou-se a exigir, em alguns casos, o exame de HIV dos candidatos. A doutrina tem-se posicionado, no geral, contra tal exigência, pois ela acaba gerando a publicidade quanto à doença, e, além de lesar a vida privada da pessoa, acarreta-lhe uma série de preconceitos no espaço do trabalho. Algumas decisões judiciais, entretanto, tem sido favoráveis a entidades que estabeleceram a obrigatoriedade do exame ao fundamento de que, conhecida a moléstia do servidor, poderá a entidade pública adotar os procedimentos necessários a seu tratamento. (...) A Lei $n^{\circ}$ 4.041, de 30.11.94, do Município de Vitória, no art. $1^{\circ}$, parágrafo único, encerra que "O teste HIV não poderá ser exigido para inscrição em concurso público, admissão ou permanência no emprego." E a Lei Municipal $n^{\circ}$ 7.400, de 4.1.94, de Porto Alegre, no art. $2^{\circ}$ dispõe que: "Consideram-se para efeitos desta Lei, como ato discriminatório aos portadores do vírus HIV/AIDS: I- a exigência do teste HIV: a) para participar de processo de seleção visando a admissão em emprego; (...) c) como condição para inscrição em concurso público."' (PINHEIRO MADEIRA, José Maria. Op.cit., pp. 102-103). 
del test de HIV para admisión en la función pública, por este ser considerado discriminatorio $^{556}$, contrariando, así, la igualdad entre los ciudadanos.

\subsubsection{1 - Las personas con discapacidad: nuevos paradigmas}

En el contexto de la capacidad funcional, el análisis de las condiciones jurídicas para la inserción de las personas con discapacidad es el tema de relevancia más destacada, ya que esta la referida medida de acción positiva es esencial para garantizar el derecho de acceso a la función pública en condiciones de igualdad a un amplio sector de la sociedad civil.

Antes de todo, se puede afirmar que un relevante medio de verificar el nivel de desarrollo social, jurídico y cultural de una determinada sociedad se halla a través del análisis del trato concedido a aquellos que suelen estar alejados de las oportunidades que la vida ofrece. Además, la protección y la inserción de las minorías es una exigencia del Estado Social y Democrático de Derecho que no puede ser olvidada por los ordenamientos jurídicos.

En este contexto, las personas con discapacidad representan un importante segmento de la sociedad, no sólo por los números absolutos que suelen abarcar hasta el $20 \%{ }^{557}$ de la población ${ }^{558}$, sino también porque pueden contribuir efectivamente con sus esfuerzos para el progreso de la sociedad ${ }^{559}$.

\footnotetext{
${ }^{556}$ En el ámbito federal, el tema ha sido objeto de la Portaria Interministerial 869, de 11 de agosto de 1992, com el siguiente contenido:"Os Ministros de Estado da Saúde e do Trabalho e da Administração, no uso das atribuições que Ihes confere o art. 87, parágrafo único, inciso IV, da Constituição Federal, e, considerando que os artigos 13 e 14 da Lei $n^{\circ} 8.1$ 12/90 exigem tão somente a apresentação de um atestado de aptidão física e mental, para posse em cargo público; considerando que a sorologia positiva para o vírus da imunodeficiência adquirida (HIV) em si não acarreta prejuízo da capacidade laborativa de seu portador; considerando que os convívios social e profissional com portadores do vírus não configuram situações de risco; considerando que as medidas para o controle da infecção são a correta informação e os procedimentos preventivos pertinentes; considerando que a solidariedade e o combate à discriminação são a fórmula de que a sociedade dispõe para minimizar o sofrimento dos portadores do HIV e das pessoas com AIDS; considerando que o manejo dos casos de AIDS deve ser conduzido segundo os preceitos da ética e do sigilo; considerando que as pesquisas relativas ao HIV vêm apresentando surpreendentes resultados, em curto espaço de tempo, no sentido de melhorar a qualidade de vida dos indivíduos infectados e doentes, resolvem:Proibir, no âmbito do Serviço Público Federal, a exigência de teste para detecção do vírus de imunodeficiência adquirida, tanto nos exames préadmissionais quanto nos exames periódicos de saúde”.

557 Según António Jímenez Lara, estos son algunos datos sobre el número de discapacitados en algunos países: $18 \%$ en el Reino Unido (2003), 17\% en Australia (2003), 19,3\% en los Estados Unidos (2000), 12,1\% en Canadá (2001), 20\% en Nueva Zelanda (2001), 7,1\% en Argentina (2001), 7,6\% en Uruguay (2004), 12,9\% en Chile (2004), 2,6\% en Honduras; la media de los 15 países de la Unión Europea en 2001 era 19,3\%. (JÍMENEZ LARA, Antonio. La población con discapacidad: estudios demográficos, en
} 
Sin embargo, aunque la mentalidad de las personas haya cambiado en las últimas décadas, habiendo sido establecido un consenso en torno a la conveniencia de protección e integración social de los discapacitados, todavía hay poca consciencia por parte de la sociedad sobre las potencialidades que pueden ser desarrolladas por tales personas. 560

Parece evidente que la integración de las personas con discapacidad depende de la disminución del nivel de dependencia que estas puedan presentar. Y también está claro que esta reducción de la dependencia solamente ocurrirá a través de la implantación de políticas de accesibilidad de las personas con discapacidad en el mercado laboral, sea en el sector privado, sea en las Administraciones Públicas.

Para la realización de los objetivos arriba mencionados, el Derecho pose un papel muy relevante, pues es un instrumento social que además de servir como un importante proceso de transformación social, dispone de la fuerza obligatoria de sus normas para garantizar su efectividad.

Tratado sobre discapacidad, Rafael de Lorenzo y Luís Cayo Pérez Bueno (Directores), Thomson Aranzadi, Pamplona, 2007, p. 223).

${ }^{558}$ En la Exposición de Motivos de la Ley 51/2003, del 2 de diciembre, de igualdad de oportunidades, no discriminación y accesibilidad universal de las personas con discapacidad, se afirma que en 1999, según el Instituto Nacional de Estadística, vivían en España 3,5 millones de personas con alguna discapacidad, lo que correspondía al $8,9 \%$ de la población española. También se ha afirmado que: "Segundo a ONU Organização das Nações Unidas, no ano de 2000, havia 500 milhões de deficientes no mundo, dos quais $80 \%$ (oitenta por cento) estão nos países em desenvolvimento. A OMS - Organização Mundial de Saúde estimou, na mesma época, que no Brasil existiam 16 milhões de deficientes, ou seja, 10\% (dez por cento) da população brasileira era portadora de algum tipo de deficiência." (TOURINHO, Rita. Op.cit., p. 130).

559 La imagen de la persona con discapacidad ha cambiado bastante en las últimas décadas, aunque todavía sufre un considerable perjuicio. Era considerada persona "cuyas deficiencias le hacen inepto para la sociedad en razón da su situación de dependencia total. Las consecuencias que derivan de tal concepción no son otras sino la marginalidad, potenciada porque muchas veces se asociaban las ideas de "enfermo" y "culpable"" (HERNÁNDEZ VITORIA, María José. Una lectura de la Ley 51/03 desde las aportaciones del ordenamiento comunitario en materia de derechos fundamentales y del principio de no discriminación, en La protección jurídica civil, penal, administrativa y social de la persona con discapacidad, Cuadernos de Derecho Judicial, Consejo General del Poder Judicial, Madrid, 2007, p. 17.)

${ }^{560}$ Ignacio Serrano García destaca: “¿Quiénes son las personas con discapacidad? Habría que comenzar afirmando que todos los seres humanos, somos capaces e incapaces a la vez y todos en consecuencia estamos capacitados y discapacitados. El ser humano, como ser social que es, necesita de los demás permanentemente. No hay nadie que esté capacitado para todas las actividades en las que ordinariamente se desenvuelve. $Y$ desde la otra perceptiva el discapacitado más afectado conserva capacidades que deben ser apreciadas y estimuladas por su más próximos, primero, y por la sociedad, después. El problema del enfoque de la discapacidad es que se fija en aspectos negativos, en lugar de tener en cuenta lo que de positivo tiene cada individuo. Hay que mirar sobre todo las capacidades de los individuos más que sus discapacidades." (SERRANO GARCÍA, Ignacio. Protección patrimonial de las personas con discapacidad, tratamiento sistemático de la Ley 41/2003, Iustel, Madrid, 2008, p.35). 
Pese a la complejidad de las tareas de definición y de realización de las políticas públicas de protección e integración de las personas con discapacidad, esta no permite que la simple creación de normas jurídicas pueda satisfacer plenamente la exigencia de igualdad entre personas con y sin alguna discapacidad.

Aunque se pueda afirmar que más relevante que la definición de un marco jurídico protector de las personas con discapacidad es el cambio de valores que debe reflejarse en la sociedad, no se puede olvidar que las normas jurídicas podrán contribuir para esta transformación.

En el mundo jurídico, la comunidad internacional viene dedicándose hace muchos años al tema de la integración de los discapacitados, a través de su accesibilidad al mercado laboral. En el contexto europeo, merece ser destacada la Directiva 2000/78 CE del Consejo del 27 de noviembre de 2000, que estableció un marco de igualdad de trato en la ocupación y en el empleo, lo que influenció en la creación, en el Derecho español, de la Ley 51/2003 y de la Ley $62 / 2003^{561}$

Sin embargo, en el Derecho español, mucho antes de la elaboración de las leyes arriba mencionadas, la Constitución de 1978 ya determinaba la protección de las personas con discapacidad. ${ }^{562}$

Es relevante destacar que la Constitución española de 1978, junto con la portuguesa de 1976, fueron pioneras, "al incluir de forma expresa un artículo - el 49 referido exclusivamente a las personas con discapacidad." $" 563$

\footnotetext{
561. Para la doctrina, "esa Directiva representa un avance muy importante en la lucha por la igualdad de oportunidades de las personas con discapacidad, ya que obliga a los Estados Miembros a establecer dentro de sus legislaciones internas un marco adecuado de respuestas a la discriminación que pueda sufrir este colectivo, y no sólo de protección frente al trato discriminatorio directo, sino de acción positiva frente a las discriminaciones indirectas." (CABRA DE LUNA, Miguel Ángel y GAZTELU SAN PÍO, Clara. Derecho Internacional y Comunitario. La protección jurídica de las personas con discapacidad en la normativa comunitaria y en los instrumentos internacionales, en Régimen Jurídico de las personas con discapacidad en España y en la Unión Europea, Esperanza Alcaín Martínez, Juan González-Badía Fraga y Carmen Molina Fernández (Coordinadores), Editorial Comares, Granada, 2006, p. 41).

562 “Art. 49. Los poderes públicos realizarán una política de previsión, tratamiento, rehabilitación e integración de los disminuidos físicos, sensoriales y psíquicos, a los que prestarán la atención especializada que requieran y los ampararán especialmente para el disfrute de los derechos que este Título otorga a todos los ciudadanos."

${ }^{563}$ LORENZO DE GARCÍA, Rafael. Las personas con discapacidad en la Constitución Española y el constitucionalismo comparado, en Tratado sobre discapacidad, Rafael de Lorenzo y Luís Cayo Pérez Bueno (Directores), Thomson Aranzadi, Pamplona, 2007, p. 512.
} 
En realidad, conviene subrayar que lo que el art. $49 \mathrm{CE}$ propone es la realización del mandamiento del art. $9.2^{564}$, de la propia Constitución española, que impone a los Poderes Públicos la remoción de los obstáculos a la efectividad de la igualdad entre las personas.

Evidentemente, del propio art. $14 \mathrm{CE}$, que establece el principio de igualdad entre todos los españoles ante la ley y el principio de no discriminación, ya sería posible extraer diversos efectos para la protección de las personas con discapacidad. En este sentido, el Tribunal Constitucional ha reconocido que "no siendo cerrado el elenco de factores diferenciales enunciado en el art. $14 \mathrm{CE}$, es claro que la minusvalía física puede constituir una causa real de discriminación." ${ }^{, 565}$

El principio de igualdad exige que a las personas, por más factores de desigualdad que posean en la realidad, les sean concedidas las mismas oportunidades para el desarrollo de sus potencialidades, y para que esto ocurra, los obstáculos que impiden el igual acceso a los bienes y derechos deben ser eliminados.

En este sentido, el Derecho debe establecer compensaciones que vengan a reequilibrar las situaciones que, en el plano de los hechos, son de desigualdades, sean estas provenidas de causas naturales, sociales o económicas. En este contexto, tanto el legislador como la Administración Pública deberán plantear y hacer efectivo, respectivamente, el ambiente necesario para que todas las personas, con o sin discapacidad, puedan disfrutar de derechos y de su condición de dignidad. ${ }^{566}$

En el nivel legislativo, como ya he destacado, es relevante la Ley 51/2003, del 2 de diciembre, de igualdad de oportunidades, no discriminación y accesibilidad

\footnotetext{
564 "Corresponde a los poderes públicos promover las condiciones para que la libertad y la igualdad del individuo y de los grupos en que se integra sean reales y efectivas; remover los obstáculos que impidan o dificulten su plenitud y facilitar la participación de todos los ciudadanos en la vida política, económica, cultural y social." ${ }_{565}^{5 T C} \mathrm{n}^{\circ} 269 / 1994$.

${ }^{566}$ Así, "la persona con discapacidad se incorpora, pues, a la vida social y política como un ciudadano titular de los derechos y deberes que la Constitución reconoce a todos, y, además, forma parte de un colectivo sometido a tratamiento especial y acreedor de un trato diferente del resto de sus conciudadanos." (JARA ANDRÉU, António. Derecho Constitucional, Estado Social, Orden Jurídico e Integración Social, en Régimen Jurídico Administrativo de las Personas con Discapacidad, en Régimen Jurídico de las Personas con Discapacidad en España y en la Unión Europea, Esperanza Alcaín Martínez y otros (Coordinadores), autores varios, Editorial Comares, p. 12).
} 
universal de las personas con discapacidad. ${ }^{567}$ Es relevante subrayar que en la Ley 51/03, el legislador español estableció el concepto de "personas con discapacidad", lo que cita en el art.1 $1^{\circ} .2 .^{568}$

A su vez, el Real Decreto1971/1999 es el instrumento normativo utilizado para la definición de las personas con discapacidad. Para la doctrina, el referido Real Decreto:

"es básico porque es el que establece cómo se determinan los
porcentajes de minusvalía que padecen algunas personas y dicho
porcentaje está permanentemente utilizado por normas de muy diverso
carácter, entre las que son de destacar las laborales y las tributarias, y
más recientemente las administrativas, para acceso a la función
pública." 569

Cabe añadir que el Real Decreto 1971/1999 establece quiénes son las personas con discapacidad. ${ }^{570}$ En relación a los baremos mencionados en el Real Decreto, estos fueron elaborados teniendo en consideración la dificultad para la realización de las actividades de la vida diaria y contemplan cinco grados de discapacidad: grado 1 discapacidad nula; grado 2 discapacidad leve; grado 3

\footnotetext{
${ }^{567}$ En esta ley, se reconoce que: "Las personas con discapacidad constituyen un sector de la población heterogéneo, pero todas tienen en común que, en mayor o menor medida, precisan de garantías suplementarias para vivir con plenitud de derechos o para participar en igualdad de condiciones que el resto de ciudadanos en la vida económica, social y cultural del país." Extraído de la Exposición de Motivos de la Ley 51/2003, de 2 de diciembre, de igualdad de oportunidades, no discriminación y accesibilidad universal de las personas con discapacidad.

568 "2. A los efectos de esta ley, tendrán la consideración de personas con discapacidad aquellas a quienes se les haya reconocido un grado de minusvalía igual o superior al 33 por ciento. En todo caso, se considerarán afectados por una minusvalía en grado igual o superior al 33 por ciento los pensionistas de la Seguridad Social que tengan reconocida una pensión de incapacidad permanente en el grado de total, absoluta o gran invalidez, y a los pensionistas de clases pasivas que tengan reconocida una pensión de jubilación o de retiro por incapacidad permanente para el servicio o inutilidad.

La acreditación del grado de minusvalía se realizará en los términos establecidos reglamentariamente y tendrá validez en todo el territorio nacional."

${ }^{569}$ SERRANO GARCÍA, Ignacio. Op.cit., p. 35.

570 "Artículo 4.1. La calificación del grado de minusvalía responde a criterios técnicos unificados, fijados mediante los baremos descritos en el anexo I del presente Real Decreto, y serán objeto de valoración tanto las discapacidades que presente la persona, como, en su caso, los factores sociales complementarios relativos, entre otros, a su entorno familiar y situación laboral, educativa y cultural, que dificulten su integración social. El grado de minusvalía se expresará en porcentaje."
} 
discapacidad moderada: grado 4 discapacidad grave; y grado 5 discapacidad muy grave. $^{571}$

Es relevante destacar que para valoración del porcentaje de la discapacidad, también serán considerados factores sociales, como el entorno familiar, la situación laboral y profesional, los niveles educativos y culturales, así como otras situaciones del entorno habitual de la persona con discapacidad (conforme art. 5.2 del Real Decreto 1971/1999).

En el derecho brasileño, se puede destacar inicialmente que la Constitución dedicó distintas normas al tema de las personas con discapacidad ${ }^{572}$, lo que ha impulsado la creación de algunas leyes que buscan la protección y la interacción de tales personas en la sociedad, en sus más distintos espacios.

Entre las citadas leyes, se puede destacar la Ley 7853/89, que “dispõe sobre o apoio às pessoas portadoras de deficiência, sua integração social (...)”; la Ley 8.213/91, que trata de los "Planos de Benefícios da Previdência Social"; la Ley 10.098/2000, que “estabelece normas gerais e critério básicos para a promoção da acessibilidade das pessoas portadoras de deficiência ou com mobilidade reduzida (...)”; además del Decreto 3.298/99, que “regulamenta a Lei $n^{\circ}$ 7.853, de 24 de outubro

\footnotetext{
${ }^{571}$ En la discapacidad nula, "los síntomas, signos o secuelas, de existir, son mínimos y no justifican una disminución de la capacidad de la persona para realizar las actividades de la vida diaria”. En la discapacidad leve "los síntomas, signos o secuelas existen y justifican alguna dificultad para llevar a cabo las actividades de la vida diaria, pero son compatibles con la práctica totalidad de las mismas": en la discapacidad moderada "los síntomas, signos o secuelas causan una disminución importante o imposibilidad de la capacidad de la personas para realizar algunas de las actividades de la vida diaria, siendo independientes en las actividades de autocuidado"; en la discapacidad grave "los síntomas, signos o secuelas causan una disminución importante o imposibilidad de la capacidad de la personas para realizar la mayoría de las actividades de la vida diaria, pudiendo estar afectada alguna de las actividades de autocuidado"; y en la discapacidad muy grave "los síntomas, signos o secuelas imposibilitan la realización de las actividades de la vida diaria." (SERRANO GARCÍA, Ignacio. Op.cit., nota a pie de página $\mathrm{n}^{\mathrm{0}} 7$, p. 37).

572 “Art. 37.(...) VIII - a lei reservará percentual dos cargos e empregos públicos para as pessoas portadoras de deficiência e definirá os critérios de sua admissão”;

"Art. 203. A assistência social será prestada a quem dela necessitar, independentemente de contribuição à seguridade social, e tem por objetivos: (...) IV - a habilitação e reabilitação das pessoas portadoras de deficiência e a promoção de sua integração à vida comunitária; $V$ - a garantia de um salário mínimo de benefício mensal à pessoa portadora de deficiência e ao idoso que comprovem não possuir meios de prover à própria manutenção ou de tê-la provida por sua família, conforme dispuser a lei”.

"Art. 244. A lei disporá sobre a adaptação dos logradouros, dos edifícios de uso público e dos veículos de transporte coletivo atualmente existentes a fim de garantir acesso adequado às pessoas portadoras de deficiência, conforme o disposto no art. 227, $\S 2^{\text {o"”. }}$
} 
de 1989, dispõe sobre a Política Nacional para a Integração da Pessoa Portadora de Deficiência, consolida as normas de proteção(...)"573.

Pese a la relevancia de las citadas normas, es indiscutible que el gran avance en el tema que debe ocurrir dice respecto al cambio de consciencia de la sociedad sobre las personas con discapacidad, ya que en este aspecto, aún hay mucho que progresar; pues es innegable la distancia que separa la realidad de las buenas intenciones previstas en el derecho. ${ }^{574}$

Sobre el panorama jurídico y social del trato concedido a las personas con discapacidad en Brasil, se ha dicho que:

\footnotetext{
${ }^{573}$ Sobre este cuadro normativo de protección e inserción de las personas con discapacidad:"Para reduzir as desigualdades reinantes nesta seara, foi criada a Lei $n^{\circ}{ }^{\circ} 7.853$, de 24 de outubro de 1989, com o objetivo de dispor acerca da integração do portador de deficiência na sociedade. Estabeleceu normas gerais a respeito do direito à educação, à saúde, formação profissional, trabalho, área de recursos humanos e área de edificações. Para a regulamentação dessa lei, o Executivo baixou o Decreto $n^{\circ}{ }^{\circ} 3.298$, de 20 de dezembro de 1999, consolidando as normas de proteção e dando outras providências, além do que, dispôs sobre a Política Nacional para integração daqueles cidadãos na sociedade. Este Decreto traz diretrizes, princípios, objetivos e instrumentos para a realização plena do portador de deficiência na comunidade.." (SETTE DE BARROS, Maria Magdala. Portadores de deficiência e o concurso público, texto extraído del sitio Jus Navigandi (http://jus2.uol.com.br/doutrina/texto.asp?id=2639), elaborado em 11.2001, acceso en 16.02.2010).
}

${ }^{574}$ Sobre las dos constataciones: "É crescente nos últimos anos o movimento em defesa dos direitos das pessoas portadoras de deficiência. Constantemente são lançadas campanhas de conscientização pelo Poder Público, pelo Ministério Público e pelo terceiro setor visando à integração social daquelas pessoas. Durante muitos anos as pessoas portadoras de deficiência foram tratadas à margem da sociedade, algumas vezes segregadas em hospitais, clínicas e outras instituições. Eram injustamente discriminadas, chegando ao ponto de serem taxadas de pessoas diferentes, "anormais". No passado predominava o entendimento de que as pessoas portadoras de deficiência, por serem "anormais", deveriam se adaptar à sociedade. O portador de deficiência é que, a despeito de suas limitações, deveria se ajustar à sociedade em que vivia, a qual em nada deveria ser alterada. Aqueles deveriam ir além de seus limites para poder desfrutar um convivio social mais amplo e justo. Pensava-se que a sociedade, nessa época, não necessitava de nenhuma modificação. Contudo, graças à iniciativa de alguns cidadãos visando à conscientização da sociedade, essa discriminação foi amenizada (amenizada, apenas, por ainda ser facilmente presenciada). Porém, apesar da discriminação não ter sido eliminada por completo, a sociedade despertou para as necessidades daquelas pessoas que de alguma forma possuem limitações, sejam elas físicas, biológicas ou mentais, buscando cada vez mais a inclusão social delas. Na atualidade, em virtude da evolução cultural e social, predomina o pensamento de que a sociedade e as pessoas portadoras de deficiência devem buscar juntas a integração social destas. Foi abandonado aquele pensamento retrógrado e individualista de que apenas os portadores de deficiência deveriam lutar por sua inclusão. Conforme o preâmbulo da nossa Constituição Federal, a igualdade é um dos valores supremos da sociedade brasileira que, apesar de bastante ignorado em tempos pretéritos, possui significativo respeito na atualidade." (MESQUITA DANTAS, Adriano. Os portadores de deficiência e o concurso para provimento de cargos e empregos públicos. A ineficácia dos dispositivos constitucionais e infraconstitucionais, texto extraído del sitio Jus Navigandi (http://jus2.uol.com.br/doutrina/texto.asp?id=7150), publicado en 12.08.2005, acceso en 16.02.2010). 
"Analisando-se o ordenamento jurídico que se destina a regular os direitos dos portadores de deficiência, duas impressões apresentam-se. A primeira delas é que as normas se encontram em número reduzido na Constituição e, não obstante serem escassas, elas não estão ordenadas por capítulo, constituindo-se em normas esparsas dentro do texto constitucional, o que dificulta sobremaneira seu estudo. A segunda impressão é que, após 13 anos de vigência da Constituição, não há, ainda, por parte da sociedade e, principalmente, do Poder Público consciência da necessidade de tratar-se a matéria de modo justo e responsável. Continuam os portadores de deficiência a encontrar dificuldade em integrar-se na comunidade, seja através do setor privado, seja do setor público" ${ }^{575}$

No hay lugar a dudas que en los países en vía de desarrollo, el papel reservado al Estado en la promoción de la igualdad entre la personas, especialmente de aquellas que encuentran mayores dificultades de inserción social, es aún más decisivo, especialmente delante de una sociedad civil descoordinada, lo que impone la planificación de políticas públicas en las más distintas áreas (salud, educación, transportes, empleo, urbanismo, etc.). Sin embargo, tampoco se puede negar que la sociedad civil puede y debe contribuir de forma fundamental en este proceso ${ }^{576}$.

\subsubsection{2 - El acceso de las personas con discapacidad a la función pública}

Una de las posibilidades más destacadas para garantizar la accesibilidad de las personas con discapacidad depende de la iniciativa de la propia Administración Pública cuando tiene que seleccionar a los empleados públicos. Si el Estado exigiera

\footnotetext{
${ }^{575}$ SETTE DE BARROS, Maria Magdala. Portadores de deficiência e o concurso público, texto extraído del sitio Jus Navigandi (http://jus2.uol.com.br/doutrina/texto.asp?id=2639), Elaborado em 11.2001, acceso en 16.02.2010.

${ }^{576}$ Sobre esta afirmación: "Em razão de circunstâncias que na maioria das vezes não lhes podem ser imputadas, os portadores de deficiência possuem dificuldade adicionais em todos os aspectos de sua vida individual e social. A prática de atos comuns, necessários à sua ação no cenário social custa-lhes mais esforço, nem sempre com certeza de êxito. Desta maneira, o pleno exercício dos direitos fundamentais constitucionalmente assegurados depende de ações da sociedade civil e do Estado, cabendo a iniciativa e coordenação destas ações a este último" (MOTTA, Fabrício. A reserva de vagas nos concursos públicos para os portadores de deficiência - análise do art. 37, inc. VIII da Constituição Federal, en Concurso público e Constituição, Fabrício Motta (Cordinador), Editora Fórum, Belo Horizonte, 2005, p. 185).
} 
que las empresas privadas reservaran plazas a las personas con discapacidad, sino que también procediera de esta forma, habría, al menos, una contradicción. ${ }^{577}$

La doctrina española ha subrayado que en contratos del sector público, "no sólo se busca la selección de los mejores adjudicatarios con el fin último de garantizar la eficacia en la prestación de los servicios públicos a favor de los usuarios, sino que también, sin abandonar esta pauta, se pueden conseguir objetivos sociales capaces de ayudar al incremento del beneficio de la colectividad"578. La misma idea debe prevalecer en el acceso a la función pública.

Así, en el derecho español, la Ley 53/2003, del 10 de diciembre, sobre el acceso al empleo público de las personas con discapacidad ${ }^{579}$, modifica la redacción de la Ley 30/1984 (ley de medidas para la reforma de la función pública), para garantizar el efectivo acceso de las referidas personas a la función pública. ${ }^{50}$

\footnotetext{
577 Sobre este tema, la doctrina destaca que "lo cierto es que, a pesar del mandato legal explícito contenido en la Ley de Medidas para Reforma de la Función Pública, la realidad es testigo de su incumplimiento". (TORRES LÓPEZ, María Asunción. Derecho Administrativo, Régimen Jurídico Administrativo de las Personas con Discapacidad, en Régimen Jurídico de las Personas con Discapacidad en España y en la Unión Europea, Esperanza Alcaín Martínez y otros (Coordinadores), autores varios, Editorial Comares, p. 218).

${ }^{578}$ RODRÍGUEZ ESCANCIANO, Suzana. El fomento de empleo de los colectivos más desfavorecidos en la legislación de contratos del sector público. Especial referencia a las personas con discapacidad, Revista Electrónica de la Facultad de Derecho de la Universidad de Granada, disponible en el sitio electrónico www.refdugr.com, fecha de publicación: 30 de octubre de 2008.

579 En la Exposición de Motivos de la referida ley se reconocía que: "El acceso de las personas con discapacidad al empleo público en las distintas Administraciones públicas sigue ofreciendo un panorama desalentador. Aunque existe un mandato legal explícito y muy claro en la Ley de la Función Pública la realidad es el lamentable incumplimiento del mismo. Según datos facilitados por el Gobierno, como respuesta a una pregunta realizada por el Grupo Parlamentario Socialista, en los años 2000 y 2001 se estima que el número de personas con discapacidad que llegaron a aprobar en las distintas convocatorias para funcionarios de la Administración General del Estado oscilaban en torno al 0,2\%. El Estado convocó un total de 94 plazas para personas con discapacidad en esos ejercicios, pero únicamente se cubrieron 10 plazas por personas con un $33 \%$ o más de minusvalía. Desde el Ejecutivo se indica que el número de aspirantes discapacitados es muy reducido, a pesar de que en el año 2000 se presentaron 129 personas con un 33 \% o más de minusvalía para 44 plazas ofertadas. En suma, las personas con discapacidad se ven sometidas a importantes barreras para acceder al empleo público, obstáculos que no son justificables pues la actividad de los servicios públicos es perfectamente compatible con la capacidad y formación de las personas con discapacidad."

${ }^{580}$ La nueva normativa modificó la disposición adicional decimonovena de la Ley 30/1984:"En las ofertas de empleo público se reservará un cupo no inferior al $5 \%$ de las vacantes para ser cubiertas entre personas con discapacidad cuyo grado de minusvalía sea igual o superior al $33 \%$, de modo que, progresivamente se alcance el dos por ciento de los efectivos totales de la Administración del Estado, siempre que superen las pruebas selectivas y que, en su momento, acrediten el indicado grado de minusvalía y la compatibilidad con el desempeño de las tareas y funciones correspondientes, según se determine reglamentariamente." A su vez, la redacción anterior era: "En las ofertas de empleo público se reservará un cupo no inferior al $3 \%$ de las vacantes para ser cubierta entre personas con discapacidad de grado igual o superior al $33 \%$, de modo que progresivamente se alcance el $2 \%$ de los efectivos
} 
Con la norma arriba mencionada, la legislación garantiza la reserva de plazas a las personas con discapacidad, con un cupo que corresponde a un porcentaje no inferior al 5\% ${ }^{581}$. Así, cuando el Estatuto Básico del Empleado Público (Ley 7/2007, del 12 de abril) fue elaborado, fue tratada una vez más la cuestión referente al acceso de las personas con discapacidad al empleo público.

Aunque los términos relativos al cupo de reserva de plazas, y otras condiciones hayan sido preservados, se puede afirmar que el trato novedoso se produjo en el apartado 2 del art. 59 de la mencionada ley ${ }^{582}$.

También se debe añadir que el Estatuto Básico del Empleado Público, al establecer los requisitos generales para acceder a la función pública, prevé la necesidad de que el aspirante posea "la capacidad funcional para el desempeño de las tareas.", según el art. 56.1, d. A su vez, en el art. 65.1, el Estatuto prevé la posibilidad de exigirse reconocimientos médicos.

En los términos arriba mencionados, se puede afirmar que:

a) para el efecto de especial protección del Derecho español, las personas con discapacidad son aquellas referidas en el art. 1.2 de la Ley 51/03;

b) para el acceso al empleo público, a tales personas se reservará un cupo no inferior al 5\% de las vacantes, conforme las Leyes 53/03 y 7/07;

c) "dichas personas deben, no obstante, superar los procesos selectivos y acreditar su discapacidad y la compatibilidad con el desempeño de las tareas y

totales de la Administración del Estado, siempre que superen las pruebas selectivas y que, en su momento, acrediten el indicado grado de discapacidad y la compatibilidad con el desempeño de las tareas y funciones correspondientes, según se determine reglamentariamente".

${ }^{581}$ Respecto al citado tema, véase RODRÍGUEZ ESCANCIANO, Suzana. La promoción del los cupos de reserva a favor de las personas con discapacidad en el nuevo contexto normativo sobre empleo público. Aranzadi Social, vol. 3, no 4 (jun), 2010, p. 81-113.

582 “Artículo 59. Personas con discapacidad. 1. En las ofertas de empleo público se reservará un cupo no inferior al cinco por ciento de las vacantes para ser cubiertas entre personas con discapacidad, considerando como tales las definidas en el apartado 2 del artículo 1 de la Ley 51/2003, de 2 de diciembre, de igualdad de oportunidades, no discriminación y accesibilidad universal de las personas con discapacidad, siempre que superen los procesos selectivos y acrediten su discapacidad y la compatibilidad con el desempeño de las tareas, de modo que progresivamente se alcance el dos por ciento de los efectivos totales en cada Administración Pública.

2. Cada Administración Pública adoptará las medidas precisas para establecer las adaptaciones y ajustes razonables de tiempos y medios en el proceso selectivo y, una vez superado dicho proceso, las adaptaciones en el puesto de trabajo a las necesidades de las personas con discapacidad." 
funciones correspondientes" ${ }^{\text {583 }}$, también de acuerdo con las dos leyes mencionadas anteriormente;

d) los procesos selectivos deben ser adaptados y ajustados a las personas con discapacidad, en especial, en lo que se refiere al tiempo y a los medios para la realización de las pruebas, conforme el art. 59.2 del Estatuto Básico del Empleado Público.

Por supuesto que la cuestión de la compatibilidad para el desempeño de las funciones a desarrollar es una exigencia imprescindible, ya que el acceso a la función pública, según el art. 103.3 CE, ocurre "de acuerdo con los principios de merito y capacidad". Así, aunque la búsqueda de una mayor integración y accesibilidad de las personas con discapacidad sea un relevante objetivo del Derecho, no sería razonable admitir la participación en procesos selectivos de personas que no conseguirán ejercer las actividades comunes del puesto de trabajo a ser ocupado.

En estos términos, ciertamente, una persona con ausencia de visión no podría participar de un proceso selectivo para cubrir una plaza de guardia de tráfico, ya que no es apta para ejercer las actividades de la mencionada función (control del tráfico, fiscalización del cumplimiento de las reglas por los conductores de los vehículos, etc.), debido a que estas tareas exigen el uso del sentido que la referida persona no pose.

Evidentemente, la Administración Pública deberá analizar la mencionada compatibilidad a través de criterios técnico-científicos, desempeñando la Medicina un papel relevante. Y también parece claro que la demostración de compatibilidad para el desempeño de las tareas habitualmente desarrolladas por los funcionarios del Cuerpo o Escala comprende no sólo a las personas con discapacidad superior al 33 por ciento, sino también a todos los aspirantes, lo que incluye aquellos que posean alguna discapacidad inferior al mencionado porcentaje. ${ }^{584}$

Además, vale destacar que como la ley exige que las Administraciones Públicas adopten como medidas las “...adaptaciones en el puesto de trabajo a las

${ }^{583}$ CAVAS MARTÍNEZ, Faustino. Op.cit., p. 606.

${ }^{584}$ Juan B. Lorenzo de Membiela cita el Dictamen de la Comisión Superior de Personal, en atención a Consulta de 2 de marzo de 1995: "Es decir, que el aspirante, con independencia del grado de minusvalía y con independencia también de si accede por el cupo de reserva o por el turno libre, debe estar capacitado para el desempeño de dichas funciones..." (LORENZO DE MEMBIELA, Juan B., Op.cit., p. 156). 
necesidades de las personas con discapacidad" (art. 59.2, Ley 7/07), la ausencia de tales medidas, si son posibles, no pueden servir como escusa para impedir el acceso de las personas con discapacidad. En este sentido, no podría la Administración Pública dejar de permitir la participación de personas minusválidas que usan sillas de ruedas en una determinada oposición, justificando que los aprobados van a trabajar en la cuarta planta de un edificio que no dispone de ascensores.

Los aspectos fundamentales de la participación de las personas con discapacidad en los procesos selectivos están regulados en el Real Decreto 2271/2004, del 03 de diciembre, que trata del acceso al empleo público y la provisión de puestos de trabajo de las referidas personas. A partir del análisis de la citada norma, se percibe que debido a la reserva de plazas para las personas con discapacidad, estas, en los procesos selectivos para el acceso al empleo público, poseen el derecho de participar en una disputa específica por determinadas plazas, sin que tengan que competir con personas sin discapacidad. No obstante, también pueden optar por concurrir por las plazas generales, lo que hará que compitan con todos los demás aspirantes. El procedimiento arriba destacado deriva del art. 2 del mencionado Real Decreto. ${ }^{585}$

Y más: según el art. 3.2 del Real Decreto 2271/04, si el aspirante que optó por disputar las plazas reservadas a las personas con discapacidad superara los ejercicios correspondientes, pero no obtuviera plaza y su puntuación fuera superior a la obtenida por otros aspirantes del sistema de acceso general, él será incluido por su orden de puntuación en el mencionado sistema de acceso general.

Para garantizar el acceso de las personas con discapacidad al empleo público, el mismo Real Decreto establece una importante regla: si las plazas cubiertas por las personas con discapacidad no alcanzan la tasa del $3 \%$ de las plazas que se han convocado, se acumularán al cupo del 5\% de la oferta siguiente, con un límite máximo del $10 \%$.

\footnotetext{
585 "La opción a estas plazas habrá de formularse en la solicitud de participación en las convocatorias, con declaración expresa de los interesados en la que hagan constar que reúnen el grado de minusvalía requerido, acreditado mediante certificado expedido al efecto por los órganos competentes del Ministerio de Trabajo y Asuntos Sociales, o en su caso de la Comunidad Autónoma competente. Las plazas reservadas para personas con discapacidad, podrán incluirse dentro de las convocatorias de plazas de ingreso ordinario o convocarse en turno independiente. “
} 
Sobre la adaptación de tiempos, según el Real Decreto, esta consiste en la concesión de un tiempo adicional para la realización de los ejercicios (art. 8.3). Cabe añadir que el Real Decreto establece la necesidad de una resolución posterior que defina exactamente el tiempo adicional en cada caso, exigencia atendida a través de la Orden Ministerial PRE/1822/2006, del 9 de julio.

A su vez, sobre la adaptación de los medios, esta pondrá a disposición del aspirante todos los medios necesarios para que pueda realizar la prueba con las ayudas técnicas y tecnologías asistidas necesarias para la realización de las pruebas en las que participe (art. 8.4). Es relevante destacar que las dos medidas arriba mencionadas dependen de la solicitud del aspirante.

Sobre el procedimiento, por fin, se puede destacar el contenido del art. 3.3 del Real Decreto $2271 / 04^{586}$, que determina que aunque haya un tratamiento diferenciado respecto a la realización de los ejercicios, habrá una relación única de los candidatos que hayan superado las pruebas selectivas, donde los aprobados serán ordenados por la puntuación total obtenida, con independencia del turno por el que hayan participado.

Evidentemente, todas estas normas serán poco eficaces si a las personas con discapacidad no les fueren ofrecidas las condiciones necesarias para que puedan participar de forma calificada de los procesos selectivos. Por ello, el art. 12.3 del Real Decreto 2271/04 fomenta la realización por la Administración Pública de cursos de formación destinados únicamente a personas con discapacidad.

A su vez, el derecho brasileño también establece mecanismos que buscan la concesión de igualdad de oportunidades a las personas con discapacidad en el acceso a la función pública. Primeramente, la Constitución Federal determina en el art. 37,

\footnotetext{
586 “Art.3.3. Las pruebas selectivas tendrán idéntico contenido para todos los aspirantes, independientemente del turno por el que se opte, sin perjuicio de las adaptaciones previstas en el artículo 8. Durante el procedimiento selectivo se dará un tratamiento diferenciado a los dos turnos, en lo que se refiere a las relaciones de admitidos, los llamamientos a los ejercicios y la relación de aprobados. No obstante, al finalizar el proceso, se elaborará una relación única en la que se incluirán todos los candidatos que hayan superado todas las pruebas selectivas, ordenados por la puntuación total obtenida, con independencia del turno por el que hayan participado. Dicha relación será la determinante para la petición y la adjudicación de destinos, excepto lo previsto en el artículo 9."
} 
VIII, que "a lei reservará percentual dos cargos e empregos públicos para as pessoas portadoras de deficiência e definirá os critérios de sua admissão" ${ }^{\text {"587. }}$.

Respecto a la norma constitucional citada, se ha destacado que la misma no es "auto-aplicável, cabendo aos interessados adotar as medidas judiciais cabíveis em caso de omissão do Poder Público na promulgação da lei (inconstitucionalidade por omissão). No âmbito federal, a Lei ${ }^{\circ}$ 8.112, de 11-12-90, assegura no $§ 2^{\circ}$ do artigo $5^{\circ}$, aos portadores de deficiência até $20 \%$ das vagas oferecidas no concurso.",588

De hecho, en el âmbito federal (legislación de la Unión), la Ley 8.112/90 determina en el $\S 2^{\circ}$ del artículo $5^{\circ}$ que; “Às pessoas portadoras de deficiência é assegurado o direito de se inscrever em concurso público para provimento de cargo cujas atribuições sejam compatíveis com a deficiência de que são portadoras; para tais pessoas serão reservadas até $20 \%$ (vinte por cento) das vagas oferecidas no concurso".

La verdad es que la norma anteriormente transcripta es la única prevista en el Estatuto Federal de los Servidores Públicos (Ley 8.112/90) que trata del tema del acceso de la personas con discapacidad a la función pública. La ausencia de más parámetros legales respecto a la aplicación de la norma constitucional (art. 37, VIII) ha causado la reacción de la doctrina:

“A Lei n. ${ }^{8} 8.112$, de 11 de dezembro de 1990, Regime Jurídico dos Servidores Públicos, estabeleceu no artigo $5^{\circ}, \S 2^{\circ}$, que seriam destinadas aos portadores de deficiência até $20 \%$ das vagas oferecidas nos concursos públicos. Tanto a Constituição, quanto a Lei n. ${ }^{\circ} 8.112$ não regulamentaram suficientemente esta matéria, de maneira que se

\footnotetext{
587 Sobre la citada norma: "Sem dúvida, por um longo período, os portadores de deficiência eram totalmente privados de oportunidades de trabalho e de liberdade para se realizarem como seres humanos. O sentimento de egoísmo que envolveu, e até hoje envolve a sociedade, voltava-se a uma seleção natural dos indivíduos, ou seja, excluía-se aqueles privados pela natureza de certas habilidades. Com efeito, o advento da norma constitucional contida no art. 37, VIII, veio garantir o princípio da igualdade, determinando a reserva de cargos e empregos públicos para categoria de pessoas historicamente discriminadas e colocadas à margem da sociedade produtiva" (TOURINHO, Rita. Op.cit., p. 130).

${ }^{588}$ ZANELLA DI PIETRO, Maria Sylvia. Op.cit., p. 499. También hay juristas que sostienen que si el ente federativo no creó la citada ley, es posible que el edital del concurso lo haga. Si no lo hace, deberá el candidato exigirlo judicialmente:"Diante de tal quadro normativo, não há dúvida de que as pessoas portadoras de deficiência têm direito subjetivo à participação nos concursos públicos, ao mesmo tempo em que o Poder Público tem o dever jurídico de fixar o percentual de cargos e empregos públicos a elas destinadas. Se a lei do ente federativo não o tiver feito, deve fazê-lo o edital de concurso. Caso ambos sejam silentes, cabe ao interessado pleitear no Judiciário a admissibilidade da participação e a respectiva reserva de vagas." (SANTOS CARVALHO FILHO, José dos. Op.cit., p. 557).
} 
dissipassem as dúvidas acerca dos direitos daqueles cidadãos no tocante às regras que iriam imperar durante o transcurso dos certames. Assim, cada edital de concurso previa, a seu modo, como seria a participação e convocação dos portadores de deficiência ao exercício do cargo ou emprego público, o que gerou abusos por parte das instituições" ${ }^{\text {"589 }}$

Aún en el ámbito federal, la reglamentación del tema surgió a través del Decreto 3.298, de 20 de diciembre de 1999, especialmente en los artículos 37 hasta 45. Antes de tratar de las cuestiones respecto a la participación de las personas con discapacidad en los procesos selectivos de acceso a la función pública, cabe destacar que quiénes son tales personas en el derecho brasileño.

En este contexto, el Decreto Presidencial 3956, de 08 de octubre de 2001, promulgó la Convención Interamericana para la Eliminación de todas las Formas de Discriminación de las Personas con Discapacidad.

Según el art. $1^{\text {o }}$ del referido decreto, la discapacidad (deficiência, en portugués) "significa uma restrição física, mental ou sensorial, de natureza permanente ou transitória, que limita a capacidade de exercer uma ou mais atividades essenciais da vida diária, causada ou agravada pelo ambiente econômico e social”.

A su vez, el ya mencionado Decreto 3.298/99, alterado por el Decreto $5296 / 2004$, en el art. $4^{\circ}$, profundiza, a través de los debidos detalles, el concepto anteriormente expuesto de discapacidad ${ }^{590}$.

\footnotetext{
${ }^{589}$ SETTE DE BARROS, Maria Magdala. Portadores de deficiência e o concurso público, texto extraído del sitio Jus Navigandi (http://jus2.uol.com.br/doutrina/texto.asp?id=2639), elaborado em 11.2001, acceso en 16.02.2010.

590 "Art. $4^{\circ}$ É considerada pessoa portadora de deficiência a que se enquadra nas seguintes categorias: I - deficiência física - alteração completa ou parcial de um ou mais segmentos do corpo humano, acarretando o comprometimento da função física, apresentando-se sob a forma de paraplegia, paraparesia, monoplegia, monoparesia, tetraplegia, tetraparesia, triplegia, triparesia, hemiplegia, hemiparesia, ostomia, amputação ou ausência de membro, paralisia cerebral, nanismo, membros com deformidade congênita ou adquirida, exceto as deformidades estéticas e as que não produzam dificuldades para o desempenho de funções;

II - deficiência auditiva - perda bilateral, parcial ou total, de quarenta e um decibéis (dB) ou mais, aferida por audiograma nas freqüências de $500 \mathrm{HZ}, 1.000 \mathrm{HZ}, 2.000 \mathrm{~Hz}$ e $3.000 \mathrm{~Hz}$;

III - deficiência visual - cegueira, na qual a acuidade visual é igual ou menor que 0,05 no melhor olho, com a melhor correção óptica; a baixa visão, que significa acuidade visual entre 0,3 e 0,05 no melhor olho, com a melhor correção óptica; os casos nos quais a somatória da medida do campo visual em
} 
Respecto a las repercusiones del trato diferenciado a las personas con discapacidad en los procesos selectivos, la primera cuestión norma que debe ser subrayada es el hecho de que si el candidato posee una determinada discapacidad (y si pretende recibir un trato diferenciado en la competición), deberá declárala, presentando el laudo médico específico, cuando se inscriba en el proceso selectivo ${ }^{591}$.

A su vez, el órgano de selección deberá comprobar la existencia o no de la discapacidad alegada por el candidato ${ }^{592}$, lo que deberá ser hecho por una equipe de profesionales especializados ${ }^{593}$.

Evidentemente, hay que destacar que "Fica assegurado à pessoa portadora de deficiência o direito de se inscrever em concurso público, em igualdade de

ambos os olhos for igual ou menor que $60^{\circ}$; ou a ocorrência simultânea de quaisquer das condições anteriores;

$I V$ - deficiência mental - funcionamento intelectual significativamente inferior à média, com manifestação antes dos dezoito anos e limitações associadas a duas ou mais áreas de habilidades adaptativas, tais como:

a) comunicação;

b) cuidado pessoal;

c) habilidades sociais;

d) utilização dos recursos da comunidade;

e) saúde e segurança;

f) habilidades acadêmicas;

g) lazer; $e$

h) trabalho;

$V$ - deficiência múltipla - associação de duas ou mais deficiências”.

${ }^{591}$ El Decreto 3.298/99 determina que en el art. 39, IV, que el edital del concurso público deba prever la "exigência de apresentação, pelo candidato portador de deficiência, no ato da inscrição, de laudo médico atestando a espécie e o grau ou nível da deficiência, com expressa referência ao código correspondente da Classificação Internacional de Doença - CID, bem como a provável causa da deficiência".

${ }^{592}$ Sobre el ingreso de las personas con discapacidad en la función pública: "É evidente que alguns requisitos devem ser observados, como o grau de extensão da deficiência e a compatibilidade desta com as funções a serem exercidas (adequação profissional), o que deve ser avaliado por equipe técnica multiprofissional; o nível de escolaridade; a necessidade de adaptação a posteriori, etc." (SANTOS CARVALHO FILHO, José dos. Op.cit., p. 557).

593 Según el Decreto 3.298/99: “Art. 43. O órgão responsável pela realização do concurso terá a assistência de equipe multiprofissional composta de três profissionais capacitados e atuantes nas áreas das deficiências em questão, sendo um deles médico, e três profissionais integrantes da carreira almejada pelo candidato.

$\S 1^{\circ}$ A equipe multiprofissional emitirá parecer observando:

I - as informações prestadas pelo candidato no ato da inscrição;

II - a natureza das atribuições e tarefas essenciais do cargo ou da função a desempenhar;

III - a viabilidade das condições de acessibilidade e as adequações do ambiente de trabalho na execução das tarefas;

IV - a possibilidade de uso, pelo candidato, de equipamentos ou outros meios que habitualmente utilize; $e$ $V$ - a CID e outros padrões reconhecidos nacional e internacionalmente.

$\S 2^{\circ}$ A equipe multiprofissional avaliará a compatibilidade entre as atribuições do cargo e a deficiência do candidato durante o estágio probatório". 
condições com os demais candidatos, para provimento de cargo cujas atribuições sejam compatíveis com a deficiência de que é portador”.

Como se puede percibir (y como no podría ser de forma distinta), el ingreso de la persona con discapacidad en la función pública dependerá de la compatibilidad de la referida limitación física o mental con las tareas del puesto de trabajo a ser cubierto. $^{594}$

Respecto a esta cuestión, ya se ha destacado que "há uma confusão de significados entre deficiência e aptidão/capacidade para o trabalho. Um deficiente pode ser apto ou não para determinado cargo ou função; mas sempre será deficiente."595

Lo que se quiere acentuar es además de la comprobación de la discapacidad del candidato, deberá también haber la demostración de su aptitud para desempeñar el puesto de trabajo ofertado por la Administración Pública ${ }^{596}$.

\footnotetext{
594 “ADMINISTRATIVO. CONCURSO PÚBLICO PARA AGENTE-FISCAL DO TESOURO NACIONAL. CANDIDATO COM VISÃO MONOCULAR. EXCLUSÃO DO BENEFÍCIO DE RESERVA DE VAGA. DISTINÇÃO ENTRE DEFICIÊNCIA E INVALIDEZ. 1 - Deficiência, para efeito de reserva de vagas em concurso público, é a situação intermediária entre a plena capacidade e a invalidez. 2 - A visão monocular cria barreiras físicas e psicológicas na disputa de oportunidades no mercado de trabalho, situação esta que o benefício de vagas tem por objetivo compensar. 3 - Caso em que não se vislumbra prejuízo concreto para outros candidatos".(TRF - $1^{\mathrm{a}}$ Região - Classe: AMS - Apelação em Mandado de Segurança - 01000817891; Processo: 199901000817891; UF: DF; Órgão Julgador: Primeira Turma; Data da decisão: 02/06/2000; Documento: TRF100095196; DJ data: 26/06/2000; página: 18 - Relator Juiz Plauto Ribeiro).

"EMBARGOS INFRINGENTES - CONCURSO PÚBLICO - DEFICIENTE FÍSICO - DEFICIÊNCIA COMPATÍVEL COM AS TAREFAS DO CARGO - INAPTIDÃO AFASTADA - 1. Verificada a compatibilidade entre a deficiência física da candidata e as funções inerentes ao cargo público a que concorrera, não se justifica a sua exclusão do certame, em que almejou justamente vaga reservada a portadores de deficiência, na forma do que estabelece o art. 37, inciso VIII, da Constituição Federal. 2. Embargos improvidos. Unânime". (TJDF - EIC 20000150041916 - 2a C.Cív. - Rel ${ }^{a}$ Des $^{\text {a }}$ Adelith de Carvalho Lopes - DJU 20.03.2002 - p. 52).

"ATO ADMINISTRATIVO - AUTORIDADE COATORA - LEGITIMIDADE DE PARTE - CONCURSO PARA PROVIMENTO DE CARGO PÚBLICO - EDITAL DO CONCURSO - INTERESSE DE DEFICIENTE FÍSICO - ORDEM CONCEDIDA - Administrativo. Legitimidade. Mandado de Segurança. Concurso Público. Deficiente físico. É parte legítima para figurar como autoridade impetrada o Secretário de Estado que determina a publicação do edital, delegando à FESP a execução do concurso. Nos termos do art. $5^{\circ}$, caput c/c 37, I, ambos da Constituição Federal, a deficiência física do Impetrante não é óbice para o desempenho do cargo para o qual concorre em concurso público. Discriminação ilegal e inconstitucional. Concessão da segurança". (MGS) (TJRJ - MS 589/98 - (Reg. 050.599) - 5 G.C.Cív. - Rel. Des. Paulo César Salomão - J. 24.02.1999).”

${ }^{595}$ MESQUITA DANTAS, Adriano. Os portadores de deficiência e o concurso para provimento de cargos e empregos públicos. A ineficácia dos dispositivos constitucionais e infraconstitucionais, texto extraído del sitio Jus Navigandi (http://jus2.uol.com.br/doutrina/texto.asp?id=7150), publicado en 12.08.2005, acceso en 16.02.2010.
} 
Como ya se ha visto en este trabajo, el acceso meritorio a la función pública impone que sean seleccionados candidatos aptos, lo que hace com que, "para efeito de reserva de vagas não se pode exigir que a deficiência seja tão acentuada que implique impossibilidade de exercer funções na Administração, fato gerador, inclusive, de aposentadoria para o servidores públicos"

Otra circunstancia relevante es que los candidatos que poseen discapacidad podrán en el acto de inscripción requerir trato diferenciado en el concurso público, indicando las condiciones especiales que necesita para realizar las pruebas. De la misma forma, podrá requerir tiempo adicional en las pruebas ${ }^{598}$.

Los citados tratos diferenciados en la realización de las pruebas son muchas veces imprescindibles para que el candidato con discapacidad pueda competir en el proceso selectivo en igualdad de condiciones ${ }^{599}$. Es lo que pasa, por ejemplo, con un candidato que no posee visión, y necesita realizar la prueba en braille, o que alguien le haga la lectura de las preguntas y que apunte le las respuestas.

Sobre este tema, se ha acentuado que:

596 Para el Decreto 3298/99: “Art. 44. A análise dos aspectos relativos ao potencial de trabalho do candidato portador de deficiência obedecerá ao disposto no art. 20 da Lei $n^{\circ}$ 8.112, de 11 de dezembro de 1990”. El mencionado artículo del Estatuto Federal del Servidor Público determina que: "Art. 20. Ao entrar em exercício, o servidor nomeado para cargo de provimento efetivo ficará sujeito a estágio probatório por período de 24 (vinte e quatro) meses, durante o qual a sua aptidão e capacidade serão objeto de avaliação para o desempenho do cargo, observados os seguinte fatores: I - assiduidade; II disciplina; III - capacidade de iniciativa; IV - produtividade; V-responsabilidade".

${ }^{597}$ MOTTA, Fabrício. A reserva de vagas nos concursos públicos para os portadores de deficiênciaanálise do art. 37, inc. VIII da Constituição Federal, en Concurso público e Constituição, Fabrício Motta (Cordinador), Editora Fórum, Belo Horizonte, 2005, p. 192.

598 Las situaciones comentadas están previstas en los dos paráfos del art. 40 del mencionado Decreto 3298/99: "§ $1^{o}$ No ato da inscrição, o candidato portador de deficiência que necessite de tratamento diferenciado nos dias do concurso deverá requerê-lo, no prazo determinado em edital, indicando as condições diferenciadas de que necessita para a realização das provas.

$\S 2^{\circ}$ O candidato portador de deficiência que necessitar de tempo adicional para realização das provas deverá requerê-lo, com justificativa acompanhada de parecer emitido por especialista da área de sua deficiência, no prazo estabelecido no edital do concurso".

${ }_{599}$ La utilización de tales medidas es uno de los intentos no siempre suficientes para eliminar las diferencias entre los candidatos con y sin discapacidad. En este contexto: "Notoriamente, contudo, assegurar que os portadores de deficiência participarão dos concursos em condições iguais às dos candidatos não portadores de deficiência não tem sido suficiente para que haja o efetivo acesso e a efetiva inclusão deles no serviço público" (PINTO DE OLIVEIRA, Renato. Sobre a reserva de vagas em concurso público para os portadores de deficiência, texto extraído del sitio Jus Navigandi (http://jus2.uol.com.br/doutrina/texto.asp?id=8963), publicado en 24.09.2006, acceso en 16.02.2010). 
"pode muito bem o candidato necessitar de intervenção de um terceiro para lhe auxiliar na realização das provas, como é o caso do ledor para os deficientes visuais ou de alguém para escrever as questões ditadas por um candidato sem movimento nos braços. Imagine-se, por exemplo, uma prova oral realizada por um candidato surdo-mudo. De certo, os membros da comissão examinadora necessitarão do auxílio de um tradutor - conhecedor da língua dos sinais - para intermediar a comunicação entre eles e o candidato." ${ }^{600}$

La doctrina también destaca que no solo se debe permitir que el candidato pueda requerir condiciones diferenciadas, sino también se debe garantizar que la Administración Pública no haga "exigências despidas de razoabilidade que obstaculem a participação desses candidatos."

Seguramente, el trato diferenciado anteriormente destacado entre los candidatos con y sin discapacidad no podrá incidir en determinados aspectos ${ }^{602}$, como el contenido de las pruebas o la nota mínima para aprobación ${ }^{603}$, para que el mecanismo de compensación no resulte en instrumento de privilegio indebido.

Pese a la relevancia de los mecanismos que intentan equilibrar la competición, la principal garantía para efectividad de la igualdad de oportunidades de

\footnotetext{
${ }^{600}$ BARBOSA MAIA, Márcio, y PINHEIRO DE QUEIROZ, Ronaldo. Op.cit., p. 222.

${ }^{601}$ MOTTA, Fabrício. A reserva de vagas nos concursos públicos para os portadores de deficiênciaanálise do art. 37, inc. VIII da Constituição Federal, en Concurso público e Constituição, Fabrício Motta (Cordinador), Editora Fórum, Belo Horizonte, 2005, p. 205-206.

${ }^{602}$ Sobre este tema, el Decreto 3.298/99 determina que: "Art. 41. A pessoa portadora de deficiência, resguardadas as condições especiais previstas neste Decreto, participará de concurso em igualdade de condições com os demais candidatos no que concerne: I - ao conteúdo das provas; II - à avaliação e aos critérios de aprovação; III - ao horário e ao local de aplicação das provas; e IV - à nota mínima exigida para todos os demais candidatos".

${ }^{603}$ Sin embargo hay juristas que piensan de forma distinta: "Ocorre que a Administração Pública tem se valido comumente de um expediente que veda o acesso dos portadores de deficiência e impede sua inclusão, em franca violação ao ordenamento jurídico vigente, consistente em estabelecer que as notas de corte serão obtidas por parametrização de notas, assim consideradas as notas de todos os candidatos, portadores de deficiência ou não. Ora: se a Constituição Federal garante que deverá haver a reserva de vagas aos deficientes, estas deverão sê-lo, com fixação de notas de corte diferenciadas para os diferentes. Ou seja: deverá haver parametrização entre os portadores de deficiência para que se atinja a nota de corte específica para o preenchimento das vagas a eles reservadas, sob pena de eugenicamente a Administração aumentar arbitrariamente, sem qualquer correlação lógica entre as atribuições do cargo e ou emprego público pretendido e as exigências da prova, com vistas a, quando da parametrização, apenas os não portadores atingirem as notas-limite." (PINTO DE OLIVEIRA, Renato. Sobre a reserva de vagas em concurso público para os portadores de deficiência, texto extraído del sitio Jus Navigandi (http://jus2.uol.com.br/doutrina/texto.asp?id=8963), publicado en 24.09.2006, acceso en 16.02.2010).
} 
acceso a la función pública para las personas con discapacidad es la reserva de plazas ${ }^{604}$. Tal medida "constitui ação afirmativa do Estado no atendimento aos valores constitucionais (...). No caso, trata-se de alocar um determinado percentual de vagas para promover, sob condições especiais, a inserção dos portadores de deficiência na Administração",605

A pesar del reconocimiento generalizado de la importancia de la reserva de plazas para las personas con discapacidad, en los concursos públicos brasileños, todavía existen determinados problemas en la aplicación del mencionado mecanismo, que muchas veces compromete los derechos de las citadas personas.

Entre las tales dificultades, se puede citar la indefinición en el ordenamiento jurídico respecto al cálculo utilizado para cómputo de las plazas reservadas a los candidatos con discapacidad y la ausencia de claridad sobre el orden que debe ser observado en la convocación de los candidatos aprobados.

La primera cuestión dice respecto a las dudas relativas a la fórmula que debe ser utilizada para calcular el número de plazas que deben ser reservadas a las personas con discapacidad en el proceso selectivo. En el ámbito federal, el Decreto 3.298/99 determina en el art. $37 \S 1^{\underline{0}}$ establece que: “O candidato portador de deficiência, em razão da necessária igualdade de condições, concorrerá a todas as vagas, sendo reservado no mínimo o percentual de cinco por cento em face da classificação obtida"; y, a continuación, determina en el $\S 2^{\underline{\alpha}}$ que: "Caso a aplicação do percentual de que trata o parágrafo anterior resulte em número fracionado, este deverá ser elevado até o primeiro número inteiro subseqüente" ${ }^{, 606}$.

\footnotetext{
${ }^{604}$ En este sentido: "A legislação brasileira confere aos deficientes algumas prerrogativas quando submetidos a concurso para provimento de cargos e empregos públicos da administração direta e indireta. A principal delas é a reserva de vagas." (MESQUITA DANTAS, Adriano. Os portadores de deficiência e o concurso para provimento de cargos e empregos públicos. A ineficácia dos dispositivos constitucionais $e$ infraconstitucionais, texto extraído del sitio Jus Navigandi (http://jus2.uol.com.br/doutrina/texto.asp?id=7150), publicado en 12.08.2005, acceso en 16.02.2010).

${ }^{605}$ MOTTA, Fabrício. A reserva de vagas nos concursos públicos para os portadores de deficiência análise do art. 37, inc. VIII da Constituição Federal, en Concurso público e Constituição, Fabrício Motta (Cordinador), Editora Fórum, Belo Horizonte, 2005, p. 190.

${ }^{606}$ En los términos arriba destacados, una situación hipotética puede ser citada para ayudar a la comprensión del tema:"Suponha que um edital de determinado concurso público preveja $6 \%$ das vagas para portadores de deficiência e o número total de vagas previstas no edital é de 10. Francisco, portador
} 
Según la jurisprudencia, aún cuando el porcentual resulte en un número de plaza inferior a uno, debe ser garantizada al menos una plaza a las personas con discapacidad. Este entendimiento fue adoptado por los tribunales, aún cuando estos analizaran procesos selectivos que no fueron sometidos al decreto federal mencionado. En este sentido:

\begin{abstract}
"Nos termos do julgado proferido no RE $\mathrm{n}^{\circ}$ 227.299/MG, da relatoria do Ministro Ilmar Galvão, 'a exigência constitucional de reserva de vagas para portadores de deficiência em concurso público se impõe ainda que o percentual legalmente previsto seja inferior a um, hipótese em que a fração deve ser arredondada. Entendimento que garante a eficácia do artigo 37, inciso VIII, da Constituição Federal. Recurso extraordinário conhecido e provido'."607
\end{abstract}

Pese a la relativa concordancia respecto al tema bajo análisis, hay otras cuestiones que todavía no están resueltas en el ámbito doctrinario y jurisprudencial brasileño, como la que dice respecto al cómputo de las plazas reservadas para las personas con discapacidad cuando la Administración Pública solamente ofrece una cuantidad muy reducida de puestos de trabajo. Para solucionar esta situación, ya han surgido algunas opiniones, no siempre coincidentes ${ }^{608}$, lo que exige una mejor definición en las normas jurídicas que tratan del asunto.

de deficiência, classifica-se para o concurso em primeiro lugar dentre os deficientes. Como o percentual é de 6\% sobre as vagas, teremos 0,6 vagas para os portadores, devendo ser essa fração ser arredondada para o primeiro inteiro subseqüente, tendo ao final 1(uma) vaga para os portadores, que irá se preenchida pelo Francisco. Portanto, a regra do parágrafo $2^{\circ}$ logo acima não deixa dúvidas de que deve ser assegurado sempre algum número de vagas para os portadores deficiência". (LUIZILO FREDERICO JÚNIOR, José. A reserva de vagas para deficientes em concursos: a lei e a jurisprudência, texto extraído do Jus Navigandi (http://jus2.uol.com.br/doutrina/texto.asp?id=8874), publicado en 04.09.2006, acceso en 16.02.2010).

${ }^{607}$ Tribunal Regional Federa $1^{\mathrm{a}}$ região - AMS 2003.01.00.037201-0 - Minas Gerais - Quinta Turma Rel. Desembargador João Batista Moreira - DJ 25/11/2004 - p. 41. En el citado RE 227229/MG, el Ministro Ilmar Galvão había entendido que: "De ter-se, em face da obrigatoriedade da reserva de vagas para portadores de deficiências, que a fração, a exemplo do disposto no Decreto $n^{\circ} 3.298 / 99$, seja elevada ao primeiro número inteiro subseqüente, no caso 1 (um), como medida necessária a emprestarse eficácia ao texto constitucional, que, caso contrário, sofreria ofensa."

${ }^{608}$ Para ejemplificar las soluciones ofertadas por la doctrina, será citada una: "Se aplicarmos o percentual mínimo de $5 \%$ em um concurso público com 05 vagas previstas em edital, chegaremos a 0,25, ou seja, um número fracionário. De acordo com o parágrafo $2^{\circ}$ do artigo 37, poderíamos arredondar o número fracionado para um. Isso fará com o que o deficiente faça jus a uma vaga. A questão é: a partir de que número fracionário é possível arredondar? O entendimento do Supremo Tribunal Federal é de que o percentual de participação dos deficientes seja de no mínimo cinco por cento e no máximo vinte, como diz a lei. Se aplicarmos 5\% sobre as 04 vagas previstas em um edital obteremos o montante de 0,20. Se 
La segunda cuestión problemática respecto a la reserva de plazas para las personas con discapacidad es relativa al orden de convocación de los candidatos aprobados, oportunidad en la que los candidatos con discapacidad suelen ser discriminados por la Administración Pública ${ }^{609}$.

La verdad es que los concursos públicos tienen dos listas: una de los candidatos con discapacidad, que concurren a las plazas que les son reservadas, y otra de los aspirantes sin discapacidad, que disputan las demás plazas ${ }^{610}$. Según la doctrina,

arredondarmos esse número para 01, chegaremos à conclusão de que nesse concurso público o percentual reservado aos deficientes ultrapassou o limite de 20\%, o que não pode acontecer por expressa disposição legal. Portanto, em concursos em que o número de vagas seja inferior ou igual a dezenove, a quinta vaga será do deficiente e a partir daí teremos que contar de vinte em vinte. O próximo deficiente será chamado para ocupar a quadragésima primeira vaga e o próximo para a sexagésima primeira vaga. A cada vinte vagas subsequente será do deficiente" (BRANDAO COSTA, Bernardo. Deficiente Físico Forma de convocação, texto extraído del sitio PCI Concursos (http://www.pciconcursos.com.br/consultoria/deficiente-fisico-forma-de-convocacao), acceso en 16.02.2010). A su vez, también hay aquellos que manifiestan la dificultad de definición de una posible solución: "Imagine a seguinte situação. Um concurso público na Administração Federal abre apenas 3 vagas para um determinado cargo, com possibilidade de abertura de novas vagas durante o prazo de validade do concurso, e atribui $20 \%$ das vagas aos deficientes. Mais uma vez, Francisco, estudioso, é novamente aprovado no concurso e fica em $5^{\circ}$ lugar. Ele tem direito a uma das vagas abertas, de plano, no edital? Se fizermos o mesmo raciocínio no concurso anterior, temos a fração de 0,6. Arredondando para o primeiro inteiro subseqüente, chegamos à conclusão de que Francisco faz jus a uma vaga. Mas isso é falacioso! Calculando o percentual de vagas que foram efetivamente destinadas aos deficientes no concurso, no caso uma, chegaremos a percentual de 33,33\%, o qual supera o percentual máximo de $20 \%$ permitido pela lei 8.112/90. Ficamos numa situação aparentemente contraditória. A Constituição garante esse direito aos deficientes, mas a legislação infraconstitucional, nesse caso, entra em contradição: se respeitarmos o arredondamento do Decreto 3.298/99, violaremos a lei 8.112/90; mas se não fizermos o arredondamento, o direito constitucionalmente garantido se torna estéril." (LUIZILO FREDERICO JÚNIOR, José. A reserva de vagas para deficientes em concursos: a lei e a jurisprudência, texto extraído do Jus Navigandi (http://jus2.uol.com.br/doutrina/texto.asp?id=8874), publicado en 04.09.2006, acceso en 16.02.2010).

${ }^{609}$ El problema citado puede ser así resumido: "Nada justifica que havendo dez vagas, entre elas duas reservadas aos deficientes, a Administração convoque os candidatos habilitados para as oito vagas, enquanto os deficientes ficam aguardando, pois geralmente acontece de não serem convocados, a não ser aqueles que se dispõem a pleitear em juízo eventual "direito". Não existe justificativa para tal conduta, senão que estamos diante de uma grosseira e arbitrária discriminação. Ocorre muitas vezes de exaurirse o prazo do concurso e o deficiente que logrou o primeiro lugar na lista de portadores de deficiência não ser convocado. Porém, os candidatos não-deficientes na maioria das vezes já se encontram trabalhando, muitos além do número de vagas previsto pela Administração." (SETTE DE BARROS, Maria Magdala. Portadores de deficiência e o concurso público, texto extraído del sitio Jus Navigandi (http://jus2.uol.com.br/doutrina/texto.asp?id=2639), Elaborado em 11.2001, acceso en 16.02.2010).

610 "Por outro lado, a participação de deficientes obriga à elaboração de duas listas de classificação, sendo uma delas composta exclusivamente por aqueles e destinada somente às vagas objeto da reserva." (SANTOS CARVALHO FILHO, José dos. Manual de Direito Administrativo, $17^{\mathrm{a}}$ ed. Lumen Juris Editora, Rio de Janeiro, 2007, p. 557). 
la existencia de las dos listas "contempla, desse modo, o princípio segundo o qual os iguais devem ser tratados igualmente e os desiguais, desigualmente."611

Así, la jurisprudencia suele destacar la necesidad de que haya la alternancia en la convocación de candidatos con y sin discapacidad:

\begin{abstract}
"Entenda-se que não se pode considerar que as primeiras vagas se destinam a candidatos não-deficientes e apenas as eventuais ou últimas a candidatos deficientes. Ao contrário, o que deve ser feito é a nomeação alternada de um e outro, até que seja alcançado o percentual limítrofe de vagas oferecidas pelo Edital a esses últimos." ${ }^{612}$
\end{abstract}

El problema surge en el momento de definir quiénes serán convocados en primer lugar. Respecto a esta cuestión, sobre la realidad de los concursos públicos brasileños, se ha observado que:

\begin{abstract}
"Havia prejuízo para esses candidatos porque, em que pese lhes serem reservadas vagas, não havia regras a respeito de sua convocação para o exercício do cargo. As instituições, com fundamento na tese de administrativistas de envergadura, escondendo o intuito discriminatório que regia seus comandos, socorriam-se da discricionariedade que imperava, e ainda impera, nos atos administrativos para convocar vários candidatos não-deficientes e não fazer o mesmo com os portadores de deficiência, que necessitavam, como ainda necessitam, pleitear seu direito perante o Judiciário. O prazo de validade do concurso se exauria e o candidato habilitado e com reserva de vaga acabava preterido." 613
\end{abstract}

Delante de la repetición de actos como el relatado, determinados concursos públicos empezaron a estipular reglas más justas para la convocación de los candidatos

611 MESQUITA DANTAS, Adriano. Os portadores de deficiência e o concurso para provimento de cargos e empregos públicos. A ineficácia dos dispositivos constitucionais e infraconstitucionais, texto extraído del sitio Jus Navigandi (http://jus2.uol.com.br/doutrina/texto.asp?id=7150), publicado en 12.08.2005, acceso en 16.02.2010.

${ }^{612}$ Extraído del RMS 18669/RJ, apud LUIZILO FREDERICO JÚNIOR, José. A reserva de vagas para deficientes em concursos: a lei e a jurisprudência, texto extraído do Jus Navigandi (http://jus2.uol.com.br/doutrina/texto.asp?id=8874), publicado en 04.09.2006, acceso en 16.02.2010.

${ }^{613}$ SETTE DE BARROS, Maria Magdala. Portadores de deficiência e o concurso público, texto extraído del sitio Jus Navigandi (http://jus2.uol.com.br/doutrina/texto.asp?id=2639), Elaborado em 11.2001, acceso en 16.02.2010. 
aprobados, de forma a permitir la equilibrada distribución de las plazas ${ }^{614}$. Sin embargo, también aquí hay que reconocerse la inmediata necesidad de la creación de reglas más objetivas e igualitarias, que sirvan de parámetro para todos los procesos selectivos realizados en el ámbito de determinado ente federativo.

La última observación que será hecha en el contexto del acceso de las personas con discapacidad trata de la necesidad de que la Administración Pública esté técnicamente preparada para resolver las cuestiones que envuelven los temas aquí analizados. En la realidad brasileña, esto no siempre ocurre, lo que podría empezar a cambiar a partir de la debida preparación de aquellos que están encargados de conducir los procesos selectivos. En este sentido:

\begin{abstract}
"verifica-se que há em nosso ordenamento jurídico dispositivos legais aptos a eliminar, ou pelo menos diminuir, as barreiras impostas aos portadores de deficiências com relação ao ingresso no serviço público através dos concursos públicos. No entanto, em decorrência da falta de preparo técnico daqueles encarregados de avaliar os candidatos e suas limitações, a garantia constitucional por vezes é desrespeitada, carecendo, assim, de eficácia. Para que a norma tenha um maior alcance, atingindo assim o seu fim social, mister se faz que as pessoas responsáveis pelo processo seletivo passem por um curso de capacitação, que deverá abordar a definição de pessoa portadora de
\end{abstract}

\footnotetext{
${ }^{614}$ Sobre este asunto: "O manual do candidato para os cargos de técnico e analista judiciários do Tribunal Superior Eleitoral, realizado em 2006/7 pela CESPE-Unb, tratou da convocação no item 3.12: "o primeiro candidato portador de deficiência classificado no concurso público será nomeado para ocupar a quinta vaga aberta, enquanto os demais serão nomeados a cada intervalo de vinte cargos providos, conforme parágrafo $3^{\circ}$ do artigo 12 da Resolução TSE n. ${ }^{\circ}$ 21.899/04.;" (BRANDAO COSTA, Bernardo. Deficiente Físico - Forma de convocação, texto extraído del sitio PCI Concursos (http://www.pciconcursos.com.br/consultoria/deficiente-fisico-forma-de-convocacao), acceso en 16.02.2010). También se ha destacado que: "Recentemente foi publicado o edital do XLI concurso público para ingresso na carreira do Ministério Público do Estado de Minas Gerais, dando-nos um exemplo quase perfeito de como deverá o Poder Público agir para não ferir direitos dos portadores de deficiência, tampouco privilegiá-los em detrimentos dos demais candidatos. No item XI, j e k estabeleceuse a seguinte regra: condicionou-se a primeira admissão de candidato portador de deficiência após o preenchimento da décima vaga dos não-deficientes, sendo as demais admissões efetivadas na vigésima, trigésima vaga e assim sucessivamente. Compreendeu o Ministério Público de Minas Gerais o objetivo buscado pelo Decreto $n^{\circ}$ 3.298199, reconhecendo o direito das pessoas portadoras de deficiência sem privilégios ou paternalismos (art.5\%, III)." (SETTE DE BARROS, Maria Magdala. Portadores de deficiência e o concurso público, texto extraído del sitio Jus Navigandi (http://jus2.uol.com.br/doutrina/texto.asp?id=2639), Elaborado em 11.2001, acceso en 16.02.2010).
} 
deficiência e as múltiplas variações e manifestações desta, destacando todas as hipóteses legalmente previstas.."

\subsection{6 - Cuestiones raciales}

Es innegable que, en la actualidad, el criterio de la raza difícilmente va a ser impuesto como requisito de acceso a la función pública, sea en España o en Brasil. Por esta razón, "o critério da cor ou da raça também só poderia ser utilizado se houvesse uma justificativa plausível para tanto. Em exemplo interessante poderia ser a abertura do concurso público para o emprego em um museu inerente à cultura africana ou indígena, em que fosse razoável exigir que os seus guias fossem negros ou índios"

Sin embargo, hay algunas cuestiones que tienen conexión con tal circunstancia y que pueden repercutir en el proceso selectivo, especialmente en el citado país latinoamericano, que merecen ser tratadas en el presente apartado.

Antes de todo, cabe acentuar que tanto la Constitución española (art. $9^{\circ}$ ), como la brasileña (art. $3^{\circ}$, IV) previeron expresamente que la raza no puede ser, como regla general, un criterio utilizado para diferenciar las personas.

No obstante, la previsión de las normas citadas, que prohíben las conductas racistas no significa que este no exista en la sociedad. En verdad, la propia existencia de la norma es la prueba irrefutable de su necesidad.

El racismo en España, así como en otros países colonizadores, está mucho más asociado a la historia de dominación de los pueblos europeos (en el caso, los españoles) sobre otros ${ }^{617}$.

\footnotetext{
${ }^{615}$ MESQUITA DANTAS, Adriano. Os portadores de deficiência e o concurso para provimento de cargos e empregos públicos. A ineficácia dos dispositivos constitucionais e infraconstitucionais, texto extraído del sitio Jus Navigandi (http://jus2.uol.com.br/doutrina/texto.asp?id=7150), publicado en 12.08.2005, acceso en 16.02.2010.

${ }^{616}$ MACHADO JÚNIOR, Agapito. Op.cit., p. 127.

${ }^{617}$ Es lo que pasó en la Reconquista, con la opresión de los moros por los cristianos, o con el intento de expulsión de los gitanos, o mismo con los indios americanos exterminados o con los negros africanos esclavizados, durante la colonización europea en otros continentes. Para que se pueda percibir el racismo histórico de la sociedad española, la Constitución Española (de Cádiz) de 1812 condicionaba el pleno derecho de los españoles de origen negro: "Art. 22. A los españoles que por cualquier línea son habidos y reputados por originarios del Africa, les queda abierta la puerta de la virtud y del merecimiento para ser ciudadanos: en su consecuencia las Cortes concederán carta de ciudadano a los que hicieren servicios calificados a la Patria, o a los que se distingan por su talento, aplicación y conducta, con la condición de
} 
También se puede afirmar que han surgido algunos problemas en las últimas dos décadas generados con el gran número de inmigrantes que han llegado a España desde otros continentes (en especial, Latinoamérica, África y Asia ${ }^{618}$ ), especialmente en el período de crisis económica experimentado en este país.

Pese a las circusntancias relatadas, no se ha percibido cualquier debate en la doctrina española respecto al acceso de personas de razas minoritarias a la función pública. Probablemente, tal hecho proviene de una circunstancia peculiar: la discusión sobre la inserción de grupos minoritarios en España es mucho más basada en otros criterios, como la lengua, la nacionalidad, la clase social o la religión, que propiamente la raza, a lo mejor por las dificultades (o mismo inexistencia de criterios cientificos) biológicas y antropológicas de definición y distinción entre las especies de razas.

En Brasil, la miscigenación de blancos (europeos), negros (africanos), índios (americanos) y hasta mismo amarillos (asiáticos) ha producido un país multirracial, hecho que aunque sea motivo de orgullo para los brasileños, también ha producido muchas situaciones de desigualdad social y económica.

En el citado contexto:

que sean hijos de legítimo matrimonio de padres ingenuos; de que estén casados con mujer ingenua, y avecindados en los dominios de las Españas, y de que ejerzan alguna profesión, oficio o industria útil con un capital propio".

${ }^{618}$ Hoy en día, más de $12 \%$ de la población española es de inmigrantes. Sobre esta cuestión:“Más de 5,6 millones de inmigrantes se registraron en el padrón durante 2009, lo que significa unos 400.000 ciudadanos más respecto al año anterior, y con crecimientos en todas las comunidades autónomas. Según los datos definitivos del padrón municipal correspondiente al año último, -que acaba de publicar el Instituto Nacional de Estadística (INE)-, los ayuntamientos inscribieron en 2009 un total de 5.648.671 extranjeros, frente a los 5.268 .762 del ejercicio 2008. Frente a esta cifra, el número de extranjeros con certificado de registro o tarjeta de residencia en vigor se elevó a 4.715.757, a fecha 30 de septiembre de 2009, el último dato disponible del Ministerio de Trabajo e Inmigración. La cifra de ciudadanos extranjeros registrados en el padrón de 2009 supone multiplicarla por cinco en apenas una década; en el 2000 los ayuntamientos censaron sólo a 923.000 foráneos. El apunte en el padrón, un registro administrativo donde constan los vecinos de un municipio, constituye para los inmigrantes la llave de acceso a derechos como la sanidad y la educación; y procede con independencia de que tengan o no residencia legal en el país. Por bloques geográficos y referido al año 2009, más dos millones y medio de ciudadanos son originarios de países comunitarios; casi 217.000 de países no comunitarios; 900.000 de África; y casi dos millones de América Latina y de América del Norte, aunque en este último caso en mucha menor proporción. El colectivo nacional con mayor presencia es el marroquí, seguido del rumano y del ecuatoriano. En cuanto a las comunidades autónomas, todas ellas experimentan crecimientos; los más elevados se producen en Andalucía (casi 52.000 empadronados extranjeros más respecto a 2008); Madrid (58.000) y Comunidad Valenciana (42.000)" (Reportaje El número de inmigrantes empadronados en España se ha multiplicado por 5 en una década, publicado en 07.02.2010 y con acceso en 04.06.2010, extraído del sitio electrónico HERALDO.ES (http://www.heraldo.es/noticias/sociedad/el_numero_inmigrantes_registrados_padron_multiplicado_por_ una_decada.html). 
"Embora exista no seio da sociedade brasileira o discurso que sustenta a ausência de racismo, a segregação campeia em quase todos os cantos do país. A diferença é que, no Brasil, diferentemente do que ocorreu nos Estados Unidos, a miscigenação e a idéia de identidade nacional, a partir da formação de um povo eminentemente mestiço, deram opacidade à questão racial, resultando na falsa impressão de que vivemos fraternalmente em uma democracia racial. ${ }^{619}$

Una de las circunstancias de la pluralidad racial brasileña es la segregación económica de determinados segmentos, como los negros e indios, lo que genera la exclusión a las oportunidades ofrecidas en la vida. En este contexto, el acceso a la función pública es uno de los aspectos donde se percibe con claridad las disparidades existentes entre blancos y negros en Brasil. ${ }^{620}$

Delante de la constatación de que los funcionarios públicos brasileños son mayoritariamente blancos ${ }^{621}$, hay muchos segmentos de la sociedad civil que han planteado la adopción de cotas para los negros en los concursos públicos. El tema de las cotas raciales en Brasil está mucho más desarrollado cuando la referida medida de acción positiva es adoptada para garantizar plazas para los negros en las universidades públicas ${ }^{622}$.

${ }^{619}$ DIAS DA SILVEIRA, Raquel. Discriminações legais em concursos públicos e o princípio da igualdade: um estudo sob o paradigma das ações afirmativas e das políticas públicas de inclusão das minorias nas últimas décadas. Revista Eletrônica de Direito do Estado (REDE), Instituto Brasileiro de Direito Público, Número 19, julho, agosto e setembro de 2009, Salvador, disponible en internet: $\mathrm{http}: / / \mathrm{www}$.direitodoestado.com.br/rede.asp, acceso en 05.02.2010.

${ }^{620}$ Sobre este tema, se ha dicho que: "assim é que, há mais de um século, o deputado abolicionista Joaquim Nabuco pregava a necessidade de políticas públicas para se reverterem os males que a escravidão enraizou na população negra deste país." (DIAS DA SILVEIRA, Raquel. Discriminações legais em concursos públicos e o princípio da igualdade: um estudo sob o paradigma das ações afirmativas e das políticas públicas de inclusão das minorias nas últimas décadas. Revista Eletrônica de Direito do Estado (REDE), Instituto Brasileiro de Direito Público, Número 19, julho, agosto e setembro de 2009, Salvador, disponible en internet: http://www.direitodoestado.com.br/rede.asp, acceso en 05.02.2010).

${ }^{621}$ Sobre tal constatación: "Há pouca informaçao sobre a representação dos negros no serviço público civil brasileiro. O estudo não publicado do IPEA/OIT/PNUD de julho de 2004 "Raça e gênero no serviço público civil" indicou que nos cargos superiores havia $18 \%$ de homens negros e $5 \%$ de mulheres negras" (Pesquisa ENAP, Gênero, raças e competências no serviço público federal, ENAP Cadernos, Brasília, 2004, p. 20)

${ }^{622}$ Tras destacar que las universidades están reservando cotas para negros (principalmente em el Distrito Federal y Rio de Janeiro, mientras Minas Gerais preferió las cotas para personas de baja renta en la selectividad), la doctrina afirma que:"Ocorre que, em dezembro de 2001, o Supremo Tribunal Federal publicou edital de licitação, visando a contratação de servidores, para o desempenho de serviços especializados do Tribunal, no qual se previa a reserva de $20 \%$ das vagas para negros. Em 13.05.2002, o 
En este contexto, ha surgido un gran debeta entre aquellos que están a favor y los que están en contra tal medida. Los primeros afirmam que tal acción visa corrigir las injustificas sofridas por los negros al largo de la historia brasileña y que son imprescindibles para garantizar una mejora de las condiciones de vida de la población negra, que suele no tener acceso a la universidad debido a su mala formación educativa.

Los que están en contra las cotas para los negros en las universidades públicas sostienen que tanto la medida no corrige el origen del problema (la mala formación educativa), como tampoco hay un criterio objetivo para definir quiénes son los negros en Brasil, ya que buena parte de la población es mezclada.

En el ámbito de los concursos públicos, ya hay algunas iniciativas que buscan instituir cotas para negros, como hizo el Estado de Mato Grosso do Sul (Ley estadual 3594, de 10 de diciembre de 2008) que establece reserva de plazas (10\%) para negros en los concursos públicos del referido Estado. En la inscripción, el candidato debe auto declararse negro, y la falsedad de la declaración implicará en la exclusión del concurso o hasta mismo la pérdida del cargo. ${ }^{623}$

Cabe destacar que algunos tribunales ya han tenido la oportunidad de apreciar la constitucionalidad de algunas leyes que instituyen cotas para negros en los concursos públicos. En determinados casos, han considerado posible la previsión del citado mecanismo de acción positiva, como se puede ver:

governo federal instituiu o Programa Nacional de Ações Afirmativas, sob a Secretaria de Estado de Direitos Humanos e o Ministério da Justiça, destinado a mulheres, portadores de necessidades especiais e afro-descendentes. Posteriormente, a Medida Provisória $n^{\circ}$ 63, de 26.08.2002, convertida na Lei $n^{o}$ 10.558, de 13.11.2002, esta regulamentada pelo Decreto $n^{\circ} 4.876 / 2002$, instituiu o Programa Diversidade na Universidade, no âmbito do Ministério da Educação, visando propiciar o acesso ao ensino superior de afro-descendentes e índios." (DIAS DA SILVEIRA, Raquel. Discriminações legais em concursos públicos e o princípio da igualdade: um estudo sob o paradigma das ações afirmativas $e$ das políticas públicas de inclusão das minorias nas últimas décadas. Revista Eletrônica de Direito do Estado (REDE), Instituto Brasileiro de Direito Público, Número 19, julho, agosto e setembro de 2009, Salvador, disponible en internet: http://www.direitodoestado.com.br/rede.asp, acceso en 05.02.2010).

${ }^{623}$ Información extraída del reportaje Lei estadual define cota para negros em concursos públicos, publicado en el sitio JusBrasil (http://www.jusbrasil.com.br/noticias/370059/lei-estadual-define-cotapara-negros-em-concursos-publicos), acceso en 10.02.2010. 
"Em decisão unânime, a $3^{\mathrm{a}}$ Câmara Cível do TJRS determinou nomeação de candidato aprovado em concurso público para a Prefeitura Municipal de São Leopoldo, preenchendo vaga reservada a afro-brasileiros. O Colegiado confirmou ser correta a regra do edital, baseada em lei municipal que estabeleceu $12 \%$ de cotas para afrodescendentes, do total de inscritos aprovados para o cargo. Segundo o relator do recurso do Município, Desembargador Rogério Gesta Leal, o ponto de vista jurídico da matéria "não é outro senão o de garantir tratamento desigual aos desiguais, na medida de suas desigualdades." Em sua avaliação, a reserva de vagas está em sintonia com a Constituição Federal e com a legislação municipal. "Haja vista que equânime em termos de razoabilidade e proporcionalidade dos percentuais assegurados." A lei, destacou o magistrado, dispôs que os candidatos negros participariam do concurso público em igualdade de condições com os demais no que se refere ao conteúdo da prova, avaliação e critérios de aprovação. Na hipótese de não-preenchimento da cota prevista no edital, as vagas remanescentes seriam revertidas para os demais qualificados no concurso, observada a ordem de classificação" ${ }^{\prime 624}$.

No obstante la presencia de fallos con el citado, se puede afirmar que el presente tema es objeto de muchas discordancias en el medio jurídico brasileño, sea en la doctrina ${ }^{625}$ o en la jurisprudencia.

\footnotetext{
${ }^{624}$ Texto extraído del reportaje Assegurada posse no cargo de cotista negro aprovado em concurso público, publicado en el sitio JusBrasil (http://www.jusbrasil.com.br/noticias/57582/assegurada-posse-nocargo-de-cotista-negro-aprovado-em-concurso-publico), acceso en 10.02.2010.

${ }^{625}$ En este sentido, hay aquellos que aunque estén en contra tal medida, confirman su necesidad: "No nosso entendimento, a discriminação legal em concursos públicos, pelo sistema de cotas, é injusta. Mas, injusta não porque fere o princípio da igualdade ou porque, de certa forma, desmantela o princípio da eficiência no serviço público. É injusta porque o Estado não faz o que deve fazer e fica fingindo que faz. Por outro lado, se, simplesmente, negarmos as ações afirmativas, alegando a injustiça desses programas que, de fato, não promovem a inclusão, certamente corremos o risco de cometermos mais injustiças, ao ignoramos os números e os dados estatísticos referentes às minorias em nossa sociedade, permitindo, de toda forma, a permanência do regime de exclusão." (DIAS DA SILVEIRA, Raquel. Discriminações legais em concursos públicos e o princípio da igualdade: um estudo sob o paradigma das ações afirmativas e das políticas públicas de inclusão das minorias nas últimas décadas. Revista Eletrônica de Direito do Estado (REDE), Instituto Brasileiro de Direito Público, Número 19, julho, agosto e setembro de 2009, Salvador, disponible en internet: http://www.direitodoestado.com.br/rede.asp, acceso en 05.02.2010).
} 
La verdad es que los doctrinadores, en su gran mayoría, no están convencidos que la institución de cotas para negros en los concursos públicos sea una medida eficaz para la eliminación (o mismo disminución) de la desigualdad racial en Brasil. El argumento principal utilizado es que el mencionado instrumento no soluciona la causa del problema, que está relacionado a las comprobadas dificultades de una buena formación educativa para los estudiantes negros que, como en general, son pobres, suelen frecuentar los institutos públicos, donde la calidad de los servicios de educación suele ser más baja.

En este contexto, se ha destacado que:

\begin{abstract}
"A instituição de cotas em um processo seletivo deve partir da constatação de que uma igualdade existente na sociedade não se repete nos resultados deste processo por deficiências suas. Por isto, entendemos que só é legítima se aplicada no mesmo instrumento público que causa a desigualdade, onde surge o defeito. Caso contrário, serviria apenas para criar novas distorções. (...) Isto quer dizer que, se a distorção que se pretende corrigir não estiver no processo de seleção dos concursos, não podemos vislumbrar a possibilidade de adoção de ações afirmativas sem ferir o princípio de igualdade." 626
\end{abstract}

No son pocas las voces que se levantan en contra la posibilidad de creación de cotas raciales en los concursos públicos brasileños. Hay incluso aquellos que afirmar que se trata de medida discriminatoria, ya que la referida cota parte del supuesto de que los candidatos estarían en una situación de desventaja en la competición por las plazas solo por el hecho de pertenecer a determinada etnia.

En el mencionado contexto, se ha subrayado que:

"Freqüentemente, surgem projetos de lei e outras propostas de inclusão de cotas raciais e/ou sociais nos concursos públicos e no acesso às Universidades Públicas. Os defensores de tais políticas

$\overline{{ }^{626} \text { LOBELLO DE OLIVEIRA ROCHA, Francisco. Op.cit., p. } 153 .}$ 
apontam a desproporcionalidade existente entre a composição da sociedade e dos quadros do funcionalismo público com relação a certas etnias, notadamente negros, índios e seus descendentes. A adoção destes critérios de discriminação, no entanto, violaria o princípio da igualdade. Como já dissemos, a diferença que motiva a adoção de um tratamento diferenciado deve ser relevante na concretização da distorção que se pretende corrigir e a etnia do candidato é absolutamente irrelevante para os resultados que alcançará no concurso. Qualquer afirmação em sentido contrário deve ser repudiada, pois significaria dizer que determinado candidato teria desvantagem competitiva exclusivamente por pertencer a determinada etnia, o que é odioso e incompatível com o regime jurídico dos concursos públicos. Além disso, ao instituir tratamento desigual entre indivíduos, o critério adotado de ser objetivo e num país de grande miscigenação, como é o Brasil, o critério racial esbarraria também neste requisito., 627

Debido a la gran oposición respecto a las cotas raciales, hay muchas personas que defienden la institución de cotas sociales, que pasarían a tener en consideración un factor más objetivo (renta) y que comprobadamente está más asociado a la exclusión, que propiamente la raza.

Sin embargo, la referida medida también no estaría solucionando el problema de la discriminación (la ausencia de igualdad de oportunidades en la formación educativa), ya que solamente intentaría minimizar uno de sus efectos (el porcentaje de personas de baja renta que aprueban los concursos públicos).

Además, afirma la doctrina que la adopción de cotas sociales podría comprometer uno de los grandes objetivos del acceso meritorio, que es la selección de los aspirantes más aptos al ejercicio de la función pública ${ }^{628}$

\footnotetext{
${ }^{627}$ LOBELLO DE OLIVEIRA ROCHA, Francisco. Op.cit., p. 162.

${ }^{628}$ En esta línea de pensamiento: "O que há na origem desta distorção, como se sabe, é uma enorme e inegável defasagem do sistema público de ensino, e não um problema racial. Por esta razão, há quem defenda a adoção de cotas para os alunos de baixa renda, que não puderam freqüentar escolas particulares, oriundos de escolas públicas, chamadas cotas sociais. Também este critério decorre de uma falácia, pois o fator relevante para o mau desempenho destes candidatos nos concursos públicos não é o
} 
No obstante, a pesar de la coherencia de los argumentos mencionados, los mismos han de ser ponderados con otros, especialmente con la necesidad de adopción de medidas que objetiven incluir los segmentos de la sociedad brasileña que tienen pocas posibilidades efectivas de ejercer, en condiciones de igualdad con los demás ciudadanos, el derecho de acceso a la función pública. En este sentido, debe la sociedad civil y aquellos que hacen parte del medio jurídico, debatir el tema y encontrar soluciones. Sobre esta circunstancia, la doctrina ha acentuado que:

"apesar de a Constituição Federal somente ter estabelecido reserva de vagas para os deficientes físicos, nada impede que os entes federados estabeleçam novas reservas, desde que voltadas à implementação de ações afirmativas, voltadas à concretização do princípio da igualdade. Ocorre que tais reservas, como implementação de ações afirmativas, devem estar em consonância com o princípio da isonomia, evitandose, assim, a criação de privilégios injustificáveis. Neste ponto, cumpre apresentar como exemplo o parágrafo $3^{\circ}$, do art. $6^{\circ}$, da Lei Complementar do Município de Salvador $n^{\circ}$ 01/91, que implantou o sistema de cotas obrigatórias para ex-presidiários em concursos públicos municipais. Tal dispositivo, inclusive, foi objeto de Ação Direta de Inconstitucionalidade, proposta pelo Ministério Público Estadual, que tramita no Tribunal de Justiça do Estado da Bahia. Argumenta-se, na referida demanda, que o dispositivo viola o princípio da isonomia, criando um privilégio injustificável. Acrescenta que sob argumento de ajudar a inserir o ex-presidiário no convívio da sociedade, termina-se por premiar aqueles que optaram por viver à margem da cidadania, praticando todo tipo de delito. Com efeito, deve-se afirmar a constante necessidade de implementação de ações afirmativas no Brasil, levando-se em consideração as desigualdades existentes entre diversas parcelas da população. No entanto, impõe-se

fato isolado de terem estudado em escolas públicas, mas a educação de má qualidade que estas escolas lhes proporcionaram. Com efeito, há entre as escolas públicas - são raras exceções, é verdade - as que proporcionam ensino de qualidade. Assim, o erro destas políticas públicas está em querer corrigir nos concursos públicos uma distorção que está no sistema público de ensino. Seria o equivalente a combater uma epidemia de gripe com vermífugos. Por esta razão, sua adoção violaria o princípio da igualdade. Violaria também o princípio da eficiência, por contratar servidores menos eficientes, e o postulado da razoabilidade por impor restrições desnecessárias ao direito fundamental de acesso a cargos e empregos públicos dos demais candidatos." (LOBELLO DE OLIVEIRA ROCHA, Francisco. Op.cit., p. 162). 
também atentar para a forma de efetivação das referidas ações que devem estar pautadas em justificativas capazes de demonstrações concretas de real eficácia." ${ }^{629}$

\subsection{7 - Cuestiones religiosas}

Así como la raza, la imposición del criterio religión como requisito de acceso a la función pública es algo que solamente puede pasar en situaciones muy anormales en Brasil y en España, debido a que sus Constituciones han consagrado la idea de Estado laico y han garantizado la libertad de credo.

No obstante, hay, al menos, dos grandes repercusiones de la religión en el acceso a la función pública brasileña y española: a) la posibilidad de exigencia de determinada religión para el ejercicio de funciones docentes (enseñanza de religión en las escuelas públicas); y b) la determinación de las fechas para la realización de las pruebas puede ser problemática para los creyentes de determinada religión; especialmente cuando los referidos días son considerados consagrados.

En el derecho español, como ya se ha destacado, la Constitución de 1978 garantiza la libertad religiosa y de culto ${ }^{630}$. Además, también declara el carácter laico del Estado, aunque haga expresa referencia al catolicismo ${ }^{631}$.

Otra norma constitucional que posee relevancia en la presente investigación es la consagrada en el art. 27.3, que trata de la enseñanza religiosa ("Los poderes públicos garantizan el derecho que asiste a los padres para que sus hijos reciban la formación religiosa y moral que esté de acuerdo con sus propias convicciones").

\footnotetext{
${ }^{629}$ TOURINHO, Rita. Op.cit., p. 135.

630 "Art. 16. 1. Se garantiza la libertad ideológica, religiosa y de culto de los individuos y las comunidades sin más limitación, en sus manifestaciones, que la necesaria para el mantenimiento del orden público protegido por la Ley. 2. Nadie podrá ser obligado a declarar sobre su ideología, religión o creencias".

631 “Art. 16. 3. Ninguna confesión tendrá carácter estatal. Los poderes públicos tendrán en cuenta las creencias religiosas de la sociedad española y mantendrán las consiguientes relaciones de cooperación con la Iglesia Católica y las demás confesiones".
} 
Para alcanzar la efectividad de la regla encima destacada, las Administraciones Públicas españolas deberán garantizar la enseñanza religiosa, que a su vez, exigirá profesionales capacitados a impartir los conocimientos, dogmas y demás aspectos correspondientes a determinados credos religiosos.

En el ámbito de la legislación, se ha afirmado que:

\begin{abstract}
"Ha sido proverbial la cautela del legislador español, a lo largo de casi tres décadas, para acometer el problema del régimen jurídico del profesorado de religión. Es indudable que el asunto, en efecto, se ha percibido siempre como problemático. No sin motivo. Cualquiera alcanza a comprender que se trata de un terreno erizado de dificultades, en el que no caben soluciones simples. Se encuentran implicados derechos fundamentales --como el de los padres que solicitan la formación moral de sus hijos-- y derechos de los trabajadores, todo ello adobado con la presencia del siempre peculiar elemento religioso" ${ }^{\prime 632}$.
\end{abstract}

En la actualidad, la enseñanza religiosa está regulada por la Ley Orgánica 2/2006, de 03 de mayo, que ha dedicado las disposiciones adicionales segunda y tercera para la enseñanza de la religión y para el profesorado de religión, respectivamente. ${ }^{633}$

\footnotetext{
${ }^{632}$ OTADUY, Jorge. Relación jurídica de los profesores de religión en España. La dimensión canónica. Extraído del sitio electrónico http://www.accessmylibrary.com/article-1G1-160029695/relacion-juridicade-los.html, publicado en 01 de julio de 2006, acceso en 07.06.2010.

633 “DISPOSICIÓN ADICIONAL SEGUNDA. Enseñanza de la religión. 1. La enseñanza de la religión católica se ajustará a lo establecido en el Acuerdo sobre Enseñanza y Asuntos Culturales suscrito entre la Santa Sede y el Estado español. A tal fin, y de conformidad con lo que disponga dicho acuerdo, se incluirá la religión católica como área o materia en los niveles educativos que corresponda, que será de oferta obligatoria para los centros y de carácter voluntario para los alumnos. 2. La enseñanza de otras religiones se ajustará a lo dispuesto en los Acuerdos de Cooperación celebrados por el Estado español con la Federación de Entidades Religiosas Evangélicas de España, la Federación de Comunidades Israelitas de España, la Comisión Islámica de España y, en su caso, a los que en el futuro puedan suscribirse con otras confesiones religiosas.

DISPOSICIÓN ADICIONAL TERCERA. Profesorado de religión. 1. Los profesores que impartan la enseñanza de las religiones deberán cumplir los requisitos de titulación establecidos para las distintas enseñanzas reguladas en la presente Ley, así como los establecidos en los acuerdos suscritos entre el Estado Español y las diferentes confesiones religiosas. 2. Los profesores que, no perteneciendo a los cuerpos de funcionarios docentes, impartan la enseñanza de las religiones en los centros públicos lo harán en régimen de contratación laboral, de conformidad con el Estatuto de los Trabajadores, con las respectivas Administraciones competentes. La regulación de su régimen laboral se hará con la participación de los representantes del profesorado. Se accederá al destino mediante criterios objetivos de igualdad, mérito y capacidad. Estos profesores percibirán las retribuciones que correspondan en el
} 
A partir de la lectura de los dispositivos citados, se percibe algunas circunstancias: primeramente, que debido a su tradición católica, la enseñanza de la mencionada religión ha recibido del Estado un trato más profundizado, tanto que desde el año de 1979 existe el Acuerdo sobre Enseñanza y Asuntos Culturales suscrito entre la Santa Sede y el Estado español ${ }^{634}$.

Cabe subrayar que la Ley Orgánica 02/2006 ha establecido, en la disposición adicional tercera, que el cuerpo docente relativo a la enseñanza religiosa en los centros públicos, que, "no perteneciendo a los cuerpos de funcionarios docentes" (...) "se accederá al destino mediante criterios objetivos de igualdad, mérito y capacidad", y que su vinculo con la Administración Pública será "en régimen de contratación laboral, de conformidad con el Estatuto de los Trabajadores”.

Sin embargo, en el Acuerdo sobre Enseñanza y Asuntos Culturales suscrito entre la Santa Sede y el Estado español se prevé que:

"Art. 3". En los niveles educativos a los que se refiere el artículo anterior, la enseñanza religiosa será impartida por las personas que, para cada año escolar, sean designadas por la autoridad académica entre aquellas que el ordinario diocesano proponga para ejercer esta enseñanza. Con antelación suficiente, el ordinario diocesano comunicará los nombres de los profesores y personas que sean consideradas competentes para dicha enseñanza".

respectivo nivel educativo a los profesores interinos. En todo caso, la propuesta para la docencia corresponderá a las entidades religiosas y se renovará automáticamente cada año. La determinación del contrato, a tiempo completo o a tiempo parcial según lo que requieran las necesidades de los centros, corresponderá a las Administraciones competentes. La remoción, en su caso, se ajustará a derecho".

${ }^{634}$ Respecto a las otras religiones, se ha dicho que: "la instrucción religiosa no-católica-reconocida y protegida por la Constitución española y por los acuerdos "cuasi-concordatos" firmados entre 1992 y 1996 con las comunidades musulmanas, protestantes y judias- no ha existido en la práctica hasta hace mиy росо tiempo”.(DIETZ, Gunther. La educación religiosa en España ¿Contribución al diálogo interculturalo factor de confl icto entre religiones?, Estudios sobre las culturas contemporáneas, vol. XIV, número 28, diciembre 2008, pp. 11-46, Universidad de Colima (Colima-Mexico), extraído del sitio electrónico http://redalyc.uaemex.mx/src/inicio/ArtPdfRed.jsp?iCve=31602802, acceso en 07 de junio de 2010. 
En los términos arriba destacados, se puede afirmar que el acceso de los profesores para la enseñanza de la religión católica, según el mencionado documento firmado entre el Estado español y la Iglesia Católica, depende de la intervención de esta última, aunque se trate de centros públicos.

La interposición de una tercera figura, entre el Estado y los aspirantes, puede comprometer el derecho del ciudadano acceder de forma igualitaria a un puesto de trabajo en la Administración Pública, aunque este no sea de funcionario. Lo que pasa es que no hay la garantía de que la Iglesia Católica (o otra que tenga la misma prerrogativa) indique de forma objetiva las personas que pueden enseñar religión en las escuelas públicas. En este sentido, se ha destacado que:

"los potenciales maestros de la ER tienen que obtener la Declaración Eclesiástica de Idoneidad, una especie de Missio Canónica que certifique su formación suplementaria en teología y enseñanza religiosa católicas, y deben pasar una entrevista individual -referente a la congruencia entre las enseñanzas de la Iglesia y su vida personal, valores y conducta moral- con los representantes de la Comisión Episcopal de la Enseñanza (Comisión Episcopal de Enseñanza y Catequesis, 2001; Fernández Almenara, 2001). En la última década, la mencionada Comisión de Enseñanza de la Iglesia empezó a suspender a aquellos maestros de ER que en la vida personal no cumplen con la moral católica, como respuesta defensiva a los procesos de secularización que han tenido lugar dentro de la sociedad española y, sobre todo, a la creciente brecha surgida entre las normas y los valores regentes para la mayoría, por un lado, y la posición oficial de la Iglesia Católica sobre la familia tradicional y los valores de género, por otro. Ahora, protegida por un decreto de 1998, que excluye a los maestros de ER de las prestaciones legales de los convenios colectivos, la Iglesia tiene la posibilidad de despedir a todos aquellos maestros que se divorcian, que se casan con una pareja divorciada, que expresan simpatía por la homosexualidad o que de cualquier otra manera expresan sus opiniones y reivindicaciones -derechos 
constitucionales como el derecho a huelga o el derecho al convenio colectivo- que sean contrarias a las posturas católicas oficiales" ${ }^{\text {635. }}$.

A partir del análisis de las normas de la Ley Orgánica 2/2006 y del Acuerdo sobre Enseñanza y Asuntos Culturales suscrito entre la Santa Sede y el Estado español, se constata una difícil armonización entre los dispositivos citados:

"El motivo de fondo por el cual la citada disposición adicional tercera de la LOE resulta criticable es que ignora la existencia de un Acuerdo con la Santa Sede, que es una pieza insustituible del sistema que se desea configurar. Llama poderosamente la atención el cuidado con el que se consigue soslayar la referencia al mencionado texto pacticio en todos y cada uno de los momentos en que esa referencia podría encontrar sentido: en el inicio de la relación, que reclama la propuesta del Ordinario, en la regulación del régimen laboral, en el acceso al destino y en la remoción. Silencios tan clamorosos sólo pueden ser reflejo de una voluntad política fuertemente determinada en conducir el desarrollo de la Ley por la misma senda del desconocimiento de las normas pacticias establecidas con la Santa Sede. ${ }^{\text {,636. }}$

Así, conviene que haya un mejor desarrollo reglamentario de las disposiciones de la Ley Orgánica 2/2006, a fin de que puedan ser garantizados a la vez los derechos constitucionales que asiste a los padres para que sus hijos reciban la formación religiosa (art. 27.3) y el que trata del acceso igualitario a la función pública $(\text { art. 23.2) })^{637}$.

\footnotetext{
${ }^{635}$ DIETZ, Gunther. La educación religiosa en España ¿Contribución al diálogo interculturalo factor de confl icto entre religiones?, Estudios sobre las culturas contemporáneas, vol. XIV, número 28, diciembre 2008, pp. 11-46, Universidad de Colima (Colima-Mexico), extraído del sitio electrónico http://redalyc.uaemex.mx/src/inicio/ArtPdfRed.jsp?iCve=31602802, acceso en 07 de junio de 2010.

${ }^{636}$ OTADUY, Jorge. Relación jurídica de los profesores de religión en España. La dimensión canónica. Extraído del sitio electrónico http://www.accessmylibrary.com/article-1G1-160029695/relacion-juridicade-los.html, publicado en 01 de julio de 2006, acceso en 07.06.2010.

${ }^{637} \mathrm{El}$ tema en España es muy polémico, como se puede percibir en este reportaje publicado poco antes de la aprobación de la Ley Orgánica 02/2006: "Con el anuncio de la inmediata eliminación de la materia de religión en las escuelas como curso con valor crediticio y el cambio de régimen para los docentes, el Partido Socialista Obrero Español (PSOE) sentenció el próximo fin de la educación religiosa en España y la violación del Concordato firmado entre el Estado y la Santa Sede en 1978. La responsable socialista de Educación, Universidades y Cultura, Carmen Chacón, declaró en una entrevista que "la primera decisión del PSOE va a ser derogar" lo que ella considera la "imposición de la Religión obligatoria". Con esta medida se elimina la reforma educativa del gobierno del Partido Popular (PP) que, con la Ley
} 
En Brasil, la Constitución Federal de 1988 garantiza el derecho fundamental de libertad religiosa, en el art. 5\%, VI ("é inviolável a liberdade de consciência e de crença, sendo assegurado o livre exercício dos cultos religiosos e garantida, na forma da lei, a proteção aos locais de culto e a suas liturgias").

A su vez, el apartado VII del art. $5^{\circ}$ determina que "é assegurada, nos termos da lei, a prestação de assistência religiosa nas entidades civis e militares de internação coletiva", mientras que el apartado VIII impone que "ninguém será privado de direitos por motivo de crença religiosa ou de convicção filosófica ou política, salvo se as invocar para eximir-se de obrigação legal a todos imposta e recusar-se a cumprir prestação alternativa, fixada em lei”.

También establece la Carta Magna brasileña, en lo que se refiere al tema bajo análisis que "o ensino religioso, de matrícula facultativa, constituirá disciplina dos horários normais das escolas públicas de ensino fundamental” (art. $210 . \S 1^{\circ}$ ).

En los términos subrayados, respecto al acceso a la función pública, algunas consecuencias derivan de las citadas normas constitucionales que tratan de la religión. En este contexto, se va a empezar por la cuestión que se ha analizado en el derecho español: la enseñanza religiosa y la necesidad de selección igualitaria de aquellos que van a impartir tal asignatura.

Orgánica de Calidad de la Educación (LOCE), estableció una nueva área denominada Sociedad, Cultura y Religión, con dos ramas optativas, evaluables y computables en la nota media: una confesional y otra no confesional. El anuncio del PSOE significa en la práctica la reedición de las condiciones del controvertido régimen educativo del gobierno socialista de Felipe González que en la práctica, eliminó la educación religiosa al convertirla en una materia sin valor crediticio, es decir, que no tenía ni calificación ni valor alguno en el currículo educativo. Los obispos españoles han expresado más bien su respaldo al avance en "el ejercicio de la libertad religiosa y de opinión" que suponía la LOCE. Según los obispos, al ofrecer una "formación de calidad acerca del hecho religioso", independientemente de la opción personal en este ámbito, "la nueva regulación de la enseñanza de la Religión conjuga la libertad con la calidad". En otro momento de la entrevista la portavoz socialista anunció también que los docentes "van a regirse por el Estatuto de los Trabajadores, el Estatuto de Autonomía y la Constitución Española”. La medida significará en la práctica la violación del Concordato entre España y la Santa Sede; ya que dicho acuerdo garantiza el derecho de la Iglesia católica a seleccionar a los profesores de religión de acuerdo a su idoneidad académica y moral. Si la selección de profesores de religión se guía según el estatuto de trabajadores, un obispo, por ejemplo, no podría relevar de su puesto a un profesor de religión que enseñara doctrina contraria a la Iglesia o se encontrara en una situación flagrantemente inmoral" (Texto extraído del reportaje PSOE anuncia fin de educación religiosa y violación del Concordato con la Santa Sede, publicado en el sitio electrónico Aciprensa (http://www.aciprensa.com/noticia.php?n=3863), en el día 22 de marzo de 2004 y con acceso en 07 de junio de 2010. 
Según el art. 210, $§ 1^{\circ}$ de la Constitución brasileña (ya transcripto), deberán las esculas públicas de enseñanza fundamental (lo que corresponde a la primaria y secundaria en España) ofrecer la asignatura religión, lo que ciertamente demandará profesionales del área ${ }^{638}$.

Delante de la necesidad mencionada, la cuestión que se presente es si es posible exigir como requisito de acceso a la función pública que el aspirante sea un profundo entendido o hasta mismo creyente de determinada religión.

Respecto a esta polémica, debe ser destacada a escasa cuantidad de juristas que se han dedicado a su análisis. En este contexto, se ha afirmado que:

\begin{abstract}
"A matrícula do aluno na disciplina é facultativa, mas a escola pública está obrigada a proporcionar o ensino religioso, o que pressupõe a admissão de professores com formação religiosa, trazendo sérios problemas para o concurso público de ingresso. A questão religiosa, na verdade, no Brasil, até o momento, possivelmente, pelo acentuado desequilíbrio de forças em relação ao catolicismo, não apresentou maior gravidade, mas foi aqui suscitada porque, agora, no Brasil, assiste-se ao crescimento acentuado de outras religiões e no mundo todo símbolos e costumes religiosos estão deflagrando conflitos e exigindo uma tomada de posição por parte da Administração Pública, alertando para que, pelo menos, se comece a pensar nesse assunto." 639
\end{abstract}

Hasta el día de hoy, como no se sabe muy bien cuál es el contenido que debe ser impartido en las clases de religión (si debe ser confesional o ecuménico), esto repercute directamente en las exigencias para admimisión de los profesores de enseñanza religiosa en Brasil, pues, por ejemplo, si los contenidos de la enseñaza

\footnotetext{
${ }^{638}$ La Ley de Diretrices y Bases de la Educación (Ley 9.394 de 20 de diciembre de 1996 con redacción alterada por la Ley 9475, de 22 de julioo de 1997), determina que: "Art.33 - O ensino religioso, de matrícula facultativa, é parte integrante da formação básica do cidadão e constitui disciplina dos horários normais das escolas públicas de ensino fundamental, assegurado o respeito à diversidade cultural religiosa do Brasil, vedadas quaisquer formas de proselitismo. $\S 1^{\circ}$ - Os sistemas de ensino regulamentarão os procedimentos para a definição dos conteúdos do ensino religioso e estabelecerão as normas para a habilitação e admissão dos professores. $\$ 2^{\circ}$ Os sistemas de ensino ouvirão entidade civil, constituída pelas diferentes denominações religiosas, para definição dos conteúdos do ensino religioso".

${ }^{639}$ ABREU DALLARI, Adilson. Princípio da isonomia e concurso público, en Concurso público e Constituição, Fabrício Motta (Cordinador), Editora Fórum, Belo Horizonte, 2005, p. 107.
} 
religiosa es confesional católica o protestante, solamente personas que han tenido la referida formación estarán aptas a impartir las referidas clases.

En el citado contexto, el Consejo Nacional de Educación emitió informe (Parecer CP/CNE 097/99) que merece ser citado para que sea destacada la referida ausencia de parâmetros:

“a lei 9475 nao se refere à formaçao de professores, isto é, ao estabelecimento de cursos que habilitem para esta docência, mas atribui aos sistemas de ensino tão somente o estabelecimento de normas para habilitaçao e admissao de professores (...), considerando estas questoes é preciso evitar que o Estado interfira na vida religiosa da populaçao e na autonomia dos sistemas de ensino (...) não cabe à Uniao determinar direta ou indiretamente, conteúdos curriculares que orientem a formação religiosa dos professores, o que interferiria tanto na liberdade de crença como nas decisões dos estados e dos municípios referente à organizaçao dos cursos em seus sistemas de ensino" 640

Otra cuestión polémica dice respecto a la posibilidad de las leyes crearen cargos de "capelães militares", para prestar, en la forma del art. 5', VII CB, la asistencia religiosa en los organismos militares, como las Fuerzas Armadas.

En este contexto, la Ley 6923, de 29 de junio de 1981, en su art. $4^{\circ}$ que: “ $O$ Serviço de Assistência Religiosa será constituído de Capelães Militares, selecionados entre sacerdotes, ministros religiosos ou pastores, pertencentes a qualquer religião que não atente contra a disciplina, a moral e as leis em vigor."

A su vez, para que hubiera al menos el respecto a la diversidad religiosa de la tropa, la referida ley previó que: “Art. . 10. Cada Ministério Militar atentará para que, no posto inicial de Capelão Militar, seja mantida a devida proporcionalidade entre os Capelães das diversas regiões e as religiões professadas na respectiva Força".

\footnotetext{
${ }^{640}$ Informe extraído del texto Ensino religioso na escola pública: o retorno de uma polêmica recorrente, elaborado por Carlos Roberto Jamil Cury, Revista Brasileira de Educaçao, set-out-nov-dez 2004, São Paulo, p. 183-191, publicado en el sitio electrónico http://redalyc.uaemex.mx/redalyc/pdf/275/27502713.pdf, acceso en 07 de junio de 2010.
} 
No lugar a dudas que las dificultades para seleccionar los referidos servidores militares son inmensas ${ }^{641}$, especialmente si no se quiere transgredir el derecho constitucional de acceso igualitario a la función pública, así como el igualmente constitucional derecho de libertad religiosa.

La última cuestión que será investigada tiene consecuencia directa en la realización de las pruebas en el proceso selectivo: tratase de la definición de las fechas en las cuales los ejercicios van a realizarse. Tras el estudio del citado tema, se ha percibido que el mismo es muy debatido en Brasil, y casi nunca es mencionado en el medio jurídico español.

En el contexto antes destacado, se ha afirmado en la doctrina brasileña que "não se pode tolher direitos ou impor obrigações a quem professe qualquer espécie de religião, sendo que a imposição de data e horário de provas, exames e concursos públicos, em colidência com a crença religiosa de qualquer pessoa, afronta direitos fundamentais insculpidos nos incisos VI e VIII do artigo $5^{\circ}$ de nossa Carta Magna."642

El hecho de que determinados aspirantes profiesan religiones que consagran determinados días y horários como sagrados los impide de participar de distintas actividades, lo que hace con que la Administración Pública tenga que actuar con la debida cautela, cuando defina las fechas de las pruebas en los concursos públicos. ${ }^{643}$

\footnotetext{
${ }^{641}$ De la misma forma, se puede afirmar que son inmensas las dificultades para ser seleccionado para el referido cargo, como se puede percibe en la ley citada. "Art. . 18 Para o ingresso no Quadro de Capelães Militares será condição o prescrito no art. $4^{\circ}$ desta Lei, bem como:

I - ser brasileiro nato;

II - ser voluntário;

Ill - ter entre 30 (trinta) e 40 (quarenta) anos de idade;

$I V$ - ter uso de formação teológica regular de nível universitário, reconhecido pela autoridade eclesiástica de sua religião;

$V$ - possuir, pelo menos, 3 (três)anos de atividades pastorais;

VI - ter consentimento expresso da autoridade eclesiástica da respectiva religião;

VII - ser julgado apto em inspeção de saúde; $e$

VIII - receber conceito favorável, atestado por 2 (dois) oficiais superiores da ativa das Forças Armadas".

642 SOARES JÚNIOR, Jair. Estado laico versus direito constitucional à liberdade de crença religiosa.Uma análise crítica acerca da imposição de data e horário de provas, exames e concursos público em colidência com crenças religiosas, texto extraído del sitio Jus Navigandi (), elaborado en 14.01.2010, acceso en 16.02.2010).

${ }^{643}$ Así: "plenamente amparado pela Constituição, no artigo 5o, incisos, VI e VIII, o discrímen utilizado para diferenciar a situação dos candidatos em provas, exames ou concursos públicos que professem religião cujos dogmas determinem o resguardo ao sábado, com relação aos demais candidatos que
} 
En el caso de la Administración haya definido como fecha de las pruebas determinado dia consagrado por cierta religión, la doctrina brasileña llega a admitir la posibilidad de que los candidatos de tal religión realicen los ejercicios en momentos distintos de los demás, siempre que no haya riesgo de transgresión del deber de sigilo. ${ }^{64}$

Tras comentar los efectos de los apartados VI y VIII de la Constitución brasileña, la doctrina acentua que

\begin{abstract}
"Ambos os incisos do art. $5^{\circ}$, acima referidos, podem trazer sérias conseqüências no tocante a horários de trabalho, e quanto ao desempenho de certas funções, em razão da incompatibilidade com convicções religiosas.(...) Certamente uma autoridade pública que, inocentemente, inadvertidamente, marcasse a realização de um concurso público para o dia do yon kipur (feriado máximo da religião judaica), correria o sério risco de responder pelo crime de racismo, sob acusação de anti-semitismo" 645
\end{abstract}

realizarão esse hipotético certame e que não professem religião que possua tal dogma. Destarte, para que não haja transtorno à Administração Pública e aos demais candidatos, é recomendável que as provas, exames ou concursos públicos não sejam realizadas em dias ou em horários que, de antemão, já se saiba que confronta determinado dogma religioso. Não se pretende subordinar o Estado e à Administração Pública a determinado dogma religioso, mas sim usar de cautela e de bom senso para que se concilie princípios fundamentais da Constituição da República, tais como a liberdade de crença religiosa, o acesso aos níveis mais elevados do ensino e o livre acesso aos cargos públicos. Como medida alternativa, caso não seja possível a alteração da data de realização da prova, exame ou concurso público, afigura-se-nos que a melhor medida a ser tomada pela Administração Pública será a alteração de horário para a realização das provas pelos candidatos em situação distinta dos demais, disponibilizando sala própria, com monitor, para que o início da realização das provas seja compatível com a doutrina religiosa seguida pelo candidato. Dessa forma, não se causará prejuízo para a realização das provas, para o candidato em situação excepcional em razão de sua doutrina religiosa, nem aos demais candidatos do certame." (SOARES JÚNIOR, Jair. Estado laico versus direito constitucional à liberdade de crença religiosa.Uma análise crítica acerca da imposição de data e horário de provas, exames e concursos público em colidência com crenças religiosas, texto extraído del sitio Jus Navigandi (), elaborado en 14.01.2010, acceso en 16.02.2010.

${ }^{644}$ En este sentido: "As provas são realizadas em data, hora e local previamente anunciados, ao mesmo tempo, a todos os candidatos, garantindo-se, assim, o princípio da isonomia. Logo, a simultaneidade é importante para garantir o sigilo das provas. Em algumas situaçoes, no entanto, a simultaneidade poderá ser quebrada. Assim, tem-se como exemplo a situação de candidato que por limitações religiosas não pode se submeter a exames em determinado dia e horário. Porém, em qualquer caso jamais se admitirá a quebra do sigilo, sob pena de nulidade do certame." (TOURINHO, Rita. Concurso público no ordenamento jurídico brasileiro, Lumen Juris Editora, Rio de Janeiro, 2008, p. 83).

${ }^{645}$ ABREU DALlARI, Adilson. Princípio da isonomia e concurso público, en Concurso público e Constituição, Fabrício Motta (Cordinador), Editora Fórum, Belo Horizonte, 2005, p. 107. 
Seguramente, hay juristas (así como Tribunales ${ }^{646}$ ) que expresan um punto de vista más moderado, destacando que hay la necesidad de compatibilización entre el la libertad de credo y la exigencia de somisón a reglas identicas entre todos los candidatos, y cuando tal armonía ocurre, es posible haber la concesión de trato diferenciado por motivos religiosos ${ }^{647}$.

En la realidad brasileña, el gran debate relativo al horario de las pruebas envuelve los candidatos seguidores de la Iglesia Adventista, que no pueden dedicarse a distintas actividades durante el sábado, por el día.

En general, cuando das pruebas de los procesos selectivos son previstas para el sábado por el día, los candidatos adventistas se insurgen contra este hecho, y cuando

\footnotetext{
646 Para ejemplificar el entendimiento de los Tribunales brasileños: "CONSTITUCIONAL. ADMINISTRATIVO. CONCURSO PÚBLICO. IMPETRANTE MEMBRO DA IGREJA ADVENTISTA DO SÉTIMO DIA. PROVA DE DIGITAÇÃO PREVISTA NO EDITAL PARA SER REALIZADA EM DOIS DIAS, SÁBADO OU DOMINGO. POSSIBILIDADE DE ESCOLHA, PELA AUTORIDADE IMPETRADA, DE DATA QUE NÃO IMPORTE OFENSA À LIBERDADE RELIGIOSA. INTERPRETAÇÃO DO CASO À LUZ DO PRINCÍPIO DA MÁXIMA EFETIVIDADE EM MATÉRIA DE DIREITOS FUNDAMENTAIS. 1. A realização de prova em concurso público, por força da liminar concedida, não exaure o objeto do mandado de segurança. Sendo possível que a autoridade impetrada persista na prática do ato aqui discutido ou invalide os atos subseqüentes do concurso, subsiste o interesse processual da impetrante quanto ao julgamento de mérito. 2. Incidência da regra do art. 515, $\S 3^{\circ}$, do Código de Processo Civil. 3. A liberdade religiosa e o direito de não ser privado de direitos por motivos religiosos (art. $5^{\circ}$, VI e VIII, da CF 88), como quaisquer direitos fundamentais, não são absolutos. Aplica-se a eles, no entanto, o princípio da máxima efetividade em matéria de hermenêutica constitucional, que impõe um resultado de interpretação que dê a esses direitos maior eficácia possível. 4. Alegações de desrespeito à isonomia e à impessoalidade administrativa, assim como à vinculação ao edital, que não se aplicam ao caso, já que o próprio edital previu a realização da prova em dias distintos e que vários outros candidatos se submeteram à prova no domingo. 5. Permitido ao administrador público que designasse, de forma indiferente, um ou outro dia para realização da prova da impetrante, a interpretação que melhor se afeiçoa à máxima efetividade da liberdade religiosa seria aplicá-la no domingo, juntamente com os diversos outros candidatos ao mesmo certame, sem desrespeitar os valores constitucionais e legais próprios do concurso público e mesmo sem maiores contratempos administrativos. 6. Apelação a que se dá provimento."(TRF da 3ª Região, AMS 200261000000265, 3ª Turma, Rel. Des. Federal Renato Barth, unânime, DJ 22/02/2006, p. 266) “

${ }^{647}$ Para ejemplificar esta línea de pensamiento: "Entendemos que, em linha de princípio, o administrado não poderá invocar sua convicção religiosa no afã de obter tratamento diferenciado no que concerne à realização das provas, em face do tratamento isonomico que deve ser dispensado para todos os candidatos (...) Por outro lado, se nas circunstâncias em que forem realizadas as provas for possível compatibilizar o exercício da liberdade de crença com o interesse público - princípio da concordância prática -, a Administração Pública é obrigada a adotar as providências necessárias no sentido de fornecer ao candidato as condições necessárias para fazer valer suas prerrogativas constitucionais" (BARBOSA MAIA, Márcio, y PINHEIRO DE QUEIROZ, Ronaldo. O regime jurídico do concurso público e o seu controle jurisdicional, Editora Saraiva, São Paulo, 2007, p. 120).
} 
no consiguen solucionar administrativamente tal problema, demandan el Estado para obtener el derecho de realizar las pruebas en otro horario. ${ }^{648}$

Muchos fallos judiciales han reconocido el referido derecho: ${ }^{649}$ Sin embargo, hay otros que negan la existencia del mencionado derecho, destacando que la definición de nuevo horario para la realización de las pruebas por determinados candidatos transgride la exigencia de igualdad de trato. ${ }^{650}$

${ }^{648}$ Es lo que sucedió el siguiente caso: "A fé move montanhas. E muda os horários de provas. Um candidato a juiz do trabalho substituto em Santa Catarina obteve na Justiça Federal o direito de prestar a primeira prova do concurso, marcada para um sábado, somente após o pôr-do-sol. A prova está marcada para acontecer no próximo sábado, dia 27, a partir das 13h30. Ocorre que o candidato é membro da Igreja Adventista do Sétimo Dia. Os adventistas observam o preceito religioso de guardar o sábado bíblico, que começa no pôr-do-sol de sexta-feira e termina no pôr-do-sol de sábado. Para garantir a mudança no horário da prova, o candidato apelou à Justiça. Na segunda-feira, dia 22, o juiz. da $2^{a}$ Vara Federal de Florianópolis, Carlos Alberto da Costa Dias, concedeu liminar que garante ao candidato participar da prova em horário diferente dos demais. Conforme a decisão do juiz, " $a$ possibilidade de acesso aos cargos públicos é direito de todos, sem discriminação de crença. Aqueles que professam a fé Adventista do Sétimo Dia ficam alijados de participar de concurso em data que medeie o sábado bíblico", sentenciou. Dias fundamentou a decisão na Constituição Federal, que assegura o direito à liberdade de consciência e de crença. Cabe recurso ao Tribunal Regional Federal da $4^{a}$ Região (TRF4). A comissão organizadora do concurso público, no entanto, não concorda com o argumento do candidato porque entende que o privilégio ao adventista caracterizaria pressão ideológica da religião contra o Estado laico. O juiz negou a tese dos organizadores, destacando que "o simples fato de prestar provas em separado não significa que o concurso seja regido pela religião". Outro argumento usado pela organização do concurso referiu-se a incompatibilidade do candidato, caso venha a ser aprovado, em exercer suas funções aos sábados. Todavia, o juiz da $2^{a}$ Vara Federal de Florianópolis, entendeu que compete à Corregedoria "verificar a conveniência e oportunidade da compatibilidade do exercício profissional com o horário de dedicar-se ao culto religioso”. Processo no 2004.72.00.017" (Información obtenida en el reportaje Justiça privilegia candidato em concurso por motivo religioso, texto extraído del sitio Consultor Jurídico (http://www.conjur.com.br/2004-nov23/justica_privilegia_candidato_concurso_motivo_religioso), publicado en 23.11.2004, acceso en 16.02.2010).

649 "MANDADO DE SEGURANÇA. CONCURSO PÚBLICO. LIBERDADE DE CRENÇA RELIGIOSA. INCISOS VI E VIII DO ARTIGO $5^{\circ}$ DA CF/88. ADVENTISTAS DO $7^{\circ}$ DIA. MEDIDA LIMINAR DEFERIDA PARA ASSEGURAR A REALIZAÇÃO DA PROVA EM HORÁRIO ESPECIAL. SEGURANÇA CONCEDIDA.1. Candidato/impetrante membro da Igreja Adventista do $7^{\circ}$ dia, que tem como um de seus pilares a guarda do sábado, restando ferido seu direito constitucional de liberdade de consciência religiosa, previsto nos incisos VI e VIII do art. $5^{\circ}$ da CF, se imposta a realização da prova nesse dia. Além do mais, o condutor monocrático ao deferir a liminar determinou que os impetrantes chegassem no horário normal de realização das provas e ficassem incomunicáveis em sala diversa dos demais candidatos até às 18 horas, quando lhe seria facultada a realização da prova objetiva 1 , com término às $22 \mathrm{~h}$ do mesmo dia. (grifou-se). 2 Não afeta direito de terceiro ou o interesse público, permitir a realização de prova de concurso público no dia seguinte àquele que, por imposição de fé religiosa, não pode participar de atividades civis, profanas, no dia do sábado. Precedente da Corte Especial: MS 2007.01.00.043148-4/DF, Rel. Desembargador Federal Jirair Aram Meguerian, Corte Especial,e-DJF1 p. 22 de 05/05/2008. 3. Apelação e remessa, não providas". (Mandado de Segurança 2004.34.00.0086881/DF, Rel. Juiz Federal Avio Mozar Jose Ferraz de Novaes, Quinta Turma, e-DJF1 p.354 de 10/12/2008). 650 "RECURSO ORDINÁRIO EM MANDADO DE SEGURANCA. CONCURSO PÚBLICO. POLICIAL MILITAR. ADVENTISTA DO SÉTIMO DIA. TESTE DE CAPACIDADE FÍSICA. REALIZAÇÃO EM DIA DIVERSO DO PROGRAMADO. LIMINAR DEFERIDA. SITUAÇÃO DE FATO CONSOLIDADA. IMPOSSIBILIDADE. ISONOMIA E VINCULAÇÃO AO EDITAL. RECURSO DESPROVIDO. I - A liminar foi deferida quando a recorrente, por ter deixado de realizar o teste de aptidão física na data 
En el ámbito de la legislación, el Estado de Sao Paulo creó la Ley 12.142 $2^{651}$, de 8 de diciembre de 2005, que contempla la prohición de la realización de procesos selectivos (incluso, concursos públicos) en el sábado.

Como se trata de una norma polémica (en el sentido de que es poco usual), merece la pena transcribir el contenido de la referida ley:

“Art. $1^{o}$. As provas de concurso público ou processo seletivo para provimento de cargos públicos e os exames vestibulares das universidades públicas e privadas serão realizados no período de domingo a sexta-feira, no horário compreendido entre as 8 he as $18 \mathrm{~h}$. $\S 1^{o}$ - Quando inviável a promoção de certames em conformidade com o "caput", a entidade organizadora poderá realizá-los no sábado, devendo permitir ao candidato que alegar motivo de crença religiosa a possibilidade de fazê-los após as 18 h.

$\S 2^{\circ}$ - A permissão de que trata o parágrafo anterior deverá ser precedida de requerimento, assinado pelo próprio interessado, dirigido à entidade organizadora, até 72 (setenta e duas) horas antes do horário de início do certame.

$\S 3^{o}$ - Na hipótese do $\S 1^{o}$, o candidato ficará incomunicável desde o horário regular previsto para os exames até o início do horário alternativo para ele estabelecido previamente".

prevista em edital de convocação, já estava eliminada do certame. Ao ser cassada pelo e. Tribunal a quo, quando do julgamento final do mandamus, a recorrente voltou à situação anterior de candidato eliminado do concurso, razão por que não poderia prosseguir no certame. II - O direito à liberdade de crença, assegurado pela Constituição da República, não pode almejar criar situações que importem tratamento diferenciado - seja de favoritismo seja de perseguição - em relação a outros candidatos de concurso público que não professam a mesma crença religiosa. Precedente. Recurso ordinário desprovido." (STJ, ROMS 200602144444, Rel. Felix Fischer, 5 Turma, 13/08/2007).

${ }^{651}$ La Procuradoria General de la República, a través de la ADI / 3714-5 ha destacado la inconstitucionalidad de la referida ley. En la citada demanda, el referido organismo ha sostenido varios argumentos formales y materiales contrarios a la ley: "Lei paulista sobre guarda sabática é inconstitucional. A norma invade competência legislativa do Executivo e da União e viola o princípio da autonomia universitária. - Ao dispor sobre dias e horários de realização de concurso público, a norma deveria ter sido de iniciativa do chefe do Executivo, e não de deputado estadual. No que diz respeito aos estabelecimentos de ensino superior, a lei paulista ofendeu o princípio da autonomia universitária, como previsto no artigo 207 da Constituição Federal. - A norma contrariou a liberdade de crença religiosa ao editar uma lei para favorecer seguidores de determinadas denominações religiosas, adeptos da guarda sabática. Isso porque o Brasil, sendo um Estado laico, deveria respeitar todas as religiões existentes, sem a submissão de umas em favor de outras. - A lei paulista é inconstitucional, em relação aos estabelecimentos de ensino fundamental e médio públicos, porque é do governador de São Paulo a competência privativa para dispor sobre organização e funcionamento da administração estadual. Quanto às escolas particulares, a lei contraria a competência privativa da União para legislar sobre diretrizes e bases da educação nacional". 
Pese a las críticas que puede recibir, la existencia de una ley que regule el asunto es mucho mejor que el vacío legislativo, que, en la práctica, ha producido muchas polémicas que no siempre son solucionadas por la doctrina y por la jurisprudencia, lo que causa una gran incertitumbre en los procesos selectivos.

Además, también se puede afirmar que aunque sea creada ley que discipline el tema bajo análisis, ninguna solución será plenamente satisfatória, ya que existen muchas religiones con creyentes en Brasil, y cada una tiene sus propios dogmas.

En este contexto, en el caso de que hubiese una religión que consagrase el domingo como día de descanso o de oración (y de hecho lo hay), y como el sábado está consagrado para los adventistas, la Administración Pública sería obligada a realizar los procesos selectivos en los días laborales, lo que seguramente causaría muchas dificultades (aunque no religiosas) a los trabajadores que participan de los procesos selectivos.

\subsubsection{Cuestiones de orientación sexual}

La orientación sexual del individuo aún es motivo de enfrentamientos jurídicos en diversos sectores de la sociedad (matrimonio, derechos de la seguridad social, adopción de hijos, mercado laboral, etc.), y pese al avance alcanzado en los últimos años en el sentido de reconocer la amplia libertad de orientación sexual, la discriminación enfrentada por aquellos que no siguen el padrón más usual de la sociedad (heterosexualidad) todavía está presente, lo que compromete la igualdad ${ }^{652}$.

\footnotetext{
${ }^{652}$ La realidad es que la discriminación por motivo de orientación sexual es más o menos intensa en determinados países, aunque siempre esté presente. En este contexto "Europa es, sin ninguna duda, el mejor lugar que haya existido nunca para las lesbianas y los gays. No obstante, sabemos que no es un paraíso: vemos cómo se restringen los derechos de reunión y asociación en varios países (Rusia, Letonia, Serbia, Moldavia, Polonia, etc.), cómo se reprimen las manifestaciones pacíficas del Orgullo LGTB (recientemente se ha visto en Rusia), cómo se promueven legislaciones restrictivas de derechos (como ya hemos visto que ocurre en Polonia) y las agresiones y la violencia son bastante más habituales de lo que pensamos, incluso en lugares como Países Bajos, Bélgica y también España, pese a tener legislaciones que reconocen la igualdad legal de las parejas del mismo sexo, con acceso al matrimonio incluido. Por no hablar de las muchas dificultades que las personas homosexuales pertenecientes a minorías religiosas siguen atravesando a la hora de vivir su sexualidad y no quedar excluidas socialmente" (MONTERO GONZÁLEZ, David. Derechos Humanos y Derechos LGBT desde una perspectiva internacional, Seminario: "Orientación sexual e identidad de género. Los derechos menos entendidos", Organiza:
} 
En el ámbito del acceso a la función pública, son muy raras las situaciones de discriminación que son manifestadas de forma abierta. Se puede decir que hasta mismo las discriminaciones veladas por motivo de orientación sexual no son frecuentes, aunque estas existan en determinados segmentos de la Administración Pública.

Se puede afirmar que Brasil y España no toleran en sus ordenamientos jurídicos la discriminación por motivo de orientación sexual, aunque este criterio específico no esté contemplado expresamente en sus Constituciones.

También debe ser advertido que el relativo grado de avance de los mencionados sistemas jurídicos respecto a la libertad de orientación sexual no siempre coincide con la realidad social, donde el prejuicio contra los homosexuales y transexuales (homofobia) suele permanecer de forma intensa, especialmente en determinados segmentos, entre los cuales el acceso al empleo se destaca ${ }^{653}$.

En España, el sistema jurídico ha avanzado en la protección de los derechos de libertad de orientación sexual, y probablemente esto tenga conexión con el hecho de que el citado país esté inserido en el contexto de la Unión Europea ${ }^{654}$. Sin embargo,

Institut de Drets Humans de Catalunya Barcelona, 21 de Mayo de 2007, texto publicado en el sitio electrónico http://www.felgtb.org/files/docs/01f268e9e436.pdf, acceso en 08 de junio de 2010).

${ }^{653}$ Sobre esta constatación: "Como ha subrayado el politólogo Kerman Calvo (autor por otra parte de una importante investigación sobre la evolución del movimiento gay en España), existe por ejemplo una posición mayoritariamente contraria a la restricción de los derechos civiles de los gays y de las lesbianas, y son ya minoría los que consideran que la homosexualidad pueda ser un pretexto de discriminación para el acceso a la Función Pública, al ejercito o la enseñanza. Si bien una cosa son los posicionamientos políticos (que reflejan un talante liberal) y otra las prácticas sociales (que distan mucho de ser las idóneas). Pese a los avances, los gays y las lesbianas siguen padeciendo sendas y notorias discriminaciones en muchos ámbitos de la vida colectiva que, si ya no obedecen a motivaciones religiosas o a argumentaciones médico-psiquiátricas como ocurría en el pasado, si continúan bebiendo de ciertas representaciones culturales y simbólicas sobre la identidad sexual y la identidad de género y los respectivos roles sociales vinculadas a éstas. El ámbito laboral es un ejemplo elocuente" (VANEGAS, Carlos Mora. Homofobia en el trabajo. .Texto publicado en el sitio electrónico Gestiopolis.com (http://www.gestiopolis.com/organizacion-talento/homofobia-en-el-trabajo.htm), en 21de enero de 2008, con acceso en 08 de julio de 2010).

654 En el derecho comunitario, "nada menos que tres Resoluciones que el Parlamento Europeo ha aprobado en el plazo de poco más de un año, condenando la Homofobia: - Resolución de 18 de enero de 2006, sobre Homofobia en Europa (en la que se condena todo tipo de violencia homófoba, incluyéndole lenguaje y el discurso del odio, e insta a los Estados miembros a que trabajen por la eliminación de toda discriminación por motivo de orientación sexual e identidad de género) - Resolución de 14 de junio de 2006, sobre el aumento de la violencia racista y homófoba en Europa (a raíz de algunos episodios dramáticos de violencia ocurridos en Bélgica, Polonia y otros países y a declaraciones muy gruesas de algunos dirigentes políticos cargando contra minorías religiosas y sexuales) - Resolución de 26 de abril 
como ha destacado la doctrina del referido país, el citado avance aun no puede ser comparado a las actuaciones de los poderes públicos en la protección de la igualdad de género (igualdad de oportunidades entre hombres y mujeres). Añade la doctrina que:

\begin{abstract}
"Em cambio, en relación a la protección de los homosexuales, transexuales o bisexuales, la intervención de los poderes públicos no es tan visible, como podemos observar en la escasa legislación específica que existe, sil olvidarnos que para llegar a esta regulación actual se ha recorrido un largo camino iniciado con la legalización de las relaciones homosexuales por la derogación parcial de la Ley de Rehabilitación y Peligrosidad Social de 1978, heredada del régimen anterior, y con la Reforma del Código Penal en 1995 en donde se cataloga la discriminación por motivo de orientación sexual como una sanción penal” ${ }^{655}$
\end{abstract}

En el ámbito de la función pública, el Estatuto Básico del Empleado Público español (Ley 7/2007) ha declarado en el art. 14, apartados h) y i), que aquellos que trabajan en el sector público tienen derecho: "al respeto de su intimidad, orientación sexual, propia imagen y dignidad en el trabajo, especialmente frente al acoso sexual y por razón de sexo, moral y laboral”; así como "a la no discriminación por razón de nacimiento, origen racial o étnico, género, sexo u orientación sexual, religión o convicciones, opinión, discapacidad, edad o cualquier otra condición o circunstancia personal o social”.

También establece la citada ley que es considerada falta muy grave del empleado público "toda actuación que suponga discriminación por razón de origen

de 2007, sobre Homofobia en Europa, en la que se condenan las restricciones de algunos Gobiernos al derechos de reunión de la población LGTB, las gravísimas declaraciones de líderes polacos contra lesbianas y gays y los inadmisibles planes legislativos en materia de educación que se proponían en Polonia, la defensora de los derechos del Niño de Polonia está elaborando una lista con las tareas que no deben confiarse a los homosexuales... etc.)" (MONTERO GONZÁLEZ, David. Derechos Humanos y Derechos LGBT desde una perspectiva internacional, Seminario: "Orientación sexual e identidad de género. Los derechos menos entendidos", Organiza: Institut de Drets Humans de Catalunya Barcelona, 21 de Mayo de 2007, texto publicado en el sitio electrónico http://www.felgtb.org/files/docs/01f268e9e436.pdf, acceso en 08 de junio de 2010).

${ }^{655}$ GONZÁLEZ BUSTOS, María Ángeles. La actuación de los poderes públicos en materia de libertad sexual, en La igualdad como compromiso, estudios de género en homenaje a la Profesora Ana Díaz Medina, Ediciones Universidad de Salamanca, septiembre 2007, p. 288. 
racial o étnico, religión o convicciones, discapacidad, edad u orientación sexual, lengua, opinión, lugar de nacimiento o vecindad, sexo o cualquier otra condición o circunstancia personal o social, así como el acoso por razón de origen racial o étnico, religión o convicciones, discapacidad, edad u orientación sexual y el acoso moral, sexual y por razón de sexo”. (art. 95.2 b)).

Respecto al acceso a la función pública española, el tema también ha progresado de forma considerable. En estos términos, se puede afirmar que, de forma oficial, no hay cualquier norma o entendimiento doctrinario o jurisprudencial que admita la posibilidad de imposición del requisito "orientación sexual" para el acceso a la función pública en España.

Además, el mencionado país europeo está consiguiendo superar la discusión respecto al ingreso (y a la permanencia) de los homosexuales en las Fuerzas Armadas, en el sentido de no admitir cualquier discriminación." ${ }^{, 656}$

En este sentido:

\begin{abstract}
"Recordemos que España derogó en 1985 una ley en la que se declaraba a la homosexualidad como "contraria al honor militar"; pues en el artículo 352 del antiguo Código de Justicia Militar, vigente desde 1945, la homosexualidad era catalogada como delito contra el honor. Una sentencia del Tribunal Supremo del 21 de septiembre de 1988 estableció que es lícito para un militar ser homosexual siempre que se someta a las mismas exigencias disciplinarias que los militares
\end{abstract}

\footnotetext{
${ }^{656}$ En este contexto: "El Tribunal Supremo (TS) ha confirmado una sentencia de la Audiencia Nacional que condenó al Estado a indemnizar con 6.000 euros, por daños morales, a un soldado que en 1979 fue excluido del servicio militar por homosexual. Así lo acuerda la Sala de lo Contencioso-Administrativo en una sentencia, en la que desestima el recurso interpuesto por el soldado Pere C. contra la dictada por la Audiencia Nacional en 2003. En 1999, el soldado se dirigió al Ministerio de Defensa y solicitó una indemnización de 961.619 euros al alegar que se incorporó al servicio militar en el cuartel naval de Cartagena el 2 de mayo de 1978 y después de jurar bandera obtuvo destino en la Base de Submarinos, donde, a su juicio, fue tratado de forma "vejatoria y denigrante por sus superiores". Según explica la sentencia, Pere C. intentó suicidarse, ingresó de urgencia en el Hospital Militar de Marina y el 12 de febrero de 1979 un decreto del Estado Mayor le excluyó del servicio militar por homosexual, lo que se hizo constar en su cartilla militar. La exclusión del servicio militar se realizó en 1979 y posteriormente fue rectificada en los años 1991 y 1995. El recurrente alega-añade la sentencia-que esta situación le ha ocasionado graves lesiones y daños morales "por la marginación sufrida por constar en un documento oficial un aspecto tan íntimo que afecta a sus derechos al honor, la intimidad y la igualdad ".(Extraído del reportaje El Supremo condena al Ejército español a indemnizar a un homosexual al que vejó y expulsó de la mili, publicado en el sitio: http://www.nodo50.org/tortuga/El-Supremo-condena-al-Ejercito, publicado en 12.07.2007, acceso en 16.02.2010).
} 
heterosexuales (que incluyen no tener relaciones con inferiores en la escala jerárquica ni en los establecimientos militares)."

Pese al avance citado, todavía hay un largo camino que debe ser seguido, ya que hay algunos sectores de la Administración Pública que, en realidad, no toleran muy bien la presencia de homosexuales. ${ }^{658}$

Por la razón antes destacada, debe ser incrementada la cautela con la posibilidad de aspirantes homosexuales reciban un trato discriminatorio en el proceso selectivo, lo que puede suceder, especialmente, en las pruebas orales, físicas y prácticas, donde hay el contacto directo del candidato con sus evaluadores.

En Brasil, el acceso de los homosexuales y transexuales a la función pública no suele ser problemático, debido al carácter objetivo de los concursos públicos, que

657 La referida información fue extraída del texto publicado en el sitio electrónico (http://www.gaycomotu.com/index.php?option=com_content\&view=article\&catid=36\%3Aactualidad\&id $=287 \% 3$ Agays-en-las-barracas\&Itemid=152), en 03 de Enero de 2010, con acceso en 08.06.2010.

${ }^{658}$ En este sentido: "José María Sánchez Silva, un teniente coronel del Cuerpo Jurídico de las Fuerzas Armadas, se ha convertido en el primer militar español de alta graduación que declara públicamente su homosexualidad. La revelación de este militar será publicada esta semana en la revista Zero. "Una opción sexual -afirma Sánchez Silva- debe llevar aparejada la posibilidad de explicitar pública y privadamente tu sexualidad. Por descontado, sin atentar contra la libertad ni contra la dignidad de ninguna otra persona". A sus 49 años, este militar parece sentirse satisfecho: "Mi gesto va a ser un referente para muchos gays que hay en las Fuerzas Armadas de nuestro país". "La legislación actual indica el teniente coronel- comenzando por la Constitución, prohíbe de modo implícito o explícito la discriminación por orientación sexual en el Ejército, pero las represalias sutiles o las discriminaciones atávicas siguen pesando en las relaciones diarias". Antes de tomar esta decisión, Sánchez Silva ha tenido que valorar muchos factores. Sabía que no iba a ser fácil. Sin embargo, y según lo que declara a la revista Zero y que ayer adelantó el diario El País, "si alguien no da este paso, transcurrirá mucho tiempo hasta que se apliquen de verdad los derechos de los homosexuales en las Fuerzas Armadas». Su carrera militar ha estado muy unida a la enseñanza y a los asuntos jurídicos. Quizá su amplia formación en Derecho le ha proporcionado el empuje necesario para tomar esta decisión. "Me he decidido a declarar públicamente mi homosexualidad porque los derechos se han de ejercer y las leyes se han de adaptar a la realidad social". Pero tras la firmeza y la seguridad que transmiten sus palabras, se esconde una cierta incertidumbre sobre cómo va a afectar su decisión a su futuro profesional. "No me van a sancionar por el hecho de declarar que soy gay. Faltaría más. Pero no se me escapa que las represalias pueden ser de muchos tipos. Puede haber un tipo de castigo sutil que apele únicamente a motivos de trabajo o a presuntos descuidos en el servicio», añade Sánchez Silva. El Ejército se ha modernizado en los últimos años. Sin embargo, aún queda un largo camino por recorrer. "Se ha incorporado la mujer y las tropas españolas participan en las misiones de paz. Pero los gays seguimos en las catacumbas", afirma el teniente. Los años de silencio parecen haberse acabado para este veterano militar. "La gente no puede hacerse una idea de lo frustrante que es no poder comportarte tal como eres, salvo con un reducido grupo de compañeros que conocen tu opción sexual. Si declararte homosexual aún es complicado en muchos ámbitos civiles, en las Fuerzas Armadas estos gestos se convierten en algo mucho más arduo", asegura." (Extraído del reportaje Un mando militar hace pública su homosexualidad, publicado en el sitio El Mundo periódico (http://www.elmundo.es/2000/09/04/sociedad/04N0080.html) en 04.09.2000, acceso en 16.02.2010). 
solamente comprueba la capacidad intelectual del candidato, y no sus inclinaciones o preferencias sexuales.

Sin embargo, hay dos circunstancias polémicas que deben ser analizadas: el riesgo de utilización indebida de la llamada "investigación social"; y el acceso a las Fuerzas Armadas ${ }^{659}$.

La investigación social, tema que será investigado de forma más profundizada en el apartado sobre los requisitos negativos de acceso a la función pública, es un procedimiento utilizado en determinados procesos selectivos brasileños, donde la Administración Pública verifica la conducta del candidato en el pasado, para analizar si la misma es compatible con el ejercicio del cargo público.

Es imprescindible que la investigación social no sea utilizada como forma de persecución a determinados candidatos que no se encuadran en perfil ${ }^{660}$ que haya

\footnotetext{
${ }^{659}$ Como se puede percibir, este tema es polemico en todos los países. Así "durante los ochos años que duró la administración Clinton (1993 - 2000) y todavía con la de Bush (2001 - 2008) teniendo en consideración el espíritu liberal de la población norteamericana, la cuestión gay al interior de sus fuerza armadas se manejó con la política del Don't ask, Don't tell ("No preguntes, No cuentes"), documento que dio cierto alivio a los gays para continuar sirviendo en el ejército. Lo único que se les pedía: mantener bajo el manto de la discreción su preferencia sin hacerlo una cuestión pública. Siempre en el camino del viejo dicho "se perdona el pecado pero no el escándalo". Antes de este tibio avance, por ejemplo, de los marines, el cuerpo de elite de las fuerzas norteamericanas, entre 1991 y 1992, fueron expulsados por homosexualidad 105 militares; a comparación de 1999 en que lo fueron sólo 97. Y en la década del presente milenio se registraron varias bajas también (...) Hay naciones en las que se están realizando políticas especiales para reclutar a gays y lesbianas en la policía o el ejército. Canadá, Reino Unido e Israel son dos ejemplos de ello, no así Turquía el único país de la OTAN que lo prohíbe de manera explícita. Entretanto Inglaterra levantó su prohibición de no aceptar gays en el ejército" (Texto $\begin{array}{llll}\text { publicado en } & \text { el } & \text { sitio } & \text { electrónico }\end{array}$ (http://www.gaycomotu.com/index.php?option=com_content\&view=article\&catid=36\%3Aactualidad\&id $=287 \% 3$ Agays-en-las-barracas\&Itemid=152), en 03 de Enero de 2010, con acceso en 08.06.2010).

${ }^{660}$ En el citado contexto: "a investigação social, também chamada de exame de vida pregressa, é o procedimento através do qual se verifica a idoneidade moral do candidato e se a sua conduta social é compatível com a do cargo que almeja. A idoneidade moral costuma ser exigida na contratação para cargos que exijam maior responsabilidade, prevenindo-se, assim, que autoridade e poder decorrentes da atribuição do cargo não sejam utilizados para atender a interesses escusos. Há carreiras em que se cria um vínculo entre a imagem da instituição e a dos seus membros. São carreiras que, mais do que um simples emprego, significam uma opção de vida. Nestes casos, a conduta do titular do cargo ser compatível com a que se espera dos membros daquela instituição, mesmo quando não estiver no exercício das suas funções. É o caso de membros da Magistratura, do Ministério Público, policiais, militares, etc. A investigação social consiste, portanto, em procedimento em que o órgão promotor do concurso envia ofícios solicitando informações a outros órgãos da Administração direta e indireta e, até mesmo, a instituições privadas que possam informar sobre a conduta elou idoneidade moral do candidato. É possível, ainda, que o edital determine que o próprio candidato forneça certidões e outras informações. Configurada a incompatibilidade da conduta social do candidato com a necessária ao
} 
sido creado por la Administración Pública de forma discriminatoria, lo que ocurriría si fueran excluidos los aspirantes homosexuales.

La mencionada discriminación puede ocurrir también durante el curso de formación, como se puede percibir en el fallo abajo transcripto, que invalidó la actuación administrativa perjudicial:

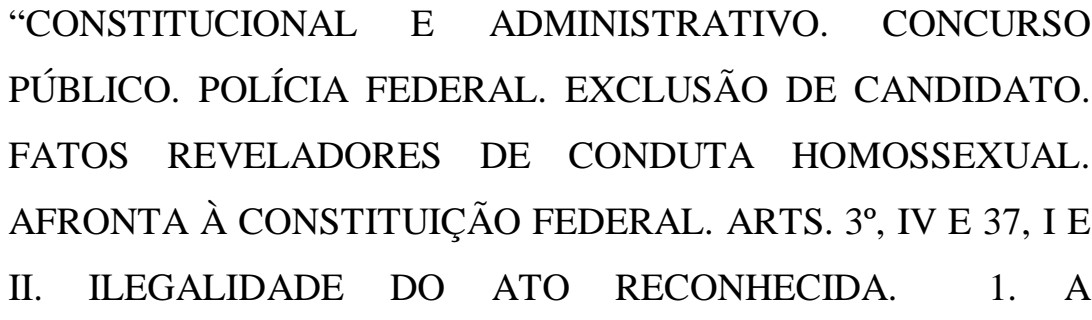
homossexualidade não constitui causa para a exclusão do candidato do curso de Formação de Agente de Polícia Federal, a teor dos arts. $3^{\circ}$, IV e 37, I, da Constituição Federal. 2. Apelação e remessa oficial improvidas",661

Respecto al acceso (y permanencia) de los homosexuales en las Fuerzas Armadas brasileña, lo que se percibe es que hay mucho aun que evolucionar ${ }^{662}$, tanto que en el Código Penal Militar (Decreto-Ley 1.001/69), hay una referencia discriminatoria a la práctica homosexual ${ }^{663}$.

cargo, este será excluído do certame." (LOBELLO DE OLIVEIRA ROCHA, Francisco. Op.cit., pp. 9091).

${ }^{661}$ Tribunal Regional Federal $1^{a}$ Región - Apelación Civil: AC 3173 DF 1999.01.00.003173-5. Relator: Juez Julier Sebastiao da Silva (Conv.), Juzgamento: 26 de septiembre de 2001, $3^{a}$ Turma Suplementar, Publicación en 15 de octubre de 2001, DJ p.234.

${ }^{662}$ En este sentido: "Por sete votos a três, o Superior Tribunal Militar (STM) aposentou o tenente coronel Osvaldo Brandão Sayd, homossexual assumido, por considerá-lo incapaz de permanecer na ativa. A maioria dos ministros entendeu que o comportamento sexual do oficial atenta contra a honra militar. A decisão tomada ontem em plenário foi baseada no processo administrativo aberto pelo Conselho de Justificação, órgão que funciona como um tribunal de honra, mas sem poder para julgar crimes militares. Cabe recurso ao STM por meio de embargo infringente. A sentença reacende a polêmica sobre a presença de gays nas Forças Armadas. Anteontem, o Senado confirmou a indicação do general Raymundo Nonato de Cerqueira Filho ao tribunal. Durante sabatina no início de fevereiro, o militar disse que as tropas não obedeceriam às ordens de um comandante homossexual" Extraído del reportaje "Tenente coronel é aposentado pelo STM porque é homossexual", publicado en 12 de marzo de 2010 en el sitio electrónico direitoshumanos, de la Comisión de Derechos Humanos y Legislación Participativa del Senado Federal brasileño (http://www.direitoshumanos.etc.br/index.php?option=com_content\&view=article\&id=8315:sopreconceito-tenente-coronel-e-aposentado-pelo-stm-porque-e homossexual\&catid=41:lgbtt\&Itemid=174), acceso en 08 de julio de 2010.

663 "Art. 235. Praticar, ou permitir o militar que com êle se pratique ato libidinoso, homossexual ou não, em lugar sujeito a administração militar: Pena - detenção, de seis meses a um ano". 
En realidad, como ya se ha destacado, "o Código Penal Militar não criminaliza a homossexualidade. Ou seja, se um soldado se declarar homossexual, ele não vai preso, mas pode ser submetido a um conselho de justificação (tribunal de honra) e acabar expulso da corporação"664.

Los problemas enfrentados por los homosexuales en las Fuerzas Armadas brasileñas llegan a los periódicos y a los tribunales. En uno de los casos más famosos, durante una audiencia realizada por el Senado Federal, un general aspirante al puesto de Ministro del Superior Tribunal Militar (STM) afirmó que las actividades desempeñadas en las Fuerzas Armadas no son adecuadas a los homosexuales.

Lo más sorprendente es que tras tal declaración, que causó una gran polémica $^{665}$, el mencionado general fue admitido en el puesto de Ministro del Superior

664 Extraído del texto Homossexualidade nas Forças Armadas, publicado en el sitio electrónico http://www.rea.pt/forum/index.php?topic=2166.0; wap2, con acceso en 08 de Julio de 2010.

${ }^{665}$ Sobre tal polémica: "O general Raymundo Nonato de Cerqueira Filho, indicado para ocupar uma vaga de ministro do Superior Tribunal Militar (STM), disse nesta quarta-feira (3) que soldados não obedecem a comandantes homossexuais. Segundo Cerqueira Filho, as atividade desempenhadas pelas Forças Armadas não são adequadas a homossexuais. "Talvez tenha outro ramo de atividade que ele [o militar homossexual] possa desempenhar", afirmou. "Tem sido provado mais de uma vez, o indivíduo não consegue comandar. O comando, principalmente em combate, tem uma série de atributos, e um deles é esse aí. O soldado, a tropa, fatalmente não vai obedecer. Está sendo provado, na Guerra do Vietnã, tem vários casos exemplificados, que a tropa não obedece normalmente indivíduos desse tipo "Cerqueira Filho disse que a Guerra do Vietnã mostrou que militares homossexuais não teriam condições de comandar tropas. As declarações do general foram feitas durante audiência na Comissão de Constituição e Justiça do Senado nesta terça. Cerqueira Filho e o almirante Álvaro Luiz Pinto, também indicado a uma vaga no STM, participavam da audiência quando foram questionados pelo senador Demóstenes Torres (DEM-GO) e Eduardo Suplicy (PT-SP) sobre o tema. "Vossas excelências são favoráveis ao ingresso de homossexuais em qualquer das forças e acham que essa polêmica tem razão de ser?", indagou Demóstenes. Suplicy quis saber se os dois militares defendiam a exclusão de homossexuais das Forças Armadas. Em sua resposta, o general Cerqueira Filho disse que iria responder "de uma maneira sincera". "Não é que eu seja contra o homossexual, cada um tem que viver sua vida. Entretanto, a vida militar se reveste de determinadas características que, em meu entender, tipos de atividades que, inclusive em combate, pode não se ajustar ao comportamento desse tipo de indivíduo", afirmou. Segundo o general, a maior parte dos exércitos do mundo não admite militares homossexuais. "O exército americano está discutindo ainda, mas os casos que ocorreram mesmo no exército americano foram praticamente rechaçados. Não é que o indivíduo seja criminoso, mas é o tipo de atividade. Se ele é assim, talvez tenha outro ramo de atividade que ele possa desempenhar", afirmou, sem dizer que atividades seriam mais adequadas a homossexuais. O almirante Luiz Pinto disse que não via problema, desde que o militar mantivesse "sua dignidade". "É uma situação muito polêmica, mas eu vou lembrar um fato que aconteceu alguns anos atrás, na França, não nas Forças Armadas, mas na Igreja, em que foi feita a mesma pergunta. O teólogo pensou, pensou, pensou e respondeu: 'Não tenho nada contra, desde que ele faça uso do voto da castidade, que é um dogma da Igreja'. Eu acho que fazendo uma similaridade com as Forças Armadas, eu não tenho nada contra desde que ele [o militar homossexual] mantenha sua dignidade, a dignidade da farda, do cargo e do trabalho que executa. Se ele exercer sua dignidade, sem nenhum problema." (Texto extraído del reportaje Tropa não obedece a militar 
Tribunal Militar. Como se puede percibir, hasta aquellos que hacen parte de los órganos jurisdiccionales poseen puntos de vista que muchas veces no están de acuerdo con los valores constitucionales, como la igualdad entre las personas.

\subsection{9 - Goce de los derechos políticos}

En el ámbito del derecho brasileño, la legislación aplicada a los funcionarios públicos de la Unión (Estatuto de los Servidores Públicos Federales, Ley 8.112/90) impone, como requisito de acceso a la función pública federal, que el aspirante esté en el goce de sus derechos políticos. Se puede afirmar que tal exigencia también está prevista en los estatutos de funcionarios de los Estados federales y de los Municípios.

Las situaciones que impiden el goce de los derechos políticos están previstas en la Constitución brasileña, en la norma inserida en el art. $15^{666}$. Conviene acentuar que la referida exigencia, prevista en el art.5\% $5^{\circ}$ II, de la Ley 8112/90, es una demostración inequívoca de que el acceso a la función pública en Brasil es considerado una consecuencia directa de la ciudadanía, y que el ejercicio de las tareas propias de un puesto de trabajo en la Administración Pública es una modalidad de participación popular (democracia participativa).

Para que se pueda percibir la estrecha relación entre los conceptos de ciudadano y elector en Brasil, la Constitución prevé, en el art. 5º LXXIII, que todo ciudadano puede hacer uso de la llamada "ação popular", instrumento que sirve para anular en el ámbito judicial actos lesivos al patrimonio público. A su vez, la Ley 4.717/65, que regula la referida acción judicial, establece en el art. $1^{\circ}, \S 3^{\circ}$, que: “ $A$ prova da cidadania, para ingresso em juízo, será feita com o título eleitoral, ou com documento que a ele corresponda".

\footnotetext{
homossexual, diz general no Senado, publicado en el sitio Globo.com (http://g1.globo.com/Noticias/Brasil/0,,MUL14758385598,00TROPA+NAO+OBEDECE+A+MILITAR+ HOMOSSEXUAL+DIZ+GENERAL+NO+SENADO.html), con acceso en 04.02.2010).

666 “Art. 15. É vedada a cassação de direitos políticos, cuja perda ou suspensão só se dará nos casos de: I - cancelamento da naturalização por sentença transitada em julgado;

II - incapacidade civil absoluta;

III - condenação criminal transitada em julgado, enquanto durarem seus efeitos;

IV - recusa de cumprir obrigação a todos imposta ou prestação alternativa, nos termos do art. $5^{\circ}$, VIII; $V$ - improbidade administrativa, nos termos do art. 37, $\$ 4^{\text {on. }}$.
} 
En el contexto antes mencionado, la doctrina ha destacado que "o gozo de direitos políticos é outro requisito, previsto na lei, que garante ao cidadão o direito subjetivo de participar da vida política Estado."

Para que los ciudadanos puedan gozar sus derechos políticos, la Constitución, en el art. $14, \S 1^{\circ}$, impone que aquellos adquieran la condición de elector, lo que dependerá de su alistamiento electoral.

Una vez adquiridos los derechos políticos, estos podrán ser perdidos o interrumpidos, en las hipótesis previstas en la Constitución (art. 15). Respecto a los derechos políticos en el ordenamiento jurídico brasileño, y su exigencia como requisito de acceso a la función pública, la doctrina subraya que:

"Requisito também exigido para o exercício de função pública é o de estar o cidadão no gozo dos direitos políticos. Direitos políticos são as prerrogativas, atributos, faculdades, ou poder de intervenção dos cidadãos ativos no governo de seu país, intervenção direta ou indireta, mais ou menos ampla, segundo a intensidade do gozo desses direitos. (...) Os cidadãos poderão ser privados do gozo de seus direitos políticos, cuja perda ou suspensão se dão nos casos de cancelamento da naturalização por sentença transitada em julgado; na incapacidade civil absoluta; na condenação criminal transitada em julgado, enquanto durarem seus efeitos; na recusa de cumprir obrigação a todos imposta ou prestação alternativa, nos termos do art. $5^{\circ}$, VIII, da Lei Magna; e nos casos de improbidade administrativa, nos termos do art. 37, $4^{\circ}$, da Constituição Federal." ${ }^{668}$

Debido al hecho de que el goce de los derechos políticos es uno de los requisitos de acceso a la función pública brasileña, el aspirante deberá hacer prueba de la regularidad su condición electoral, lo que se hará a partir de la juntada del documento emitido por la Justicia Electoral brasileña (titulo de elector).

\footnotetext{
${ }^{667}$ TOURINHO, Rita. Op.cit., p. 67.

${ }^{668}$ PINHEIRO MADEIRA, José Maria. Op.cit., p. 77.
} 
En el ámbito del derecho español, no se ha encontrado ninguna referencia a la referida exigencia, ni en la doctrina, ni tampoco en el Estatuto Básico del Empleado Público, que en su art. 56, no hace cualquier referencia al goce de los derechos políticos como condición de acceso a la función pública.

Sin embargo, como se verá adelante, el mencionado estatuto prevé como requisito negativo de acceso a la función pública la circunstancia de que el aspirante no se halle "en inhabilitación absoluta o especial para empleos o cargos públicos por resolución judicial, para el acceso al cuerpo o escala de funcionario, o para ejercer funciones similares a las que desempeñaban en el caso del personal laboral, en el que hubiese sido separado o inhabilitado"(art. 56.1, d).

\subsubsection{0 - Cumplimiento de las obligaciones electorales y militares}

Otra exigencia prevista en el ordenamiento jurídico brasileño para acceso a la función pública es el cumplimiento de las obligaciones electorales y militares. Tal requisito, en el ámbito federal, está previsto en el art. $5^{\circ}$, III; del Estatuto de los Servidores Públicos Federales (Ley 8.1127/90).

Para el derecho brasileño, sería incoherente permitir el acceso a la función pública a alguien que no ha demostrado el espíritu cívico que acompaña las exigencias de alistamiento militar y de participación en las elecciones. ${ }^{669}$

Es que en Brasil, el alistamiento militar, pese a la polémica existente ${ }^{670}$, es obligatorio a los hombres ${ }^{671}$, cuando ellos cumplen 18 años. Cumplidas las exigencias

\footnotetext{
669 En este sentido: "Quanto à quitação com as obrigações eleitorais esta se concretiza com o cumprimento do alistamento eleitoral e o voto, que são obrigatórios para os maiores de dezoito anos. Outra condição essencial para o exercício da função pública é a quitação com o serviço militar. $O$ fundamento dessa exigência é que não se pode admitir que o cidadão, usufruindo diversas regalias concedidas pelo Estado, não tenha o dever de, em retribuição, suportar um ônus relativamente pequeno, qual seja, o de dedicar pequeno período de sua vida em adestrar-se no exercício da atividade concernente à defesa da pátria, a fim de que possa defendê-la no caso em que isso se faça necessário" (PINHEIRO MADEIRA, José Maria. Servidor público na atualidade, $3^{\text {a }}$ ed., Editora América Jurídica, Rio de Janeiro, 2006, p. 77-78).

${ }^{670}$ En este contexto: "A lei do serviço militar válida hoje entrou em vigor em agosto de 1964 e obriga todo o cidadão brasileiro do sexo masculino que complete 18 anos a prestar o serviço militar, mesmo que
} 
legales relativas a las obligaciones militares (Ley 4.345/64), el ciudadano recibirá el certificado de alistamiento militar, documento que le permitirá participar de los procesos selectivos de acceso a la función pública.

Respecto a las obligaciones electorales, cabe destacar que el voto en Brasil es obligatorio a todos los ciudadanos que poseen entre 18 y 70 años de edad, y facultativo para los analfabetos, para los que posen más de 16 y menos de 18 años, y para los que tienen edad superior a 70 años (art. $\left.14, \S 1^{\circ}, \mathrm{CB}\right)$.

Así, en regla general, debe el ciudadano alistarse como elector y participar de las elecciones, sea votando o justificando la imposibilidad de votar, cuando, por ejemplo, encuéntrese fuera de su domicilio electoral en el día de las elecciones. De la misma forma que aquel que no ha cumplido con las obligaciones militares no puede acceder a la función pública, los que no han satisfecho las exigencias electorales mencionadas están impedidos de participar de los procesos selectivos para cubertura de los puestos de trabajo en la Administración Pública.

more fora do país. Quem não cumpre, além de pagamento de multa, fica impedido de tirar o passaporte, prestar concurso público, ser funcionário de órgão do governo, matricular-se em instituição de ensino e assinar contrato com a administração pública. Entretanto, após o alistamento, grande parte dos jovens é dispensada aleatoriamente. Segundo dados de 2006, dos 1.648 .550 jovens alistados, apenas cerca de 4,5\% foram incorporados a alguma instituição militar. Na prática, acaba servindo quem quer. Jovens que buscam a dispensa do serviço costumam recorrer a conhecidos nas próprias Forças Armadas para garantir a dispensa. "Durante o exame médico, mencionei que havia falado com um coronel e fui liberado na hora, nem precisei mencionar o nome dele”, relembra Marcelo Figueiras, estudante de sistema da informação. Há também aqueles que querem servir. Dentre as motivações podem estar a falta de recursos e a dificuldade para encontrar emprego, passando a ver o serviço militar, que paga um salário mínimo mensal, como uma fonte de renda. "Eu quis servir pelo dinheiro e pretendo ficar até conseguir coisa melhor”, afirma o recruta Gabriel Ecard. Mas o salário não é o único atrativo. Gabriel diz que existem muitas vantagens e se diz favorável à obrigatoriedade. "Você chega muito imaturo e sai com disciplina, amadurece. Você ainda não sabe muito bem o que quer e essa fase é importante, por isso acho que tem que ser obrigatório sim”. A opinião é compartilhada por William Amorim, das Forças Especiais do Exército: "Participar do serviço militar é um exercício de cidadania e soberania nacional. Prestar serviço militar não é só capinar quintais, 'servir' nas matas, manter guarda nos quartéis ou estar de patrulha, é virar 'gente' de verdade e cumprir seu 'papel' de cidadão ativo." (Texto extraído del reportaje Obrigatoriedade do Serviço Militar é polêmica, escrito por Fabiana Born, publicado en el sitio electrónico Ibase., Juventudes Sudamericans/Sulamericanas., (http://www.juventudesulamericanas.org.br/index.php/noticias/38-materias/107-obrigatoriedade-doservico-militar-e-polemica), en 19 de noviembre de 2008, con acceso en 09 de junio de 2010).

${ }^{671}$ Según la Constitución brasileña: "Art. 143. O serviço militar é obrigatório nos termos da lei. $\$ 1^{\circ}$ - às Forças Armadas compete, na forma da lei, atribuir serviço alternativo aos que, em tempo de paz, após alistados, alegarem imperativo de consciência, entendendo-se como tal o decorrente de crença religiosa e de convicção filosófica ou política, para se eximirem de atividades de caráter essencialmente militar. $\$$ $2^{\circ}$ - As mulheres e os eclesiásticos ficam isentos do serviço militar obrigatório em tempo de paz, sujeitos, porém, a outros encargos que a lei lhes atribuir". 
La comprobación del cumplimiento de las obligaciones mencionadas en este apartado ocurrirá con la juntada de la "documentação militar (certificado de dispensa de incorporação ou certificado de reservista) e eleitoral (comprovante de votação, normalmente das últimas eleições)."672

En el derecho español, el alistamiento militar obligatorio fue abolido en 31 de diciembre de 2001, tras la gran cuantidad de personas que alegaba objeción de conciencia para no atender a la convocación ${ }^{673}$.

Además, en el referido país, hubo la opción en el comienzo del siglo XXI por un modelo profesional de las Fuerzas Armadas, lo que sería incompatible con la obligatoriedad del reclutamiento.

Por las circunstancias antes mencionadas, la exigencia de cumplimiento de las obligaciones militares como requisito de acceso a la función pública no tería cualquier sentido.

\footnotetext{
672 TOURINHO, Rita. Op.cit., p. 68.

${ }^{673}$ Sobre este hecho: "Ayer se cerró una etapa importante en la Historia de España. Un avanzado sistema informático realizó el último sorteo para reclutar a los jóvenes que formarán el último reemplazo. Se termina así con una práctica que ha sido una etapa de la vida de vuestros padres, abuelos y sus abuelos. Fue en 1800 cuando el servicio militar obligatorio se impuso en España. En aquella época y hasta 1912, el ser rico eximía de hacer la mili. De todas formas, siempre os quedará el haceros soldados profesionales Es el fin de una época. 200 años de Historia tocan a su fin (...). Siempre han existido maneras de librarse de la mili. Hasta principios de siglo se pagaba la exención y muchos de los convocados decidían fugarse o desertar. Surgía así la opción de la insumisión. Muchos jóvenes de los reemplazos huían a otros países, bajo la amenaza de ser encarcelados si les cogían. Esta figura todavía despierta muchas controversias en la actualidad. Hoy por hoy, 10 jóvenes insumisos están en la cárcel acusados de deserción. Un paso menos radical es el que dan los objetores de conciencia. Los primeros en España fueron los testigos de Jehová, que también eran encarcelados por este motivo en los años 50. En el año 84, el PSOE creó una ley que regulaba la objeción de conciencia. Desde entonces, cada vez más jóvenes han optado por esta vía para manifestar su antimilitarismo. En 1998, los objetores superaron por primera vez en número a los reclutas: 144.823. Una de las causas que han adelantado la eliminación de la mili ha sido el escaso número de jóvenes que atendieron la llamada gubernamental a filas. En 1999, el Ejército convocó 5.800 plazas de tropa y marinería profesional, y solamente se presentaron 2'16 aspirantes para cubrir cada uno esos puestos. Era la proporción más baja que se registraba desde que en 1993 se iniciara la recluta de tropa profesional, en la que Defensa invirtió un buen número de millones en publicidad. El Ejército profesional costará al Estado más de un billón de pesetas al año. Alrededor de un $25 \%$ de los aspirantes quedaba eliminado por no pasar los tests psicotécnicos, las pruebas físicas o el reconocimiento médico." (Texto extraído del reportaje Servicio Militar. Cuenta atrás para que el último recluta vaya a la mili, publicado en el sitio electrónico Aula de El Mundo (http://aula2.el-mundo.es/aula/noticia.php/2000/11/09/aula973701814.html), en 09 de noviembre de 2000, con acceso en 09 de julio de 2010.
} 
Respecto al cumplimiento de las obligaciones electorales, cabe destacar que, en España, el voto es voluntario (facultativo), ya que, de forma distinta de lo que pasa en Brasil, el voto es solamente un derecho, no un deber del ciudadano ${ }^{674}$.

En este contexto, no habría ningún fundamento para que fuera exigido el cumplimiento de obligaciones electorales, ya que estas, al menos en lo se refiere al acto de votar, no existen en España.

\subsubsection{1 - Titulación}

Para que uno pueda ejercer determinados puestos en la Administración Pública, es necesario estar en posesión del título exigido para cada caso. La mencionada exigencia deriva de la imposición constitucional de eficacia administrativa, ya que no sería aceptable admitir el ingreso de funcionarios que no poseen los conocimientos técnicos necesarios para el desempeño de su función.

En España, en los procesos selectivos para el acceso a la función pública, será requerida la presentación de la titulación ${ }^{675}$ exigida para uno de los grupos de los

674 Según la Ley Orgánica 5/1985, que trata del Régimen Electoral General en España:

"Artículo 2. 1. El derecho de sufragio corresponde a los españoles mayores de edad que no estén comprendidos en ninguno de los supuestos previstos en el artículo siguiente. 2. Para su ejercicio es indispensable la inscripción en el censo electoral vigente.

Artículo 3. 1. Carecen de derecho de sufragio: a) Los condenados por sentencia judicial firme a la pena principal o accesoria de privación del derecho de sufragio durante el tiempo de su cumplimiento.

b) Los declarados incapaces en virtud de sentencia judicial firme, siempre que la misma declare expresamente la incapacidad para el ejercicio del derecho de sufragio.

c) Los internados en un hospital psiquiátrico con autorización judicial, durante el período que dure su internamiento siempre que en la autorización el Juez declare expresamente la incapacidad para el ejercicio del derecho de sufragio. 2. A los efectos previstos en este artículo, los Jueces o Tribunales que entiendan de los procedimientos de incapacitación o internamiento deberán pronunciarse expresamente sobre la incapacidad para el ejercicio del sufragio. En el supuesto de que ésta sea apreciada, lo comunicarán al Registro Civil para que se proceda a la anotación correspondiente.

Artículo 4. 1. El derecho de sufragio se ejerce personalmente en la Sección en la que el elector se halle inscrito según el censo y en la Mesa Electoral que le corresponda, sin perjuicio de las disposiciones sobre el voto por correspondencia y el voto de los interventores. 2. Nadie puede votar más de una vez en las mismas elecciones.

Artículo 5. Nadie puede ser obligado o coaccionado bajo ningún pretexto en el ejercicio de su derecho de sufragio, ni a revelar su voto".

${ }^{675}$ Sobre esta cuestión, conviene destacar que "la titulación se acredita mediante la presentación del título oficial expedido por la autoridad competente que acredita la superación de un ciclo de estudios oficiales, incluido, en su caso, el periodo de prácticas necesarias a su obtención. A los títulos válidamente expedidos en otros Estados se les atribuye validez siempre que hayan sido homologados. La homologación implica el reconocimiento del grado académico, y conlleva el reconocimiento de los efectos profesionales inherentes al título español de referencia. Cuando entre en vigor el Espacio Europeo de Educación Superior (EEES), que se espera que sea en el año 2010, todos los títulos 
cuerpos y escalas de funcionarios. Esto se debe a que en el derecho español, los funcionarios son divididos en grupos, en función de lo que la legislación establece como titulación mínima exigida para el ingreso ${ }^{676}$.

Delante de las normas previstas en el ordenamiento jurídico español, se constata que cada proceso selectivo deberá, según el puesto que se va a desempeñar, exigir como requisito de participación de los aspirantes que estos estén en posesión de la titulación mínima correspondiente. Para que se pueda ejemplificar, para un puesto del grupo C1, será exigido, como mínimo, el Título de Bachiller o Técnico.

Sin embargo, hay algunas consideraciones que deben ser destacadas: en primer lugar, que para el cumplimiento del requisito bajo análisis, es necesario poseer la titulación exigida en el perfil de la plaza o estar en condiciones de obtenerla en la fecha en la que termine el plazo de presentación de instancias para la participación del proceso selectivo. ${ }^{677}$

En segundo lugar, cabe mencionar que, como regla, las normas de los procesos selectivos exigen como requisito de los aspirantes la posesión de las

obtenidos en cualquier Estado miembro serán iguales, existirá lo que se ha denominado "comparabilidad a escala transnacional, tanto en el plano académico como en el de la subsiguiente inserción laboral y profesional"' (NAVARRO, Pilar. Prepara oposiciones con éxito. Las técnicas y los trucos para superar todas las pruebas, Editorial Planeta, Barcelona, 2006, p. 36-37).

${ }^{676}$ Así, en el ámbito del personal funcionario de carrera, según el art. 76 del Estatuto Básico del Empleado Público, los grupos están divididos en los siguientes términos:

“Artículo 76. Grupos de clasificación profesional del personal funcionario de carrera.

Los cuerpos y escalas se clasifican, de acuerdo con la titulación exigida para el acceso a los mismos, en los siguientes grupos:

Grupo A, dividido en dos Subgrupos A1 y A2.

Para el acceso a los cuerpos o escalas de este Grupo se exigirá estar en posesión del título universitario de Grado. En aquellos supuestos en los que la Ley exija otro título universitario será éste el que se tenga en cuenta.

La clasificación de los cuerpos y escalas en cada Subgrupo estará en función del nivel de responsabilidad de las funciones a desempeñar y de las características de las pruebas de acceso.

Grupo B. Para el acceso a los cuerpos o escalas del Grupo B se exigirá estar en posesión del título de Técnico Superior.

Grupo C. Dividido en dos Subgrupos, C1 y C2, según la titulación exigida para el ingreso.

C1: título de bachiller o técnico.

C2: título de graduado en educación secundaria obligatoria."

Para la doctrina, "el artículo 76 del EBEP establece una nueva clasificación de los grupos profesionales adaptada al futuro sistema de titulaciones, la cual a nuestro juicio, presenta una gran complejidad para su puesta en marcha, en especial, con relación a los grupos A y C." (FONDEVILA ANTOLÍN, Jorge. Op.cit., p. 68).

${ }^{677}$ El Real Decreto 364/1995, del 10 de marzo, por el que se aprueba el Reglamento General de Ingreso del Personal al Servicio de la Administración General del Estado y de Provisión de puestos de trabajo y Promoción Profesional de los Funcionarios Civiles de la Administración General del Estado establece tal posibilidad en el art. 18.2. 
titulaciones generales, no importando cuál. Así, usualmente, para acceder a un puesto del grupo A, es irrelevante, para esos efectos, si el aspirante es Licenciado en Biología, Derecho o Medicina.

Sin embargo, en distintas situaciones, para unos concretos puestos de trabajo, será exigida una determinada titulación, ya que para estos casos, se necesita una preparación técnica especializada.

Además, la mencionada exigencia de titulación específica muchas veces es “imprescindible no sólo para un correcto ejercicio de tareas en la Administración, sino para un legal ejercicio de funciones, ya que ciertas actuaciones requieren ex lege que las firme, asuma o dirija personal cualificado conforme a planes de estudios oficiales $\mathrm{u}$ homologados"

Por esta razón, solamente los licenciados en Derecho podrán participar de los procesos selectivos ${ }^{679}$ para las carreras de procurador de los Tribunales, judicatura, fiscalía, abogado del Estado, entre otras; y solamente los licenciados en Medicina podrán opositar a plazas de médico.

Sobre la exigencia de titulación específica, el Tribunal Superior de Justicia de Murcia decidió que:

“...no puede exigirse la posesión de título alguno como requisito necesario para el desempeño de las tareas propias de la plaza de técnico superior de Cultura, al tratarse de plaza de cometidos especiales, como expresamente se contiene en la convocatoria, a diferencia de lo que sucede en el caso de las Subescalas Técnicas, a la que pertenecen los funcionarios que desarrollan tareas que son objeto de una carrera para cuyo ejercicio exijan las leyes estar en posesión de determinados títulos académicos o profesionales." ${ }^{\circ 80}$

\footnotetext{
${ }^{678}$ ILDEFONSO HUERTAS, Rosa María. Op.cit., p. 265.

${ }^{679}$ Cabe añadir que la titulación exigida para el acceso es un requisito que también deberá ser atendido durante toda la carrera del funcionario, hasta su jubilación. Por esta razón, si por algún motivo, el funcionario está impedido para ejercer su profesión, este hecho afectará su condición en la Administración Pública.

${ }^{680}$ STSJ de Murcia de 26 de enero de 2000.
} 
No obstante, según advierte la doctrina "es obvio que la titulación, en tanto que requisito de capacidad, debe guardar una relación razonable con las funciones a desempeñar en el empleo que se pretende." 681

La advertencia arriba mencionada sirve para destacar que, en el contexto examinado, el derecho del ciudadano de acceso a la función pública en condiciones de igualdad solamente puede ser limitado si hay una justificación razonable que demuestre la necesidad de la exigencia de determinada formación académica para el ejercicio de ciertas actividades públicas.

En el contexto mencionado, se puede destacar que la razonabilidad en cuestión no se verifica cuando "la relación entre la titulación y la descripción del puesto de trabajo no quedan dentro de la misma área de conocimiento o de sector profesional" ${ }^{\prime 682}$.

Es relevante también que se subraye que el hecho de que el aspirante haya superado las pruebas, lo que para alguien podría ser considerada una prueba inequívoca de su capacidad, no puede hacer que la ausencia de la titulación exigida pueda ser olvidada. En esto este camino, decidió el Tribunal Supremo:

“...no es jurídicamente procedente entender que la admisión a la realización de las pruebas selectivas de un concurso u oposición, e incluso la superación de las mismas, determine para los que carezcan de la titulación exigida para participar en el referido concurso u oposición el nacimiento de un derecho adquirido a no ser posteriormente excluido cuando se advierta la aludida falta de titulación, ya que aquella admisión inicial lo único que permite o concede es el derecho a la práctica de las pruebas selectivas..."683

Otra cuestión de gran importancia para la atención al derecho de igualdad de oportunidades en el proceso selectivo para el acceso a la función pública es la imposibilidad de exigir una titulación en un determinado centro de estudios o iter académico específico, ya que tales medidas privilegiarían a determinadas personas que

${ }^{681}$ SANCHÉZ MORÓN; Miguel. Op.cit., p. 122.

${ }_{682}^{682}$ ILDEFONSO HUERTAS, Rosa María, Op.cit., p. 264.

${ }^{683}$ STS de 8 de julio de 1994. 
hayan gozado de esa vía de estudio o formación (interdicción de reservas explícitas o implícitas de plazas de empleo público ad personam). ${ }^{684}$

En el derecho brasileño, la exigencia de titulación suele estar presente en las legislaciones de los entes federados que tratan de los requisitos de acceso a la función pública. En este contexto, en el ámbito federal, la Ley 8.112/90, en su art. 5, IV, exige como requisito de ingreso que el aspirante posea "o nível de escolaridade exigido para o exercício do cargo".

Muchas de las consideraciones aquí realizadas sobre la exigencia de titulación en el derecho español también pueden servir para el contexto brasileño, mientras otras no podrán ser aplicadas.

En estos términos, entre los aspectos no coincidentes entre los dos derechos, se puede subrayar que en el sistema jurídico brasileño, la exigencia de titulación debe ser demostrada tan solo cuando el aspirante va a tomar posesión, lo que se diferencia de la previsión del derecho español, ya que según el art. 18.2 del Real Decreto 364/1995, los aspirantes deberán manifestar en sus solicitudes de inscripción que "reúnen todas y cada una de las condiciones exigidas, referidas siempre a la fecha de expiración del plazo de presentación”.

La verdad es que, como ya se ha destacado, según la Constitución brasileña (art. 37, I), los requisitos previstos en las leyes deben ser para acceso a los cargos, y no para participación en los procesos selectivos.

Otro aspecto a ser subrayado dice respecto a la naturaleza de la titulación exigida en los concursos públicos. Es que en Brasil, cada carrera deberá ser creada en una ley específica, que determinará el nivel de escolaridad necesario para el ejercicio del cargo. Se puede añadir que tanto hay carreras que exigen del aspirante la posesión de titulaciones generales (por ejemplo, cualquier licenciatura), como también hay aquellas que imponen la tenencia de determinada titulación.

Lo que es inalterable es que la exigencia respecto a la titulación debe ser prevista en ley

${ }^{684}$ ILDEFONSO HUERTAS, Rosa María. Op.cit., p. 265. 
"Com efeito, se a lei não faz restrições quanto à formação profissional para o exercício de cargo ou emprego público, não poderá a regra regulamentar impor tais restrições. (...) Além do nível de escolaridade (alfabetização, ensino fundamental, ensino médio ou nível superior), pode-se exigir também a espécie de escolaridade, a depender das atribuições do cargo. Assim, o cargo de assessor jurídico exige a formação em Direito, como o cargo de médico exige a comprovação do candidato de que cursou a faculdade de Medicina, com registro do diploma no ente de fiscalização competente. Acrescente-se que a escolaridade deverá ser demonstrada quando do provimento do cargo e não no momento da inscrição"

Lo que también siempre suele ser objeto de debate en la doctrina brasileña es la necesidad de que la exigencia de titulación sea razonable y proporcional, de forma a no impedir sin que haya la debida justificación (necesidad y adecuación) el ejercicio del derecho constitucional de acceso a la función pública.

Para que se pueda ejemplificar el significado de la referida exigencia, la doctrina rechazó la imposición de que los aspirantes tuvieran nivel superior (lo que corresponde a la licenciatura) para el concurso público realizado para plazas de soldado del Distrito Federal:

"É oportuno esclarecer que não ser portador de nível superior nos tempos atuais não significa demérito, haja vista que não se gradua apenas quem não tem dinheiro ou tempo. $\mathrm{O}$ fato de ser bacharel, ou correspondente, em área sem distinção, não fará com que o militar se torne mais eficiente nas atividades pertinentes ao soldado, ou assimile com mais convicção os valores propostos pela Corporação miliciana. Numa observação cuidadosa se percebe que, em verdade, manter a exigência representa excluir do certame pessoas com chances de aprovação. Se de outra forma fosse, não haveria motivo para a restrição, já que a própria concorrência afastaria os desprovidos de canudo. Nota-se, pois, em última análise, que o escopo da exigência, que muitos acham apropriada, é impedir que aqueles que, mesmo não tendo "nível superior", consigam superar os que têm (e por isso

$\overline{{ }^{685} \text { TOURINHO, Rita. Op.cit., pp. } 67-68 .}$ 
mesmo aqueles são detentores de maior mérito) e assim ocupem os cargos de soldado, que no Distrito Federal tem remuneração bem mais atraente, em relação a outras unidades federativas. Seria um evidente petardo na meritocracia, tão cantada em programas de governo." 686

\subsubsection{2 - Experiencia y servicios prestados a la Administración Pública}

En determinados procesos selectivos brasileños y españoles, la Administración Pública considera que, para que haya el buen desempeno de las tareas del puesto de trabajo a ser cubierto, es conveniente que el candidato demuestre que ya ha tenido experiencia relacionada a las mencionadas actividades.

Se puede anadir que en muchos de estos casos, los procesos selectivos valoran aún más si la referida experiencia ha ocurrido en el ámbito de la própia Administración Pública, ya que tal circunstancia hace con que el candidato posea una condición diferenciada, en comparación a aquellos que no han tenido contacto previo con las actividades en el sector público.

En los terminos destacados, hay procesos selectivos que imponen como requisito de acceso a la función pública la comprobación de que el candidato posea experiencia en el desarrollo de actividades relacionadas a las tareas que serán desempenadas en el puesto de trabajo ofrecido, especialmente si la referida experiencia sucedió en un organismo público.

Conviene subrayar que la imposición del criterio experiencia, sea en el sector público o no, debe ser utilizada con la debida cautela, ya que, en muchas situaciones, impedirá el de acceso a la función pública a una gran cuantidad de aspirantes que no han tenido la oportunidad de ejercer una actividad laboral, de forma general (especialmente, por su juventud), o en la Administración Pública, muchas veces porque no fueron favorecidos por un nombramiento político.

En el derecho español, como ya se ha visto, los requisitos generales para el acceso a la función pública están previstos en el art. 56.1 del Estatuto Básico del Empleado Público. A su vez, la referida ley autoriza en el art. 56.3 la previsión de

${ }^{686}$ SANTOS, Waldir. Concurso público e exigência de nível superior. Texto extraído del sitio Jus Navigandi (http://jus2.uol.com.br/doutrina/texto.asp?id=12782), acceso en 16 de agosto de 2010. 
requisitos específicos, siempre que estos “...guarden relación objetiva y proporcionada con las funciones asumidas y las tareas a desempeñar" (principio de adecuación) y sean establecidos “...de manera abstracta y general” (principio de abstracción). ${ }^{687}$

En este contexto, hay algunas exigencias que si estuvieran presentes en los procesos selectivos llevados a cabo por las Administraciones Públicas españolas, estarían violando el derecho de igualdad genéricamente previsto en el art. 14 y en un sentido más específico, el art. 23.2 de la Constitución española.

El propio art. 14 CE hace referencia a la prohibición de discriminación en razón de nacimiento, raza, sexo, religión, opinión o cualquier otra condición o circunstancia personal o social. Como la citada regla es abierta, hay una cantidad amplia de situaciones por ella abarcada. Así, no sería factible hacer una investigación que analizara todas las posibles circunstancias que, si previstas como requisitos de acceso a la función pública, estarían violando el derecho del ciudadano establecido en el art. 23.2 de la Constitución.

Entre los requisitos específicos más usuales en los procesos selectivos espanoles, se puede destacar la experiencia del candidato, más precisamente en el sector público. Por la razón arriba mencionada, y dada su relevancia, se impone el análisis de este requisito, que es una cuestión considerada de las más polémicas que suelen ser usualmente tratadas por los doctrinadores.

Sobre la referida exigencia, esta muchas veces configura las llamadas pruebas restringidas, que se refieren a los procesos selectivos donde son exigidos "requisitos adicionales con los que se revisten determinados méritos o capacidades, éstos solo son satisfechos por un grupo de candidatos, produciéndose una configuración ad personam de aquellos incompatible con el principio de igualdad." ${ }^{688}$

Como destaca la doctrina espanola, sobre la cuestión arriba citada, hay que diferenciar dos situaciones distintas: los procesos selectivos restringidos, a los que solo tienen acceso las personas que han prestado servicios en la Administración, y las pruebas "abiertas", donde se valora el mencionado periodo de servicios.

${ }^{687}$ LÁZARO, José Luis. Op.cit., p. 689.

${ }^{688}$ LÁZARO, José Luis. Op.cit., p. 690. 
Mientras la primera situación se dio de forma episódica bajo circunstancias especiales y excepcionales en determinadas Comunidades Autónomas, que convocaron pruebas específicas de acceso a la función pública para el personal contratado administrativo $^{689}$, la segunda situación suele ser más frecuente en la realidad española. $^{690}$

La previsión de procesos restringidos que establezcan como requisito de acceso que los candidatos sean personas que ya prestan servicios a la Administración es, tanto para la doctrina, como para los Tribunales, una medida excepcionalísima, y solo se legitima como medida extrema para garantizar la eficacia organizativa. ${ }^{691}$

La doctrina resume el entendimiento del Tribunal Constitucional espanol sobre las pruebas restringidas:

"Este derecho a la igualdad en la ley que consagra el artículo 23.2 CE ha llevado al Tribunal Constitucional a afirmar que, en principio, no es compatible con el derecho de igualdad en el acceso a las funciones públicas la convocatoria de pruebas restringidas, esto es, la convocatoria de pruebas a las que sólo puedan concurrir quienes hayan tenido una previa relación de servicios con la Administración como contratados o interinos (por todas, STC 27/1991). No obstante, el Tribunal hay entendido también que en determinados supuestos la desigualdad que conlleva este tipo de convocatorias puede considerarse razonable, no arbitraria y proporcionada y, por tanto,

\footnotetext{
689 Vid. STC 27/1991 y 185/1994. En la primera, el Tribunal Constitucional analizó cuestiones de inconstitucionalidad sobre la LMRFP y leyes de función pública de Andalucía y Canarias. En su decisión, destacó que las pruebas restringidas analizadas se trataban de "medidas de carácter transitorio y excepcional para resolver una situación singular y derivada de un proceso único y irrepetible de creación de una nueva forma de organización de las Administraciones públicas a nivel autonómico que dio lugar a la necesidad de adscribir, de forma inmediata, a personal en régimen de Derecho administrativo, cuando ni existían plantillas de funcionarios ni había tiempo para poder acudir a las formas normales de ingreso en la Administración pública como funcionario de carrera. Además, a esta situación se añadió la prohibición que establecía la LMRFP de celebrar contratos administrativos por las Administraciones públicas, lo que requeriría también que el legislador adoptar medidas para solucionar los problemas coyunturales que esa importante modificación normativa producía en relación con situaciones personales".

${ }^{690}$ Ob.cit., p. 691.

691 Sobre este tema, ya se destacó que: "En particular, en las Comunidades Autónomas y en los Entes Locales; en general, convocar restringidamente pruebas de acceso para quienes hayan prestado servicios previos como interino o como contratado en la Administración General del Estado, ha sido una práctica con antecedentes en épocas preconstitucionales y que posee consiguientes en la década de los ochenta. En ésta el desempleo en España era elevado y la contratación temporal en la Administración fue utilizada como medida coyuntural de fomento de empleo." (LORENZO DE MEMBIELA, Juan B. Op.cit., p, 75)
} 
entenderse compatible con el derecho fundamental que se está analizando." ${ }^{692}$

Sin embargo, aquí se está de acuerdo con la opinión del autor que destaca que "no convence la invocación al principio de eficacia de la Administración, que justifica aquí el sacrificio de un derecho fundamental, como tampoco termina de ser aceptable la excusa del complejo proceso de consolidación de las Administraciones autonómicas." 693

En el camino arriba apuntado, sobre la práctica mencionada, se dijo que "la problemática de las pruebas restringidas para el acceso a la Administración son, en muchas ocasiones, producto de una deficiente gestión y planificación de los recursos humanos por los responsables administrativos." ${ }^{694}$

De hecho, lo que pasa en las pruebas restringidas es que aquellos que participaron de la competición pasaron a tener esta condición favorable porque habían ingresado previamente en la Administración pública a través de un procedimiento selectivo que no siempre tuvo las garantías de libre acceso.

Para la doctrina, sería privilegiar a quienes fueron reclutados, de forma directa o encubierta, por la voluntad de los gobernantes. ${ }^{695}$ Así, una situación de transgresión de la igualdad pasaría a legitimar otra ruptura del mencionado principio.

A su vez, sobre la valoración de los servicios ya prestados a la Administración ${ }^{696}$, conviene destacar que aquella no puede ser excesiva (principio de proporcionalidad), ya que, en caso contrario, sería vulnerado el derecho de acceso en condiciones de igualdad a la función pública, en la medida que redujera a casi cero la

\footnotetext{
${ }^{692}$ BELADIEZ ROJO, Margarita. "El derecho fundamental de acceder en condiciones de igualdad a las funciones públicas (artículo 23.2 CE)", Justicia Administrativa Revista de Derecho Administrativo, Lex Nova, n 45, octubre 2009, (Director Miguel Sánchez Morón), p. 12.

${ }^{693}$ RIVERO ORTEGA, Ricardo. "Acceso a la función pública autonómica y doctrina constitucional (Comentario a la STC de 11 de febrero de 1999)”, en Revista de Administración Pública, Núm. 151, p. 343-358, Enero-abril 2000, Madrid, p. 351.

${ }^{694}$ LORENZO DE MEMBIELA, Juan B. Op.cit., p. 76.

${ }^{695}$ Véase SÁNCHEZ MORÓN, Miguel. Igualdad de oportunidades en el acceso a la función pública y estabilización funcionarial de los interinos (Comentario a la Sentencia 12/1999, de 11 de febrero, del Tribunal Constitucional), en Revista Andaluza de Administración Pública, núm. 34, 1999.

${ }^{696}$ La doctrina sostiene que la valoración de los servicios prestados a las Administraciones Públicas que vulnera el derecho a acceder en condiciones de igualdad a la función pública es la definición de la aquella como requisito de acceso. Sin embargo, sería aceptable como valoración del mérito, siempre que realizada de forma razonable y proporcionada. (BELADIEZ ROJO, Margarita. Op.cit., p. 13).
} 
competencia (posibilidad de éxito muy reducida para los candidatos de "fuera" de la Administración).

Esta cautela específica para la valoración de los servicios prestados a la Administración es consecuencia de la propia regla general prevista en el propio Estatuto Básico del Empleado Público (art. 61.3) ${ }^{697}$, que repele el abuso de la valoración mencionada.

Todo lo dicho conlleva a que en diversas oportunidades, la valoración de los servicios ya prestados a la Administración Pública sea utilizada de forma indebida para estabilizar situaciones de precariedad (contratados e interinos). Sobre esta práctica, la doctrina ya destacó que:

"Las vías para estabilizar a estos colectivos de personal interino, ya sea en puestos de trabajo reservado a funcionarios, ya sea en puestos de trabajo de naturaleza laboral, tiene un denominador común. Este punto común no va a ser otro que la valoración de su antigüedad, entendiendo por tal el simple paso del tiempo en el puesto de trabajo (sin referencias a rendimiento o resultados de la actividad laboral) como factor de consolidación de su relación de empleo." ${ }^{\text {698 }}$

Así, como bien destaca doctrina, la indebida hipervaloración de la experiencia en la Administración acaba por tornarse una sutil forma de reserva de plazas de modo exclusivo a los candidatos que ya prestan sus servicios en la Administración.

Sin embargo, si se prevé de forma proporcional y conectado y con los principios de mérito y capacidad, "el criterio de antigüedad o servicios prestados en la Administración como forma de valoración del mérito de los aspirantes al empleo público es tan válido como otros, según la legalidad vigente y la opinión de los jueces" ${ }^{\prime 699}$.

\footnotetext{
697 "Los procesos selectivos que incluyan, además de las preceptivas pruebas de capacidad, la valoración de méritos de los aspirantes sólo podrán otorgar a dicha valoración una puntuación proporcionada que no determinará, en ningún caso, por sí misma el resultado del proceso selectivo."

${ }^{698}$ ILDEFONSO HUERTAS, Rosa María. Op.cit., p. 244.

${ }^{699}$ ILDEFONSO HUERTAS, Rosa María. Idem, p. 248.
} 
Sobre esta cuestión, al analizar la constitucionalidad de una convocatoria del letrado del asesor de la Comunidad Autónoma de Murcia, el propio Tribunal Constitucional destacó que:

\begin{abstract}
"Es indudable, como señala la Comunidad demandada, que la consideración de los servicios prestados no es ajena al concepto de mérito y capacidad, pues el tiempo efectivo de servicios puede poner de manifiesto la aptitud o capacidad para desarrollar determinada función pública, y puede suponer unos méritos que pueden ser reconocidos y valorados. No surgiría ningún problema si se considerasen los servicios prestados, no como un requisito necesario para poder participar en el concurso, sino como un mérito a valorar en una fase posterior del concurso..."
\end{abstract}

Otra cuestión relevante versa sobre la posibilidad de trato favorable a aquellos que tienen experiencia relativa a servicios prestados en la Administración que está realizando el proceso selectivo. La cuestión que se plantea aborda la verificación de la legitimidad de trato diferenciado de aquellos que desempeñaron los mismos puestos de trabajo fuera de determinada Administración pública.

Parece evidente que la valoración de la experiencia, en términos generales, necesitaría una fundamentación que estableciera su vinculación con los principios de mérito y capacidad, la previsión de un trato más favorable a quienes ya hayan prestado sus servicios a determinada Administración exigiría una justificación aún más contundente, ya que, en principio, aquellos que ya hayan desempeñado la función pública prevista en la convocatoria en otras localidades presuntamente ya demostraron poseer la aptitud y capacidad para su ejercicio en cualquier sitio.

Así, la estipulación en términos indebidos de la exigencia de experiencia traducida en servicios prestados a la Administración produce algo distinto a lo que pasa en la mayoría de los tratos discriminatorios en el acceso a la función pública.

Mientras, en distintas situaciones se niega indebidamente el acceso a determinados grupos minoritarios (personas con discapacidad, extranjeros, personas con

${ }^{700}$ STC 60/1994, de 28 de febrero. 
edad avanzada, etc.), en las pruebas restringidas, se impide el ingreso en la función pública a la mayoría de la población, violando el acceso igualitario.

En el derecho brasileno, también se puede afirmar que el tema de la imposición de la experiencia como requisito de acceso a la función pública ha despertado muchas polémicas, sea en el ámbito doctrinario o jurisprudencial.

Además, el mencionado criterio ha sido utilizado por las Administraciones Públicas brasileñas en determinados contextos muy asemejados a lo de la realidad española (como los concursos internos, que se asemeja a las pruebas restringidas), aunque también se constata que la imposición de la experiencia se ha manifiestado en circunstancias bien peculiares al contexto brasileno, como es el caso de los concursos públicos para las carreras jurídicas (Magistratura y Fiscalía), donde se exige el requisito de comprobación de 3 anos de actividad jurídica.

Entre los aspectos del tema bajo analisis donde hay una gran similitud con la realidad española, se puede subrayar el intento, hoy en día rechazado, de algunas Administraciones Públicas para realización de procesos selectivos restringidos a los funcionarios, lo que la doctrina y jurisprudencia brasilena llama de concurso interno.

Para la doctrina brasilena,el concurso interno no es concurso público, ya que no hay la posibilidad de participación del ciudadano en el proceso selectivo:

"Concurso interno ou restrito é o processo seletivo realizado
exclusivamente dentro do âmbito de pessoas administrativas ou
órgãos públicos. Esse tipo de certame não pode ser tido como
concurso público, sabido que a participação de candidatos é de
caráter limitado. O concurso interno só é constitucional quando
utilizado para a elevação de servidores na carreira (promoção ou
acesso), ou conforme exigido em lei", 701

En los términos destacados, la utilización del concurso interno sirve para permitir la promoción de los funcionarios públicos en la carrera. Además, se puede añadir que el mencionado instituto también se maneja para viabilizar la remoção (desplazamiento del funcionario), donde se instaura una disputa para definir aquellos,

\footnotetext{
${ }^{701}$ PINHEIRO MADEIRA, José Maria. Op.cit., p. 71.
} 
entre los muchos interesados, que ocuparán las plazas vacantes en determinadas localidades.

En el derecho brasileño, la exigencia de experiencia no suele ser un requisito de acceso a la función pública, pues la doctrina cree que tal criterio es discriminatorio e inviabiliza el acceso universal a la función pública ${ }^{702}$. En este contexto, analizando proceso selectivo que condicionaba el acceso a la función pública a la demostración de 2 años de experiencia en el área de hospitales, la doctrina ha afirmado que:

"O Legislador, visando oferecer oportunidade igual a todos os candidatos e precavendo-se contra eventuais tentativas de favorecimento individual ou de grupo, sabiamente substituiu o tempo de experiência prévia pelo estágio probatório. (...) A eventual manutenção da exigência de comprovação de experiência representa de fato uma "reserva de mercado" para os candidatos que já trabalham na área hospitalar há dois anos ou mais. Desempregados e profissionais recém formados teriam o seu direito ao trabalho injusta e ilegalmente cerceado."

Sin embargo, si reunidas determinadas circunstancias especiales, que atesten su necesidad para el buen desempeño de las actividades administrativas, la exigencia de experiencia puede ser válida. En este sentido:

\begin{abstract}
"Quanto à exigência de tempo de experiência profissional, há decisões proferidas por tribunais superiores aceitando-a (...) Assim, é perfeitamente aceitável para provimento do emprego de piloto no
\end{abstract}

\footnotetext{
702 "O juiz da 1 a Vara Federal de Pelotas, Cláudio Gonsales Valério, condenou a Universidade Federal de Pelotas (Ufpel) a não exigir como pré-requisito dos candidatos ao cargo de Assistente em Administração no concurso público aberto por meio do Edital CES no 18/2008 a comprovação de experiência profissional de doze meses. A ação civil pública ajuizada pelo Ministério Público Federal alegou que esta exigência é inconstitucional. Ao julgar o processo, o magistrado entendeu que há de ser prestigiado o princípio do livre acesso aos cargos públicos. O cargo de assistente, por sua natureza, não tem uma complexidade ímpar que pressuponha experiência profissional prévia. Na sentença, o juiz manteve a liminar concedida no início deste ano, que suspendeu a realização das provas para o cargo e determinou a retificação do Edital, reabrindo o prazo de inscrição." (Texto extraído del reportage Ufpel não pode exigir comprovação de experiência profissional no cargo de Assistente Administrativo, publicado en el sitio JusBrasil (http://www.jusbrasil.com.br/noticias/55444/ufpel-nao-pode-exigir-comprovacao-deexperiencia-profissional-no-cargo-de-assistente-administrativo.), acceso en 11 de julio de 2010.

${ }^{703}$ BARCAROL, Amarildo José. Exigência de experiência prévia em concursos públicos é ilegal?, texto extraído del sitio: http://forum.jus.uol.com.br/2268/exigencia-de-experiencia-previa-em-concursospublicos-e-ilegal/, acceso en 15 de junio de 2010.
} 
âmbito da Administração Indireta, a exigência de tempo de experiência. No entanto, entendemos que, somente excepcionalmente, tal exigência deve ser admitida, uma vez que há uma inegável dificuldade em se estabelecer qual o tempo de experiência necessário para atender as expectativas administrativas. Ademais, nada impede que a prova de títulos oferte maior pontuação àquele que apresenta maior tempo de exercício da profissão. Atentese, no entanto, que tempo de experiência não se confunde com tempo de graduação. Desta forma, a exigência de prazo de emissão de diploma não revela e per se a experiência do candidato." 704

Cuando la Administración Pública brasileña considera que la experiencia del candidato debe ser valorada, se suele establecer en el proceso selectivo que la referida circunstancia será computada como título (merito). Aunque sea un aspecto que tiene relación con la capacidad del candidato, la experiencia no puede ser valorada de forma excesiva $^{705}$, ni tampoco causar un gran desequilibrio en la competición:

“É perfeitamente admissível que o tempo de serviço público seja um título valorizado, mas somente se for um entre diversos outros títulos. Também é admissível que o tempo de serviço prestado na própria entidade que realiza o concurso possa ter alguma pontuação, mas não a ponto de resultar em reserva de vaga e desde que não configure desvio de poder; uma forma disfarçada da burlar a isonomia que deve presidir o concurso."

Otro aspecto que debe ser llevado en consideración es que, como regla general, la experiencia del candidato debe alcanzar todas las actividades que el mismo ha desarrollado en su vida laboral, no importando si las mismas han ocurrido en el sector público o privado. En este contexto, debe ser considerado irrelevante la circunstancia de si la experiencia que un medico ha tenido en cirugía sucedió en un hospital público o privado.

\footnotetext{
${ }^{704}$ TOURINHO, Rita. Op.cit., p. 72.

${ }^{705}$ En este sentido: "Discrepa da razoabilidade norteadora dos atos da Administração Pública o fato de o edital de concurso emprestar ao tempo de serviço público pontuação superior a títulos referentes a pós-graduação." ( RE 205.535-AgR, Rel. Min. Marco Aurélio, juzgamento em 22-5-98, DJ de 14-8-98)

706 ABREU DALLARI, Adilson. Princípio da isonomia e concurso público, en Concurso público e Constituição, Fabrício Motta (Cordinador), Editora Fórum, Belo Horizonte, 2005, p. 117.
} 
También se debe destacar que, como regla general, no puede el proceso selectivo atribuir puntos en los títulos (meritos) al candidato por el simples hecho de que este ya sea funcionario público ${ }^{707}$, ya que tal circunstancia, si no tiene una fuerte justificación, transgrede el derecho de acceso a la función pública en condiciones de igualdad:

\begin{abstract}
"Muito criticado tem sido o procedimento de se computar pontos na prova de títulos aos candidatos que já sejam pertencentes ao serviço público. Essa contagem de pontos tem como fundamento a experiência que tais agentes detêm e que deve ser levada em consideração pelo Poder Público no momento da classificação dos concursados. Tal procedimento tem sido considerado ofensivo ao princípio da igualdade, porque na prática se torna inacessível aos não-servidores.",708
\end{abstract}

En el derecho brasileño, la experiencia es un requisito de acceso a las carreras de la Magistratura y del Ministerio Público (Fiscalía). Desde la edición de la Enmienda Constitucional 45, de 08 de diciembre de 2004, la Constitución Federal exige que los procesos selectivos relativos a las referidas carreras exijan de los aspirantes la comprobación de que los mismos poseen, al menos, 3 años de actividad jurídica ${ }^{709}$.

La Constitución brasileña ha considerado que para el ejercicio de las carreras de la Magistratura y del Ministerio Público, teniendo en consideración su extrema relevancia a la vida social y la necesidad de madurez profesional, debe ser exigida la experiencia en actividades jurídicas.

\footnotetext{
707 "Concurso público. (...) Prova de títulos: exercício de funções públicas. Viola o princípio constitucional da isonomia norma que estabelece como título o mero exercício de função pública." (ADI 3.443, Rel. Min. Carlos Velloso, julgamento em 8-9-05, DJ de 23-9-05). No mesmo sentido: ADI 3.522, Rel. Min. Marco Aurélio, julgamento em 24-11-05, DJ de 12-5-06.

${ }^{708}$ PINHEIRO MADEIRA, José Maria. Op.cit., p. 70.

709 "Art. 93. Lei complementar, de iniciativa do Supremo Tribunal Federal, disporá sobre o Estatuto da Magistratura, observados os seguintes princípios:

I - ingresso na carreira, cujo cargo inicial será o de juiz substituto, mediante concurso público de provas e títulos, com a participação da Ordem dos Advogados do Brasil em todas as fases, exigindo-se do bacharel em direito, no mínimo, três anos de atividade jurídica e obedecendo-se, nas nomeações, à ordem de classificação;" (Redacción conferida por la EC 45, de 08.12.2004)

"Art. 129. $3^{\circ} \mathrm{O}$ ingresso na carreira do Ministério Público far-se-á mediante concurso público de provas e títulos, assegurada a participação da Ordem dos Advogados do Brasil em sua realização, exigindo-se do bacharel em direito, no mínimo, três anos de atividade jurídica e observando-se, nas nomeações, a ordem de classificação." (Redacción conferida por la EC 45, de 08.12.2004)."
} 
Respecto a la citada exigencia, la doctrina ha subrayado sus objetivos, así como la necesidad de la legislación establecer el alcance de la expresión actividad jurídica, como se puede percibir:

“A Emenda Constitucional no 45/04, com a inclusão expressa da exigência de três anos de atividade jurídica como requisito ao ingresso nas carreiras da magistratura e do Ministério Público, visou assegurar que os candidatos às mesmas encontrem-se imbuídos de um mínimo de experiência e maturidade profissional para o ingresso nelas, com evidente intuito de segurança jurídica, haja vista a relevância das funções exercidas pelos integrantes daquelas. Com efeito, em princípio, não se vislumbra qualquer inconstitucionalidade na Emenda Constitucional em comento, no particular, vez que assim como a lei pode exigir qualificações para o exercício, em princípio livre, de qualquer emprego, ofício ou profissão, tanto mais pode a Carta Política estabelecer requisitos à investidura em cargos, empregos ou funções públicas, especialmente de grande relevo e responsabilidade, e de caráter político, como os das mencionadas carreiras. Pode-se traçar, até mesmo, um paralelo, afirmando-se que, assim como o estabelecimento de requisitos, pelo legislador, para o exercício profissional não fere, à primeira vista, o Princípio do Livre Exercício Profissional, o estabelecimento de requisitos, pelo legislador constituinte, para a investidura em cargos públicos não fere, a priori, o Princípio da ampla acessibilidade dos cargos, empregos e funções públicas, inserto no art. 37, inciso I, da Carta Magna. Não obstante, a Constituição, na redação conferida pela retromencionada Emenda, não esclareceu - tampouco deveria tê-lo feito, eis que tal atribuição é do legislador infraconstitucional - o que deve ser considerado como "atividade jurídica", para tais fins."710

\footnotetext{
710 SGARBOSSA, Luís Fernando y JENSEN, Gesiela. O princípio da ampla acessibilidade aos cargos públicos. A exigência de três anos de atividade jurídica para os concursos à Magistratura e ao Ministério Público, texto extraído del sitio Jus Navigandi (http://jus2.uol.com.br/doutrina/texto.asp?id=7427).
} 
Trás un intenso debate en el medio jurídico brasileño, el alcance de la expresión actividad jurídica ha sido definido por los Consejos Nacional de la Magistratura - $\mathrm{CNJ}^{711}$, y del Ministerio Público - $\mathrm{CNMP}^{712}$.

${ }^{711}$ En el ámbito de la Magistratura, hay la Resolución 75, de 12 de mayo de 2009, del Consejo Nacional de la Magistratura, que establece:

"Art. 59. Considera-se atividade jurídica, para os efeitos do art. 58, $\S 1^{\circ}$, alínea " $i$ ":

I - aquela exercida com exclusividade por bacharel em Direito;

II - o efetivo exercício de advocacia, inclusive voluntária, mediante a participação anual mínima em 5 (cinco) atos privativos de advogado (Lei $n^{\circ}$ 8.906, 4 de julho de 1994, art. $1^{\circ}$ ) em causas ou questões distintas;

III - o exercício de cargos, empregos ou funções, inclusive de magistério superior, que exija a utilização preponderante de conhecimento jurídico;

IV - o exercício da função de conciliador junto a tribunais judiciais, juizados especiais, varas especiais, anexos de juizados especiais ou de varas judiciais, no mínimo por 16 (dezesseis) horas mensais e durante 1 (um) ano;

$V$ - o exercício da atividade de mediação ou de arbitragem na composição de litígios.

$\S 1^{\circ} E$ vedada, para efeito de comprovação de atividade jurídica, a contagem do estágio acadêmico ou qualquer outra atividade anterior à obtenção do grau de bacharel em Direito.

$\S 2^{\circ}$ A comprovação do tempo de atividade jurídica relativamente a cargos, empregos ou funções não privativos de bacharel em Direito será realizada mediante certidão circunstanciada, expedida pelo órgão competente, indicando as respectivas atribuições e a prática reiterada de atos que exijam a utilização preponderante de conhecimento jurídico, cabendo à Comissão de Concurso, em decisão fundamentada, analisar a validade do documento".

${ }^{712}$ A su vez, en el ámbito del Ministerio Público, hay que destacar la Resolución 40, de 26 de mayo de 2009, que determina que:

"Art. $1^{\circ}$ Considera-se atividade jurídica, desempenhada exclusivamente após a conclusão do curso de bacharelado em Direito:

I-O efetivo exercício de advocacia, inclusive voluntária, com a participação anual mínima em 5 (cinco) atos privativos de advogado (Lei $n^{\circ} 8.906$, de 4 Julho de 1994), em causas ou questões distintas.

II - O exercício de cargo, emprego ou função, inclusive de magistério superior, que exija a utilização preponderante de conhecimentos jurídicos.

III - O exercício de função de conciliador em tribunais judiciais, juizados especiais, varas especiais, anexos de juizados especiais ou de varas judiciais, assim como o exercício de mediação ou de arbitragem na composição de litígios, pelo período mínimo de 16 (dezesseis) horas mensais e durante 1 (um) ano.

$\S 1^{\circ}$ É vedada, para efeito de comprovação de atividade jurídica, a contagem de tempo de estágio ou de qualquer outra atividade anterior à conclusão do curso de bacharelado em Direito.

$\S 2^{\circ}$ A comprovação do tempo de atividade jurídica relativa a cargos, empregos ou funções não privativas de bacharel em Direito será realizada por meio da apresentação de certidão circunstanciada, expedida pelo órgão competente, indicando as respectivas atribuições e a prática reiterada de atos que exijam a utilização preponderante de conhecimentos jurídicos, cabendo à comissão de concurso analisar a pertinência do documento e reconhecer sua validade em decisão fundamentada.

Art. $2^{o}$ Também serão considerados atividade jurídica, desde que integralmente concluídos com aprovação, os cursos de pós-graduação em Direito ministrados pelas Escolas do Ministério Público, da Magistratura e da Ordem dos Advogados do Brasil, bem como os cursos de pós-graduação reconhecidos, autorizados ou supervisionados pelo Ministério da Educação ou pelo órgão competente.

$\S 1^{\circ}$ Os cursos referidos no caput deste artigo deverão ser presenciais, com toda a carga horária cumprida após a conclusão do curso de bacharelado em Direito, não se admitindo, no cômputo da atividade jurídica, a concomitância de cursos nem de atividade jurídica de outra natureza.

$\$ 2^{\circ}$ Os cursos lato sensu compreendidos no caput deste artigo deverão ter, no mínimo, um ano de duração e carga horária total de 360 horas-aulas, distribuídas semanalmente.

$\S 3^{\circ}$ Independente do tempo de duração superior, serão computados como prática jurídica:

a) Um ano para pós-graduação lato sensu.

b) Dois anos para Mestrado.

c) Três anos para Doutorado. 
Cabe destacar, especialmente porque se trata de una situación poco usual en el derecho brasileño, que la comprobación del referido requisito debe ser realizada en el momento de la inscripción definitiva del candidato, y no, como suele suceder en la mayoría de los procesos selectivos, en el momento de la toma de posesión.

\section{3 - Requisitos negativos}

Además de establecer distintos requisitos de carácter positivo, que imponen la tenencia de determinadas condiciones imprescindibles para el acceso a la función pública (nacionalidad, edad, conocimiento lingüístico, titulación, capacidad funcional, etc.), los ordenamientos jurídicos también exigen de los aspirantes, para que puedan hacer parte de los procesos selectivos, requisitos negativos, que son demostrados a través de manifestaciones expresas de los aspirantes, en las cuales van a declarar que no se encuentran bajo determinadas situaciones impeditivas del acceso a la función pública.

Aunque se pueda afirmar que tanto en los sistemas jurídicos brasileño como español hay la previsión de las mencionadas circunstancias que impiden la participación del ciudadano en los procesos selectivos, también se puede subrayar que la sistematización del asunto bajo estudio es mayor en el país europeo, que dedicó algunas normas del Estatuto Básico del Empleado Público para regular la materia.

A su vez, en el derecho brasileño, lo que se percibe es la existencia de variadas normas de diferentes naturalezas (constitucional, penal, administrativa o política) que no fueron consolidadas en una sola ley, lo que muchas veces dificulta la perfecta comprensión del tema.

\subsection{1 - En el derecho español}

En los términos antes destacados, en el derecho español, según el art. 56.1 d) del Estatuto Básico del Empleado Público, cabrá al aspirante declarar que:

$\$ 4^{\circ}$ Os cursos de pós-graduação (lato sensu ou stricto sensu) que exigirem apresentação de trabalho monográfico final serão considerados integralmente concluídos na data da respectiva aprovação desse trabalho". 
a) no haya sido separado mediante expediente disciplinario del servicio de cualquiera de las Administraciones Públicas o de los órganos constitucionales o estatutarios de las Comunidades Autónomas;

b) no se halla en inhabilitación absoluta o especial para empleos o cargos públicos por resolución judicial, para el acceso al cuerpo o escala de funcionario, o para ejercer funciones similares a las que desempeñaba en el caso del personal laboral, en el que hubiese sido separado o inhabilitado;

c) en el caso de ser nacional de otro Estado, que no se halla inhabilitado o en situación equivalente ni haya sido sometido a sanción disciplinaria o equivalente que impida, en su Estado, en los mismos términos el acceso al empleo público.

Sobre las mencionadas hipótesis, cabe destacar que lo que el Estatuto Básico del Empleado Público hace es impedir el nuevo ingreso de aquellos que ya fueron alejados del servicio público a través de decisiones administrativas o judiciales. En estos términos, el art. 63 del Estatuto aclara cuáles son causas de pérdida de la condición de funcionario de carrera. ${ }^{713}$

Así, lo que se percibe es que el Derecho español no permite el nuevo acceso a la función pública de aquellos que, en otros momentos, ya habían sido funcionarios, pero como habían practicado ilícitos administrativos o penales de naturaleza grave, fueron punidos severamente con la pérdida de la condición de funcionario de carrera.

Por supuesto, el Estatuto Básico del Empleado Público podría haber aprovechado mejor la oportunidad para "introducir algunas mejoras técnicas sugeridas en el Informe CEBEP y otras apuntadas por la doctrina en relación con la conveniencia jurídica de acotar los efectos temporales de conductas pasadas, tal y como ha reconocido el propio Tribunal Constitucional (STC 174/1996, de 11 de noviembre)., ${ }^{, 714}$

Es evidente que la definición de un límite temporal es una medida necesaria para evitar que la separación del servicio tenga efectos permanentes. Así, el

\footnotetext{
713 “d) La sanción disciplinaria de separación del servicio que tuviere carácter firme.

e) La pena principal o accesoria de inhabilitación absoluta o especial para cargo público que tuviere carácter firme."

${ }^{714}$ LÁZARO, José Luis. Op.cit., p. 685.
} 
Informe de la Comisión para el Estudio y Preparación del Estatuto Básico del Empleado Público sugirió ${ }^{715}$ (sin que haya habido el atendimiento a la sugerencia por el legislador) la equiparación de la duración de los efectos de la separación del servicio (que no tiene, en la legislación, ningún límite temporal) a la de la pena máxima de inhabilitación para el ejercicio de funciones públicas prevista en el Código Penal. ${ }^{716}$

Antes de analizar cada una de las referidas hipótesis, cabe destacar que la declaración jurada del aspirante, "en caso de ser falsa, además de poder constituir un ilícito penal, comportaría la nulidad absoluta de su nombramiento."717

\subsubsection{1 - Ausencia de separación del servicio}

El primer requisito de carácter negativo que debe ser cumplido por los aspirantes impone que estos declaren que no han sido separados del servicio de cualquiera de las Administraciones Públicas o de los órganos constitucionales o estatutarios de las Comunidades Autónomas.

La separación del servicio es una de las modalidades de sanción disciplinar previstas en el Estatuto Básico del Empleado Público. En efecto, la mencionada sanción, que tiene carácter administrativo, es la de mayor gravedad que puede ser impuesta por la Administración Pública al funcionario y sólo puede ser impuesta para sancionar faltas muy graves. Esta está prevista en los términos del art. 96 del EBEP. ${ }^{718}$

Para algunos doctrinadores:

"resulta lógico que quien con su actuación anterior ha merecido ser
expulsado del servicio público no tenga ocasión de volver a ingresar
en él y, por ello, esta medida ha sido tradicionalmente incluida como
un requisito para ingresar, antes en la función pública, y ahora, con

\footnotetext{
715 Informe de la Comisión para el estudio y preparación del Estatuto Básico del Empleado Público, INAP, Miguel Sánchez Morón (Presidente), Abril 2005, p. 95.

${ }^{716}$ Según el art. 40 del Código Penal, el plazo máximo es de 20 (veinte) años si se trata de pena principal.

${ }^{717}$ PÉREZ GÓMES, José María. Capítulo “Acceso al empleo público y adquisición de la relación de servicio", del libro Comentarios a la Ley 7/2007, de 12 de abril, del Estatuto Básico del Empleado Público. Alberto Palomar Olmeda, Antonio V. Sempere Navarro (Directores), R. Yolanda Quintanilla Navarro (Coordinadora), Thomson Aranzadi, Cizur Menor (Navarra), 2008, p. 500-501.

718 “Artículo 96. Sanciones.

1. Por razón de las faltas cometidas podrán imponerse las siguientes sanciones:

a) Separación del servicio de los funcionarios, que en el caso de los funcionarios interinos comportará la revocación de su nombramiento, y que sólo podrá sancionar la comisión de faltas muy graves."
} 
carácter general en el empleo público en los términos un tanto confusos de la letra d) del art. 56 EBEP." 719

Sin embargo, como ya se ha destacado, el Estatuto no estableció un límite temporal para que el funcionario que haya sido separado pueda volver a participar de procesos selectivos para el acceso a la función pública, lo que es un desproporcionado efecto de la referida sanción administrativa, y que viola el derecho del ciudadano contemplado en el art. 23.2 de la Constitución española.

La lamentable ausencia de previsión legislativa de rehabilitación del funcionario punido por un ilícito administrativo es "una consecuencia de tal sanción que el separado del servicio arrastra de por vida, a diferencia del que es inhabilitado para el ejercicio de funciones públicas por resolución judicial por la comisión de un delito."720

\subsubsection{2- Ausencia de inhabilitación para el ejercicio de funciones públicas}

A su vez no pueden participar de los procesos selectivos para el acceso a la función pública aquellos que se hallan en inhabilitación absoluta o especial para empleos o cargos públicos por resolución judicial, para el acceso al cuerpo o escala de funcionario, o para ejercer funciones similares a las que desempeñaban en el caso del personal laboral, en el que hubiese sido separado o inhabilitado. (cf. art. 56.1.d) del Estatuto Básico del Empleado Público).

La misma lógica que fundamenta la imposibilidad de regreso de quien fuera punido gravemente por la Administración Pública también se aplica a aquellos que fueron condenados por sentencia firme a la pena de inhabilitación para el ejercicio de empleos públicos.

Es relevante destacar que la mencionada pena puede ser de carácter absoluto, cuando inhabilita el ejercicio de cualquier cargo o empleo público durante el tiempo de la condena (cf. art. 41 del Código Penal), o de carácter relativo, cuando la inhabilitación solamente compete a determinadas situaciones.

\footnotetext{
${ }^{719}$ PÉREZ GÓMES, José María. Op.cit., p. 501.

${ }^{720}$ SÁNCHEZ MORÓN, Miguel. Autor del capítulo décimo del libro Comentarios a la Ley del Estatuto Básico del Empleado Público, Miguel Sánchez Morón (Director); Federico A. Castillo Blanco, Alberto

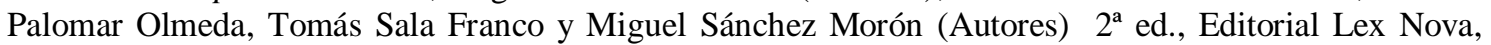
Valladolid, 2008, p. 408.
} 
Sobre esta última cuestión, cabe añadir que tampoco puede participar de los procesos selectivos quien ha recibido una condena de inhabilitación que se refiere al desempeño de determinada profesión, "que es la que debería desempeñar el aspirante en caso de superar los sistemas selectivos." 721

Para aclarar la situación arriba descrita, cabe subrayar que el Tribunal Superior de Justicia de Castilla-La Mancha analizó el caso de un médico que había sido condenado a una pena de inhabilitación especial para el ejercicio de la medicina durante siete meses, y dentro del referido período de vigencia de la condena, se presentó en un proceso selectivo, aprobó y fue nombrado funcionario. En su decisión, el citado Tribunal destacó que:

“el nombramiento ha recaído sobre una persona que no reúne el requisito esencial de titulación preciso para participar en la propia convocatoria de ingreso en la Fundación Pública en la especialidad pretendida. Concurriría así el motivo de nulidad contemplado en el primer inciso del artículo 47.1.b) de la Ley de Procedimiento Administrativo." 722

También es relevante mencionar que las resoluciones impeditivas (separación del servicio e inhabilitación para el ejercicio de funciones públicas deberán estar "revestidas de la fuerza suficiente, en vía administrativa o judicial (según proceda), para desvirtuar la presunción de inocencia y provocar las graves consecuencias que ambas situaciones acarean a quienes pretenden participar de los procedimientos de selección para el ingreso en la Administración." 723

\subsubsection{3 - Los requisitos negativos para los nacionales de otros Estados}

El Estatuto Básico del Empleado Público ha tenido en consideración el hecho de que hay la posibilidad de acceso de los extranjeros a la función pública española, como ya se ha visto, cuando se ha analizado el requisito "nacionalidad".

Así, impidió la participación en los procesos selectivos del nacional de otro Estado que se halla inhabilitado o en situación equivalente o haya sido sometido a

\footnotetext{
${ }^{721}$ PÉREZ GÓMES, José María. Op.cit., p. 501.

722 STSJ (CONT) de Castilla-La Mancha de 20 de mayo de 2003.

${ }^{723}$ FERNÁNDEZ DOMÍNGUEZ, Juan J. y RODRÍGUEZ ESCANCIANO, Susana. Op.cit., p. 45.
} 
sanción disciplinaria o equivalente que impida, en su Estado, en los mismos términos el acceso al empleo público.

La mencionada regla busca conceder un trato igualitario entre españoles y los nacionales de otros países. Sin embargo, la ley no es clara cuando el extranjero ha trabajado en un tercer Estado en el que ha podido ser punido. ${ }^{724}$

También es relevante destacar que hay entendimientos doctrinarios que sostienen que los españoles que actuaron como funcionarios de otros Estados y que se hallan inhabilitados al ejercicio de funciones públicas o sometidos a sanción disciplinaria impeditiva del acceso al empleo público en los referidos Estados tampoco pueden participar de procesos selectivos realizados en España. ${ }^{725}$

\subsection{2 - En el derecho brasileño}

Como ya se ha acentuado, en el sistema jurídico brasileño, las circunstancias impeditivas de acceso a la función pública no están contempladas en una única ley. La verdad es que los llamados requisitos negativos de acceso a la función pública deben ser extraídos de normas de naturaleza constitucional, administrativa, política y penal.

Las situaciones anteriormente destacadas dicen respecto, respectivamente, a la acumulación de cargos públicos, prohibida por la Constitución Federal; la permanencia de los efectos de la punición disciplinar; la suspensión de los derechos políticos debido a condenación por acto de improbidad administrativa; y las consecuencias del cumplimiento de la pena impuesta por práctica de crimen.

\subsubsection{1 - No ejercicio de otro cargo o empleo público}

En el derecho brasileño, la propia Constitución Federal ya determina una circunstancia que, aunque no impida la participación del candidato en el proceso

\footnotetext{
${ }^{724}$ Sobre esta cuestión, "habrá que esperar a que una reforma legal cubra las carencias señaladas y mientras tanto confiar a que los Tribunales interpreten adecuadamente el espíritu de la Ley a fin de evitar inexcusables diferencias de trato en su aplicación y que, por estas fisuras se cuelen en nuestra Administración Pública sujetos que han merecido ser expulsados o inhabilitados para el ejercicio de funciones públicas en otras Administraciones Públicas extranjeras." (PÉREZ GÓMES, José María. Op.cit., p. 503).

${ }^{725}$ SANCHÉZ MORÓN; Miguel. Op.cit., p. 122.
} 
selectivo, no permitirá que el mismo tome posesión del cargo. Es la hipótesis de acumulación de cargos o empleos públicos, vedada por la Carta Magna brasileira, en el art. $37, \mathrm{XVI}^{726}$.

Lo que pasa es que en el ordenamiento jurídico brasileño, como regla general, cada persona solo podrá ejercer un único cargo o empleo público. En el caso de que apruebe un nuevo concurso público, antes de que tome posesión, deberá el candidato dejar su antiguo cargo o empleo público.

El Estatuto Federal del Servidor Público (Ley 8.112/90) determina en su art. 13 $\S 5^{\circ}$ que: "No ato da posse, o servidor apresentará declaração de bens e valores que constituem seu patrimônio e declaração quanto ao exercício ou não de outro cargo, emprego ou função pública”.

Así, el candidato que ya ocupe cargo o empleo público, excepcto en las situaciones autorizadas por la Constitución Federal, no podrá acceder a nuevo cargo o empleo en la Adminsitración Pública. En el caso de que opte por el nuevo cargo, deberá requerer su exoneración del cargo anteriormente ocupado.

\subsubsection{2 - No permanencia de los efectos de punición disciplinar}

Otro aspecto impeditivo del acceso a la función pública dice respecto al hecho de que el candidato se halle en situación incompatible con el ejercicio de cargo público debido a punición en el ámbito administrativo.

Lo que se quiere subrayar es que hay casos en los que el individuo que ya haya ejercido cargo público y haya sido punido, no podrá retornar a la función pública en

\footnotetext{
726 “Art. 37. XVI - é vedada a acumulação remunerada de cargos públicos, exceto, quando houver compatibilidade de horários, observado em qualquer caso o disposto no inciso XI.

a) a de dois cargos de professor; b) a de um cargo de professor com outro técnico ou científico; c) a de dois cargos ou empregos privativos de profissionais de saúde, com profissões regulamentadas;

XVII - a proibição de acumular estende-se a empregos e funções e abrange autarquias, fundações, empresas públicas, sociedades de economia mista, suas subsidiárias, e sociedades controladas, direta ou indiretamente, pelo poder público"
} 
determinado período. Como cada ente federativo tiene autonomía para legislar sobre la materia, no se puede hacer una afirmación general respecto a los referidos plazos.

En el ámbito de la legislación aplicada a los funcionarios públicos de la Unión, la Ley Federal 8.112/90 determinó que tanto hay casos en los que el funcionario punido queda impedido de regresar al servicio público federal durante cinco años, como también previó que, en situaciones más graves, no más podrá volver a ejercer un cargo público federal. $^{727}$

Sobre la circunstancia mencionada en las líneas anteriores, conviene acentuar que la constitucionalidad de la posibilidad de imposición de penalidad disciplinar de naturaleza perenne es discutible, ya que la Constitución Federal prohíbe de forma expresa, en su art. $5^{\circ}$, XLVII, b), las penas de carácter perpetuo.

Para que no haya el nuevo ingreso en la función pública de candidato que aún se halle punido en el ámbito disciplinar, deberá el edital del concurso público establecer la exigencia de que el aspirante declare la inexistencia de la referida circunstancia.

\subsubsection{3 - No suspensión de los derechos políticos por acto de improbidad administrativa}

Además de las circunstancias de naturaleza constitucional y administrativa que pueden impedir el acceso a la función pública, hay que destacar los aspectos políticos, más precisamente aquellos relacionados a la práctica (y su condenación) de actos de improbidad administrativa.

En Brasil, los agentes públicos, además de la posibilidad de punición en el ámbito penal, civil y administrativo, también están sujetos a penalidades previstas en la Ley 8.429/92, la llamada Ley de Improbidad Administrativa, una de las normas más rígidas en el combate a la corrupción en el citado país, aunque su aplicación en el

\footnotetext{
727 “Art. 137. A demissão ou a destituição de cargo em comissão, por infringência do art. 117, incisos IX e XI, incompatibiliza o ex-servidor para nova investidura em cargo público federal, pelo prazo de 5 (cinco) anos. Parágrafo único. Não poderá retornar ao serviço público federal o servidor que for demitido ou destituído do cargo em comissão por infringência do art. 132, incisos I, IV, VIII, X e XI”
} 
ámbito judicial todavía encuentre algunos problemas a fin de que haya la efectiva punición de aquellos que transgreden las normas jurídicas.

La referida ley establece como medidas punitivas a los agentes públicos que hayan practicado actos de improbidad administrativa varias medidas, entre las cuales se destacan la perdida de la función pública, resarcimiento integral del daño causado al patrimonio público, multa y la suspensión de los derechos políticos.

La última medida punitiva arriba citada se puede imponer por el plazo de 8 a 10 años (cuando el acto de improbidad genera el enriquecimiento ilícito del agente público); de 5 a 8 años (cuando el acto de improbidad causa daño al patrimonio público); y de 3 a 5 años (cuando el acto de improbidad transgrede principio de la Administración Pública). ${ }^{728}$

La persona que se halla con los derechos políticos suspensos no podrá, durante el plazo de la suspensión, acceder a la función pública, pues, como ya se ha analizado, el goce de los derechos políticos es un requisito previsto en la legislación brasileña para que se pueda ejercer un cargo o empleo público.

\footnotetext{
728 "Art. 12. Independentemente das sanções penais, civis e administrativas previstas na legislação específica, está o responsável pelo ato de improbidade sujeito às seguintes cominações, que podem ser aplicadas isolada ou cumulativamente, de acordo com a gravidade do fato:

I - na hipótese do art. $9^{\circ}$, perda dos bens ou valores acrescidos ilicitamente ao patrimônio, ressarcimento integral do dano, quando houver, perda da função pública, suspensão dos direitos políticos de oito a dez anos, pagamento de multa civil de até três vezes o valor do acréscimo patrimonial e proibição de contratar com o Poder Público ou receber benefícios ou incentivos fiscais ou creditícios, direta ou indiretamente, ainda que por intermédio de pessoa jurídica da qual seja sócio majoritário, pelo prazo de dez anos;

II - na hipótese do art. 10, ressarcimento integral do dano, perda dos bens ou valores acrescidos ilicitamente ao patrimônio, se concorrer esta circunstância, perda da função pública, suspensão dos direitos políticos de cinco a oito anos, pagamento de multa civil de até duas vezes o valor do dano e proibição de contratar com o Poder Público ou receber benefícios ou incentivos fiscais ou creditícios, direta ou indiretamente, ainda que por intermédio de pessoa jurídica da qual seja sócio majoritário, pelo prazo de cinco anos;

III - na hipótese do art. 11, ressarcimento integral do dano, se houver, perda da função pública, suspensão dos direitos políticos de três a cinco anos, pagamento de multa civil de até cem vezes o valor da remuneração percebida pelo agente e proibição de contratar com o Poder Público ou receber benefícios ou incentivos fiscais ou creditícios, direta ou indiretamente, ainda que por intermédio de pessoa jurídica da qual seja sócio majoritário, pelo prazo de três anos.

Parágrafo único. Na fixação das penas previstas nesta lei o juiz levará em conta a extensão do dano causado, assim como o proveito patrimonial obtido pelo agente".
} 


\subsubsection{4 - No permanencia de los efectos de la sentencia criminal condenatoria y la cuestión de la investigación social}

La última (y más polémica) cuestión que deberá ser investigada dice respecto la posibilidad del candidato, que haya sido condenado por el Poder Judicial por la práctica de crimen, participar de procesos selectivos de acceso a la función pública.

En el contexto antes acentuado, hay dos momentos distintos que deberán ser analizados respecto a la participación del candidato punido criminalmente: a) mientras perduran los efectos de la condenación; b) tras su rehabilitación criminal.

Antes de todo, cabe subrayar que el citado tema en Brasil es tan traumático que hay muchos concursos públicos que impiden de forma ilegal el ingreso de candidatos en la función pública por el hecho de que todavía están siendo acusados en proceso criminal, sin que haya, hasta entonces, cualquier decisión final condenatoria.

En general, tal exclusión ocurre a través de la utilización de la "investigación social", que es un instrumento utilizado para verificar la idoneidad moral de los candidatos en determinados concursos públicos.

La justificativa adoptada para fundamentar el uso de la citada herramienta selectiva es la necesidad de exclusión de los candidatos que hayan se comportado en el pasado de forma incompatible con el ejercicio de determinada función pública (especialmente en el ámbito de la Policía, Magistratura, Fiscalía, Cuerpo Diplomático, etc.), ya que la Administración Pública, sometida al principio de moralidad, debe garantizar que en sus plantillas no estén presente personas inidóneas.

Sin embargo, en diversas ocasiones, la mala utilización de la investigación social compromete la garantía constitucional de la presunción de inocencia ("ninguém será considerado culpado até o trânsito em julgado de sentença penal condenatória", art. $5^{\circ}$, LVII), además de discriminar candidatos de forma injusta. 
Respecto a la realidad de los concursos públicos en Brasil, la doctrina ha destacado los abusos del uso indebido de la investigación social:

"Questão delicada e complexa é aquela que diz respeito à capacidade moral do candidato instituída como requisito de acesso. Esse tipo de aferição nem sempre é muito simples e pode dar margem à arbitrariedade por parte dos agentes integrantes da comissão de concurso. Para que seja legítima, necessário se faz que a condição moral do candidato seja efetivamente incompatível com as funções do cargo a que aspira. O STF, por exemplo, já teve a oportunidade de sentenciar, em concurso para escrivão de polícia, inclusive reformando acórdão do TJ-RS, que a só existência de ação penal instaurada contra o candidato por crime de corrupção passiva não rende ensejo à definição de falta de capacidade moral, sendo fundamento o fato de que o afastamento ofenderia o art. $5^{\circ}$, LVII, da $\mathrm{CF}$, pelo qual ninguém pode ser considerado culpado até o trânsito em julgado de sentença penal condenatória." 729

Para el citado jurista, incluso las circunstancias que determinan la exclusión de la punibilidad, como la prescripción criminal también impediría la exclusión del candidato en la investigación social ${ }^{730}$.

El uso de la investigación social, en el contexto brasileño, tanto es problemático debido a la ausencia de ley que establezca sus objetivos y métodos, así como también por el carácter extremamente subjetivo de su realización, lo que se puede percibir en los comentarios abajo:

“A investigação social, em concurso público, não se resume a analisar a vida pregressa do candidato quanto às infrações penais que porventura tenha praticado. Serve, também, para avaliar a sua conduta

\footnotetext{
${ }^{729}$ SANTOS CARVALHO FILHO, José dos. Op.cit., p. 559.

${ }^{730}$ Sobre tal circunstancia: "Hipótese diversa, entretanto, é aquela em que o delito já foi alcançado pela prescrição. Como se trata de instituto que rende ensejo à extinção da punibilidade, a prática do delito não pode servir como óbice à capacitação moral do candidato, permitindo que este concorra em igualdade de condições com os demais candidatos. Com esse entendimento, o STF, reformando acórdão do TJ-RS e restabelecendo a sentença monocrática, decidiu em favor de candidato cujo delito de falsidade ideológica havia sido objeto de prescrição." (SANTOS CARVALHO FILHO, José dos. Op.cit., p. 559).
} 
moral e social no decorrer de sua vida, visando aferir seu comportamento frente aos deveres e proibições impostos ao ocupante de cargo público da carreira policial e de outras carreiras do serviço público não menos importantes. Tal análise deve ser pautada em critérios objetivos e não subjetivos.(..) Caso não seja feita a análise pautada em critérios objetivos, assegurado o direito ao contraditório e ampla defesa e o princípio da motivação o ato administrativo será irregular",731

Pese a los problemas detectados, la utilización de la investigación social suele ser aceptada por los tribunales brasileños, que no siempre controlan los excesos de su realización discriminatoria. En este contexto, cabe destacar que tal instrumento debe ser pasible de control por el candidato ${ }^{732}$.

La exigencia de control es imprescindible para:

"afastar-se o subjetivismo puro, arbitrário, violador do princípio constitucional da isonomia, ao qual a Administração Pública está vinculada; para tanto, haverá que apurar-se se foi guardada "a devida congruência entre a realidade fática e a sua motivação", não sendo de se olvidar, quando da ponderação da razoabilidade da exclusão, as circunstâncias fáticas específicas do candidato envolvidas"733.

\footnotetext{
731 BRANDAO COSTA, Bernardo. Investigação Social. Texto extraído del sitio:http://www.pciconcursos.com.br/consultoria/investigacao-social, acceso en 09 de junio de 2010.

${ }^{732}$ En este sentido: "A investigação social, como etapa provida de caráter eliminatório nos concursos públicos, é procedimento constitucional e legal, sendo retificados, por reiteradas vezes, pelos nossos Tribunais. (...) o simples fato de o candidato haver sido investigado em inquérito policial posteriormente arquivado ante a ocorrência da extinção da punibilidade, também pela prescrição, não pode ser considerado como desabonador de sua conduta de forma a impedir sua participação em concurso público, sob pena de ofensa ao princípio da presunção de inocência. Embora seja a investigação social meio idôneo para averiguar a prontidão e a probidade do candidato, a sua eliminação deve fundar-se em fatos verídicos, demonstrativos da inidoneidade de comportamento, incompatível com o cargo. (...) $O$ candidato pode, conhecendo os motivos de sua reprovação, reduzidos a especulações sem base factual demonstrada, ou relacionada a fatos sem potencial lesivo ao interesse público, ou referente a episódios de passado longínquo, desvinculados da conduta atual do candidato, submetê-los à tutela jurisdicional" (PINHEIRO MADEIRA, José Maria. Op.cit., pp. 109-110).

${ }^{733}$ NOGUEIRA JÚNIOR, Alberto. Eliminação de candidato em concurso público: a "investigação social dos bons antecedentes" $x$ o princípio da presunção da inocência, texto extraído del sitio electrónico JusVigilantibus, http://jusvi.com/artigos/29386, publicado en 29 de octubre de 2007, com acceso en 10 de junio de 2010.
} 
Además, cabe añadir que eventual exclusión del candidato del proceso selectivo solo debe basarse en hechos (y no suposiciones) que sean graves ${ }^{734}$ y que generen una incompatibilidad que tenga conexión directa con el ejercicio del cargo o empleo público a ser cubierto.

Como se ha visto, la investigación social tiene como objetivo la verificación del comportamiento del candidato que pueda comprometer el ejercicio del cargo, lo que también puede ser comprobado a través de la exigencia, prevista en muchas convocatorias, de la presentación de documentos emitidos por el Poder Judicial que demuestren si el aspirante a la función pública posee "antecedentes criminales".

La gran indagación que se hace es la siguiente: ¿en qué circunstancias es posible haber la exclusión del candidato que ya haya sido condenado criminalmente? En otras palabras, lo que se indaga es ¿cuál es el significado de la expresión "antecedentes criminales" para efecto de exclusión del candidato de un proceso selectivo para acceso a la función pública?

La contestación a las citadas preguntas depende del análisis del instituto de la rehabilitación criminal, previsto en los Códigos Penal y de Proceso Penal brasileños. Según el Código Penal ${ }^{735}$, la rehabilitación criminal asegura al condenado el sigilo de los registros de su proceso de condenación.

\footnotetext{
${ }^{734}$ Por eso: "Não é qualquer fato real, comprovado e imputável ao candidato que pode justificar sua eliminação do concurso. Os fatos devem ser graves, proporcionalmente à restrição que se perpetuará ao direito do candidato de acesso ao cargo ou emprego almejado." (LOBELLO DE OLIVEIRA ROCHA, Francisco. Op.cit., p. 94).

735 “Art. 93 - A reabilitação alcança quaisquer penas aplicadas em sentença definitiva, assegurando ao condenado o sigilo dos registros sobre o seu processo e condenação.

Parágrafo único - A reabilitação poderá, também, atingir os efeitos da condenação, previstos no art. 92 deste Código, vedada reintegração na situação anterior, nos casos dos incisos I e II do mesmo artigo.

Art. 94 - A reabilitação poderá ser requerida, decorridos 2 (dois) anos do dia em que for extinta, de qualquer modo, a pena ou terminar sua execução, computando-se o período de prova da suspensão e o do livramento condicional, se não sobrevier revogação, desde que o condenado:

I - tenha tido domicílio no País no prazo acima referido;

II - tenha dado, durante esse tempo, demonstração efetiva e constante de bom comportamento público e privado;

III - tenha ressarcido o dano causado pelo crime ou demonstre a absoluta impossibilidade de o fazer, até o dia do pedido, ou exiba documento que comprove a renúncia da vítima ou novação da dívida. Parágrafo único - Negada a reabilitação, poderá ser requerida, a qualquer tempo, desde que o pedido seja instruído com novos elementos comprobatórios dos requisitos necessários.

Art. 95 - A reabilitação será revogada, de ofício ou a requerimento do Ministério Público, se o reabilitado for condenado, como reincidente, por decisão definitiva, a pena que não seja de multa”.
} 
En estos términos, una vez rehabilitado criminalmente, el candidato no tendrá "antecedentes criminales", lo que le permitirá acceder a la función pública. Lo que sucede es que, según el art. 748 del Código de Proceso Penal brasileño: " $A$ condenação ou condenações anteriores não será mencionada na folha de antecedentes do reabilitado, nem em certidão extraída dos livros do juízo, salvo quando requisitadas por juiz criminal”.

A su vez, los candidatos que hayan sido condenados (con sentencia firme), mientras no se encuentren rehabilitados (durante el período de la condenación o hasta dos años tras el termino del cumplimiento de la pena), no podrán ingresar en la función pública, en el caso de que el concurso público, de forma expresa, vede el ingreso de aquellos que poseen "antecedentes criminales".

Sin embargo, aunque el concurso público no establezca expresamente la exigencia de presentación de documento que ateste la existencia o no de antecedentes criminales, conviene mencionar que si el candidato se encuentra cumpliendo pena decurrente de una condenación criminal, habrá una incompatibilidad para el ejercicio del cargo público, en los términos de la Constitución Federal, que prevé: “Art. 15. É vedada a cassação de direitos políticos, cuja perda ou suspensão só se dará nos casos de: (...) III - condenação criminal transitada em julgado, enquanto durarem seus efeitos"

Como ya se ha visto, el goce de los derechos políticos es uno de los requisitos de acceso a la función pública brasileña. Por esta razón, como la condenación criminal suspende los derechos políticos (según determina la Constitución), mientras duren los efectos de la mencionada condenación, no podrá la persona condenada acceder a la función pública.

Pese a la sencillez de la norma constitucional, cabe subrayar que el tema bajo análisis no es tan pacifico en la doctrina y en la jurisprudencia brasileña, ya que hay también aquellos que sostienen que la suspensión de los derechos políticos solamente debería ocurrir si estuviera presente de forma expresa en la sentencia que estableció la condenación, como efecto secundário. También hay aquellos que defienden la necesidad de que el art. 15 de la Constitución Federal sea reglamentado por 
una ley (lo que aun no se hizo), exigencia no prevista en la actual Carta Magna, pero contemplada en la anterior ${ }^{736}$.

Sin embargo, "a interpretação predominante na doutrina e jurisprudência é no sentido de que enquanto estiver sendo cumprida a pena imposta, o condenado criminalmente permanece com os direitos políticos suspensos" ${ }^{\text {737 }}$. En estos términos, la doctrina sostiene que:

"Todos os sentenciados que sofrerem condenação criminal com trânsito em julgado estarão com seus direitos políticos supensos até que ocorra a extinção da punibilidade, como consequiência automática e inafastável da sentença condenatória. A duração dessa suspensão cessa com a já citada ocorrência da extinção da punibilidade, seja pelo

\footnotetext{
${ }^{736}$ Sobre la polémica presente en el derecho brasileño respecto al citado tema, cabe transcribir las palabras de la doctrina que resumen la situación y opinan pela auto aplicabilidad de las normas constitucionales: "Suspendem-se os direitos políticos por "condenação criminal transitada em julgado, enquanto durarem seus efeitos", diz o inc. III do art. 15 da CF. A Constituição anterior tinha dispositivo semelhante no $\S 2^{\circ}$, alínea " $c$ ", do art. 149, cuja aplicabilidade a jurisprudência e a doutrina condicionaram à edição da Lei Complementar referida no $\S 3^{\circ}$ daquele artigo, a saber: "Lei Complementar disporá sobre a especificação dos direitos políticos, o gozo, o exercício, a perda ou suspensão de todos ou de qualquer deles e os casos e as condições de sua reaquisição". Essa Lei nunca foi editada, a CF atual, entretanto, não fez nenhuma referência à legislação infra-constitucional, pelo que é plena a eficácia desse dispositivo (inc. III, art. 15, CF). A suspensão dos direitos políticos, nos casos de condenação criminal, não se enquadra como pena acessória, sendo unicamente conseqüência da condenação, independentemente de referência expressa. Vale salientar que não deve prosperar o entendimento que restringe a suspensão dos direitos políticos apenas às hipóteses previstas no art. $1 .{ }^{\circ}$. I, "e”, da LEI COMPLEMENTAR N. ${ }^{\circ}$ 64/90, a chamada Lei das Inelegibilidades. Na verdade a LC $n$. . 64/90 regula estabelece apenas que dura 03 anos, após o cumprimento da pena, a inelegibilidade decorrente de condenação criminal transitada em julgado pela prática de crimes contra a economia popular, a fé pública, a administração pública, o patrimônio público, o mercado financeiro, pelo tráfico de entorpecentes e por crimes eleitorais". A inelegibilidade aí se prolonga por mais 03 anos após o cumprimento da pena. $O$ texto constitucional não faz qualquer exceção, daí prevalecer o entendimento que, mesmo nos casos de condenação por crime culposo, delitos de menor potencial ofensivo e, inclusive contravenção penal, persiste a regra da inelegibilidade. Em virtude disso é que se deve exercer rigoroso controle nos pedidos de registro de candidaturas, quanto aos antecedentes criminais dos requerentes. A suspensão dos direitos políticos perdura enquanto perdurarem os efeitos da condenação. Embora alguns Tribunais Regionais adotem a tese de que a inelegibilidade deve acompanhar os efeitos secundários da condenação, o TRIBUNAL SUPERIOR ELEITORAL adota entendimento mais limitado, limitando inelegibilidade ao cumprimento da pena, ainda que perdurem seus efeitos secundários. A reaquisição dos direitos políticos opera-se automaticamente, com o cumprimento da pena, independendo de processo formal ou de reabilitação criminal" (SAMPAIO ANGELIM, Augusto. Perda e suspensão dos direitos políticos $I$, texto extraído del sitio electrónico DireitoNet, http://www.direitonet.com.br/artigos/exibir/1530/Perda-e-suspensao-dos-Direitos-Politicos-I, publicado en 08 de abril de 2004, con acceso en 10 de junio de 2010.

${ }^{737}$ CERELLO, Anselmo. Suspensão de Direitos Políticos para o Condenado Beneficiado pelo Sursis e Liberdade Condicional. Texto extraído del sitio electrónico del Tribunal Regional Electoral del Estado de Santa Catarina, RESENHA ELEITORAL - Nova Série, v.9, n.1 (jan./jun. 2002), http://www.tresc.gov.br/site/institucional/publicacoes/artigos-doutrinarios-publicados-na-resenha-eleitoral/resenhas/v9n1-janjun-2002/a-suspensao-de-direitos-politicos-para-o-condenado-beneficiado-pelo-sursis-e-liberdadecondicional/index.html, publicado en enero de 2002, con acceso en 10 de junio de 2010.
} 
cumprimento da pena, seja por qualquer outras das espécies previstas no Código Penal, independentemente de reabilitação ou de prova de reparação de danos" ${ }^{\text {738. }}$.

En el ámbito de la jurisprudencia, para ilustrar la línea de pensamiento:

“APELAÇÃO CÍVEL. CONCURSO PÚBLICO. MUNICÍPIO DE SANTANA DO LIVRAMENTO. CARGO DE OPERÁRIO. CONDENAÇÃO CRIMINAL TRÂNSITA EM JULGADO. SUSPENSÃO DOS DIREITO POLÍTICOS. Pretensão de apenado em livramento condicional de tomar posse em cargo público municipal de Operário obtido através de concurso público. Ausência de ilegalidade do ato que tornou sem efeito a nomeação do autor por não preenchimento dos requisitos legais. Exigência que decorre não apenas do Estatuto do Servidor Público de Santana do Livramento, mas de todo o ordenamento jurídico nacional. Suspensão dos direitos políticos estabelecida pelo art. 15 , III, da CF, em consonância com o Código Penal, ao estabelecer, como efeito da condenação a pena superior a quatro anos de reclusão, a perda do cargo, função pública ou mandato eletivo (art. 92). Certidão da justiça eleitoral a evidenciar a suspensão dos direitos políticos em face de condenação criminal.

SENTENÇA DE IMPROCEDÊNCIA MANTIDA. APELO
DESPROVIDO, ${ }^{, 739}$.

\footnotetext{
${ }^{738}$ DE MORAES, Alexandre. Condenaçao criminal e suspensao dos direitos políticos, texto publicado en el sitio electrónico del Ministerio Público del Estado de Goiás, http://www.mp.go.gov.br/portalweb/hp/7/docs/artigo_alexandre_de_morais.pdf, acceso en 10 de junio de 2010.

${ }^{739}$ Tribunal de Justicia del Estado del Rio Grande do Sul, Apelación Civil 70011174885, Tercera Camara Civil, Relator: Paulo de Tarso Vieira Sanseverino, juzgado en 05/05/2005.
} 
CAPITULO 4 - LA IGUALDAD Y LOS PRINCÍPIOS DE LOS PROCESOS SELECTIVOS PARA ACCESO A LA FUNCIÓN PÚBLICA ESPAÑOLA Y BRASILEÑA 


\section{1 - Características de los procesos selectivos de acceso a la función pública en España y en Brasil}

Antes de todo, merece registro que los procesos selectivos utilizados para el acceso a la función pública son una modalidad de proceso administrativo. A su vez, la idea de proceso (en cualquiera de sus clasificaciones) está asociada a un conjunto de actos sucesivos que son preparatorios de una decisión final: Representa una marcha siempre dirigida a la obtención de resultados concretos, que, en el ámbito de los poderes públicos, se traduce en la creación de leyes, actos administrativos y fallos judiciales.

Como la Administración pública está sometida a las exigencias constitucionales que imponen el acceso igualitario y meritorio a la función pública (art. 23.2 y $103.3 \mathrm{CE}$ y art. 37, I y II, CB), a aquella compete el deber de determinar la abertura de procesos administrativos propios para que se proceda la selección de los funcionarios públicos.

Conviene subrayar que tanto los procesos selectivos de acceso a la función pública brasileña como a la española poseen las citadas características, ya que estas son imprescindibles para que sea garantizado el respecto a los principios constitucionales de igualdad, mérito y capacidad. No obstante, la incidencia particular de cada una de las características que serán vistas a continuación en cada sistema jurídico hace que tengan matices distintas en Brasil y en España.

En el camino anteriormente apuntado, se puede destacar que los procesos selectivos brasileños y españoles innegablemente están sometido a control. Sin embargo, cada ordenamiento jurídico ha establecido mecanismos propios para controlar la actividad administrativa de selección de los funcionarios públicos (por ejemplo, en España, hay que agotarse la instancia administrativa).

A su vez, también se puede afirmar que los concursos públicos brasileños y las oposiciones españolas son procedimientos reglados, aunque esto suceda de forma distinta en cada país (presencia, sobre todo, de normas administrativas en Brasil y de leyes en España). 
Pese a la existencia de otras características, se ha elegido las que se considera las más destacadas, esencialmente porque la eventual ausencia de cualquiera de ellas significaría la perdida del carácter igualitario y meritorio del proceso selectivo.

\subsection{1 - Carácter abierto}

Sobre las mencionadas características de los procesos selectivos de acceso a la función pública, lo que primeramente llama la atención es su carácter abierto, garantía imprescindible para que todos los que así lo deseen puedan participar de la competición convocada por la Administración pública ${ }^{740}$.

Sin embargo, para que efectivamente todos los interesados puedan participar de la disputa y puedan competir en condiciones de igualdad (igualdad de oportunidades), deben ser superados algunos obstáculos relativos a la:

a) preparación para las pruebas (como la ausencia de clases preparatorias en determinados sitios, o de becas y ayudas a los candidatos que no disponen de recursos económicos para cubrir los altos costes de preparación);

b) inscripción en el proceso selectivo (como el alto valor de las tasas, la poca diversidad de lugares para inscribirse o mismo la no previsión de la inscripción a través de internet);

c) realización de las pruebas (como los constantes desplazamientos para la ejecución de las pruebas, cuando el proceso selectivo es realizado en distintos momentos, adaptación de los ejercicios para las personas con discapacidad, y, en las pruebas físicas, a las mujeres).

En el intento de resumir las exigencias que se imponen para garantizar el carácter abierto de los procesos selectivos, se puede transcribir que:

"a solução que deve ser aplicada, independentemente de previsão legal
e por força dos princípios do concurso público, consiste numa ampla
publicidade do edital do certame e na estipulação de regras de

${ }^{740}$ Por esa razón, respecto al concurso público se ha afirmado que: "não existe um outro sistema conhecido que garanta o acesso de qualquer um do povo a um cargo público e que dê primazia ao conhecimento técnico, e não às relaçães pessoais" (PACHECO BARROS, Wellington. Direito Administrativo. Concurso público. Teoria e prática, Livraria do Advogado Editora, Porto Alegre, 2007, p. 11). 
participação dos interessados desvestidas de entraves burocráticos desnecessários ao cumprimento do interesse público, contempladoras de todas as formas admitidas em direito com vistas à formalização do ato de inscrição dos candidatos." 741

No obstante, se puede destacar que ya hay iniciativas muy interesantes que buscan facilitar la amplia participación de los ciudadanos en los procesos selectivos de acceso a la función pública española, sea en España, como en Brasil.

En España, como se expone a continuación:

“en la Oferta Pública de Empleo de 2005 se daba la posibilidad a los aspirantes de inscribirse en la convocatoria y pagar las tasas por Internet, en la Oferta Pública de Empleo de 2006 se fomenta aún más esta posibilidad, de forma que a través de la página web del Ministerio de Administraciones Públicas (www.map.es), los aspirantes se pueden descargar el impreso 790, rellenarlo, dar sus datos bancarios $\mathrm{y}$ enviarlo a través de la web."742

En Brasil, a su vez, una cuestión que muchas veces impide la participación de los aspirantes en el concurso público es el valor de las tasas de inscripción. Cabe subrayar que la mayoría de los potenciales candidatos a la función pública no poseen buena condición económica, sea porque están en paro, sea porque, espontáneamente, decidieron dedicarse exclusivamente a la preparación para los concursos, lo que les ha retirado una renta fija.

Así, cuando el valor de la tasa de inscripción es elevado, muchos dejan de participar del proceso selectivo, lo que compromete su carácter abierto. Por esta razón, muchos candidatos buscan el Poder Judicial (en general, a través del Defensor del Pueblo) para garantizar el derecho de participación en los concursos públicos. En tales oportunidades:

"visando garantir os princípios da isonomia e livre acesso aos cargos e
empregos públicos, a jurisprudência vem reiteradamente
reconhecendo a isenção de taxa de inscrição de candidatos

${ }_{741}$ BARBOSA MAIA, Márcio, y PINHEIRO DE QUEIROZ, Ronaldo. Op.cit., p. 96.
${ }^{742}$ NAVARRO, Pilar. Op.cit., pp. 57-58. 
hipossuficientes, assim considerados aqueles que não podem comprovadamente arcar com o ônus da referida taxa sem sacrifício próprio ou de sua família."743

Como ya se ha visto en el capítulo anterior, otra práctica que viola la exigencia de trato igualitario entre los ciudadanos es la realización de pruebas restringidas, debido a que estas crean favoritismos a quienes han ejercido actividades previamente en la Administración pública ${ }^{744}$.

De la misma forma, las exigencias indebidas de requisitos de participación de los aspirantes constituyen una gran amenaza al carácter abierto del proceso selectivo, ya que excluyen, desde el inicio de la competición, determinadas personas.

\subsection{2 - Carácter obligatorio}

No solo se puede decir que los procesos selectivos de acceso a la función pública son abiertos, sino también que los ordenamientos jurídicos brasileño y español imponen, como regla, su realización (obligatoriedad), siempre que haya la necesidad de cubrir una plaza de funcionario.

En España, la figura del personal eventual, que representa la posibilidad de libre designación por la autoridad administrativa, es de carácter excepcional, aunque utilizada asiduamente.

Sobre el personal eventual, el Estatuto Básico del Empleado Público establece que cabrá determinar a las leyes de función pública los órganos de gobierno de las Administraciones públicas que podrán disponer de este tipo de personal. ${ }^{745}$ Sin embargo, como destaca la doctrina española, el Estatuto no estableció garantías precisas

\footnotetext{
${ }^{743}$ TOURINHO, Rita. Op.cit., p. 76.

${ }^{744}$ Sobre esta cuestión, la doctrina brasileña ha subrayado que: "Desde que o concurso visa a selecionar os candidatos mais capazes, é inadmissível e tem sido julgada inconstitucional a concessão inicial de vantagens ou privilégios a determinadas pessoas ou categorias de servidores, porque isso cria desigualdade entre os concorrentes" (LOPES MEIRELLOS, Hely. Op.cit., p. 397)

${ }^{745}$ El Estatuto dispone en el art. 12 que: "1. Es personal eventual el que, en virtud de nombramiento y con carácter no permanente, sólo realiza funciones expresamente calificadas como de confianza o asesoramiento especial, siendo retribuido con cargo a los créditos presupuestarios consignados para este fin. 2. Las leyes de Función Pública que se dicten en desarrollo de este Estatuto determinarán los órganos de gobierno de las Administraciones Públicas que podrán disponer de este tipo de personal. El número máximo se establecerá por los respectivos órganos de gobierno. Este número y las condiciones retributivas serán públicas. 3. El nombramiento y cese serán libres. El cese tendrá lugar, en todo caso, cuando se produzca el de la autoridad a la que se preste la función de confianza o asesoramiento."
} 
para evitar el abuso que suele ocurrir en todos los niveles territoriales de la Administración pública española. ${ }^{746}$

En el segundo capítulo, se ha visto que, en Brasil, la Constitución de 1988 exige la instauración del debido proceso selectivo (concurso público) para todas las personas que hacen parte de la Administración Pública (administração direta $e$ indireta). Además, se ha analizado que la regla citada se impone no solo a los cargos, sino también a los empleos públicos.

Las excepciones a la regla general del concurso público están establecidas en la propia Constitución. En este contexto, se ha destacado las figuras de los cargos em comissão y las situaciones donde se autoriza la contratación temporaria.

\subsection{3 - Carácter reglado}

También se puede destacar que los procesos selectivos, además de abiertos y obligatorios, son reglados, ya que la Administración pública está sometida a distintas normas que direccionan su actuación, lo que garantiza su objetividad y la previsibilidad de sus comportamientos, siendo de gran relevancia para los ciudadanos.

La ausencia de normas previas (o de la sumisión a estas) que establecieran la forma de conducta administrativa cuando fuera necesario seleccionar funcionarios daría lugar a la subjetividad del administrador, primer rasgo de una actuación arbitraria, sin planificación y no profesional.

Así, es necesario que el proceso selectivo sea suficientemente detallado en normas (leyes, reglamentos, bases de la convocatoria) que abarquen todas las cuestiones que envuelven tanto la actuación de la Administración pública, como la de los aspirantes.

Respecto al carácter reglado de los procesos selectivos, verdadera exigencia de la burocracia, hay que se llegar a un buen término, a fin de que la estipulación de las reglas de la competición, al mismo tiempo, retire del órgano encargado la posibilidad de actuación arbitraria (esencialmente, a través del subjetivismo) y no impida la existencia de una margen de discrecionalidad para toma de determinadas decisiones de contenido

\footnotetext{
${ }^{746}$ SANCHÉZ MORÓN; Miguel. Op.cit., p. 80.
} 
técnico, como por ejemplo, el temario de las pruebas o el grado de dificultadad de las mismas.

Es que aunque se reconozca la necesidad de estipulación previa de los parámetros jurídicos del proceso selectivo, cada uno de ellos posee peculiaridades (naturaleza de la plaza a ser cubierta, cuantidad de plazas, etc.) que deben ser tomadas en cuenta por el órgano responsable.

Otra preocupación consiste en no permitirse que el cuidado que se tiene con la definición de las reglas detalladas de la competición no sea un obstáculo a la eficacia y la agilidad del proceso selectivo, lo que se verá en las próximas páginas.

En el contexto del derecho español, el carácter reglado de los procesos de selección para acceso a la función pública cuenta con distintas leyes. Algunas de ellas, editadas por el Estado, son obligatorias para el propio, para las Comunidades Autónomas y para los Municipios.

Entre las principales leyes españolas que tratan del acceso a la función pública, se puede destacar la Ley 7/2007 (Estatuto Básico del Empleado Público), que ha dedicado normas respecto a los principios de los procesos selectivos, a los requisitos de acceso, a los órganos de selección y a los sistemas selectivos. También se puede citar la Ley 30/1984 (Ley de Medidas para la Reforma de la Función Pública)

En el ámbito reglamentario, cabe subrayar el papel ejercido por el Real Decreto 364/1995, que aprueba el "reglamento general de ingreso del personal al servicio de la Administración General del Estado y de provisión de puestos de trabajo y promisión profesional de los funcionarios civiles de la Administración General del Estado".

En Brasil, como se verá en el quinto capítulo de este trabajo, todavía no hay una ley que contemple los principales aspectos relativos al acceso a la función pública. Hoy en día, lo que existen son leyes de cada ente federativo (en general, los estatutos de los funcionarios públicos) que dedican poquísimas normas respecto al tema, como es el caso del Estatuto de la Unión (Lei Federal 8.112/90) que ha dedicado tan solo dos artículos al concurso público (arts. 11 y 12) y otro a los requisitos de acceso (art. $5^{\circ}$ ). 
De momento, los concursos públicos brasileños, en su gran mayoría, están sometidos a principios generales previstos en la Constitución, a las pocas normas legales, a reglamentos ${ }^{747}$, y, especialmente, a las bases de las convocatorias establecidas para cada proceso selectivo.

El dato anteriormente destacado que es muy preocupante, ya que no permite la consolidación de reglas generales que sirvan como referencia en todos los concursos públicos realizados en Brasil, lo que seguramente traería más seguridad jurídica a los aspirantes, que de forma anticipada ya conocerían sus derechos y deberes, y tranquilidad en la conducción de los procesos a la propia Administración, que no precisaría crear nuevas reglas para cada selección.

Debido a la relevancia del tema arriba mencionado, se volverá a analizarlo en la primera parte del capítulo cinco de este trabajo.

\subsection{4 - Carácter controlado}

Otra característica de los procesos selectivos de acceso a la función pública es que estos deben ser sometidos a control, lo que se impone, por supuesto, a toda actividad administrativa.

$\mathrm{Si}$, como ya se ha destacado, hay la necesidad de que la Administración pública sea sometida a reglas, se impone, consecuentemente, que haya la posibilidad de verificación del cumplimiento de tales reglas, y si es necesario, que haya la previsión de corrección de la conducta administrativa que no observó los parámetros establecidos.

La posibilidad de control de los procedimientos selectivos de acceso a la función pública es un mecanismo de protección del ciudadano y una garantía necesaria para permitir el respeto al principio de igualdad.

Cabe añadir que la exigencia de control no solo debe ser considerada sobe el punto de vista de los aspirantes que forman parte de la competición, sino de toda la sociedad, que tiene interés en la selección de funcionarios siempre respetando los principios constitucionales de igualdad, mérito y capacidad.

\footnotetext{
${ }^{747}$ En el ámbito de la Unión, hay el Decreto Federal 6.944, de 21 de agosto de 2009, que ha sido una buena medida, aunque totalmente insuficiente para cubrir el vacío legal existente.
} 
Por su relevancia, el control de los procesos selectivos de acceso a la función pública será el objeto de análisis más profundizado en este cuarto capítulo del trabajo, cuando sea presentado el principio de sumisión a control, oportunidad en la cual habrá la investigación de los mecanismos de control de los procesos selectivos españoles y brasileños, destacándose las identidades y diferencias existentes entre los dos mencionados sistemas jurídicos.

\subsection{5 - Carácter eficaz}

Como ya se ha visto, los procesos selectivos de acceso a la función pública deben ser abiertos, obligatorios, reglados y controlables. Estas cuatro características son, seguramente, las más destacadas.

No obstante, hay que subrayar otra: la necesidad de que el proceso sea eficaz, lo que correspondería a la real selección de personas calificadas para el desempeño de las tareas demandadas por la Administración.

Desgraciadamente, la Administración Pública, en muchos procesos selectivos, suele olvidar que el funcionario a ser seleccionado no debe poseer solamente una gran capacidad de memorización, sino principalmente de raciocinio, destreza técnica e inteligencia emocional, características imprescindibles para el buen ejercicio de sus funciones.

Así, cada vez más se debe buscar el perfeccionamiento de los sistemas selectivos, a través de la utilización de técnicas más avanzadas, que sean más adecuadas al perfil exigido de los funcionarios que van a desempeñar sus actividades en cada función pública.

Sin embargo, la referida eficacia solamente puede ser alcanzada a partir del cumplimiento de las cuatro características anteriores, debido a que el olvido del carácter abierto, obligatorio, reglado y controlable de los procesos selectivos es un sacrificio que no puede ser aceptado, aunque sea en nombre de presuntos mejores resultados.

Merece también ser registrado que todas las cinco características analizadas son esenciales a la efectividad de la igualdad en los procesos selectivos, que 
seguramente no que alcanza a través de una solo medida o exigencia. En verdad, "os concursos públicos devem contemplar a igualdade em todas as suas feições"748.

Por la razón arriba mencionada, se impone la armonización de los valores ya referidos, para garantizar las dos grandes finalidades de los procesos selectivos, especialmente aquí, de acceso a la función pública: la concesión de un trato igualitario a los opositores y la selección de los aspirantes más calificados.

Para esto, la comprensión de los principios jurídicos propios de los procesos selectivos (además de aquellos que son inherentes a toda actividad administrativa) es indispensable, lo que se verá a continuación.

Antes, como una especie de invitación al estudio del próximo tema, cabe añadir que "não se pode imaginar um concurso público que deixe de atender, de forma rígida, ao princípio de igualdade. Este princípio é o coração do concurso público, sem ele o concurso morre, ou nem chega a existir."749

Por esta razón, ya se puede afirmar desde ahora que todos los demás principios de los procesos selectivos deben ser medios aptos para la realización de la igualdad, tarea que no es nada fácil ${ }^{750}$

\section{2 - Los principios de los procesos selectivos de acceso a la función pública}

La sumisión a los principios jurídicos es una consecuencia natural de un Estado que se califica de Derecho y tiene una Constitución que consagra diversos valores. Se puede añadir que la referida sumisión es una necesidad aún más presente en la actividad administrativa que en el sector privado. ${ }^{751}$

\footnotetext{
${ }^{748}$ LOBELLO DE OLIVEIRA ROCHA, Francisco. Op.cit., pp. 28-29.

${ }^{749}$ DA SILVA OLIVEIRA JÚNIOR, Dario, y CAMPOS OLIVEIRA, Isabel. Concurso público. Teoria e prática. Lumen Juris Editora, Rio de Janeiro, 2008, p. 22.

${ }^{750}$ En este sentido: "É importante ressaltar, no entanto, que a igualdade nos concursos públicos não se pode resumir à mera generalidade-uniformidade de aplicação dos critérios. Com freqüência, o Poder Judiciário tem convalidado gravíssimas afrontas ao princípio de igualdade praticadas por bancas examinadoras devido à conclusão simplista de que determinado critério é válido, pois aplicado a todos os candidatos. A igualdade, no entanto, não se resume à generalidade. É preciso verificar, também, a validade e adequação dos critérios de desiquiparaçao adotado." (LOBELLO DE OLIVEIRA ROCHA, Francisco. Op.cit., p. 31).

${ }^{751}$ En este camino, ya he destacado que hay dos grandes razones que justifican la mayor influencia de los principios jurídicos en la actividad de la Administración Pública: "A primera se justifica pela necessidade de dar coerência sistêmica e teleológica ao emaranhado de regras jurídicas esparsas que vinculam a atuação administrativa. Por ser a lei o elemento que reflete as legítimas aspirações populares (princípio
} 
Es en la Constitución donde se puede identificar los valores superiores del ordenamiento jurídico y que influencian de forma decisiva todo el proceso de creación, interpretación y aplicación de las normas jurídicas. En este contexto, para delimitar la actuación de la Administración Pública, tanto el ordenamiento jurídico brasileño como el español han consagrado distintos principios en la Constitución ${ }^{752}$.

Por supuesto, los mencionados principios, debido a su carácter más genérico, deben ser observados en los procesos selectivos ${ }^{753}$, así como en toda actividad administrativa. Sin embargo, se puede añadir que tanto hay principios propios para los procesos selectivos en general, como también hay otros aún más específicos para los procesos selectivos de acceso a la función pública, y que cada uno de ellos, aunque puedan ser adoptados en los dos sistemas jurídicos analizados, posee, además de puntos comunes, algunas incidencias particulares en cada uno de los citados derechos.

Se puede afirmar que los principios específicos son derivaciones de los principios más genéricos. Así, por ejemplo, el principio de la vinculación a las bases de la convocatoria proviene del deber de obediencia a la legalidad; así como el principio de agilidad procede de la exigencia de eficacia.

Sobre la sumisión de los procesos selectivos a los principios jurídicos, se puede decir que:

"Las Administraciones Públicas, cuando han de seleccionar personal,
están sometidas a un conjunto de principios constitucionales, que
deben ser observados, so riesgo de cometer un acto inconstitucional, si

da legalidade e da representatividade), toda atividade administrativa haverá de buscar expressa autorização nos preceitos legais. Todavia, diante da inexistência de uma codificação de Direito Administrativo, a harmonização de sua aplicação só é possível graças à intervenção dos princípios constitucionais, que subordinam todas as regras aos seus comandos. A segunda razão que torna imprescindível a submissão da Administração Pública aos princípios jurídicos consiste na irrefutável necessidade de se dotar o administrador público de mecanismos jurídicos mais flexíveis (por exemplo, a discricionariedade), que possam assegurar a efetiva tutela das finalidades públicas diante da complexidade, variedade e mutabilidade dos problemas confiados à Administração Pública." (LINS DE LESSA CARVALHO, Fábio. Op.cit., p. 52).

${ }^{752}$ Mientras la Constitución brasileña previó en el art. 37 que “. A administração pública direta e indireta de qualquer dos Poderes da União, dos Estados, do Distrito Federal e dos Municípios obedecerá aos princípios de legalidade, impessoalidade, moralidade, publicidade e eficiência”, la Constitución española destaco en el artículo 103.1 que: "La Administración Pública sirve con objetividad los intereses generales y actúa de acuerdo con los principios de eficacia, jerarquía, descentralización. desconcentración y coordinación, con sometimiento pleno a la ley y al Derecho”.

${ }^{753}$ En este camino: "os concursos públicos estão sujeitos, de um modo geral, ao mesmo regime jurídico a que se submete a Administração Pública. Há, no entanto, certas normas que adquirem relevância destacada" (LOBELLO DE OLIVEIRA ROCHA, Francisco. Op.cit., p. 25). 
se apartan de ellos. Estos principios, unos se refieren a todo tipo de actividad de la Administración Pública o que ella debe tenerlos en cuenta y observarlos en cualquier actividad y, por tanto, son de aplicación a la selección de personal, como una actividad propia de la Administración Pública, y otros son ya de aplicación concreta en la específica actividad de la selección de personal." ${ }^{, 754}$

Para desarrollar la cuestión arriba citada, el Estatuto Básico del Empleado Público español (Ley 7/200/) estableció en su art. 55, apartados 1 y 2, los principios que rigen los procesos selectivos. ${ }^{755}$

Como se puede percibir, en el apartado primero del art. 55, el Estatuto Básico del Empleado Público de España hizo referencia a los principios constitucionales ya analizados en este trabajo (igualdad, mérito y capacidad), que repercuten en todas las cuestiones relativas al acceso a la función pública (creación de normas jurídicas y su interpretación y aplicación por los órganos administrativos y judiciales).

A su vez, en el apartado segundo, fueron elegidos principios que determinarán la conducción del procedimiento administrativo de selección de los funcionarios públicos. Como se puede observar, son principios dirigidos a la Administración Pública, sirviendo como verdaderos nortes para orientar a los responsables designados a dirigir la competición entre los aspirantes a la función pública.

Cabe añadir que la Comisión para el estudio y preparación del Estatuto Básico del Empleado Público español consideró relevante destacar en la citada ley que

\footnotetext{
${ }^{754}$ PERÉZ LUQUE, Antonio. Op.cit., p. 39-40.

755 “1. Todos los ciudadanos tienen derecho al acceso al empleo público de acuerdo con los principios constitucionales de igualdad, mérito y capacidad, y de acuerdo con lo previsto en el presente Estatuto y en el resto del ordenamiento jurídico.

2. Las Administraciones Públicas, entidades y organismos a que se refiere el artículo 2 del presente Estatuto seleccionarán a su personal funcionario y laboral mediante procedimientos en los que se garanticen los principios constitucionales antes expresados, así como los establecidos a continuación:

a) Publicidad de las convocatorias y de sus bases.

b) Transparencia.

c) Imparcialidad y profesionalidad de los miembros de los órganos de selección.

d) Independencia y discrecionalidad técnica en la actuación de los órganos de selección.

e) Adecuación entre el contenido de los procesos selectivos y las funciones o tareas a desarrollar.

f) Agilidad, sin perjuicio de la objetividad, en los procesos de selección."
} 
los principios deben presidir "por entero y sin excepción alguna el acceso al empleo público.",756

Sobre la distinción de los principios del proceso selectivo entre principios constitucionales y del procedimiento, la doctrina ya afirmó que: "consideramos acertada esa diferenciación, por cuánto estos se configuran como instrumentos necesarios para poder garantizar el acceso al empleo público en condiciones de igualdad y respecto a los principios de mérito y capacidad."757

Además de los principios indicados en el Estatuto (sean constitucionales o procedimentales), hay otros dos que han sido seleccionados en este trabajo, y que debido a su relevancia, no podrían dejar de ser aquí analizados: la competitividad y la vinculación a las bases de la convocatoria.

En el sistema jurídico brasileño, debido a la ausencia de una ley que trate de las normas de acceso a la función pública, suelen ser destacados por la doctrina los principios constitucionales de la Administración Pública, explícitos ${ }^{758}$ o implícitos ${ }^{759}$, los principios de los procesos administrativos en general $^{760}$ y determinados principios

\footnotetext{
${ }^{756}$ Informe de la Comisión para estudio y preparación del Estatuto Básico del Empleado Público, INAP, Madrid, Miguel Sánchez Morón (Presidente), abril 2005, p. 91.

${ }^{757}$ FONDEVILA ANTOLÍN, Jorge. Op.cit., p. 115.

${ }^{758}$ En el derecho brasileño, a lo mejor la impersonalidad (impessoalidade) sea el principio constitucional explícito de la Administración Pública que más conexión posee con el concurso público: "Não há dúvidas de que o concurso público seja uma forma de garantir maior impessoalidade nas contratações de agentes públicos. Todavia, a existência do concurso público por si só não garante a impessoalidade na contratação. É necessário que o concurso seja realizado à luz deste princípio, evitando-se que interesses alheios ao interesse público interfiram em seus resultados." (LOBELLO DE OLIVEIRA ROCHA, Francisco. Op.cit., p. 35-36).

${ }^{759}$ Respecto al principio de supremacia del interés público sobre el privado: "é em atenção a esta norma que, nos concursos públicos, se podem impor restrições ao amplo acesso aos cargos e empregos públicos para atender às necessidades da Administração, pois, contrapostos o direito de o particular aceder aos cargos públicos e o zelo pela qualidade dos serviços públicos, deve prevalecer este último." (LOBELLO DE OLIVEIRA ROCHA, Francisco. Idem, p. 27).

${ }^{760}$ En el ámbito de la Unión, la Ley Federal 9.784/99, que trata de los procesos administrativos de la Administración Federal, es un buen ejemplo de sistematización de los principios jurídicos y que debe inspirar los procesos selectivos realizados en el referido ámbito. Ella determina que:

"Art. $2^{o}$ A Administração Pública obedecerá, dentre outros, aos princípios da legalidade, finalidade, motivação, razoabilidade, proporcionalidade, moralidade, ampla defesa, contraditório, segurança jurídica, interesse público e eficiência.

Parágrafo único. Nos processos administrativos serão observados, entre outros, os critérios de:

I - atuação conforme a lei e o Direito;

II - atendimento a fins de interesse geral, vedada a renúncia total ou parcial de poderes ou competências, salvo autorização em lei;

III - objetividade no atendimento do interesse público, vedada a promoção pessoal de agentes ou autoridades;

IV - atuação segundo padrões éticos de probidade, decoro e boa-fé;
} 
que serian más propios de los procesos selectivos, especialmente, debido a su carácter competitivo.

La aplicabilidad de la legislación respecto al proceso administrativo a los concursos públicos es una importante herramienta para disciplinar el tema, especialmente delante de las omisiones legales existentes. Así:

“A caracterização do concurso como processo administrativo determina a aplicação de uma série de princípios constitucionais e legais. De se realçar, imediatamente, que a Constituição assegurou como garantia fundamental aos acusados em geral e aos litigantes em processo administrativo o contraditório e a ampla defesa, com os meios e recursos a ela inerentes. Na mesma esteira, a lei que regula o processo administrativo na administração pública federal - Lei 9.784/99, aplicável, ainda que subsidiariamente, aos concursos públicos - determina ainda a obediência a outros princípios não referidos explicitamente pela Constituição, mas identificáveis no sistema constitucional. Parecem assumir mais relevância para a correta implementação, interpretação e controle dos concursos públicos os princípios da isonomia, legalidade, publicidade, moralidade, ampla defesa, contraditório, motivação, razoabilidade, proporcionalidade e finalmente vinculação ao edital"761

$V$ - divulgação oficial dos atos administrativos, ressalvadas as hipóteses de sigilo previstas na Constituição;

$V I$ - adequação entre meios e fins, vedada a imposição de obrigações, restrições e sanções em medida superior àquelas estritamente necessárias ao atendimento do interesse público;

VII - indicação dos pressupostos de fato e de direito que determinarem a decisão;

VIII - observância das formalidades essenciais à garantia dos direitos dos administrados;

$I X$ - adoção de formas simples, suficientes para propiciar adequado grau de certeza, segurança e respeito aos direitos dos administrados;

$X$ - garantia dos direitos à comunicação, à apresentação de alegaçães finais, à produção de provas e à interposição de recursos, nos processos de que possam resultar sanções e nas situações de litígio;

$X I$ - proibição de cobrança de despesas processuais, ressalvadas as previstas em lei;

XII - impulsão, de ofício, do processo administrativo, sem prejuízo da atuação dos interessados;

XIII - interpretação da norma administrativa da forma que melhor garanta o atendimento do fim público a que se dirige, vedada aplicação retroativa de nova interpretação".

${ }^{761}$ MOTTA, Fabrício. Concursos públicos e o princípio da vinculação ao edital. Texto extraído del sitio Jus Navigandi (http://jus2.uol.com.br/doutrina/texto.asp?id=8035, elaborado em 03.2005). 
En el contexto anterior, hay que subrayar que, debido a la ausencia de una ley específica, la doctrina ha ejercido un papel relevante en la elucidación de los principios de los procesos selectivos de acceso a la función pública brasileña.

En esta labor, una importante referencia es la legislación (y todos los libros, artículos y publicaciones jurídicas) respecto a las licitaciones públicas, ya que también se trata de una modalidad de proceso de competición entre administrados ${ }^{762}$.

Así, delante de la ausencia de normas legales, los principios pasan a ejercer una función muy relevante en la conducción del proceso selectivo en Brasil. En este sentido, se ha dicho que "a indiferença por parte da legislação infraconstitucional realça a importância dos princípios e regras residentes na Constituição Federal que precisam as intenções, limites e procedimentos nos concursos públicos"

Además, cabe añadir que, en Brasil, el estudio de los principios de los procesos selectivos de acceso a la función pública gaña una mayor relevancia cuando no hay una literatura jurídica sólida respecto al tema. Sobre esta cuestión:

O tema concurso público "até hoje não mereceu um tratamento destacado e sistematizado pela doutrina e jurisprudência, sem contar com o descaso - e até mesmo desprezo - por vezes operado pela própria Administração Pública. (...) Contudo, o que mais nos chamou a atenção - e também nos trouxe dificuldade - foi a ausência de estudos densos e sistematizados na doutrina e as grandes divergências nos julgamentos dos tribunais, sendo que somente em poucos caso é possível dizer que se formou jurisprudência. O que se verificou, na verdade foram lacunas! Seja por não enfrentar várias questões que fazem parte do cotidiano dos concursos, seja pelo casuísmo exacerbado que dificulta a formação de uma dogmática sólida."764

\footnotetext{
${ }^{762}$ La Ley 8.666/93, que trata de las normas de licitaciones y contratos administrativos, establece que: "Art. $3^{o}$ A licitação destina-se a garantir a observância do princípio constitucional da isonomia e a selecionar a proposta mais vantajosa para a Administração e será processada e julgada em estrita conformidade com os princípios básicos da legalidade, da impessoalidade, da moralidade, da igualdade, da publicidade, da probidade administrativa, da vinculação ao instrumento convocatório, do julgamento objetivo e dos que lhes são correlatos". Tales principios también son aplicables a los concursos públicos. ${ }^{763}$ MOTTA, Fabrício. Concurso público e Constituiçao, Fabrício Motta (Coordinador), Editora Fórum, Belo Horizonte, 2005, presentación, p. 11.

${ }^{764}$ BARBOSA MAIA, Márcio, y PINHEIRO DE QUEIROZ, Ronaldo. Op.cit., presentación, pp. XV y XVI.
} 
Debido a las circunstancias mencionadas (ausencia de ley y poca tradición doctrinaria y jurisprudencial), en Brasil, no es una tarea tan sencilla definir cuáles son los principios más relevantes del acceso a la función pública.Sin embargo, en general, siempre están presentes la igualdad $^{765}$, la competitividad ${ }^{766}$, la objetividad ${ }^{767}$, entre otros que también son destacados por el derecho español.

Así, aunque tal vez no sea posible afirmar con convicción que haya una teoría general de los procesos selectivos de acceso a la función pública de aplicabilidad universal, ya que cada ordenamiento jurídico establece sistema propios de selección, sí es posible identificar principios comunes en los derechos brasileño y español, esencialmente porque los dos adoptan, en sus Constituciones, los valores de igualdad, merito y capacidad en el acceso, lo que va a influenciar todo el procedimiento de selección.

En verdad, casi todas las consecuencias de la incidencia de cada uno de los principios del proceso selectivo de acceso a la función pública conducen al respeto a la igualdad. Evidentemente, esta posee muchas facetas, que traducen sus muchas

\footnotetext{
${ }^{765}$ Así: "a expressão-chave do concurso público é igualdade de oportunidades" (DA SILVA OLIVEIRA JÚNIOR, Dario, y CAMPOS OLIVEIRA, Isabel. Concurso público. Teoria e prática. Lumen Juris Editora, Rio de Janeiro, 2008, p. 19). O entonces:. "o concurso público como instituição humana está sujeito a toda sorte de vícios, e a única fórmula capaz de evitar desmandos, abusos e desvios do Poder Público e das bancas examinadoras é a observância rigorosa dos princípios jurídicos, mormente a igualdade, a probidade e a razoabilidade" (BARBOSA MAIA, Márcio, y PINHEIRO DE QUEIROZ, Ronaldo. Op.cit., p. 6).

${ }^{766}$ En este sentido: "Baseia-se o concurso em três postulados fundamentais. O primeiro é o princípio da igualdade, pelo qual se permite que todos os interessados em ingressar no serviço público disputem a vaga em condições idênticas para todos. Depois, o princípio da moralidade administrativa, indicativo de que o concurso veda favorecimentos e perseguições pessoais, bem como situações de nepotismo, em ordem a demonstrar que o real escopo da Administração é o de selecionar os melhores candidatos. Por fim, o princípio da competição, que significa que os candidatos participam de um certame, procurando alçar-se a classificação que os coloque em condições de ingressar no serviço público." (SANTOS CARVALHO FILHO, José dos. Op.cit., p. 541).

${ }^{767}$ En tal contexto:"A padronização é a regra da generalidade, decorrente do princípio da igualdade, aplicada nos concursos públicos. É lógica a conclusão de que só é válida a comparação entre duas coisas se submetidas às mesmas condições. Sendo o concurso público uma mecanismo de comparação dos candidatos a uma mesma vaga, tem-se que ambos deverão ser submetidos às mesmíssimas condições, a fim de que a seleção realizada seja válida." (LOBELLO DE OLIVEIRA ROCHA, Francisco. Op.cit., p. 70). También se puede destacar que: "Os parâmetros de seleção dos candidatos utilizados nos concursos públicos deverão ser sempre objetivos. Nunca é demais repetir que objetivo é tudo aquilo sobre o que todas as pessoas compartilham da mesma impressão, ou seja, que independe de opiniões ou juízos de valor. A objetividade nos concursos significa que não pode haver interferências subjetivas do examinador nos resultados" (DA SILVA OLIVEIRA JÚNIOR, Dario, y CAMPOS OLIVEIRA, Isabel. Op.cit., p. 19).
} 
exigencias. En los procesos administrativos, la igualdad se desdobla en tres aspectos: la igualdad de riesgos, la igualdad de oportunidades y la igualdad de trato:

"a igualdade de riscos, necessária à credibilidade do processo como instrumento de solução de conflitos de interesses. Todos os envolvidos podem nutrir esperança de êxito (...) Também a igualdade de oportunidades para influir na marcha e solução do processo compõe o princípio da isonomia processual. Trata-se de possibilidade de atuação e deveres de submissão idênticos entre as partes envolvidas, no curso do processo.(...) Por fim, há o subprincípio da igualdade de tratamento pelo órgão público, externado através de dose razoável de formalismo, que visa ao equilíbrio entre o poder coletivo e direitos das pessoas privadas. $" 768$

Son los mencionados principios comunes ${ }^{769}$ a los procesos selectivos de acceso a la función pública brasileña y española que serán analizados a continuación, que dedicará especial atención a las repercusiones de tales principios en cada uno de los sistemas jurídicos bajo comparación.

768 BOCKMANN MOREIRA, Egon. Processo Administrativo: princípios constitucionais e a Lei 9.749/99, Editora Malheiros, São Paulo, 2000, p. 76-77.

${ }^{769}$ Según la Carta Iberoamericana de la Función Pública, que tiene aplicabilidad en Brasil y en España, los principios del acceso son:

"Acceso al empleo. 20. La gestión de los procesos de acceso al empleo público se ha de llevar a cabo en todo caso de acuerdo con los principios siguientes:

a) Publicidad, entendiendo por tal la difusión efectiva de las convocatorias en unas condiciones que permitan que sean conocidas por la totalidad de candidatos potenciales.

b) Libre concurrencia, de acuerdo con unos requisitos generales de acceso al empleo público y sin más restricciones que las derivadas del perfil de competencias, que en todo caso deber corresponderse con los requerimientos funcionales del puesto.

c) Transparencia en la gestión de los procesos así como en el funcionamiento de los órganos de reclutamiento y selección.

d) Especialización de los órganos técnicos encargados de gestionar y resolver los procedimientos de acceso, lo que exige la cualificación profesional de sus integrantes, derivada tanto del conocimiento de la tarea como del manejo de los instrumentos de selección de personas.

e) Garantía de imparcialidad de los órganos encargados de gestionar y resolver los procedimientos de acceso, y en particular de cada uno de sus miembros considerados individualmente.

f) Fiabilidad y validez probadas de los instrumentos utilizados para verificar las competencias de los aspirantes.

g) Elección del mejor candidato, de acuerdo con los principios de mérito y capacidad.

h) Eficacia de los procesos de reclutamiento y selección para garantizar la adecuación de los candidatos seleccionados al perfil del puesto.

i) Eficiencia y agilidad de los procesos de reclutamiento y selección, sin perjuicio del respeto de todas y cada una de las garantías que deben rodearlos." 
Puesto que los principios constitucionales de igualdad, mérito y capacidad ya fueron objeto de los capítulos primero y segundo de este trabajo, ahora serán analizados los principios administrativos del proceso selectivo de acceso a la función pública.

\subsection{1 - Competitividad}

Todos los años en Brasil y en España, miles de personas preparan y toman parte en las oposiciones y en los concursos públicos ${ }^{770}$ para cubrir una gran cantidad de plazas ofertadas por las Administraciones Públicas de aquellos países. ${ }^{771}$

En realidad, los empleos en la Administración Pública corresponden a una buena parcela del mercado laboral español ${ }^{772} \mathrm{y}$ brasileño ${ }^{773}$, sea en términos cuantitativos, sea en el significado que representan la clase de los funcionarios públicos en la economía, especialmente porque poseen la tan deseada estabilidad, lo que les permite, entre otras cosas, una mayor planificación (y cumplimiento) de los gastos

\footnotetext{
${ }^{770}$ En verdad, en Brasil, no son miles, sino millones de personas: "A estimativa é de que, nesse momento dez milhoes de brasileiros estejam estudando para prestar algum concurso público nos próximos doze meses.(...) O número absoluto impressiona, mas impressiona ainda mais quando olhado em perspectiva em relaçao ao número de habitantes do País: na prática, $5 \%$ da população brasileira não apenas quer como também se prepara para conquistar uma vaga no serviço público". (Texto extraído del reportaje Concurso público: o sonho da estabilidade, publicado en la revista Istoé, 3 de febrero de 2010, p. 78).

${ }^{771}$ Sobre esta cuestión, cabe añadir que la Administración pública de España "salvo en situaciones de crisis, la Administración realiza todos los años una oferta de empleo público en la que, sumando la diversidad de organismos convocantes - Ministerios, Comunidades Autónomas, Diputaciones Provinciales y Ayuntamientos -, se aproximan a las 30.000 plazas convocadas." (SALAS PARRILLA, Miguel. Cómo aprobar oposiciones, Pedagogía Alianza Editorial, Tercera reimpresión, Madrid, 2008, p. 12). En Brasil, respecto a las plazas ofertadas en 2010, "estao abertas mais de 80 mil delas nos serviços públicos federal, estadual e municipal. Outras 220 mil serão oferecidas para aqueles que quiserem trabalhar por apenas um ano como recenseadores do IBGE, que fará um novo censo. Existem ainda outros 100 mil postos que estão programados para ser abertos apenas no âmbito federal, mas ainda não foram aprovadas por conta de restrições orçamentárias. Ao todo, entre abertas, temporárias e programadas, são quase 400 mil vagas de emprego no serviço público" (Texto extraído del reportaje Concurso público: o sonho da estabilidade, publicado en la revista Istoé, 3 de febrero de 2010, p. 78)

${ }^{772}$ Según el Boletín Estadístico del Personal al Servicio de las Administraciones Públicas (Extracto de la redacción impresa de julio de 2008), hay en España 2.594.664 empleados públicos, divididos en los siguientes niveles territoriales: Administración Pública Estatal (557.383 empleados, lo que representa un 21,4\%); Administración de las Comunidades Autonómicas (1.316.683 empleados, representando el 50,8\%), Administración Local, que abarca los Ayuntamientos, Diputaciones/Cabildos/Consejos Insulares (619.947 empleados, lo que representa el 23,9\%) y Universidades (100.671 empleados, representando un $3,9 \%$ del total).

773 En 2007, el porcentual de funcionarios entre el total de ocupados llegaba a casi $11 \%$, lo que correspondía a poco menos de $6 \%$ de la población brasileña. En números absolutos, en 2007, existían 10.168.680 funcionarios. Los datos fueron fornecidos por Instituto de Pesquisa Econômica Aplicada IPEA, publicado en 30 de marzo de 2009 y retirados del sitio http://www.ipea.gov.br/sites/000/2/comunicado_presidencia/09_03_30_ComunicaPresi_EmpPublico_v19 .pdf., con acceso en 20 de mayo de 2010.
} 
familiares y inversiones a medio y a largo plazo (adquisición de viviendas, viajes, vehículos, etc.), factores positivos para la economía de un país.

Los datos arriba referidos confirman la existencia de una disputa muy intensa por las plazas ofertadas, lo que impone aún más la necesidad de trato igualitario a los opositores por parte de la Administración Pública. No sería exagerado decir que la mala conducta administrativa, en la conducción de los procesos selectivos, influencia no solo en el resultado de la competición, sino también en la vida de miles de opositores, así como la de aquellos que se encuentran a su alrededor. Es que:

"para afrontar las oposiciones con ciertas garantías, debe plantearte que vas a prepararlas durante varios años, y a un ritmo bastante fuerte, como si estuvieras permanentemente en época de exámenes. Y para eso hay que estar bien mentalizado del sacrificio que hay que realizar, y de las renuncias que vas a tener que hacer." 774

Los procesos administrativos selectivos de forma general se caracterizan por su carácter competitivo ${ }^{775}$, lo que hace que aquellos que conducen la disputa deban conceder a los que de ella forman parte un trato igualitario. ${ }^{776}$ Tal circunstancia también impone el estricto cumplimiento de las reglas de la disputa, lo que hace que no haya espacio para flexibilizaciones o interpretaciones que sólo alcancen a determinados aspirantes.

En otras palabras, debido al principio de competitividad, en los procesos selectivos no se admite la concesión individualizada de formalidades que fueron exigidas a todos los aspirantes. Todo ello se debe a que el acto dirigido a determinado aspirante interesa a todos los demás, influyendo en la competición.

Cabe subrayar que la palabra concurso viene del latin concursus, de concurrere, y "significa o ato ou fato de concorrer, em virtude do que mostra, em regra,

\footnotetext{
${ }^{774}$ NAVARRO, Pilar. Prepara oposiciones con éxito. Las técnicas y los trucos para superar todas las pruebas. Planeta Prácticos, Barcelona, 2006, p. 60.

${ }^{775} \mathrm{El}$ proceso selectivo de acceso a la función pública "não é procedimento de simples habilitação (todos que lograrem ultrapassar certo mínimo são considerados aptos ou habilitados)... É um processo competitivo, em que os cargos são disputados pelos vários candidatos." (GASPARINI, Diógenes. Direito administrativo, $9^{\mathrm{a}}$ ed., Editora Saraiva, São Paulo, 2004, p. 171).

${ }^{776}$ La doctrina española también llama el mencionado principio de competitividad de libre concurrencia, y sobre los procesos selectivos de acceso a la función pública, destaca que "llama la atención que entre los principios rectores no aparezca el de libre concurrencia, que ha sido relegado a una característica de los procesos selectivos (art. 61.1 EBEP).” (LÁZARO, José Luis. Op.cit., p. 677).
} 
a participação de várias pessoas a um ato, ou a influência de coisas ou atos para a composição de outra coisa, evidência de um fato, ou constituição de um ato" "777

Sobre la disputa que se establece entre los opositores ${ }^{778}$, se puede destacar que "para aprobar una oposición...no basta con superar las pruebas, sino que hay que obtener una calificación superior a los demás opositores.",779

En esta misma dirección, ya se subrayó que:

"Preparar oposiciones es un reto personal en el que han de realizarse esfuerzos superiores a los acostumbrados en los estudios previos, ya fueran medios o universitarios. La elevada "ratio" de número de opositores por plaza, los exámenes orales, el considerable número de temas de algunas oposiciones, la ansiedad, etc., suponen un grado de dificultad añadido. En la oposición, para aprobar no basta con conocer los temas, como en la enseñanza académica, además hay que exponerlos en el tiempo preciso y mucho mejor que los otros compañeros competidores." ${ }^{\text {780 }}$

La doctrina siempre ha destacado la conexión entre la competividad y la igualdad. Así, se puede decir que "o postulado da competitividade configura um subprincípio concretizador e um aspecto dinâmico do cânone magno da isonomia na seara dos concursos públicos",781.

Además, "inexiste meritocracia sem competição, e competição pressupõe igualdade para todos os candidatos." ${ }^{, 782}$. A su vez, ya se ha subrayado que en los procesos administrativos donde son establecidas competiciones entre los ciudadanos, "os candidatos partem de uma igualdade (todos podem habilitar-se para disputa e sujeitam-se às mesmas condições) para chegar a uma desigualdade (a pessoa mais apta,

\footnotetext{
${ }^{777}$ SILVA, De Plácido e. Vocabulário jurídico, Editora Forense, Rio de Janeiro, 1999, p. 194.

${ }^{778}$ Ya se ha afirmado que: "Como série de atos concatenados tendente a selecionar, de forma impessoal, os mais aptos a ocuparem cargos ou empregos públicos, o concurso público é ontologicamente marcado pelo conflito de interesses entre os concorrentes e, eventualmente, entre qualquer destes $e$ a Administração" (MOTTA, Fabrício. Op.cit., p. 142).

${ }^{779}$ NAVARRO, Pilar. Op.cit., p. 13.

${ }^{780}$ SALAS PARRILLA, Miguel. Op.cit., p. 7.

781 BARBOSA MAIA, Márcio, y PINHEIRO DE QUEIROZ, Ronaldo. Op.cit., p. 27

${ }^{782}$ Extraído del voto de Joaquim Falcão, miembro del Consejo Nacional de Justicia brasileño, en el análisis del procedimiento de control administrativo $\mathrm{n}^{\circ}$ 510, en Revista de Direito Administrativo, $\mathrm{n}^{\circ} 248$, maio-agosto de 2008, Fundaçao Getúlio Vargas Jurídico Atlas, Ed. Atlas, Sao Paulo, p. 163.
} 
a melhor proposta) comportada pelo sistema jurídico. Em razão disto, os candidatos devem submeter-se às mesmas exigências e condições de realização das provas." ${ }^{783}$

Lo que pasa es que las pocas oportunidades ofertadas por la Administración Pública no son suficientes para atender a gran demanda verificada en la sociedad. ¿Cómo decidir cuáles ciudadanos serán y cuáles no serán los que recibirán el bien o derecho disputado? La concesión de trato igualitario es el primer paso que se debe realizar en cualquier disputa fomentada por el Estado, incluso en el acceso a la función pública:

\begin{abstract}
"Ocorre que o número de cidadãos detentores deste direito é muito maior que a quantidade de cargos e empregos públicos. Configura-se, assim, situação em que várias pessoas disputam determinado benefício não alcançável por todas, e, nesta hipótese, impõe-se a observância do princípio da igualdade de oportunidades. Ou seja, aqueles que pretendam exercem este direito deverão concorrer em condições de igualdade." 784
\end{abstract}

A fin de que la competición suceda de forma transparente, hay que ser tomadas algunas precauciones, entre las cuales se incluye la previsión de un reglamento que disponga respecto a los parámetros de decisión de la Administración Pública y la estipulación de criterios objetivos de elección ${ }^{785}$.

En verdad, es que los procesos administrativos concurrenciales, se puede decir que "em todas as suas espécies, guardam características comuns, tais como, a existência de um edital, que é a lei interna do procedimento, o caráter competitivo e

\footnotetext{
${ }_{783}$ LOBELLO DE OLIVEIRA ROCHA, Francisco. Op.cit., p. 29.

${ }^{784}$ LOBELLO DE OLIVEIRA ROCHA, Francisco. Idem, p. 51.

${ }^{785} \mathrm{La}$ adopción de criterios objetivos y de reglas claras son esenciales para el éxito del proceso selectivo. $S i n$ embargo, no es una garantía absoluta de éxito. En este sentido, conviene transcribir que: "É difícil julgar, é difícil avaliar. Julgar em concurso público é ainda mais difícil, dada a exigüidade do tempo e as limitações dos instrumentos de avaliação. Hoje, qualquer concurso público no Brasil atrai milhares de candidatos em ferrenha disputa por poucas vagas, o que torna ainda mais difícil a avaliação de competências. Em tal situação, a necessidade de um verdadeiro "desbaste" torna o concurso mais eliminatório do que seletivo. E como o número de vagas oferecidas é geralmente muito menor do que o de candidatos, freqüentemente não chegando a 2 ou $5 \%$, sabe-se de antemão que a grande maioria dos candidatos ficará fora da lista dos selecionados. Haverá sempre, então, uma grande maioria insatisfeita" (MORHY, Lauro. A realidade dos concursos públicos. Texto extraído del sitio de la Universidade de Brasilia - UnB, dirección electrónica http://www.unb.br/administracao/reitoria/artigos/20050616.php).
} 
seletivo inerente ao certame, a necessidade de critérios objetivos de julgamento, a obediência à ordem de classificação, dentre outros aspectos procedimentais comuns",786

La doctrina también destaca la existencia de distintos actos que afectan el carácter competitivo de los procesos selectivos, como los "horários restritos e inadequados para a realização das inscrições, postos de inscrições em número insuficiente, proibição de inscrição através de procurador",787

La competitividad es esencial para que la decisión de la Administración Pública sea la más eficaz posible, ya que el incremento de la disputa hace con que aumenten las chances de participación de candidatos aptos. Es muy relevante que se tenga en cuenta que "não pode a Administração dirigir o concurso a determinado candidato, exigindo no edital critérios assaz particulares que se saiba de antemão de somente ele poderá cumpri-los. Nesse caso, o concurso caracterizaria mero engodo, já que inexistiria qualquer possibilidade de acesso a outros candidatos."

Así, para que la Administración actúe de forma igualitaria, se impone que las "reglas del juego" sean previamente establecidas, lo que impone el estudio del próximo principio.

\subsection{2 - Vinculación a las bases de las convocatorias}

El reconocimiento de que la Administración Pública debe obediencia a las leyes fue pieza fundamental para la instauración del Estado de Derecho. El concepto desarrollado durante la Revolución Francesa de que la ley es el elemento que permite la expresión de la voluntad general (y de que esta es soberana) hasta el día de hoy, está presente en las bases de la sociedad, del Estado y del Derecho.

La adopción del principio de legalidad hizo que surgiera una nueva rama del Derecho: el Derecho Público, y también fue determinante para el desarrollo de una de sus áreas más destacadas: el Derecho Administrativo, como conjunto de normas de contención del poder, de reglamentación de la actividad estatal de la aplicación de las leyes. Todo eso a través de la ley.

\footnotetext{
${ }^{786}$ BARBOSA MAIA, Márcio, y PINHEIRO DE QUEIROZ, Ronaldo. Op.cit., p. 23.

${ }^{787}$ BARBOSA MAIA, Márcio, e PINHEIRO DE QUEIROZ, Ronaldo. Idem, p. 95.

${ }^{788}$ LOBELLO DE OLIVEIRA ROCHA, Francisco. Op.cit., p. 31.
} 
En los ordenamientos jurídicos español y brasileño, el principio de legalidad ejerce un papel fundamental, ya que tales países adoptan el sistema jurídico romanogermánico (europeo continental) que tiene el derecho positivo (especialmente, las leyes) como principal referencia normativa, lo que los diferencia de los países que utilizan el sistema anglo saxónico, donde los procedentes judiciales tienen la primacía (es lo que pasa en Inglaterra, Estados Unidos, y otros países).

La Constitución española de 1978 no olvidó la grandeza del principio de legalidad y lo adoptó en su art. 103.1. En esta norma constitucional, está claro que la Administración Pública actúa con sometimiento pleno "a la ley y al Derecho".

En el contexto señalado, queda evidente que además de la ley, en tanto que producto de la creación del Poder Legislativo, hay otras fuentes normativas que sirven para someter la actuación de la Administración Pública. El uso de la expresión "a la ley y al Derecho" sirve para demostrar que el último es mayor que el primero.

En esta línea de pensamiento, en la selección de los funcionarios públicos, en la que pese a ser la ley la principal fuente normativa, bajo la Constitución, hay que destacar el papel ejercido por los reglamentos administrativos y, principalmente, por las bases de la convocatoria de los procesos selectivos.

En la Constitución brasileña de 1988, el principio de legalidad tiene una acepción más genérica, cuando el art. 5\%, II, establece que "ninguém será obrigado a fazer ou deixar de fazer alguma coisa senão em virtude de lei”, y otra más específica, en el art. 37, cuando la Carta Magna instituye que el mencionado principio es obligatorio para la Administración Pública.

Así, mientras la legalidad genérica es una garantía de la sociedad, ya que es un mecanismo de protección del ciudadano contra el arbitrio del Estado, la legalidad estricta $^{789}$ (administrativa) es un norte para la actuación de la Administración Pública, pues todos los actos administrativos deberán estar fundamentados en una ley, lo que

\footnotetext{
${ }^{789}$ En el âmbito del acceso a la función pública: "Em atenção à legalidade, desta feita vislumbrada restritamente, não se admite que qualquer ato normativo editado pela Administração para reger o concurso traga imposições ou estabeleça distinções onde a lei não o fez" (MOTTA, Fabrício. Concurso público e confiança na atuação administrativa: análise dos princípios de motivação, vinculação ao edital e publicidade, en Concurso público e Constituição, Fabrício Motta (Cordinador), Editora Fórum, Belo Horizonte, 2005, p. 144).
} 
también se trata de una relevante precaución para impedir la mala utilización de los poderes del Estado.

Las bases de la convocatoria en España y el edital en Brasil son llamados "ley del concurso o de la oposición”, y reciben esta denominación por instituir las reglas específicas para cada proceso selectivo, pese a que las leyes y reglamentos establezcan las normas generales que deben ser observadas en la definición de las referidas bases.

La necesidad de la creación de reglas adecuadas a cada proceso selectivo es indiscutible, y en propio ordenamiento jurídico español, el Estatuto Básico del Empleado Público (art. 55.2, e) consagra como principio la "adecuación entre el contenido de los procesos selectivos y las funciones o tareas a desarrollar”, lo que será analizado próximamente.

Una vez elaboradas las referidas reglas, estas pasan a vincular toda la actuación de la Administración Pública, así como la de todos aquellos que participan del proceso selectivo, como reconocen los órganos judiciales españoles: "las bases de la convocatoria vinculan a la Administración, a los Tribunales que han de juzgar las pruebas selectivas y a quienes toman parte de ellas" ${ }^{\text {,790. }}$.

En la doctrina brasileña, muchos juristas afirman que: "uma vez estabelecidas as regras disciplinadoras do concurso público, o Poder Público, conquanto tenha se valido de certa carga de competência discricionária, autolimitou-se às diretrizes editalícias, as quais, uma vez aperfeiçoadas e publicadas, gozam de força obrigatória e vinculante, tanto para a Administração quanto para os administrados."791

Se puede añadir que la exigencia de que las reglas del proceso de selección sean detalladas proviene de la necesidad de seguridad jurídica para los candidatos, que deben conocer con antelación las pautas de la competición de la cual participarán:

"O concurso público, entendido como o conjunto de atos administrativos que visa à aferição das aptidões de candidatos ao fito de selecionar os melhores para o provimento dos cargos públicos, por se tratar de procedimento marcado por acirradas disputas entre os

\footnotetext{
${ }^{790}$ STS de 18 de abril de 1998.

${ }^{791}$ BARBOSA MAIA, Márcio, y PINHEIRO DE QUEIROZ, Ronaldo. Op.cit., p. 38.
} 
candidatos, deve ter suas regras disciplinadoras minuciosamente traçadas no edital que lhe dá publicidade. $\mathrm{E}$ isso porque à Administração, em nome da segurança jurídica, não é lícito agir incoerentemente com as diretrizes adotadas, de modo a exigir do candidato determinada postura a que não fez referência no edital, uma vez que suas opções geram na coletividade a expectativa do seu cumprimento, e nunca o contrário.",792

La sumisión a reglas claras y previas a la competición es condicio sine qua non para la conducción objetiva del proceso selectivo, y, como consecuencia, para que sea concedido un trato igualitario a los aspirantes a la función pública.

Los mencionados aspirantes también se someten a las bases de la convocatoria, de forma que:

“...consentidas las bases de la convocatoria no es posible, normalmente, que quien se aquietó ante las mismas y tomó parte en las pruebas de selección, pueda después, ante el resultado adverso de las pruebas, impugnarlas con base en discutibles motivos de legalidad..."793

Por la razón arriba citada, existe la posibilidad jurídica de impugnación, mediante recurso administrativo cuando el aspirante no está de acuerdo con el contenido de las bases de la convocatoria.

Sin embargo, la nueva interpretación del principio de legalidad, que privilegia el contenido y que atribuye a forma un valor relativo (como medio, y no como $\mathrm{fin}^{794}$ ), hace con que el entendimiento anteriormente expresado, que no admite cualquier impugnación de las bases de la convocatoria tras el resultado del proceso selectivo, deba ser repensado. En este sentido:

\footnotetext{
${ }^{792}$ ALVES DIAS, Fábio Henrique. Concurso público: uma vinculação recíproca. O direito subjetivo à nomeação de candidatos aprovados em concurso público. Texto extraído del sitio http://jusvi.com/artigos/36202.

${ }_{793}^{793}$ STS de 10 de febrero de 1987.

${ }^{794}$ En este sentido: "O procedimento especial do concurso público, ao contrário da generalidade dos processos administrativos, não se sujeita ao princípio do informalismo, dada a magnitude dos interesses em jogo e a dimensão social de seu objeto. (...) Sem embargo das circunstâncias acima delineadas, cumpre assinalar que as formalidades não guardam uma razão em si mesmas e devem sempre estar a serviço de uma finalidade juridicamente relevante" (BARBOSA MAIA, Márcio, y PINHEIRO DE QUEIROZ, Ronaldo. Op.cit., pp. 29-30).
} 
“a compreensão teleológica desse princípio leva a questionar a orientação, que tem predominado, pela estrita e rigorosa vinculação do processo de concurso ao respectivo edital (lei do concurso), o qual, passada a fase de impugnação e sob a justificativa de preservar o princípio da isonomia entre os candidatos, é colocado em posição superior à própria Constituição." 795

Debido a la importancia para este trabajo del control del proceso selectivo y de las garantías de los aspirantes, esta cuestión será investigada con más intensidad aun en este capítulo. Asimismo, el análisis de las bases de la convocatoria será realizado en el estudio del procedimiento de selección, lo que será objeto de estudio del capítulo quinto.

En definitiva, lo que se debe destacar es que los ciudadanos (aquí, aspirantes) tienen la legítima expectativa de que la Administración Pública va a actuar bajo la observación del ordenamiento jurídico ${ }^{796}$ (aquí, bases de la convocatoria). Sin embargo, se puede añadir que los organismos públicos también esperan que los aspirantes se comporten de buena fe, debido a que estos se encuentran obligados a respectar las normas del proceso selectivo.

La exigencia de buena fe de todos aquellos que hacen parte del proceso selectivo es condición imprescindible para la justa conducción de la disputa que se realiza entre los candidatos. En tales términos, se puede destacar que:

"na preparação, realização e controle dos concursos públicos, deve a
Administração primar pela absoluta boa-fé, vinculando-se
estritamente às regras legalmente e normativamente regentes do
certame. Não se admite, assim, que desrespeite as regras do jogo,
estatua uma coisa e faça outra. A confiança na atuação de acordo com

${ }^{795}$ BATISTA GOMES MOREIRA, João. Op.cit., p. 133.

${ }^{796}$ La referida creencia de los ciudadanos es lo que se llama principio de confianza legítima. Sobre esto, ya se dijo que: "La Administración tiene la obligación de respectar ese principio de confianza legítima, pues, si lo violenta, causa la desconfianza en el administrado y esa desconfianza es el primer paso de la pérdida de valor de todo sistema democrático, social y de Derecho, pues el administrado toma consciencia de que no puede fiarse de quienes ejercen el poder público, ya que actúan desproporcionada y subjetivamente." (PERÉZ LUQUE, Antonio. Op.cit., p. 96). 
o Direito posto é o mínimo que esperam os cidadãos concorrentes a um cargo ou emprego público." ${ }^{797}$

La doctrina anteriormente transcripta también sostiene que de la exigencia de buena fe derivase el principio de vinculación a las bases de la convocatoria, haciendo surgir tres consecuencias:
“a) qualquer alteração do edital, após sua divulgação, deve ser seguida de comunicação aos candidatos e nova publicação; b) iniciado o certame, não se admitem mudanças nos critérios inicialmente estabelecidos $^{798}$ para apuração de médias (atribuição de pesos a determinadas matérias ou etapas), correção de provas, cálculo de vagas e pontuação de títulos, dentre outros, sob pena de nulidade do certame; e, c) não pode a Administração buscar qualquer expediente astucioso de interpretação para fugir da aplicação das regras

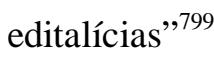

Por todo ello, tanto hay consecuencias jurídicas para el incumplimiento de las bases de la convocatoria por la Administración Pública (por ejemplo, nulidad del proceso $^{800}$ ), como también para por la no observación de las referidas normas por parte de los aspirantes (por ejemplo, su exclusión de la competición).

\subsection{3 - Publicidad}

El espíritu democrático de las Constituciones brasileña y española ha inspirado todo ordenamiento jurídico, lo que hace que los valores del referido régimen

\footnotetext{
${ }^{797}$ MOTTA, Fabrício. Concursos públicos e o princípio da vinculação ao edital. Texto extraído del sitio Jus Navigandi (http://jus2.uol.com.br/doutrina/texto.asp?id=8035, elaborado em 03.2005).

${ }^{798}$ Este tema será tratado en el quinto capítulo, que analizará el procedimiento del proceso selectivo. Sin embargo, la afirmación que no admite cambios en los criterios establecidos para la evaluación no es absoluta. De momento, se puede afirmar que deve haber una "distinção entre normas (do edital) protetoras de direitos individuais e normas protetoras apenas do interesse público. As primeiras têm caráter vinculante, mas as segundas admitem aplicação flexível e interpretação evolutiva pela Administração." (BATISTA GOMES MOREIRA, João. Op.cit., p. 133).

${ }^{799}$ MOTTA, Fabrício. Concursos públicos e o princípio da vinculação ao edital. Texto extraído del sitio Jus Navigandi (http://jus2.uol.com.br/doutrina/texto.asp?id=8035, elaborado em 03.2005).

${ }^{800}$ Respecto a este tema: "Insta notar, por relevante, que a aplicação do princípio da instrumentalidade das formas no concurso público constitui um dos métodos que devem ser aplicados pela Administração Pública e pelo Poder Judiciário no afa de se evitar a decretação de nulidade de certames findos ou em estágio avançado de realização, cujo vício de ilegalidade verificado não é suscetível de comprometer o seu caráter competitivo e os princípios da moralidade e da impessoalidade" (BARBOSA MAIA, Márcio, y PINHEIRO DE QUEIROZ, Ronaldo. Op.cit., pp. 29-30).
} 
estén insertos en todas sus normas. Entre los citados valores, hay que destacar especialmente la publicidad, ya que representa la aniquilación de los particularismos y del acceso restringido a la información que versa sobre la sociedad.

Respecto a la relación entre publicidad y democracia, se ha dicho que:

“o princípio da publicidade é da essência de um Estado Democrático de Direito, inerente ao exercício da função administrativa. A atividade do agente público deve sempre ser realizada no interesse da coletividade, cumprindo determinações legais previamente fixadas. A consequiência é óbvia: não existem assuntos internos ou reservados à intimidade da Administração. A regra é a da ampla transparência, clara e franca, de todos os aspectos da conduta administrativa estatal." $" 801$

El principio de publicidad impone que la Administración Pública divulgue ampliamente sus actos, a través de los mecanismos establecidos en el ordenamiento jurídico, a fin de que con esto los ciudadanos puedan:

a) tener conocimiento de las actuaciones administrativas; sean estas de carácter general o las que les afectan directamente, para que sepan de qué forma los organismos administrativos están utilizando los recursos públicos (publicidad con la finalidad de permitir la divulgación);

b) conociendo el comportamiento de los organismos administrativos, que tengan la posibilidad de controlarlos, de forma colectiva o individual, y, si fuera necesario, ser juzgados (publicidad con la finalidad de permitir el ejercicio del control);

c) a partir de la obtención de la información sobre las actuaciones administrativas, tomar medidas en el sentido de adaptarse a las referidas iniciativas (publicidad con la finalidad de permitir la actuación de los ciudadanos).

En el ámbito del proceso selectivo de acceso a la función pública, el principio de publicidad es una exigencia constitucional y tiene distintas consecuencias:

801 BOCKMANN MOREIRA, Egon. Processo Administrativo: princípios constitucionais e a Lei 9.749/99, Editora Malheiros, São Paulo, 2000, p. 96. 
"é imperioso afirmar que a publicidade e transparência dos certames são regras, somente sendo admissível sigilo para preservar a intimidade, a vida privada, a imagem das pessoas ou a segurança da sociedade e do Estado. Especificamente, podemos estatuir que: a) a divulgação dos certames deve ser ampla o suficiente para possibilitar que se alcance o maior número de candidatos possível. (...); b) a divulgação dos resultados das etapas preliminares também deve ser ampla e com antecedência razoável para permitir interposições de recursos. (...); c) o acesso aos atos que servem como elementos de defesa deve ser facilitado e irrestrito, não havendo fundamento para negativa de vista de provas, laudos ou atas de correção, por exemplo...(...); d) em razão da produção contemporânea de atos com posterior efeitos jurídicos, o acesso aos locais onde se realizam provas orais ou práticas deve ser liberado ao público...(...); e) a publicidade oficial é condição de eficácia de todos os atos referentes ao concurso" 802

Así, siempre que la Administración Pública realice un proceso selectivo para el acceso a la función pública, es imprescindible su divulgación, sea para que la sociedad tome conocimiento de la referida decisión, sea para que haya la posibilidad de impugnación de supuestas actuaciones irregulares, o aún para que aquellos que tengan interés, puedan tomar parte en la competición.

Aunque la cuestión de la forma de divulgación de los actos del proceso selectivo (base de la convocatoria, transcurrir de los ejercicios, resultado final, etc.) va a ser analizada durante el estudio de las normas de la oposición/concurso, ya se puede adelantar que la ausencia o simple deficiencia de la publicidad del proceso selectivo puede generar graves consecuencias, entre ellas la nulidad del proceso.

En este momento, es relevante destacar cómo la publicidad (o su deficiencia) puede afectar a la igualdad entre los ciudadanos en la competición. En consecuencia, debe garantizarse las condiciones que permitan el total conocimiento por

\footnotetext{
${ }^{802}$ MOTTA, Fabrício. Concurso público e confiança na atuação administrativa: análise dos princípios de motivação, vinculação ao edital e publicidade, en Concurso público e Constituição, Fabrício Motta (Cordinador), Editora Fórum, Belo Horizonte, 2005, p. 156-157.
} 
parte de los candidatos potenciales, tanto de las bases de la convocatoria, como de los actos subsecuentes del procedimiento ${ }^{803}$.

En este sentido, "nos concursos públicos, a publicidade significa a ampla e efetiva comunicação de todos os atos, em cada fase do concurso, informando os candidatos sobre seus deveres e obrigações e garantindo o controle destes, bem como da sociedade como um todo, sobre os atos praticados pela Administração", 804

En el sentido arriba descrito, cabe destacar que "La garantía de publicidad alcanza dos aspectos: uno, conocimiento de la existencia de los procesos selectivos correspondientes; otro, referido a la necesaria difusión del transcurrir de los ejercicios." ${ }^{, 805}$

En España, se ha destacado que la exigencia subrayada evitaría "los desafortunados "procesos", por denominarlos de alguna manera, que han poblado toda nuestra geografía nacional, donde ha sido habitual el reclutamiento sobre todo de empleo temporal, mediante simples anuncios en tablones municipales..."806

A su vez, en Brasil se ha subrayado que

"É muito comum ainda nos dias atuais, principalmente em pequenos Municípios, a realização de concursos públicos sem a devida divulgação, fato este que é passível de nulidade. Inclusive o veículo utilizado de divulgação deverá ser idôneo, pois, em muitos casos, a divulgação ou a simples aposição de cópia do edital do concurso público em edifício público da Prefeitura ou do Fórum Estadual são insuficientes, sendo mesmo uma forma velada de burlar a sua publicidade" ${ }^{\text {807 }}$

\footnotetext{
${ }^{803}$ Seguramente, hay circunstancias que no deben ser divulgadas por la Administración Pública, para que se garantice la idoneidad de la competición; "É importante salientar que as únicas restrições que podem ser impostas ao princípio da publicidade em nome do interesse público e do princípio da isonomia diz respeito ao conteúdo das provas escritas, em face da aplicação dos critérios da sigilosidade e da simultaneidade, e ao perfil profissiográfico da avaliação psicológica" (BARBOSA MAIA, Márcio, y PINHEIRO DE QUEIROZ, Ronaldo. Op.cit., pp. 31-32).

${ }^{804}$ LOBELLO DE OLIVEIRA ROCHA, Francisco. Op.cit., pp. 39-40.

${ }^{805}$ CASTILLO BLANCO, Federico A. Acceso a la función pública local (políticas selectiva y control jurisdiccional), Comares Editorial, Granada, 1993, p. 89.

${ }^{806}$ FONDEVILA ANTOLÍN, Jorge. Op.cit., p. 116.

${ }^{807}$ MACHADO JÚNIOR, Agapito. Op.cit., p. 96.
} 
Es posible afirmar que el incumplimiento del deber de publicidad viola el derecho del ciudadano al acceso a la función pública en condiciones de igualdad $^{808}$, además de otros principios constitucionales ${ }^{809}$, ya que la selección deja de tener un carácter público efectivo cuando solamente se posibilita el conocimiento limitado de la realización de la oposición/concurso, o de sus condiciones.

Sobre la mencionada vinculación entre la publicidad y la igualdad, el Tribunal Supremo español hace muchos años ya declaró que:

"La publicidad tiene por objeto llegar a la generalidad de los posibles interesados el conocimiento de la existencia y características de la convocatoria para que aquellos puedan decidir lo oportuno respecto de su concurrencia, y teniendo en cuenta que dichos interesados pueden no residir en la localidad donde radica el organismo en cuyo tablón de anuncios se exponen las bases -para su conocimiento podrían verse obligados a hacer un viaje,-habrá que concluir que la finalidad del precepto se logra mejor insertando las propias bases en el texto a publicar en el Diario Oficial,...si se piensa que la publicidad a través del Diario Oficial es un factor de igualación (art. 9.2 $\mathrm{CE}), \ldots$ contribuyendo, por tanto, a eliminar diferencias por razón de la residencia." 810

El reto del ordenamiento jurídico es garantizar la ampliación de la eficacia de la publicidad, que se podría obtener a partir de la obligatoriedad de divulgación de la realización de los procesos selectivos en otros medios de comunicación, como internet, revistas, periódicos, radio y televisión.

\footnotetext{
808 En esta dirección:"para assegurar a objetividade e a isonomia, é imprescindivel respeitar a publicidade. Isso significa a necessidade de o concurso público ser antecedido de ato convocatório ao qual se reconheça a mais ampla publicidade, nele se estabelecendo todas as condições de participação, os critérios de julgamento e o modo de sua promoção" (JUSTEN FILHO, Marçal. Op.cit., pp. 743-749).

${ }^{809}$ En este camino: "A publicidade do concurso, além de atender ao princípio da publicidade constante do art. 37 da CF/88, denota a um só tempo: (a) a possibilidade de controle dos atos do concurso público por parte do povo que traduz o princípio democrático, além de garantir a moralidade; (b) a ampliação da concorrência através do maior número de candidatos, o que favorecerá a qualidade dos aprovados em plena observância ao princípio da eficiência; (c) a garantia do amplo acesso a cargos públicos, o que antes se restringia a uma pequena casta de privilegiados, o que indica também respeito ao princípio da impessoalidade" (MACHADO JÚNIOR, Agapito. Op.cit., p. 96).
}

${ }^{810}$ STS de 26 de septiembre de 1984. 


\subsection{4 - Transparencia}

Para que los ciudadanos puedan obtener de la Administración Pública un trato igualitario en el acceso a la función pública, conviene que aquellos puedan saber con anterioridad cuáles serán los parámetros de actuación administrativa. En otras palabras, cuáles son y de qué forma se llevarán a cabo las reglas del juego.

La objetividad en la definición de las reglas del proceso selectivo es una exigencia inamovible, y es una garantía para los candidatos:

"O regulamento do concurso deverá estabelecer todos os critérios para
o julgamento, de modo que a avaliação do desempenho dos
interessados se faça segundo critérios objetivos predeterminados. A
objetividade consiste na eliminação de julgamentos subjetivos,
fundados em impressões, preferências ou concepções puramente
individuais dos julgadores “ 811

De la misma forma, en el momento siguiente, se impone que aquellos que resolvieran participar del proceso selectivo puedan presenciar la actuación administrativa, de manera que cada paso del órgano responsable por la selección pueda ser fiscalizado ${ }^{812}$, sin que haya espacio para desempeñar actos secretos o que no sean controlables.

En efecto, como ha destacado la doctrina española:

"El reconocimiento de un derecho de acceso a la documentación
pública -vertiente subjetiva- y del correspondiente principio de
transparencia administrativa -vertiente objetiva- constituye una fase o
etapa avanzada de los sistemas democraticos, pues debe recordarse
que la democracia no es tanto un estado como un proceso siempre
abierto (...) El principio de transparencia constituye la dimensión
objetiva del derecho de acceso a los documentos administrativos como

${ }^{811}$ JUSTEN FILHO, Marçal. Op.cit., p. 743-749.

${ }^{812}$ Así es que: "atendendo à impostergável imposição de transparência, a divulgação dos resultados, em regra geral, deve identificar nominalmente os aprovados em cada etapa, afrontando este princípio e o da moralidade a divulgação somente de número de inscrição" (MOTTA, Fabrício. Concurso público e confiança na atuação administrativa: análise dos princípios de motivação, vinculação ao edital e publicidade, en Concurso público e Constituição, Fabrício Motta (Cordinador), Editora Fórum, Belo Horizonte, 2005, p. 157). 
principio objetivo del funcionamiento de la administración pública. De hecho, el principio de transparencia constituye hoy, junto con los de legalidad y eficacia, uno de los tres grandes principios que informan la actividad de las administraciones públicas. Cada uno de estos principios tiene su fundamento propio en las tres grandes cláusulas que históricamente se han ido superponiendo hasta constituir los pilares de los modernos Estados: así el principio de legalidad trae causa en la idea de Estado de derecho, el principio de eficacia en la de Estado social, y el principio de transparencia es un corolario inmediato del Estado democrático" ${ }^{\sharp 13}$

En este contexto, se exige que la Administración Pública actúe con transparencia, cuya descripción en el ámbito de este trabajo sea la definición y utilización de criterios objetivos y controlables de selección.

De igual manera, ya se destacó que el principio de transparencia "reclama, entre otras cosas, que los criterios que se utilicen en la selección, incluso si no están pautados o baremados previamente, sean claros y conocidos...que todos puedan conocer los actos de trámite del procedimiento que les afecten directa o indirectamente" 814

Sobre el principio de transparencia adoptado por el Estatuto Básico del Empleado Público, la doctrina española ya subrayó que:

"La única formulación novedosa es la del principio de transparencia (art. 55.2 b EBEP), pero su relevancia práctica en los procesos selectivos es poco novedosa, pues ya está recogido de forma genérica en el art. 3.5 de la Ley de Régimen Jurídico de las Administraciones Públicas y del Procedimiento Administrativo Común y el art. 54.2 de esta misma Ley concreta una de sus consecuencias jurídicas más relevantes: el deber de motivar los actos que pongan fin a los procedimientos selectivos." ${ }^{\text {815 }}$

\footnotetext{
${ }^{813}$ FERNÁNDEZ RAMOS, Severiano. Algunas proposiciones para una ley de acceso a la información, Boletín Mexicano de Derecho comparado, Instituto de Investigaciones Jurídicas de la UNAM, número 105, septiembre-deciembre 2002, p. 881-882.

${ }^{814}$ CAVAS MARTÍNEZ, Faustino. Op.cit., p. 589.

${ }^{815}$ LÁZARO, José Luis. Op.cit., p. 677.
} 
Así, se puede percibir que la motivación es esencial para garantizar la transparencia, y esta, para permitir la igualdad. En el acceso a la función pública española, el deber de motivación está presente desde el trámite previo de la oferta de empleo hasta la resolución final del proceso selectivo. En las palabras de la doctrina ${ }^{816}$, el mencionado deber de transparencia “colorea todo el procedimiento de selección”"817.

Sin embargo, como destacó la Comisión para el estudio y preparación del Estatuto Básico del Empleado Público, el principio de transparencia ha de conciliarse con el necesario carácter reservado a las deliberaciones del órgano de selección ${ }^{818 .}$

En Brasil, el deber general de motivación está previsto en la legislación federal de los procesos administrativos (Ley Federal 9.784/99), como un principio general (art. $2^{\circ}$, parágrafo único, VII). Además, en la referida ley, se exige de forma más específica en el art. 50, III que "Os atos administrativos deverão ser motivados, com indicação dos fatos e dos fundamentos jurídicos, quando: (...):III - decidam processos administrativos de concurso ou seleção pública”

A su vez, la doctrina brasileña, respecto a la exigencia de motivación de los procesos selectivos ${ }^{819}$, ha afirmado que:

“todas as ações e decisões relativas a concursos públicos devem ser motivadas de forma explícita, contemporânea, clara e congruente. Merecem realce os seguintes aspectos que dizem respeito à motivação, sobretudo no tocante à sua importância para a efetividade dos

\footnotetext{
${ }^{816}$ Respecto a la motivación de las actuaciones de la Administración Pública, véase la obra de Marcos Fernando Pablo, La motivación de los actos administrativos, Ed. Tecnos, Madrid, 1993.

${ }^{817}$ SANCHÉZ MORÓN; Miguel. Op.cit., p. 132.

${ }^{818}$ Informe de la Comisión para estudio y preparación del Estatuto Básico del Empleado Público, INAP, Madrid, Miguel Sánchez Morón (Presidente), abril 2005, p. 91.

${ }^{819}$ También se puede destacar la siguiente opinión doctrinária respecto a la motivación y transparencia em los procesos selectivos brasileños: "O concurso público, por ostentar índole competitiva, implica no julgamento de provas e, até certo ponto, expõe os participantes-administrados à censura pública, tendo em vista que a divulgação dos resultados possibilitará o exame social da performance individual dos candidatos. Ao lado de tal ônus, deve ser assegurado aos candidatos dos concursos públicos o direito de ter acesso prévio aos nomes dos componentes das bancas examinadoras e à sua qualificação profissional, pois não é justo alguém ser submetido ao julgamento de seu conhecimento por intermédio de um processo obscuro, em que se ignora, por completo, os responsáveis pela respectiva avaliação. Assim, afigura-se um rematado desconchavo jurídico e conduta atentatória à transparência administrativa a postura estatal que resiste à divulgação dos nomes dos membros da bancas examinadoras dos concursos públicos, imprimindo-lhe regime de sigilo, pois impossibilita a aferição da competência científica e técnica da comissão,bem como inviabiliza a argüição de suspeição ou impedimento em desfavor de seus membros." (BARBOSA MAIA, Márcio, y PINHEIRO DE QUEIROZ, Ronaldo. Op.cit., p. 84).
} 
princípios da ampla defesa e do contraditório: a) a avaliação das provas, sobretudo subjetivas, deve ser expressa e temporaneamente motivada, devendo estar claro os critérios utilizados para correção; b) as decisões que importam em atribuições de pontos, avaliação de inscrições, documentos, títulos e recursos interpostos devem ser motivadas para permitir o exercício do contraditório; c) as provas orais devem ser gravadas, taquigrafadas, ou por qualquer meio técnico registradas, a fim de possibilitar eventuais recursos ou impugnações. A avaliação das mesmas deve ser motivada, admitindo-se, para tais efeitos, exposição e motivação realizadas em ata ou instrumento semelhante; e d) a motivação dos atos de guardar congruência com as disposições do edital e da legislação correlata" ${ }^{820}$

\subsection{5 - Sumisión a control}

Una de las cuestiones más centrales en el contexto del acceso a la función pública, especialmente en lo que respecta a la efectividad del derecho de igualdad que ostentan los aspirantes en los procesos de selección, es el control de la actividad seleccionadora.

Hasta el presente momento, este trabajo ha analizado distintas cuestiones que envuelven el derecho previsto en el art. 23.2 de la Constitución española y en el art. 37, I y II, de la Constitución brasileña, destacando las repercusiones que el mismo ejerce sobre la actividad administrativa de selección de los funcionarios públicos en los sistemas jurídicos de los dos países citados.

Para alcanzar el referido propósito, fueron estudiados el significado y el alcance de la igualdad, sea esta considerada en términos genéricos, así como contextualizada en el acceso a la función pública. A continuación, hubo la necesidad de investigar las consecuencias que la exigencia de igualdad impone cuando se definen los requisitos de participación de los ciudadanos en los procesos selectivos (capítulo tercero).

\footnotetext{
${ }^{820}$ MOTTA, Fabrício. Concurso público e confiança na atuação administrativa: análise dos princípios de motivação, vinculação ao edital e publicidade, en Concurso público e Constituição, Fabrício Motta (Cordinador), Editora Fórum, Belo Horizonte, 2005, p. 151.
} 
En efecto, el tema de la incidencia de la igualdad en el procedimiento administrativo de selección de los funcionarios también será tratado en el próximo capítulo, oportunidad en la cual se procurará demostrar cuáles son los efectos (que no son pocos) que el derecho de acceso a la función pública en condiciones de igualdad proyecta en cada momento de la selección.

En realidad, todos los efectos y repercusiones de la igualdad en el proceso selectivo son relevantes y demuestran su amplitud. Sin embargo, deberá el ordenamiento jurídico establecer garantías de la efectividad del derecho de acceder en condiciones igualitarias a la función pública ${ }^{821}$.

Ello se debe a que el control jurídico (administrativo o judicial) de la actividad administrativa seleccionadora es un aspecto cuyo olvido o menosprecio puede poner en riesgo todas las repercusiones de la igualdad.

Durante la elaboración de este trabajo, se ha intentado establecer cuáles son las actuaciones administrativas que deben ser observadas para que el proceso de selección de funcionarios sea conducido de forma imparcial y objetiva, corolarios de la igualdad. Pese a la relevancia de la labor, conviene destacar que la Administración Pública, sea en Brasil o en España, muchas veces no sigue los parámetros que le son impuestos por el ordenamiento jurídico, lo que fragiliza la situación de los ciudadanos, ya que estos pasan a tener un derecho fundamental denegado.

Ciertamente, la cantidad y la potencialidad de daños de los actos administrativos practicados en el curso del proceso selectivo que huyen de los patrones de conducta establecidos por el Derecho dependerán del grado de eficacia de la reacción de cada ordenamiento jurídico frente a estas arbitrariedades.

Cabe añadir que muchas de estas arbitrariedades están previstas en las normas que la propia Administración Pública produce, especialmente en la definición de las reglas del proceso selectivo.

\footnotetext{
${ }^{821}$ En realidad, la presencia de mecanismos de control es condición indispensable para la efectividad de todos los principios de los procesos selectivos. En este sentido "O concurso público estará sempre sujeito ao controle exercido pela Administração Pública, pelo Judiciário e pelo Legislativo, através do Tribunal de Contas.(...) Logo, para que se verifique a real obediência aos princípios da legalidade, impessoalidade e moralidade no concurso público, o mesmo deve se desenvolver de forma a viabilizar a possibilidade de controle, seja interno ou externo." (TOURINHO, Rita. Op.cit., p. 139).
} 
En este contexto, se ha afirmado en el contexto del derecho brasileño que:

\begin{abstract}
"Tampouco é rara a situação em que a própria banca examinadora estabelece, no edital de abertura do concurso, que determinada fase do certame não estará sujeita à interposição de recursos. É situação que ofende frontalmente o contraditório e a ampla defesa, além de vários outros princípios administrativos, pois, divulgada a nota, não há possibilidade de o candidato apresentar seu entendimento sobre o gabarito, questionando sua validade e exatidão." 822
\end{abstract}

Para que la sobredicha reacción del ordenamiento jurídico contra los arbitrios tarea sea exitosa, hay que adoptar de forma integral la tesis que sostiene que "el poder administrativo es de suyo un poder esencial y universalmente justiciable." ${ }^{\prime \prime 2}$

Además, debe prevalecer el entendimiento que destaca que todos los ciudadanos, aunque no sean partícipes directos del proceso selectivo (en la condición de opositores), poseen legitimidad para ejercer el control de los actos de selección, ya que les interesa los resultados de la actuación administrativa ${ }^{824}$.

A fin de que haya la efectiva posibilidad de fiscalización de los procesos selectivos, estos deben ser sometidos a parámetros objetivos, definidos en las bases de la convocatoria de forma precisa.

Cabrá al órgano que va a ejercer el control hacer la confrontación entre la actuación administrativa y los referidos parámetros objetivamente definidos en las normas de la selección ${ }^{825}$.

\footnotetext{
${ }^{822}$ DA SILVA OLIVEIRA, Luciano Henrique. O contraditório e a ampla defesa nos concursos públicos, texto extraído del sitio Jus Navigandi (http://jus2.uol.com.br/doutrina/texto.asp?id=12006), inserido em 25.11.2008, acceso en 16.02.2010.

${ }^{823}$ GARCÍA DE ENTERRÍA, Eduardo. La lucha contra las inmunidades del poder, tercera eddción, Thomson Civitas, Madrid, 1983, p. 107.

${ }^{824}$ Respecto a esta cuestión, se ha subrayado que: "O controle público é da essência do concurso público. Significa que a realização do concurso público envolve o interesse coletivo, e todos os integrantes da comunidade têm interesse na condução ilibada e perfeita do concurso. Por isso, estão autorizados a acompanhar todos os atos pertinentes ao concurso, inclusive formulando pedidos de esclarecimento quanto a fatos relevantes" (JUSTEN FILHO, Marçal. Op.cit., p. 743-749).

${ }_{825}$ Por esta razón, se impone que: "Todo concurso público, em quaisquer de suas fases, submete-se ao princípio do julgamento objetivo, que se traduz no preestabelecimento, no edital do certame, dos critérios de julgamento e correção das futuras provas." (BARBOSA MAIA, Márcio, y PINHEIRO DE QUEIROZ, Ronaldo. Op.cit., p. 41).
} 


\subsubsection{1 - La relevancia del control de los procesos selectivos de acceso a la función pública}

Para empezar este aparatado, cabe insistir que todo el sistema constitucional de acceso igualitario y meritorio al servicio público sería inútil si no fuera previsto (y si no funcionara bien) el correspondiente sistema de control de la actuación administrativa de selección de los funcionarios públicos.

En verdad, el hecho de que la cubertura de los puestos de trabajo en la Administración Pública siempre haya sido una fuente de favorecimientos ilegítimos (clientelismo) hace con que el referido ámbito de la actividad administrativa sea sometido de forma permanente a distintos factores de presión que intentan alejar la exigencia de selección meritoria. En este contexto, la existencia de mecanismos de fiscalización de la actividad seleccionadora del Estado es esencial para garantizar la probidad en las decisiones administrativas.

De forma general, sobre la relevancia del control de la actividad administrativa, la doctrina española ya destacaba que:

"el control no sólo comporta frenos y contrapesos al poder y sus posibles excesos, así como garantías para los ciudadanos, sino que también, y si es llevado a cabo funcionalmente, introduce racionalidad y eficacia dentro de las organizaciones, ya que frente a la que podíamos denominar faceta represiva del control (anulación de actos o disposiciones, declaración de responsabilidades), se encuentra el momento preventivo o simplemente intimidatorio del mismo, la necesidad de actuar conforme a Derecho, para evitar el señalado efecto represivo." ${ }^{826}$

A su vez, la doctrina brasileña también ha destacado que la relevancia del control de los procesos selectivos de acceso a la función pública es aún más presente debido a la gran disputa por las plazas y los inevitables conflictos que surgen entre los miles de candidatos que suelen participar de los concursos públicos y la Administración Pública. En este sentido:

826 TARDIO PATO, José Antonio. Control jurisdiccional de concurso de meritos, oposiciones y exámenes académicos, Editorial Civitas, Madrid, 1984, p. 18. 
"Por se tratar de procedimento administrativo em cujo cerne se encontra densa competitividade entre os aspirantes a cargos e empregos públicos, o concurso público não raras vezes rende ensejo à instauração de conflitos entre os candidatos, ou entre estes e o próprio Poder Público. É importante, em conseqüência, que essa característica marcante seja solucionada de forma legítima, sobretudo com a aplicação dos princípios da motivação e do contraditório e da ampla da defesa (art. $5^{\circ}$, LV, CF)." 827

Sin embargo, aunque se pueda afirmar que el desarrollo doctrinario y jurisprudencial respecto a las posibilidades de realización de la referida proposición sea avanzado, tampoco se puede negar que en el sector de los procesos selectivos de acceso a la función pública las dificultades para que haya su real aplicación son considerables, por distintas razones que serán analizadas en las próximas páginas.

\subsubsection{2 - Las hipótesis en que cabe el control}

Antes de todo, conviene subrayar que, pese a la necesidad de verificación de cuáles son las situaciones más usualmente sujetas a la fiscalización, es plenamente posible afirmar que todos los procesos de selección para ingreso en la función pública están sometidos a control, sea administrativo o judicial, tanto que este es uno de los principios de la referida actividad administrativa, como ya se ha subrayado.

La afirmación anterior, aunque parezca indiscutible, debe ser acentuada, ya que durante muchos años prevalecía la teoría que rechazaba el control de determinados actos de los órganos de selección, bajo el argumento de que los mismos actuaban con discrecionalidad técnica.

A pesar de que el mencionado tema será objeto de investigación en un apartado propio, aún en este capítulo, cabe aquí destacar que el control (judicial) de la

${ }^{827}$ SANTOS CARVALHO FILHO, José dos. Op.cit., p. 540. 
discrecionalidad en los procesos selectivos es un medio para asegurar su adecuado ejercicio, teniendo como referencia los aspectos jurídicos ${ }^{828}$.

Los referidos aspectos, evidentemente, no se limitan a una apreciación y control de índole formalista de los actos administrativos, sino a una amplia fiscalización que tiene por base los principios de igualdad, eficacia, razonabilidad, proporcionalidad y de mérito y capacidad.

Respecto a la distinción entre el contenido que es de apreciación bajo el prisma jurídico y el que representa la evaluación meramente técnica del órgano de selección, la doctrina española, basada en la jurisprudencia (STC 215/1991) diferencia:

“a) el núcleo material de la decisión técnica, reservado en exclusiva a los órganos juzgadores y vetado a los órganos jurisdiccionales, b) sus aledaños, constituidos por la verificación de que se haya respectado la igualdad de condiciones de los candidatos y los principios de merito y capacidad de los mismos en el procedimiento de adjudicación de las plazas. $" 829$

Así, se admite el control siempre que existan parámetros jurídicos para la confrontación de los actos realizados por el órgano seleccionador. Sin embargo, la existencia eventual de otro entendimiento que amplíe los poderes de los órganos jurisdiccionales se implicaría en el reconocimiento de su omnisciencia.

Sobre los parámetros jurídicos arriba mencionados, la doctrina española enfatiza que, a pesar de que la jurisprudencia de este país aún mantiene el argumento de la necesidad de preservación de la discrecionalidad técnica de los tribunales calificadores, hay la posibilidad de intervención a partir de los siguientes aspectos:

a) la regularidad del procedimiento y de las formas en general;

b) el requisito de "la motivación suficiente";

828 SANCHÉZ MORÓN, Miguel. "Siete tesis sobre el control judicial de la discrecionalidad administrativa”, en Cuadernos de Derecho Judicial. Eficacia, discrecionalidad y control judicial en el ámbito administrativo, Consejo General del Poder Judicial, Madrid, 1994, p. 160.

${ }^{829}$ LÁZARO ALBA, Eduardo y GONZÁLEZ BOTIJA, Fernando. "A vueltas con la discrecionalidad técnica en oposiciones y concursos: jurisprudencia reciente y reflexiones críticas", en Revista Española de Derecho Administrativo, Civitas n. 127, 2005, p. 522. 
c) la existencia de dolo, coacción u otros vicios que restrinjan la libertad de formación de la decisión de los tribunales calificadores;

d) la "desviación de poder", el control del fin como elemento reglado;

e) el control de los hechos jurídicos determinantes (un verdadero control de causas determinantes de la decisión administrativa); y

f) los principios generales del Derecho, las invocaciones genéricas a la razón y a la justicia, y consideración especial del los principios del mérito y la capacidad como límites y elementos de control de la discrecionalidad selectiva. ${ }^{830}$

Por todo lo destacado arriba, es evidente que el argumento que sostiene la necesidad de preservación de la independencia de la actuación de los órganos seleccionadores no debe ser utilizado como una barrera que se aleje de los intentos de su fiscalización, sino, más bien, para garantizar la objetividad de la selección.

Para que eso suceda, es indiscutible que haya la protección de la autonomía de la evaluación de los órganos técnicos encargados de la selección, sea contra las interferencias de la Administración Pública, sea contra los abusos del Poder Judicial.

La necesidad de reconocimiento de la posibilidad de control de los actos de selección también es subrayada por la doctrina brasileña, que afirma que la aceptación de una concepción distinta autorizaría el arbitrio de la Administración Pública. ${ }^{831}$

Sobre la cuestión del control judicial de la discrecionalidad administrativa en los procesos selectivos, no se espera un activismo judicial donde no se reconozcan la especialización técnica y la legitimidad decisoria de la Administración Pública, especialmente cuando actúa a través de personas comprobadamente expertas, ni tampoco un Poder Judicial omiso, que ni siquiera tenga ambición de proteger a los ciudadanos frente a las opresiones y abusos estatales.

\footnotetext{
${ }^{830}$ TARDIO PATO, José Antonio. Op.cit., pp. 81-108.

${ }^{831}$ En este sentido: "o concurso público para admissão nos serviços do Estado é um procedimento sério de seleção de candidatos, no qual deverá existir, em linha de princípio, a possibilidade de controle - não apenas administrativo, pelos caminhos dos recursos pertinentes - mas também de caráter jurisdicional, dos critérios de correção das provas, sob pena de poder transformarem-se em fraude e burla dos interesses dos competidores. Já foi anteriormente ressaltado que a Administração Pública não tem o poder incontrastável de reputar como certo o que bem lhe parece, pois isso seria arbítrio". (COUTO E SILVA, Armiro. Direito Público, em Estudos em homenagem ao Professor Adilson Abreu Dallari, Editora Del Rey, Belo Horizonte, 2001, p. 26, apud TOURINHO, Rita. Op.cit., p.87).
} 
Respecto a las hipótesis donde está presente la posibilidad de control de los actos que tratan del acceso a la función pública, es interesante aludir que "as lides envolvendo o concurso público podem surgir, por sua não-realização ou quando de sua realização, neste último caso, na fase interna ou externa, sendo mais comuns as ocorrentes na última situação" 832

En el primer caso, podría ser destacada la fiscalización que viniera a cohibir los actos administrativos que permitieran la admisión de funcionarios de libre designación o la contratación temporaria, en las situaciones donde la realización del debido proceso de selección es obligatoria. ${ }^{833}$

En otro caso, es admisible el control de la decisión administrativa que dejara de realizar el proceso selectivo. En la realidad española, se puede destacar la situación en la cual el proceso de selección está previsto en la Oferta de Empleo Público, y aún así, la Administración Pública no instaura la oposición en el plazo máximo admitido.

En el caso brasileño, es muy usual la instauración del proceso selectivo, con la admisión de las solicitudes de inscripción por los candidatos y la posterior no realización del concurso público, lo que ensejaría distintas discusiones judiciales. ${ }^{834}$

Tras la instauración del proceso de selección, la posibilidad de control es aún más presente. En el ámbito de la fiscalización de los actos del procedimiento, cabe acentuar que el control preventivo ejercido por los propios órganos de la

\footnotetext{
${ }^{832}$ MACHADO JÚNIOR, Agapito. Op.cit., p. 175.

${ }^{833}$ Sobre esta circunstancia, se puede añadir que: "a escolha do servidor pelo critério da confiança, dado o seu caráter subjetivo, não é facilmente objeto de controle administrativo ou jurisdicional. Daí ser difícil analisar se a escolha da pessoa se orientou pela confiança e pelo mérito, ou somente pela confiança, desconsiderando totalmente o mérito, o que agrediria os princípios da isonomia, impessoalidade, moralidade e eficiência" (MACHADO JÚNIOR, Agapito. Op.cit., p. 108).

${ }^{834}$ En este contexto: "Uma situação que sempre tem ocorrido e que dá ensejo à discussão judicial é relativa à inscrição no certame e o suposto direito à realização do concurso. Não há direito à realização do concurso público com o simples pagamento do valor da inscrição, à medida que, em tese, fica à discricionariedade da Administração realizar ou não o certame (conveniência e oportunidade). Não há também direito à indenização por prejuízos ou expectativas frustradas pela não-realização do concurso, à medida que o candidato nunca teve direito à sua realização, mas tão-somente expectativa de sua execução. Contudo, há para o candidato o direito de reaver o valor pago a título de inscrição no certame, com correção monetária, se for o caso, sob pena de enriquecimento ilícito da Administração Pública" (MACHADO JÚNIOR, Agapito. Idem, p. 120).
} 
Administración Pública es un mecanismo muy relevante para impedir que surjan problemas durante la fase de disputa entre los candidatos.

Por esta razón, se ha dicho que "em matéria de concurso, é muito importante uma atuação preventiva. Quanto mais célere for o desfecho do problema, menores serão os prejuízos para a administração e para os candidatos"

Con la publicación de las bases de la convocatoria, surgen otras oportunidades de fiscalización del proceso selectivo, especialmente a partir de la provocación de los candidatos, impugnando los términos de las reglas de la competición. ${ }^{836}$

Pese a la relevancia de la fase interna del procedimiento de selección y la necesidad de su fiscalización, no hay lugar a dudas que es en la fase externa donde surgen con más intensidad las circunstancias que permiten el control del proceso selectivo, esencialmente por una razón principal: es en la fase externa en la que habrá la disputa entre los candidatos, lo que hace con que en esta etapa los candidatos se relacionen con la Administración Pública. ${ }^{837}$

A pesar del reconocimiento de que los más diversos actos del proceso de selección deben ser sometidos a la fiscalización, "é necessário ampliar o leque da

\footnotetext{
835 BARBOSA MAIA, Márcio, y PINHEIRO DE QUEIROZ, Ronaldo. Op.cit., p. 167.

${ }^{836}$ Respecto a este momento, se ha destacado que "Nesta etapa podem ocorrer impugnações a edital. (...) Tais impugnações serão processadas de acordo com o estabelecido em lei ou regulamento. Inexistindo previsão legal ou regulamentar, processar-se-á na forma estabelecida no ato convocatório. Trata-se, em verdade, de um controle interno provocado a ser exercido pelo ente que promove o concurso." (TOURINHO, Rita. Op.cit., p. 80).

837 Sobre este hecho, se ha afirmado que: "A etapa externa do certame, por seu turno, ganha uma dimensão técnico-científica, própria de um procedimento competitivo e seletivo, e entram em cena dois novos centros de vontade, quais sejam, a banca examinadora, órgão dotado de ampla autonomia, e os candidatos inscritos no concurso. No contexto da etapa externa, é preciso levar em consideração que o procedimento é plúrimo, ou seja, dotado de multifárias relações jurídicas, nascidas do vínculo de cada candidato com a Administração. Essa observação é relevante, principalmente no contexto do controle de legalidade do concurso público, na medida em que se deve perquirir, em cada caso, se eventual nulidade alcançara o todo o procedimento ou tão-só algumas das relações jurídicas que compõem sua estrutura." (BARBOSA MAIA, Márcio, y PINHEIRO DE QUEIROZ, Ronaldo. Op.cit., pp. 138-140).
} 
garantias dos indivíduos que se submetem, num país de milhões de desempregados, aos - cada vez mais disputados - concursos públicos" $" 838$

\subsubsection{3 - Modalidades de control de los procesos selectivos.}

Como es notorio, la actividad administrativa está sometida a distintos mecanismos de fiscalización, lo que hace que se de la posibilidad de intervención de distintos órganos que, a su vez, actuarán cuándo, cómo y en la medida prevista en el ordenamiento jurídico.

Sobre las modalidades de control arriba referidas, respecto al derecho español, cabe añadir que:

"Los actos que ponen fin al procedimiento de selección de los funcionarios son actos administrativos y como tales son objetos de impugnación tanto en vía administrativa como judicial. También podrán impugnarse por los aspirantes los actos de trámite que impidan su continuación en el proceso selectivo. La Administración misma puede revisar de oficio los actos si incurre en nulidad de pleno derecho $^{839}$ de conformidad con los procedimientos establecidos en la Ley de Régimen Jurídico de la Administraciones públicas y del procedimiento común." $\$ 40$

En el contexto arriba señalado, se puede destacar que respecto al órgano que ejerce la fiscalización, sea en el contexto español, como en el brasileño, hay dos grandes

${ }^{838}$ FERRAZ, Luciano. Concurso público e direito à nomeação, en Concurso público e Constituição, Fabrício Motta (Cordinador), Editora Fórum, Belo Horizonte, 2005, p. 254.

${ }^{839}$ En los términos del art.62.1 y 2 de la Ley 30/1992: “1. Los actos de las Administraciones públicas son nulos de pleno derecho en los casos siguientes:

a) Los que lesionen los derechos y libertades susceptibles de amparo constitucional.

b) Los dictados por órgano manifiestamente incompetente por razón de la materia o del territorio.

c) Los que tengan un contenido imposible.

d) Los que sean constitutivos de infracción penal o se dicten como consecuencia de ésta.

e) Los dictados prescindiendo total y absolutamente del procedimiento legalmente establecido o de las normas que contienen las reglas esenciales para la formación de la voluntad de los órganos colegiados.

f) Los actos expresos o presuntos contrarios al ordenamiento jurídico por los que se adquieren facultades o derechos cuando se carezca de los requisitos esenciales para su adquisición.

g) Cualquier otro que se establezca expresamente en una disposición de rango legal.

2. También serán nulas de pleno derecho las disposiciones administrativas que vulneren la Constitución, las leyes u otras disposiciones administrativas de rango superior, las que regulen materias reservadas a la Ley, y las que establezcan la retroactividad de disposiciones sancionadoras no favorables o restrictivas de derechos individuales."

${ }^{840}$ PARADA, Ramón. Derecho del empleo público, Marcial Pons, Barcelona, 2007, p. 147. 
modalidades de control de la actividad de selección llevada a cabo por la Administración Pública: el control en vía administrativa y el control en vía judicial. ${ }^{841}$

Sobre la utilización de las referidas vías, cabe destacar que en el derecho español, hay dos consideraciones que se deben tener en cuenta: en primer lugar, la necesidad de que sea previamente superada la vía administrativa para que se pueda utilizar la vía judicial. ${ }^{842}$

Sobre tal circunstancia, se ha destacado que:

"En efecto, conforme a nuestro ordenamiento jurídico, los particulares afectados por un acto administrativo han de agotar la vía administrativa antes de poder interponer un recurso contencioso administrativo frente al acto que entienden les perjudica. Es decir, los particulares, salvo que el acto sea de los que por sí mismo agote la vía administrativa, no pueden acudir directamente a los jueces y tribunales a que, como terceros neutrales, decidan acerca de la legalidad de la actuación de la Administración. Necesariamente han de interponer previamente el correspondiente recurso administrativo frente al acto en cuestión para agotar dicha vía, para luego acudir a los tribunales. Se trata, por tanto, de ante un auténtico privilegio administrativo, que

\footnotetext{
${ }^{841}$ En el ámbito de este trabajo, por cuestiones de delimitación del tema, no se pretende profundizar en el estudio de los instrumentos procesuales de carácter administrativo y jurisdiccional que permiten el control de los actos del proceso selectivo.

${ }^{842}$ Según el art. 109 de la Ley 30/1992 (ley del Régimen Jurídico de las Administraciones Públicas y del Procedimiento Administrativo Común):

"Ponen fin a la vía administrativa:

a) Las resoluciones de los recursos de alzada.

b) Las resoluciones de los procedimientos de impugnación a que se refiere el artículo 107.2.

c) Las resoluciones de los órganos administrativos que carezcan de superior jerárquico, salvo que una Ley establezca lo contrario.

d) Las demás resoluciones de órganos administrativos cuando una disposición legal o reglamentaria así lo establezca.

e) Los acuerdos, pactos, convenios o contratos que tengan la consideración de finalizadores del procedimiento."

A su vez, el art. 25 de la Ley 29/1998 (ley reguladora de la Jurisdicción contencioso-administrativa) dispone que:

"1. El recurso contencioso-administrativo es admisible en relación con las disposiciones de carácter general y con los actos expresos y presuntos de la Administración pública que pongan fin a la vía administrativa, ya sean definitivos o de trámite, si estos últimos deciden directa o indirectamente el fondo del asunto, determinan la imposibilidad de continuar el procedimiento, producen indefensión o perjuicio irreparable a derechos o intereses legítimos.2. También es admisible el recurso contra la inactividad de la Administración y contra sus actuaciones materiales que constituyan vía de hecho, en los términos establecidos en esta Ley".
} 
se justifica, como las demás manifestaciones de autotutela, en el hecho de que la Administración actúa en defensa del interés general" ${ }^{" 843}$.

El hecho arriba destacado hace que, en muchas ocasiones, cuando haya una decisión judicial que venga a afectar el proceso selectivo, este ya esté concluido desde hace mucho tiempo. Sobre esto, la doctrina apunta que:

"no puede dejar de consignarse las graves disfunciones que origina la estimación judicial, siempre tardía, de los recursos en esta materia. Sobre todo cuando se trata de procesos selectivos en que participan cientos o miles de aspirantes a los que se sume en la inseguridad, ni fáciles de resolver los problemas que origina la anulación de los nombramientos." $\$ 44$

No se puede negar que el hecho de que las demandas judiciales relativas a los procesos selectivos tarden muchos años produce dos graves consecuencias, ambas comprometedoras de la igualdad. En primer lugar, sirve como desestímulo a los candidatos indebidamente perjudicados, que muchas veces creen que no merece la pena luchar por sus derechos, especialmente cuando saben que los Tribunales suelen adoptar una posición más conservadora.

También se puede añadir que la excesiva duración de las demandas judiciales que cuestionan la validad de los procesos selectivos produce un indeseable efecto sobre las propias decisiones judiciales.

En realidad, ante las circunstancias arriba mencionadas, para los Tribunales, no deja de ser más cómoda (bajo el aspecto "seguridad jurídica") la decisión judicial que no modifica el resultado final del proceso selectivo, lo que provoca que el argumento que sostiene la prevalencia de la discrecionalidad técnica sea tan utilizado.

Como se percibe, la ausencia de celeridad de las prestaciones que el Poder Judicial ofrece a los candidatos es una circunstancia que sirve de desestimulo para que

\footnotetext{
${ }^{843}$ Texto extraído de material producido por el Instituto Nacional de Administración Pública - INAP. Los Recursos Administrativos: concepto y clases. Recursos de alzada, reposición y extraordinário de revisión. La Jurisdicción contencioso-administrativa. Extraído del sitio electrónico del INAP: http://www.inap.map.es/NR/rdonlyres/D472D70A-AE0C-4874-A6518A5D49587DEA/0/adm_adm3.pdf, acceso en 13 de agosto de 2010.

${ }^{844}$ PARADA, Ramón. Derecho del empleo público, Marcial Pons, Barcelona, 2007, p. 147.
} 
estos cuestionen la legitimidad del proceso selectivo y, al mismo tiempo, sugiere la manutención del status quo ante ${ }^{845}$, aunque este represente una transgresión de la igualdad.

La segunda consideración sobre el Derecho español dice respecto a la existencia de la Jurisdicción Contencioso-Administrativa, que es una Justicia especializada que está situada en el ámbito del Poder Judicial.

En teoría, este hecho sería relevante porque garantizaría la especialización de los órganos encargados del control judicial, lo que podría facilitar la apreciación de los procesos selectivos, puesto que estarían habituados a analizar el mencionado tema.

Sin embargo, según la doctrina, es relevante destacar que la circunstancia de que los órganos de la Jurisdicción contencioso-administrativa dispongan del conocimiento de materias jurídicas no quiere decir que puedan sustituir las evaluaciones técnicas realizadas por los tribunales administrativos, aunque las pruebas traten de cuestiones jurídicas, ya que la especialización de los órganos de selección también tiene en consideración las distintas procedencias de sus miembros...

“...dirigida a establecer no solamente la objetividad e imparcialidad, sino también el valor circunstancial que debe darse a cada una de las pruebas o ejercicio en función de la finalidad de la selección, de modo que según las plazas que traten de cubrirse, la Comisión pueda considerar más o menos puntuales los diversos contenidos de las contestaciones, misión en la que no puede ser sustituido por ningún órgano ni administrativo ni jurisdiccional ${ }^{846}$

No obstante, no hay como negar que el hecho de que haya una Justicia especializada en cuestiones administrativas sea relevante para la consolidación de una

\footnotetext{
${ }^{845}$ Todo ello viene motivado porque cuando el Poder Judicial estima las pretensiones de los candidatos, la doctrina apunta la existencia de dos situaciones: la nulidad de las actuaciones con reposición del expediente o la declaración del mejor derecho a la plaza controvertida (TARDIO PATO, José Antonio. Control jurisdiccional de concurso de meritos, oposiciones y exámenes académicos, Editorial Civitas, Madrid, 1984, p. 109). En las dos situaciones, todo el proceso selectivo se verá afectado, y consecuentemente, todos los aspirantes, lo que hace que, en la práctica, los órganos jurisdiccionales prefieran actuar de forma más conservadora. Por esta razón, deben ser concebidos (y utilizados, cuando ya existan) mecanismos procesuales que permitan la pronta respuesta judicial a las pretensiones de los candidatos.

846." LÁZARO ALBA, Eduardo y GONZÁLEZ BOTIJA, Fernando. “A vueltas con la discrecionalidad técnica en oposiciones y concursos: jurisprudencia reciente y reflexiones críticas", en Revista Española de Derecho Administrativo, Civitas n. 127, 2005, p. 525.
} 
jurisprudencia que esté adaptada a las peculiaridades de los temas que envuelven la actividad de la Administración Pública. Sobre esta circunstancia, es suficiente no olvidar que el Derecho Administrativo, especialmente de los países de Europa continental y Latinoamérica, se desarrolló y se diferenció del Derecho Privado a partir de las inestimables contribuciones del Consejo de Estado francés ${ }^{847}$.

Respecto a los mecanismos de control de la actividad administrativa en España, se ha subrayado que:

"El Estado de Derecho y, más concretamente, el principio de legalidad de la Administración Pública cuenta con una serie de instrumentos para su realización efectiva: en particular, el sistema de recursos en vía administrativa y, sobre todo, la revisión de las resoluciones administrativas ante los jueces y tribunales, constituyen las principales garantías de protección de los derechos e intereses de los ciudadanos ante la actuación de la Administración. La constitución española de 1978 contiene diversas manifestaciones de esta concepción de la relación entre los ciudadanos y la Administración. Entre ellas, las siguientes: - El principio de legalidad (art. 9) como manifestación del Estado de Derecho que se consagra en el art. 1, y que se concreta, en el ámbito de la Administración, en el art. 103.1.; - El derecho fundamental a la tutela judicial efectiva de todas las personas en el ejercicio de sus derechos e intereses, no ya directos, sino legítimos (art. 24).; - El control por los tribunales de la potestad reglamentaria, la legalidad de la actuación administrativa y su sometimiento a los fines que la justifican (106)" ${ }^{\natural 48}$.

Respecto al derecho brasileño, hay que aclarar que, de forma distinta de lo que sucede en el ámbito español, no hay la exigencia de superación de la esfera administrativa para que sea posible el ejercicio de la facultad de ajuiciamiento de una demanda judicial.

\footnotetext{
${ }^{847}$ GARCÍA DE ENTERRÍA, Eduardo. La lengua de los derechos. La formación del Derecho Público europeo tras la Revolución Francesa, Alianza Editorial, Madrid, 1994, p. 194.

${ }^{848}$ Texto extraído de material producido por el Instituto Nacional de Administración Pública - INAP. Los Recursos Administrativos: concepto y clases. Recursos de alzada, reposición y extraordinário de revisión. La Jurisdicción contencioso-administrativa. Extraído del sitio electrónico del INAP: http://www.inap.map.es/NR/rdonlyres/D472D70A-AE0C-4874-A6518A5D49587DEA/0/adm_adm3.pdf, acceso en 13 de agosto de 2010.
} 
En este sentido, la Constitución Federal de 1988 determina en el art. 5º, XXXV, que "a lei não excluirá da apreciação do Poder Judiciário lesão ou ameaça a direito", lo que hace con que no haya la necesidad de superación de las instancias administrativas como condición para discusión judicial de una determinada cuestión.

Debido a la circunstancia mencionada, el candidato podrá elegir si ingresará con recurso administrativo o no, antes de utilizar la via judicial. En estos términos, cabe subrayar que "não é demais repetir que a possibilidade de interposição de recurso administrativo não afasta o controle jurisdicional dos atos administrativos, mesmo que o recurso tenha sido indeferido, ou ainda que o candidato não o tenha interposto, nos termos do art. $5^{\circ}$, inc. XXXV da CF/88." 849

Aún sobre el derecho brasileño, merece la pena observar que en el ámbito del Poder Judicial del referido país, no hay una Justicia Administrativa, como existe en España. Como mucho, cuando hay alguna especialización, esto sucede en las ciudades más grandes, donde hay jueces de los Estados Federados encargados de analizar las demandas que envuelven las entidades públicas (Varas da Fazenda Pública). A su vez, también cabe destacar la existencia de la Justicia Federal, especializada en cuestiones que dicen respecto a la Unión. ${ }^{850}$

Así, de forma general, el mismo juez que analiza las demandas de naturaleza civil, penal, comercial, fiscal, etc., será el que decidirá el destino de los candidatos en el concurso público. Tal hecho hace con que el mismo no siempre disponga de la posibilidad de la debida especialización técnica en los asuntos relacionados a la Administración Pública, circunstancia que fragiliza la tutela jurisdiccional.

\footnotetext{
${ }^{849}$ LOBELLO DE OLIVEIRA ROCHA, Francisco. Op.cit., p. 134.

${ }^{850}$ La Constitución de 1988 determina que: "Art. 109. Aos juízes federais compete processar e julgar:I as causas em que a União, entidade autárquica ou empresa pública federal forem interessadas na condição de autoras, rés, assistentes ou oponentes, exceto as de falência, as de acidentes de trabalho e as sujeitas à Justiça Eleitoral e à Justiça do Trabalho; (...)”
} 
A continuación, serán apreciados los aspectos más relevantes ${ }^{851}$ de los dos grandes modalidades de control de los procesos selectivos de acceso a la función pública: el control administrativo y el control judicial.

\subsubsection{1 - Control administrativo}

En el ámbito del proceso selectivo, debe la Administración Pública fiscalizar sus propios actos, verificando si las normas jurídicas que orientan sus conductas fueron o no cumplidas. Tal circunstancia proviene de la exigencia de sumisión de la actividad administrativa al ordenamiento jurídico (principio de legalidad), lo que impone el deber de revisión de los actos administrativos que no hayan sido ejecutados según los patrones legales.

El control administrativo puede ser provocado por el interesado o por iniciativa de la propia Administración Pública ejecutora del acto. En este último caso, hay que subrayar la presencia de órganos que ejercen el control de legalidad de los actos administrativos. En general, tales órganos actúan de forma preventiva, en la medida en que analizan la regularidad jurídica de los actos antes de su producción. En el caso de los procesos selectivos, cabe a los citados órganos de control preventivo la verificación del cumplimiento de las formalidades legales respecto al procedimiento administrativo, especialmente a las bases de la convocatoria.

Tras la publicación de las reglas de la competición, conviene destacar que todos los actos de la fase externa del proceso selectivo también deben ser objeto de inspección por la entidad administrativa promotora del concurso. Además, en el caso de que la Administración Pública perciba la existencia de alguna circunstancia irregular en determinado acto administrativo, tendrá la obligación de tomar alguna medida, sea para rectificar o para extinguir el referido acto.

\footnotetext{
${ }^{851}$ El objectivo del presente analisis es presentar las posibilidades de control de los procesos selectivos como forma de garantía de la igualdad de los candidatos. Por esta razón, en este trabajo, no habrá preocupación con la exposición detallada de cada uno de los mecanismos procesuales (administrativos y judiciales) previstos en las legislaciones de España y Brasil para controlar la legalidad de los procesos selectivos de acceso a la función pública.
} 
En el derecho administrativo español, la legislación (Ley 30/1992) prevé la existencia de distintos grados de disconformidad del acto administrativo: nulidad de pleno derecho, anulabilidad, conversión y convalidación ${ }^{852}$. Según la situación detectada, deberá la Administración Pública tomar la medida adecuada, extinguindo el acto o mismo subsanando los vicios del mismo.

Pese a la existencia de distintas posibilidades de control administrativo ejercidas por iniciativa de la propia Administración Pública (actuación de oficio), en

852 “Artículo 62. Nulidad de pleno derecho.

1. Los actos de las Administraciones públicas son nulos de pleno derecho en los casos siguientes:

a. Los que lesionen los derechos y libertades susceptibles de amparo constitucional.

b. $\quad$ Los dictados por órgano manifiestamente incompetente por razón de la materia o del territorio.

c. Los que tengan un contenido imposible.

d. Los que sean constitutivos de infracción penal o se dicten como consecuencia de ésta.

e. Los dictados prescindiendo total y absolutamente del procedimiento legalmente establecido o de las normas que contienen las reglas esenciales para la formación de la voluntad de los órganos colegiados.

f. Los actos expresos o presuntos contrarios al ordenamiento jurídico por los que se adquieren facultades o derechos cuando se carezca de los requisitos esenciales para su adquisición.

g. $\quad$ Cualquier otro que se establezca expresamente en una disposición de rango legal.

2. También serán nulas de pleno derecho las disposiciones administrativas que vulneren la Constitución, las leyes $u$ otras disposiciones administrativas de rango superior, las que regulen materias reservadas a la Ley, y las que establezcan la retroactividad de disposiciones sancionadoras no favorables o restrictivas de derechos individuales.

Artículo 63. Anulabilidad.

1. Son anulables los actos de la Administración que incurran en cualquier infracción del ordenamiento jurídico, incluso la desviación de poder.

2. No obstante, el defecto de forma sólo determinará la anulabilidad cuando el acto carezca de los requisitos formales indispensables para alcanzar su fin o dé lugar a la indefensión de los interesados.

3. La realización de actuaciones administrativas fuera del tiempo establecido para ellas sólo implicará la anulabilidad del acto cuando así lo imponga la naturaleza del término o plazo.

Artículo 64. Transmisibilidad.

1. La nulidad o anulabilidad de un acto no implicará la de los sucesivos en el procedimiento que sean independientes del primero.

2. La nulidad o anulabilidad en parte del acto administrativo no implicará la de las partes del mismo independientes de aquélla salvo que la parte viciada sea de tal importancia que sin ella el acto administrativo no hubiera sido dictado.

Artículo 65. Conversión de actos viciados.

Los actos nulos o anulables que, sin embargo, contengan los elementos constitutivos de otro distinto producirán los efectos de éste.

Artículo 66. Conservación de actos y trámites.

El órgano que declare la nulidad o anule las actuaciones dispondrá siempre la conservación de aquellos actos y trámites cuyo contenido se hubiera mantenido igual de no haberse cometido la infracción.

Artículo 67. Convalidación.

1. La Administración podrá convalidar los actos anulables, subsanando los vicios de que adolezcan.

2. El acto de convalidación producirá efecto desde su fecha, salvo lo dispuesto anteriormente para la retroactividad de los actos administrativos.

3. Si el vicio consistiera en incompetencia no determinante de nulidad, la convalidación podrá realizarse por el órgano competente cuando sea superior jerárquico del que dictó el acto viciado.

4. Si el vicio consistiese en la falta de alguna autorización, podrá ser convalidado el acto mediante el otorgamiento de la misma por el órgano competente." 
general, en el ámbito del proceso selectivo, debido a su competitividad, es el candidato que suele apuntar una determinada irregularidad, exigiendo de la entidad administrativa una providencia.

La circunstancia anteriormente mencionada ocurre a través de los mecanismos de impugnación previstos en la legislació, que son instrumentos esenciales para resguardar el trato igualitario entre los candidatos, hasta mismo porque, como ya se ha destacado, en el derecho español, la previa impugnación administrativa es condición para la impugnación judicial.

La referida facultad conferida al candidato deriva del hecho de que el derecho de acceso a la función pública en condiciones de igualdad, como ya se ha visto en el segundo capítulo, es de carácter reaccional. En estos términos, según la doctrina española: "El interés legítimo para reaccionar frente a un acto que nos causa un perjuicio o nos evita un beneficio se ha calificado como derecho subjetivo reaccional. De hecho en este caso el ordenamiento jurídico nos reconoce el derecho a impugnar la actuación administrativa que consideramos no ajustada al ordenamiento" ${ }^{\text {853. }}$.

La Ley 32/1992 (que trata del Régimen Jurídico de las Administraciones Públicas y del Procedimiento Administrativo Común) establece en los artículos 102 a 119 los distintos medios de impugnación administrativa ${ }^{854}$ (recursos de alzada, potestativo de reposición y extraordinario de revisión ${ }^{855}$ ).

\footnotetext{
${ }^{853}$ TORNOS MAS, Joaquín. Los ciudadanos y su posición jurídica. Lección 1 del libro Lecciones y materiales para el estudio dl Derecho Administrativo, tomo IV, Las Garantías de los ciudadanos y el control de las Administraciones Públicas, Tomás Cano Campos (Coordinador), Iustel, Madrid, 2009.

${ }^{854}$ Aunque no sea objeto del presente estudio el análisis de los referidos instrumentos procesuales, es conveniente que se transcriba que: "Con carácter general los actos inicial y final (la convocatoria y el nombramiento final), admiten recurso de reposición potestativo y ulterior recurso contenciosoadministrativo. Los actos intermedios desarrollados por el Tribunal Calificador admiten recurso de alzada ante la autoridad que designó el Presidente del Tribunal (art. 114.1 LPAC). Finalmente existen actos que admiten una reclamación escrita, bien por expresa previsión de la convocatoria (caso de listas de admitidos) o bien por la tácita admisión por el Tribunal calificador (caso de puntuación de ejercicio parcial o valoración preliminar de méritos)." (RAMÓN CHAVES GARCÍA, José. Control de concursos y oposiciones en la jurisprudencia, Editorial Reus, Colección Claves de la Jurisprudencia, Madrid, 2009, p. 206).

855 “SECCIÓN II. RECURSO DE ALZADA

Artículo 114. Objeto.

1. Las resoluciones y actos a que se refiere el artículo 107.1, cuando no pongan fin a la vía administrativa, podrán ser recurridos en alzada ante el órgano superior jerárquico del que los dictó. A estos efectos, los Tribunales y órganos de selección del personal al servicio de las Administraciones
} 
Cabe destacar que el control administrativo en el curso de la selección, para que sea eficaz, muchas veces necesita una decisión administrativa que determine la suspensión del proceso selectivo, ya que, en el caso de que esta no ocurra, podrán surgir situaciones irreversibles o de difícil reversibilidad. ${ }^{856}$

Por esta razón, la doctrina sostiene que con ocasión de un recurso administrativo, "el afectado suele solicitar la suspensión del acto impugnado hasta su resolución. En este punto normalmente en vía administrativa no se aprecia perjuicio

públicas y cualesquiera otros que, en el seno de éstas, actúen con autonomía funcional, se considerarán dependientes del órgano al que estén adscritos o, en su defecto, del que haya nombrado al presidente de los mismos.(...)

SECCIÓN III. RECURSO POTESTATIVO DE REPOSICIÓN.

Artículo 116. Objeto y naturaleza.

1. Los actos administrativos que pongan fin a la vía administrativa podrán ser recurridos potestativamente en reposición ante el mismo órgano que los hubiera dictado o ser impugnados directamente ante el orden jurisdiccional contencioso-administrativo.

2. No se podrá interponer recurso contencioso-administrativo hasta que sea resuelto expresamente o se haya producido la desestimación presunta del recurso de reposición interpuesto.(...)

SECCIÓN IV. RECURSO EXTRAORDINARIO DE REVISIÓN.

Artículo 118. Objeto y plazos.

1. Contra los actos firmes en vía administrativa podrá interponerse el recurso extraordinario de revisión ante el órgano administrativo que los dictó, que también será el competente para su resolución, cuando concurra alguna de las circunstancias siguientes:

1. Que al dictarlos se hubiera incurrido en error de hecho, que resulte de los propios documentos incorporados al expediente.

2. Que aparezcan documentos de valor esencial para la resolución del asunto que, aunque sean posteriores, evidencien el error de la resolución recurrida.

3. Que en la resolución hayan influido esencialmente documentos o testimonios declarados falsos por sentencia judicial firme, anterior o posterior a aquella resolución.

4. Que la resolución se hubiese dictado como consecuencia de prevaricación, cohecho, violencia, maquinación fraudulenta u otra conducta punible y se haya declarado así en virtud de sentencia judicial firme.(...)”

${ }^{856}$ Respecto a la suspensión del proceso selectivo, se ha acentuado que: "La regla general al respecto es que la interposición de un recurso, salvo que una Ley diga lo contrario, no suspende la ejecución de la resolución impugnada. Sin embargo, la Ley permite que el órgano competente para resolver el recurso, bien sea de oficio, bien sea a instancia del recurrente, pueda suspender la ejecución de dicha resolución. Para ello, el órgano competente debe en primer lugar ponderar de forma razonada el perjuicio que causaría al interés público o a terceros la suspensión y el perjuicio que causa al recurrente la eficacia inmediata del acto recurrido. Si el resultado de esa ponderación es favorable a la suspensión, ésta sólo se podrá acordar si concurren las siguientes circunstancias: a) Que la ejecución pudiera causar daños de imposible o difícil reparación. b) Que la impugnación se fundamente en alguna de las causas de nulidad del art. 62.1 de la LRJPAC" (Texto extraído de material producido por el Instituto Nacional de Administración Pública - INAP. Los Recursos Administrativos: concepto y clases. Recursos de alzada, reposición y extraordinário de revisión. La Jurisdicción contencioso-administrativa. Extraído del sitio electrónico del INAP: http://www.inap.map.es/NR/rdonlyres/D472D70A-AE0C-4874A6518A5D49587DEA/0/adm_adm3.pdf, acceso en 13 de agosto de 2010). 
irreparable alguno frente al perjuicio cierto y inmediato que se provoca a los demás aspirantes, por lo que suele desestimarse esta petición" ${ }^{\sharp 57}$.

Los instrumentos que permiten el control administrativo de los procesos de selección de los funcionarios también son manejados en el derecho brasileño. Tal garantía constitucional posibilita la censura de los actos administrativos que afectan los ciudadanos que desean participar o que ya estén participando de los concursos públicos. En verdad, aunque el ciudadano no tenga intención de tomar parte de la competición, ya se reconoce el derecho del mismo impugnar las bases de la selección debido al hecho de que el mismo ostente la condición de ciudadano. ${ }^{858}$

En el ordenamiento jurídico brasileño, el derecho al recurso administrativo es una consecuencia de la norma prevista en el art. 5 XXXIV, a), de la Constitución Federal, que determina que "são a todos assegurados, independentemente do pagamento de taxas: a) o direito de petição aos Poderes Públicos em defesa de direitos ou contra ilegalidade ou abuso de poder"; así como del contenido del art. $5^{\circ}$, LV, que establece que: "aos litigantes, em processo judicial ou administrativo, e aos acusados em geral são assegurados o contraditório e ampla defesa, com os meios e recursos a ela inerentes".

En estos términos, delante de una decisión administrativa la cual no le sea favorable, "se o candidato não se conforma com o resultado, deve ser-lhe assegurado o direito a recurso, dirigido à autoridade mencionada no edital ou na lei ou ato de organização da entidade pública»"859

857 RAMÓN CHAVES GARCÍA, José. Control de concursos y oposiciones en la jurisprudencia, Editorial Reus, Colección Claves de la Jurisprudencia, Madrid, 2009, p. 206

${ }^{858}$ La cuestión respecto a la legitimidad del ejercicio del control de los procesos selectivos será objeto de otro apartado de este trabajo. Sin embargo, ya se puede adelantar que el ciudadano también dispone de la posibilidad de impugnar las reglas de la selección, aunque, en general, no la ejerza. Sobre esta situación, se ha dicho que: "como em tais casos ainda não há que se falar em candidatos, pois sequer iniciaram as inscrições no certame, geralmente as lides aqui ocorrentes dizem respeito a interesses difusos ou coletivos, normalmente consistentes em preservar o erário e o patrimônio público ou mesmo a probidade administrativa diante de contratações ilícitas ou da realização de certames com intuito meramente arrecadatório ou manipulados a favorecerem futuros candidatos, tudo a ser objeto de ações civis públicas movidas em geral pelo Ministério Público" (MACHADO JÚNIOR, Agapito. Op.cit., p. 175).

${ }^{859}$ SANTOS CARVALHO FILHO, José dos. Manual de Direito Administrativo, $17^{\mathrm{a}}$ ed. Lumen Juris Editora, Rio de Janeiro, 2007, p. 551. 
Respecto al órgano que debe apreciar el recurso administrativo, conviene destacar que "mesmo quando firmas especializadas são contratadas para elaborar o concurso público, permanece a entidade como responsável pelo mesmo. Destarte, qualquer recurso deverá ser sempre encaminhado à autoridade competente, e não à firma elaboradora do concurso." 860

El derecho al recurso administrativo es una garantía que debe estar presente en todos los procesos selectivos de acceso a la función pública. Por esta razón, la doctrina brasileña ha afirmado que "cláusula prevista no edital de concurso que impeça explicitamente a utilização de recurso administrativo é nula, contrariando expressamente dispositivo constitucional." ${ }^{, 861}$

Sin embargo, como denuncia la doctrina brasileña, la Administración Pública utiliza muchos expedientes para inviabilizar el ejercicio del referido derecho. En este contexto, se ha subrayado que:

"tem sido comum a previsão do direito a recurso administrativo em face da correção das provas em concurso público. Contudo, através de outros meios escusos, termina-se por inviabilizar tal direito, por exemplo, como se viu, não se divulga a correção das provas, não se aponta o que o candidato errou, não há espelho da correção para provas subjetivas. Assim, ainda que presente o direito a recurso no regulamento do concurso, em verdade, ele não existe" ${ }^{\text {862 }}$

El éxito del control administrativo del proceso de selección de los funcionarios públicos depende de distintos factores. Como ya se ha acentuado, esta modalidad de control presenta algunas dificultades ${ }^{863}$, ya que el órgano encargado de la decisión es el mismo que tuvo un acto suyo impugnado.

\footnotetext{
${ }^{860}$ DA SILVA OLIVEIRA JÚNIOR, Dario, y CAMPOS OLIVEIRA, Isabel. Concurso público. Teoria e prática. Lumen Juris Editora, Rio de Janeiro, 2008, p. 66.

${ }^{861}$ TOURINHO, Rita. Op.cit., p. 141.

${ }^{862}$ MACHADO JÚNIOR, Agapito. Op.cit., p. 147.

863 Sobre tales problemas: "é de longa data que candidatos de concursos públicos reclamam da falta de razoabilidade e transparência das bancas na análise de recursos contra questões de prova. É bem conhecida a situação de enunciados flagrantemente nulos, por conterem mais de uma (ou nenhuma) alternativa correta, mas que não são anulados pelas bancas. Muitas vezes, os gabaritos divulgados são claramente contrários à lei ou à doutrina e, mesmo assim, a instituição não altera as respostas preliminares. Esse, provavelmente, é o ponto de maior discussão entre candidatos e bancas
} 
Debido a las peculiaridades del control administrativo, debe ser garantizado a los candidatos el acceso a las informaciones que les digan respecto. En este camino, "assiste aos candidatos o direito de obterem da banca examinadora, tempestivamente, as informações que embasaram as respectivas notas e pontuações, em ordem de viabilizar, conforme o caso, as medidas necessárias ao efetivo exercício do direito de ampla defesa, inclusive por intermédio de competente recurso administrativo" ${ }^{\circ 64}$

La doctrina brasileña reconoce las distintas posibilidades de control administrativo del concurso público, que podrá ser ejercido de oficio ${ }^{865}$ o mediante provocación del interesado; a través de la revocación ${ }^{866}$ o de la anulación ${ }^{867}$; y será

examinadoras, as quais, de forma insensível e até mesmo arbitrária, ignoram as reclamações dos candidatos, mantendo-se inalcançáveis, em verdadeiros pedestais supremos.(...) Obviamente, o examinador é humano e sujeito a erros. O que não se admite é a não-modificação dos gabaritos quando esses erros são plenamente demonstrados pelos candidatos, mediante a interposição de recursos. Para agravar a situação, raramente as bancas divulgam os fundamentos do indeferimento dos recursos, em aberta afronta ao princípio da motivação, deixando os candidatos em total perplexidade diante da negativa de seus pedidos.(...) De nada adianta a organizadora do concurso oferecer a possibilidade de recurso contra os gabaritos das questões, se não há um julgamento justo e correto da impugnação do candidato. As bancas examinadoras atualmente têm relegado os princípios do contraditório e da ampla defesa nos concursos públicos a uma mera formalidade editalícia, sem qualquer substância."(DA SILVA OLIVEIRA, Luciano Henrique. O contraditório e a ampla defesa nos concursos públicos, texto extraído del sitio Jus Navigandi (http://jus2.uol.com.br/doutrina/texto.asp?id=12006), inserido em 25.11.2008, acceso en 16.02.2010).

${ }^{864}$ BARBOSA MAIA, Márcio, y PINHEIRO DE QUEIROZ, Ronaldo. Op.cit., p. 113.

${ }^{865}$ Cabe insistir que una de las grandes oportunidades que dispone la Administración Pública para que pueda ejerecer el control del proceso selectivo ocurre cuando el órgano encargado de control de legalidad analiza los actos de la fase interna del proceso, en especial las bases de la convocatoria (edital). Sobre tal control, se ha dicho que: "De posse de todas essas informações, deve-se minutar o edital de concurso de ingresso de pessoal no serviço público. Uma vez minutado, deve ser obtida a análise da assessoria jurídica, que pode com ele concordar, não concordar ou concordar apenas em parte. Naquele caso, basta devolver o processo mediante cota de expediente em que essa assessoria declara que nada há a opor quanto à minuta examinada, ao passo que nestes casos deve, também por cota de expediente, solicitar nova minuta ou que sejam promovidos ajustes indispensáveis à regularidade do edital e, por conseguinte, do certame." (GASPARINI, Diógenes. Concurso público - imposição constitucional e sua operacionalização, en Concurso público e Constituição, Fabrício Motta (Coordinador), Editora Fórum, Belo Horizonte, 2005, p. 56).

${ }^{866}$ Respecto a esta situación, se ha destacado que: "para revogação do concurso público, necessária se faz a demonstração de que o certame instaurado se tornou inconveniente ou inoportuno. Com efeito, deve-se demonstrar a incidência de circunstâncias novas, inexistentes ou desconhecidas à época anterior." (TOURINHO, Rita. Concurso público no ordenamento jurídico brasileiro, Lumen Juris Editora, Rio de Janeiro, 2008, p. 113). También se ha acentuado que: "o concurso de ingresso no serviço público pode ser revogado quando se revelar supervenientemente inconveniente ou inoportuno. O motivo da revogação, sobre ser superveniente, é a inconveniência ou inoportunidade do procedimento concursal. É o que ocorreria se aberto o concurso para o provimento de certos cargos ou empregos públicos, o serviço prestado pelos novos titulares viesse a ser privatizado. Se não for superveniente, cuida-se de anulação, pois na instauração não estava presente o interesse público." (GASPARINI, Diógenes. Idem, p. 43). 
realizado en la fase interna (actos preparatorios) o en la fase externa (actos relativos a la competición) del proceso.

Respecto a la diversidad de tales posibilidades, se ha subrayado que:

"Sendo o concurso público um processo administrativo composto por uma série de atos, estará sujeito ao controle administrativo. Este poderá ocorrer na fase interna ou externa do concurso público. Na fase interna, quando serão definidos os termos do certame concursal, como por exemplo, os cargos que serão disponibilizados, os requisitos a serem preenchidos pelos candidatos, o valor da taxa de inscrição, as provas que serão prestadas com seus respectivos conteúdos, o concurso sujeita-se ao controle hierárquico, de legalidade ou de mérito, ou ainda, o controle decorrente de relação de vinculação, exercido, em regra, pelos órgãos da Administração direta sobre os entes da Administração indireta que lhe são vinculados. Na fase externa do concurso, após a publicação do edital, o controle administrativo poderá decorrer também por iniciativa dos candidatos, através de recursos administrativos. Assim, afirma-se que o controle administrativo poderá ocorrer de ofício, quando a Administração Pública detectar o vício de legalidade ou inconveniência de seus termos, ou provocado quando os interesses dos concorrentes forem atingidos por conduta administrativa ilegítima." 868

En los concursos públicos brasileños, dos grandes momentos son objeto de impugnaciones y recursos administrativos presentados por los candidatos: tras la

\footnotetext{
${ }^{867}$ Respecto a la anulación, se ha destacado que, en el contexto brasileño: "Atualmente, importante controle sobre concursos públicos vem sendo realizado pelos Conselhos Nacionais de Justiça e do Ministério Público, em que alguns concursos foram suspensos por suspeita de fraude e outros anulados por ilegalidade. Discute-se bastante a possibilidade de esses órgãos anular certames, mas, em razão de sua competência definida pela Constituição Federal como órgão de controle administrativo do Poder Judiciário e do Ministério Público, essas medidas acabam sendo aceitas como uma oportunidade a mais para se conseguir a lisura e seriedade tão desejadas nos concursos públicos." (MARINELA DE SANTOS SOUZA, Fernanda. Op.cit., p. 212). ${ }^{868}$ TOURINHO, Rita. Op.cit., p. 140.
} 
publicación de las reglas de la competición (edital) ${ }^{869}$ y tras la realización (y evaluación) de las pruebas.

Cuestión polémica dice respecto a la existencia o no de preclusión administrativa, cuando el candidato, tras la publicación del edital, no objeta sus normas ${ }^{870}$. De forma general, prevalece el entendimiento que sostiene que el silencio del candidato debe ser traducido como su concordancia, lo que impide su posterior discusión en el ámbito administrativo. ${ }^{871}$

Sin embargo, también hay los que defienden que "deve ser atenuado o rigor da assertiva de que não tendo havido impugnação, presumem-se aceitas e tornam-se indiscutíveis as regras do edital" ${ }^{172}$

A fin de que el candidato pueda ejercer su derecho de recurrir de las decisiones administrativas, se impone que las mismas sean debidamente motivadas, lo que proporcionaría al aspirante la posibilidad de conocer los fundamentos de la Administración Pública y consecuentemente, cuestionar su coherencia lógica y jurídica.

\footnotetext{
869 "Normalmente as impugnações são oferecidas por possíveis candidatos que, depois de apresentarem sua qualificação, aduzem as regras e princípios que entendem violados. Os recursos impetrados, após protocolados, são instruídos pela comissão de concurso e remetidos à autoridade superior para julgamento. Essa autoridade superior normalmente é aquela que autorizou a abertura do certame, mas nada impede que seja outra por determinação legal. Julgadas procedentes as impugnações, dois caminhos podem ser traçados. Ou se procede à retificação do edital, devolvendo-se o prazo para inscrição, ou anula-se o procedimento, instaurando-se outro, se for o caso. Entende-se ocorrida a preclusão em relação ao candidato que não tenha impugnado vício do edital no momento da inscrição. Nesta fase podem ser ainda solicitadas informações sobre pontos obscuros ou omissos do ato convocatório, que deverão ser prestadas". (TOURINHO, Rita. Idem, p. 80).

${ }^{870}$ Tal problema también está presente en el derecho español. Sobre este hecho, se ha denunciado que cuando el candidato no impugna las bases de la convocatoria y aun así posteriormente intenta cuestionar judicialmente la legalidad de la selección, el “...tropezaría con la objeción del acto firme y consentido, ya que por no haber impugnado la convocatoria, ahora no podría jurídicamente volverse contra ella. Basta repasar las sentencias de los tribunales contencioso-administrativos de los últimos años para constatar cientos de sentencias que desestiman el recurso de un aspirante burlado por una perversa convocatoria con la expeditiva fórmula o tecnicismo procesal de reprocharle el no haber impugnado la convocatoria antes de someterse a los exámenes" (Texto extraído del artículo El Tribunal Constitucional otorga un amparo histórico al control de oposiciones y concursos, publicado en el blog Contensioso es José Ramón Chaves García, El blog de Derecho Público de Sevach, disponible en la pagina web http://contencioso.es/2009/02/28/el-tribunal-constitucional-otorga-un-amparo-historico-al-control-deoposiciones-y-concursos/, acceso en 16 de agosto de 2010).

${ }^{871}$ Respecto a esta teoria: "Superado o prazo de impugnação, dar-se-á a preclusão administrativa, ou seja, não mais se poderá alegar a ilegalidade das normas do edital perante a Administraçao Pública, presumindo-se que os administrados as acataram. Ademais, a impugnação tardia seria bastante prejudicial ao andamento do certame, que jamais teria um mínimo de segurança jurídica em seguir adiante. Note-se que a preclusão administrativa, porém, não obsta a possibilidade de discussão judicial, dada a inafastabilidade do controle jurisdicional." (MACHADO JÚNIOR, Agapito. Op.cit., p. 177).

${ }^{872}$ BATISTA GOMES MOREIRA, João. Op.cit., p. 134.
} 
De la misma forma, es obligatoria la motivación de la decisión administrativa que aprecie el recurso administrativo presentado por el candidato ${ }^{873}$.

\subsubsection{2 - Control judicial}

Pese a la importancia de la autotutela administrativa como mecanismo de control preventivo y hasta mismo represivo de los procesos selectivos de acceso a la función pública, es innegable que, por distintos factores, no siempre la Administración Pública reconoce sus propios equívocos, lo que precariza la condición jurídica de los candidatos en la competición por las plazas ofertadas.

Respecto a los referidos factores que fragilizan la eficacia del control administrativo, se puede destacar el indiscutible interés de la Administración Pública en la continuidad y en la rápida terminación de la selección, circunstancias que, a priori, podrían ser comprometidas en el caso de que fuera considerada procedente una determinada impugnación presentada por los candidatos.

Otra causa que dificulta la plena realización del control administrativo es la reconocida ausencia de imparcialidad del órgano administrativo que irá a apreciar el recurso administrativo. La referida condición no significa que la Administración Pública deba actuar a favor de su propio interés y de forma contraria a los intereses de los ciudadanos (en el caso, de los candidatos), ya que es el verdadero interés que debe ser perseguido es el público.

Lo que se intenta aquí demostrar es que la comunión de interés, la gran proximidad, la pertenencia al mismo órgano, las relaciones estrechas y los contactos inevitables entre los que ejecutan el acto administrativo recurrido y los que van a analizar el recurso hacen con que haya una tendencia natural (aunque muchas veces reprochable) a la admisión del entendimiento sostenido por la Administración y al rechazo a la solicitud del candidato.

\footnotetext{
${ }^{873}$ Según la Ley Federal 9.784/1999, que trata de los procesos administrativos federales: "Art. 50. Os atos administrativos deverão ser motivados, com indicação dos fatos e dos fundamentos jurídicos, quando: (...) III - decidam processos administrativos de concurso ou seleção pública; (...) V-decidam recursos administrativos;"
} 
Debido a las razones apuntadas, es imprescindible que el ordenamiento jurídico disponga de mecanismos de control externo de los actos administrativos. En este contexto, el control ejercido por el Poder Judicial tiene destaque especial. En verdad, como ya ha subrayado la doctrina brasileña, "o candidato que pretenda impugnar o concurso pode dispensar a utilização da via administrativa, ingressando imediatamente na esfera judicial. Tem-se, muitas vezes, preferido este caminho diante da discutível imparcialidade das decisões adotadas no âmbito administrativo." ${ }^{, 874}$

Las Constituciones de España y de Brasil reconocen el derecho fundamental a la tutela jurisdiccional. Mientras la Carta Magna del país europeo prevé en el art. 24.1 que "Todas las personas tienen derecho a obtener la tutela efectiva de los jueces y tribunales en el ejercicio de sus derechos e intereses legítimos, sin que, en ningún caso, pueda producirse indefensión"; la del país sudamericano establece en el art. 5 $\mathrm{XXXV}$, que "a lei não excluirá da apreciação do Poder Judiciário lesão ou ameaça a direito" .

Aunque los dos citados ordenamientos jurídicos garanticen la protección del Poder Judiciario a los ciudadanos, especialmente contra los arbitrios del Poder Público, conviene insistir que en el caso español, hay la exigencia de agotamiento de la esfera administrativa para que uno pueda acudirse de recurso contencioso-administrativo (utilización de vía judicial) ${ }^{875}$.

Antes mismo del análisis de algunas cuestiones relativas al control judicial de los procesos selectivos, conviene acentuar la contribución de la jurisprudencia respecto a la consolidación del derecho bajo investigación en este trabajo. En este sentido, en el ámbito brasileño, se ha dicho que "o estudo dos concursos, apesar de baste escasso na doutrina pátria, termina por corriqueiro na jurisprudência, haja vista o constante embate entre o jurisdicionado e o ente público para o qual se presta o concurso" 876

\footnotetext{
${ }^{874}$ TOURINHO, Rita. Op.cit., p. 144.

${ }^{875}$ Véase Ley 29/1998, de 13 de julio, reguladora de la Jurisdicción Contencioso-Administrativa.

${ }^{876}$ MACHADO JÚNIOR, Agapito. Op.cit., p. 2.
} 
Lo que pasa es que los constantes embates entre candidatos y la Administración Pública encaminados al Poder Judicial han hecho con que hayan sido consolidados muchos entendimientos que han representando verdaderas vitorias de la ciudadanía, muchas de las cuales siquiera estaban contempladas en la legislación (especialmente en el caso brasileño, donde hasta hoy no hay ley que regule los concursos públicos). En el contexto destacado:

\begin{abstract}
"Na prática, no cotidiano da Administração Pública, com a realização de uma multiplicidade de concursos públicos, promovidos por diferentes autoridades, as dúvidas e controvérsias foram pouco a pouco aflorando e se cristalizando. Uma boa parte dessas questões recebeu tratamento doutrinário suficiente para eliminar problemas, mas uma grande parte acabou sendo submetida ao exame do Poder Judiciário, que, por sua vez, em alguns casos conseguiu estabelecer uma orientação segura, mas em outros ainda claudica, em busca de uma uniformização jurisprudencial." ${ }^{, 877}$
\end{abstract}

El control judicial de los procesos selectivos de acceso a la función pública posee algunas dificultades inherentes al hecho de que las referidas disputas envuelven miles de candidatos, circunstancia que hace con que la demanda judicial mencionada diferénciese intensamente de las demás acciones juzgadas en el ámbito judicial. ${ }^{878}$

Otro aspecto problemático dice respecto a la suspensión cautelar del proceso selectivo, medida que algunas veces será necesaria para garantizar la eficacia de una

877 ABREU DALlARI, Adilson. Princípio da isonomia e concurso público, en Concurso público e Constituição, Fabrício Motta (Cordinador), Editora Fórum, Belo Horizonte, 2005, p. 98.

${ }^{878}$ Entre las referidas distinciones, se puede citar la circunstancia de que la demanda presentada por um determinado candidato, en muchos casos, poderá afectar la situación jurídica de todos los demás candidatos. Em este sentido, se ha afirmado que: "Não é difícil de identificar que os demais candidatos do concurso público são litisconsortes necessários em causas que envolvem a revisão de questões de provas, haja vista o vínculo jurídico iniciado entre eles e a Administração Pública por ocasião da inscrição no certame (regime jurídico especial). Ou seja, todos estão submetidos à relação jurídico-administrativa do concurso público (pois se inscreveram no certame), de tal forma que a decisão da Banca Examinadora ou do juiz acerca de determinada questão de prova certamente trará repercussão na situação jurídica de todos os candidatos. Outrossim, faz-se mister que todos participem da relação processual, pra que tenha a possibilidade de defesa e manifestação acerca da situação jurídica que será estabelecida após a revisão da prova. Assim, em havendo a revisão, todos deverão suportar os benefícios ou prejuízos decorrentes de tal decisão. Ademais, com todos os candidatos integrando a lide, certamente, os critérios adotados para a revisão administrativa ou judicial da prova serão isonomicamente suportados. A jurisprudência dos tribunais sempre foi atenta ao necessário respeito à isonomia" (MACHADO JÚNIOR, Agapito. Op.cit., p. 156). 
eventual decisión futura favorable al candidato demandante. Sin embargo, la suspensión de la competición suele traer muchos perjuicios para la Administración Pública y para los demás candidatos, circunstancia que debe ser sopesada por el Poder Judicial ${ }^{879}$.

Sobre esta situación, la doctrina ha acentuado con precisión que:

"En principio y como regla general, cuando un aspirante o sindicato insta la paralización de un procedimiento selectivo en sede jurisdiccional, ha de estarse a una ponderación de los intereses en presencia. De ahí que habitualmente se enfrenta de un lado, el interés del aspirante recurrente (en no ser eliminado del procedimiento y poder examinarse u obtener la plaza) y de otro lado, el interés de los restantes aspirantes (en continuar el procedimiento o en desempeñar la plaza obtenida) al que se sumaría el interés de la Administración en cubrir prontamente las plazas para la eficacia del servicio público. Bajo un criterio puramente cuantitativo, unido a la reversibilidad de la situación que pudiera generarse (a través del reconocimiento retroactivo de efectos administrativos y económicos) es evidente que la inmensa mayoría de las peticiones de medidas cautelares de suspensión de un procedimiento selectivo estarán abocadas a la desestimación. (...) Apartándose de la regla general de la no suspensión del procedimiento selectivo, hay casos en que la ilegalidad es tan clamorosa (los vestigios del fumus boni iuris) que el Tribunal considera adecuada la suspensión del procedimiento para evitar los daños a los aspirantes (...) No es infrecuente que quando se solicita la admisión cautelar a un procedimiento selectivo (por discutirse la titulación, por ejemplo), los tribunales decreten la admisión provisional, permitiendo al recurrente su participación en las pruebas selectivas, condicionando su eficacia a lo que se resuelva finalmente por sentencia sobre la cuestión principal $" 880$

\footnotetext{
${ }^{879}$ Respecto al tema, véase SIERRA MORÓN, Susana de la. Tutela cautelar contencioso-administrativa y derecho europeo. Ed. Aranzadi, Cizur Menor (Navarra), 2004.

${ }^{880}$ RAMÓN CHAVES GARCÍA, José. Control de concursos y oposiciones en la jurisprudencia, Editorial Reus, Colección Claves de la Jurisprudencia, Madrid, 2009, p. 225-226
} 
Respecto al control judicial, la gran discusión presente en el ámbito de la doctrina y de los Tribunales trata del alcance de la referida intervención, especialmente en lo que refiere a la posibilidad de control de la discrecionalidad técnica de los órganos de selección (control de los actos de evaluación técnica).

Debido a la relevancia del tema del control de la discrecionalidad técnica de las Comisiones evaluadoras y de su control por el Poder Judicial (que indudablemente es el asunto que causa más polémica, sea en el ámbito doctrinário o jurisprudencial), será creado un apartado proprio para su investigación aun en este capítulo cuarto.

Aunque se reconozca que aún hay muchas dudas, es indiscutible la evolución del tema en los últimos años, sea en España, sea en Brasil ${ }^{881}$. De la misma forma, es innegable lo tanto que hay aún que progresar la discusión de las mencionadas cuestiones $^{882}$.

\footnotetext{
${ }^{881}$ Sobre este hecho: "No que tange à possibilidade de controle dos concursos públicos, felizmente, nos dias de hoje, a jurisprudência dos Tribunais brasileiros já reconhece algumas possibilidades. A orientação é de que o Poder Judiciário não pode controlar todos os aspectos do concurso, como, por exemplo, adentrar nas discussões sobre as questões das provas, admitindo-se esse que esse controle aconteça nos aspectos de legalidade do certame. Dessa forma, admite-se o controle dos concursos no que diz respeito às regras e exigências do edital, considerando a aplicação de todos os princípios constitucionais, tais como isonomia, razoabilidade, proporcionalidade, moralidade, impessoalidade e outros, considerando tratar-se de controle de legalidade em sentido amplo, sendo um controle de regras constitucionais. Seguindo essas orientações, já se reconheceu também a possibilidade de o Poder Judiciário controlar a adequação das questões da prova do concurso ao programa proposto no edital, considerando tratar-se de controle de legalidade, tendo em vista que o edital é ato administrativo vinculado e o administrador deve cumprir rigorosamente as suas regras. Ressalte-se que essa mesma possibilidade de controle não é admitida, pela posição majoritária da jurisprudência, quando se tratar de polêmicas sobre o gabarito das questões nem mesmo em provas objetivas" (MARINELA DE SANTOS SOUZA, Fernanda. Op.cit., pp. 211-212).

${ }^{882}$ Respecto a esta necesidad de avance, se ha destacado em el contexto brasileño que: "existe, ainda, uma resistência de nossos Tribunais em conferir um maior controle de legalidade no que tange à formulação e à avaliação das questões objetivas dos concursos públicos, sob o fundamento que não é dado ao Judiciário substituir-se à banca examinadora, salvo no que se refere a vícios de legalidade ocorrentes no próprio procedimento administrativo, à luz do edital e demais regras do certame. Por outro lado, não é menos verdade que, ultimamente, a construção pretoriana vem, paulatinamente, deixando de aplicar o entendimento acima em situações que evidenciam, de forma patente, o equívoco da banca examinadora na avaliação e correção da prova objetiva. Não se trata, neste caso, de substituição dos critérios da Administração Pública pelos do Poder Judiciário, mas de conformação da conduta da banca examinadora aos princípios da legalidade, da razoabilidade e da eficiência, bem como aos parâmetros delineados pela técnica e pelos estudos científicos consagrados quando da realização e aplicação das provas objetivas." (BARBOSA MAIA, Márcio, y PINHEIRO DE QUEIROZ, Ronaldo. Op.cit., p. 198).
} 
Entre los avances que deberán ocurrir, uno de ellos dice respecto a la necesidad de la tutela judicial atender de forma ágil las demandas que les son enderezadas por los candidatos ${ }^{883}$.

Otra circunstancia que debe ser perfeccionada dice respecto a la postura adoptada por el Poder Judicial delante de los casos que aprecia, que muchas veces oscila entre la manifiesta omisión y el flagrante arbitrio.

Para que se pueda percibir lo que se ha afirmado anteriormente, cabe destacar dos comentarios realizados por la doctrina brasileña respecto a la actuación del Poder Judicial de aquel país en el control de los concursos públicos.

En primer lugar, hay aquellos que revelan que el carácter conservador de las decisiones judiciales frenan los avances introducidos en el ordenamiento jurídico. En este sentido, se puede subrayar la siguiente opinión que atesta que, en general, los Tribunales no admiten el control de los actos de evaluación de las pruebas:

"A jurisprudência pátria, talvez ainda muito atrelada à concepção liberal de controle pelo único parâmetro jurídico, qual seja o da legalidade, tem-se demonstrado muito tímida e incipiente em termos de controle jurisdicional, tendo fixado entendimento de que o Poder Judiciário não pode, em hipótese alguma, aferir critérios de correção de provas utilizados pela comissão do concurso público. (...) Verificase, pois, a predominância de entendimento de que o Poder Judiciário, salvo se houver violação ao edital ou lei, como é o caso de abordagem de conteúdo não previsto no programa constante do edital. Vê-se, pois, que a posição do STJ é conservadora no sentido de limitar o controle jurisdicional apenas ao parâmetro da legalidade.(...) A despeito da posição majoritária (STJ e STF) no sentido de que o julgador não pode analisar os critérios científicos e pedagógicos afetos

\footnotetext{
${ }^{883}$ La doctrina brasileña ha denunciado que "a jurisprudência não pode olvidar uma dura realidade brasileira: é preciso o transcurso de vários anos, não raro mais de uma década, para uma sentença passar em julgado, diante da multiplicidade de ações, do sistema processual vigente e das prerrogativas da Fazenda Pública, do manifesto propósito protelatório do Poder Público em juízo e da falta de estrutura do Poder Judiciário pátrio" (BARBOSA MAIA, Márcio, y PINHEIRO DE QUEIROZ, Ronaldo. Idem, p. 196).
} 
ao administrador, têm-se, em verdade, novos rumos para o controle jurisdicional no que concerne à revisão das provas. Em comunhão com a análise da jurisprudência, faz-se salutar a indicação de duas teorias adotadas na Europa, que, aos poucos, vêm sendo absorvidas pelos intérpretes pátrios e certamente guardam total pertinência com a idéia de controle jurisdicional mais justo e adequado ao Estado Democrático de Direito a ser realizado na juridicidade: (a) acerto da decisão tecnicamente sustentável e (b) redução da discricionariedade a zero." $^{, 884}$

Sin embargo, también hay aquellos que denuncian que a través de decisiones judiciales, consideradas excesivas, el candidato consigue hacer con que el resultado del concurso público sea desprezado y comprometida la igualdad en relación a los demás candidatos, en la medida en que obteniene su toma de posesión mediante un fallo provisional de un juez ${ }^{885}$ (y no a través de una decisión administrativa):

\begin{abstract}
"Trata-se de concurso público em que, a despeito de o candidato não preencher algum requisito para a aprovação (reprovação em exame, ausência no dia da prova, exame físico etc.), consegue, em ação judicial (normalmente o mandado de segurança), ser beneficiado com a concessão de medida liminar na qual se determina que o Poder Público dê posse ao candidato. Esse tipo de decisão cautelar in limine é totalmente inconstitucional e carece de qualquer técnica jurídica. A medida cautelar pode, quando muito, ordenar a reserva de vaga, mas nunca impor a formação da relação funcional pela investidura, porque isso ofende diretamente a prerrogativa da presunção de legitimidade
\end{abstract}

\footnotetext{
${ }^{884}$ MACHADO JÚNIOR, Agapito. Op.cit., p. 162.

${ }^{885}$ En este sentido: "seria violar o tratamento igualitário que a Administração Pública deve dispensar a todos os cidadãos, sem dúvida, permitir que pessoas não aprovadas em todas as provas e etapas de concurso público, porque o Poder Judiciário abonou sua reprovação administrativa no certame, pudessem ingressar ou permanecer no quadro do funcionalismo estatal, apenas pelo fato de que obtiveram provimento judicial provisório para lhes assegurar a posse no cargo administrativo, posteriormente cassado por decisão judiciária definitiva. Seria o mesmo que dispensar, em última instância, a exigência constitucional de aprovação em concurso público para certos cidadãos pelo mero fato de que tomaram a iniciativa de discutir judicialmente, ao final sem sucesso, sua reprovação no certame concursal." (ALENCAR CARVALHO, Antônio Carlos. A efetivação de servidores precariamente empossados "sub judice" em cargos de provimento efetivo à luz da Constituição Federal, Texto extraído del sitio Jus Navigandi (http://jus2.uol.com.br/doutrina/texto.asp?id=12017=), acceso en 14 de agosto de 2010).
} 
de que são dotados os atos da Administração. Se o juiz vem a acolher o pedido do candidato, todos os efeitos do erro administrativo deverão ser reparados, inclusive, se for o caso, a responsabilização funcional da autoridade. Mas daí não se pode extrair a conclusão de que o órgão judicial possa ordenar que a posse seja ultimada. O certo é que, em virtude dessa grave erronia técnica, dezenas e até centenas de candidatos são empossados e só após a lenta tramitação do processo é que o Judiciário decide o litígio em desfavor dos candidatos. Por causa do tempo já decorrido a partir da ilegítima investidura, postulam eles a convalidação de sua situação. Pedido em tal direção é nitidamente injurídico (quando não eivado de má-fé), de modo que o único desfecho possível no caso é o desfazimento da posse através da anulação, sem qualquer direito ao candidato que não cumpriu requisito para a aprovação do certame. Nesses casos, é mister destacar, inexiste qualquer motivo para invalidar o concurso. A Administração deve, isto sim, diligenciar no sentido da anulação das nomeações ilegítimas e prematuras, tão logo o Judiciário reconheça ter sido improcedente a pretensão dos candidatos" $" 886$

\subsubsection{4 - Actos del procedimiento de selección sujetos al control.}

Analizadas las modalidades de control en el proceso selectivo, conviene que sean apreciadas las posibilidades de fiscalización de los distintos momentos que configuran la selección de los funcionarios.

Para empezar, cabe acentuar que en el capítulo quinto, en la medida que sean analizados los actos del procedimiento selectivo, también serán hechas algunas consideraciones respecto a las exigencias de control de los mismos. Por esta razón, la presente exposición será más breve y tendrá el objetivo de demostrar de forma panorámica la diversidad de actos pasibles de fiscalización.

En el siguiente capítulo del trabajo, a principal finalidad del análisis será la investigación de las posibles transgresiones del derecho del ciudadano a acceder a la función pública en condiciones de igualdad, que podrían ocurrir en el curso del procedimiento de selección llevado a cabo por la Administración Pública. Ahora,

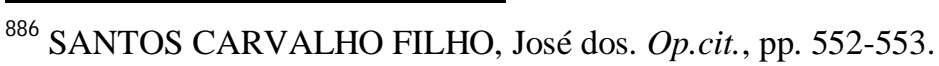


conviene que sean identificadas, aunque de forma general, las posibilidades por las cuáles los aspirantes pueden realizar el reproche respecto a los mencionados actos, a fin de que no sean improductivas las prescripciones jurídicas declarativas del sobredicho derecho fundamental.

El ordenamiento jurídico que no ofrece las debidas garantías del cumplimiento de los derechos que ha consagrado no es compatible con las exigencias del Estado Social y Democrático de Derecho. Por esta razón, es conveniente subrayar la diversidad de actos sobre los cuales se puede ejercer el control de los procesos selectivos. En este sentido, se ha afirmado que:

"Son muy variados los reproches que pueden hacerse a los actos con que termina los procedimientos administrativos: reproches orgánicos como defectuosa composición de los tribunales, infracciones de procedimiento o de fondo por haberse apartado la resolución de los criterios de capacidad y méritos implícitos en el procedimiento o consignados en la convocatoria o los baremos establecidos por los tribunales. También es frecuente la alegación de desviación de poder para corregir supuestos tratos de favor."

En el derecho español, el primer apunte que puede ser destacado ocurre tras la elaboración de la Oferta de Empleo Público, pues, si esta no establece que las plazas vacantes desempeñadas por interinos sean cubiertas por funcionarios de carrera, habrá la posibilidad de su impugnación.

Otra posibilidad de control ocurre si tras la publicación de la Oferta de Empleo Público, la Administración Pública no convoca los procesos selectivos previstos, según el plazo máximo previsto en el referido instrumento, o si los convoca de forma parcial.

A su vez, aún en el contexto español, otro momento que propicia la fiscalización por los legitimados es la composición de los órganos de selección. Así, si sus miembros no son funcionarios de carrera, o si no ostentan los conocimientos especializados en el área objeto de la selección, podrán los interesados exigir el cumplimiento de la normativa aplicable.

${ }^{887}$ PARADA, Ramón. Derecho del empleo público, Marcial Pons, Barcelona, 2007, p. 147. 
De la misma forma, se podrá ejercer un control sobre la formación del órgano colegiado si en el citado órgano alguno de sus miembros ha sido seleccionado en representación de alguien o de alguna asociación, o también si no hay la necesaria paridad entre hombres y mujeres.

También estará sujeto a la fiscalización si alguno de los miembros del órgano seleccionador es un funcionario que hubiera realizado tareas de preparación de aspirantes a pruebas selectivas en los cinco años anteriores a la publicación de la correspondiente convocatoria.

Otro momento oportuno para la realización de los actos de control se manifiesta tras la elaboración y publicación de las bases de la convocatoria, pues si las bases previstas para regir el proceso selectivo no siguen los parámetros establecidos en las normas de rango superior, estas podrán ser impugnadas.

Las impugnaciones realizadas por los interesados podrán hacer con que haya la necesidad de exclusión de determinados aspectos ilegales, especialmente cuando establecen discriminaciones indebidas, o la modificación de ciertos puntos de las bases de la convocatoria que no se ajustan a las normas de rango superior.

Observada por la Administración Pública la necesidad de innovación (por exclusión o modificación) en determinados aspectos de las bases de la convocatoria, deben ser observadas las normas propias para tal fin ${ }^{888}$, que deberán garantizar el debido deber de divulgación.

Los aspectos de las bases de la convocatoria que más están sujetos a la fiscalización son los requisitos de participación y la previsión de las pruebas que serán realizadas en el curso del proceso selectivo.

Otro momento apropiado para el ejercicio de la fiscalización trata sobre la definición de los aspirantes admitidos y de los excluidos ${ }^{889}$. Cabe resaltar que tanto el

\footnotetext{
${ }^{888}$ El Real Decreto 364/1995, en su art. 15.5, establece que: "Las convocatorias o sus bases, una vez publicadas, solamente podrán ser modificadas con sujeción estricta a las normas de la Ley de Régimen Jurídico de las Administraciones Públicas y del Procedimiento Administrativo Común."

${ }^{889}$ El Real Decreto 364/1995, en su art. 20.3, establece que: "La publicación de la Resolución en el Boletín Oficial del Estado será determinante de los plazos a efectos de posibles impugnaciones o recursos."
} 
candidato puede contestar el acto que le excluyó injustamente de la competición, como también aquel que admitió la participación de otro candidato de forma indebida.

Seguramente, la fase del proceso selectivo donde surgen más problemas que son sujetos a la fiscalización es la realización y evaluación de las pruebas, así como la valoración de los méritos. Los citados problemas dicen respecto a la dificultad del candidato confrontar las evaluaciones del órgano seleccionador, tarea que se torna más viable cuando hay criterios objetivos de valoración.

El candidato podrá hacer uso de recursos administrativos dirigidos hacia la autoridad que haya nombrado al órgano seleccionador. ${ }^{890}$ Sin embargo, no sólo el candidato podrá fiscalizar la actuación de los miembros de los órganos seleccionadores, sino también la propia Administración Pública ${ }^{891}$.

En la ejecución de los actos subsecuentes a la evaluación de las pruebas, pueden surgir distintas cuestiones que estarán sujetas al debido control. En este contexto, se puede destacar el acto de divulgación de los resultados finales, que deberán estar en conformidad con el efectivo desempeño de los candidatos, además de estar debidamente motivado ${ }^{892}$.

También se puede subrayar la aportación de documentos, oportunidad en la que el candidato perjudicado por una actuación indebida de la Administración podrá impugnar los actos (de admisión o exclusión) que no se hayan puesto en práctica correctamente.

Como la realización de cursos selectivos y periodos de prácticas pueden influenciar decisivamente en la situación jurídica de los aspirantes, sea a partir de la exclusión de la selección, sea afectando su futura carrera funcional (por ejemplo, para efectos de promoción), también cabrá el control de los mismos.

\footnotetext{
${ }^{890}$ En los términos del art. 14.2 del Real Decreto 364/1995,"Contra las resoluciones y actos de los órganos de selección y sus actos de trámite que impidan continuar el procedimiento o produzcan indefensión podrá interponerse recurso ordinario ante la autoridad que haya nombrado a su presidente". ${ }^{891}$ Según el art. 14.1 del Real Decreto 364/1995: "Las resoluciones de los Tribunales o Comisiones Permanentes de Selección vinculan a la Administración, sin perjuicio de que ésta, en su caso, pueda proceder a su revisión, conforme a lo previsto en los artículos 102 y siguientes de la Ley de Régimen Jurídico de las Administraciones Públicas y del Procedimiento Administrativo Común”.

${ }^{892}$ El Real Decreto 364/1995, en su art. 22.2, establece que "Los actos que pongan fin a los procedimientos selectivos deberán ser motivados. La motivación de los actos de los órganos de selección dictados en virtud de discrecionalidad técnica en el desarrollo de su cometido de valoración estará referida al cumplimiento de las normas reglamentarias y de las bases de la convocatoria."
} 
Por fin, los actos de nombramiento y toma de posesión (así como su ausencia o impedimento) también están sujetos a la debida fiscalización, especialmente cuando no se observa el orden de prelación de los candidatos o cuando no se respetan las solicitudes relativas a la asignación inicial de puestos de trabajo, lo que también ser respetado por/respetar el orden obtenido en el proceso selectivo ${ }^{893}$.

Los actos arriba mencionados ciertamente no integran una lista cerrada, ya que cada uno de los procesos selectivos puede tener peculiaridades, lo que hace que puedan existir distintos actos no previstos en los procedimientos estándares. Sin embargo, también estarán sujetos a los debidos mecanismos de control, ya que toda actividad administrativa de selección debe ser sometida a fiscalización.

En el contexto brasileño, con las debidas adaptaciones debido a las distinciones respecto a los actos del procedimiento y a las dificultades históricas, política, sociales y económicas ${ }^{894}$, se puede afirmar que las consideraciones hechas respecto a las distintas oportunidades de control también se aplican al proceso selectivo de acceso a la función público de aquél país.

Sin que se pretenda repetir el análisis emprendido en las líneas anteriores, es posible destacar que todos los actos de la selección están sujetos a control, aunque haya situaciones más usuales en las cuales la fiscalización es ejercida con más vigor. En este contexto, conviene subrayar la elaboración de las reglas de la competición, la realización de las pruebas y los actos de nombramiento de los aprobados.

\footnotetext{
893 Según el art. 26.1, del Real Decreto 364/1995: “La adjudicación de puestos de trabajo a los funcionarios de nuevo ingreso se efectuará de acuerdo con las peticiones de los interesados entre los puestos ofertados a los mismos, según el orden obtenido en el proceso selectivo, siempre que reúnan los requisitos objetivos determinados para cada puesto en las relaciones de puestos de trabajo."

${ }^{894}$ Respecto a la realidad brasileña, se ha acentuado que: "restabelece-se, no país, a vetusta prática de apadrinhamento e favoritismo na admissão de pessoal no serviço público brasileiro, imbuída, no mais das vezes, de perigosa condução política, administrativa e eleitoral, em detrimento da moralidade administrativa e da isonomia constitucional. Destacam-se, entre tais expedientes, as terceirizações, as contratações temporárias fraudulentas, a nomeação para cargos em comissão que não se destinam às "atribuições de direção, chefia e assessoramento" (CF/88, art. 37, V, in fine), as contratações decorrentes de contrato de gestão, convênios, termos de parcerias e outros vínculos jurídicos com as organizações sociais, entidades de apoio e demais entidades paraestatais, entre outras formas de parceria. Constata-se que o objetivo do Governo, ao enfraquecer o instituto do concurso público e demais mecanismos moralizadores, é a implantação do propalado "Estado Gerencial", no afa de escapar das restrições do regime publicístico, via reforma administrativa, o qual pretende, de forma ilegítima e injurídica, fazer as vezes do Estado Constitucional, única e verdadeira forma de organização soberana autorizada pelo nosso ordenamento jurídico nacional." (BARBOSA MAIA, Márcio, y PINHEIRO DE QUEIROZ, Ronaldo. Op.cit., p. 59).
} 
Respecto a las distintas posibilidades de control, se ha dicho en la doctrina brasileña que:

"O edital do concurso que estabeleça limite de idade e exija a apresentação de diploma por ocasião da inscrição; o questionamento sobre matéria não-prevista no conteúdo programático; a correção de prova sem motivação e o recurso sem fundamentação; a nomeação de candidato sem obediência à ordem de classificação são os exemplos mais comuns sobre a possibilidade de controle do concurso pelo Poder Judiciário" ${ }^{, 895}$

Otros doctrinadores también apuntan como posibles hipotesis de control "o direito de isenção de taxa do hipossuficiente, o direito a exigência dos requisitos de habilitação para o concurso somente na posse ou no ato de contratação, o do direito de utilizar recurso administrativo, o direito de observância da ordem de classificação do concurso, direito a nomeação em caso de contratação precária, dentre outros." ${ }^{, 896}$

A su vez, también se puede decir que determinadas situaciones, que en España son usualmente objeto de control, como la Oferta de Empleo Público y la formación del órgano seleccionador, no son frecuentemente fiscalizadas en Brasil.

La afirmación arriba se debe al hecho de que en los procesos selectivos brasileños (como se verá en el capítulo quinto), no hay el instituto de la oferta de empleo público. En verdad, lo que existe como mecanismo de planificación de los procesos selectivos es la ley presupuestaria, que, desgraciadamente, no es vinculante (tiene solamente el carácter de autorización). Así, aunque esté previsto en la ley presupuestaria la realización de determinado concurso público, este solamente ocurrirá se la Administración Pública decidir de forma discrecional que va a ejecútalo.

Respecto al control de formación del órgano seleccionador, como se verá en el siguiente capítulo, en la realidad brasileña, en general, los procesos selectivos son organizados por entidades (con o sin finalidad lucrativa) contratadas por la Administración Pública, y no por órganos colegiados formados por funcionarios.

${ }^{895}$ PACHECO BARROS, Wellington. Op.cit., p. 61.

${ }^{896}$ TOURINHO, Rita. Op.cit., p. 161. 
De hecho, cuando hay control sobre la contratación, el aspecto que más se verifica no es la imparcialidad y profesionalidad de los miembros de la entidad, sino la regularidad jurídica de la contratación administrativa (si hubo o no proceso de licitación, por ejemplo).

Sin embargo, cuando hay la formación de una banca examinadora (concursos públicos con un cierto grado de complejidad técnica), también se admite que "a faculdade de se argüir o impedimento e a suspeição dos componentes das bancas examinadoras de concursos públicos independe de dispositivo legal expresso ou de regra regulamentar ou editalícia específica, já que decorre do dever de imparcialidade dos agentes públicos e dos princiípios gerais da atividade administrativa"

Se puede decir que el control sobre la elaboración de las reglas de la competición, a través de impugnaciones de los futuros candidatos o hasta mismo por el Ministerio Público (Fiscalía), aunque permita muchas posibilidades, en la realidad, no es utilizado con la frecuencia de se podría esperar. Quizá esto suceda porque el candidato no está suficientemente esclarecido de sus derechos o mismo porque, aunque esté, no quiere ser conocido por el órgano seleccionador como alguien que va a tumultuar el trámite de la selección.

No cabe dudas de que, en la realidad del contexto brasileño, los actos de realización y evaluación de las pruebas son los que más están sujetos al control por los candidatos. Sobre esto, se ha destacado que "a motivação e publicidade da correção das provas não bastam para evitar injustiças. Deve ser dado ao candidato o direito de questionar o resultado a ele atribuído no concurso, para que, identificando-se eventuais erros na avaliação, se possa corrigi-los." 898

La doctrina brasileña denuncia determinados aspectos sensibles de los concursos públicos, especialmente delante de la dificultad de implementación de control, como es lo que pasa con la ausencia de parámetros de valoración de las pruebas

\footnotetext{
${ }^{897}$ BARBOSA MAIA, Márcio, y PINHEIRO DE QUEIROZ, Ronaldo. Op.cit., p. 86.

${ }^{898}$ LOBELLO DE OLIVEIRA ROCHA, Francisco. Op.cit., p. 133.
} 
orales $^{899}$, con el subjetivismo de los tests psicotécnicos ${ }^{900}$, el extremo rigor de las prubas físicas $^{901}$, el arbitrio en la valoración de los méritos (títulos ${ }^{902}$ ) y hasta mismo con la timidez en la efetivación del control de la evaluación de las pruebas escritas ${ }^{903}$.

Sin embargo, parece innegable el avance (aunque lento) que está ocurrindo en este contexto, especialmente debido a las publicaciones de algunos pocos doctrinadores y a las decisiones de determinados Tribunales. ${ }^{904}$

${ }^{899}$ Respecto a este hecho, se ha afirmado que: "infelizmente, constata-se que a forma com que vem sendo
conduzida e aplicada a prova oral pelas bancas examinadoras dos concursos públicos realizados no país
tem inviabilizado o acesso efetivo dos candidatos ao Poder Judiciário, mormente diante da falta da
exteriorização material de seu conteúdo para o mundo jurídico e da ausência de sua motivaçãa, o que
impossibilita, inclusive, a interposição de recurso administrativo perante a própria comissão de
concurso. Tal postura, sob a nossa ótica, afigura-se inadmissível, diante dos princípios que informa o
procedimento do concurso público" (BARBOSA MAIA, Márcio, y PINHEIRO DE QUEIROZ, Ronaldo. Op.cit., p. 206).

900 Respecto a tales métodos, se ha afirmado que: "A avaliação psicológica constitui o aspecto mais polêmico do concurso público e quem tem suscitado o maior número de debates na esfera judicial. É curioso notar que a mesma jurisprudência que vem, de um lado, reconhecendo um amplo poder discricionário em sede de provas discursivas e orais, com a conseqüente adoção de critérios subjetivos dos examinadores na avaliação e correção das respectivas questões, não vem tolerando, de outro lado, a adoção desses mesmos critérios em sede de provas psicotécnicas." (BARBOSA MAIA, Márcio, y PINHEIRO DE QUEIROZ, Ronaldo. Idem, p. 210).

${ }^{901}$ Sobre tales pruebas: "a maioria esmagadora dos precedentes jurisprudenciais construídos em torno das provas de capacidade física e das provas de habilidade específica refere-se ao entendimento pacífico no sentido de reconhecer o direito dos candidatos em realizar os testes e exames em ocasião diversa daquela prevista no cronograma inicial do concurso, diante de incapacidades ou perturbações temporárias plenamente compatíveis com o cronograma do concurso público e nas situações de gravidez e convicção religiosa" (BARBOSA MAIA, Márcio, y PINHEIRO DE QUEIROZ, Ronaldo. Idem, pp. 209-210).

${ }^{902}$ Respecto a la valoración de los méritos: "A natureza objetiva da prova de títulos e a delimitação dos critérios de pontuação e avaliação no edital do certame têm proporcionado um controle jurisdicional mais efetivo do que aquele aplicado para as provas de conhecimento." (BARBOSA MAIA, Márcio, y PINHEIRO DE QUEIROZ, Ronaldo. Idem, p. 212).

${ }^{903}$ Sobre este panorama, se puede resumir el entendimiento general respecto al tema (y su evolución) em los siguientes términos: "em regra o Poder Judiciário não poderia aferir a resposta dada pela Administração Pública através da Banca Examinadora (órgão competente para avaliar as respostas dadas), limitando-se apenas a anular a questão, se for o caso, por vício de legalidade, estendendo os pontos a todos os candidatos do certame. Todavia, excepcionalmente, valendo-se dos parâmetros da juridicidade (princípios constitucionais), haverá a possibilidade de aferição dos critérios de avaliação e de correção utilizados pela banca examinadora por parte do Poder Judiciário, em especial, quando for o caso da aplicação das doutrinas retroreferidas, pois, existirão situações (casos concretos) em que: (a) a resposta dada pelo candidato é sustentável no ramo científico avaliado, não podendo ser desprezada pela banca examinadora, sob pena de ser violado o princípio da razoabilidade, entre outros; (b) haverá situações em que existirá apenas uma única opção para ser validamente adotada pelo administrador na correção do quesito, podendo, em tais casos, o Poder Judiciário substituir a resposta ofertada pela Administração Pública indicando outra." (MACHADO JÚNIOR, Agapito. Op.cit., p. 166).

${ }_{904}$ Respecto a tal circunstancia, se ha subrayado que: "em casos de "manifestos erros na correção da prova discursiva", alguns julgados, acertadamente, vêm admitindo a possibilidade de seu controle jurisdicional, inclusive por intermédio de produção de prova pericial." (BARBOSA MAIA, Márcio, y PINHEIRO DE QUEIROZ, Ronaldo. Op.cit., p. 204). 
El otro momento que causa muchos trastornos en el ámbito del proceso selectivo dice respecto al control del acto de nombramiento, que en Brasil hasta poco tiempo dependía de la decisión discrecional de la Administración Pública, lo que provocaba mucha insatisfacción en los candidatos.

Sobre tal circunstancia, la doctrina ha destacado que: "ocorrendo lesão ao direito subjetivo de nomeação, há possibilidade de interposição de mandado de segurança, devendo ser observado o prazo de validade do certame.." 905

\subsubsection{5 - Legitimidad para el ejercicio del control de los procesos selectivos}

Tras el análisis de las modalidades de control y de los actos administrativos que están sujetos a fiscalización, conviene que la presente investigación tenga como objeto el estudio de la legitimidad para el ejercicio del control de los procesos selectivos de acceso a la función pública.

En este contexto, en el contexto del derecho español, respecto a quiénes tienen la iniciativa de suscitar el control, se puede decir que, de forma general, se entiende que este puede ser promovido mediante la acción de los aspirantes ${ }^{906}$ o de la propia Administración Pública, cuando esta actúa de oficio ${ }^{907}$.

Teniendo en consideración la afirmación arriba citada y ante lo que se ha visto en el ítem anterior, se puede percibir que además de la existencia de distintas oportunidades para que el control pueda ser realizado, el ordenamiento jurídico

\footnotetext{
${ }^{905}$ MARINELA DE SANTOS SOUZA, Fernanda. Op.cit., p. 209.

906 Según el art. 107 de la Ley 30/1992: “Contra las resoluciones y los actos de trámite, si estos últimos deciden directa o indirectamente el fondo del asunto, determinan la imposibilidad de continuar el procedimiento, producen indefensión o perjuicio irreparable a derechos e intereses legítimos, podrán interponerse por los interesados los recursos de alzada y potestativo de reposición, que cabrá fundar en cualquiera de los motivos de nulidad o anulabilidad previstos en los artículos 62 y 63 de esta Ley. La oposición a los restantes actos de trámite podrá alegarse por los interesados para su consideración en la resolución que ponga fin al procedimiento."

907 En los términos del art. 102 de la Ley 30/1992: “1. Las Administraciones públicas, en cualquier momento, por iniciativa propia o a solicitud de interesado, y previo dictamen favorable del Consejo de Estado u órgano consultivo equivalente de la Comunidad Autónoma, si lo hubiere, declararán de oficio la nulidad de los actos administrativos que hayan puesto fin a la vía administrativa o que no hayan sido recurridos en plazo, en los supuestos previstos en el artículo 62.1.

2. Asimismo, en cualquier momento, las Administraciones públicas de oficio, y previo dictamen favorable del Consejo de Estado u órgano consultivo equivalente de la Comunidad Autónoma si lo hubiere, podrán declarar la nulidad de las disposiciones administrativas en los supuestos previstos en el artículo 62.2."
} 
reconoce la legitimidad con el fin de que los aspirantes puedan impugnar los más distintos actos del procedimiento selectivo.

Ello se debe a que en los procesos selectivos, los aspirantes tienen un doble interés: primeramente, lo de no ser alejados de la competición de forma injusta y, en segundo lugar, que sus adversarios no permanezcan en la disputa de manera indebida.

En verdad, los Tribunales españoles sostienen que:

"el interés legítimo alcanza a impugnar las valoraciones propias y la de aquéllos que superen su puntuación obteniendo las plazas, pero no las de los demás por carecer de efecto alguno para la misma (STSJ de Asturias de 13 de mayo de 2002, rec. 60/2001). En esta línea, aunque se pruebe que a otros aspirantes se les ha aplicado algún criterio alejado de las bases, se rechazará tal objeción si con ello no experimenta mejora la situación del recurrente"

Conviene resaltar que los términos del art. 31.1 de la Ley 32/1992 (Ley de Régimen Jurídico de las Administraciones Públicas y del Procedimiento Administrativo Común) ratifican la afirmación arriba transcripta, cuando reconocen quiénes son los interesados en el procedimiento administrativo ${ }^{909}$.

Así, en los procesos selectivos, dada su naturaleza competitiva, el aspirante puede verse afectado injustamente, pasando a tener la condición de interesado (y así legitimado para suscitar el control), cuando haya un acto o resolución ilegítima que le atinja directamente (la no admisión injustificada de sus documentos como válidos, evaluación negativa de su buen desempeño en las pruebas orales, etc.).

No obstante, también será afectado ilegítimamente, aunque de forma refleja, cuando el acto o resolución favorezca indebidamente a otros candidatos (admisión indebida de los documentos de otro aspirante, evaluación positiva del desempeño en una

\footnotetext{
908 RAMÓN CHAVES GARCÍA, José. Control de concursos y oposiciones en la jurisprudencia, Editorial Reus, Colección Claves de la Jurisprudencia, Madrid, 2009, p. 217.

909 “Art. 31.1 Se consideran interesados en el procedimiento administrativo:

a) quienes lo promuevan como titulares de derechos o intereses legítimos individuales o colectivos.

b) los que, sin haber iniciado el procedimiento, tengan derechos que puedan resultar afectados por la decisión que en el mismo se adopte.

c) aquéllos cuyos intereses legítimos, individuales o colectivos, puedan resultar afectados por la resolución y se personen en el procedimiento en tanto no haya recaído resolución definitiva."
} 
prueba práctica mal realizada, etc.), ya que tales eventos van a repercutir en su posición en la competición. En estos casos, también tendrá legitimidad para suscitar el control del proceso selectivo.

En las mencionadas situaciones, se ve que la igualdad es transgredida, cuando la Administración Pública establece una desventaja injusta, lo que reduce las oportunidades de determinado aspirante a conseguir la plaza deseada, o cuando concede una ventaja indebida, lo cual amplía las oportunidades de otros competidores.

Aunque la concepción general que prevalecía en el derecho español limitaba la mencionada legitimidad a aquellos que estaban participando directamente del proceso selectivo en la condición de aspirantes, ya hay importantes decisiones judiciales que han dilatado el rol de legitimados para suscitar el control la legalidad de la competición. En este sentido, se ha reconocido la legitimidad de asociaciones para la defensa de los intereses de los ciudadanos, como se puede verificar a continuación:

\begin{abstract}
"Tradicionalmente las oposiciones y concursos de méritos para ser empleado público podían ser impugnadas ante los Tribunales contencioso-administrativos por quienes tuvieran «legitimación», concepto procesal que limitaba la posibilidad de recurrir a los aspirantes admitidos al procedimiento (quienes no solían hacerlo por ignorancia o prudencia), mientras la ciudadanía contemplaba impasible los chanchullos de convocatorias de promociones internas $\mathrm{u}$ oposiciones libres en que las plazas se diseñaban a la medida de algún candidato. Pues bien, la Sentencia del Tribunal Constitucional STC 28/2009, de 26 de enero de reconoce la legitimación impugnatoria a una asociación para defensa de opositores (Unión Nacional de Opositores "Justicia y Ley"), rompiendo con la consolidada jurisprudencia contencioso-administrativa de que las Asociaciones no ostentaban legitimación para velar por la pureza de los procedimientos selectivos"910.
\end{abstract}

\footnotetext{
910 Texto extraído del artículo El Tribunal Constitucional otorga un amparo histórico al control de oposiciones y concursos, publicado en el blog Contensioso es José Ramón Chaves García, El blog de Derecho Público de Sevach, disponible en la pagina web http://contencioso.es/2009/02/28/el-tribunalconstitucional-otorga-un-amparo-historico-al-control-de-oposiciones-y-concursos/, acceso en 16 de agosto de 2010.
} 
También debe ser acentuado el papel del Defensor del Pueblo, a quién, según el art. 54 de la Constitución española, cabe la defensa de los derechos fundamentales, “ (...) a cuyo efecto podrá supervisar la actividad de la Administración, dando cuenta a las Cortes Generales”. En este míster, destacase el papel investigativo del referido órgano ${ }^{911}$.

Pese el avance en este ámbito (donde incluso se ha permitido la actuación de los sindicatos), hay que destacar que, en España, no se ha reconocido la legitimidad del Ministerio Fiscal ${ }^{912}$ para impugnación de los procesos selectivos cuando los mismos están viciados. Seguramente, en este trabajo defiende la opinión de que "lo deseable sería que la Ley, al igual que en materia de defensa del consumidor, hubiese optado por dotar de legitimación al Ministerio Fiscal para impugnar los casos más sangrantes"913

Aunque se reconozca la necesidad de ampliación continúa del rol de legitimados para fiscalizar los procesos selectivos, el gran paso en este ámbito será el

\footnotetext{
${ }^{911}$ Según la Ley Orgánica 3/1981, de 06 de abril, del Defensor del Pueblo:

"Artículo 9. Uno. El Defensor del Pueblo podrá iniciar y proseguir de oficio o a petición de parte, cualquier investigación conducente al esclarecimiento de los actos y resoluciones de la Administración pública y sus agentes, en relación con los ciudadanos, a la luz de lo dispuesto en el artículo 103.1 de la Constitución, y el respeto debido a los derechos proclamados en su Título primero dos. Las atribuciones del Defensor del Pueblo se extienden a la actividad de los ministros, autoridades administrativas, funcionarios y cualquier persona que actúe al servicio de las administraciones públicas.

Artículo 10.Uno. Podrá dirigirse al Defensor del Pueblo toda persona natural o jurídica que invoque un interés legítimo, sin restricción alguna. No podrán constituir impedimento para ello la nacionalidad, residencia, sexo, minoría de edad, la incapacidad legal del sujeto, el internamiento en un centro penitenciario o de reclusión o, en general, cualquier relación especial de sujeción o dependencia de una Administración o poder público.(...)"

${ }_{912}$ En el constitucionalismo español, el Ministerio Fiscal, aunque posea muchas competencias, siempre relacionadas al Poder Judicial, no tiene el mismo grado de autonomia que hay en el derecho brasileño, donde es considerado como se fuera un cuarto Poder. En la Constitución española de 1978, se ha establecido que:

"Artículo 124. 1. El Ministerio Fiscal, sin perjuicio de las funciones encomendadas a otros órganos, tiene por misión promover la acción de la justicia en defensa de la legalidad, de los derechos de los ciudadanos y del interés público tutelado por la Ley, de oficio o a petición de los interesados, así como velar por la independencia de los Tribunales y procurar ante éstos la satisfacción del interés social.

2. El Ministerio Fiscal ejerce sus funciones por medio de órganos propios conforme a los principios de unidad de actuación y dependencia jerárquica y con sujeción, en todo caso, a los de legalidad e imparcialidad.

3. La Ley regulará el estatuto orgánico del Ministerio Fiscal.

4. El Fiscal General del Estado será nombrado por el Rey, a propuesta del Gobierno, oído el Consejo General del Poder Judicial."

913 Texto extraído del artículo El Tribunal Constitucional otorga un amparo histórico al control de oposiciones y concursos, publicado en el blog Contensioso es José Ramón Chaves García, El blog de Derecho Público de Sevach, disponible en la pagina web http://contencioso.es/2009/02/28/el-tribunalconstitucional-otorga-un-amparo-historico-al-control-de-oposiciones-y-concursos/, acceso en 16 de agosto de 2010.
} 
incremento (especialmente cualitativo) de la participación ciudadana en el control, no sólo represivo ${ }^{914}$, sino también preventivo.

Respecto al control de naturaleza represivo, hay que ser destacada la circunstancia (hasta cierto punto reprochable) de que, en España, no se reconoce legitimación universal para que el ciudadano (que no sea candidato) pueda impugnar el proceso selectivo. En este sentido:

\begin{abstract}
"Muchos son los procedimientos selectivos y muchos los potenciales aspirantes. Pero el Ordenamiento Jurídico no quiere que nadie recurra por capricho o por fines ilegítimos. Por eso no hay acción pública en materia de concursos y oposiciones, y sólo podrá admitirse a trámite su recurso, ya sea administrativo o jurisdiccional, si existe algún beneficio material, moral o jurídico que puede derivarse de la anulación de la actuación administrativa del procedimiento selectivo concreto. En consecuencia, en sede contencioso-administrativo, en lo que atañe a la materia de acceso a la función pública no existe acción pública o legitimación universal, sino que se requiere la existencia de un interés legítimo, real y actual para impugnar una convocatoria selectiva o sus actos consiguientes. Y por supuesto, la legitimación exigible en vía contencioso-administrativa es la misma que se posee en vía administrativa" 915
\end{abstract}

En lo que se refiere al control preventivo, se impone que se incremente la intervención participativa de los ciudadanos desde el momento en que las normas (legales, reglamentarias y de las propias bases de la convocatoria) están en proceso de elaboración. ${ }^{916}$

\footnotetext{
${ }^{914} \mathrm{El}$ instituto de la acción popular también está previsto en la Constitución española:

"Artículo 125. Los ciudadanos podrán ejercer la acción popular y participar en la Administración de Justicia mediante la institución del Jurado, en la forma y con respecto a aquellos procesos penales que la Ley determine, así como en los Tribunales consuetudinarios y tradicionales."

${ }_{915}$ RAMÓN CHAVES GARCÍA, José. Op.cit., p. 215.

${ }^{916}$ Respecto a esta circunstancia, se ha subrayado que: "No sólo hay que destacar la defensa enérgica que corresponde realizar a los ciudadanos ante la lesión del derecho fundamental examinado, sino la participación en la elaboración de las disposiciones generales en materia de función pública. En este plano y sin perjuicio de la negociación con las organizaciones sindicales deben ser escuchados los interesados y las asociaciones que les representan" (MARTÍN MORENO, José Luís. El control de las oposiciones y concursos en el Estado Constitucional, Liberlex, 2007, p. 325).
} 
En el contexto brasileño, los legitimados para el control de los procesos selectivos son muchos, lo que necesariamente no significa que ejerzan su papel de la forma y con la intensidad con que se desearía.

Antes de todo, hay que subrayar que la propia Administración Pública posee no el poder, sino también el deber (deber-poder) de ejercer la autotutela de los actos administrativos, lo que impone su anulación siempre que estén viciados. En el ámbito de la Administración, los órganos encargados del control de legalidad de los procesos administrativos $^{917}$ tienen un relevante papel, especialmente en lo que se refiere a la actuación de naturaleza preventiva.

Otro legitimado para la fiscalización de los procesos selectivos brasileños es el Ministerio Público ${ }^{918}$, órgano com amplia autonomia, y que tiene como misión, según el art. 127 de la Constitución: “(...) a defesa da ordem jurídica, do regime democrático e dos interesses sociais e individuais indisponíveis”.

El Ministerio Público tanto puede actuar en el ámbito administrativo, a través de procedimientos investigativos (inquérito administrativo), donde puede solicitar informaciones respecto a actos de la Administración (en el caso, procesos selectivos), y, si necesario, instar la celebración de Termos de Ajustamento de Conduta, como también puede intervenir en el ámbito judicial, sea en el ámbito penal ${ }^{919}$, como en el civil, especialmente a través de la ação civil pública.

\footnotetext{
917 En este contexto, se puede destacar los órganos que hacen parte de la Abogacía Pública, como la Abocacía General de la Unión y las Procuradorias de los Estados, previstos en la propia Constitución brasileña (arts 131-132), y con funciones de judiciales (defensa de las entidades públicas) y extrajudiciales (consultoria, asesoramiento y control interno de legalidad de los actos administrativos).

918 En este contexto: "burlar um concurso público é o mesmo que agredir vários princípios constitucionais - e, portanto, a própria Constituição -, constituindo afronta ao patrimônio moral do Estado, que tem uma imagem a zelar perante a sua base de legitimação-o povo-, sendo poder-dever do Ministério Público o combate a esse tipo de prática, na qualidade de guardião do patrimônio público em sentido amplo." (BARBOSA MAIA, Márcio, y PINHEIRO DE QUEIROZ, Ronaldo. Op.cit., p. 157).

${ }^{919}$ Respecto a la represión penal de los actos ilícitos en los concursos públicos, se ha destacado que: "Apesar dessas disposições legais prevendo, inclusive como crime, punição para os administradores avessos à regra do concurso público, tal responsabilização não é fácil, na prática (...) a legitimidade para promoção dessas ações é do Ministério Público (Federal ou Estadual) que oficia na Justiça comum.(...). Outra dificuldade para encaminhamento dessa responsabilização é a identificação do autor do ato inconstitucional. Principalmente nas admissões sem concurso público, os infratores não costumam materializar a irregularidade. O trabalhador ingressa no serviço público mediante ordem verbal do Prefeito, Secretário municipal, Secretário de Estado, do próprio Governador ou outra autoridade com poderes para "empregar". E dificilmente se encontra uma carteira de trabalho anotada ou um ato de nomeação que comprove isso. Apenas aparece o nome do favorecido na folha de pagamento do órgão.
} 
Respecto a este instrumento, se ha dicho que:

"Dentre todos os instrumentos de controle jurisdicional do concurso público parece-nos que a ação civil pública ocupa um lugar de destaque, diante da legitimidade conferida ao Ministério Público na defesa dos direitos dos cidadãos, que no nosso país pouco sabem ou nada sabem quanto aos seus direitos perante a Administração Pública e à forma de exigi-los. Por outro lado, como defensor da ordem jurídica, o Ministério Público não pode abrir mão de eficaz instrumento capaz de impedir a realização de concursos públicos com flagrantes afrontas aos princípios abraçados no nosso ordenamento, que levam a uma seleção de candidatos bastante questionável, comprometendo, por conseguinte, a prestação de serviços essenciais à coletividade." 920

Otra institución que posee legitimidad de actuación en el control de los procesos selectivos es la Defensoría Pública, aunque aquella esté limitada a su competencia constitucional de defensa de los necesitados ${ }^{921}$, lo que, en Brasil, muchas veces abarca un grupo numeroso de personas. Una situación donde se suele percibir la actuación de la Defensoría Pública dice respecto a la lucha por la gratuidad para los necesitados en la inscripción en los concursos públicos.

También merece la pena citar la actuación del Tribunal de Cuentas en el control de los procesos selectivos de admisión de personal, considerado por la Constitución Federal como órgano auxiliar del Poder Legislativo y encargado, según el art. 70, de la “(...) fiscalização contábil, financeira, orçamentária, operacional e patrimonial(...)" de las entidades públicas ${ }^{922}$.

Esses dois aspectos dificultam bastante a formulação da notícia crime contra as autoridades públicas infratoras, e, consequentemente, sua punição. E muitos são os outros obstáculos encontrados pelo Ministério Público Federal e Estadual para responsabilizar tais infratores, na Justiça competente (...). Também por isso que, raramente, se vê uma autoridade pública punida por descumprir a regra do concurso público." (SOARES, Evanna. Percalços na implementação do concurso público. Texto extraído del sitio Jus Navigandi (http://jus2.uol.com.br/doutrina/texto.asp?id=13424).

${ }^{920}$ TOURINHO, Rita. Op.cit., p. 175.

921 "Art. 134. A Defensoria Pública é instituição essencial à função jurisdicional do Estado, incumbindolhe a orientação jurídica e a defesa, em todos os graus, dos necessitados, na forma do art. $5^{\circ}$, LXXIV'.

${ }^{922}$ Según la Constitución Federal:

"Art. 71. O controle externo, a cargo do Congresso Nacional, será exercido com o auxílio do Tribunal de Contas da União, ao qual compete: (...) III- apreciar, para fins de registro, a legalidade dos atos de 
Pese a la relevancia de actuación de los órganos citados (Abogacía Pública, Ministerio Público, Defensoría Pública y Tribunal de Cuentas), no hay dudas que el ciudadano es el gran legitimado para ejercicio del control de los procesos selectivos.

En el citado contexto, el ciudadano tanto es legitimado para actuar en la defensa del interés público ${ }^{923}$, a través de distintos mecanismos, sean administrativos (derecho de petición ${ }^{924}$ ) o judiciales.

Entre los instrumentos judiciales puestos a disposición del ciudadano, destacase la acción popular ${ }^{925}$. Respecto la misma se ha dicho que:

“No caso específico do concurso público poderá ser proposta ação popular visando contestar vícios constantes no edital do concurso ou na sua tramitação. Outra possibilidade é a de se argüir, através do referido remédio constitucional, a contratação irregular de pessoal, realizada pela Administração Pública, em substituição à nomeação precedida de aprovação em certame concursal" ${ }^{926}$

Aunque presente en el ordenamiento jurídico, el mencionado instrumento de la democracia participativa es poco utilizado en materia de concurso público, especialmente debido al bajo grado de concientización ciudadana ${ }^{927}$ (y jurídica) de la

admissão de pessoal, a qualquer título, na administração direta e indireta, incluídas as fundações instituídas e mantidas pelo poder público, excetuadas as nomeações para cargo de provimento em comissão, bem como a das concessões de aposentadorias, reformas e pensões, ressalvadas as melhorias posteriores que não alterem o fundamento legal do ato concessório";

${ }^{923}$ Sobre esta constatación, se ha dicho que: "resulta evidente que tudo quanto disser respeito a aspectos de legalidade, no sentido amplo, de um concurso público, comporta apreciação pelo Judiciário desde que provocado por quem tenha legítimo interesse para agir, seja um candidato prejudicado, seja qualquer cidadão na defesa da moralidade administrativa violada (CR, art. $5^{\circ}$, LXXII), seja o Ministério Público quando couber atuar" (CAMMAROSANO, Márcio. Concurso público: avaliação das provas. Vinculação ou discricionaridade?, en Concurso público e Constituição, Fabrício Motta (Cordinador), Editora Fórum, Belo Horizonte, 2005, p. 173).

${ }_{924}$ Según el art. $5^{\circ}$, XXXIV, a) de la Constitución Federal: "são a todos assegurados, independentemente do pagamento de taxas:a) o direito de petição aos Poderes Públicos em defesa de direitos ou contra ilegalidade ou abuso de poder";

${ }^{925}$ En los términos del art. $5^{\circ}$, LXXIII, de la Constitución Federal: "qualquer cidadão é parte legítima para propor ação popular que vise a anular ato lesivo ao patrimônio público ou de entidade de que o Estado participe, à moralidade administrativa, ao meio ambiente e ao patrimônio histórico e cultural, ficando o autor, salvo comprovada má-fé, isento de custas judiciais e do ônus da sucumbência";

${ }_{926}$ TOURINHO, Rita. Concurso público no ordenamento jurídico brasileiro, Lumen Juris Editora, Rio de Janeiro, 2008, p. 164.

${ }_{927}$ Sobre tal hecho, se ha subrayado que aunque el ciudadano sea candidato, no suele utilizarse de los médios de control: "Também nas mãos dos candidatos, ou de potenciais interessados, está a solução do problema. Muitos, lesados por normas ou decisões inconstitucionais ou injustas, deixam de recorrer ao 
población y a los revanchismos políticos que hacen con que el ciudadano no se sienta cómodo para ajuiciar demanda contra el Poder Público.

Respecto a la actuación del ciudadano cuando este ya tiene (o va a tener) la condición de candidato, cabe acentuar que el mismo podrá actuar siempre que su derecho constitucional de amplia accesibilidad a los cargos y empleos públicos esté bajo amenaza, debido a alguna actuación ilegítima de la Administración Pública. Sin embargo, como ya ha denunciado la doctrina:

“Alguns concursos públicos no Brasil são verdadeiramente imorais ao trazerem em seus editais normas que proíbam os candidatos a exercerem seu direito constitucional de peticionar à Administração Pública em busca da defesa de direito individual prejudicado. Tal situação não pode ser admitida, devendo o Poder Judiciário, quando chamado ao caso, anular essas normas, que se figuram abusivas. (...). Por força de decisões desse tipo, a sociedade, muitas vezes, deixa de ter em seus quadros, candidatos de excelente nível, que ao se depararem com essa situação, muitas vezes, deixam de realizar um determinado concurso por considerá-lo imoral e de sobremaneira injusto. O assunto não é tão abordado pelos envolvidos, sobretudo, pelo medo de possíveis e futuras represálias, motivo pelo qual, a maioria dos candidatos não chega nem ao ponto de levá-lo ao conhecimento e análise do Poder Judiciário",928

\subsection{6 - Imparcialidad y profesionalidad de los miembros de los órganos de selección}

En el derecho español, teniendo en consideración la relevancia del tema, el Estatuto Básico del Empleado Público adoptó expresamente dos principios relacionados

\footnotetext{
Judiciário, preferindo prejulgar esse Poder, como se ele fosse composto de um único homem, dirigindolhe descrença. Sequer o Ministério Público é provocado pelos candidatos para que promova, como é seu dever, medidas para sanar, preventiva ou repressivamente, irregularidades que atingem não somente os candidatos, mas toda a sociedade, pelo resultado que se pode esperar de um concurso fraudulento ou dirigido sem respeito ao princípio da impessoalidade. A cômoda e descabida desculpa de que não é útil recorrer ao Judiciário mantém os maus administradores no erro, incentivando-lhes, inclusive, à prática de outros desmandos, além de desamparar o caso concreto, que se omite da Justiça." (SANTOS, Waldir. Concurso público.Uma ferramenta democrática subutilizada. Texto extraído del sitio: http://jus2.uol.com.br/doutrina/texto.asp?id=3726, acceso en 16 de agosto de 2010).

928 BRAGA CALHAU, Lélio. Da inconstitucionalidade da decisão irrecorrível de bancas examinadoras de concurso público. Texto extraído del sitio: http://jus2.uol.com.br/doutrina/texto.asp?id=390, acceso en 16 de agosto de 2010.
} 
a los órganos de selección: lo que impone la imparcialidad y profesionalidad de sus miembros y garantiza la independencia y discrecionalidad técnica en su actuación.

Sobre el primero, se puede destacar que cuando se exige que la actuación de los miembros de los órganos de selección sea imparcial, se busca la eliminación de los actos que contemplan las apreciaciones de carácter personal. Esta circunstancia, probablemente, acontecería si los citados miembros tuvieran vínculos de amistad o parentesco con los aspirantes.

Por la razón arriba mencionada, la legislación vigente (Ley 30/1992) determina la abstención de la actuación en procedimientos administrativos de los funcionarios que mantienen alguna relación que compromete la imparcialidad. ${ }^{929}$

También se puede destacar que, según el ordenamiento jurídico, la imparcialidad también se vería comprometida si los miembros de los órganos de selección no poseyesen un vínculo de estabilidad, ya que, de esta forma, la precariedad que caracteriza a sus relaciones con la Administración no garantizaría que estuvieran libres de presiones políticas. Por esta razón, el Estatuto Básico del Empleado Público prohíbe en el art. 60.2 que determinados empleados públicos admitidos en carácter precario puedan estar presentes en los órganos de selección ${ }^{930}$.

Otra norma introducida con el objeto de garantizar la imparcialidad de los órganos de selección es la regla que determina la paridad entre hombres y mujeres en la composición de los referidos órganos (art. 60.1).

${ }^{929} \mathrm{El}$ art. 28.2 de la Ley 32/1992 (Ley de Procedimiento Administrativo) determina: "Son motivos de abstención los siguientes:

A) tener interés personal en el asunto de que se trate o en otro en cuya resolución pudiera influir la de aquél ser administrador de sociedad o entidad interesada, o tener cuestión litigiosa pendiente con algún interesado.

B) tener parentesco de consanguinidad dentro del cuarto grado o de afinidad dentro del segundo, con cualquiera de los interesados, con los administradores de entidades o sociedades interesadas y también con los asesores, representantes legales o mandatarios que intervengan en el procedimiento, así como compartir despacho profesional o estar asociado con éstos para el asesoramiento, la representación o el mandato.

C) tener amistad íntima o enemistad manifiesta con alguna de las personas mencionadas en el apartado anterior.

D) haber tenido intervención como perito o como testigo en el procedimiento de que se trate. E) Tener relación de servicio con persona natural o jurídica interesada directamente en el asunto, o haberle prestado en los dos últimos años servicios profesionales de cualquier tipo y en cualquier circunstancia o lugar."

930 "El personal de elección o de designación política, los funcionarios interinos y el personal eventual no podrán formar parte de los órganos de selección." 
La imparcialidad de la selección es esencial para que el trato concedido a los aspirantes sea igualitario, puesto que, de esta forma, todos serán tratados bajo los mismos criterios por la Administración Pública, sin que haya la posibilidad de que perjuicios, preferencias o revanchismos puedan contaminar las decisiones administrativas.

A su vez, cuando se exige que los miembros de los órganos de selección actúen con profesionalidad, lo que se desea es que "las personas que van a evaluar los candidatos sean idóneas, es decir, conocedoras de las materias sobre las que versarán las pruebas selectivas." 931

También cabe añadir que cada uno de los miembros del órgano seleccionador debe reunir las características necesarias para la evaluación de la labor a desempeñar por parte de los candidatos. Hay quien sostiene que "la falta de profesionalidad de alguno de esas personas podría determinar la nulidad del proceso selectivo, al menos en los casos que su intervención haya sido decisiva." ${ }^{932}$

Además, parece incuestionable que no es suficiente el dominio del área de conocimiento que se va a evaluar. El profesionalismo del seleccionador también impone que este sea apto para actuar de forma eficaz en la selección ${ }^{933}$.

En este sentido, "los conocimientos propios de área no bastan cuando hay que decidir entre varios candidatos y es necesario el dominio de técnicas de selección en las que hay que estar formado y entrenado." 934

Sobre la cuestión arriba citada, cabe enfatizar la deficiencia de las Administraciones Públicas en la capacitación de funcionarios para la conducción de procesos selectivos de acceso a la función pública, lo cual afecta a la calidad de la selección, que en numerosas ocasiones suele ser gestionada con amateurismo.

\footnotetext{
931 ILDEFONSO HUERTAS, Rosa María. Op.cit., p. 382.

932 SÁNCHEZ MORÓN, Miguel. Autor del capítulo décimo del libro Comentarios a la Ley del Estatuto Básico del Empleado Público, Miguel Sánchez Morón (Director); Federico A. Castillo Blanco, Alberto Palomar Olmeda, Tomás Sala Franco y Miguel Sánchez Morón (Autores) 2a ed., Editorial Lex Nova, Valladolid, 2008, p. 403.

933 El Estatuto Básico del Empleado Público sustituyó la expresión "especialización” por "profesionalidad". Este hecho hizo que la doctrina haya destacado que ahora se exige mucho más de los miembros de los órganos de selección, que además del conocimiento de las materias, también deben tener dominio de las técnicas selectivas. (LÁZARO, José Luis. Op.cit., p. 693).

${ }^{934}$ ILDEFONSO HUERTAS, Rosa María, Op.cit., p. 382.
} 
En el derecho brasileño, debido a la ausencia de ley que trate de forma detallada del acceso a la función pública, las exigencias de imparcialidad y de profesionalidad de los miembros de los órganos de selección es advertida solamente por la doctrina ${ }^{935}$.

Así, se puede destacar, por ejemplo, respecto a la imparcialidad, que los funcionarios públicos que hacen parte de la comisiones de organización y evaluación del concurso público no pueden tener interés en los resultados ${ }^{936}$. En este camino:

"Os membros da Comissão de Concurso, de regra, são servidores públicos, e não podem ter qualquer interesse na realização do concurso público. Existindo, estão impedidos e assim devem ser substituídos. Não o fazendo, poderão sofrer a argüição de suspeição por qualquer interessado legítimo no âmbito da própria comissão ou através de ações de controle como mandado de segurança, ou até mesmo a ação civil pública pelo Ministério Público. A permanência do membro da comissão impedido poderá acarretar a nulidade do concurso." ${ }^{937}$

A su vez, en el que refiere a la exigencia de profesionalidad, hay doctrinadores brasileños que exigen la presencia de la mencionada característica en las comisiones de los concursos públicos:

\footnotetext{
${ }^{935}$ En verdad, las leyes que tratan del proceso administrativo en general establecen las circunstancias que impiden la actuación de los funcionarios públicos. Son las hipótesis de "impedimento e suspeiçao", como se puede verificar en la ley federal 9784/99:

"Art. 18. É impedido de atuar em processo administrativo o servidor ou autoridade que:

I - tenha interesse direto ou indireto na matéria;

II - tenha participado ou venha a participar como perito, testemunha ou representante, ou se tais situações ocorrem quanto ao cônjuge, companheiro ou parente e afins até o terceiro grau;

III - esteja litigando judicial ou administrativamente com o interessado ou respectivo cônjuge ou companheiro.

Art. 19. A autoridade ou servidor que incorrer em impedimento deve comunicar o fato à autoridade competente, abstendo-se de atuar.

Parágrafo único. A omissão do dever de comunicar o impedimento constitui falta grave, para efeitos disciplinares.

Art. 20. Pode ser argüida a suspeição de autoridade ou servidor que tenha amizade íntima ou inimizade notória com algum dos interessados ou com os respectivos cônjuges, companheiros, parentes e afins até o terceiro grau.

Art. 21. O indeferimento de alegação de suspeição poderá ser objeto de recurso, sem efeito suspensivo".

${ }^{936}$ En este sentido: "Obviamente que o concurso público seria de absoluta inutilidade caso inexistisse a imparcialidade da banca examinadora. Assim, há situações que revelam a incapacidade subjetiva absoluta ou relativa que impedem a participação no mencionado órgão colegiado. Fala-se então de situação de impedimento e suspeição." (TOURINHO, Rita. Op.cit., p. 64).

${ }^{937}$ PACHECO BARROS, Wellington. Op.cit., p. 39.
} 


\begin{abstract}
"As provas deverão ser elaboradas por profissionais qualificados, com habilitação específica na área que se pretende avaliar e, preferencialmente, com experiência no magistério. A qualificação que esses profissionais deverão ter varia de acordo com a natureza e a complexidade dos cargos ou empregos a serem preenchidos. Assim, quanto maior for a complexidade do cargo, mais qualificado deverá ser o profissional responsável por elaborar a prova." ${ }^{938}$
\end{abstract}

Además, como hay una manifiesta ausencia de planificación de los procesos selectivos en Brasil, destaca la doctrina que la profesionalidad impone no sólo la presencias de funcionarios con conocimientos técnicos del área de evaluación de las pruebas $^{939}$, sino también respecto a la organización y conducción de concursos públicos.

En este sentido: "os membros indicados não só devem ter idoneidade funcional, mas conhecimentos específicos sobre a realização de um concurso, sob pena de ações tumulturárias no seu desenvolvimento." 940

\title{
4.2.7 - Independencia y discrecionalidad técnica en la actuación de los órganos de selección
}

Como ya se ha visto, la actuación de los órganos encargados de la selección de los funcionarios públicos se debe caracterizar por la imparcialidad y profesionalidad, todo esto para garantizar que la decisión administrativa se base exclusivamente en los criterios de mérito y capacidad.

Es usual la afirmación que sostiene el carácter técnico de los juicios y decisiones de los mencionados órganos, debido a la exigencia de profesionalismo

\footnotetext{
${ }^{938}$ LOBELLO DE OLIVEIRA ROCHA, Francisco. Op.cit., p. 128.

939 Así: "O Administrador encarregado de elaborar provas objetivas em concursos públicos deve estar ciente de que sua tarefa é, sobretudo, técnica. Daí porque recomendável que os técnicos e especialistas, em cada matéria, sejam escolhidos para composição de uma Banca Examinadora" (MEDINA OSÓRIO, Fábio. Os limites da discricionariedade técnica e as provas objetivas nos concursos públicos para ingresso nas carreiras jurídicas, em Revista Diálogo Jurídico, n 13, abril-mayo de 2002, Salvador, p. 13, extraído del sitio: http://www.direitopublico.com.br/PDF_13/DIALOGO-JURIDICO-13-ABRIL-MAIO2002-FABIO-MEDINA-OSORIO.pdf, acceso en 16 de agosto de 2010.).

${ }^{940}$ PACHECO BARROS, Wellington. Op.cit., p. 43.
} 
(especialización) de sus miembros, lo que hace que sus evaluaciones ostenten una presunción de legitimidad.

Evidentemente, si los miembros de los órganos de selección han sido escogidos por sus calificaciones, por su capacidad de discernimiento, es sensato que sus apreciaciones se acepten como razonables. Por esta razón, se dice que "el discernimiento del mérito y la capacidad de los aspirantes a una plaza en la función pública ha de corresponder en exclusiva a los tribunales y órganos calificadores integrados por personas dotadas de la debida calificación científica en la materia propia de la función pública y situadas en una posición de imparcialidad objetiva."941

Para que los órganos de selección puedan emitir sus apreciaciones de forma ajustada, hay que garantizar la independencia de su actuación, así como de sus miembros, lo cual ha provocado que, en el derecho español, el Estatuto Básico del Empleado Público haya determinado en el art. 60.3 que la pertenencia a los órganos de selección sea siempre a título individual, no pudiendo ostentarse ésta en representación o por cuenta de nadie.

Lo que se busca evitar es que los órganos de selección estén formados por personas que actúan en nombre de determinados grupos de interés (sindicatos, partidos políticos, asociaciones, etc.), puesto que tales vínculos podrían poner en riesgo la imparcialidad de sus apreciaciones.

También se puede subrayar sobre la independencia de los órganos de selección que "tales órganos no pueden estar sujetos a instrucciones de ningún tipo, ni a interferencias o influencia espurias por parte de persona o organización alguna. Algo no siempre fácil de lograr en la práctica." ${ }^{942}$

Además, los órganos de selección actúan con discrecionalidad técnica, que es consecuencia lógica de su profesionalidad. La mencionada característica hace que los órganos bajo análisis tengan la capacidad de valorar los méritos y capacidades de los

\footnotetext{
${ }^{941}$ MAURI BAJÓS, Joan. Op.cit., p. 260.

942 SÁNCHEZ MORÓN, Miguel. Autor del capítulo décimo del libro Comentarios a la Ley del Estatuto Básico del Empleado Público, Miguel Sánchez Morón (Director); Federico A. Castillo Blanco, Alberto Palomar Olmeda, Tomás Sala Franco y Miguel Sánchez Morón (Autores) 2a ed., Editorial Lex Nova, Valladolid, 2008, p. 403.
} 
candidatos según patrones técnicos y científicos, lo que hace que sus evaluaciones sean, a priori, consideradas adecuadas.

Sobre el ejercicio de la referida potestad, se puede destacar que esto es:

$$
\begin{aligned}
& \text { "insustituible, de tal manera que el núcleo sustantivo de la } \\
& \text { discrecionalidad técnica -la valoración- no puede ser sustituido por } \\
& \text { ningún otro órgano, administrativo o judicial, en vía de recurso o } \\
& \text { revisión de oficio, salvo que se constate algún vicio de procedimiento } \\
& \text { o de formación de la voluntad del órgano o de la libertad de decisión } \\
& \text { de sus miembros o la existencia de desviación de poder." }
\end{aligned}
$$

En el derecho brasileño, la exigencia de independencia de los órganos de selección es subrayada por la doctrina y reconocida por los Tribunales, así como la presencia de discrecionalidad técnica en sus deliberaciones.

Así, respecto a la primera exigencia (independencia), la doctrina ha destacado "a necessidade de se criar órgãos colegiados dotados de ampla autonomia administrativa, técnica e científica para a execução de atividades relacionadas à seleção e ao recrutamento de pessoal, sem a ingerência política das autoridades superiores dos órgãos e das entidades diretamente interessadas no concurso público."944

Sin embargo, como ya se ha subrayado en este trabajo, una gran dificultad que surge en el contexto brasileño es la ausencia de legislación que defina los límites de la discrecionalidad, aunque esta ostente un carácter técnico.

En verdad, se puede ratificar integralmente la opinión doctrinaria que sostiene que "a falta de regulamentação legal do instituto do concurso público realmente tem dado azo a uma ampla margem de discricionariedade às bancas examinadoras no que se refere à valoração e à escolha dos critérios de avaliação dos candidatos e das demais condições gerais do concurso público." 945

\footnotetext{
943 SÁNCHEZ MORÓN, Miguel. Idem, p. 404.

944 BARBOSA MAIA, Márcio, y PINHEIRO DE QUEIROZ, Ronaldo. Op.cit., p. 83.

945 BARBOSA MAIA, Márcio, y PINHEIRO DE QUEIROZ, Ronaldo. Idem, p. 37.
} 
Aunque el entendimiento que defiende la amplia discrecionalidad de las comisiones de concursos públicos en Brasil sea mayoritario, ya surgen algunas voces que analizan con más racionalidad la cuestión relativa a los límites de la referida potestad $^{946}$. En este camino, se puede destacar que:

"É certo que existem margens imensas de liberdade na eleição dos temas dentro do amplo universo do Edital. É certo, também, que dentro de cada tema é possível formatar numerosas perguntas, aí incidindo, desde logo, a subjetividade do Administrador Público, seus valores e convicções íntimos, suas preferências e seus desejos, sendo viável realizar escolhas extremamente elásticas e flexíveis. Esse subjetivismo não é, todavia, absoluto, nem incontrolável em todos seus aspectos, porque não se confunde com arbitrariedade. A discricionariedade envolve decisões administrativas e, portanto, jurídicas, sujeitas ao império dos princípios constitucionais que presidem a Administração Pública, v.g., legalidade, eficiência, impessoalidade, publicidade e moralidade administrativas (art. 37, caput, $\mathrm{CF} / 88$ ), além de submeter-se aos princípios constitucionais da igualdade, devido processo legal, razoabilidade, direitos de defesa das posições jurídicas, motivação administrativa e interdição à arbitrariedade dos Poderes Públicos, garantias dos administrados vazadas em normas constitucionais. Os limites jurídicos da discricionariedade administrativa constituem inevitável decorrência do Estado Democrático de Direito, eis que nessa espécie de ordem normativa não há poderes absolutos ou incontroláveis" ${ }^{947}$

\footnotetext{
${ }^{946}$ De forma adecuada, se ha dicho que:"Há certas particularidades nos concursos públicos, no entanto, que fazem remanescer margem para atuação discricionária mesmo após a elaboração do edital. Ocorre que a aplicação de provas no decorrer do concurso, especialmente as provas de conhecimento, exige a manutenção do sigilo quanto às questões formuladas. Isto dá espaço à existência de decisões de mérito dos membros da banca examinadora - ressalte-se, apenas para escolher as questões a serem abordadas, não para escolher as respostas corretas - mesmo após a publicação do edital. (...) No caso de restar alguma margem de discricionariedade após a elaboração do edital, esta deverá, ainda, ser exaurida antes de os atos produzirem efeito, ou seja, antes de os candidatos cumprirem ou demonstrarem os requisitos exigidos. Isto porque as normas do concurso devem ser genéricas e, se a comissão examinadora define requisitos após conhecer os candidatos e seus atributos, estes ficam comprometidos." (LOBELLO DE OLIVEIRA ROCHA, Francisco. Op.cit., p. 23).

${ }^{947}$ MEDINA OSÓRIO, Fábio. Os limites da discricionariedade técnica e as provas objetivas nos concursos públicos para ingresso nas carreiras jurídicas, em Revista Diálogo Jurídico, $\mathrm{n}^{\circ} 13$, abril-mayo de 2002, Salvador, p. 13, extraído del sitio: http://www.direitopublico.com.br/PDF_13/DIALOGOJURIDICO-13-ABRIL-MAIO-2002-FABIO-MEDINA-OSORIO.pdf, acceso en 16 de agosto de 2010.
} 
Por supuesto, la complejidad de este tema (y su carácter polémico) hace que sea necesario su análisis de forma más intensa en los próximos apartados, que serán dedicados a la discrecionalidad técnica y su control en el ámbito del proceso selectivo de acceso a la función pública.

\subsubsection{1 - La discrecionalidad técnica en el derecho español}

No hay duda de que, con relación a todos los temas del Derecho Administrativo, el control judicial de la discrecionalidad administrativa es lo que más polémica causa en los medios jurídicos ${ }^{948}$, tanto, que respecto a las cuestiones que envuelven las oposiciones y concursos, el examen de las posibilidades de control jurisdiccional de la Administración "presenta innumerables problemas y exige, pese a lo que en un primer momento pudiera parecer, cuestionarse no pocos de los interrogantes que hoy hacen tambalear las bases mismas de las concepciones más clásicas del Derecho Administrativo." 949

Es una circunstancia innegable que a la hora de realizar la selección de los mejores no se puede pedir a los órganos de selección decisiones matemáticas. ${ }^{950}$ En el control de los procesos selectivos, los Tribunales de la Jurisdicción Contenciosoadministrativa suelen basar sus sentencias en la necesidad de salvaguardia de la "discrecionalidad técnica" que dispone las Comisiones calificadoras.

Sobre este tema, la doctrina explica que:

"El control mínimo es aquí la regla, que se aplica sistemáticamente por nuestros Tribunales sin embarazo alguno, sobre la sola base de la afirmación apodíctica de la "soberanía" (sic) de las Comisiones calificadoras de las oposiciones y concursos, cuyo juicio profesional y

\footnotetext{
${ }^{948}$ Para Domingo Sesín“....desde hace aproximadamente dos siglos, el Derecho Administrativo busca establecer un justo equilibrio que haga posible la convivencia de lo discrecional, lo reglado y lo técnico, la autoridad y la libertad, lo determinado y lo indeterminado, lo político y lo jurídico." (SESÍN, Domingos. "El control judicial de la discrecionalidad administrativa", en Documentación Administrativa, n. 269-270 (mayo-diciembre 2004), Madrid, p. 87.)

949 PIÑAR MAÑAS, José Luís. "El pleno control jurisdiccional de los concurso y oposiciones", en Documentación Administrativa, n.220 (octubre-diciembre 1989), Madrid, p. 135.

${ }^{950}$ LÁZARO ALBA, Eduardo y GONZÁLEZ BOTIJA, Fernando. "A vueltas con la discrecionalidad técnica en oposiciones y concursos: jurisprudencia reciente y reflexiones críticas", en Revista Española de Derecho Administrativo, Civitas n. 127, 2005, p. 521
} 
técnico, formulado de conformidad con los meritos alegados $\mathrm{y}$ probados por los aspirantes, que no se puede impugnar." 951

Usualmente, la Jurisdicción Contencioso-administrativa afirma que como la discrecionalidad técnica de la Administración proviene de la especialización de sus órganos, el Poder Judicial no puede verificar los criterios profesionales de las decisiones administrativas en los procesos selectivos, sustituyendo tales criterios (de los miembros de las Comisiones) por los suyos.

El argumento utilizado es muy sencillo: si los órganos de selección están formados por profesionales que poseen amplios conocimientos técnicos y específicos respecto al área relacionada al proceso selectivo, hay una presunción de que sus decisiones son adecuadas, no siendo posible que los Jueces, que tan solo poseen conocimientos jurídicos, puedan rechazar tales decisiones técnicas ${ }^{952}$. Además, sería una intervención no admitida por el principio de separación de los Poderes.

Como se ha visto, en el Estatuto Básico del Empleado Público (art. 55.2, c) y d)), se imponen como principios del proceso selectivo la imparcialidad y profesionalidad de los miembros de los órganos de selección y la independencia y discrecionalidad técnica en la actuación de los órganos de selección.

En los términos arriba subrayados, la propia legislación vigente legitima la presunción de imparcialidad y profesionalidad de los componentes de las Comisiones calificadoras, lo cual se ve reforzado por la circunstancia de que tales órganos administrativos poseen independencia y discrecionalidad técnica en su actuación.

Así, la teoría defendida usualmente es que los órganos jurisdiccionales no pueden convertirse en Comisiones calificadoras cuyas potestades valorativas sólo

\footnotetext{
951 R.FERNANDEZ, Tomás. De la arbitrariedad de la Administración, tercera edición, Civitas, Madrid, 1999 , p. 35

952 Según la doctrina española, tradicionalmente, para los Tribunales del Contensioso-Administrativo, "...el fundamento de la prerrogativa de declarar el juicio técnico blindado por la discrecionalidad es triple: la imparcialidad, la especialización y la inmediatez. La imparcialidad elimina el riesgo de desviaciones de juicio para favorecer a un aspirante; la especialización del Tribunal evita el juicio errado por desconocimiento; y la inmediatez asegura que el juicio se realice de forma espontánea y directa sobre los méritos o aptitud del aspirante" (RAMÓN CHAVES GARCÍA, José. Control de concursos y oposiciones en la jurisprudencia, Editorial Reus, Colección Claves de la Jurisprudencia, Madrid, 2009, p. 230.
} 
corresponden a tales órganos de la Administración. En el camino arriba demostrado, el Tribunal Constitucional ya destacó que el control judicial:

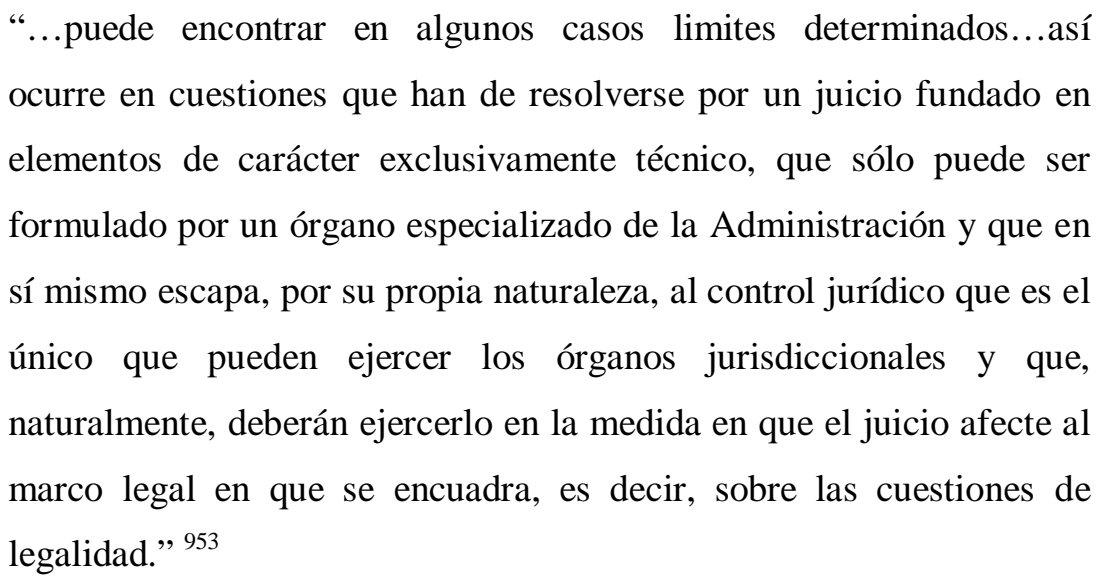

A su vez, en el contexto de la doctrina, para resumir la posición que suele (o al menos solía) prevalecer respecto al control de los actos de los Tribunales Calificadores, se ha acentuado que:

"Tradicionalmente, en el ámbito de las oposiciones y los concursos para acceder al empleo público, se ha aplicado el dogma de la discrecionalidad técnica de las Comisiones y Tribunales Calificadores fundada en su especialización, que cerraba el paso a la revisión por la Jurisdicción Contencioso-Administrativa. En términos simples, si el legislador confía o doposita en el Tribunal Calificador la responsabililidad de valorar méritos y pruebas, ni la propia Administración Pública ni nos Tribunales pueden sustituirlo. La Ley no ha declarado que los Tribunales calificadores administrativos sean infalibles pero sí desea que sus juicios tengan la fuerza de la infalibilidad"954

Sin embargo, aunque el citado entendimiento respecto al control de la discrecionalidad técnica sea la "opción más cómoda" para la mayoría de las sentencias de la Jurisdicción contencioso-administrativa, cuando analizan la actuación de las Comisiones calificadoras de procesos selectivos de acceso a la función pública, también se puede encontrar muchas opiniones doctrinarias y algunas sentencias que admiten un control más intenso.

${ }^{953}$ Sentencia del Tribunal Constitucional de 17 de mayo de 1983

${ }^{954}$ RAMÓN CHAVES GARCÍA, José. Op.cit., p. 229. 
De forma general, se puede subrayar que el argumento más admitido para permitir el control judicial de las decisiones de los Tribunales de oposiciones es la desviación de poder, tras, evidentemente, del incumplimiento de las bases de las convocatorias (control de legalidad formal). Así, si la Administración Pública favorece o persigue a uno de los aspirantes, seria legítima la intervención judicial.

Respecto a esa afirmación, que traduce el pensamiento tradicional de los Tribunales españoles, una lección clásica debe ser aquí expuesta: "El fallo del Tribunal examinador (...) no es un acto administrativo susceptible de impugnación, salvo cuando se justifica la existencia de dolo, coacción, violencia, error originado por tercero o justificación de infracciones de las normas reglamentarias aplicables." 955

Además, hay casos en que, de forma tímida, los Tribunales del Contenciosoadministrativo determinan la anulación de actos de las Comisiones calificadoras, a través de una simple evaluación de los resultados de las pruebas y valoración de los méritos, cuando sea posible percibir que las resoluciones administrativas son equivocadas o desproporcionales. ${ }^{956}$

En algunas sentencias "aisladas", incluso de los mismos Tribunales Supremo y Constitucional, hay una visión más amplia del alcance del control jurisdiccional sobre la discrecionalidad. Por ejemplo: el Tribunal Supremo decidió que el entendimiento de que los Tribunales jurisdiccionales tienen siempre que resignarse delante de los juicios técnicos del Tribunal calificador en cuanto compuesto por especialistas en la materia conduciría:

“...a la incorrecta conclusión de sometimiento del Juzgador a las apreciaciones del órgano administrativo cuyo acto calificador es precisamente el objeto de la revisión contencioso-administrativa, lo que en el nivel pragmático implicaría claro quebranto de la tutela jurisdiccional efectiva asegurada por el artículo 24.1 de la

\footnotetext{
${ }^{955}$ SERRANO GUIRADO, Enrique. El régimen de oposiciones y concursos de funcionarios, Instituto de Estudios Políticos, Madrid, 1956, p. 300-303, en PIÑAR MAÑAS, J. L., "El pleno control jurisdiccional de los concurso y oposiciones", en Documentación Administrativa, n.220 (octubre-diciembre 1989), Madrid, nota 1, p. 136.

${ }^{956}$ Sentencia de Tribunal Supremo de 27 de junio de 1986.
} 
Constitución al quedar así de hecho inimpugnables las estimaciones técnicas del mencionado Tribunal calificador." 957

La cuestión que surge es: si es admisible el control judicial de las decisiones técnicas de los Tribunales calificadores, ¿cómo sería posible al Juzgador constatar que la valoración administrativa está equivocada y que, por tanto, no debe ser preservada? En la misma sentencia arriba transcrita, el Tribunal Supremo destaca que las valoraciones de los Tribunales Calificadores pueden ser “...desvirtuadas por elementos probatorios, periciales o no, que es a la parte recurrente a quien corresponde aportar para que, en definitiva, el Juzgador pueda pronunciarse en valoración conjunta de la prueba y con arreglo a criterios lógicos."

Entre las dos posiciones ya mencionadas, una más conservadora y otra más avanzada en el sentido de admitir el pleno control, aparece una tercera, que consiste en la limitación a un control mínimo en lo referente a la valoración de exámenes y pruebas y en la afirmación de un control normal o pleno en lo concerniente a la valoración de los méritos. ${ }^{958}$ En relación a este entendimiento, puede ser subrayada la Sentencia del Tribunal Supremo que afirma que:

“...aunque es cierto que para calificar los ejercicios, teóricos o prácticos, de una oposición el Tribunal goza de una soberanía y discrecionalidad inevitable....en cambio, no dispone de aquéllas...cuando se trata de la estimación de méritos y de aplicar el baremo correspondiente, por ser este un elemento objetivo y normativo que impone un respecto incluso superior al concedido a las Bases específicas de la convocatoria..." 959

En la doctrina del Derecho Administrativo español, también hay quien piensa que las decisiones de las Comisiones calificadoras, como cualquier actividad administrativa, están sometidas plenamente al control jurisdiccional, aunque esto presente mayores dificultades. Es más: si el propio Tribunal Supremo hace referencia al "desconocimiento de todos los elementos para juzgar" para negar la posibilidad de

\footnotetext{
957 Sentencia del Tribunal Supremo de 02 de abril de 1985

${ }_{958}$ R.FERNANDEZ, Tomás. Op.cit., p. 42.

${ }^{959}$ Sentencia del Tribunal Supremo de 17 de abril de 1986.
} 
control jurisdiccional, significa que “...cuando estos datos se conocen y pueden contrastarse, el juicio debe ser posible." $" 960$

En realidad, en el análisis judicial de las actuaciones de los órganos de selección, hay situaciones de zona de certeza positiva, otras de zona de certeza negativa y las zona de penumbra o gris (de dudas), que se ubica entre ambas. ${ }^{961}$ En las dos primeras situaciones, el Juzgador está obligado a reconocer lo obvio, pero en la tercera, sólo los órganos técnicamente especializados podrán evaluar la cuestión y emitir un juicio de valor, que será eminentemente técnico.

Sin embargo, en estos casos, la necesidad de motivación está siempre presente, para que todos aquellos que no disponen de conocimientos técnicos específicos puedan convencerse de las razones que condujeron a la decisión. Respecto al deber de motivación (previsto en el art. $54^{962}$ de la Ley 30/1992, que regula el Procedimiento Administrativo Común), la legislación ha exigido que queden acreditados los fundamentos de la decisión respecto a la selección.

Así, para que la decisión de las Comisiones calificadoras sea objetiva e imparcial, es necesario que antes de las evaluaciones, estas ya sean sometidas a criterios precisos y claros, y que tras la valoración, tal operación sea revelada al público.

Los referidos criterios previos son balizas que sirven para ofrecer una densidad normativa más intensa a los conceptos jurídicos indeterminados. No obstante, en diversos procesos selectivos, las bases reguladoras atribuyen expresamente al órgano

960 SESÍN, Domingos. "El control judicial de la discrecionalidad administrativa", Documentación Administrativa, n. 269-270 (mayo-diciembre 2004), Madrid, p. 154

${ }^{961}$ SESÍN, Domingos. Op.cit., p. 90.

962 Respecto a la aplicación de la citada norma en el contexto de los procesos selectivos, debe ser destacado que el deber de motivación ocurre especialmente: en relación al apartado 1 del art. 54, en los ítems a), que trata de los actos que afetan derechos subjetivos (de acceder a la función pública en condiciones de igualdad); y f), que dice respecto a los actos praticados en el ejercicio de potestades discrecionales; además del apartado 2, que exige expresamente la motivación de los actos que pongan fin a los procedimientos selectivos y de concurrencia competitiva.

"Artículo 54. Motivación.

1. Serán motivados, con sucinta referencia de hechos y fundamentos de derecho:

a. Los actos que limiten derechos subjetivos o intereses legítimos.(...)

$b$. Los que se dicten en el ejercicio de potestades discrecionales, así como los que deban serlo en virtud de disposición legal o reglamentaria expresa.

2. La motivación de los actos que pongan fin a los procedimientos selectivos y de concurrencia competitiva se realizará de conformidad con lo que dispongan las normas que regulen sus convocatorias, debiendo, en todo caso, quedar acreditados en el procedimiento los fundamentos de la resolución que se adopte". 
encargado facultades o poderes para apreciar subjetivamente ciertos méritos que presentan mayor grado de indeterminación lógica, como sucede cuando se admite "título equivalente" a otro concreto, o "haber desempeñado plaza análoga"963.

Por eso, si las bases de la convocatoria fueran redactadas de la forma más precisa posible, a lo mejor sólo habría una única solución admisible. En este sentido: "las decisiones que tengan un determinado nivel de programación (densidad normativa que puede venir determinada por el legislador o por la propia Administración) el intérprete, ya sea el administrador o el juez, sí podría extraer del Derecho esa única solución válida." 964

Para que sea posible una mejor exposición (y consecuente comprensión) de las peculiaridades del control de los actos de los procesos selectivos, especialmente el ejercido por el Poder Judicial, cabe destacar una sentencia del Tribunal Constitucional de España que versa sobre el tema del control judicial de la discrecionalidad administrativa en las oposiciones y concursos ${ }^{965}$.

En la citada oportunidad, el Instituto Nacional de Técnica Aeroespacial (INTA), mediante Resolución del 27 de diciembre de 1990, había convocado pruebas selectivas para el ingreso en la escala de Científicos Superiores, área de especialización Física de Ionosfera. El procedimiento administrativo contaba con la participación de tres candidatos. Uno de ellos, tras la Resolución final, interpuso recurso admistrativo (sin éxito) y posteriormente un recurso contencioso-administrativo, alegando la no observación de las reglas del proceso selectivo por el Tribunal calificador.

\footnotetext{
963 MOZO SEOANE, A. La discrecionalidad de la Administración Pública en España. Análisis jurisprudencial, legislativo y doctrinal, 1834-1983, Editorial Montercorvo S.A., Madrid, 1985, 329.

964 BELTRÁN DE FELIPE, Miguel. "Discrecionalidad administrativa y Constitución”, en Temas Clave de la Constitución Española, Tecnos, Madrid, 1995, p. 111.

965 "DERECHO FUNDAMENTAL A ACCEDER EN CONDICIONES DE IGUALDAD A LAS FUNCIONES Y CARGOS PÚBLICOS: Cargo público no representativo: alcance: opera reaccionalmente en una doble dirección: por un lado, respecto a la potestad normativa para configurar el procedimiento de acceso y selección, permitiendo la impugnación de aquellas bases de convocatoria que desconocieren los principios de merito y capacidad, de otra, que garantiza la igualdad de oportunidades en el acceso a la función pública: doctrina constitucional. Jurisdicción y Proceso Contencioso-Administrativo: pruebas selectivas para el ingreso en la escala de Científicos Superiores del INTA, área de Física da Ionosfera: discrepancia con la valoración de las dos fases de las pruebas llevadas a cabo por el Tribunal seleccionador: ámbito de la "discrecionalidad técnica": escapan del control de la jurisdicción contencioso-administrativa: vulneración inexistente." (STC de 22 de marzo de 1999).
} 
La principal cuestión que el candidato argumentó fue que, en relación a los méritos analizados, el trabajo presentado por el vencedor no tenía carácter científico y no habría tratado sobre la física de la estratosfera, mientras que su trabajo habría estudiado efectivamente la física de la ionosfera.

La Sala Segunda del Tribunal Constitucional no aceptó los argumentos del recurrente, y, a través de la Sentencia del 22 de marzo de 1999, consideró que, en el caso analizado, no sería posible intervenir en el proceso selectivo, en especial, en la valoración de las pruebas que llevó a cabo el Tribunal calificador.

En la sentencia aquí analizada, el Tribunal Constitucional fundamentó su fallo en la imposibilidad de intervención en la discrecionalidad técnica de la valoración de las pruebas por la Comisión evaluadora de la oposición. El Tribunal Constitucional entendió que el recurrente "...se limita a anteponer sus propios criterios valorativos a los empleados por el Tribunal...".

De hecho, lo que llama la atención es que el Tribunal Constitucional ni siquiera osó verificar si el trabajo presentado por el candidato vencedor era o no de carácter científico, a pesar de que el recurrente afirmaba que aquel seria era de carácter meramente estadístico, y si el trabajo decía respecto o no a la Física de la Ionosfera.

Evidentemente, ningún miembro del Poder Judicial está obligado a tener conocimientos científicos relacionados con la Física. Por supuesto, la Comisión calificadora creada por el Instituto Nacional de Técnica Aeroespacial (INTA) para conducir la pruebas selectivas para el ingreso en la escala de Científicos Superiores, área de especialización Física de la Ionosfera, podía efectivamente analizar si el trabajo presentado por el candidato vencedor estaba o no relacionado con el citado sector científico.

Suponiendo que la convocatoria decía que solamente serían admitidos trabajos científicos que tuviesen relación directa con el puesto de trabajo a ser cubierto, estaríamos delante de un concepto jurídico indeterminado, que ocurre cuando hay una regla en cuyo lenguaje hay un concepto cuyos límites son imprecisos. En estos casos, siempre hay una zona de certeza positiva, otra zona de certeza negativa y otra zona de 
penumbra (de dudas), que se ubica entre ambas. ${ }^{966}$ En otras palabras: sobre el fallo que está siendo analizado, habrá trabajo científico que todos dirán que indubitablemente tiene relación directa con la función pública de Científico Superior, área de especialización Física de la Ionosfera. Respecto a otros trabajos todos serán unánimes y dirán: “No, no tiene ninguna relación directa con el puesto de trabajo.”. Sin embargo, en algunos casos, podrán existir dudas.

Así, por ejemplo, si las bases de la convocatoria del concurso-oposición analizado en este estudio establecían que los candidatos podían presentar como mérito publicaciones de trabajos científicos con relación directa con el puesto de trabajo a ser cubierto, las convocatorias también deberían haber precisado las características del trabajo científico a ser presentado por los aspirantes, como contenido (ej.: asuntos afrontados, y todo lo que fuera necesario para explicar lo que significa trabajo científico), forma (ej.:, número mínimo de páginas), especie de publicación (ej.: revistas científicas), período de publicación (ej.: en los últimos diez años), entre otros aspectos.

En la Sentencia analizada, probablemente, el Tribunal Constitucional estaba ante un vacío de información, causado, quizá, por la escasa precisión de los términos de la convocatoria y por la extrema especificidad técnica de la cuestión. En estos casos, si la decisión administrativa era razonable y motivada, debe prevalecer el principio de presunción de legalidad de los actos administrativos, además del reconocimiento de la propia ley de que los miembros de las Comisiones calificadoras actúan con imparcialidad y profesionalidad, y que los órganos de selección se conducen con independencia y discrecionalidad técnica.

De hecho, sería temerario exigir que el Tribunal Constitucional analizara la adecuación de un trabajo científico relacionado a la Física de la Ionosfera, actividad que demandaría la intervención de un órgano técnico versado en el tema mencionado, lo que comprobadamente ya existía en el proceso selectivo analizado.

En definitiva, en el contexto español, la discusión respecto al control de las actuaciones de los Tribunales Calificadores de las oposiones aún está muy lejos de

966 SESÍN, Domingos. "El control judicial de la discrecionalidad administrativa", Documentación Administrativa, n. 269-270 (mayo-diciembre 2004), Madrid, p. 90 
llegar al consenso, que ciertamente no será en ningún de los puntos extremos (ausencia de control y control ilimitado).

De momento, conviene destacar, como ha acentuado el STSJ de Madrid, "los esfuerzos que la jurisprudencia y la doctrina han realizado y realizan para que tal control judicial sea lo más amplio y efectivo posible". Sin embargo, la misma sentencia ha subrayado que "no puede olvidarse tampoco que ese control puede encontrar en algunos caso límites determinados"967.

\subsubsection{2 - La discrecionalidad técnica en el derecho brasileño}

En Brasil, el problema de la posibilidad de control de la evaluación de las evaluaciones de los órganos seleccionadores también llegó al seno de la doctrina, aunque los debates sean limitados a un pequeño grupo de juristas. ${ }^{968}$

En los últimos años, ya se percibe que hay algunos administrativistas brasileños que admiten un control jurisdiccional mucho más extenso de lo que se solía aceptar. Sobre este tema, hay los que entienden que siempre es posible la verificación de la evaluación de las pruebas y méritos, reduciendo al máximo los riesgos de tratamiento no equitativo, desrazonable, abusivo, arbitrario y equivocado. ${ }^{969}$

\footnotetext{
967 Sentencia del Superior Tribunal de Justicia de Madrid, Sala de lo Contencioso-Administrativo, Sección $6^{\mathrm{a}}$, de 28 de abril de 2008.

968 En este sentido, se ha acentuado que: "Apenas recentemente a doutrina, ainda timidamente, tem voltado atenção para esse tema, mormente no que tange aos limites do controle judicial da discricionariedade dos atos administrativos" (CAMMAROSANO, Márcio. Concurso público: avaliação das provas. Vinculação ou discricionaridade?, en Concurso público e Constituição, Fabrício Motta (Cordinador), Editora Fórum, Belo Horizonte, 2005, p. 177).

${ }^{969}$ En este sentido: "É bastante óbvio, portanto, que uma Banca Examinadora não possa adotar posturas arbitrárias ou equivocadas. Os poderes da Banca são jurídicos e, mais precisamente, discricionários, movimentando-se entre alternativas igualmente válidas, porém sempre entre limites ou marcos conceituais mínimos. Não se trata, a toda evidência, de poderes ilimitados, eis que, fosse assim, teríamos Bancas dotadas de poderes ajurídicos, incontroláveis, situação impensável num Estado Democrático de Direito. A existência de limites, por si só, é indicativa de que existem marcos conceituais básicos que devem ser respeitados pelas Bancas Examinadoras, ainda que se diga que o Judiciário não possa adentrar o mérito do ato administrativo" (MEDINA OSÓRIO, Fábio. Os limites da discricionariedade técnica e as provas objetivas nos concursos públicos para ingresso nas carreiras jurídicas, em Revista Diálogo Jurídico, $\mathrm{n}^{\mathbf{0}}$ 13, abril-mayo de 2002, Salvador, p. 8, extraído del sitio: http://www.direitopublico.com.br/PDF_13/DIALOGO-JURIDICO-13-ABRIL-MAIO-2002-FABIOMEDINA-OSORIO.pdf, acceso en 17 de agosto de 2010).
} 
Incluso hay los que sostienen que si la evaluación de las pruebas es objeto de una acción judicial, será posible la contribución de asistentes técnicos designados por las partes o de peritos judiciales ${ }^{970}$

Aunque se reconozca la contribución de los estudios doctrinales que permiten un avance en el control de la discrecionalidad técnica, no cabe dudas que, incluso en el ambiente académico, prevalece la teoría que defiende que "a discricionariedade contém um núcleo insindicável pelo Poder Judiciário - o mérito, reduto no qual a complementação do motivo e do objeto do ato administrativo se opera mediante recurso a critérios não positivados",971

En el ámbito de los concursos públicos, la doctrina brasileña suele sostener que: "as bancas examinadoras detêm a chamada discricionariedade técnica, proveniente da liberdade de adotar, dentre um leque de posições cientificamente razoáveis, aquela que melhor atenda ao escopo do concurso público, a partir de critérios eleitos pela comissão e tendo em vista o princípio de eficiência administrativa"972

En el contexto de los Tribunales jurisdiccionales, en general, las sentencias de los Tribunales Superiores son conservadoras ${ }^{973}$, o sea, garantizan la manutención del dogma de la discrecionalidad técnica de las Comisiones calificadoras.

Las sentencias más progresistas se encuentran en los Juzgados locales (Juez singular) y regionales (órganos colegiados). Sin embargo, estas sentencias no siempre

\footnotetext{
${ }^{970}$ CAMMAROSANO, Márcio. Op.cit., p. 174.)

971 OLIVEIRA MORAES, Germana de. Controle jurisdicional da Administração Pública, Editora Dialética, São Paulo, 1999, p. 39.

972 BARBOSA MAIA, Márcio, y PINHEIRO DE QUEIROZ, Ronaldo. Op.cit., p. 192.

${ }^{973}$ Respecto a la tendência conservadora de los Tribunales: "Problema que merece a atenção da doutrina diz respeito aos limites dos administradores responsáveis pela elaboração de provas objetivas nos concursos públicos. Sabemos que a tendência do Poder Judiciário é reconhecer campos largos de imunidade aos administradores que elaboram provas de ingresso às carreiras jurídicas, talvez até mesmo porque o próprio Judiciário - e, diga-se de passagem, também o Ministério Público, instituição fiscalizadora por excelência - realiza numerosos concursos públicos, não se revelando interessante propiciar abertura aos Juízes de primeiro grau no sentido de que pudessem efetuar controles mais rigorosos, fiscalizando atos de uma Banca Examinadora composta por autoridades superiores no plano administrativo. Desta forma, os Tribunais teriam uma forte motivação psicológica e institucional para construir uma jurisprudência de imunidade em favor de seus próprios atos administrativos." (MEDINA OSÓRIO, Fábio. Os limites da discricionariedade técnica e as provas objetivas nos concursos públicos para ingresso nas carreiras jurídicas, em Revista Diálogo Jurídico, no 13, abril-mayo de 2002, Salvador, p. 3, extraído del sitio: http://www.direitopublico.com.br/PDF_13/DIALOGO-JURIDICO-13-ABRILMAIO-2002-FABIO-MEDINA-OSORIO.pdf, acceso en 17 de agosto de 2010).
} 
son mantenidas por los Tribunales Superiores (Nacionales), como el Supremo Tribunal Federal y el Superior Tribunal de Justiça.

El Supremo Tribunal Federal de Brasil ha declarado que:

\begin{abstract}
"Nao cabe ao Judiciário, no controle jurisdicional do ato administrativo, valorizar o conteúdo das opções adotadas pela banca examinadora, substituindo-se a esta, mas verificar se ocorreu ilegalidade no procedimento administrativo, apenas, dado que, se as opções adotadas pela banca foram exigidas de todos os candidatos, todos foram tratados igualmente." 974
\end{abstract}

El análisis de las decisiones judiciales respecto a los concursos públicos permite que uno constate que cuando el órgano jurisdiccional está delante de ilegalidades ${ }^{975}$ o errores manifiestos, la intervención suele ocurrir ${ }^{976}$.

A su vez, cuando el Poder Judicial es llamado a la apreciación de situaciones más complejas, la opción más usual es la denegación del pedido del candidato recurrente, bajo el argumento de la imposibilidad de intervención en la discrecionalidad técnica de las Comisiones de Evaluación.

\footnotetext{
${ }^{974}$ Supremo Tribunal Federal brasileño, Recurso Extraordinário 140242/DF, juzgado en 14.04.1997. En ese mismo sentido, los Recursos Extraordinários 268244/CE, de 09.05.2000; y 243056 Ag/CE, de 06.03.2001).

${ }^{975}$ Respecto a tal constatación: “A jurisprudência tem se orientado no sentido de que só são passíveis de reexame no Judiciário as questões cuja impugnação se funda na ilegalidade da avaliação ou dos graus conferidos pelos examinadores. O mais comum nesses casos é a chamada prova de múltipla escolha, nas quais apenas uma alternativa é aceita pela banca. Se o interessado comprova que há mais de uma alternativa, a questão e de legalidade, e o Judiciário deve anular a questão, atribuindo ao candidato os pontos que perdeu em relação a ela." (SANTOS CARVALHO FILHO, José dos. Manual. Op.cit., p. $550)$.

${ }^{976}$ En este sentido: “ADMINISTRATIVO. CONCURSO PÚBLICO. ANULAÇAO DE QUESTOES. Ação ordinária proposta em face da União Federal, objetivando a anulação de questões referentes ao concurso público para o cargo de Auditor Fiscal da Receita Federal, com o conseguinte cômputo dos pontos, de modo que os Autores sejam considerados habilitados para a segunda fase do certame. Tratando-se de prova envolvendo contabilidade, ciência exata, a prova é objetiva, podendo o Judiciário se manifestar quando há erro de fato. Concluindo o laudo pericial pela correção das respostas dos candidatos, é nula a sentença, eis que divorciou-se dos elementos constantes nos autos, não tendo sido observado o princípio da persuasão racional do Magistrado e do seu livre conhecimento. Em resposta ao princípio da economia processual, impõe-se anular as questões em tela, para admitir que os candidatos habilitados prossigam no concurso." (Tribunal Regional Federal da $2^{a}$ Região, Apelação Cível 213600, Processo no 1999.02.01.048427-1/RJ, Segunda Turma. DJU 18/03/2003, p. 275).
} 
En el contexto anteriormente destacado, hay algunas cuestiones que deben ser subrayadas. En primer lugar, debe ser reconocido que en el sistema constitucional brasileño, no hay ninguno espacio de decisión inmune a control jurídico ${ }^{977}$, y, en lo que se refiere a los concursos públicos, a priori, todas las etapas y actos del procedimiento son pasibles de fiscalización y censura ${ }^{978}$.

Otro aspecto que debe ser acentuado es la necesidad de que todas las decisiones administrativas (incluso y especialmente las que aprecian situaciones bajo potestades discrecionales) deben ser motivadas. En el contexto de los concursos público, esto equivale a decir que:

\begin{abstract}
"Se é verdade que a avaliaçao de certas provas a que se submetem os candidatos pode se apresentar insusceptível de redução a objetividade absoluta, o que só questões de múltipla escolha pode proporcionar, não é menos verdade que exatamente por comportarem alguma subjetividade do examinador ou responsável pela correção é que se impõe prefixação de balizas avaliatórias, devidamente justificadas e adequadas a justa aferição do merecimento de cada candidato, sem embargo do reconhecimento de que algumas dessas balizas também sejam insuscetíveis de rigorosa dosimetria. De qualquer forma, deverão ser preestabelecidos os tipos de provas a que os candidatos se submeterão - teóricas ou práticas, escritas ou orais - , e os fatores a serem levados em consideração - clareza e correção de linguagem, sob os aspectos de ortografia, pontuação, acentuação, etc, desencadeamento lógico do raciocínio, conhecimento do direito
\end{abstract}

\footnotetext{
977 En este camino: "Não há Poder Democrático imune ao controle jurídico. Não há hipótese de existir uma esfera de atividades do Poder Público que esteja tão acima da Justiça que possa cometer a mais ampla injustiça sem que os indivíduos que a ele se submetem possam fazer algo para opor travas a esta atuação. Não há, na Democracia pensada como princípio realizável materialmente pelas técnicas jurídicas colocadas à disposição da sociedade, competência posta à revelia da própria sociedade para atuar, inclusive, contra ela própria." (ANTUNES ROCHA, Cármen Lúcia. O principio constitucional da igualdade. Editora Lê, Belo Horizonte, 1990, p. 84).

${ }^{978}$ Sin embargo, "estranhamente, apesar de a jurisprudência reconhecer a necessidade de objetividade e recorribilidade em todas as demais fases do concurso público, como provas de aptidão física, testes psicológicos e investigação social, consolidou-se um entendimento de que as provas estariam sob o poder discricionário da Administração, e de que seria vedado ao Judiciário intervir, substituindo-se à banca examinadora. Esta interpretação não nos parecer correta e entendemos que é necessária uma reformulação da jurisprudência sobre a matéria." (LOBELLO DE OLIVEIRA ROCHA, Francisco. Op.cit., pp. 141-142).
} 
aplicável a espécie, propriedade e domínio da linguagem técnica utilizada etc- e os critérios para avaliação desses mesmos fatores"

Como se puede percibir, la actuación de los órganos seleccionadores tienen límites, y estos deberán ser verificados por el Poder Judicial cuando llamado a controlar las decisiones administrativas en los concursos públicos ${ }^{980}$

Otra cuestión que debe ser aclarada es que el grado de discrecionalidad técnica para evaluar las pruebas es mucho más limitado que la relativa a la elaboración ${ }^{981}$ de las mismas, por ejemplo. ${ }^{982}$ Tal afirmación se debe al hecho de que la

${ }^{979}$ CAMMAROSANO, Márcio, Concurso Público. Op.cit., p. 173
${ }^{980}$ Respecto a tales limites: “A revisão judicial da atuação administrativa deverá, igualmente, verificar a realidade dos fatos e também a coerência lógica da decisão discricionária com os fatos. Se ausente a coerência, a decisão estará viciada por infringência ao ordenamento jurídico, e mais especificamente, ao princípio da proibição da arbitrariedade dos poderes públicos que impede o extravasamento dos limites razoáveis da discricionariedade, evitando que esta se converta em causa de decisões desprovidas de justificação fática, e conseqüentemente, arbitrarias, pois o exame da legalidade e moralidade, além do aspecto formal, compreende também a análise dos fatos levados em conta pelo Executivo." (DE MORAES, Alexandre. Princípio da eficiência e controle jurisdicional dos atos administrativos discricionários, artículo publicado en la Revista de Direito Administrativo, no 243 , Fundação Getúlio Vargas - Direito Rio, Rio de Janeiro, p. 26). También se ha destacado que: "Em realidade, é possível reverter essa orientação jurisprudencial restritiva e conservadora, equivocada em suas bases teóricas, reconhecendo limites técnicos a esses administradores que elaboram e corrigem provas em concursos públicos, em homenagem à Ciência Jurídica e às fontes formais do Direito, bem assim aos princípios constitucionais que governam a Administração Pública brasileira (art.37 CF). É que, precisamente, a Ciência Jurídica e as fontes formais do Direito constituem os limites técnicos à discricionariedade da Banca Examinadora na elaboração e correção das provas objetivas em concursos públicos. Se existem limites técnicos, esses limites podem e devem ser controlados e fiscalizados pelo Judiciário. Por isso, quando a jurisprudência menciona a expressão "discricionariedade técnica", há que se considerar a inarredável presença dos limites técnicos às liberdades de escolhas, pena de esvaziar-se o sentido lógico dessa espécie de discricionariedade, que é mais limitada do que outras modalidades. Essa discricionariedade não é pura, mas sim técnica, o que revela sua maior limitação frente à Ciência e aos paradigmas técnicos de controle e qualidade. As Bancas Examinadoras, nos concursos públicos, gozam de discricionariedade técnica, é dizer, aquela liberdade de escolha balizada pela Ciência e pela técnica, sobretudo pelas fontes formais do Direito. Devem os examinadores, portanto, formular questões e alternativas corretas, juridicamente razoáveis, de tal sorte que os candidatos possam, em condições isonômicas e dentro da lei, competir livremente, culminando na escolha dos melhores." (MEDINA OSÓRIO, Fábio. Os limites da discricionariedade técnica e as provas objetivas nos concursos públicos para ingresso nas carreiras jurídicas, em Revista Diálogo Jurídico, $\mathrm{n}^{\circ}$ 13, abril-mayo de 2002, Salvador, p. 6, extraído del sitio: http://www.direitopublico.com.br/PDF_13/DIALOGO-JURIDICO-13-ABRILMAIO-2002-FABIO-MEDINA-OSORIO.pdf, acceso en 17 de agosto de 2010).

${ }^{981}$ Sobre los límites a la elaboración de las cuestiones, la doctrina y la jurisprudencia suelen destacar que cuando hay "indagações sobre matérias não contempladas no edital, anula-se toda a questão. Antes disso, contudo, compete ao judiciário analisar comparativamente a essência da questão com o conteúdo programático previsto no edital. Nesse aspecto, a jurisprudência mostra-se, ao revés, mais contundente. Confira-se o precedente:"209995 - CONCURSO PÚBLICO - QUESITO DE PROVA OBJETIVA ADMISSIBILIDADE DE ANULAÇÃO PELO PODER JUDICIÁRIO EM CASOS EXCEPCIONAIS INOCORRENNCIA DE PREJUÍZOS AOS DEMAIS CANDIDATOS APROVADOS - LITISCONSÓRCIO NECESSÁRIO - INEXISTÊNCIA - Excepcionalmente, restando demonstrado que a resposta considerada correta pela banca examinadora está, objetivamente, em desacordo com o ramo de conhecimento 
cuestión, una vez formulada, es sometida a los parámetros consolidados en el sector científico respectivo y hasta mismo a las exigencias de la lógica. Así, según destaca la doctrina:

“uma Banca Examinadora não poderia, num concurso público dominado pela legalidade, igualdade, eficiência e impessoalidade administrativas, adotar qualquer dos seguintes procedimentos ilícitos:

(a) eleger como correta uma alternativa incorreta à luz da doutrina e jurisprudência dominantes;

(b) exigir que se assinale a alternativa correta, quando não existem alternativas corretas e não há uma alternativa indicando que todas as demais estão incorretas;

(c) exigir que se assinale a única alternativa correta, quando, em realidade, existem pelo menos duas, gerando, com essa espécie de comportamento administrativo, perplexidade nos candidatos;

(d) propor uma questão/resposta ambígua, que deixe no espírito do candidato fundadas e razoáveis dúvidas quanto ao seu alcance e precisão, gerando perplexidade que dificulte a eleição da alternativa correta, ante a possibilidade razoável de que não esteja correta a alternativa ou que haja outra alternativa igualmente correta na mesma questão." 983

investigado, houver erro material ou vício na formulação da questão, é admissível o Poder Judiciário anular questão de concurso. (...). Preliminar de nulidade da sentença rejeitada. Apelação dos autores parcialmente provida. Apelação da União e remessa oficial improvidas." (TRF $5^{a} R$. - AC $106.703-$ (96.05.27664-0) - PE - $3^{a}$ T. - Rel. Des. Fed. Conv. Manoel Erhardt - DJU 24.10.2002 - p. 888) Resta claro, assim, que nesta parte a jurisprudência mostra-se mais evoluída, ao ponto de anular questões de concurso em desacordo com a matéria expressamente prevista no edital." (BENDINI MADALENA, Lenoar. Controle jurisdicional nos concursos públicos. Texto extraído do sitio Jus Navigandi (http://jus2.uol.com.br/doutrina/texto.asp?id=6560, acceso en 17 de agosto de 2010).

982 Hay incluso aquellos que sostienen que no existe discrecionalidad en la evaluación de las pruebas: "Deve-se observar que a discricionariedade sobrevém tão-somente na elaboração das provas, jamais na formulação do gabarito, correção e pontuação, onde existe vinculação. Mesmo na elaboração das provas, onde existe discricionariedade, as decisões de mérito limitam-se à escolha dos pontos a serem abordados e da forma de questioná-los. Não se pode cogitar que a discricionariedade que resta à Administração para elaborar provas seja ilimitada, concedendo-lhe permissão para exigir conhecimentos desnecessários ou impor gabaritos que não condigam com a realidade das disciplinas avaliadas. Mais ainda, o fato de existir discricionariedade não significa imunidade ao controle jurisdicional. Ao Judiciário somente é vedado interferir nos juízos de mérito do Administrador, quando houver, e nos limites deste." (LOBELLO DE OLIVEIRA ROCHA, Francisco. Op.cit., p. 142).

${ }_{983}$ MEDINA OSÓRIO, Fábio. Os limites da discricionariedade técnica e as provas objetivas nos concursos públicos para ingresso nas carreiras jurídicas, em Revista Diálogo Jurídico, $\mathrm{n}^{\circ} 13$, abril-mayo de 2002, Salvador, p. 7, extraído del sitio: http://www.direitopublico.com.br/PDF_13/DIALOGOJURIDICO-13-ABRIL-MAIO-2002-FABIO-MEDINA-OSORIO.pdf. 
El control de la evaluación de las distintas modalidades de pruebas también es diferenciado, ya que delante de las pruebas objetivas (tipo test), el margen de apreciación técnica del evaluador es mucho más reducida (casi zero). ${ }^{984}$

Respecto al control de la evaluación de las pruebas objetivas, se ha destacado que:

\begin{abstract}
"Há divergências jurisprudenciais quanto à possibilidade de reexame judicial de questões. Argumenta-se que ao proceder a anulação de questão acolhendo a tese segundo a qual a banca examinadora considerou como certa alternativa errada, o Judiciário estaria substituindo o órgão examinador, ingressando na seara do mérito administrativo, o que não seria permitido. No entanto, Tribunais vêm admitindo o reexame judicial de questões, quando a impugnação se fundamenta na ilegalidade da avaliação. Tal situação é mais comum nas provas de múltipla escolha, quando apenas uma alternativa é aceita pela banca e o candidato comprova que há na questão mais de uma alternativa certa. Caso desta natureza deve levar à anulação do quesito contestado, atribuindo-se ao candidato os pontos perdidos, salvo outra solução constante do edital",985
\end{abstract}

Evidentemente, cuando se está delante de cuestiones discursivas, se puede decir que "não há como evitar que as bancas examinadoras sejam dotadas de certo poder discricionário para avaliar as respostas e chegar à sua graduação"986. Además, cabe acentuar que "nos casos de dúvida ou incerteza, na denominada zona de penumbra, há de prevalecer a decisão do administrador." $" 987$

\footnotetext{
${ }^{984}$ En este camino: "A jurisprudência dos nossos Tribunais tem-se orientado no sentido de que só são passíveis de reexame no Judiciário as questões cuja impugnação se funda na ilegalidade da avaliação ou dos graus conferidos pelos examinadores. O mais comum nesses casos é a chamada prova de múltipla escolha, nas quais apenas uma alternativa é aceita pela banca. Se o interessado comprova que há mais de uma alternativa, a questão é de legalidade e o Judiciário deve anular a questão, atribuindo a todos os candidatos os pontos que perderam em relação a ela." (PINHEIRO MADEIRA, José Maria. Op.cit., pp. 123-124).

${ }^{985}$ TOURINHO, Rita. Op.cit., pp. 84-85.

${ }^{986}$ SANTOS CARVALHO FILHO, José dos. Op.cit., p. 550

${ }^{987}$ CAMMAROSANO, Márcio. Op.cit., p. 180.
} 
En lo que se refiere al control de las pruebas discursivas, hay opiniones muy distintas en el ámbito doctrinario. En este contexto, hay aquellos que sostienen que debe prevalecer un control mínimo, como se puede percibir abajo:

\begin{abstract}
"Quando se cuida da intitulada prova discursiva, a situação é diversa, porque a avaliação das respostas levadas a efeito pelos examinadores pode levar em consideração diversos aspectos além do fator estritamente ligado ao conhecimento. Nesses casos, não há como evitar que as bancas examinadoras sejam dotadas de certo poder discricionário para avaliar as respostas e chegar à sua graduação. Esses critérios não podem ser reavaliados pelo Poder Judiciário, pois que, além serem privativos da Administraçao, sua reapreciação implicaria ofensa ao princípio da separação dos poderes." 988
\end{abstract}

A su vez, también hay doctrinadores que defienden un control más amplio de las pruebas discursivas, lo que ocurriría a partir del momento que fuera exigida la previsión de parámetros de evaluación de las referidas pruebas:

"Se é verdade que a avaliação de certas provas a que se submetem os candidatos pode se apresentar insusceptível de redução a objetividade absoluta, que só questões tipo teste de múltipla escolha pode proporcionar, não é menos verdade que exatamente por comportarem alguma subjetividade do examinador ou responsável pela correçao é que se impõe prefixação de balizas avaliatórias, devidamente justificadas e adequadas à justa aferição do merecimento de cada candidato, sem embargo do reconhecimento de que algumas dessas balizas também sejam insusceptíveis de rigorosa dosimetria"989

De todas las formas, hay determinados aspectos que deberan estar siempre sujetos a fiscalización del Poder Judicial, especialmente los que decurren de los principios constitucionales de la Administración Pública ${ }^{990}$.

\footnotetext{
988 PINHEIRO MADEIRA, José Maria. Op.cit., p. 125.

${ }^{989}$ CAMMAROSANO, Márcio. Op.cit., p. 173.

${ }^{990}$ En este sentido: “além da legalidade, a banca examinadora deve atentar para os outros princípios constitucionais. Assim, viola a isonomia a utilização de critérios diferenciados para a correção das provas dos candidatos. Já a desconsideração de respostas apresentadas, em conformidade com entendimento de parte da doutrina, viola o princípio da razoabilidade. Por outro lado, a falta de apresentação dos motivos da nota conferida ao candidato afronta o princípio da motivação. Assim,
} 
Por fin, otro aspecto que debe ser acentuado es que en el caso de que el Poder Judicial reconozca la ilegitimidad en la evaluación de las pruebas discursivas, no deberá el referido Poder sustituir la valoración de la Administración por la suya. En este caso, deberá determinar una nueva evaluación, que sea alejada del vicio detectado ${ }^{991}$.

\subsection{8 - Adecuación entre el contenido de los procesos selectivos y las funciones o tareas a desarrollar}

Una de las consecuencias de la exigencia de actuación razonable en la conducción de los procesos selectivos es que la Administración Pública los adecúe a las funciones que serán desempeñadas por los funcionarios seleccionados.

La mencionada exigencia fue adoptada en España por el Estatuto Básico del Empleado Público como principio, y debe regir la acción administrativa en los más distintos momentos, como la elección del sistema selectivo, la definición del temario y de algunos requisitos específicos de acceso, la elaboración de las pruebas, o también su corrección.

El principio en cuestión tiene en consideración que para cada función a ser desarrollada en la Administración Pública, deben ser seleccionados funcionarios con perfiles compatibles, que reúnan determinadas capacidades consideradas relevantes para el desempeño eficaz de sus tareas.

\footnotetext{
poderíamos apresentar uma série de situações que, violando princípios administrativos, permitem o controle jurisdicional das provas dissertativas" (TOURINHO, Rita. Op.cit., p. 85-86). En este camino, también hay los que destacan que "Conquanto não possa o Judiciário aferir os critérios adotados pela banca examinadora na solução das questões discursivas, é absolutamente legítimo que se confronte as questões com o programa do concurso, tendo em vista que este faz parte do edital. Se questão formulada não se insere na relação dos pontos constantes do programa, está contaminada de vício de legalidade e se torna suscetível de invalidação na via administrativa ou na judicial. Aqui não se cuida de controle de mérito, nem de substituir valoração reservada ao administrador; cuida-se, isto sim, de controle de legalidade sobre o edital, ato de natureza vinculada, sendo, pois, permitido ao Judiciário exercê-lo em toda a sua plenitude." (SANTOS CARVALHO FILHO, José dos. Op.cit., p. 551).

${ }^{991}$ En este camino: "Existindo dúvida quanto à ocorrência de vício na correção da prova dissertativa, entendemos que esta poderá ser submetida à exame pelo Poder Judiciário que poderá, inclusive, utilizarse de prova pericial para solver o impasse. Porventura detectado algum vício, determinará o reexame da prova pela banca examinadora, não podendo ele mesmo fazê-lo, sob pena de comprometer o princípio da igualdade, além de colocar em xeque o princípio da separação dos poderes." (TOURINHO, Rita. Op.cit., p. 86).
} 
Por la razón arriba apuntada, se exige de la Administración un buen manejo de los medios de que disponen para seleccionar a los funcionarios. Tal reivindicación garantiza una cierta dosis de flexibilidad en la definición de los ejercicios:

"este principio es, sin duda, prueba de la posibilidad de coordinar y hacer posible en el ámbito público las técnicas de selección usualmente utilizadas en el ámbito privado, con los requerimiento y exigencias singulares que el sector público requiere y no son otras, volvemos a repetir, que la objetividad y la igualdad en el acceso." 992

La adecuada definición de los medios de selección impide el riesgo de la concesión de un trato absolutamente genérico a todos los ciudadanos, que no apreciara sus distintas capacidades, lo que seguramente afrontaría la igualdad.

En este contexto, no sería legítima la adopción del mismo temario, de los mismos requisitos de acceso, de los mismos sistemas selectivos ni de las mismas pruebas para la selección de funcionarios objetivando la cobertura de puestos de naturaleza distinta.

Así, es relevante resaltar una vez más que la exigencia de igualdad muchas veces reivindica un trato diferenciado, y en estas oportunidades, si se actúa de forma idéntica delante de situaciones claramente diferenciadas, hay una manifiesta transgresión de la igualdad, que deberá ser cohibida.

En el derecho brasileño, hay distintos juristas que destacan la necesidad de adecuación entre el contenido de los procesos selectivos y las funciones o tareas a desarrollar. En este sentido, es posible acentuar el concurso público objetiva selecionar “os indivíduos titulares de maior capacitação para o desempenho das funções públicas inerentes aos cargos ou empregos públicos. Isso impõe um vínculo de pertinência e adequação entre as provas realizadas e as qualidades reputadas indispensáveis para o exercício de funções inerentes ao cargo ou emprego. ",993

\footnotetext{
992 CASTILLO BLANCO, Federico A. Acceso a la función pública local (políticas selectiva y control jurisdiccional), Comares Editorial, Granada, 1993, p. 89.

${ }_{993}$ JUSTEN FILHO, Marçal. Op.cit., pp. 743-749.
} 
El jurista que hizo la observación anterior fue uno de los que mejor desarrolló el principio bajo análisis en el derecho brasileño. Para él, las más relevantes exigencias del citado principio imponen que:

"o conjunto de disciplinas e temas objeto das provas de conhecimento e das condições gerais dos demais tipos de exames, bem como os critérios de avaliação e a metodologia de sua aplicação, guardem plena consonância com as atividades a serem desempenhadas pelos futuros agentes públicos, sob pena de se recrutar pessoas com perfil inadequado para o exercício das respectivas funções públicas, frustrando-se, assim, o cerne do princípio da seletividade" 994

En distintas situaciones, la doctrina y la jurisprudencia brasileña ya subrayaba la necesidad de observancia de los principio de razonabilidad y de proporcionalidad $^{995}$ en la conducción del proceso selectivo, especialmente cuando es definido el temario de las pruebas, así como en su evaluación.

Así, ya se destacaba que "os concursos públicos que exigirem dos candidatos conhecimentos muito mais amplos do que os necessários para o exercício da profissão ou atividade em razão das quais foram instituídos devem ser considerados inválidos por desatenderem o princípio da proporcionalidade e, conseqüentemente, o da razoabilidade" $" 996$

Además, se añadía que "também não pode ser considerado válido concurso público que exige dos concursandos capacitação física não compatível com o exercício da profissão que motivou a abertura do concurso. $\mathrm{O}$ mesmo se dá quando a exigência de capacitação técnico-profissional for excessiva para o desempenho de um dado cargo" "997

\footnotetext{
994 BARBOSA MAIA, Márcio, y PINHEIRO DE QUEIROZ, Ronaldo. Op.cit., p. 33.

${ }^{995}$ En este camino: "Por fugir à razoabilidade, o TRF $1^{a}$ Região já anulou, por exemplo, reprovação de candidato a cargo de agente de Polícia Federal que, na prova de capacidade física, triscou por três vezes seguidas na faixa a partir da qual se media a distância do salto, mesmo tendo saltado a distância mínima necessária para aprovação. Considerou a Turma do Tribunal que a finalidade da prova era avaliar capacidade física (não habilidade), o que o candidato revelara, embora desobedecendo à forma estritamente prescrita." (BATISTA GOMES MOREIRA, João. Op.cit., pp. 135-136).

${ }_{996}$ ZANCANER, Weida. O concurso público e os princípios da razoabilidade e da proporcionalidade, en Concurso público e Constituição, Fabrício Motta (Cordinador), Editora Fórum, Belo Horizonte, 2005, p. 167.
}

997. ZANCANER, Weida. Op.cit., p. 167. 
La doctrina brasileña también ha apuntado los caminos para la realización del principio de adecuación entre los procesos selectivos y las funciones a desarrollar. En este contexto, se ha acentuado que:

\begin{abstract}
"na elaboração do edital do concurso, o Administrador deve ter em mente a natureza do cargo a ser preenchido e das funções a ele inerentes. Cada parâmetro nele inserido deve ser relevante, adequado e necessário. Tal avaliação fica sujeita à discricionariedade da Administração, sempre dentro dos limites do Direito. Na identificação das características necessárias para o exercício do cargo, a Administração deve seguir os seguintes passos: 1) identificar as funções inerentes ao cargo; 2) em face das funções, relacionar as habilitações, conhecimentos, características e habilidades necessárias e convenientes para o exercício do cargo; 3) escolher métodos de avaliação adequados para aferir tais elementos; e 4) em face das particularidades inerentes às funções do cargo, escolher o conteúdo da avaliação. Neste processo, devem ser observados os princípios da razoabilidade, igualdade, objetividade e finalidade." 998
\end{abstract}

Pese a la relevancia de las lecciones doctrinarias, especialmente de aquellos juristas que se dedican a la investigación del derecho administrativo, es innegable que el gran avance en el contexto brasileño respecto al principio bajo análisis (adecuación entre el contenido de los procesos selectivos y las funciones o tareas a desarrollar) ocurrió tras la edición de la Enmienda Constitucional 19/1998.

La citada enmienda estableció de forma expresa que " $a$ investidura em cargo ou emprego público depende de aprovação prévia em concurso público de provas ou de provas e títulos, de acordo com a natureza e a complexidade do cargo ou emprego" (art. 37, $\left.\mathrm{II}^{999}\right)$.

\footnotetext{
${ }^{998}$ LOBELLO DE OLIVEIRA ROCHA, Francisco. Op.cit., p. 71.

999 Además, se puede añadir que la referida Enmienda Constitucional determinó que "Art. $39 . \S 1^{\circ} \mathrm{A}$ fixação dos padrões de vencimento e dos demais componentes do sistema remuneratório observará: I - a natureza, o grau de responsabilidade e a complexidade dos cargos componentes de cada carreira; II - os requisitos para a investidura; III - as peculiaridades dos cargos", destacando así la necesidad de observancia de las distinciones entre las funciones públicas, lo que repercute incluso en forma de selección.
} 
Respecto a los cambios introducidos por la Enmienda Constitucional 19/1998, la doctrina brasileña ha destacado sus repercusiones en el concurso público en los siguientes términos:

"Demonstrando que ainda se encontra em processo de evolução, a Emenda Constitucional $\mathrm{n}^{\circ}$ 19, de 1998, reestruturou essa forma de ingresso na Administração Pública quando estabeleceu que o concurso seria concurso de provas ou concurso de provas e títulos e deveria ocorrer "de acordo com a natureza e a complexidade do cargo ou emprego", numa clara demonstração principiológica de que, para a investidura em cada cargo ou emprego público, um concurso específico que considere as estruturas próprias de tais cargos ou empregos. Isto significa que, preencher cargos de juiz federal, juiz de direito, procurador da República, promotor de justiça ou de advogado público, embora os concursos tenham base comum, a necessidade de conhecimentos de direito, no entanto, a natureza de cada um destes cargos e a resultante complexidade exigem uma aferição específica típica das diferenças que os separam." ${ }^{1000}$

A pesar de la preocupación constitucional con el tema y con la buena contribución de la doctrina brasileña, hay una distancia considerable entre el ideal y el real en los concursos públicos promovidos por la Administración Pública en Brasil.

En realidad, en las últimas tres décadas, los procesos selectivos de acceso a la función pública han experimentado una mejora visible en determinados aspectos, como la transparencia y la objetividad, pero no han avanzado tanto en otros puntos, como la coherencia y adecuación entre las pruebas y las funciones a desarrollar.

Sobre la mencionada circunstancia, se ha advertido que:

“infelizmente, hoje observa-se que as provas aplicada em concursos públicos parecem ter como preocupação primordial a rápida eliminação do maior número possível de candidatos. Para tal, utiliza-

${ }^{1000}$ PACHECO BARROS, Wellington. Op.cit., pp. 12-13. 
se questões sem qualquer utilidade prática, privilegiando não aqueles que demonstram habilidade de raciocínio e elevada capacidade técnica, mas sim os que, com tempo disponível, aprendem a assimilar as chamadas "questões de bolso", desprovidas de qualquer serventia no dia-a-dia da atividade administrativa." 1001

\subsection{9 - Agilidad}

La exigencia de agilidad de los procesos selectivos está prevista en el derecho español, más precisamente en el Estatuto Básico del Empleado Público (art.55.2 f), con la observación de que aquella no puede comprometer la objetividad ("agilidad, sin perjuicio de la objetividad").

A pesar de no estar previsto en la legislación brasileña con esta denominación (ni tampoco tratado por la doctrina), la agilidad también es un reto que se impone a los procesos selectivos de acceso a la función en Brasil. En el ordenamiento jurídico del referido país, la agilidad sería una de las consecuencias del principio de eficiencia, que exige que la actuación administrativa sea la más calificada, la más producente y la más rápida posible, sin que haya el sacrificio de los parámetros impersonales definidos por las leyes.

El mencionado principio, por estar ligado al de eficiencia, busca evitar que los procesos selectivos se extiendan en demasía. Sobre esta práctica, en España, se puede decir que "no es extraño encontrar procesos de selección que se prolongan en el tiempo a lo largo de varios meses, hasta el punto de llegar a solaparse con la siguiente convocatoria de empleo público". ${ }^{1002}$

En Brasil, además de la gran cuantidad de opositores, lo que hace con que el proceso selectivo lleve mucho tiempo para concluirse, el gran problema reside en el largo plazo definido en el ordenamiento jurídico para que se realicen los nombramientos (hasta cuatro años, cuando es utilizado el plazo máximo de dos años y este es prorrogado). Esto hace con que haya la posibilidad de que los candidatos seleccionados,

\footnotetext{
${ }^{1001}$ TOURINHO, Rita. Op.cit., p. 20.

${ }^{1002}$ PÉREZ GÓMES, José María. Op.cit., p. 494.
} 
cuando tengan que empezar a desarrollar sus funciones, no más ostenten los conocimientos que tenían cuando de la selección muchos años antes ${ }^{1003}$.

También se puede afirmar que es evidente que no se puede hacer una generalización respecto al tiempo razonable de duración de cada proceso selectivo, ya que cada uno de ellos presenta características propias que pueden demandar un tiempo mayor o menor.

Así, sobre la agilidad en los procesos selectivos de acceso a la función público pública, conviene destacar que "las consecuencias concretas de este principio variarán según el tipo de empleado que se trate de seleccionar, el número de candidatos y otras variantes." 1004

Como medidas que pueden ayudar a la agilidad de los procesos selectivos, pueden ser citadas "la creación de varios Tribunales que actúan de forma paralela, introducción de exámenes preliminares tipo test, que permitan la corrección rápida para hacer una primera criba de los aspirantes, utilización de medios informáticos para el procesamiento de los ejercicios" ${ }^{\text {"1005 }}$, así como la concentración de ejercicios en determinados fines de semana, la capacitación de los miembros de los órganos de selección para la corrección de las pruebas, a partir de la estipulación de criterios y baremos de evaluación de los ejercicios, entre otras medidas.

Conviene destacar que los procesos selectivos que no son concluidos de forma ágil pueden comprometer la igualdad entre los ciudadanos, especialmente cuando aquellos tienen una duración prevista en las bases de la convocatoria para varios meses o cuando poseen varias fases que exigen muchos desplazamientos, circunstancias que pueden disuadir a distintos aspirantes que no tengan la disponibilidad de tiempo y de recursos económicos para hacer frente a las exigencias mencionadas.

\footnotetext{
${ }^{1003}$ La cuestión relativa al largo plazo para nombramiento (plazo de validez del concurso público) en Brasil también produce otras consecuencias maléficas, como la inseguridad generada para los opositores, que no saben al cierto cuando serán nombrados, ya que la definición de la oportunidad del acto de nombramiento es un acto discrecional.

${ }^{1004}$ SÁNCHEZ MORÓN, Miguel. Autor del capítulo décimo del libro Comentarios a la Ley del Estatuto Básico del Empleado Público, Miguel Sánchez Morón (Director); Federico A. Castillo Blanco, Alberto Palomar Olmeda, Tomás Sala Franco y Miguel Sánchez Morón (Autores) $2^{\mathrm{a}}$ ed., Editorial Lex Nova, Valladolid, 2008, p. 404.

${ }^{1005}$ PÉREZ GÓMES, José María. Op.cit., pp. 494-495.
} 
En cambio, también se puede resaltar que la búsqueda de la agilidad por encima de todo puede comprometer la igualdad, en la medida en que se realicen correcciones superficiales que no estimen las diferencias entre las pruebas, o cuando hay un abuso de la utilización de ejercicios tipo test que no verifique las distinciones respecto a la capacidad de los candidatos. 


\section{CAPÍTULO 5 - LA IGUALDAD EN EL PROCEDIMIENTO SELECTIVO DE ACCESO A LA FUNCIÓN PÚBLICA ESPAÑOLA Y BRASILEÑA}




\section{1 - Competencia para la reglamentación de los procesos selectivos de acceso a la función pública}

Antes de empezar el análisis del procedimiento de selección de los funcionarios públicos en Brasil y en España, es necesario que se verifique la competencia establecida en las respectivas Constituciones para la creación de normas generales y específicas sobre el referido tema.

La relevancia de la cuestión de la competencia legislativa es considerable, pues el análisis de la presencia de una o varias fuentes de creación normativa puede ser imprescindible para la efectividad de la igualdad.

En este contexto, tanto es posible que haya la transgresión de la igualdad cuando son establecidas normas distintas para situaciones equivalentes (por ejemplo, en el caso de que determinados Estados brasileños permitieran y otros prohibieran el acceso de las personas con menos de $1.70 \mathrm{~m}$ a la función de bombero), como también cuando hay la misma norma para situaciones diferenciadas (como ejemplo, en el caso de que la legislación sobre el acceso a la función pública española no tuviera en consideración la existencia de lenguas cooficiales en determinadas Comunidades Autónomas, y exigiera solamente el conocimiento del castellano en las oposiciones).

El presente estudio deberá tener en cuenta el hecho de que los países bajo análisis tienen distintos modelos de Estado, ya que mientras la Constitución de Brasil determina que este es una federación ${ }^{1006}$, formado por tres niveles de competencia (federal, estadual y municipal, aunque también existan competencias del Distrito Federal), la Constitución española crió un modelo de Estado considerado por muchos como Estado autonómico, que consiste en el reconocimiento de autonomías para las

\footnotetext{
1006 “Art. $1^{\circ}$ A República Federativa do Brasil, formada pela união indissolúvel dos Estados e Municípios e do Distrito Federal (...)" También se puede destacar el art. 18, que establece que: "A organização político-administrativa da República Federativa do Brasil compreende a União, os Estados, o Distrito Federal e os Municípios, todos autônomos, nos termos desta Constituição”.
} 
regiones que poseen rasgos históricos, culturales y económicos comunes ${ }^{1007}$, y de soberanía para la Nación española.

\subsection{1 - En España}

La cuestión de la división de competencias en España es un tema muy problemático, ya que el modelo de Estado creado en su Constitución ha generado muchas tensiones entre el Gobierno central, que siempre ha intentado concentrar más atribuciones, y las Comunidades Autónomas (especialmente algunas de ellas, como Catalunya y País Vasco), que han buscado la ampliación de sus potestades.

Respecto la competencia para definición de las normas sobre la función pública, la Constitución española, tras establecer en el art. 103.3 que "La Ley regulará el estatuto de los funcionarios públicos, el acceso a la función pública de acuerdo con los principios de mérito y capacidad, las peculiaridades del ejercicio de su derecho a sindicación, el sistema de incompatibilidades y las garantías para la imparcialidad en el ejercicio de sus funciones", determinó, en el art. 149.1.18, que el Estado tendría competencia exclusiva para regular "Las bases del régimen jurídico de las Administraciones públicas y del régimen estatutario de sus funcionarios que, en todo caso, garantizarán a los administrados un tratamiento común ante ellas; el procedimiento administrativo común, sin perjuicio de las especialidades derivadas de la organización propia de las Comunidades Autónomas (...);”.

En los términos transcriptos, cabe al Estado la definición de las normas básicas sobre la función pública (lo que incluye el acceso a la misma), que deberán ser observadas por el propio Estado, por las Comunidades Autónomas y por las Corporaciones locales (provincias y municipios).

\footnotetext{
1007 "Artículo 2. La Constitución se fundamenta en la indisoluble unidad de la Nación española, patria común e indivisible de todos los españoles, y reconoce y garantiza el derecho a la autonomía de las nacionalidades y regiones que la integran y la solidaridad entre todas ellas" También se debe subrayar la existencia del art. 137"El Estado se organiza territorialmente en municipios, en provincias y en las Comunidades Autónomas que se constituyan. Todas estas entidades gozan de autonomía para la gestión de sus respectivos intereses". Además, hay el artículo 143.1: "En el ejercicio del derecho a la autonomía reconocido en el artículo 2 de la Constitución, las provincias limítrofes con características históricas, culturales y económicas comunes, los territorios insulares y las provincias con entidad regional histórica podrán acceder a su autogobierno y constituirse en Comunidades Autónomas con arreglo a lo previsto en este Título y en los respectivos Estatutos".
} 


\subsubsection{1 - Las normas básicas}

Como se ha visto, la Constitución española, visando la preservación del trato igualitario a todos los ciudadanos residentes en el territorio español, consideró más conveniente que las normas básicas respecto a la función pública (incluso el acceso) fueran establecidas por el Estado.

Además de la previsión de que el Estado debería establecer las normas básicas respecto a la función pública, la Constitución española también previó que las normas estatales serían supletorias de las creadas por las Comunidades Autónomas ${ }^{1008}$.

Es evidente que la norma constitucional, al establecer que cabe al Estado la previsión de normas básicas, ha forjado muchas polémicas, ya que el concepto indeterminado de "normas básicas" está sometido a muchas interpretaciones. Sobre esta circunstancia, se ha destacado que:

"El art. 149.1.18 CE atribuye la competencia exclusiva del Estado para establecer las bases del régimen (...), lo cual significa que este marco concreto - en su total dimensión material y procedimental, y para todas las Administraciones - pertenece al Gobierno central, ciñéndose la actividad legislativa de las Comunidades Autónomas al desarrollo y ejecución de aquellas cuestiones cuando de funcionarios a su servicio se trate y así lo hayan previsto de manera expresa sus Estatutos. La dificultad, nadie lo ignora, radicará en determinar la medida de lo básico en la materia, como límite último a la actividad legislativa regional y situado por el TCo en cualesquiera normas "aplicables para preservar el principio de igualdad"1009

\footnotetext{
1008 “Art. 149. 3 Las materias no atribuidas expresamente al Estado por esta Constitución podrán corresponder a las Comunidades Autónomas, en virtud de sus respectivos Estatutos. La competencia sobre las materias que no se hayan asumido por los Estatutos de Autonomía corresponderá al Estado cuyas normas prevalecerán, en caso de conflicto, sobre las de las Comunidades Autónomas en todo lo que no esté atribuido a la exclusiva competencia de éstas. El derecho estatal será, en todo caso, supletorio del derecho de las Comunidades Autónomas".

${ }^{1009}$ FERNÁNDEZ DOMÍNGUEZ, Juan J. y RODRÍGUEZ ESCANCIANO, Susana. Op.cit., pp. 94-95.
} 
Aún en este contexto que subraya la necesidad de preservación de la igualdad, la doctrina española ha destacado que, en materia de acceso a la función pública, "podemos diferenciar contenidos que deberían ser regulados con carácter homogéneo para todo el territorio nacional y por ello ser básico, de otros aspectos que son susceptibles de un tratamiento diferenciado en cada ámbito autónomico sin necesariamente constituir una vulneración del principio de igualdad"1010

Con el objetivo de aclarar la cuestión, el Tribunal Constitucional entendió que son considerados aspectos básicos:

\footnotetext{
"los procedimientos de acceso (pero no la publicación de la convocatoria o una regulación detallada de los tribunales y comisiones de selección, aún cuando formen parte del sistema a estos efectos) y, en consecuencia, la convocatoria y resolución de concursos para proveer plazas y la existencia misma de cuerpos de funcionarios que permitan su selección y adscripción a puestos concretos, garantizando los principios de igualdad, mérito y capacidad" ${ }^{\text {1011 }}$
}

Interpretando las decisiones del Tribunal Constitucional respecto al contenido de las normas básicas estatales, la doctrina española acentúa a aquellas cabe determinar "no sólo los aspectos jurídicos de la relación funcionarial (conceptos de funcionario, derechos y deberes, situaciones administrativas, potestad disciplinaria...) sino también las reglas definidoras de modelo de organización de función pública (sistema de puestos de trabajo, régimen de selección y carrera, formación, etc...)"1012.

\subsubsection{2 - El papel de las normas autonómicas y locales}

Si a las normas estatales cabe el establecimiento de las normas básicas, y como se ha visto, estas tienen un amplio contenido, la indagación que surge dice respecto al papel de las normas autonómicas y locales. Antes de todo, cabe destacar que,

\footnotetext{
${ }^{1010}$ ILDEFONSO HUERTAS, Rosa María. Op.cit., pp. 240-241.

${ }^{1011}$ FERNÁNDEZ DOMÍNGUEZ, Juan J. y RODRÍGUEZ ESCANCIANO, Susana. Op.cit., pp. 95-96.

1012 CASTILLO BLANCO, Federico A., Op.cit., p. 56.
} 
en el derecho español, solamente las Comunidades Autónomas poseen competencia legislativa, potestad no atribuida a las Corporaciones locales.

En el ámbito de las Comunidades Autónomas, hay algunas convicciones y muchas dudas. Entre las certezas, hay que destacar la necesidad de que las normas producidas por las referidas entidades respecten las normas básicas estatales. A su vez, entre las principales dudas, destacase la incertidumbre respecto a los aspectos que pueden ser tratados por las leyes de las Comunidades Autónomas. Para la doctrina, estas:

"podrán dictar legislación de desarrollo propia para sus funcionarios y respectando en todo caso las bases previamente reguladas por el Estado. Es aceptado que las Comunidades Autónomas singularicen las previsiones estatales a sus especiales características, aunque si se analiza la normativa funcionarial autonómica suele ser una transposición más o menos fidedigna de la regulación del Estado"1013

La mencionada constatación sobre el reducido espacio reservado a las normas sobre función pública producidas por las Comunidades Autónomas también es destacada por otros doctrinadores: "el resultado final de tal interpretación conduce a una patente ampliación de las competencias centrales en la materia que deja poco espacio para el desarrollo y condiciona notadamente la ejecución" ${ }^{\prime 1014}$.

En este contexto, para la doctrina, la competencia legislativa de las Comunidades Autónomas es limitada. Sin embargo:

"tal dato no puede impedir, en último extremo, que cada una de ellas intente, sin violar la igualdad, adecuar el régimen proprio de sus funcionarios a las características peculiares bajo las cuales aquéllos han de desenvolver su actividad (lingüísticas, culturales, de atención a servicios propios, de organización interna y un etcétera conocido), siempre con el debido respeto a

${ }^{1013}$ ILDEFONSO HUERTAS, Rosa María. Op.cit., pp.237-238.

${ }^{1014}$ FERNÁNDEZ DOMÍNGUEZ, Juan J. y RODRÍGUEZ ESCANCIANO, Susana. Op.cit., pp. 94-95. 
los principios de mérito y capacidad en la condiciones de acceso"1015

A su vez, respecto a las entidades locales (provincias y municipios), aclara la doctrina que a estas son aplicadas las normas básicas del Estado; la legislación de la Comunidad Autónoma "la dada específicamente para las Corporaciones locales, que es la legislación de desarrollo de la normativa básica estatal”; las normas del Estado, "que no tengan la condición de básicas y que éste haya hecho expresamente para las Corporaciones locales"; los reglamentos del Estado, "que da para sí mismo, y que en ellos se dicen ser supletorios para la Administración local; y los reglamentos internos, "que aprueben las Corporaciones locales". ${ }^{1016}$

Toda la normativa aplicada a las entidades locales hace que estas sean sometidas a leyes de diferentes fuentes (estatales y autonómicas) ${ }^{1017}$, en el manifisto intento de que no haya la regionalización de la función pública local. ${ }^{1018}$

Pese a las dificultades experimentadas en el contexto español, debe ser subrayada la existencia de un marco legal general respecto al acceso a la función pública en todo territorio del mencionado país, lo que garantiza la presencia de procedimientos estándares, sin que sea negada la posibilidad de respeto a las diferencias regionales; circunstancias muy relevantes para la efectividad del derecho previsto en el art. 23.2 de la Constitución española.

\subsection{2 - En Brasil}

El tema bajo estudio en el ordenamiento jurídico brasileño ha recibido un trato normativo muy distinto de aquel previsto en el derecho español. La primera gran diferencia trata de la inexistencia de norma constitucional que atribuya a la Unión

\footnotetext{
${ }^{1015}$ FERNÁNDEZ DOMÍNGUEZ, Juan J. y RODRÍGUEZ ESCANCIANO, Susana. Idem, p. 96. ${ }^{1016}$ PERÉZ LUQUE, Antonio. Op.cit., pp. 56-60.

1017 Según el art. 3.1 del Estatuto Básico del Empleado Público: "El personal funcionario de las Entidades Locales se rige por la legislación estatal que resulte de aplicación, de la que forma parte este Estatuto y por la legislación de las Comunidades Autónomas, con respeto a la autonomía local" ${ }^{1018}$ SÁNCHEZ MORÓN, Miguel. La distribución de competencias entre el Estado y las Comunidades Autónomas en materia de Administración Local, en el libro Tratado de Derecho Municipal, Santiago Muñoz Machado (Dirección), vol. I, 2 ${ }^{\mathrm{a}}$ ed., Civitas, Madrid, 2003, p. 215.
} 
Federal la competencia para el establecimiento de normas generales respecto al acceso a la función pública.

Como se verá a continuación, otro aspecto que distingue la realidad brasileña de la española es que no suele haber ley (ni federal, ni estadual, ni municipal) que regule el acceso a la función pública, circunstancia que hace con que los reglamentos infralegales ejerzan un papel predominante, aunque ni siempre según las normas constitucionales.

\subsubsection{1 - La ausencia de normas generales}

Como se ha subrayado, en el sistema constitucional brasileño, no existe norma que imponga a determinado entidad (por ejemplo, a la Unión ${ }^{1019}$ ) la competencia exclusiva para creación de ley que establezca las normas básicas sobre el acceso a la función pública.

En la realidad, cada entidad de la Federación (Unión, Estados, Municipios y Distrito Federal) tiene competencia legislativa sobre la materia, lo que le permitiría crear su propia ley respecto el referido tema, aunque esto no suela suceder.

La justificación de la ausencia de la citada norma que atribuyera a la Unión la competencia para definición de las normas generales de acceso a la función pública seria el reconocimiento de la propia Constitución de la autonomía administrativa de las entidades federativas ${ }^{1020}$.

\footnotetext{
${ }^{1019}$ Por esta razón, "a lei implementadora do concurso público poderá ser federal, estadual ou municipal dependendo da unidade federativa em que deva se realizar o certame. As regras criadas por lei federal para um concurso dentro de sua esfera não têm qualquer ingerência dentro da órbita estadual e municipal, mesmo que ele se destine ao provimento de cargos ou empregos idênticos, pela simples conclusão de que o Brasil é uma federação e, como conseqüência, tem pessoas políticas com autonomia administrativa para regrar-se desde que respeitados os princípios constitucionais." (PACHECO BARROS, Wellington. Op.cit., pp. 16-17).

${ }^{1020}$ En este sentido: "cada unidade federativa goza de ampla autonomia para dispor sobre a organização de seus próprios serviços públicos e, por via de conseqüência, sobre a forma e o meio de admissão aos cargos e empregos públicos que compõem a sua estrutura administrativa. Dessa forma, a competência para legislar sobre concurso público compete, indistintamente, à União, aos Estados-membros, ao Distrito Federal e aos Municípios, mediante adoção de leis próprias em cada esfera governamental" (BARBOSA MAIA, Márcio, y PINHEIRO DE QUEIROZ, Ronaldo. Op.cit., p. 12). Para comprender la realidad brasileña, cabe añadir las siguientes líneas doctrinárias: "A União, os Estados-Membros, os Municípios e, agora, também o Distrito Federal, como corolário da autonomia que lhes é assegurado
} 
Sin embargo, lo interesante es que la Constitución Federal determinó en el apartado XXVII del art. 22 que compete privativamente a la Unión la creación de las "normas gerais de licitação e contratação, em todas as modalidades, para as administrações públicas diretas, autárquicas e fundacionais da União, Estados, Distrito Federal e Municípios”, y lo hizo con la preocupación de que hubiera el mismo marco legal para todos los contratos administrativos celebrados en el país, sin que esto suprimiera la autonomía administrativa de los demás entes federativos.

Lo más paradoxal es que aunque la Constitución haya atribuido a cada uno de los entes federativos la competencia para definición de las reglas de sus procesos selectivos de acceso a la función pública, aquellos no han utilizado de forma plena su potestad, ya que prácticamente no hay leyes en este sentido en Brasil, especialmente para normalizar el procedimiento a ser observado por la Administración Pública, así como por los candidatos.

No son poco los doctrinadores que reconocen este hecho. En este sentido, "apesar de sua inegável importância, o instituto do concurso público não tem sido objeto de atenção doutrinária. Da mesma maneira, é escassa em todos os entes federados a elaboração legislativa sobre o tema, limitando-se as leis existentes, em sua maioria, a dispor sobre cargos e requisitos para seu provimento."

También se ha reconocido que "o concurso público constitui princípio constitucional explícito desde a Carta de 1934, mas, infelizmente, não tem gozado de

pelo art. 18 da Constituição da República, podem dispor sobre a organização de seus servidores de modo muito abrangente, mediante as respectivas leis federal, estadual, distrital e municipal, quando escolherem o regime institucional ou estatutário para a eles se ligarem. Assim, cabe-lhes regular, no que respeita a seus servidores estatutários, a admissão, a promoção, os direitos, os deveres, a ação e o procedimento disciplinar, as penas cabíveis e a extinção do vínculo. Cada uma dessas entidades é, assim, autônoma para organizar seu pessoal. [...] A competência do Estado-Membro e do Distrito Federal para organizar seu pessoal é ampla, devendo o seu exercício observar os princípios estabelecidos na Constituição Federal, as disposições das respectivas Constituições e as normas nacionais relativas a servidores. Assim, nenhuma lei federal editada para organizar os servidores federais é aplicável aos servidores públicos estaduais, distritais e municipais. Em relação ao Município, ocorre o mesmo. Este, atendidas as disposições constitucionais federais, as normas nacionais e as de sua Lei Orgânica, tem liberdade para organizar seu pessoal, segundo o interesse local. De sorte que pode elaborar a lei de seus servidores sem qualquer ingerência das demais esferas de governo." (GASPARINI, Diógenes. Direito administrativo. 14 ed $^{\mathrm{a}}$. rev. , Ed. Saraiva, São Paulo, 2009, pp. 174-175).

${ }^{1021}$ MOTTA, Fabrício. Concurso público e Constituiçao, Fabrício Motta (Coordinador), Editora Fórum, Belo Horizonte, 2005, presentación, p. 10. 
idêntico prestígio perante o legislador infraconstitucional, uma vez que (...) o instituto carece de uma sistemática legal"1022

En el caso de que el ente federativo no haya creado ley para regular el acceso a la función pública, el papel ejercido por las normas constitucionales (reglas y principios) es aún más intenso, como reconoce la doctrina brasileña:

“cada ente político deverá ter uma lei para regulamentar o concurso público na sua esfera (...). Todavia, sabe-se que em muitos Estados e Municípios não existe lei. Poderia em um desses Estados ou Municípios ser realizado concurso público? A resposta é sim, perfeitamente. A falta de lei reguladora não impede que se realize o concurso, desde que sejam seguidos os princípios gerais que regem o concurso público. Evidentemente que em existindo lei para regular o concurso a sua elaboração ficará muito mais fácil, e dará mais segurança para quem montá-lo e, por óbvio, para os candidatos." 1023

No obstante, los problemas no se limitan a la no ocupación del espacio reservado pela Constitución a la ley, sino también de la invasión del mismo por el administrador público, como se verá en el próximo apartado.

Otra dificultad que se debe añadir es que "a inexistência de uma legislação voltada para o disciplinamento da realização dos concursos públicos dificulta a concretização da impessoalidade nos referidos processos seletivos." ${ }^{1024}$, ya que en cada proceso selectivo, hay la posibilidad (y es lo que suele pasar) de que sean previstas reglas propias, como requisitos discriminatorios de acceso o realización de pruebas que no respeten las exigencias de la igualdad ${ }^{1025}$.

\footnotetext{
1022 BARBOSA MAIA, Márcio, y PINHEIRO DE QUEIROZ, Ronaldo. Op.cit., p. 11.

${ }^{1023}$ DA SILVA OLIVEIRA JÚNIOR, Dario, y CAMPOS OLIVEIRA, Isabel. Op.cit., p. 30.

1024 LINS DE LESSA CARVALHO, Fábio. O princípio da impessoalidade nas licitações, Edufal, Maceió, 2005, p. 74.

${ }^{1025}$ Respecto a los aspectos que deben estar previstos en la ley, se ha afirmado que: "Antes da Emenda Constitucional $n^{\circ}$ 19, de 1998, a regulamentação de todos os atos procedimentais referentes ao concurso público era feita por decreto do Chefe do Executivo. Todavia, a referida Emenda Constitucional modificou esta forma de agir, exigindo lei para regulamentar tais atos. (...) Portanto, deverá existir lei que disponha sobre a convocação dos candidatos e a elaboração dos editais; sobre a inscrição dos candidatos e os documentos a serem exigidos; sobre a designação da comissão de elaboração; aplicação, correção e identificação das provas, sua composição, a escolha de seus membros e as suas atribuições; sobre a elaboração, correção e julgamento das provas; sobre a homologação do concurso,
} 
En la labor de análisis comparativo entre las reglas de acceso a la función pública brasileña y española, no hay dudas de que una de las más grandes aportaciones que el derecho español puede ofrecer al derecho brasileño es la existencia de una ley que establiece las normas básicas de acceso a la función pública.

La reivindicación destacada en este trabajo también es realizada por la doctrina brasileña, como se puede percibir abajo:

"Diante do casuísmo da jurisprudência e das dificuldades do acesso efetivo da população ao Poder Judiciário (...), julgamos de suma importância a questão relativa à positivação do concurso público, em ordem a eliminar o arbítrio das bancas examinadoras nos procedimentos de seleção e recrutamento de agentes públicos e a conferir maiores garantias para a coletividade. Com efeito, a ausência de regras claras sobre as etapas procedimentais dos concursos, os prazos e as condições legais para sua deflagração, a constituição das bancas examinadoras, o conteúdo dos editais, a disciplina dos recursos, a sujeição aos princípios da Administração, dentre outros aspectos relevantes, afigura-nos uma situação deveras preocupante e plenamente inadmissível na atualidade, o que tem acarretado transtornos de todas as ordens para os administrados, em forma de desvios e desmandos da Administração e das bancas examinadoras, cujo excesso de poder discricionário, que muitas vezes descamba para a arbitrariedade, tem comprometido a seriedade, a imparcialidade e o caráter seletivo dos concursos públicos. Exsurge, assim, a necessidade de estabelecer normas gerais sobre concursos públicos, pois a omissão estatal em se adotar tal providência funciona, na prática, como uma "delegação normativa" aos editais dos certames, os quais nem sempre são bem elaborados e, muitas vezes, transmudam-se em verdadeiros regulamentos autônomos, visto que não se respaldam em uma matriz normativa de índole legal." 1026

bem como sobre os recursos e pedidos de revisão de provas, entre outros." (DA SILVA OLIVEIRA JÚNIOR, Dario, y CAMPOS OLIVEIRA, Isabel. Op.cit., p. 28).

${ }^{1026}$ BARBOSA MAIA, Márcio, y PINHEIRO DE QUEIROZ, Ronaldo. Op.cit., pp. 12-13. 


\subsubsection{2 - La presencia de reglamentos infralegales}

En la realidad brasileña, la ausencia de leyes que traten del acceso a la función pública es sustituida por la actuación indebida de la Administración Pública. En este contexto, hay que subrayar que:

"O princípio da necessidade de realização prévia de concurso público para o ingresso na Administração Pública não é auto-aplicável. Sua implementação está condicionada à regulamentação legal prévia. Dessa forma, embora a exigência de concurso público para ingresso na Administração Pública seja expressa na Constituição Federal, como típico princípio administrativo-constitucional, no entanto, a própria Lei Maior estabelece que este princípio constitucional somente poderá ser implementado através de lei, que, dentro do contexto, significa ato formal emanado do Poder Legislativo através de processo específico de criação. Por consequiência, fica afastada a possibilidade de a Administração Pública, por ato administrativo próprio, implementar as regras de um concurso público. Se o faz, o concurso público fere o princípio da legalidade." 1027

La referida actuación indebida de la Administración Pública suele suceder de dos formas: a través de la adopción de reglamentos (decretos, portarías, etc.) que establecen las normas que deben ser observadas en todos los procesos selectivos ${ }^{1028}, \mathrm{y}$ por razón de la definición de reglas específicas para cada disputa, a través de las bases de la convocatoria (edital, en el derecho brasileño) ${ }^{1029}$.

\footnotetext{
${ }^{1027}$ PACHECO BARROS, Wellington. Op.cit., p. 16.

${ }^{1028}$ Sobre esto, se ha destacado que "a ausência de uma lei básica sobre concurso público tem despertado uma fúria regulamentar ilegítima do Poder Público, a qual, infelizmente, é respaldada pela completa conivência e omissão dos órgãos de controle e do Poder Legislativo.” (BARBOSA MAIA, Márcio, y PINHEIRO DE QUEIROZ, Ronaldo. Op.cit., p. 13).

${ }^{1029}$ En este camino, se ha apuntado que: "Edital de concurso é ato infralegal, não se confundindo, por conseguinte, com a lei e não servindo de instrumento hábil para inovar no ordenamento jurídico, criando obrigações para os candidatos em concurso público. Pode-se, outrossim, concluir que o estabelecimento de regras por um Edital sem que exista lei anterior regulamentando a matéria fere, também, o princípio da separação entre os Poderes. Com efeito, estar-se-ia transferindo, de forma indevida, competências que a Constituição atribuiu ao Legislativo para os demais Poderes, o que não se admite." (SPITZCOVSKY, Celso. Limitações constitucionais aos editais de concursos públicos. Texto extraído del sitio Jus Navigandi (http://jus2.uol.com.br/doutrina/texto.asp?id=5125)).
} 
Respecto a las dos situaciones, la doctrina ha acentuado que "é inoportuna a edição de decreto para estipular regras, salvo, tão-somente, para regulamentar o que diz a lei, sem restringir onde ela não restringe. O edital é instrumento hábil para regras menores, bem assim para ampliar a divulgação daquilo que a lei quis, repetindo-a nos pontos essenciais",1030

Lo que aquí se sostiene no es la imposibilidad de la edición de reglamentos para normalización de los concursos públicos, sino la necesidad de que las referidas normas no ocupen el espacio reservado a las leyes, ni que contraríen sus disposiciones, cuando existentes. En este contexto:

\begin{abstract}
"Nada impede que a especificação das exigências legais, o detalhamento dos meios e os modos de cumprimento da lei e a configuração de cada específico concurso público seja objeto de algum decreto ou outro ato normativo regulamentar ou, ainda, que constem do próprio texto do edital, mas a lei que vai assegurar o tratamento isonômico a todos os eventuais interessados. Ou seja, as opções fundamentais quanto à forma de realização do concurso, as condições de participação de interessados e os critérios de avaliação das provas e, eventualmente, dos títulos, deverão estar fixadas em lei." 1031
\end{abstract}

Analizando el contexto brasileño respecto a la presencia de normas sobre concursos públicos, se puede afirmar que hay tres grupos de entes federativos: a) el primero y más numeroso, reúne aquellos que no poseen ni ley ni reglamento sobre la materia; b) los que poseen sólo reglamentos ${ }^{1032}$, ya que las leyes (en general, los

${ }^{1030}$ SANTOS, Waldir. Concurso público e exigência de nível superior. Texto extraído del sitio Jus Navigandi (http://jus2.uol.com.br/doutrina/texto.asp?id=12782).

${ }^{1031}$ ABREU DALLARI, Adilson. Princípio da isonomia e concurso público, en Concurso público e Constituição, Fabrício Motta (Cordinador), Editora Fórum, Belo Horizonte, 2005, p. 95-96.

${ }^{1032}$ En este grupo, está la Unión, que posee el Decreto Federal 6944/2009. Este hecho, aunque esté lejos de lo que es ideal, ha recibido aplausos de la doctrina: “"Há que se elogiar a iniciativa do Presidente Lula, por se tratar de um primeiro trabalho sério do Poder Executivo para padronização e regulamentação dos concursos públicos, muito bom exemplo a ser seguido pelos governadores dos Estados e do Distrito Federal, pelos prefeitos de todos os municípios brasileiros, pelo Advogado-Geral da União, pelo Defensor Público Geral, e pelo Ministro de Estado das Relações Exteriores - todos eles responsáveis por concursos em suas áreas -, caso queiram ser avaliados como administradores comprometidos com a moralização de nossas instituições." (PIMENTEL, Ernani. O decreto presidencial e os concursos públicos. Texto extraído del sitio de la Associação Nacional de Proteção e Apoio aos 
Estatutos de los Funcionarios Públicos) solamente han dedicado poquísimos artículo al tema; y c) los raros entes que poseen ley y reglamento.

No hay dudas de que estos últimos son los que están en peor situación, ya que, en sus ámbitos, inexisten parámetros jurídicos para la realización de los procedimientos de selección para acceder a la función pública.

También es evidente que la efectividad de la igualdad en los procesos selectivos depende de la adopción de ley que regule los aspectos procedimentales del concurso público, tema que será investigado a continuación, siempre a través del panorama ofrecido por el análisis comparativo de los derechos español y brasileño.

\section{2 - Los sistemas selectivos para acceso a la función pública}

El presente tema es uno de los más relevantes entre aquellos que tratan respecto al proceso selectivo y que tiene una gran repercusión en el derecho del ciudadano a acceder a la función pública en condiciones de igualdad. Esto se debe a que la elección del sistema selectivo es pieza fundamental para la definición de la manera en que la Administración Pública va a elegir, entre tantos aspirantes, aquellos que van a ser considerados los más aptos.

Ya se ha analizado en este trabajo la imposición constitucional, sea en Brasil como en España, de la utilización exclusiva de los criterios de mérito y capacidad para la selección de los funcionarios públicos.

Sin embargo, estas expresiones genéricas demandan una delimitación legislativa de su contenido y alcance, ya que sin la mencionada reglamentación, la Administración Pública quedaría libre para definir de qué forma serían comprobados los citados criterios constitucionales de selección igualitaria.

Sobre la afirmación arriba descrita, cabe subrayar que hay distintos Estados que consagraron en sus Constituciones el principio de selección meritoria de sus funcionarios. No obstante, este hecho no ha inducido a que los mencionados Estados, a

Concursos - ANPAC (http://www.anpac.org.br/portal/index.php/artigos/52-anpac-e-o-decretopresidencial-dos-concursos). 
través de sus Administraciones Públicas, hayan utilizado los mismos métodos para el citado fin.

Por el contrario, cada uno de ellos ha considerado oportuna la adopción de técnicas propias de selección ${ }^{1033}$ (pruebas escritas en sus más distintas modalidades, pruebas orales, entrevistas, análisis de currículo, se han enfatizando los títulos académicos o la actividad profesional, combinación de dos o más métodos selectivos, solo para citar algunas de las referidas técnicas.).

Además, el hecho de que dos Estados hayan elegido el mismo método de selección de sus funcionarios públicos no significa que utilicen las referidas técnicas de la misma forma. Para ilustrar esta situación, se posible acentuar que la aplicación de las pruebas orales o de las tests psicotécnicos no se da de la misma manera en Brasil y en España, pues cada sistema jurídico tiene sus propios matices, lo que impide que determinado país repita exactamente las fórmulas adoptadas por otro.

No obstante, la afirmación arriba no imposibilita que un país observe las soluciones legislativas previstas en los demás, y analize la viabilidad de adopción de alguna de ellas, siempre que sean adaptadas a su realidad social y jurídica.

Por esta razón, se verá a continuación los sistemas selectivos utilizados por Brasil y España, destacando sus convenientes, problemas y repercusiones en el acceso igualitário a la función pública.

\subsection{1 - En el Derecho español}

Como se ha subrayado, cabe a la legislación de cada Estado la definición de cuáles son los sistemas selectivos, cuándo deben ser utilizados cada uno de ellos, y cuál es el trámite de los mismos. En eso sentido, los sistemas selectivos de acceso a la

\footnotetext{
${ }^{1033}$ Sobre esta cuestión, se recomienda la lectura de diversas obras que comparan modelos de selección de funcionarios, entre las cuales se destaca el libro de Rosa María Ildefonso Huertas: Tres modelos de función pública y sus procesos de selección, Sevilla, 2004, donde analiza los procesos selectivos en Italia, en los Estados Unidos de América y en España.
} 
función pública española están previstos en el art. 60.6 del Estatuto Básico del Empleado Público. ${ }^{1034}$

Hay que destacar la diferencia entre los sentidos amplio y estricto de la expresión "sistema selectivo". Mientras en sentido amplio abarca todas las normas que tratan sobre el procedimiento de selección (principios, reglas, orientaciones, criterios), en el restricto enfatiza los métodos utilizados para la definición de aquellos que, entre los aspirantes, serán seleccionados por la Administración Pública.

En esto este último sentido el Estatuto Básico del Empleado Público utilizó la expresión analizada, destacando la existencia de tres sistemas: la oposición, el concurso-oposición y el concurso.

La utilización de las tres modalidades de sistemas selectivos es un dato histórico, y en las últimas décadas ha habido pocos cambios. Poco antes de la aprobación del Estatuto Básico del Empleado Público (Ley 7/2007), que, como se ha visto, también utilizó la referida división, fue destacado que:

"Como es sabido, la regulación vigente se basa al respecto en la clásica división tripartita de estos sistemas en oposición, concurso y concurso-oposición. Sin menoscabo de esta terminología, acuñada desde hace tiempo, la Comisión considera que la regulación de los sistemas de selección debe basarse en un orden de conceptos que den cuenta de la variedad de fórmulas de selección existentes o deseables, variedad que no refleja adecuadamente aquella división tripartida, sobre todo cuando es entendida por relación a modelos estereotipados." 1035

La relación de la modalidad del sistema selectivo con respecto al derecho del ciudadano de acceso a la función pública en condiciones de igualdad es algo patente,

\footnotetext{
1034 “Los sistemas selectivos de funcionarios de carrera serán los de oposición y concurso-oposición que deberán incluir, en todo caso, una o varias pruebas para determinar la capacidad de los aspirantes y establecer el orden de prelación.

Sólo en virtud de ley podrá aplicarse, con carácter excepcional, el sistema de concurso que consistirá únicamente en la valoración de méritos."

${ }^{1035}$ Informe de la Comisión para estudio y preparación del Estatuto Básico del Empleado Público, INAP, Madrid, Miguel Sánchez Morón (Presidente), abril 2005, p. 96.
} 
especialmente cuando no es utilizado el sistema adecuado a determinada situación ${ }^{1036}, \mathrm{y}$ cuando, aunque adoptado el sistema indicado por la legislación vigente, no son observadas las normas relativas a su trámite ${ }^{1037}$.

Las mencionadas situaciones serán analizadas en el estudio de cada uno de los tipos de sistemas selectivos de acceso a la función pública. Con todo, cabe ahora la advertencia de que “...no hay buenos y malos procedimientos de selección, tal como se dice en el Informe de la Comisión para el Estudio y Preparación del Estatuto Básico del Empleado Público; éstos pueden variar de acuerdo con las circunstancias, esto es, con el tipo de empleo o el perfil objetivo de las funciones a desarrollar."1038

\subsubsection{1 - Oposición}

La opción preferida del ordenamiento jurídico español para la selección de los funcionarios públicos es la oposición. Pues, tras la consagración del sistema de acceso meritorio a la función pública, siempre ha sido así, ya que esta idea ha estado presente en el Derecho español desde el Real Decreto del 18 de julio de 1852, que consagró el referido sistema selectivo, hasta la actualidad ${ }^{1039}$, y por esa razón, se puede afirmar que "en la actualidad, como regla general y tributaria de los antecedentes históricos, la oposición ha sido el sistema ordinario de acceso."1040

La oposición, en los términos de la legislación vigente (Real Decreto 364/1995, art. 4.2), “consiste en la celebración de una o más pruebas para determinar la capacidad y la aptitud de los aspirantes y fijar su orden de prelación". Como se

\footnotetext{
1036 Para ilustrar esta hipótesis, se puede ofrecer el ejemplo del uso del concurso (en lugar de la oposición), cuando se desee favorecer a determinados candidatos que se sabe que ostentan méritos considerables.

${ }^{1037}$ Es lo que pasaría en un concurso-oposición donde el resultado final estuviera más influenciado por el análisis de los méritos que por la evaluación de la acción de los aspirantes en las pruebas.

1038 MAURI BAJÓS, Joan. Op.cit., p. 306.

1039 Según el Real Decreto 364/1995, de 10 de marzo, por el que se aprueba el Reglamento General de Ingreso del Personal al Servicio de la Administración General del Estado y de Provisión de puestos de trabajo y Promoción Profesional de los Funcionarios Civiles de la Administración General del Estado: "Art.4. El ingreso del personal funcionario se llevará a cabo a través de los sistemas de oposición, concurso-oposición o concurso libres, en los que se garanticen, en todo caso, los principios de igualdad, mérito y capacidad, así como el de publicidad. La oposición será el sistema ordinario de ingreso, salvo cuando, por la naturaleza de las funciones a desempeñar, sea más adecuada la utilización del concursooposición y, excepcionalmente, del concurso." No obstante, cabe subrayar que "Hoy tras la Ley 7/2007, EBEP, oposición y concurso-oposición se equiparan para la función pública de carrera." (LORENZO DE MEMBIELA, Juan B., Op.cit., p. 182).

${ }^{1040}$ LORENZO DE MEMBIELA, Juan B., Idem., p. 182.
} 
puede percibir, la principal característica de la oposición es la realización de pruebas durante el proceso selectivo, para comprobar la capacidad y la aptitud de los candidatos.

Así pues, la oposición se particulariza por la valoración exclusiva de las pruebas y ejercicios, "de manera que sólo puede considerarse válida y ser objeto de evaluación la actuación de los candidatos en el momento de su celebración."1041

En la oposición, como la evaluación de los aspirantes se realiza de forma exclusiva en el curso de la selección, se puede afirmar, con la debida cautela, que aquellos empiezan la competición en los mismos puntos de partida, distinto de lo que pasa en los otros dos sistemas selectivos, donde las experiencias de los candidatos (factores previos a la selección) son aspectos que ya son tomados en consideración por la Administración Pública.

Por supuesto, la afirmación arriba escrita debe ser relativizada, puesto que cada uno de los aspirantes llega a la oposición con distintos niveles de formación intelectual, aunque se pueda resaltar que ellos dispondrán de las mismas herramientas en la competición (lo diferencial será el cómo saber utilizarlas). Quizá debido a esta circunstancia (ecualización inicial de los aspirantes), la oposición es el sistema selectivo de acceso a la función pública más utilizado.

También hay que destacar que el hecho de que en la oposición la competición se establezca a partir de la apertura del proceso selectivo no ocasiona que cualquiera pueda tomar parte en la disputa. Como ya se ha visto, los aspirantes han de cumplir los requisitos de participación en el proceso selectivo, lo que funciona como una especie de filtro.

Además, según enfatiza la doctrina española:

"está muy claro que el sistema que ofrece las mayores garantías de objetividad es la oposición, que, aunque tenga sus detractores por exceso a veces de ejercicios memorísticos (en la mayoría de las ocasiones es para obviarla por o para no estudiar), se presenta como el

${ }^{1041}$ MAURI BAJÓS, Joan. Op.cit., p. 303. 
que proporciona tanto a los aspirantes como a la Administración los resultados más imparciales de selección." 1042

En la misma dirección, hay que subrayar que "la objetividad que preside la articulación de la oposición se cohonesta con una mejor defensa del principio de igualdad, lo que otorga a este sistema la condición de ordinario para la selección de aquellos cuerpos y escalas de funcionarios de carácter general". ${ }^{1043}$

En la oposición, a través de la celebración de las pruebas, la Administración Pública buscará determinar la capacidad y la aptitud de los aspirantes. Tal reto no es de fácil realización, puesto que los mencionados conceptos son abiertos, y por tanto, están sujetos a distintas matizaciones.

En este contexto, las principales dificultades que la Administración Pública encontraría para determinar la capacidad y la aptitud de los aspirantes estarían relacionadas con la definición del perfil ideal de los funcionarios (evidentemente, debe tenerse en consideración cada función a ser desempeñada) y al manejo de los medios disponibles para la selección de los más capaces y aptos.

Sobre la cuestión de la utilización adecuada de los medios de selección, el Estatuto Básico del Empleado Público destaca en su art.61.2 $2^{1044}$, última parte, las distintas posibilidades puestas a disposición de la Administración Pública.

Como se puede percibir, el Estatuto ha establecido un catálogo variado de posibilidades, responsabilizando a la Administración Pública la elección de los medios adecuados. En esta tarea, deberá ser atendida la norma del art. $61.2^{1045}$, primera parte, del Estatuto Básico del Empleado Público, que exige la conexión entre el tipo de prueba y las tareas relativas a la plaza que será cubierta.

\footnotetext{
1042 PERÉZ LUQUE, Antonio. Op.cit., p. 156.

1043 MAURI BAJÓS, Joan. Op.cit., p. 303.

1044 "Las pruebas podrán consistir en la comprobación de los conocimientos y la capacidad analítica de los aspirantes, expresados de forma oral o escrita, en la realización de ejercicios que demuestren la posesión de habilidades y destrezas, en la comprobación del dominio de lenguas extranjeras y, en su caso, en la superación de pruebas físicas"

1045 "Los procedimientos de selección cuidarán especialmente la conexión entre el tipo de pruebas a superar y la adecuación al desempeño de las tareas de los puestos de trabajo convocados, incluyendo, en su caso, las pruebas prácticas que sean precisas."
} 
Aún en este capítulo, serán analizadas con el necesario rigor los distintos tipos de pruebas (escritas, orales, prácticas, físicas, testes psicotécnicos, etc. ${ }^{1046}$.) que pueden ser realizadas en el curso de una oposición. En el citado estudio, será atribuido el debido énfasis al estudio de las repercusiones de uno de los distintos tipos de pruebas en el derecho del ciudadano a acceder a la función pública en condiciones de igualdad.

\subsubsection{2 - Concurso}

Al contrario de la oposición, donde la competición entre los aspirantes es realizada a partir de la evaluación del rendimiento de los mismos en las pruebas realizadas en el curso de la selección, en el concurso, el método de selección adoptado es el análisis de los méritos aportados por los aspirantes, que se refieren a situaciones previas a la disputa.

En el referido sistema selectivo, cabe a la Administración indicar en las bases de la convocatoria cuáles son los méritos que pueden ser aportados por los aspirantes, y establecer un baremo para que pueda evaluarlos.

Según la doctrina, los méritos consisten "en la valoración de una serie de actividades realizadas antes del proceso selectivo en la presunción que la capacidad evidenciada en el pasado tiene aún vigencia y puede ser proyectada hacia el futuro."1047

Como se puede fácilmente percibir, en el concurso, la competición se caracteriza por la comprobación por parte de los aspirantes de que ya han realizado actividades que son consideradas relevantes por la Administración para el ejercicio de la función pública. En las palabras de la doctrina, lo que el Tribunal calificador debe hacer es un verdadero "juicio retrospectivo" 1048 .

\footnotetext{
${ }^{1046}$ Cabe añadir que el Estatuto Básico del Empleado Público prevé en el art. 61.5 que: "Para asegurar la objetividad y la racionalidad de los procesos selectivos, las pruebas podrán completarse con la superación de cursos, de periodos de prácticas, con la exposición curricular por los candidatos, con pruebas psicotécnicas o con la realización de entrevistas. Igualmente podrán exigirse reconocimientos médicos."

${ }_{1047}$ MAURI BAJÓS, Joan. Op.cit., p. 304.

1048 JUNQUERA GONZÁLEZ, Juan. "El sistema de oposición", Revista de Derecho Administrativo, n 137, Septiembre-octubre de 1970, p. 25.
} 
Sobre la utilización del concurso, debe resaltarse que la legislación vigente lo considera un sistema selectivo de carácter excepcional, como se verifica en el art. 61.6, última parte ${ }^{1049}$, del Estatuto Básico del Empleado Público.

El trato legislativo atribuido al concurso, relegándole un papel supletorio, así como exigiendo la previsión por ley de su utilización, demuestra la actual madurez del ordenamiento jurídico español, quizá delante de las sombrías experiencias observadas en las Administraciones Públicas (especialmente las locales y autonómicas), que se manejaran la mencionada modalidad para disfrazar irregularidades diversas.

Pues el concurso es la modalidad de proceso selectivo que está más sujeta a legitimar prácticas de favoritismos, especialmente por la amplia posibilidad atribuida a la Administración Pública de estipular ciertos méritos (o establecer un gran valor a los mismos) que son direccionados a ayudar a determinadas personas.

Sobre la sobredicha conducta administrativa, la doctrina ya dijo en una ocasión, al hacer comentarios sobre las modalidades de procesos selectivos de acceso a la función pública, que:

"Sin lugar a dudas, también, el menos objetivo es el concurso. Aunque no esté así previsto en la ley, de facto y en manos de la realidad de actuación de las Corporaciones locales se están viendo sus auténticas utilizaciones. La ayuda ad personam en el concurso le convierte en el sistema más desviado de los tres sistemas permitidos, porque siempre los méritos son los del aspirante preelegido, o se usa para eliminar los temarios y exámenes, con la consiguiente ayuda igualmente a personas concretas o grupos de ellas. No es el concurso un instrumento pacificador entre los ciudadanos y las Corporaciones locales, pues, aunque el beneficiado ad hoc esté contento, el colectivo vecinal no." 1050

Los riesgos de violación de la igualdad, a partir de la utilización indebida del concurso, son varios:

1049 "Sólo en virtud de ley podrá aplicarse, con carácter excepcional, el sistema de concurso que consistirá únicamente en la valoración de méritos."

${ }^{1050}$ PERÉZ LUQUE, Antonio. Op.cit., p. 156-157. 
a) en primer lugar, como ya se ha visto, estaría la previsión de méritos no relevantes (no adecuados a las funciones a desarrollar) que favorecerían a determinados candidatos que los poseen ${ }^{1051}$. En la mencionada situación, el principio de razonabilidad sería violentado.

b) en segundo lugar, se podría citar la supervaloración de méritos, sean estos razonables o no, una vez más, para beneficiar a los afortunados que los ostentan. En esta hipótesis, se daría la transgresión al principio de proporcionalidad.

c) la tercera hipótesis sería la evaluación subjetiva del cumplimiento o no de las actividades definidas como méritos en las bases de la convocatoria por la Administración Pública. Dependiendo de las expresiones utilizadas en las bases de la convocatoria, su eventual alto nivel de generalidad podría legitimar interpretaciones más abiertas, que favorecerían indebidamente a determinados candidatos que, de hecho, no habrían cumplido las exigencias.

d) se produciría una cuarta situación de riesgo si la Administración admitiera experiencias obtenidas por los aspirantes hace muchos años o de forma superficial, sin que hubiera un mecanismo que verificara si tales conocimientos adquiridos fueron preservados (si pueden ser efectivamente utilizados hoy en día). ${ }^{1052}$

No obstante todo lo se ha mencionado, cabe subrayar que la necesidad de selección de personas con comprobada experiencia y madurez profesional puede ser el fundamento para la utilización de la mencionada modalidad de sistema selectivo.

En los términos arriba descritos, el concurso "puede, sin embargo, ser un sistema muy adecuado para puestos de características especiales o, como digo, para el

\footnotetext{
${ }^{1051}$ Desde la década de 1930 el Tribunal Supremo ya destacaba que "Es viciosa la convocatoria que al particularizar tanto las condiciones, hace ilusorias las garantías de la inmensa mayoría de los aspirantes" (STS de 26 de junio de 193), en PERÉZ LUQUE, Antonio. Op.cit., p. 143.

${ }^{1052}$ Sobre esta cuestión, la doctrina destaca que "es posible dividir el concurso en dos fases y distinguir entre la valoración del merito y su comprobación, entendiendo que se valoran los méritos que se tienen y que se pueden probar documentalmente, pero también su vigencia, es decir, el hecho de saberlos utilizar y la manera como se utilizan. Precisamente, esta segunda fase sirve para comprobar en qué medida el mérito acreditado ha generado capacidades específicas que puedan ser de aplicación en el desempeño del correspondiente puesto de trabajo." (MAURI BAJÓS, Joan. Op.cit., pp. 304-305).
} 
personal directivo donde lo que se debe buscar es la experiencia previa en otros trabajos, incluso ajenos al ámbito público."1053

Para ratificar este entendimiento, conviene transcribir que:

“el sistema de concurso bien utilizado puede ser el mecanismo más adecuado para evaluar el perfil profesional necesario para el acceso a un puesto de trabajo de naturaleza especial, en la cobertura del cual se haya de acreditar una determinada experiencia práctica, unos conocimientos específicos no formalizados en una titulación concreta y una serie de habilidades y aptitudes relacionadas con la capacidad de interacción que a menudo dependen de las características individuales de las personas". ${ }^{1054}$

\subsubsection{3 - Concurso-oposición}

La modalidad de proceso selectivo denominada "concurso-oposición" se caracteriza por la existencia de dos fases distintas: una donde serán comprobadas la capacidad y aptitudes de los aspirantes (como en la oposición), y otra donde serán evaluados los méritos (como en el concurso). Así, el concurso-oposición se destaca por mezclar los dos sistemas selectivos ya analizados.

Tras el Estatuto Básico del Empleado Público, el concurso-oposición, así como la oposición, pasaron a ser considerados los sistemas selectivos ordinarios para el acceso de los funcionarios de carrera (art.61.6). Sin embargo, la doctrina continúa atribuyendo a la oposición la primacía entre los sistemas selectivos.

En este sentido, destaca la existencia de otras normas (Real Decreto 364/1995 y Ley de Medidas de Reforma de la Función Pública, de 1984) que confieren la preferencia a la oposición. Así, a partir de la interpretación sistemática de todas las normas citadas, se debe "considerar la oposición como el sistema de selección ordinario en régimen de alternatividad con el concurso-oposición en base a la oportuna motivación de la elección."1055

${ }^{1053}$ MARTÍN REBOLLO, Luís. Prólogo del libro La selección y pérdida de la condición de empleado público. Especial referencia a su aplicación en la Administración Local, Jorge Fondevila Antolín, Atelier Libros Jurídicos, Barcelona, 2008, p. 13.

${ }_{1054}^{1054}$ MAURI BAJÓS, Joan. Op.cit., pp. 305-306.

${ }^{1055}$ MAURI BAJÓS, Joan. Op.cit., p. 304. 
Sobre la cuestión arriba expuesta, conviene subrayar que la doctrina no está convencida de la posibilidad de que la Administración Pública elija, de forma discrecional, el sistema selectivo a ser utilizado. En estos términos, "Desde una perspectiva general, introducir el factor de la interpretación discrecional en la elección del sistema de selección, sin más parámetro que el enjuiciamiento de la función que es, de por sí, un criterio bastante incorrecto desde una consideración de estudio técnicojurídico."1056

La misma ley tuvo la preocupación de no permitir que la evaluación de los méritos pudiera suplantar la fase de pruebas ${ }^{1057}$. Esta norma tiene su justificación en las frecuentes prácticas detectadas en las Administraciones Públicas españolas, que atribuían una gran valoración a los méritos, en especial a los servicios a ellas prestados por interinos y temporales, con el objetivo de convertirlos en funcionarios de carrera.

En el mismo año que se aprobó la Constitución española (1978), la doctrina ya destacaba que los procesos selectivos se habían convertido en una farsa, debido a la gran cantidad de interinos que pasaban a titulares, ya que la Administración Pública consideraba que el hecho de que uno ya hubiera prestado servicios era una prueba de eficacia, mejor que las oposiciones. ${ }^{1058}$

Comentando los procesos selectivos llevados a cabo por las Corporaciones locales, la doctrina enfatizó que "hoy el sistema que más se usa es el concursooposición, pues con él se premian a los interinos y temporales y los consolidan en el empleo público, impidiendo que otra gente de la calle pueda entrar."

En realidad, la percepción arriba descrita es compartida con otros autores. En este sentido, se puede destacar que se observa "en las Administraciones Autonómica y Local una inmotivada preterición frecuente de la oposición a favor del concurso-

\footnotetext{
${ }^{1056}$ PALOMAR OLMEDA, Alberto. Op.cit., p. 298.

1057 “Art. 61.3. Los procesos selectivos que incluyan, además de las preceptivas pruebas de capacidad, la valoración de méritos de los aspirantes sólo podrán otorgar a dicha valoración una puntuación proporcionada que no determinará, en ningún caso, por sí misma el resultado del proceso selectivo."

1058 NIETO, Alejandro. "Función pública local”, en Cuadernos de documentación e Información, n 4/1978. Delegación Interprovincial del Instituto de Estudios de Administración Local, Granada, 1978, p. 43.

${ }^{1059}$ PERÉZ LUQUE, Antonio. Op.cit., p. 157
} 
oposición, en el que la puntuación atribuida a la fase concursal sobre la de esta última desequilibra el más elemental y básico principio de igualdad."1060

En la misma dirección, "la desnaturalización de los sistemas de selección se ha producido con una sobrevaloración de méritos como el tiempo de servicios previos en la Administración convocante, o en la Administración en general, hasta el punto de ser éste el único mérito evaluable."

Así, es razonable que la norma impida que la valoración de los méritos sea decisiva en el resultado final de la competición, y tal previsión tiene una justificación histórica, debido a los excesos praticados por las Administraciones Públicas españolas.

Sin embargo, no se defiende aquí la prohibición absoluta o la total inadecuación de la valoración de los servicios prestados a la Administración, ya que, en algunas oportunidades, tal comprobación no es ajena al concepto de mérito y capacidad $^{1062}$, y puede reflejar la aptitud o capacidad para desarrollar una función o empleo público.

En este contexto "no supondría una violación del principio de igualdad la consideración como mérito de los servicios prestados, sino únicamente la relevancia cuantitativa desproporcionada que las bases de la convocatoria den a ese merito concreto." 1063

En definitiva, el Tribunal Constitucional español decidió que el sobredicho mérito "no puede llegar a convertirse en un requisito que excluya la posibilidad de concurrencia de terceros, ni tener una dimensión cuantitativa que rebase el límite de lo tolerable." 1064

\footnotetext{
${ }^{1060}$ MARTÍNEZ MARÍN, Antonio. Régimen jurídico de los funcionarios, Editorial Tecnos, 1999, p. 50.

${ }^{1061}$ PALOMAR OLMEDA, Alberto. Derecho de la función pública: régimen jurídico de los funcionarios públicos, $5^{\text {a }}$ ed., Dykinson, Madrid, 2000, p. 297.

1062 Según la STC 67/1989., de 18 de abril.

1063 CANTERO MARTÍNEZ, Josefa. Apartado sobre "Sistemas selectivos", que hace parte del capítulo Acceso al empleo público y adquisición de la relación de servicio, del libro Comentarios a la Ley 7/2007, de 12 de abril, del Estatuto Básico del Empleado Público. Alberto Palomar Olmeda, Antonio V. Sempere Navarro (Directores), R. Yolanda Quintanilla Navarro (Coordinadora), Thomson Aranzadi, Cizur Menor (Navarra), 2008, p. 547.

${ }^{1064}$ STC 67/1989, de 18 de abril.
} 


\subsection{2 - En el Derecho brasileño}

Como suele suceder respecto a diversos asuntos, debido al carácter analítico de la Constitución brasileña de 1988, el tema de los sistemas selectivos en el citado país tiene previsión constitucional. En este contexto, el apartado II del art. 37 de la Carta Magna brasileña prevé la existencia de dos especies de sistemas selectivos: el concurso público de pruebas y el concurso público de pruebas y títulos.

En una sencilla comparación con el derecho español, el concurso público de pruebas correspondería a la oposición, mientras el concurso público de pruebas y títulos tendría conexión con el concurso-oposición. La expresión títulos, del derecho brasileño, en el contexto del derecho español podría ser traducida por mérito.

Así, como se puede percibir, en el derecho brasileño, no hay la modalidad de sistema selectivo que solamente lleve en consideración los meritos (títulos) de los aspirantes a la función pública.

La verdad es que en el medio jurídico brasileño, hay un gran prejuicio contra los procesos selectivos que sólo analizan los meritos de los candidatos. En general, la doctrina asocia este tipo de sistema selectivo a los actos patrimonialistas, ya que en la definición y evaluación de los meritos, pueden suceder muchas arbitrariedades, sean estas para favorecer o para perjudicar determinadas personas ${ }^{1065}$.

En el sentido antes destacado, la doctrina brasileña ha afirmado que "o concurso pode ser de provas ou de provas e títulos. Atualmente não mais é

\footnotetext{
1065 En un país donde pocos tienen acceso a buenas condiciones de formación educacional, la competición a través de títulos tendría un cierto carácter elitista. En este camino, se ha dicho que la prohibición de los concursos de títulos fue una medida que favoreció la igualdad de oportunidades entre las personas, ya que: "Num país onde a desigualdade social é clara como o Brasil, foi prudente o constituinte, haja vista que as pessoas mais abastadas acabariam tendo mais chance de vitória, haja a vista a dificuldade de se conseguir e custear a realização de cursos de pós-graduação no Brasil. Não resta dúvida de que o oferecimento de vagas em universidades públicas é insuficiente para o atendimento da demanda" (BRAGA CALHAU, Lélio. Da inconstitucionalidade da decisão irrecorrível de bancas examinadoras de concurso público. Texto extraído del sitio Jus Navigandi: http://jus2.uol.com.br/doutrina/texto.asp?id=390, acceso en 10.02.2010). La realidad es que mismo en los concursos de pruebas, el factor "formación educacional" aún es decisivo, no que dificulta el acceso de los más pobres (que han tenido menos oportunidades en su formación educacional) a la función pública.
} 
juridicamente possível o concurso apenas de títulos, porque esta forma de seleção não permite uma disputa em igualdade de condições. "1066

A su vez, otro doctrinador ha acentuado que eventual concurso de títulos (meritos) pondría en riesgo la igualdad en el proceso selectivo:

\begin{abstract}
"O concurso de títulos é aquele que consiste na apresentação, pelo candidato, de todos os documentos que se relacionem diretamente com a natureza da função a desempenhar e que demonstrem atividades reais do indivíduo, tais como, diplomas, experiência profissional, cursos de especialização, livros, artigos, etc. O concurso somente de títulos não é mais possível, pois não foi previsto pela atual Constituição, até porque esta forma de seleção não permite uma disputa em igualdade de condições e também porque pode ser fraudado mais facilmente ou se prestar a nepotismo ou favoritismo velados."1067
\end{abstract}

El riesgo de transgresión de la igualdad en el acceso a la función pública también sucedería, en el caso de la adopción de la figura del concurso de títulos, debido a la disminución de las chances de los más jóvenes, que aún no hubieran tenido oportunidades profesionales y académicas suficientes para disputar en condiciones de igualdad con aquellos que tienen una edad más avanzada. ${ }^{1068}$

Además, se suele reconocer en el medio jurídico brasileño que la competición entre los candidatos debe ocurrir a través de la comparación entre los conocimientos y capacidades actuales de los candidatos (lo que se verifica a través de pruebas), y no de sus experiencias en el pasado (lo que se cotejaría por los títulos). ${ }^{1069}$

\footnotetext{
${ }^{1066}$ SANTOS CARVALHO FILHO, José dos. Op.cit., p. 540.

${ }^{1067}$ PINHEIRO MADEIRA, José Maria. Op.cit., p. 67.

${ }^{1068}$ La doctrina afirma que: "No Brasil, hoje, é vedada a prova somente de títulos por prejudicar a disputa igualitária. A prova de titulação não pode ser o único parâmetro para a seleção de candidatos a cargo ou emprego público, sob pena de excluir as pessoas que estão no início da carreira, servindo apenas como mecanismo para definir a classificação dos candidatos no concurso." (MARINELA DE SANTOS SOUZA, Fernanda. Op.cit., p. 185).

${ }^{1069}$ En esta línea de pensamiento: "Se fosse o caso de se presumir, e não provar, o conhecimento, a lei estabeleceria que a prova seria somente de títulos e experiência" (SANTOS, Waldir. Concurso público e exigência de nível superior. Texto extraído del sitio Jus Navigandi (http://jus2.uol.com.br/doutrina/texto.asp?id=12782), con acceso en 15 de julio de 2010.
} 
Para justificar la decisión de la Constitución brasileña por la prohibición de los concursos de títulos, se puede añadir que la propia noción de concurso público en este país es mucho más asociada a la capacidad que al merito ${ }^{1070}$. En este sentido:

\begin{abstract}
"Concurso público é o procedimento administrativo que tem por fim aferir as aptidões pessoais e selecionar os melhores candidatos ao provimento de cargos e funções públicas. Na aferição pessoal, o Estado verifica a capacidade intelectual, física e psíquica dos interessados em ocupar funções públicas e no aspecto seletivo são escolhidos aqueles que ultrapassam as barreiras opostas no procedimento, obedecidos a ordem de classificação. Cuida-se, em verdade, do mais idôneo meio de recrutamento de servidores públicos." 1071
\end{abstract}

\title{
5.2.2.1 - El concurso público de pruebas
}

La modalidad de sistema selectivo más utilizada en el contexto brasileño es el concurso público de pruebas. En verdad, la doctrina no suele mencionar cuáles son los casos que exigen la adopción de un sistema o del otro. A pesar del relativo silencio doctrinal, la respuesta está en la propia Constitución brasileña.

En el contexto acentuado ${ }^{1072}$, la Carta Magna de 1988 determina en el apartado II del art. 37 que "a investidura em cargo ou emprego público depende de

\footnotetext{
${ }^{1070}$ La prohibición de los concursos de títulos existe en Brasil desde la Constitución de 1967. En este sentido: "A prova de títulos, de caráter meramente classificatório, consiste na avaliação cultural do candidato, a partir da análise de sua efetiva produção científica, técnica ou artística pregressa, consoante os critérios estabelecidos no regulamento e no edital do concurso público. Desde a Constituição de 1967/69 foi proibida a seleção de candidatos com base exclusiva na titulação, o que representou um grande avanço no processo de recrutamento dos agentes público, visto que a adoção de tal critério, por si só, não é capaz de aferir a efetiva capacidade e aptidão do candidato para assumir uma função pública, além do que impossibilitaria o Poder Público de fomentar uma maior competitividade entre os interessados, em franco detrimento dos desígnios que animam o instituto democrático do concurso público" (BARBOSA MAIA, Márcio, y PINHEIRO DE QUEIROZ, Ronaldo. Op.cit., p. 132-133).

${ }^{1071}$ SANTOS CARVALHO FILHO, José dos. Op.cit., p. 540.

1072 También se debe acentuar que, según la Constitución brasileña, serán de pruebas y títulos los concursos públicos para la enseñanza pública (art. 206, V), para el Ministério Público (art. 129, §. $3^{\circ}$ ), para la Magistratura (art. 93, I), para las Procuradorias de los Estados y del Distrito Federal (art. 132), y para las Defensorias Pública (art. 134, §.1\%).
} 
aprovação prévia em concurso público de provas ou de provas e títulos, de acordo com a natureza e a complexidade do cargo ou emprego, na forma prevista em lei”.

Como se ha analizado en este capítulo, en Brasil, las leyes que tratan de la función pública no han dedicado mucha atención al tema de los procesos selectivos. Así, no ha sido definido en ley un criterio seguro para que sea utilizado el sistema de pruebas o el de pruebas y títulos.

Sin embargo, como la Constitución brasileña determina que el concurso público deba suceder según la naturaleza y complejidad del cargo o empleo público, se puede afirmar que las situaciones más sencillas (cargos o empleos menos complejos) no demandan la exigencia de los títulos de los candidatos.

A su vez, cuando se está delante de un cargo o empleo más complejo (en el sentido de relevancia y dificultad de la realización de sus tareas, sobre todo las de naturaleza intelectual), deberán ser exigidos y valorados los títulos de los aspirantes.

Para ilustrar una de las pocas aportaciones doctrinales sobre cuáles son los requisitos para definición del sistema selectivo a ser utilizado, sigue la siguiente opinión, que destaca el carácter facultativo de la prueba de títulos, aunque delante de cargos complejos, idea que no se comunga en este trabajo:

\footnotetext{
"As provas de títulos, de caráter facultativo, somente se justificam para os cargos de mais elevado nível, quando para seu preenchimento se recrutam candidatos dos quais são exigidos atributos relacionados à experiência e à especialização, verificáveis através da comprovação de exercício de cargos congêneres, cursos de nível superior e de pósgraduação, publicação de trabalhos científicos, divulgados em periódicos especializados, vinculação a entidades científicas etc. A cada um desses atributos são contemplados pontos, de acordo com a
} 
sua maior ou menor relevância para o exercício do cargo, de modo a tornar objetiva a nota atribuída ao candidato nesse item."1073

En concurso de pruebas, como ya se ha destacado cuando se ha analizada la oposición en el derecho español, verificará la capacidad del candidato para realizar las tareas relacionadas al cargo o empleo a ser cubierto en el proceso selectivo.

En este sentido, la doctrina brasileña ha subrayado que el concurso de pruebas es el que "depende da apresentação do candidato, no momento, de suas qualidades intelectuais, relacionadas com o futuro cargo ou emprego a ser ocupado, caso o candidato seja aprovado e classificado dentro das vagas do concurso. Este concurso se dá através de provas escritas, práticas, orais, ou através de todas elas."1074

La expresión "pruebas" demuestra la posibilidad de que sean realizadas distintos ejercicios, en más de una etapa ${ }^{1075}$. En general, los procesos selectivos son realizados en dos etapas: en la primera, participan todos los candidatos, que son sometidos a pruebas tipo test; evaluadas tales pruebas, solamente pasarán para la segunda etapa una determinada cuantidad de aspirantes, que ahora tendrán que realizar pruebas discursivas, orales, prácticas, etc..

Las primera y segunda etapas de los concursos públicos brasileños suelen ser llamadas de "pruebas objetivas y pruebas subjetivas", respectivamente. Respecto a estas denominaciones usualmente utilizadas en los editales, la doctrina brasileña afirma con adecuación que:

\footnotetext{
"Não é correta a divisão entre provas objetivas e subjetivas que muitas vezes se vê em editais de concurso. Não é admissível a existência de qualquer subjetividade nos concursos públicos, sob pena de afronta ao princípio da igualdade. Por outro lado, não se pode negar que em
}

1073 SÁTIRO FERNANDES, Flávio. A prova oral como elemento defraudador dos princípios da impessoalidade $e$ da moralidade. Texto extraído del sitio Jus Navigandi (http://jus2.uol.com.br/doutrina/texto.asp?id=8691), publicado en 26.07.2006, acceso en 16.02.2010.

${ }^{1074}$ PINHEIRO MADEIRA, José Maria. Op.cit., p. 67.

1075 En el âmbito federal, la Ley 8.112/90 establece que: "Art.11. O concurso será de provas ou de provas e títulos, podendo ser realizado em duas etapas, conforme dispuserem a lei e o regulamento do respectivo plano de carreira (...)" 
determinados tipos de provas há menos objetividade do que em outros." 1076

\title{
5.2.2.2 - El concurso público de pruebas y títulos
}

Esta modalidad de sistema selectivo de acceso a la función pública brasileña es asemejada al concurso-oposición español, ya que en ella hay dos momentos distintos: primeramente, serán realizadas las pruebas para verificar la capacidad de los candidatos, y posteriormente serán evaluados sus títulos (meritos). ${ }^{1077}$

Para la doctrina brasileña:

\begin{abstract}
"Os títulos consistem numa forma indireta de avaliação do mérito dos candidatos, através de sua experiência profissional e acadêmica em atividades relevantes e pertinentes ao cargo a ser provido, como sua experiência profissional, os títulos acadêmicos que tenha obtido, participação em cursos, seminários, palestras, de sua produção científico-literária, do exercício do magistério, etc. Os títulos atestam, portanto, a capacidade demonstrada pelo candidato ao longo de sua vida, e sua avaliação, em conjunto com as provas, traz para o concurso público uma visão mais abrangente dos seus méritos.(...) Ao contrário das provas, de realização obrigatória em qualquer concurso, a avaliação dos títulos não é obrigatória, senão nos casos constitucionalmente previstos, em que sua realização é exigida" 1078
\end{abstract}

En el medio jurídico brasileño (doctrina y jurisprudencia), siempre se ha destacado que la evaluación de los títulos debe ser un aspecto accesorio en el proceso selectivo $^{1079}$, ya que el protagonismo debe ser ejercido por las pruebas. Así:

\footnotetext{
${ }^{1076}$ LOBELLO DE OLIVEIRA ROCHA, Francisco. Op.cit., p. 134.

${ }^{1077}$ En este camino: "Concurso de provas e títulos é a modalidade de concurso público onde se alinham, em primeiro lugar, todas as etapas do concurso de provas, e, em segundo, se afere sobre os títulos do candidato." (PACHECO BARROS, Wellington. Op.cit., p. 26).

${ }^{1078}$ LOBELLO DE OLIVEIRA ROCHA, Francisco. Op.cit., p. 149.

1079 Para comprobar esta tendência: "os títulos apresentados pelos candidatos revelam um tipo de habilitação ou conhecimento apenas presumido e não testado, uma vez que o candidato não é posto à prova quanto ao seu efetivo preparo, expresso apenas em histórico da vida profissional e intelectual de cada concorrente. Não constituindo tipo de prova, os títulos não aprovam, nem reprovam." (TOURINHO, Rita. Op.cit., p. 91).
} 
"O concurso de provas e títulos, se observarmos com lógica e coerência o intento constitucional, indica que os candidatos devem ter seu conhecimento medido pelas provas a que se submeterem, porque esse é o objetivo delas. Por esse motivo é que são comumente denominadas provas de conhecimento. Obviamente, não é esse o escopo do concurso de títulos, integrante do concurso de provas e títulos. A titulação dos candidatos não pode servir como parâmetro para aprovação ou reprovação no concurso público, pena de serem prejudicados seriamente aqueles que, contrariamente a outros candidatos, e às vezes por estarem em início da profissão, ainda não tenham tido oportunidade de obterem esta ou aquela titulação. Entendemos, pois, que os pontos atribuídos à prova de títulos só podem refletir-se na classificação dos candidatos, e não em sua aprovação ou reprovação." 1080

No son pocas las voces de la doctrina brasileña que tienen la misma opinión que los títulos sirven solamente como criterio de clasificación de los candidatos, ya que si "ostentassem natureza eliminatória, fariam com que os candidatos carecedores de densos currículos (os mais jovens e mais pobres, principalmente) já entrassem para a prova de conhecimentos com a obrigação de saber mais do que os outros. E é intuitivo que tal "obrigação antecipada" de saber mais lesionaria o princípio da igualdade."1081

De forma resumida, se puede decir que a pesar de la mayoría de la doctrina brasileña no admitir que la evaluación de los títulos pueda decidir el proceso selectivo, excluyendo candidatos, opinión que también es compartida por muchos Tribunales, hay una decisión del Supremo Tribunal Federal que sostiene que la puntuación atribuida a los títulos puede influenciar de forma decisiva el resultado del concurso:

“Apesar de haver certa polêmica, a fase de títulos, por si só, não pode obstar o acesso ao cargo público, pois não seria razoável o candidato ter êxito nas provas (escritas e/ou orais), demonstrando aptidão para o

\footnotetext{
1080 SANTOS CARVALHO FILHO, José dos. Op.cit., p. 541.

1081 AYRES DE BRITTO, Carlos. Concurso público: requisitos de inscrição, en Revista Trimestral de Direito Público, nº 6, Editora Malheiros, São Paulo, 1994, p. 70.
} 
exercício das atribuições pública, contudo, por ausência da devida experiência ou evidência profissional (muito comum para os recémformados), jamais chegar ao cargo ou emprego público. (...) Todavia, inevitável é fazer referência ao precedente do STF, cujo relator foi o Ministro Marco Aurélio de Mello, em que ficou estabelecido que a prova de títulos pode ensejar pontuação, que, conjugada com a das provas, seja apta a levar o candidato à reprovação" 1082

No obstante, hay que denunciar que en la realidad de los procesos selectivos, "não é incomum a existência de "concursos públicos" nos quais as provas não possuem peso significativo, de tal forma que nelas qualquer candidato será aprovado, deslocando-se a disputa para a avaliação de títulos, onde sempre é possível dar maior valor a títulos sabidamente ostentados por determinadas pessoas."1083

La definición de cuáles situaciones será valoradas como títulos, así como el peso que debe ser atribuído a ellos, debe respetar, respectivamente, los principios de razonabilidad (solamente los títulos necesarios a la demostración del merito ${ }^{1084}$ del candidato para realizar las tareas del cargo deben ser computados ${ }^{1085}$ ) y de proporcionalidad $^{1086}$ (no debe ser atribuida una puntuación muy elevada o muy reducida a los títulos; la actividad de definición de los pesos de los títulos deberá ser realizada de acuerdo con el grado de relevancia y conexión del título con las actividades que son desempeñadas en el puesto de trabajo).

1082 MACHADO JÚNIOR, Agapito. Op.cit., p. 98.

La referida decisión del STF es en el Recurso Extraordinario 221.966, Relator: Ministro Marco Aurelio Mello, DJU 9.6.99, Informativo 151

${ }^{1083}$ ABREU DALLARI, Adilson. Princípio da isonomia e concurso público, en Concurso público e Constituição, Fabrício Motta (Cordinador), Editora Fórum, Belo Horizonte, 2005, p. 117.

${ }^{1084}$ Hay que acentuar que: "Só devem ser considerados títulos que atestem capacitação relevante para o exercício do cargo oи emprego público. Assim, títulos que indiquem características que, apesar de demonstrar mérito do candidato, sejam alheias à natureza do cargo devem ser desconsiderados." (LOBELLO DE OLIVEIRA ROCHA, Francisco. Op.cit., p. 149.)

${ }^{1085}$ En esta dirección: "Como no concurso de provas, quando o questionamento deve ser referir ao cargo ou emprego objeto do concurso público, os títulos do candidato devem manter relação direta ou indireta com o cargo ou emprego público." (PACHECO BARROS, Wellington. Direito Administrativo. Op.cit., p. 26).

${ }^{1086}$ Sobre esta exigencia: "Revela-se ilegítima a pontuação desproporcional atribuída a títulos; aqui a Administração deve respeitar o princípio da proporcionalidade, pois que, não agindo dessa maneira, pesarão fundadas suspeitas sobre o propósito de favorecimento de determinados candidatos. Só assim é possível considerar o concurso de provas e títulos compatível com o princípio da impessoalidade inscrito no art. 37 da CF." (SANTOS CARVALHO FILHO, José dos. Op.cit., p. 541). 
También se debe garantizar que la definición de los títulos (así como de su puntuación) respete el principio de impersonalidad (impessoalidade, en portugués), a fín de que tal etapa del proceso selectivo no sirva para favorecer determinados candidatos $^{1087}$.

La doctrina ha comentado respecto a las cautelas mencionadas:

"cabe à Administração Pública definir discricionariamente quais os títulos a serem considerados na avaliação; contudo, sempre se observarão os princípios constitucionais, em especial, o da razoabilidade e o da impessoalidade. Na escolha ou discriminação dos títulos afetos ao concurso público, o primeiro aspecto a considerar é a pertinência do título para efeito de utilização no certame, em especial, verificar se ele oferece algum indicativo da aptidão do candidato para o desempenho das atribuições do cargo a ser provido" 1088

Otro momento que impone que la Administración Pública actúe con la debida cautela dice respecto a la evaluación de los títulos, ya que aunque estos hayan sido previstos de forma adecuada en el edital, siempre hay el riesgo de que el órgano seleccionador tome decisiones ilegítimas.

De hecho, tanto puede haber irregularidades cuando se aceptan títulos que no corresponden a los previstos en las normas del concurso público, así como cuando se rechazan indebidamente aquellos que cumplen los parámetros del edital. Para evitar que tales situaciones sucedan, es conveniente que las reglas que tratan de la especificación de los títulos sean las más detallistas posibles.

En este sentido, la doctrina administrativista brasileña ha subrayado que "para garantir-se a objetividade da avaliação dos títulos é necessária a determinação

\footnotetext{
1087 Así: "Em certas situações, tem-se visto que, em certos concursos públicos para determinada atividade pública, a Administração Pública tem atribuído pontuação muito elevada para quem já tem atuação na mencionada atividade objeto do certame ou atividade afim, sendo mesmo a prova de títulos a definidora da classificação do certame, o que induz ao final provocar quebra da isonomia, pois quem não detiver tal experiência prévia ao concurso, já estará em situação de grande desvantagem a quem a detiver" (MACHADO JÚNIOR, Agapito. Op.cit., p. 97).

${ }^{1088}$ MACHADO JÚNIOR, Agapito. Idem, p. 97.
} 
prévia, já no edital, dos títulos que deverão ser considerados e dos critérios objetivos que serão utilizados na sua avaliação. Tais critérios deverão respeitar proporcionalidade em relação à importância dos títulos e à sua relevância no exercício do cargo."1089

Pese a la relevancia de tal medida, es innegable que a esta providencia debe ser añadida la exigencia de actuación objetiva del órgano seleccionador, que no puede disponer de la potestad que le permita valorar, a partir de criterios subjetivos, si es aceptable o no determinado título.

En verdad, aunque siempre exista una baja margen de apreciación discrecional en los actos administrativos (que, en este caso, debe ser reducida al máximo), especialmente delante de expresiones de contenido indeterminado, la tarea de evaluación de los títulos presentados por los candidatos debe ser realizada de forma objetiva (casi automática), sin que haya espacios para dudas.

En otras palabras, se impone que la valoración hecha por el órgano seleccionador, si hubiera que ser repetida otras veces, pero a través de otros miembros, se llegaría siempre al mismo resultado, pues no se trata de una evaluación que admita valoraciones distintas, que dependan de la persona que las realice. Por esta razón, se ha destacado que:

\footnotetext{
"Publicado o edital, não deve restar qualquer margem de subjetividade para a avaliação dos títulos. O edital do concurso deverá conter o número de ponto que será atribuído a cada título e os critérios objetivos para sua avaliação. Qualquer margem de subjetividade que reste após a publicação do edital na avaliação dos títulos é ilícita e afronta o princípio da impessoalidade." 1090
}

\section{3 - El procedimiento selectivo de acceso a la función pública española y brasileña}

Tras el estudio de los principios de los procesos selectivos y de las modalidades de sistemas de selección previstos en los ordenamientos jurídicos brasileño

\footnotetext{
${ }^{1089}$ LOBELLO DE OLIVEIRA ROCHA, Francisco. Op.cit., p. 150.

${ }^{1090}$ LOBELLO DE OLIVEIRA ROCHA, Francisco. Idem, p. 151.
} 
y español, conviene que sean analizados los actos que forman parte del procedimiento administrativo que las Administraciones Públicas de aquellos países utilizan para definir los aspirantes que serán elegidos para cubrir las plazas ofertadas.

En el referido estudio, cabe subrayar que no se busca un análisis descriptivo del procedimiento, ni tampoco una investigación detallada sobre cada uno de sus actos, tareas propias de los manuales de derecho administrativo, sino la verificación de las repercusiones del derecho de acceso a la función pública en condiciones de igualdad que inciden en los trámites de la selección en Brasil y en España.

En el contexto arriba referido, el grado de profundización del análisis de cada acto del procedimiento selectivo será directamente proporcional a la mayor o menor repercusión del mismo sobre la igualdad entre los aspirantes.

Antes de empezar este estudio, conviene enfatizar que, durante el curso del procedimiento de selección de los funcionarios públicos, hay múltiples posibilidades de transgresión a los valores que son derivados del principio de igualdad, como la concesión de condiciones equivalentes a todos los aspirantes (igualdad de oportunidades); el trato impersonal a los candidatos, sin que haya discriminaciones de algunos o privilegios de otros; la evaluación objetiva de sus desempeños, entre otros.

En otra oportunidad, hemos comentado sobre la impersonalidad (derivación de la igualdad) en los concursos públicos realizados en Brasil, lo que también sirve en gran parte para la realidad española, que:

“Apesar de sua consagração no mundo jurídico, na prática, diversos são os artifícios utilizados para frustrar a efetivação do princípio da impessoalidade nos concursos públicos na Administração Pública brasileira. Basicamente, existem duas formas de fraudar a regra do concurso público: a primeira consiste na utilização proliferada dos cargos em comissão, das funções de confiança e das contratações temporárias, situações excepcionais, previstas no ordenamento jurídico que afastam a própria realização do concurso público. (...). Outros expedientes utilizados pelos administradores públicos brasileiros se resumem na manipulação dos concursos públicos. Nestes casos, estes atos consistem no direcionamento do resultado do 
processo seletivo. Dentro deste contexto, estes artifícios podem ocorrer em diversos momentos do concurso: na elaboração do Edital, a partir da inserção de cláusulas que favoreçam ou prejudiquem determinados candidatos; na realização das provas escritas, principalmente através da correção das questões abertas; na utilização de provas práticas, em especial quando se faz uso de rigor excessivo. E ainda, na exigência de exames psicotécnicos, quando estes não podem ser controlados ou contestados a partir de parâmetros científicos; na realização de prova oral, onde a nota é conferida simplesmente de acordo com a opinião e o humor dos julgadores; na avaliação dos títulos, na medida em que se valorizam situações irrelevantes para o exercício do cargo, ou quando são desprezadas certas habilidades que tornam o candidato mais apto em relação aos demais para o desempenho das atribuições do cargo." 1091

Como se puede percibir, hay muchas situaciones que ocurren durante el proceso selectivo que demuestran los riesgos a los cuáles el derecho de acceso igualitario a la función pública está sometido. Sin embargo, conviene que se empiece la investigación referida por actos que son previos al propio procedimiento de selección, ya que estos producen efectos que no pueden dejar de ser tenidos en consideración.

En este contexto, en el próximo apartado serán realizados dos estudios: el primero para analizar los actos previos a la selección en el derecho español, especialmente la cuestión de la oferta de empleo público; el segundo para investigar las exigencias que el derecho brasileño impone para la realización de un concurso público que, como se verá, son muchas, aunque no siempre sean observadas.

\subsection{1 - Evaluación de las necesidades de personal: la oferta de empleo público y la previsión presupuestaria brasileña}

El ordenamiento jurídico español exige que todas las Administraciones Públicas planifiquen sus políticas de recursos humanos, y para tal fin, establece determinados instrumentos.

${ }^{1091}$ LINS DE LESSA CARVALHO, Fábio. Op.cit., p. 74. 
En los términos del Estatuto Básico del Empleado Público, los objetivos de la planificación referida están relacionados a la eficacia en la prestación de los servicios y a la eficiencia en la utilización de los recursos económicos disponibles. Y esto se garantizará mediante una mejor distribución, formación, promoción profesional y movilidad del personal a disposición de la Administración Púbica (según el art. 69.1 del Estatuto).

En relación a los instrumentos disponibles para la consecución de los referidos fines, hay que destacar la figura de la Oferta de Empleo Público, que trata "de un documento mediante el que cada Administración hace pública la relación de puestos de trabajo o plazas vacantes que pretende cubrir en cada ejercicio presupuestario a través de procedimientos de selección de personal."1092

El Estatuto Básico del Empleado Público trata del mencionado instrumento de planificación de los recursos humanos en su art. $70.1^{1093}$. Sobre la referida disposición, se puede percibir en primer lugar, el carácter obligatorio de la creación anual de la Oferta de Empleo Público (o instrumento equivalente).

Como es notorio, siempre que haya el riesgo de no poder observar espontáneamente determinadas medidas consideradas relevantes, deben las leyes exigir de forma incondicional su cumplimiento. De esta forma, la determinación de la elaboración obligatoria de la Oferta de Empleo es una medida necesaria, ya que impone, al menos, que las Administraciones Públicas dediquen algún tiempo a la planificación de sus necesidades de personal, lo que puede evitar la necesidad de manejo de expedientes excepcionales y urgentes, o la utilización de temporales e interinos.

También es relevante resaltar que una vez previstos los procesos selectivos en la Oferta de Empleo Público, estos deberán ser convocados, según el plazo máximo previsto en el referido instrumento.

\footnotetext{
${ }^{1092}$ SANCHÉZ MORÓN; Miguel. Derecho de la Función Pública, quinta edición, Tecnos, Madrid, 2008, p. 107.

1093 "Las necesidades de recursos humanos, con asignación presupuestaria, que deban proveerse mediante la incorporación de personal de nuevo ingreso serán objeto de la Oferta de empleo público, o a través de otro instrumento similar de gestión de la provisión de las necesidades de personal, lo que comportará la obligación de convocar los correspondientes procesos selectivos para las plazas comprometidas y hasta un diez por cien adicional, fijando el plazo máximo para la convocatoria de los mismos. En todo caso, la ejecución de la oferta de empleo público o instrumento similar deberá desarrollarse dentro del plazo improrrogable de tres años."
} 
Esta medida es relevante, ya que tanto crea la posibilidad (de hecho, obligación) de que las Administraciones Públicas se organicen con la anterioridad necesaria para la realización de los procesos selectivos, como permite que los aspirantes puedan, con la debida antelación, preparase para los exámenes.

Las dos consecuencias anteriormente referidas de la elaboración obligatoria del sobredicho instrumento afectan directamente al derecho del ciudadano a acceder a la función pública en condiciones de igualdad, sea porque la ley impone que la Administración Pública establezca que las plazas vacantes desempeñadas por interinos sean previstas en la Oferta de Empleo (art. 10.4 del EBEP), sea porque aleja la posibilidad de convocatoria de un proceso selectivo de forma repentina.

Sobre la mencionada primera repercusión de la Oferta de Empleo Público sobre la igualdad (la ley impone que la Administración Pública establezca que las plazas vacantes desempeñadas por interinos sean previstas en la Oferta de Empleo), cabe añadir que "llama la atención la ausencia de una exigencia de la misma naturaleza con relación a las plazas desempeñadas por personal laboral temporal, lo que resulta inexplicable, más si tenemos en cuenta que uno de los más graves problemas de nuestra administración pública...es la excesiva temporalidad."1094

Otra circunstancia lamentable es la previsión de que la Administración Pública podrá ejecutar la Oferta de Empleo Público en el plazo de hasta tres años, lo que es demasiado, especialmente cuando el mismo Estatuto establece, como ya se ha visto, que uno de los principios de los procesos selectivos es la agilidad.

A su vez, respecto a la segunda repercusión de la Oferta de Empleo Público sobre el derecho del ciudadano a acceder a la función pública en condiciones de igualdad (permite que los aspirantes puedan, con la debida antelación, preparase para los exámenes), se puede destacar que una de las finalidades del sobredicho instrumento es la de "informar a los ciudadanos de las plazas vacantes que serán objeto de las correspondientes convocatorias de selección, sirviendo al principio de publicidad que

${ }^{1094}$ FONDEVILA ANTOLÍN, Jorge. Constitución y empleo público. Estudios y propuestas en relación a un régimen jurídico común, Comares, Granada, 2000, p. 85. 
garantiza la igualdad en el acceso a la función pública y al interés público al facilitar una mayor concurrencia de aspirantes preparados."1095

Según la doctrina española, con la publicación de la Oferta de Empleo Público se da "cumplimiento a uno de los principios vertebradores de los procesos selectivos y que garantizará la igualdad en el acceso de todos los potenciales candidatos: el principio de publicidad. A partir de este momento es obligada la transparencia de la totalidad de actuaciones sucesivas que la Administración desarrolle."1096

También destacando la referida finalidad de la Oferta de Empleo Público, esta provoca "unos efectos beneficiosos para el candidato, pues la decisión efectiva de concurrir dependerá de la información disponible sobre la oferta existente y de la valoración de los incentivos anejos a los trabajos ofrecidos."1097

En los términos analizados, aprobada y publicada la Oferta de Empleo Público, nace la obligación de la Administración Pública de convocar los correspondientes procesos selectivos, en los plazos designados en el mencionado instrumento. En este sentido, "la publicación de la OEP vincula, a nuestro juicio, a la convocatoria por parte de los órganos competentes de las pruebas selectivas de acceso para las plazas vacantes comprometidas en la misma". 1098

Así, el procedimiento de selección tendrá su iniciación, que se materializará a través de una propuesta de convocatoria elaborada por el órgano competente, que, a su vez, debe contener "la indicación del sistema selectivo, las pruebas en que consiste, el programa, la forma de calificación y composición de los órganos de selección, esto es, la totalidad de elementos que van a configurar la convocatoria. El segundo momento, es la publicación de la convocatoria"1099

Como se puede percibir, se destacan dos actos muy relevantes en el comienzo del procedimiento de selección: la designación del órgano de selección y la elaboración de convocatoria (y sus bases).

\footnotetext{
${ }^{1095}$ MAURI BAJÓS, Joan. Op.cit., p. 263.

1096 ILDEFONSO HUERTAS, Rosa María. Op.cit., p. 349.

${ }^{1097}$ FERNÁNDEZ DOMÍNGUEZ, Juan J. y RODRÍGUEZ ESCANCIANO, Susana. Op.cit., p. 20.

${ }^{1098}$ ILDEFONSO HUERTAS, Rosa María. Op.cit., p. 347.

${ }^{1099}$ PALOMAR OLMEDA, Alberto. Derecho de la función pública: régimen jurídico de los funcionarios públicos, 7 ed., Dykinson, Madrid, 2003, p. 298.
} 
Antes del análisis de los referidos actos, se impone la investigación de las exigencias que el ordenamiento jurídico brasileño hace para la iniciación del proceso selectivo de acceso a la función pública (concurso público).

Como ya se ha resaltado en otras oportunidades, el presente estudio no busca la exposición de todos los procedimientos necesarios a la realización del concurso público, sino el examen de las repercusiones de la igualdad y sus posibles transgresiones en el procedimiento administrativo de selección de los funcionarios.

En el mencionado contexto, la Constitución brasileña, consciente de los riesgos y de la tradición de una Administración Pública que no suele planificar sus actividades, impulso diversas exigencias para la realización de los concursos públicos.

Las primeras exigencias constitucionales están relacionadas a la obligación, prevista en el art. $61, \S 1^{\circ}$, II, $\mathrm{a}^{1100}$ ), de que los cargos y empleos públicos sean creados a través de ley. El hecho de que se exija que los puestos de trabajo en la Administración Pública sean establecidos a través de ley proporciona la debida publicidad, lo que favorece el amplio conocimiento por la sociedad y la posibilidad de control.

Además, permite que la Administración Pública esté advertida para realizar los trámites necesarios a la cubertura de las plazas abiertas. En este sentido, se ha dicho que "o correto é, pois, ao ser criado determinado cargo ou emprego público, a Administração Pública já estar preparada para realizar de forma objetiva e célere o concurso para provimento de tais cargos e não se valer de forma torpe da exceção contida no art. 37, IX, da CF/88 para aguardar a realização do certame" 1101

En el caso de que la Administración Pública decida realizar el concurso público, deberán ser observadas las reglas previstas en el art. 169 . $1^{\text {o1102 }}$ de la

\footnotetext{
1100 “Art. 61. \$ $1^{\circ}$ - São de iniciativa privativa do Presidente da República as leis que: (...) II - disponham sobre: a) criação de cargos, funções ou empregos públicos na administração direta e autárquica ou aumento de sua remuneração";

${ }^{1101}$ MACHADO JÚNIOR, Agapito. Op.cit., p. 103.

1102 “Art. 169. $\S 1^{\circ}$ A concessão de qualquer vantagem ou aumento de remuneração, a criação de cargos, empregos e funções ou alteração de estrutura de carreiras, bem como a admissão ou contratação de pessoal, a qualquer título, pelos órgãos e entidades da administração direta ou indireta, inclusive fundações instituídas e mantidas pelo poder público, só poderão ser feitas: I - se houver prévia dotação orçamentária suficiente para atender às projeções de despesa de pessoal e aos acréscimos dela decorrentes; II - se houver autorização específica na lei de diretrizes orçamentárias, ressalvadas as empresas públicas e as sociedades de economia mista”.
} 
Constitución Federal, que tratan de la necesidad de que las leyes presupuestarias autoricen las costes que serán implementados con la admisión de nuevos funcionarios.

Las mencionadas exigencias fueron impuestas a partir de Enmienda Constitucional 19/1998, que tuvo como gran preocupación la necesidad del Estado brasileño desarrollar la noción de responsabilidad fiscal, especialmente en los gastos con los sueldos de los funcionarios, tanto que el art. 169 pasó a exigir que " $A$ despesa com pessoal ativo e inativo da União, dos Estados, do Distrito Federal e dos Municípios não poderá exceder os limites estabelecidos em lei complementar”..

A pesar del intento moralizador de los cambios que fueron introducidos en la Constitución brasileña, hay que denunciar muchas Administraciones Públicas pasaron a utilizar el expediente de las tercerizaciones ${ }^{1103}$ para burlar la referida exigencia constitucional, acto prohibido por la Ley de Responsabilidad Fiscal (Ley Complementar 101/2000). En este sentido:

\begin{abstract}
"Logo que foi promulgada a Emenda Constitucional $\mathrm{n}^{\circ}$ 19, as autoridades administrativas apressaram-se em socorrer-se de contratos de fornecimento de mão-de-obra ou de locação de serviços, para atender a suas necessidades de pessoal. Para impedir este tipo de contratação, que apenas substitui o item orçamentário em que se enquadra a despesa, o artigo $18, \S 1^{\circ}$, da lei veio estabelecer que "os valores dos contratos de terceirização de mão-de-obra que se referem à substituição de servidores e empregados públicos serão contabilizados como Outras Despesas de Pessoal." 1104
\end{abstract}

No hay duda que, tras la existencia de la Ley de Responsabilidad Fiscal, las actividades desarrolladas por las Administraciones Públicas brasileñas tanto están cada vez más sometidas a la obligación de planificación, como también sujetas a muchos más

\footnotetext{
${ }^{1103}$ Sin embargo, hay que acentuar que, en la Ley de Responsabilidad Fiscal: "Não é qualquer despesa com terceirização que se inclui no limite de despesa com pessoal, mas apenas a que é feita com o evidente intuito de colocar pessoal de empresas terceirizadas para exercer atribuições próprias de servidores, especialmente quando estes estão organizados em carreiras ou existem cargos, empregos ou funções específicos criados em lei. Na realidade, este tipo de terceirização, além de infringir as normas constitucionais sobre ingresso no serviço público, ainda constitui forma de burlar o limite de despesa previsto no artigo 169 da Constituição." (ZANELLA DI PIETRO, Maria Sylvia. Op.cit., p. 567).

${ }^{1104}$ ZANELLA DI PIETRO, Maria Sylvia. Idem, p. 567.
} 
mecanismos de control. Afortunadamente, las dos circunstancias destacadas se aplican a la realización de los concursos públicos ${ }^{1105}$.

Todas las muchas exigencias previstas en la Constitución Federal y en la Ley de Responsabilidad Fiscal son imprescindibles para garantizar la idoneidad jurídica y financiera del concurso público.

Sin embargo, tales normas no están siendo suficientemente eficaces en el sentido de imponer la realización del propio concurso, ya que, en muchas situaciones, los entes federativos crean cargos y empleos públicos, pero no los cubre, o lo hace a través de subterfugios ilegítimos, lo que compromete el acceso igualitario a la función pública. Para ilustrar este panorama, la doctrina ha subrayado que:

\begin{abstract}
"o ideal é que a lei estabeleça os critérios objetivos e vinculantes para a abertura de concurso público, em ordem a evitar que ação discricionária da Administração descambe para o desvio de finalidade e para outros expedientes arbitrários em detrimento da coletividade. Infelizmente, constata-se que muitas entidades administrativas passam um tempo considerável sem realizar concursos públicos e, ao mesmo tempo, valem-se de expedientes fraudulentos para admitir pessoal,
\end{abstract}

\footnotetext{
${ }^{1105}$ En este sentido: "A realização de concurso público pressupõe o cumprimento de diversas etapas prévias à publicação do edital. É preciso apurar, em processo administrativo devidamente instruído, o preenchimento dos seguintes requisitos materiais e formais: (a) a existência de vagas devidamente instituídas por lei; (b) a real necessidade de novos servidores para dar conta da demanda de serviços; (c) demonstrativo de estimativa de impacto orçamentário-financeiro no exercício em que iniciar a execução e nos dois seguintes (art. 16, I, da LRF); (d) demonstração da origem dos recursos para o custeio (art. 17, $\S 1^{\circ}$, da LRF); (e) comprovação de que a despesa a ser criada não afetará as metas de resultado fiscal previstas no Anexo de Metas Fiscais (art. 17, $\S 2^{\circ}$, da LRF), indicando a forma de compensação dos efeitos financeiros nos exercícios seguintes; $(f)$ comprovação de compatibilidade com a LDO e de adequação orçamentário-financeira (dotação na LOA e disponibilidade financeira); $(\mathrm{g}$ ) declaração do ordenador da despesa sobre adequação orçamentária e financeira à LOA (art. 16, I, LRF) e de compatibilidade com o PPA e da LDO (art. 16, II); (h) autorização específica na LDO (art. 169, § $1^{\circ}, I I, C F / 88$ e art. 118 da CE/SC); e (i) prévia dotação orçamentária suficiente para atender às projeções de despesa de pessoal e aos acréscimos dela decorrentes (art. 169, $\$ 1^{\circ}, \mathrm{I}, \mathrm{CF} / 88$ e art. $118 \mathrm{da}$ $C E / S C)$. (...) Verifica-se, assim, a total necessidade de planejamento estatal para a realização de concurso público. A realização do referido procedimento enseja a expansão das despesas obrigatórias de caráter continuado, razão pela qual é impositiva análise prévia das suas conseqüências fiscais antes do seu lançamento, para evitar o cometimento de ilegalidades insanáveis. A ausência do preenchimento de qualquer um dos referidos elementos poderá ocasionar a nulidade do edital. Tudo isso possui o nítido propósito de evitar que o Poder ou Órgão seja submetido ao desequilíbrio fiscal devido à prática de atos destituídos de planejamento e responsabilidade fiscal." (TAVARES DE JESUS, Noel Antônio. $O$ direito subjetivo à nomeação dos concursados aprovados e os limites de despesas com pessoal. Texto extraído del sitio Jus Navigandi (http://jus2.uol.com.br/doutrina/texto.asp?id=13545), acceso en 08.02.2010).
} 
burlando tal princípio constitucional, como acontece, por exemplo, com as contrações por prazo determinado para atender às necessidades permanentes do Poder Público e com as ilegais terceirizações." 1106

Otro aspecto relevantes es que, de forma distinta de lo que sucede en el derecho español, donde la oferta de empleo público es divulgada con gran antelación, en el sistema jurídico brasileño, a pesar de la necesidad de que haya las debidas previsiones en las leyes presupuestarias y que ya existen intentos de una mayor planificación, especialmente en el ámbito federal, los concursos públicos no suelen ser precedidos de la debida divulgación (excepto a partir de la publicación del edital).

Lo que sucede es que, aunque cuando hay un cierta previsión, muchos de los concursos son adiados o cancelados por motivaciones políticas (por ejemplo, cuando el proceso selectivo había sido programado o iniciado en el Gobierno anterior) y financieras (recorte de gastos debido a la crisis económica, cambios de prioridades o de políticas públicas del Gobierno, etc.)

Tales hechos hacen con que los candidatos no puedan programarse con gran antelación o no siempre se sientan estimulados a someterse a la dura preparación, esencialmente debido al riesgo de que el concurso no sea realizado.

En este sentido, la doctrina enfatiza que:

"Também maléfico ao instituto do concurso público é a pouca importância que os gestores dão à sua divulgação antecipada. No mais das vezes, o público interessado somente toma conhecimento de que a Administração irá selecionar pessoas quando muito pouco falta para a realização das provas, ou seja, por ocasião da publicação do edital de convocação para as inscrições, o que configura fator de desestímulo, notadamente para os mais responsáveis, o que faz com que sejam

${ }^{1106}$ BARBOSA MAIA, Márcio, y PINHEIRO DE QUEIROZ, Ronaldo. Op.cit., p. 81. 
beneficiados com a numérica e qualitativamente baixa concorrência os aventureiros e despreparados." 1107

A continuación, serán analizadas las repercusiones del derecho de igualdad en el trato de los aspirantes en los diversos actos del proceso selectivo.

\subsection{2 - Organización del proceso selectivo: los órganos de selección españoles y la contratación de entidades externas en Brasil}

El éxito o el fracaso de un proceso selectivo de acceso a la función pública depende de muchos factores, entre los cuáles se destaca el grado de profesionalidad de aquellos que van a conducir la referida competición.

Como se ha visto, la referida exigencia, que es uno de los principios que debe regir los procesos de selección, impone que la Administración Pública elija a través de criterios técnicos aquellos que van a participar de forma directa en la organización de las distintas fases de la disputa, en la realización de las pruebas y en la evaluación del desempeño de los candidatos.

Se puede ratificar que la conducción profesional, técnica, objetiva e impersonal del proceso selectivo es un gran paso para la efectividad del derecho de acceso igualitario a la función pública, sea en Brasil o sea en España. No obstante, cada ordenamiento jurídico ha elegido una forma específica para garantizar tales postulados.

En el ordenamiento jurídico español, los procesos selectivos suelen ${ }^{1108}$ estar dirigidos por órganos colegiados ${ }^{1109}$, cuyos miembros son funcionarios de carrera, que

\footnotetext{
${ }^{1107}$ SANTOS, Waldir. Concurso público.Uma ferramenta democrática subutilizada. Texto extraído del sitio Jus Navigandi (http://jus2.uol.com.br/doutrina/texto.asp?id=3726), acceso en 10.02.2010.

${ }^{1108}$ Aunque la vía general sea la designación de órganos de selección para cada uno de los procesos selectivos, y cuyos miembros sean funcionarios de la Administración, el Estatuto Básico del Empleado Público también admite en su art. 61.4 que: "Las Administraciones Públicas podrán crear órganos especializados y permanentes para la organización de procesos selectivos, pudiéndose encomendar estas funciones a los Institutos o Escuelas de Administración Pública."

${ }^{1109} \mathrm{La}$ doctrina destaca una distinción entre los dos tipos de órganos colegiados: los tribunales y comisiones permanentes de selección: "mientras que los Tribunales se constituyen para un proceso selectivo concreto, la Comisiones Permanentes de Selección se crean para un indeterminado, a priori, número de procesos selectivos" (LORENZO DE MEMBIELA, Juan B. Op.cit., p. 219).
} 
ostentan los conocimientos especializados en el área objeto de la selección y que son designados por la Administración Pública para el referido fin ${ }^{1110}$.

Como ya se ha visto en el capítulo anterior, son principios de los procesos selectivos de acceso a la función pública la imparcialidad y profesionalidad de los miembros de los órganos de selección, así como la independencia y discrecionalidad técnica en la actuación de los referidos órganos. Cabe subrayar que el Estatuto Básico del Empleado Público hace algunas pocas referencias a los órganos de selección, destacándose el art. $61^{1111}$.

La relación entre la composición de los órganos de selección y el respeto a la igualdad es extraordinaria, puesto que la decisión final sobre aquellos que ingresarán en la función pública depende de la actuación de los citados órganos colegiados.

En el contexto arriba mencionado, es posible destacar algunos aspectos centrales: en primer lugar, es esencial la exigencia de calificación técnica de los miembros de los órganos de selección con el fin de que la evaluación del rendimiento de los aspirantes sea la más adecuada y objetiva posible.

Esto se debe a que la garantía de evaluación objetiva hace que el mérito y la capacidad de los aspirantes sean los únicos criterios tenidos en consideración para el acceso a la función pública. Y para que la evaluación sea objetiva, conviene que se base en patrones técnicos y científicos, que no permitan la consideración de apreciaciones subjetivas.

\footnotetext{
${ }^{1110}$ Según el art. 11 del Real Decreto 364/1995, “Los Tribunales serán nombrados, salvo excepción justificada, en cada orden de convocatoria y con arreglo a la misma les corresponderá el desarrollo y la calificación de las pruebas selectivas. Estarán constituidos por un número impar de miembros, funcionarios de carrera, no inferior a cinco, debiendo designarse el mismo número de miembros suplentes y en su composición se velará por el cumplimiento del principio de especialidad. La totalidad de los miembros deberá poseer un nivel de titulación igual o superior al exigido para el ingreso en el Cuerpo o Escala de que se trate." Sobre la posibilidad de constitución de comisiones permanentes, el citado Real Decreto, en su art. 12.1 destaca que: "A las Comisiones Permanentes de Selección se encomienda el desarrollo y la calificación de las pruebas selectivas para el acceso a aquellos Cuerpos y Escalas en los que el elevado número de aspirantes y el nivel de titulación o especialización exigidos así lo aconseje."

1111 “1. Los órganos de selección serán colegiados y su composición deberá ajustarse a los principios de imparcialidad y profesionalidad de sus miembros, y se tenderá, asimismo, a la paridad entre mujer y hombre.

2. El personal de elección o de designación política, los funcionarios interinos y el personal eventual no podrán formar parte de los órganos de selección.

3. La pertenencia a los órganos de selección será siempre a título individual, no pudiendo ostentarse ésta en representación o por cuenta de nadie."
} 
Así, la doctrina española destaca que la existencia de órganos y personas especializadas en la selección:

\begin{abstract}
"puede suponer un importante alivio para la Administración en la medida en que le permite olvidarse de esta complicada tarea al contar con empleados expertos en las técnicas y métodos selectivos que asumen la organización y gestión de todo el proceso. Asimismo, su especialización y profesionalización contribuyen significativamente a la elección del candidato más adecuado y, por ello mismo, a garantizar en mayor medida los principios de igualdad, mérito y capacidad." ${ }^{1112}$
\end{abstract}

Por la razón arriba destacada, la legislación consagra el principio de profesionalidad de los miembros de los órganos de selección (especialización), como ya se ha visto en el capítulo anterior.

La gran preocupación del ordenamiento jurídico español con la imparcialidad de los órganos de selección se traduce en la regla, prevista en el Real Decreto 364/1995 (art. 13.2 ${ }^{1113}$ ) que prohíbe que los que hayan participado de la preparación de aspirantes puedan estar presente en los mencionados órganos.

Sobre la norma arriba transcrita, la doctrina destaca que "este artículo es una especialización procedimental tributaria del principio de imparcialidad del art. 103.3 ${ }^{\circ}$ de la CE que protege la actuación administrativa sin favoritismo... subsidiario del principio de igualdad, correlativo a los principios de objetividad e independencia."1114

Otro ejemplo del rigor respecto a la exigencia de imparcialidad de los órganos de selección está presente en el art. 12.1 del Real Decreto 364/1995, que impone que, en condiciones normales, los órganos de selección no podrán estar formados mayoritariamente por funcionarios pertenecientes al mismo Cuerpo o Escala objeto de la selección.

\footnotetext{
1112 CANTERO MARTÍNEZ, Josefa. Apartado sobre "Sistemas selectivos", que hace parte del capítulo Acceso al empleo público y adquisición de la relación de servicio, del libro Comentarios a la Ley 7/2007, de 12 de abril, del Estatuto Básico del Empleado Público. Alberto Palomar Olmeda, Antonio V. Sempere Navarro (Directores), R. Yolanda Quintanilla Navarro (Coordinadora), Thomson Aranzadi, Cizur Menor (Navarra), 2008, p. 549.

1113 "No podrán formar parte de los órganos de selección aquellos funcionarios que hubiesen realizado tareas de preparación de aspirantes a pruebas selectivas en los cinco años anteriores a la publicación de la correspondiente convocatoria."

${ }^{1114}$ LORENZO DE MEMBIELA, Juan B. Op.cit., p. 227.
} 
Otro aspecto central de la composición de los órganos de selección (y su relación con la igualdad) que debe ser acentuado es la exigencia de que sus miembros sean funcionarios de carrera, lo que intenta garantizar una actuación independiente.

Así, es apreciable la prohibición prevista en el art. 61.2 del Estatuto Básico del Empleado Público, que veta expresamente la designación del personal de elección o de designación política, de los funcionarios interinos y del personal eventual para formar parte de los órganos de selección.

En realidad, lo que aquí se defiende como justificación de la prohibición arriba destacada no es la falta de idoneidad, sea moral o profesional, de los mencionados empleados públicos, sino la precaria condición funcional de los mismos, especialmente delante de su vínculo, sea político y/o efímero, con la Administración Pública.

A su vez, los funcionarios de carrera, por la estabilidad que ostentan, pueden oponer resistencia a las presiones políticas que ciertamente sufrirán en el curso del proceso selectivo, lo cual garantizará el trato igualitario de los aspirantes.

Tampoco se debe olvidar la importancia de la norma que determina que la pertenencia a los órganos de selección "será siempre a título individual, no pudiendo ostentarse ésta en representación o por cuenta de nadie.” (art. 61.3, EBEP).

Sobre la necesidad de alejar posibles e indeseables influencias políticas y corporativas de los procesos selectivos, la Comisión para el Estudio y Preparación del Estatuto Básico del Empleado Público destacó que:

"No cabe duda que una de las claves fundamentales de la credibilidad de todo proceso de selección para el acceso al empleo público gira en torno de la imparcialidad y objetividad de los órganos de selección. Eso significa que su composición debe quedar por completo al margen de toda influencia o interferencia partidaria, gremial o corporativa. Debe, pues, asegurarse al máximo la independencia de actuación de los mismos." 1115

1115 Informe de la Comisión para estudio y preparación del Estatuto Básico del Empleado Público, INAP, Madrid, Miguel Sánchez Morón (Presidente), abril 2005, p. 98. 
En el derecho brasileño, la organización de los procesos selectivos de acceso a la función pública (concursos públicos) es más compleja que la del derecho español. Lo que sucede es que suele haber la participación de distintas figuras en este contexto, tanto públicas, como privadas, como se verá a continuación.

La verdad es que, más una vez, la ausencia de normas jurídicas respecto a la organización y realización de los concursos públicos hace con que no exista un único modelo adoptado en el citado país ${ }^{1116}$.

En este panorama, básicamente, hay tres posibilidades que se destacan ${ }^{1117}$ : a) la organización y realización del concurso público, así como la evaluación de lo desempeño de los candidatos, a través de la actuación de los propios órganos públicos (ejecución directa); b) la práctica de las referidas actividades por intermedio de entidades privadas especializadas (con o sin finalidad lucrativa), contratadas por la Administración Pública para actuar en determinado concurso (ejecución indirecta); y c) la actuación conjunta de órganos de la propia Administración Pública y de una entidad privada, donde cada uno tendrá tareas específicas (ejecución mista).

Antes de todo, respecto a la conducción de los procesos selectivos en Brasil, cabe subrayar que debido a la ausencia de sistematización legal, hay muchas denominaciones utilizadas sin criterios sobre las figuras que actúan en este ámbito, como apunta la doctrina:

"Não há que se confundir comissão organizadora, banca examinadora e servidores auxiliares do concurso público. Comissão organizadora

\footnotetext{
${ }^{1116}$ España y Brasil tienen como factor común el hecho de que poseen unaa gran cuantidad de municipios (más de 5 mil), donde la mayor parte de ellos parte tiene una población reducida y una infraestructura administrativa insuficiente. En este contexto, para la organización de procesos selectivos de acceso a la función pública, sería recomendable la realización de pactos entre los municipios, situación ya prevista en la legislación española (mancomunidades municipales) y brasileña (consorcio público, Ley 11.107/2005). Respecto a las mancomunidades españolas, véase QUINTANA LÓPEZ, Tomás. Las mancomunidades en nuestro derecho local. Instituto Nacioanal de Administración Pública, Madrid, 1991, y FERNÁNDEZ DE GATTA SÁNCHEZ, Dionisio. Fórmulas asociativas para la mejor prestación de los servicios públicos: mancomunidades de municipios y consorcios. Revista de Estudios Locales. Los Servicios Públicos Locales, Valentín Merino Estrada, Extra 2007, Madrid., pp. 203-227.

${ }^{1117}$ La doctrina suele reconocer dos posibilidades: "No contexto da fase interna do procedimento, a Administração decidirá se o concurso público será realizado por seus próprios meios (execução direta) ou por intermédio de outro órgão ou entidade (execução indireta)" (BARBOSA MAIA, Márcio, y PINHEIRO DE QUEIROZ, Ronaldo. Op.cit., p. 82).
} 
será composta por aquelas pessoas que se incumbirão de elaborar e montar o concurso público. Cabe a esta comissão os preparativos do concurso (...). Compõem a comissão organizadora os técnicos da empresa contratada para elaborar o concurso, se houver, ou um misto de servidores da administração pública e técnicos da empresa. No caso do concurso público ser elaborado sem a participação de uma firma contratada para tal, os componentes serão os próprios servidores. Banca examinadora são as pessoas que elaborarão, aplicarão e identificarão as provas. Essa comissão é composta por técnicos específicos da área ou disciplina de cada prova, podendo ser originários dos servidores da administração, de empresa contratada para elaborar o concurso ou pessoas que não fazem parte nem da administração, nem da firma contratada." 1118

En la primera posibilidad antes subrayada (la ejecución directa, que es la que más se parece con la prevista en el derecho español), todos los actos del concurso público serán conducidos por los órganos administrativos.

En este contexto, o la Administración Pública suele designar un órgano colegiado (comisión del concurso), constituido por funcionarios públicos, que tendrá como competencia la realización de todos los actos necesarios al desenlace del proceso selectivo; o habrá la designación de dos órganos colegiados: uno, de carácter más administrativo, para la organización del concurso (comisión organizadora) y otro, de carácter más técnico (del área científico relativo a los puestos de trabajo que serán cubiertos) para la elaboración y evaluación de las pruebas (banca examinadora).

En esta segunda situación, el órgano colegiado designado por la Administración Pública para acompañar todo el proceso selectivo, aquí llamado comisión del concurso, suele ser formado por funcionarios públicos de la propia entidad, y deberá tomar las medidas iniciales del procedimiento (contratación de la empresa especializada, elaboración de las normas del edital, designación de los miembros de la banca examinadora, etc.).

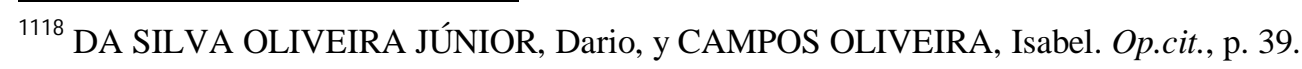


A pesar del diferente uso de las denominaciones de los órganos colegiados de la Administración Pública que actúan en los procesos selectivos, merece la pena destacar la siguiente opinión doctrinaria respecto a la actuación y composición de la comisión del concurso:

“como a realização de concurso não está dentre as atividades diárias da Administração Pública, quando da sua efetivação faz-se necessária a constituição de uma banca examinadora ou comissão de concurso (...) Caberá a esse órgão colegiado o encaminhamento do certame, com a elaboração do edital, realização das provas, até a sua homologação, que ficará a cargo da autoridade máxima do respectivo órgão ou entidade (...) Caso a banca seja constituída de servidores, é conveniente que participem apenas os efetivos, evitando-se influências estranhas $(\ldots)^{1119}$

A su vez, el órgano colegiado nombrado para elaborar las pruebas y evalúalas, aquí llamado banca examinadora, suele ser formado por personas de reconocido conocimiento técnico científico en el área relativo a la naturaleza de las plazas ofertadas, sean aquellas funcionarios públicos (de la entidad responsable por el concurso público o de otra) o no.

Respecto a los miembros de las bancas examinadoras, se ha destacado que: "deve a Administração ter o redobrado cuidado de selecionar, para os seus concursos, examinadores dotados de muito equilíbrio e imparcialidade, de modo a reduzir os riscos de resultados injustos provocados pela atuação de examinadores desequilibrados e desajustados aos objetivos reais visados pelos certames públicos."1120

También se há acentuado que "a escolha dos examinadores pelo mérito constitui uma garantia substancial do Estado Democrático de Direito, no sentido de

${ }^{1119}$ TOURINHO, Rita. Op.cit., pp. 62-63.

${ }^{1120}$ SANTOS CARVALHO FILHO, José dos. Op.cit., p. 551. 
serem atingidos os fins da realização do próprio concurso que é uma escolha eficiente do Estado pelos melhores candidatos."1121

A su vez, hay juristas que sostienen la necesidad de sigilo sobre los nombres de los miembros de las bancas examinadoras ${ }^{1122}$, medida que debe ser utilizada cuando extremamente necesaria, ya que no estaría de acuerdo con el principio de transparencia.

La segunda posibilidad relativa a la organización y realización de los concursos públicos en Brasil dice respecto a la contratación de entidades privadas especializadas por la Administración Pública (ejecución indirecta).

La primera exigencia que se impone al manejo del referido expediente es la necesidad de selección impersonal de la entidad a ser contratada, para garantizar la independencia de la misma en sus relaciones con la Administración y con los candidatos. En este contexto, la doctrina ha acentuado que "poder ocorrer que o concurso seja realizado por entidade estranha à Administração Pública. Nessa situação a escolha do ente deverá ocorrer, em regra, através de um processo licitatório"1123

Hay juristas que aplauden la utilización del mencionado expediente, ya que en el caso de que sean contratadas entidades idóneas, el riesgo de abusos, que suelen ser practicados por la Administración Pública, disminuiría. En este contexto:

\begin{abstract}
"Em realidade, para se evitar a ingerência direta da Administração no processo de recrutamento e seleção de seu pessoal, o Poder Público, em regra, deveria delegar sua execução para órgão distinto da repartição interessada, em ordem a garantir maior imparcialidade na sua realização. (...) Ademais, impede ressaltar que o modo indireto de
\end{abstract}

\footnotetext{
${ }^{1121}$ BRAGA CALHAU, Lélio. Da inconstitucionalidade da decisão irrecorrível de bancas examinadoras de concurso público. Texto extraído del sitio Jus Navigandi (http://jus2.uol.com.br/doutrina/texto.asp?id=390), acceso en 10.02.2010.

${ }^{1122}$ En este sentido: "Seus nomes não serão divulgados, pois somente assim estarão livres de possível assédio dos candidatos." (GASPARINI, Diógenes. Concurso público - imposição constitucional e sua operacionalização, en Concurso público e Constituição, Fabrício Motta (Coordinador), Editora Fórum, Belo Horizonte, 2005, p. 60).

${ }^{1123}$ TOURINHO, Rita. Op.cit., pp. 62-63.
} 
execução do concurso público não retira da Administração Pública o poder de estabelecer as condições gerais do certame"1124

A pesar de la opinión arriba transcripta, la preferencia por la contratación de entidades privadas para la organización del concurso público no es tan consensual $^{1125}$, ya que ofrece muchas cuestiones polémicas, lo que siempre sucede cuando una actividad estatal de gran relevancia para la sociedad pasa a ser conducida por una entidad privada.

La verdad es que la organización de los concursos públicos por entidades privadas ya hace parte de la realidad brasileña ${ }^{1126}$, tanto que, según ha destacado:

\begin{abstract}
"os candidatos direcionam seus estudos de acordo com a organizadora responsável pelo concurso público, pois cada uma tem estilos e conteúdos distintos de prova. Tanto que uma das maiores angústias é saber qual será a instituição escolhida pelo órgão público para aplicar a prova. Além disso, outra preocupação tem se tornado frequente entre os candidatos devido ao grande número de suspensões de concursos causadas por denúncias de irregularidades envolvendo bancas organizadoras. Essas entidades e empresas são responsáveis pela divulgação do concurso, inscrição, pela elaboração do conteúdo da prova, logística de aplicação, fiscalização no dia do exame, correção,
\end{abstract}

\footnotetext{
1124 BARBOSA MAIA, Márcio, y PINHEIRO DE QUEIROZ, Ronaldo. Op.cit., pp. 82-83.

1125 En este sentido: "Devemos, entretanto, nos esforçar para que os concursos públicos sejam sempre realizados com o mínimo de vulnerabilidade. São raras as instituições brasileiras que ainda conseguem fazer concursos com resultados satisfatórios." (MORHY, Lauro. A realidade dos concursos públicos. Texto extraído del sitio de la Universidade de Brasilia - UnB (http://www.unb.br/administracao/reitoria/artigos/20050616.php), acceso en 08.02.2010).

1126 Sobre la "industria" de los concursos públicos" en Brasil, se ha dicho que tal actividad económica: "movimenta algo próximo a $R \$ 30$ bilhões todos os anos no Brasil. Fazem parte dela empresas especializadas em organizar concursos, cursinhos preparatórios, professores particulares, locadores de imóveis dedicados a pessoas que vão para os grandes centros se preparar, empresas de transporte e uma série de prestadores de serviço que, indiretamente, também lucram com os gastos dos candidatos a uma vaga no serviço público (...) As principais organizadoras de concursos, por exemplo, movimentaram sozinhas quase R\$120 milhões em 2007. Organizaram quase 200 concursos, com mais de 2 milhões de inscritos" (Extraído del reportaje: Concurso:o sonho da estabilidade, texto elaborado por Wilson Aquino, Adriana Nicacio y Fabiana Guedes, publicado en la revista Isto é, no 2099, de 3 de febrero de 2010, Três Editorial Ltda, Sao Paulo, p. 80).
} 
divulgação dos resultados e julgamento dos recursos dos candidatos questionando provas e gabaritos." 1127

No obstante la constatación respecto al predominio de este modelo de organización de los concursos públicos, es imprescindible que el hecho de que sea una entidad estraña a la Administración Pública aquella que va a conducir la competición no comprometa el derecho de acceso igualitario del ciudadano a la función pública.

Así, se impone que la Administración no olvide ni por un único momento su responsabilidad de fiscalizar el desempeño de la entidad contratada y que haya la posibilidad del candidato ejercer el control de todos los actos del concurso público, sean practicados por la Administración Pública o por una entidad por ella contratada.

La tercera posibilidad analizada es la conjunción de la labor de órganos colegiados designados por la Administración Pública, sea para el acompañamiento del proceso selectivo (comisión organizadora), sea para la evaluación de las pruebas (banca examinadora), y de la entidad privada contratada para la realización de las medidas operacionales necesarias a la realización de las pruebas (ejecución de los ejercicios, fiscalización de los mismos, corrección mecánica de los exámenes tipo test, etc.).

\subsection{3 - Elaboración y publicación de la convocatoria}

La definición de las reglas de la competición, así como su divulgación a la sociedad son relevantes aspectos relativos al cumplimiento del derecho del ciudadano de acceder a la función pública en condiciones de igualdad.

Ciertamente, la Administración Pública dispone de una considerable dosis de discrecionalidad para establecer el contenido de la convocatoria, aunque haya varias normas de distintos rangos que disciplinan los procesos selectivos, lo cual limita y condiciona la definición de las bases del referido acto administrativo.

\footnotetext{
${ }^{1127}$ Texto extraído del reportaje Saiba como são escolhidas as entidades responsáveis por concursos, publicado en 25 de diciembre de 2009, el sitio Globo.com (http://g1.globo.com/Noticias/Concursos_Empregos/0,,MUL1420670-9654,00.html), con acceso en 17 de junio de 2010.
} 
En la misma dirección, la doctrina apunta que la elaboración de las bases de la convocatoria de un proceso selectivo constituye "la manifestación del ejercicio de una potestad discrecional que a mi juicio no es puramente ejecutiva, aunque tampoco constituye el ejercicio puro de una potestad normativa."1128

Esto se debe a que cada uno de los referidos procesos, por sus características concretas y singulares, exige la previsión de reglas propias, adaptadas a sus peculiaridades (especialmente, la plaza a ser cubierta) y que, por esta razón, no pudieron ser previstas en normas de mayor nivel de generalidad.

En este momento, la Administración Pública debe actuar con la debida cautela, siempre teniendo en consideración la exigencia de estipulación de normas que garanticen la igualdad entre los aspirantes. Así, se puede afirmar que las bases de la convocatoria, si bien redactadas, constituyen un importante paso para la conducción sin atropellos del proceso selectivo.

Por el contrario, también es posible decir que si el contenido de las bases compromete los principios constitucionales (especialmente la igualdad), todos los actos seguientes del procedimiento de selección estarán fatalmente contaminados.

Otro aspecto relativo a la convocatoria que repercute en el trato igualitario de los aspirantes es su divulgación. Como ya se ha visto, cuando se ha analizado el principio de publicidad, para que haya oportunidades iguales en la competición, todos los individuos deben tener acceso a toda la información que tenga relevancia en el proceso selectivo.

La relevancia del cumplimento del debido deber de publicar las bases de la convocatoria, permitiendo el acceso de todos a las informaciones respecto a la competición (reglas, actos, resultados, etc.), se puede percibir a partir de la exposición del entendimiento doctrinario que impone que toda alteración superveniente en las normas del proceso selectivo deba ser sometida a la misma forma de publicidad utilizada para la divulgación inicial de las bases de la convocatoria.

Además, también sostiene la doctrina que si el cambio producido afecta la disputa entre los candidatos (por ejemplo, tras la modificación, fue admitida la $\overline{{ }^{1128} \text { CASTILLO BLANCO, Federico A., Op.cit., p. } 96 .}$ 
participación de los extranjeros), debe ser abierto nuevo plazo para las inscripciones. En este sentido:

\begin{abstract}
"As alterações supervenientes no edital que, de alguma forma, comprometerem o caráter competitivo do certame sujeitar-se-ao às mesmas formalidades exigidas para a validade do ato convocatório e, em qualquer caso, implicará na renovação integral do prazo de inscrição previamente estipulado, em ordem a salvaguardar o postulados fundamental da isonomia."
\end{abstract}

A continuación, serán analizados los dos aspectos más importantes de la convocatoria en el contexto de este trabajo: su contenido y su publicación.

\title{
5.3.3.1 - Contenido de las bases de la convocatoria
}

Es posible afirmar que las normas que van a disciplinar los trámites del proceso selectivo son de dos naturalezas: las que se establecen para todos los procesos (normas constitucionales, legales y reglamentares) y aquellas que se crean para regular determinada selección (bases de la convocatoria ${ }^{1130}$ ) y, que, por supuesto, deben obedecer las primeras, en el orden arriba indicado.

En el contexto delineado, las normas de rango superior a las bases de la convocatoria buscan delimitar la discrecionalidad administrativa, estableciendo parámetros para la actuación de la Administración Pública.

En el ámbito del derecho español, el Real Decreto 364/1995 estableció el contenido mínimo de las bases de las convocatorias de procesos selectivos de acceso a la función pública. ${ }^{1131}$ No obstante la previsión en cuestión, quedan aún distintas

\footnotetext{
1129 BARBOSA MAIA, Márcio, y PINHEIRO DE QUEIROZ, Ronaldo. Op.cit., p. 91.

${ }^{1130}$ Sin embargo, ciertamente hay polémica respecto a la naturaleza normativa o no de las bases de la convocatoria. En sentido contrario a su carácter normativo, el Tribunal Supremo entendió que la convocatoria es "un acto administrativo de carácter general, referido a una actuación singular y concreta como es la apertura de un procedimiento selectivo para la provisión de plazas vacantes, sin que a tal calificación sea obstáculo la pluralidad o indeterminación de sus destinatarios, agotándose sus efectos y eficacia jurídica cuando el proceso selectiva finaliza" (STS de 22 de junio de 1975). Aunque la discusión tenga efectivamente su relevancia, la misma no será profundizada en este momento. Ahora, será acepta la concepción pragmática que dice que "las bases no son normas, pero norman el procedimiento selectivo." (PERÉZ LUQUE, Antonio. Op.cit., p. 218).

1131 "Artículo 16. Contenido de las convocatorias.

Las convocatorias deberán contener, al menos, las siguientes circunstancias: a. Número y características de las plazas convocadas.
} 
posibilidades de transgresión del principio constitucional de igualdad, lo que será visto en las siguientes líneas.

Sobre la afirmación arriba citada, seguramente, se puede subrayar que es en la definición de las bases de la convocatoria donde residen los problemas más graves en el contexto del respeto a la igualdad en el procedimiento administrativo de selección, debido a que la previsión de normas violadoras del mencionado principio hace que las futuras relaciones entre la Administración Pública y los aspirantes sean pautadas en parámetros ilegítimos que comprometen la competición, que ya nace desequilibrada.

En la misma línea de raciocinio, la doctrina subraya que "las bases son lo primero del proceso selectivo y, por lo tanto, lo más importante, pues de ellas depende la tranquilidad en la selección o su complicación."1132

En el mencionado contexto de la definición de las bases de la convocatoria, llama la atención la circunstancia respecto a la oportunidad de la Administración Pública de exigir requisitos específicos de participación de los aspirantes en el proceso selectivo. En este momento, lo que está en riesgo no es el trato igualitario de los aspirantes, sino la posibilidad de que el ciudadano llegue a tener o no la mencionada condición, lo que podrá comprometer la igualdad de oportunidades.

Como ya ha analizado en el tercer capítulo de este trabajo, la estipulación de requisitos específicos de participación puede ser admitida, siempre que estos guarden

b. Declaración expresa de que no se podrá declarar superado el proceso selectivo a un número de aspirantes superior al de plazas convocadas.

c. Órgano, centro o unidad administrativa a que deben dirigirse las solicitudes de participación.

d. Condiciones o requisitos que deben reunir o cumplir los aspirantes.

e. Sistema selectivo.

f. Pruebas selectivas que hayan de celebrarse y, en su caso, relación de méritos que han de ser tenidos en cuenta en la selección.

g. Designación del Tribunal calificador o indicación de la Comisión Permanente de Selección que haya de actuar, sin perjuicio de lo dispuesto en el artículo 11 del presente Reglamento.

h. Sistema de calificación.

i. Programa que ha de regir las pruebas o indicación del Boletín Oficial del Estado en que se haya publicado con anterioridad.

j. Duración máxima del proceso de celebración de los ejercicios. Desde la total conclusión de un ejercicio o prueba hasta el comienzo del siguiente deberá transcurrir un plazo mínimo de setenta y dos horas y máximo de cuarenta y cinco días naturales.

k. Orden de actuación de los aspirantes según el resultado del sorteo a que se refiere el artículo 17 de este Reglamento.

l. Determinación, en su caso, de las características, duración, plazo máximo para el comienzo y centro u órgano responsable de la evaluación del período de prácticas o curso selectivo."

${ }^{1132}$ PERÉZ LUQUE, Antonio. Op.cit., p. 213. 
relación objetiva y proporcionada con las funciones asumidas y las tareas a desempeñar, y que sean establecidos de manera abstracta y general.

No son infrecuentes las bases de convocatorias que contienen exigencias de participación que sirven solamente para favorecer a determinadas personas o grupos que ostentan los referidos requisitos, o también para perjudicar a aquellos que fatalmente no los tienen. En los dos casos, el principio de competitividad (y consecuentemente, de igualdad) del proceso selectivo sucumbe de forma ilegítima delante de actos de desviación de poder.

Otra posibilidad de transgresión de la igualdad en la definición de las bases de la convocatoria trata sobre la elección inadecuada del sistema selectivo, tal y como se ha visto anteriormente en este trabajo.

Como se sabe, dependiendo del sistema selectivo adoptado, el procedimiento puede o no valorar las experiencias profesionales y académicas de los candidatos. En caso positivo, tal actitud, aunque adecuada, puede optar por situaciones no relevantes, cuando se tienen en consideración las tareas a desarrollar (violando la razonabilidad).

En otras oportunidades, las bases de la convocatoria permiten indebidamente que la fase de valoración de las referidas experiencias de los aspirantes sea conducida a través de baremos desproporcionales, en general, para favorecer a quienes pueden presentar determinados méritos (supervaloración) o para perjudicar a quienes no los poseen (hipo valoración).

Otra circunstancia que tiene gran relevancia en el presente contexto está relacionada con la definición de las pruebas selectivas, lo que se profundizará en algunas de las próximas páginas de este capítulo.

De momento, es posible acentuar que la incompatibilidad del modelo de prueba elegida (pruebas escritas, orales, físicas, prácticas, pruebas psicotécnicas, etc.), especialmente con el perfil de la plaza y del funcionario, o también su utilización inadecuada, pueden comprometer la exigencia de trato igualitario entre los aspirantes, especialmente cuando se olvida (lo que no es raro) que el mérito y la capacidad son los únicos criterios de selección que constitucionalmente pueden ser admitidos. 
También es en la convocatoria donde se otorga la designación de los miembros de los Tribunales o Comisiones de selección. De hecho, si la Administración Pública obra mal en ente momento, todos sus esfuerzos para garantizar la conducción ajustada del proceso selectivo serán infructíferos.

Pues el elemento humano (presencia de personas técnicamente capaces y moralmente idóneas) es esencial para que haya una conducción adecuada de cualquier procedimiento administrativo, y con mucha más razón, de aquellos donde hay la necesidad de selección de pocos entre muchos.

Así, en la definición de las bases de la convocatoria, hay que tener en cuenta, para que sea respetada la igualdad entre los aspirantes, las exigencias ya analizadas de profesionalidad e imparcialidad de los miembros de los Tribunales.

Otro aspecto fundamental en el presente estudio trata sobre el programa que ha de regir las pruebas del proceso selectivo. Parece obvio que no sólo la elección de los modelos de pruebas puede afectar a la igualdad, sino también los temarios exigidos a los aspirantes.

Conviene subrayar que los contenidos de las pruebas han de tener conexión con el desempeño de las tareas de los puestos de trabajo convocados, para que no sea admitida la previsión de temas ajenos a la realidad administrativa, y que muchas veces son previstos de forma direccionada a determinados candidatos especialistas en los mencionados asuntos.

Además, siempre hay que tener en consideración si efectivamente hay la posibilidad de acceso universal de los aspirantes a los temas. Por ejemplo, no sería adecuada la previsión de un tema que dice respecto a una teoría científica desarrollada por determinada persona que nunca haya sido publicada en los debidos medios. De la misma forma, no sería coherente exigir de los candidatos el conocimiento de determinada interpretación o punto de vista aislado, que ni siquiera llega a ser debatido con intensidad en la comunidad científica específica.

También es relevante indicar que en la redacción de las bases de la convocatoria, la Administración Pública puede establecer la necesidad de evaluación del 
período de prácticas y cursos selectivos, tras la realización de las pruebas, como forma de complementación de estas.

En verdad, todos los métodos complementares que puedan ser utilizados para garantizar que la elección sea la más idónea posible deben ser admitidos a priori. Sin embargo, lo que debe ser combatido, destacando en este momento los períodos de prácticas y los cursos selectivos, es su utilización indebida, lo que pasaría si fueran evaluados de forma subjetiva o si fueran considerados como el núcleo de la selección.

En este contexto, la doctrina española ha enfatizado el hecho de que:

"la superación de cursos, el establecimiento de períodos de prácticas, la exposición biográfica o curricular del candidato, la realización de pruebas psicotécnicas, la práctica de entrevistas personales o la exigencia de reconocimientos médicos, sólo pueden utilizarse como agregado o complemento del sistema selectivo, como una fase más del mismo." 1133

Todas las observaciones hechas sirven para la realidad del derecho brasileño, donde las reglas de las bases de la convocatoria (edital) también desempeñan un papel muy relevante en la competición por las plazas ofertadas por la Administración Pública.

La verdad es que, en el contexto brasileño, las normas del edital son aún más decisivas en el proceso selectivo, ya que, en muchos de los entes federativos, como ya se ha analizado, no hay ley, ni siquiera reglamento para definir cuáles son los parámetros que deben ser observados en todos los concursos públicos, lo que hace con que el edital sea, primordialmente, la ley del concurso.

A pesar del silencio del legislador sobre el tema, la doctrina brasileña ha insistido que:

“As regras de acesso ao cargo ou emprego público devem constar necessariamente da lei (art. 37, I, da CF/88), podendo o edital apenas reproduzi-las, sem inovação, haja vista que não se pode restringir um direito com base em norma secundária. Contudo, as regras de

${ }^{1133}$ CANTERO MARTÍNEZ, Josefa. Op.cit., p. 551. 
execução do concurso deverão estar previstas de forma genérica na lei (art. 37, II, da CF/88), podendo, contudo, o edital desenvolvê-las de forma racional, tornando mais minuciosas as respectivas etapas" 1134

Muchos doctrinadores han destacado cuáles aspectos deben ser contemplados en el edital del concurso público. Algunos juristas lo han hecho de forma resumida. Así, se ha afirmado que "como ato administrativo em que extingue a discricionariedade do administrador, o edital deve descrever, com a maior riqueza de detalhes, o procedimento que será obedecido na aplicação das provas, sua forma, os critérios e métodos de avaliação e as notas mínima exigidas"1135

A su vez, otros doctrinadores han intentado expresar con más detalles cuál debe ser el contenido del edital. En este sentido, se puede transcribir que:

"O concurso púbico é precedido de edital, publicado com a antecedência mínima necessária para que todos os possíveis interessados tenham oportunidade de tomar conhecimento do certame. Além disso, o edital deve conter todas as informações essenciais, tais como o prazo de inscrição, o valor da inscrição, o número de cargos a serem providos, a natureza deles, a escolaridade mínima necessária, o vencimento do cargo na data do edital, as matérias a serem exigidas nas provas, os títulos que serão admitidos e o respectivo valor, quando for o caso, o prazo de validade do concurso, entre outros. A Administração e os candidatos vinculam-se às disposições contidas no edital. Daí o cuidado que se deve ter na elaboração deste instrumento convocatório. O edital, por sua vez, não pode criar outras condições de acesso que não as que se definam em lei."1136

En un intento de cambiar la tradición de los concursos públicos brasileños, donde se destaca la ausencia de normas que sirvan como parámetros al edital, la Unión creó el Decreto Federal 6944/2009, para que, al menos, mientras no sea elaborada una

\footnotetext{
${ }^{1134}$ MACHADO JÚNIOR, Agapito. Op.cit., p. 118.

1135 LOBELLO DE OLIVEIRA ROCHA, Op.cit., p. 125.

${ }^{1136}$ PINHEIRO MADEIRA, José Maria. Op.cit., p. 69.
} 
ley sobre el tema, sirva como limite a la Administración Pública Federal, cuando esta tenga que elaborar las normas del edital ${ }^{1137}$.

Conviene subrayar que hay que haber la debida distinción entre los aspectos del proceso selectivo que pueden ser previstos directamente en el edital, de los que deben ser contemplados en ley o en reglamento.

Antes de todo, como ya se ha analizado, los requisitos de participación del ciudadano en el proceso selectivo debe ser materia reservada a la ley, según determina el art. 37, I, de la Constitución Federal.

También deben ser tratados en la ley todos los aspectos que digan respecto a los derechos y deberes del ciudadano, mientras esté participando de la competición. En

${ }^{1137}$ En este contexto, debe ser destacado el art. 19 del citado decreto federal:

"Art. 19. Deverão constar do edital de abertura de inscrições, no mínimo, as seguintes informações:

I - identificação da instituição realizadora do certame e do órgão ou entidade que o promove;

II - menção ao ato ministerial que autorizar a realização do concurso público, quando for o caso;

III - número de cargos ou empregos públicos a serem providos;

IV - quantitativo de cargos ou empregos reservados às pessoas com deficiência e critérios para sua admissão, em consonância com o disposto nos arts. 37 a 44 do Decreto $n^{\circ} 3.298$, de 20 de dezembro de 1999;

$V$ - denominação do cargo ou emprego público, a classe de ingresso e a remuneração inicial, discriminando-se as parcelas que a compõem;

VI - lei de criação do cargo, emprego público ou carreira, e seus regulamentos;

VII - descrição das atribuições do cargo ou emprego público;

VIII - indicação do nível de escolaridade exigido para a posse no cargo ou emprego;

$I X$ - indicação precisa dos locais, horários e procedimentos de inscrição, bem como das formalidades para sua confirmação;

$X$ - valor da taxa de inscrição e hipóteses de isenção;

$X I$ - orientações para a apresentação do requerimento de isenção da taxa de inscrição, conforme legislação aplicável;

XII - indicação da documentação a ser apresentada no ato de inscrição e quando da realização das provas, bem como do material de uso não permitido nesta fase;

XIII - enunciação precisa das disciplinas das provas e dos eventuais agrupamentos de provas;

$X I V$ - indicação das prováveis datas de realização das provas;

$X V$ - número de etapas do concurso público, com indicação das respectivas fases, seu caráter eliminatório ou eliminatório e classificatório, e indicativo sobre a existência e condições do curso de formação, se for o caso;

XVI - informação de que haverá gravação em caso de prova oral ou defesa de memorial;

XVII - explicitação detalhada da metodologia para classificação no concurso público;

XVIII - exigência, quando cabível, de exames médicos específicos para a carreira ou de exame psicotécnico ou sindicância da vida pregressa;

$X I X$ - regulamentação dos meios de aferição do desempenho do candidato nas provas, observado o disposto na Lei $n^{\circ} 10.741$, de $1^{\circ}$ de outubro de 2003;

$X X$ - fixação do prazo de validade do concurso e da possibilidade de sua prorrogação; $e$

XXI - disposições sobre o processo de elaboração, apresentação, julgamento, decisão e conhecimento do resultado de recursos.

Parágrafo único. A escolaridade mínima, e a experiência profissional, quando exigidas, deverão ser comprovadas no ato de posse no cargo ou emprego, vedada a exigência de comprovação no ato de inscrição no concurso público ou em qualquer de suas etapas, ressalvado o disposto em legislação específica”. 
este contexto, por ejemplo, la ley debe definir las condiciones de ejercicio el derecho de control del procedimiento por el candidato, así como la exigencia que imponga el deber de pagamento de tasa de inscripción por el mismo.

Otra cuestión que debe ser destacada es los procesos administrativos deben ser regidos por ley, ya que la actividad administrativa está sometido al principio constitucional de la legalidad.

La obediencia de la Administración Pública a la ley tanto servirá para reprimir los arbitrios de los agentes públicos, como también garantizará una mayor previsibilidad de los comportamientos administrativos, lo que es un factor muy relevante para que los ciudadanos puedan se adaptar a los patrones de conducta establecidos por la propia sociedad y controlar la actuación de los responsables públicos.

Los reglamentos, a su vez, deberán detallar los aspectos necesarios a execución de la ley por la Administración Pública, no debendo innovar en el ordenamiento jurídico, al menos en lo que se refiere a la imposición de deberes.

La última fuente normativa, en el contexto del concurso público, es el edital, que adaptará las reglas legales y reglamentares a las peculiaridades de cada proceso selectivo, siempre que respecte las normas de rango superior y, en especial, el derecho del ciudadano de acceso igualitario a la función pública.

En este sentido, la doctrina ha enfatizado que:

"o poder normativo do edital se restringe, ao contrário do que se pensa, aos aspectos que não representem impedimento à participação dos interessados, como prazo de validade, critérios de aprovação, conteúdo das provas, período e valor da inscrição, entre outros. Pretendendo a administração impor requisito restritivo, ou seja, que impeça determinado candidato de participar do certame, deve se socorrer do poder do legislador, encaminhando-lhe o projeto. Neste sentido, cometendo à lei tal atribuição, vem dispondo a Constituição 
Federal desde 1824, com a compreensível exceção da breve Carta ditatorial de 1937, que expandia o poder aos "regulamentos". ${ }^{1138}$

\subsubsection{2 - Publicación de la convocatoria y de los demás actos del proceso}

La exigencia de igualdad en el proceso de selección para el acceso a la función pública impone que haya la más amplia divulgación, debido a que no es posible la consagración, inicialmente, de la igualdad de oportunidades, y en según qué momento, de la igualdad de trato, sin que haya el conocimiento general sobre todos los aspectos relevantes del proceso selectivo.

Ante la circunstancia arriba destacada, el ordenamiento jurídico garantiza la publicidad de los procesos selectivos, sea mediante la obligatoriedad de la divulgación de su existencia, sea mediante la determinación de la debida propagación respecto al contenido de sus bases y actos relativos al desarrollo de la competición entre los aspirantes.

En este contexto, en el derecho español, primeramente, como ya se ha analizado, se impone la divulgación de la Oferta de Empleo Público, lo que permite que los posibles interesados puedan tomar conocimiento respecto del proceso selectivo con una cierta antelación.

En un momento posterior, según el art. 55.2 a) del Estatuto Básico del Empleado Público, se exige la divulgación de las bases de la convocatoria, y esto, así como los demás actos del procedimiento, se hará en los diarios oficiales correspondientes. $^{1139}$

Garantizado el amplio conocimiento respecto de la realización de un proceso selectivo por determinada Administración Pública, permitiendo que todos los interesados puedan participar de la competición, hay que resguardar la publicidad en los demás actos del procedimiento selectivo, para que la disputa entre los aspirantes pueda ocurrir de forma transparente.

1138 SANTOS, Waldir. Concurso público e exigência de nível superior. Texto extraído del sitio Jus Navigandi (http://jus2.uol.com.br/doutrina/texto.asp?id=12782).

${ }^{1139}$ En el ámbito de la Administración General del Estado, el Real Decreto 364/1995 establece en su art. 15.1 que: "Las convocatorias, juntamente con sus bases, se publicarán en el Boletín Oficial del Estado". 
En este sentido, el ordenamiento jurídico exige la publicación en el diario oficial correspondiente de distintos actos, destacándose la realización del sorteo para definir el orden de actuación de los aspirantes en todas las pruebas ${ }^{1140}$, resolución con la aprobación de la lista de admitidos y excluidos ${ }^{1141}$, anuncios de celebración de las pruebas (aunque de forma diferenciada) ${ }^{1142}$ y relación de aprobados ${ }^{1143}$.

Así, se puede afirmar que el ordenamiento jurídico estableció de forma adecuada que todos los actos que repercuten en la competición deban ser debidamente publicados. Sin embargo, como ya se ha destacado, cuando fue analizado el principio de publicidad en el comienzo de este capítulo, el reto que se tiene que enfrentar es garantizar la ampliación de la eficacia de la publicidad, imponiendo la obligatoriedad de divulgación de la realización de los procesos selectivos en otros medios de comunicación.

Sobre esta cuestión, debe destacarse que:

"la realidad es que una mayor publicidad no se consigue porque se publique, valga la redundancia, es más periódicos oficiales (dada la escasa lectura de los mismos). Tal vez lo que se requiere son soluciones más actuales como puedan ser la utilización de medios de

\footnotetext{
${ }^{1140}$ Según el Real Decreto 364/1995 (art. 17), “Con anterioridad al inicio de los ejercicios o pruebas de los procesos de selección, la Secretaría de Estado para la Administración Pública determinará, mediante un único sorteo público celebrado previo anuncio en el Boletín Oficial del Estado, el orden de actuación de los aspirantes en todas las pruebas selectivas de ingreso que se celebren durante el año. El resultado del sorteo se publicará en dicho periódico oficial."

${ }^{1141}$ Una vez más, el Real Decreto 364/1995 impone en su art. 20.1 que: "Expirado el plazo de presentación de solicitudes, la autoridad convocante dictará resolución, en el plazo máximo de un mes, declarando aprobada la lista de admitidos y excluidos. En dicha resolución, que deberá publicarse en el Boletín Oficial del Estado, se indicarán los lugares en que se encuentran expuestas al público las listas certificadas completas de aspirantes admitidos y excluidos, señalándose un plazo de diez días hábiles para subsanación y determinándose el lugar y fecha de comienzo de los ejercicios y, en su caso, el orden de actuación de los aspirantes."

${ }^{1142}$ Es lo que prevé el art. 21 del Real Decreto 364/1995: "Una vez comenzados los procesos selectivos no será obligatoria la publicación de los sucesivos anuncios de la celebración de las restantes pruebas en el Boletín Oficial del Estado. En dicho supuesto estos anuncios deberán hacerse públicos por el órgano de selección en los locales donde se haya celebrado la prueba anterior, con doce horas, al menos, de antelación al comienzo de éste, si se trata del mismo ejercicio, o de veinticuatro horas, si se trata de uno nиеvo."

${ }^{1143}$ Según el art. 22.1 del Real Decreto 364/1995: "Una vez terminada la calificación de los aspirantes, los Tribunales o las Comisiones Permanentes de Selección harán pública la relación de aprobados por orden de puntuación en los locales en donde se haya celebrado la última prueba, siendo de aplicación, en su caso, lo dispuesto en el artículo 14.2 de este Reglamento. Dicha relación se elevará a la autoridad competente, que la publicará en el Boletín Oficial del Estado."
} 
comunicación social de uso masivo, creación de un Diario oficial de acceso al empleo público etc...."

En el derecho brasileño, el deber de publicidad de los actos administrativos es uma exigencia prevista en la propia Constitución Federal (art. 37), circunstancia que somada al carácter público del proceso selectivo de acceso a la función pública, impone la amplia divulgación de las normas del edital.

A partir del momento en que las normas de la competición son publicadas, se puede afirmar que la misma empieza oficialmente ${ }^{1145}$, lo que exigirá que las partes interesadas (Administración Pública y candidatos) deban cumplir con los parámetros definidos. Así, "publicado o edital, estarão a ele vinculados candidatos e a própria Administração. A Administração não poderá agir contra aquilo que ela mesma fez constar do edital, que somente em raras exceções e respeitadas as formalidades legais, poderá ser alterado."1146

El deber de publicidad impone que la divulgación de la realización del concurso público, así com de sus reglas, sea realizada de la forma más amplia posible, lo que no siempre sucede en la realidad brasileña, especialmente en los municipios que no disponen de boletín oficial.

Debido a la ausencia de ley sobre el tema en muchas de las entidades federativas, la doctrina ha intetando fijar algunos parámetros respecto a los medios de divulgación del concurso público:

"Deve-se, também, atentar à publicação do edital, que será o mais ampla possível. No âmbito federal, a Lei $n^{\circ} 8.112 / 90$, no parágrafo $1^{\circ}$, do art. 12, determina que o edital seja publicado no Diário Oficial da

\footnotetext{
${ }^{1144}$ CASTILLO BLANCO, Federico A. Op.cit., p. 105.

1145 Por esta razón, sostiene la doctrina que : "desde o início até a publicação do edital do concurso de ingresso no serviço público, deve ocorrer sem o conhecimento direto ou indireto dos eventuais interessados, sob pena de violação dos princípios da moralidade administrativa e da igualdade. Em suma: não se deve levar diretamente a certos interessados informações relativas ao concurso cujo processo se acha em andamento" (GASPARINI, Diógenes. Concurso público - imposição constitucional e sua operacionalização, en Concurso público e Constituição, Fabrício Motta (Coordinador), Editora Fórum, Belo Horizonte, 2005, p. 51).

${ }^{1146}$ LOBELLO DE OLIVEIRA ROCHA, Francisco. Op.cit., p. 57.
} 
União e em jornal de grande circulação. Essa ampla publicidade ao certame, ainda que onere os cofres públicos, justifica-se no plano técnico e moral, uma vez que os jornais de grande circulação asseguram a notoriedade ao concurso, muito maior do que a publicação apenas realizada em Diário Oficial, o qual, com exceção dos servidores públicos e certas categorias profissionais, poucos lêem. Deve-se, também, fazer menção à publicação via eletrônica." ${ }^{1147}$

En el ámbito de la Unión, el Decreto Federal 6944/2009 $9^{1148}$ ha regulado la materia, también exigiendo la divulgación en medio electrónico, lo que puede ser considerado un gran avance para garantizar el amplio conocimiento por los posibles interesados en participar del proceso selectivo. Sin embargo, hay que subrayar que el citado decreto no hace referencia a la divulgación del edital en periódico de gran circulación, exigencia que debe prevalecer, pues está prevista en el art. $12, \S 1^{\circ}$-de la Ley 8112/1990.

\subsection{4 - Solicitudes de participación y admisión de candidatos}

A través de un análisis superficial y apresurado, se podría considerar la cuestión de las solicitudes de participación en el proceso selectivo como un tema secundario, sin que tuviera considerables consecuencias en la igualdad.

Sin embargo, si uno verifica este asunto con el merecido grado de profundización percibirá que muchas veces el tema de la admisión de los candidatos puede traer problemas de naturaleza jurídica, como se verá a continuación.

En realidad, la cuestión arriba destacada es determinante para la condición jurídica del ciudadano, ya que si este no ultrapasa esta fase de la selección, ni siquiera

\footnotetext{
${ }^{1147}$ TOURINHO, Rita. Op.cit., p. 66.

${ }^{1148}$ En este sentido, el citado decreto establece que:

"Art. 18. O edital do concurso público será:

I - publicado integralmente no Diário Oficial da União, com antecedência mínima de sessenta dias da realização da primeira prova; $e$

II - divulgado no sitio oficial do órgão ou entidade responsável pela realização do concurso público e da instituição que executará o certame, logo após a sua publicação.

$\S 1^{\circ}$ A alteração de qualquer dispositivo do edital deverá ser publicada no Diário Oficial da União e divulgada na forma do disposto no inciso II.

$\S 2^{\circ}$ O prazo de que trata o inciso I poderá ser reduzido mediante ato motivado do Ministro de Estado sob cuja subordinação ou supervisão se encontrar o órgão ou entidade responsável pela realização do concurso público".
} 
estará apto a para participar en la competición por los puestos de trabajo ofertados por la Administración Pública.

Aunque no sea discrecional la actividad administrativa de verificación de la posibilidad de admisión de los ciudadanos que presentaron sus solicitudes, la Administración Pública algunas veces deniega la participación de determinadas personas, justificando su actuación en interpretaciones no siempre adecuadas de las bases de la convocatoria.

Sobre el tema analizado, en el ámbito del sistema jurídico español, el Real Decreto 364/1995 establece en su art. $18^{1149}$ el procedimiento para la presentación de solicitudes de participación en los procesos selectivos.

El primer punto que llama la atención es la necesidad de que sea observado el plazo establecido para la presentación de solicitudes, el cual, por supuesto, es lo mínimo que debe ser previsto.

Cabe subrayar que la Administración Pública no podrá, aunque alegue urgencia, reducir el referido plazo, ya que este es relevante para que los ciudadanos puedan tomar conocimiento del proceso selectivo, así como ajustarse a las normas relativas a la presentación de solicitudes.

En este contexto, conviene destacar que muchas veces el ciudadano tendrá que desplazarse para que pueda inscribirse en el proceso selectivo, lo que demanda un tiempo razonable, o tomar determinadas providencias exigidas en las bases de la convocatoria.

Sin embargo, aquí se considera plenamente admisible la estipulación de un plazo superior al previsto en la norma arriba destacada, siempre que sea demostrada la necesidad de su previsión.

\footnotetext{
1149 “Art. 18.1. La solicitud para participar en los procedimientos de ingreso, ajustada al modelo oficial aprobado por la Secretaría de Estado para la Administración Pública, deberá presentarse en el plazo de veinte días naturales a partir del siguiente al de publicación de la convocatoria respectiva en el Boletín Oficial del Estado.

2. Para ser admitido y, en su caso, tomar parte en las pruebas selectivas correspondientes, bastará con que los aspirantes manifiesten en sus solicitudes de participación que reúnen todas y cada una de las condiciones exigidas, referidas siempre a la fecha de expiración del plazo de presentación.

3. La autoridad convocante, por sí o a propuesta del Presidente del Tribunal o de la Comisión Permanente de Selección, deberá dar cuenta a los órganos competentes de las inexactitudes o falsedades en que hubieran podido incurrir los aspirantes, a los efectos procedentes."
} 
Otro aspecto relevante versa sobre la propia presentación de la solicitud de participación. En los términos previstos en el mencionado Real Decreto, el ciudadano deberá solamente declarar que reúne todas las condiciones exigidas, y estas se refieren a la fecha de expiración del plazo de presentación de las solicitudes.

Así, si el ciudadano va a implementar una de las exigencias de participación hasta el último día designado para la presentación de solicitudes (según el plazo consignado en las bases de la convocatoria), podrá manifestar su interés de participar del proceso selectivo antes de ostentar efectivamente el referido requisito.

La tercera y más relevante cuestión se refiere a los efectos provenientes de las inexactitudes o falsedades verificadas en las solicitudes de inscripción. Es exactamente en este momento cuando la Administración Pública debe de actuar con la debida cautela, sea para que no admita candidatos cuando debería excluirlos, o para que no impida la participación de aquellos que han cumplido las exigencias de la selección.

La posibilidad (necesidad) de análisis de las solicitudes de participación se traduce en una oportunidad donde la Administración Pública, en el inicio de la selección, cometa irregularidades que pueden favorecer o perjudicar a determinados ciudadanos o grupos de ellos. Y esto sucede con o sin la intención deliberada de transgresión de la igualdad entre los ciudadanos, ya que muchas veces la Administración Pública actúa de forma inadecuada debido al desconocimiento o al mal manejo de los principios jurídicos que deben regir su comportamiento.

Respecto a los referidos principios, que orientarán la actuación administrativa en el análisis de la admisión de los ciudadanos, se ha destacado que: "el primero de ellos es un principio interpretativo claramente favorable a la participación y admisión de todos los aspirantes que se manifiesta, principalmente, en dos aspectos: flexibilidad interpretativa para lograr la máxima admisibilidad...(y) no exigencia de acreditación de los requisitos de participación hasta un momento posterior",1150

El referido segundo principio, que ya ha sido analizado en el tercer capítulo de este trabajo, busca garantizar la economía procedimental y la propia agilidad del proceso selectivo, sin que se produzca ningún riesgo a la seguridad jurídica o a la

${ }^{1150}$ CASTILLO BLANCO, Federico A., Op.cit., p. 136. 
calidad de los resultados de la selección, puesto que los aprobados deberán comprobar el cumplimiento de los requisitos una vez superado el proceso selectivo.

Respecto el primer principio, deben ser atendidas las máximas posibilidades de participación, lo que, para el Tribunal Supremo de España significa “...que las reglas que rigen los concursos y oposiciones han de ser interpretadas en el sentido más favorable a la admisión."1151

Sin embargo, hay situaciones en que las exigencias formales son esenciales para garantizar la seguridad jurídica. Por ello, no debe ser olvidado el carácter competitivo del proceso selectivo, pues el mismo principio de competitividad que impone el incremento de la disputa, para que haya una efectiva y amplia competición y, consecuentemente, para que sean seleccionados los más aptos, también exige que aquellos que no respectaran las reglas del juego sean eliminados, ya que los demás candidatos tienen interés directo en ello y el derecho al cumplimiento objetivo por la Administración Pública de las normas de la disputa.

En este sentido, en la misma sentencia arriba referida, el Tribunal Supremo español ya declaró que:

"Una vez cerrado el plazo de presentación de instancias el interés de los participantes es ya distinto y por razones de seguridad jurídica, dará lugar a que no pueda concurrir nadie que no haya manifestado su voluntad de ser admitido a la selección dentro del plazo. Así pues, el criterio antes expuesto de flexibilidad interpretativa para lograr la máxima admisibilidad, encuentra un límite en la necesidad de la existencia de una voluntad de concurrir dentro del plazo." ${ }^{1152}$

Tras la presentación de las solicitudes de participación por los ciudadanos, deberá la autoridad convocante dictar resolución (que será publicada en el diario oficial) conteniendo la lista de admitidos y excluidos.

También merece la pena registrar que las bases de la convocatoria deberían establecer determinadas situaciones para que haya la posibilidad de esención del pago

${ }^{1151}$ STS de 09 de diciembre de 1986.

1152 STS de 09 de diciembre de 1986. 
de la tasa de inscripción, especialmente en los casos en que los candidatos se encuentren desempleados o cuando no poseen la suficiente capacidad económica.

En el derecho brasileño, el panorama jurídico de las solicitudes de participación de los candidatos en los concursos públicos es casuista, ya que cada proceso selectivo suele definir sus propias reglas respecto al referido tema.

No obstante, la doctrina ya ha manifestado algunas opiniones sobre este relevante aspecto del proceso selectivo, especialmente respecto a las situaciones que suelen repetirse en todos los concursos públicos ${ }^{1153}$. En este contexto, se puede subrayar que la doctrina brasileña, en términos generales, sostiene:

a) la posibilidad de presentación de la solicitud a través de terceros, o a través de medios electrónicos o por correo, o lo que sea necesario para garantizar la amplia competitividad;

b) la necesidad de que sea observado un plazo razonable para la presentación de las solicitudes;

c) la exigencia de que la actuación administrativa, en el momento de análisis de las solicitudes de participación, observe los parámetros jurídicos previstos en las normas de rango superior y en el edital;

d) la necesidad de que el valor de la tasa de inscripción en el proceso selectivo no sea elevado, lo que excluiría la participación de un gran número de candidatos.

Sobre el primer aspecto destacado, la doctrina brasileña ha sostenido que las reglas del concurso público deben permitir la admisión de distintos medios de inscripción, a fin de que puedan participar del proceso selectivo todas las personas que demuestren interés, siempre que reúnan los requisitos legales de acceso ${ }^{1154}$.

\footnotetext{
${ }^{1153}$ Sobre el referido tema, la doctrina brasileña enseña que: "Quanto à participação do interessado no concurso público, esta depende da submissão do mesmo a um processo de inscrição. A inscrição seria, então, a manifestação de vontade do candidato de participar do certame seletivo, na qual é exigida uma série de documentos em consonância com edital e compatível com o cargo ou emprego a ser ocupado." (TOURINHO, Rita. Op.cit., p. 65).

${ }^{1154}$ La idea principal es que las exigencias para presentación de las solicitudes deber ser las más sencillas posibles. En este contexto, se ha subrayado que: "No ato da inscrição exige-se do candidato apenas a
} 
En este contexto, se ha defendido la posibilidad de inscripción en el concurso público a través de internet o por otros medios ${ }^{1155}$, como fax, correo, etc. En este sentido, se ha afirmado que "o requerimento poderá ser apresentado diretamente pelo candidato ou ser disponibilizado pela Comissão de Concurso, através de formulário impresso no endereço que for fornecido ou ainda acessado via site da Internet." ${ }^{\text {"156 }}$

También debe el edital establecer la posibilidad de que la solicitud de inscripción puede ser presentada directamente por el candidato o a través de una tercera persona, que esté representando el mismo. Sobre esta cuestión, se ha defendido que "em regra, admite-se que a inscrição seja realizada por procurador, mediante entrega do respectivo mandato, acompanhada de cópia do documento de identidade do candidato e do procurador." 1157

La verdad es que las reglas respecto a las condiciones para presentación de las solicitudes deben ser elaboradas según el principio de competititividad, ya analizado en este trabajo, oportunidad en que se ha verificado que el mismo es una condición imprescindible para la efectividad de derecho de acceso igualitario a la función pública.

La doctrina brasileá ha acentuado que las referidas reglas sobre la presentación de solicitudes no pueden:

\footnotetext{
“impor obstáculos desnecessários para o exercício de tal faculdade, sob pena de comprometer o caráter competitivo do concurso público, como nas hipóteses a seguir listadas: 1) horários restritos e inadequados para a realização da inscrição; 2) postos de atendimento insuficientes ou localizados em áreas de difícil acesso ou muito longínquas; 3) proibição de inscrição por intermédio de procurador; 4) proibição de inscrição por intermédio de sedex, fac-símile, correio eletrônico, Internet ou qualquer outro meio prático e tecnologicamente eficaz." 1158
}

\footnotetext{
ficha de inscrição, devidamente preenchida, acompanhada da cópia do documento de identidade $e$ comprovante de pagamento da respectiva taxa de inscrição." (TOURINHO, Rita. Idem, p. 69).

${ }^{1155}$ Sobre esta cuestión: "O edital de abertura do concurso poderá ou não facultar que as inscrições sejam feitas via postal, fax ou internet, esta dirigida ao endereço eletrônico que a Comissão de Concurso indicar" (PACHECO BARROS, Wellington. Op.cit., p. 44).

${ }^{1156}$ PACHECO BARROS, Wellington. Op.cit., p. 44.

${ }^{1157}$ TOURINHO, Rita. Op.cit., p. 79.

${ }^{1158}$ BARBOSA MAIA, Márcio, y PINHEIRO DE QUEIROZ, Ronaldo. Op.cit., p. 95.
} 
Otro aspecto relevante tratado por la doctrina, en el ámbito de la presentación de las solicitudes de inscripción, dice respecto a los plazos para ejercicio de tal facultad. Distintos juristas brasileños han insistido que el citado plazo debe ser definido según la razonabilidad.

En este contexto, se ha afirmado que "publicado o edital do concurso público, inicia-se a fase de inscrição dos interessados, de acordo com as datas, horários e prazos previamente estipulados no ato convocatório. $\mathrm{O}$ edital, sob pena de sua nulidade, não pode contemplar prazos irrisórios para a inscrição dos candidatos"1159

Aún respecto al referido tema de los plazos, también se puede añadir que “quanto ao prazo de inscrição, este deverá ser compatível com a natureza dos cargos e empregos oferecidos, o número de vagas e o possível interesse gerado pelo certame. Percebe-se, então, a necessidade de observância do princípio da razoabilidade na fixação de tal prazo, sob pena de violação do princípio da ampla competitividade." ${ }^{1160}$

Los plazos para presentación de las solicitudes de inscripción, además de razonables, deben ser establecidos sin que haya la posibilidad de que ellos sean extendidos (excepto si hay una justificación extraordinaria), ya que tal hecho podría comprometer la igualdad en el trato de los aspirantes a la función pública.

En este contexto, se ha sostenido que "as inscrições têm prazo certo para serem apresentadas. E o prazo estabelecido no edital é resolutivo, não podendo sofrer interrupção, suspensão ou prorrogação, sob pena de ferir o princípio da isonomia que deve nortear o concurso público."1161

El tercer aspecto destacado en este trabajo está relacionado a la necesidad de que la Administración Pública, al analizar las solicitudes de inscripción de los candidatos en el proceso selectivo, actúe según los principios constitucionales, especialmente los que tienen conexión con el tema del concurso público (igualdad,

\footnotetext{
${ }^{1159}$ BARBOSA MAIA, Márcio, y PINHEIRO DE QUEIROZ, Ronaldo. Idem, p. 95.

1160 TOURINHO, Rita. Op.cit., p. 66.

${ }^{1161}$ PACHECO BARROS, Wellington. Op.cit., p. 47.
} 
vinculación a las bases de la convocatoria, impersonalidad, competitividad, razonabilidad, proporcionalidad, etc.).

La actividad de análisis de las solicitudes de participación debe ser ejercida con mucha cautela, pues se trata de un proceso de competición, donde no solamente los actos que impiden la participación de determinado candidato tienen repercusión en la disputa, sino también aquellos que la permiten.

En el contexto antes destacado, hay que subrayar que, tras las solicitudes de los candidatos, "a comissão de concurso em despacho fundamentado arrolará as inscrições deferidas e indeferidas. O fundamento das deferidas é bem simples, pois basta mencionar que atenderam às exigências do concurso. No caso das indeferidas não é tão simples assim, pois a cada uma deve ser dado o motivo do indeferimento."1162

El último aspecto a ser analizado tiene una especial incidencia en el derecho brasileño. Lo que sucede es que casi todos los procesos selectivos de acceso a la función pública exigen de los candidatos el pago de una tasa de inscripción cuyo valor muchas veces se constituye en un factor de exclusión de muchos ciudadanos que, aunque tengan interés de participar del concurso público, no disponen de los medios económicos suficientes para efectuar el referido dispendio.

Además, en la realidad brasileña, diversos concursos públicos son realizados con el objetivo no declarado de recaudación de recursos financieros por la Administración Pública. Por esta razón, la doctrina ha denunciado que "não se pode pensar na taxa de inscrição como uma forma de lucro para a Administração Pública"1163

Sobre el tema de las tasas de inscripción, algunas consideraciones deben ser aquí realizadas. En primer lugar, la exigencia del pago de la referida tasa no puede ser utilizada como medio de impedir la amplia participación de los ciudadanos en el proceso selectivo. Sin embargo, no siempre esto sucede, como se puede percibir abajo:

\footnotetext{
1162 GASPARINI, Diógenes. Concurso público - imposição constitucional e sua operacionalização, en Concurso público e Constituição, Fabrício Motta (Coordinador), Editora Fórum, Belo Horizonte, 2005, p. 59. ${ }^{1163}$ TOURINHO, Rita. Op.cit., p. 75.
} 
“A Constituição Federal de 1988, erigindo os princípios vetoriais da Administração Pública definiu, no que se refere ao ingresso no serviço público, o princípio da ampla acessibilidade aos cargos, empregos e funções públicas (art. 37, I). Esse princípio, na prática, vem sendo frustrado por editais que estabelecem restrições não essenciais ao desenvolvimento das atribuições a serem desempenhadas e, outras vezes, apenas úteis aos interesses secundários da Administração, como, por exemplo, arrecadação de valores. Erigiu-se, no passado, com base em Lei, a permissividade para os agentes públicos fazerem do poder aquisitivo dos candidatos barreiras quase intransponíveis para o acesso a cargos, empregos e funções" ${ }^{1164}$

También en este sentido, "o certo é que valor a ser cobrado na inscrição para o certame não pode se constituir em um fator discriminatório, ou seja, o poder aquisitivo do candidato é, sem dúvida, um odioso meio de seleção. A exigência de altos valores na inscrição se constitui restrição injustificável à competição."1165

Debido a la necesidad de que la referida exigencia de participación no sea una fuente de discriminaciones, el valor de la tasa de inscripción debe ser módico, y, según entendimiento del Tribunal de Cuentas y de determinadas normas ${ }^{1166}$, corresponder tan solo al que sea suficiente para cubrir los costes del proceso selectivo. ${ }^{1167}$

1164 JACOBY FERNANDES, Jorge Ulisses. Concurso público $e$ os direitos dos candidatos. Texto extraído del sitio Jus Navigandi (http://jus2.uol.com.br/doutrina/texto.asp?id=389).

${ }^{1165}$ TOURINHO, Rita. Op.cit., p. 75.

${ }^{1166}$ En este contexto, la Ley 8112/90 define que: "Art. 11. O concurso será de provas ou de provas e títulos, podendo ser realizado em duas etapas, conforme dispuserem a lei e o regulamento do respectivo plano de carreira, condicionada a inscrição do candidato ao pagamento do valor fixado no edital, quando indispensável ao seu custeio, e ressalvadas as hipóteses de isenção nele expressamente previstas. (Redacción alterada por la Ley 9.527, de 10.12.97)"

${ }^{1167}$ Sobre esta cuestión: "Na esfera federal, o Decreto $n^{\circ}$ 86.364, de 14 de setembro de 1981, permitiu a cobrança do valor da taxa de inscrição correspondente a 2,5\% (dois e meio pontos percentuais) da remuneração fixada para a referência inicial do cargo ou emprego. No Distrito Federal, esse limite chegou a ser de $10 \%$ (dez por cento). O valor limite definido, por via oblíqua, constitui-se em restrição à competição em nada justificável; verdadeiramente ilegítimo. A seleção, além dos fatores pessoais do candidato, exige uma concorrência entre esses, nem sempre sendo disponível cifras dessa ordem, que vinham impostas para permitir apenas o direito de disputar uma vaga. Dessa forma, o poder aquisitivo resultava em meio odioso de seleção. Competiu ao Tribunal de Contas da União, pelo seu valoroso corpo técnico, estabelecer que a taxa de inscrição em concurso deve ser fixada de modo a apenas cobrir os custos do certame. A decisão não alcançou a ressonância que era de se esperar e continuaram essas taxas sendo fixadas em valores muito próximos aos limites estabelecidos em Lei. Recentemente a Medida Provisória 1573, - em suas reedições (a propósito, o Brasil tem Congresso Nacional?) estabeleceu 
Otra circunstancia que debe ser tenida en consideración es la necesidad de definición de hipótesis de exención del pago de la tasa de inscripción para los candidatos que sean comprobadamente pobres o que no dispongan, en el momento, de los recursos suficientes para efectuar el referido pago (por ejemplo, en el caso de que el candidato esté en paro).

Respecto a la referida exención, se ha afirmado que:

“a isenção da taxa de inscrição em concurso público se fundamenta no princípio da igualdade (art. $5^{\circ}$, caput da $\mathrm{CR} / 88$ ). Tal princípio passa a idéia de que os iguais serão tratados igualmente e os desiguais serão tratados desigualmente na medida das suas desigualdades. $\mathrm{O}$ candidato hipossuficiente é desigual, fazendo jus a essa isenção. $\mathrm{O}$ entendimento contrário impossibilita o mesmo de participar do certame por ausência de condições financeiras em arcar com o pagamento da citada taxa. Tal posicionamento constitucional por si só já se impõe à Administração Pública e às bancas de concurso. Entretanto, lamentavelmente, o Supremo Tribunal Federal (STF) entende, na maioria dos seus julgados, que é necessário a existência de lei local para a efetivação desse direito. Esse posicionamento vai na contramão dos objetivos fundamentais da República Federativa do Brasil, entre eles a erradicar da pobreza e da marginalização e redução das desigualdades sociais (art. $\left.3^{\circ}, \mathrm{CR} / 88\right) .{ }^{, 1168}$

En el âmbito federal, como la Ley 8112/90, en su art. 11 previó que será cobrada la tasa de inscripción, "ressalvadas as hipóteses de isenção nele expressamente previstas”, la jurisprudencia ha admitido la obligaroriedad de la exención ${ }^{169}$ y la

exatamente a mesma determinação: o valor da taxa deve ser apenas o suficiente para cobrir os custos do concurso. São passos tímidos, mas firmes na direção de melhor definir o interesse público. Infelizmente, é forçoso reconhecer a dificuldade que o cidadão terá para coibir a fixação das taxas elevadas, porque oneroso o questionamento junto ao Poder Judiciário." (JACOBY FERNANDES, Jorge Ulisses. Concurso público e os direitos dos candidatos. Texto extraído del sitio Jus Navigandi (http://jus2.uol.com.br/doutrina/texto.asp?id=389), acceso en 18 de junio de 2010).

1168 QUEIROZ, Tiago. Isenção da taxa de inscrição. Trecho extraído del sitio: http://www.pciconcursos.com.br/consultoria/isencao-da-taxa-de-inscricao.

1169 "ADMINISTRATIVO. CONCURSO PÚBLICO. TAXA DE INSCRIÇÃO. AUSÊNCIA DE PREVISÃO, NO EDITAL, DAS HIPÓTESES DE ISENÇÃO.1. A cobrança de taxa de inscrição para realização de concurso público está prevista no art. 11 da Lei $n^{\circ} 8.112 / 90$, que ressalva hipóteses de isenção previstas 
doctrina ha considerado que, en los concursos públicos realizados por la Administración Pública Federal, hay:

"a obrigação legal de fixarem-se no edital as hipóteses de isenção da taxa de inscrição para o concurso público. Ademais, não é razoável a argumentação de que a possibilidade de isenção de taxa de inscrição ocasionaria prejuízo econômico que inviabilizaria a realização dos concursos públicos, à medida em que: 1) já foram executados, sem qualquer problema, inúmeros certames com a previsão de isenção para as pessoas carentes; 2) o valor da taxa de inscrição a ser fixada já levaria em consideração um número estimado de isenções."

\subsection{5 - Celebración de las pruebas}

Superada la fase de solicitación de participación y la consecuente verificación de la posibilidad de admisión por la Administración Pública, el proceso selectivo se desarrollará a través de la realización de pruebas y/o a través de la evaluación de los méritos de los candidatos ${ }^{1171}$.

En realidad, es exactamente en este momento (que se dilata en el tiempo) en el que sucede la verdadera selección, a partir de la comparación del rendimiento de los aspirantes: en las pruebas realizadas durante el proceso selectivo, en actividades anteriores a la selección o en los dos casos.

no edital. 2. Garante-se isenção ao candidato que não tem condições econômicas de arcar com referida taxa, se omisso o edital a respeito. 3. Remessa oficial improvida." (TRF $1^{\text {a }}$ Reg., Recurso en Mandado de Segurança 200434000006051- Processo: 200434000006051 UF: DF Órgano Juzgador: Quinta Turma Fecha de la decisión: 5/11/2004 Relactor(a) Desemb. Federal Joao Batista Moreira).

" ADMINISTRATIVO. CONCURSO PÚBLICO. TAXA DE INSCRIÇÃO. LEGALIDADE (LEI N. 8.112/90, ART. 11). ISENÇÃO. 1. Embora seja legal a cobrança de taxa para inscrição em concurso público (Lei n. 8.112/90, art. 11), ilegal se mostra disposição editalícia que veda a concessão de isenção, "seja qual for o motivo alegado", por contrariar não apenas o dispositivo legal mencionado, que prevê, expressamente, casos de isenção, mas, também, preceitos constitucionais que asseguram a todos igualdade de livre acesso aos cargos públicos. 2. Segurança concedida. 3. Sentença confirmada 4. Apelação e remessa oficial, desprovidas." (TRF $1^{\mathrm{a}}$ Reg.- Apelación en Mandado de Segurança 199934000023686, Proceso: 199934000023686 UF: DF Órgano Juzgador: Sexta Turma. Fecha de la decisión: 14/9/2001 Relactor(a) Juez Daniel Paes Ribeiro)

${ }^{1170}$ LEOPOLDINO KOEHLER, Frederico Augusto. Da obrigatoriedade de isenção de taxa de inscrição para os reconhecidamente pobres em edital de concurso para o provimento de cargos públicos, texto extraído del sitio Jus Navigandi (http://jus2.uol.com.br/doutrina/texto.asp?id=9008), publicado en 05.10.2006, acceso en 16.02.2010.

${ }^{1171}$ Como se ha analizado, en uno de los sistemas de selección español, solo habrá la realización de pruebas (oposición), en el otro tan solo evaluación de meritos (concurso) y en el tercero, las dos situaciones (concurso-oposición). En Brasi, hay dos modalidades de concurso público: una de pruebas (concurso público de provas), y la otra de pruebas y méritos (concurso público de provas e títulos). 
Las modalidades de pruebas realizadas en el proceso selectivo dependerá de la apreciación de la Administración Pública, que analizará lo(s) mejor(es) instrumento(s) de evaluación de los candidatos según el puesto de trabajo a ser cubierto. Indiscutiblemente, cada sistema jurídico tendrá sus peculiaridades, que se traducen en preferencias por determinados métodos de evaluación y en el rechazo de otros.

Sin embargo, tanto en los sistemas jurídicos brasileño como español, se ha percibido que las referidas Administraciones Públicas habitualmente utilizan métodos de selección coincidentes (pruebas escritas, orales, físicas, prácticas, tests psicotécnicos, etc.), aunque existan muchas diferencias en relación a la forma de ejecución de los mencionados instrumentos de evaluación de la capacidad de los aspirantes, y consecuentemente, diferentes riesgos a la igualdad, lo que se verá a continuación.

En el derecho español, tras exigir que los procedimientos de selección sean adecuados al conjunto de puestos de trabajo que pueden ser desempeñados por los funcionarios de carrera (art. 5.1), el Real Decreto 364/1995, en el art. 5.2 $2^{1172}$, establece los medios que podrán ser utilizados en la selección.

A su vez, el Estatuto Básico del Empleado Público (Ley 7/2007) también determina en su art. 61.2 que los procedimientos de selección cuidarán especialmente la conexión entre el tipo de pruebas a superar y la adecuación al desempeño de las tareas de los puestos de trabajo convocados, incluyendo, en su caso, las pruebas prácticas que sean precisas. Además, añade en la segunda parte del art. $61.2^{1173}$ los medios que serán manejados para el alcance del referido objetivo.

Es notoria la dificultad encontrada por las Administraciones Públicas referente a la selección de personas que, efectivamente, puedan asumir las tareas llevadas a cabo por los organismos públicos. En este contexto, llama la atención "la

\footnotetext{
1172 "A tal efecto, los procedimientos de selección deberán consistir en pruebas de conocimientos generales o específicos. Pueden incluir la realización de test psicotécnicos, entrevistas y cualesquiera otros sistemas que aseguren la objetividad y racionalidad del proceso selectivo. Salvo excepciones debidamente justificadas, en los procedimientos de selección que consten de varios ejercicios, al menos uno deberá tener carácter práctico.”

1173 "Las pruebas podrán consistir en la comprobación de los conocimientos y la capacidad analítica de los aspirantes, expresados de forma oral o escrita, en la realización de ejercicios que demuestren la posesión de habilidades y destrezas, en la comprobación del dominio de lenguas extranjeras y, en su caso, en la superación de pruebas físicas.”
} 
incapacidad de los sistemas selectivos para garantizar la adecuación de los aspirantes seleccionados a las necesidades concretas de los servicios administrativos."

Las cuestiones relativas a las políticas de selección, que envuelven todas las discusiones sobre los modelos de pruebas y ejercicios, la utilidad de los cursos de formación y de los períodos de prácticas, deben ser priorizadas por las Administraciones Públicas, ya que son fundamentales para la mejora de la calidad de los servicios públicos prestados a la sociedad.

Respecto a la realización de las pruebas en los procesos selectivos, cabe destacar que las mismas suelen presentar muchos problemas, debido a que las decisiones administrativas no siempre están de acuerdo con el entendimiento de los aspirantes. En verdad, siempre alguien saldrá insatisfecho, especialmente por el carácter competitivo de la selección. Lo que es relevante es saber si la referida insatisfacción proviene de una actuación ilegítima o no de la Administración Pública ${ }^{1175}$.

Así, conviene que sean estudiadas las distintas modalidades de pruebas ${ }^{1176}$ que pueden ser utilizadas en el proceso selectivo, siempre destacando las amenazas a la igualdad entre los aspirantes y lo que se debe hacer para evitarlas.

En el derecho brasileño, todos los procesos selectivos de acceso a la función pública deberán someter los candidatos a pruebas, con el objetivo de evaluar la capacidad de los aquellos para el ejercicio del cargo o empleo público, y comparar sus desempeños para efecto de clasificación en el concurso público.

\footnotetext{
${ }^{1174}$ SANTAMARÍA PASTOR, Juan Alfonso. Prólogo al libro El acceso del personal y la provisión de puestos de trabajo en la Administración del Estado y de las Comunidades Autónomas, Vicente M. Escuin Palop, INAP, Madrid, 1986, p. 5.

1175 Sobre esta cuestión, llama la atención una circunstancia poco debatida: las fechas designadas para la realización de las pruebas. Lo que se quiere destacar es que, siempre que sea posible, la Administración Pública debe evitar "que las pruebas o ejercicios se señalen en sábados, dado el carácter especial que este día tiene para algunas religiones, lo que ha comportado más de una denuncia de los miembros de las iglesias evangélicas o adventistas, que lo han considerado una discriminación por razón religiosa en el acceso al empleo público." (MAURI MAJÓS, Joan. Op.cit., pp. 333-334). Sin embargo, si las pruebas se señalan en días laborables, se podrá argumentar que habrá una discriminación (al menos, perjuicio) contra todos los opositores que se encuentran empleados.

${ }^{1176}$ Según la doctrina, los ejercicios del proceso selectivo pueden estar divididos en los siguientes grupos: a) teóricos y prácticos; b) obligatorios y voluntarios; c) eliminatorios y no eliminatorios; d)orales y escritos; e)de campo y de gabinete; f) de pruebas físicas e intelectuales; g)públicos y no públicos; h)de realización obligatoria y opcional; i) impuestos por el tribunal y elegidos por el opositor al azar; j) simples y complejos. (PERÉZ LUQUE, Antonio. Op.cit., pp. 320-331).
} 
Sobre las finalidades de las pruebas, ya se ha afirmado que estas son "o aspecto mais evidente dos concursos públicos. São procedimentos padronizados e objetivos aplicados aos candidatos do concurso com a finalidade de aferir, de forma direta, sua aptidão para o exercício do cargo ou emprego que se pretende preencher e, através da comparação dos resultados obtidos por cada candidato, classificá-los."1177

La ausencia de norma de rango superior que determine cuáles son las modalidades de pruebas hace con que la Administración Pública elija, en cada situación, los métodos selectivos que serán utilizados.

Sin embargo, parece claro que la elección de los métodos de selección deberá tener en consideración las características del puesto de trabajo a ser cubierto por la Administración Pública. La realidad es que la propia Constitución Federal impone que esto suceda, cuando en el art. 37, II, determina que el concurso público ocurrirá "de acordo com a natureza e a complexidade do cargo ou emprego".

Respecto a la vinculación entre las peculiaridades del cargo y los métodos de selección utilizados en el concurso público, se ha destacado que:

"Nas provas, o que se pretende é prever como o candidato se comportaria no exercício do cargo ou emprego, pois é esta a finalidade do concurso público: selecionar entre os candidatos habilitados os mais aptos para o exercício do cargo ou emprego. Assim, a forma de avaliação da aptidão dos candidatos variará de acordo com as peculiaridades do cargo ou emprego a ser preenchido. Foi para preservar esta flexibilidade na avaliação dos candidatos que o constituinte, apesar de eleger as provas como forma obrigatória (art. 37, II) de mensuração do mérito dos candidatos a cargos e empregos públicos, deu competência à lei para determinar a forma do concurso (de provas ou provas e títulos) e das provas, de acordo com a natureza e a complexidade do cargo ou emprego a ser preenchido.(...) Exigir preparo físico de candidatos a juiz ou promotor, por exemplo, ou, até mesmo, utilizar-se este critério como forma de classificação violaria

${ }_{1177}^{110 B E L L O ~ D E ~ O L I V E I R A ~ R O C H A, ~ F r a n c i s c o . ~ O p . c i t ., ~ p . ~} 121$. 
frontalmente o princípio da razoabilidade, eis que a medida seria absolutamente desnecessária" ${ }^{1178}$

La gran variedad de métodos de selección permite que la Administración Pública maneje los instrumentos adecuados para verificación de cuáles candidatos son más aptos para ingresar en la función pública. Para tanto, es imprescindible que los entes federativos desenvuelvan políticas públicas de personal, que dispongan de funcionarios especializados en técnicas de selección y que enfrenten este tema con la debida seriedad ${ }^{1179}$.

La referida variedad de especies de pruebas es confirmada por la doctrina, que ha apuntado algunos criterios de clasificación de las mismas:

\begin{abstract}
"Quanto à natureza, as provas dos concursos públicos, podem ser escritas (objetivas, discursivas/dissertativas e mistas), orais, de capacidade física, psicotécnicas, práticas e de títulos; quanto à existência, ou não, de caráter excludente do certame, as provas podem ser exclusivamente classificatórias, exclusivamente eliminatórias ou classificatórias e eliminatórias; quanto ao objeto da avaliação, as provas podem ser de conhecimento (provas escritas e orais), de habilidade específica (provas práticas), físico-orgânicas (prova de capacidade física), de aptidão psicológica (provas psicotécnicas) e culturais (provas de títulos)."1180
\end{abstract}

La elección de los métodos selectivos no es la única decisión que debe ser tomada por la Administración Pública en el momento de la definición de las reglas del

\footnotetext{
${ }^{1178}$ LOBELLO DE OLIVEIRA ROCHA, Francisco. Op.cit., pp. 122-123.

1179 Sobre estas circunstancias, se ha subrayado que: "qualquer fórmula que se adote em concursos públicos provoca insatisfações e reações, uma vez que as pessoas geralmente analisam as normas estabelecidas segundo os seus interesses e habilidades. Quanto a isso, somente um elevado grau de compreensão, educação e disciplina dos concorrentes pode tornar mais suave o clima dos concursos, havendo também, é óbvio, a necessidade de elevado grau de seriedade e autocrítica dos seus organizadores." (MORHY, Lauro. A realidade dos concursos públicos. Texto extraído del sitio de la Universidade de Brasilia - UnB (http://www.unb.br/administracao/reitoria/artigos/20050616.php), con acceso en 20 de junio de 2010.

${ }^{1180}$ BARBOSA MAIA, Márcio, y PINHEIRO DE QUEIROZ, Ronaldo. Op.cit., p. 104.
} 
concurso público. También se impone que sean tratados otros aspectos de las pruebas, especialmente aquellos relacionados a su ejecución ${ }^{1181}$.

Lo que es importante acentuar es que todos los aspectos del procedimiento de ejecución de las pruebas deben estar reglados en las bases de la convocatoria (edital), para que no haya espacio para decisiones arbitrarias o subjetivas de la Administración Pública. Por esta razón, se ha acentuado que:

"Não basta, todavia, que o edital contenha os critérios de avaliação dos candidatos. É imperioso que descreva, de forma minudente e exaustiva, a forma de avaliação e pontuação atribuída a cada critério. Isto porque, após publicação do edital, não pode restar ao Administrador qualquer margem de discricionariedade que pudesse ter sido exaurido no momento de sua elaboração." 1182

En la celebración de las pruebas, para que sea alcanzada la igualdad de los todos los aspirantes, deben ser observadas diversas circunstancias, como la exigencia de que todos los candidatos sean sometidos a las mismas pruebas ${ }^{1183}$.

También se impone que, siempre que posible, todos los candidatos realicen las pruebas en el mismo momento. En este contexto, se ha afirmado que "no afã de preservar a plena igualdade de condições entre os candidatos por ocasião da aplicação das provas objetivas, a Administração deverá garantir a simultaneidade de sua realização e a sigilosidade do conteúdo dos respectivos exames."1184

Respecto al referido sigilo del contenido de los examenes, lo que se quiere subrayar es la necesidad de que los candidatos no sepan com antelación cuáles son las

\footnotetext{
${ }^{1181}$ Respecto a este tema: "O procedimento das provas inclui as datas de sua realização e de divulgação dos resultados, o tempo mínimo e máximo que o candidato terá para realizá-la, tempo de permanência mínima no local da prova, os instrumentos que o candidato poderá utilizar (consulta bibliográfica, legislação, legislação comentada, calculadora, réguas, etc.) e outras regras que devam ser obedecidas durante a realização das provas" (LOBELLO DE OLIVEIRA ROCHA, Francisco. Op.cit., p. 126).

${ }_{1182}$ LOBELLO DE OLIVEIRA ROCHA, Francisco. Idem, p. 57.

${ }^{1183}$ Por esta razón, se ha destacado que: "Se os candidatos forem submetidos a provas diferentes, não é possivel comparar seus resultados, pois estará quebrada a igualdade que deve existir nos concursos. Por disposição do princípio da igualdade, portanto, os candidatos devem ser submetidos a condições idênticas. Qualquer diferença de dificuldade entre as provas, por menor e mais subjetiva que seja, quebra a padronização do concurso e viola o mencionado princípio." (LOBELLO DE OLIVEIRA ROCHA, Francisco. Idem, p. 130).

${ }^{1184}$ BARBOSA MAIA, Márcio, y PINHEIRO DE QUEIROZ, Ronaldo. Op.cit., p. 110.
} 
cuestiones que constarán en las pruebas, medida imprescindible para que todos lleguen al concurso público en condiciones de igualdad.

Debe ser destacado que los examinadores también no deben saber quiénes son los aspirantes que realizaron las pruebas que van a evaluar. ${ }^{185}$ El tema del anonimato de los candidatos es muy relevante para garantizar la igualdad, especialmente en las pruebas que demandan una evaluación de contenidos menos objetivos ${ }^{1186}$, como es el caso de las pruebas discursivas.

En este contexto, hay muchas medidas que deben ser adoptadas para evitar las posibles preferencias o perjuicios a determinados candidatos. Sobre este tema, se puede enfatizar que:

\begin{abstract}
"Sempre que a natureza da capacidade a ser avaliada ou da prova adotada envolver uma redução da objetividade na avaliação dos mais capacitados, deverão ser incorporadas cautelas destinadas a evitar preferências reprováveis. Assim, deverá ser adotado o anonimato quanto à autoria dos trabalhos, a convocação de sujeitos oriundos de diversos extratos alheios aos quadros públicos para compor a banca de julgamento, a realização de provas pública, o sorteio de tema imediatamente antes da realização da prova e assim por diante. Se não for possível estabelecer critérios predeterminados de avaliação do desempenho do candidato, deverão ser previstos instrumentos de neutralização da influência de simpatias ou antipatias pessoais (mesmo que inconscientes). Assim, por exemplo, será império que diversos julgadores avaliem a mesma prova, produzindo-se um
\end{abstract}

\footnotetext{
${ }^{1185}$ En este contexto, se ha afirmado que en los procesos selectivos, hay que "garantir que o examinador não saiba de quem é a prova que está corrigindo" (LOBELLO DE OLIVEIRA ROCHA, Francisco. Op.cit., p. 35).

${ }^{1186} \mathrm{La}$ objetividad es una exigencia que debe estar presente con gran intensidad en la celebración y evaluación de las pruebas. Sin embargo, el mayor grado de la objetividad dependerá de la utilización de modelos de prueba que no admitan interferencias de cada juzgador, como se puede percibir: "A prova objetiva é aquela cujo resultado não depende de qualquer avaliação subjetiva do examinador. Isto quer dizer que independentemente de quem aplicar ou corrigir a prova, o resultado será sempre o mesmo. Este requisito deve estar presente em todas as etapas da avaliação: na elaboração das questões, na correção das provas e na atribuição de pontos aos candidatos." (LOBELLO DE OLIVEIRA ROCHA, Francisco. Idem, p. 121).
} 
tratamento estatístico destinado a evitar que a opinião de um único indivíduo desnature o resultado." 1187

Para la igualdad, tan relevante como la elección de los métodos de selección es la definición de los criterios de evaluación de los desempeños de los candidatos, ya que si estos son evaluados a través de criterios que no sean uniformes para todos, o que no valoren de forma adecuada sus actuaciones, la selección llegará a un resultado ilegítimo. Sobre este tema, se puede resaltar que:

\begin{abstract}
"Os critérios de avaliação são os parâmetros de valoração do desempenho dos candidatos nas provas. Sua determinação passa por um juízo discricionário da Administração que, no entanto, deve levar em conta os princípios da igualdade, da razoabilidade, da impessoalidade e a da eficiência. Preservar o princípio da igualdade na valoração do desempenho dos candidatos implica a utilização de critérios objetivos e padronizados, que não devem permitir que candidatos que demonstrem o mesmo desempenho recebam tratamentos diferentes." 1188
\end{abstract}

Antes de empezar el analisis de los modelos de pruebas aplicados en los procesos selectivos, conviene destacar la necesidad de que haya la posibilidad del candidato tener acceso a las pruebas ${ }^{1189}$ (suyas o de los otros) tras su corrección, así como debe ser garantizado el derecho de recurso a aquellos que no están de acuerdo con los criterios de evaluación adoptados.

\title{
5.3.5.1 - Las pruebas escritas y los exámenes tipo test
}

Lo que se llama aquí en este trabajo "pruebas escritas" envuelve distintos ejercicios que exigen de los aspirantes la lectura de determinadas cuestiones y la

\footnotetext{
1187 JUSTEN FILHO, Marçal. Op.cit., p. 587.

${ }^{1188}$ LOBELLO DE OLIVEIRA ROCHA, Francisco. Op.cit., p. 126.

${ }^{1189}$ Sobre el derecho de acceso (direito de vista) a las pruebas trás su correción, se ha dicho que "trata-se direito que precisa ser assegurado ao candidato, já que somente através da vista é que poderá ele verificar a existência de erros materiais ou de arbitrariedade cometidas por examinadores. Em nosso entender, a vista de provas decorre do próprio princípio da publicidade, inscrito no art. 37, caput, da $C F$, como um dos princípios fundamentais da Administração Pública." (SANTOS CARVALHO FILHO, José dos. Op.cit., p. 550).
} 
presentación de las respuestas adecuadas de forma escrita, en el debido lugar y en el plazo designado por la Administración Pública.

La utilización de pruebas escritas es el expediente más usual en los procesos selectivos, puesto que permite: a) la realización simultánea de los ejercicios con cantidades considerables de aspirantes; y b) la corrección más rápida, especialmente en los cuestionarios tipo test.

Sin embargo, probablemente, la ventaja más destacada de las pruebas escritas es la mayor posibilidad de control que ofrece, pues las preguntas y respuestas están documentadas, proporcionando un acceso más fácil a los propios aspirantes y a los órganos de control (sean administrativos o judiciales).

Además, debe ser subrayada la objetividad que las pruebas escritas pueden ofrecer, aunque esta característica cambie su matiz según el tipo de ejercicio que sea utilizado en el proceso selectivo.

En el derecho español, las pruebas escritas que más usualmente son utilizadas por la Administración Pública son los exámenes objetivos tipo test, de composición, de desarrollo, de preguntas cortas, entre otras opciones.

Los exámenes tipo test "consisten en presentar al aspirante varios cuestionarios sobre la totalidad o parte del programa con respuestas alternativas, entre las que sólo hay una correcta." 1190 La gran ventaja de las mencionadas pruebas es la mayor objetividad de la corrección, ya que solamente será admitida una única respuesta como válida.

La objetividad de los métodos selectivos es un reto que debe ser buscado por la Administración Pública, ya que el subjetivismo es una grave amenaza a la igualdad entre los aspirantes. En este contexto, los exámenes tipo test satisfacen esta

${ }^{1190}$ NAVARRO, Pilar. Prepara oposiciones con éxito. Las técnicas y los trucos para superar todas las pruebas. Planeta Prácticos, Barcelona, 2006, p. 136. 
exigencia, aunque presenten otras inconveniencias, principalmente si es el único método selectivo utilizado ${ }^{1191}$.

Como destaca la doctrina especializada en la preparación para oposiciones, para que un examen pueda ser considerado totalmente objetivo, debe reunir las siguientes características:

\begin{abstract}
" 1 a Brevedad de la respuesta, que puede consistir en hacer una señal, rodear una letra con un círculo, completar un texto con una palabra, un número, una frase, etcétera. $2^{\text {a }}$ Exactitud de la corrección. La respuesta es evaluada mediante una clave, de modo que esta evaluación pueda ser hecha por cualquier persona $o$, incluso, mediante algún procedimiento mecánico." 1192
\end{abstract}

En la elaboración de estos exámenes, hay que tener en cuenta la necesidad de absoluta claridad de las preguntas y de las respuestas, evitando la ambigüedad en el sentido de las palabras y expresiones. En este contexto, aunque sean usuales los "trucos" y "trampas" para dificultar la cuestión, estos solamente son válidos si pueden ser reconocidos por el lector con un nivel normal de atención y comprensión.

Cabe añadir que los exámenes tipo test suelen ser utilizados como un ejercicio que se desarrolla al inicio del proceso selectivo, lo que hace que, en muchas ocasiones, un gran contingente de aspirantes sea suspendido tras la referida prueba.

En este contexto, ya se destacó que en las oposiciones en las que "el número de opositores es elevado, el primer examen suele consistir en una prueba objetiva. La finalidad de esta prueba es poder realizar una corrección mecanizada rápida y eliminar

\footnotetext{
${ }^{1191}$ La supervaloración de los exámenes tipo test hace que el proceso selectivo sea convertido en una competición memorística, que deja de tener en consideración otras y más relevantes aptitudes que los funcionarios deben tener. Sin embargo, como los procesos selectivos exigen una alta dosis de memorización de los aspirantes, estos son obligados a aprender técnicas que ciertamente no les serán tan útiles en el desempeño de sus futuras actividades funcionales. Desgraciadamente, la mencionada habilidad es más enfatizada que el grado de iniciativa, de responsabilidad, entre otras. Es que "el opositor sabe que no le basta preparar los temas y estudiarlos. Todo este trabajo será en vano memorizarlos con la calidad necesaria para exponerlos en el examen durante el tiempo marcado y de forma brillante." (SALAS PARRILlA, Miguel. Cómo aprobar oposiciones, Pedagogía Alianza Editorial, Tercera reimpresión, Madrid, 2008, p. 121).
}

${ }^{1192}$ NAVARRO, Pilar. Op.cit., p. 137. 
al 75\% o más de los opositores. Si no actuara así, las oposiciones con exámenes orales y 30.000 opositores podrían durar años."1193

Así, como se ve, la dimensión que se atribuye en la actualidad a los exámenes tipo test, así como el papel que estos ejercen en el proceso selectivo (con una amplia capacidad de influenciar la situación jurídica de tantos opositores), obliga a que su utilización sea la más idónea posible.

A su vez, los exámenes de composición "son aquellos en los que se formula al aspirante una o varias preguntas para que responda libremente. De esta forma, el opositor puede demostrar su habilidad para organizar sus respuestas y exponer sus ideas, así como mostrar sus criterios personales."1194

En los mencionados exámenes, para que su uso sea lo más objetivo posible, es relevante acentuar que la Administración Pública debe definir previamente cuáles son los aspectos que deben ser tratados por el candidato, el contenido que puede ser aceptado como total y parcialmente válido y la puntuación para cada uno de los ítems destacados. Como el aspirante tiene una mayor "libertad" en la elaboración de la respuesta, conviene que los evaluadores estén circunscriptos a determinados parámetros de corrección, para permitir una cierta uniformidad.

La afirmación arriba mencionada quiere subrayar la necesidad de la previsión de mecanismos que impidan la existencia de estimaciones radicalmente distintas, por el simple hecho de que fueron realizadas por diferentes personas.

Así, no se puede utilizar el argumento de que para resolver eventuales controversias, la legislación estableció que en la composición de los tribunales, estos deben tener un número impar de miembros. En realidad, pueden surgir divergencias entre los miembros de los tribunales, pero estas nunca deben tratarse de evaluaciones diametralmente opuestas, ya que esto significaría la ausencia de uniformidad en la corrección y su consecuente transgresión de la objetividad e igualdad de trato.

1193 SALAS PARRILLA, Miguel. Op.cit., p. 203.

${ }^{1194}$ NAVARRO, Pilar Op.cit., p. 144. 
La cuestión antes destacada es muy relevante para la garantía de la igualdad, puesto que sería inadmisible que el destino de los aspirantes en el proceso selectivo se decidiera por la buena o mala suerte de tener sus ejercicios corregidos por este o aquel evaluador.

Sobre la labor de corrección de las pruebas de composición, la doctrina destaca que:

\begin{abstract}
"una vez terminada la prueba y entregados los ejercicios por los aspirantes, éstos se pueden distribuir entre los miembros del órgano de selección para su corrección individual o separada, siempre que previamente se haya acordado el nivel y los criterios de valoración, a través, por ejemplo, de la lectura conjunta de un número significativo de ejercicios, y la calificación definitiva se fije en una sesión para que las dudas que se planteen puedan resolver mediante la consulta y el intercambio de opiniones entre los miembros del órganos de selección que, en definitiva resulta ser el órgano colegiado llamado a asumir las evaluaciones correspondientes." 1195
\end{abstract}

A su vez, los exámenes de desarrollo consisten en la exposición ordenada de ideas de forma escrita sobre un determinado tema. En esta modalidad de prueba, el aspirante deberá elaborar un texto estructurado de acuerdo con las normas previstas en las bases de la convocatoria (por ejemplo, según el número mínimo o máximo de páginas, líneas o palabras).

En el contexto de las pruebas escritas, si el nivel de objetividad de la corrección alcanza su punto máximo en los exámenes tipo test, disminuyendo en los exámenes de composición, se puede añadir que llega a su punto mínimo tolerable en los exámenes de desarrollo, debido a que tanto el aspirante, como el evaluador disponen de una dosis más considerable de libertad de actuación.

Las observaciones hechas para la corrección de los exámenes de composición también se aplican (y con más énfasis) a los de desarrollo. Cabe añadir que para que estos se puedan caracterizar por la transparencia en su corrección, las bases de

${ }^{1195}$ MAURI BAJÓS, Joan. Op.cit., p. 334. 
la convocatoria pueden establecer que los ejercicios serán leídos por cada opositor. Además, la doctrina también destaca que la lectura de los ejercicios por el opositor "facilita la labor del tribunal, pues muchas escrituras de oposiciones son bastante ilegibles y pueden inducir al tribunal a errores en la apreciación de lo escrito."1196

Como ya se ha destacado, cabe ratificar que otra observación relevante para que sea garantizada la igualdad entre los aspirantes habla acerca de la exigencia de anonimato de los mismos, siempre que sea posible preservarla (cuando hay la previsión de lectura, no sería posible el anonimato), delante de la naturaleza de los ejercicios. Tal medida podrá impedir o dificultar las prácticas de favoritismo o de revanchismo, tornando la corrección de las pruebas una actividad lo más objetiva posible.

También cabe añadir que "tiene que estar fijado con precisión, con mucha precisión y claridad, el sistema de calificación de los distintos ejercicios y pruebas, porque es una garantía de seguridad jurídica hacia los aspirantes, reduciéndose a lo máximo la posible discrecionalidad en la actuación del órgano seleccionador."1197

Conviene además que las bases de la convocatoria indiquen qué modalidades de ejercicios serán utilizadas en el proceso selectivo, lo que permitirá que el aspirante pueda prepararse de acuerdo con cada tipo de prueba.

En definitiva, se puede destacar que las pruebas escritas consisten en el método selectivo más utilizado y que contribuye de forma más decisiva a la definición de aquellos que serán seleccionados por la Administración Pública, sea por ofrecer distintas posibilidades de realización ${ }^{198}$, o porque pueden ser elaboradas y corregidas con mayor nivel de objetividad, circunstancias que ciertamente no garantizan que las referidas pruebas dejen de estar sujetas a la transgresión de la igualdad.

En los procesos selectivos brasileños, las pruebas escritas también son el expediente más utilizado por la Administración Pública, especialmente porque hay el

\footnotetext{
${ }^{1196}$ PERÉZ LUQUE, Antonio. Op.cit., p. 326.

${ }^{1197}$ PERÉZ LUQUE, Antonio. Op.cit., p. 319.

${ }^{1198}$ Para la doctrina especializada en la preparación de los candidatos, "los exámenes escritos ofrecen una amplia diversidad que va desde el típico tema para desarrollar hasta la resolución de problemas, comentarios de textos, traducciones, resolución de casos prácticos, redacción libre, etc." (SALAS PARRILLA, Miguel. Op.cit., p. 207).
} 
reconocimiento de que este método selectivo es el que mejor verifica la capacidad intelectual de los candidatos ${ }^{1199}$.

La realidad es que, en la mayoría absoluta de los concursos públicos realizados en este país, solamente suele haber pruebas escritas, ya que las demás modalidades de pruebas (orales, físicas, prácticas, etc.) sólo son utilizadas en determinados contextos.

También se puede añadir que en casi todos los concursos públicos brasileños, hay la utilización de los exámenes tipo test ${ }^{1200}$, especialmente debido a la facilidad de su ejecución y evaluación. En este contexto, se ha destacado que:

\begin{abstract}
"A pesquisa científica provou a eficiência de testes objetivos, também mais baratos e de correções mais rápidas. Tais testes são, de fato, recursos indispensáveis em exames de massas, pois permitem cobrir melhor a matéria, possibilitando que se chegue a um bom perfil do candidato, sem variação de critérios na correção (a variação é 0 ). $\mathrm{E}$ associados a exames práticos ou provas discursivas subseqüentes, permitem que se chegue a resultados satisfatórios." ${ }^{1201}$
\end{abstract}

Pese a las ventajas del referido método de selección, también deben ser subrayados sus inconvenientes, entre los cuales se destacan la imposibilidad de evaluación integral de la capacidad del candidato y el riesgo de que el mismo pueda

\footnotetext{
1199 La doctrina brasileña ha acentuado que: "A finalidade da prova escrita é medir a capacidade de conhecimento do candidato para aquela função, além de por a prova seu raciocínio e sua intelectualidade. Portanto, é fundamental que ao se elaborar uma prova escrita tudo isto seja levado em conta. De nada adianta uma prova escrita que não consiga auferir estas qualidades do candidato, ou as suas dificuldades." (DA SILVA OLIVEIRA JÚNIOR, Dario, y CAMPOS OLIVEIRA, Isabel. Op.cit., p. 49).

${ }^{1200}$ En Brasil, se suele llamar estos examenes de prova objetiva. Sobre tal método, se ha destacado que "Prova objetiva é modalidade de concurso público de provas em que são oferecidas aos candidatos premissas prontas para que este escolha a correta ou a incorreta. Esta modalidade de concurso é a mais utilizada pela Administração Pública nos concursos públicos para preenchimento de grande número de cargos ou empregos idênticos e que possuem alta rotatividade, como é o caso do magistério, diante do grande número de candidatos que sempre acorrem a esse certame, e a dificuldade que uma prova discursiva escrita pode acarretar tanto pela demora de sua correção como pela ausência de parâmetros uniforme para essa mesma correção." (PACHECO BARROS, Wellington. Op.cit., p. 22).

${ }^{1201}$ MORHY, Lauro. A realidade dos concursos públicos. Texto extraído del sitio de la Universidade de Brasilia - UnB (http://www.unb.br/administracao/reitoria/artigos/20050616.php), con acceso en $20 \mathrm{de}$ junio de 2010.
} 
tener un buen desempeño en la prueba sin que efectivamente disponga de los conocimientos de las materias previstas en el temario del concurso público ${ }^{1202}$.

Respecto a los inconvenientes de los exámenes tipo test, la doctrina brasileña ha subrayado que:

\begin{abstract}
"Não há dúvidas que os testes são as formas mais objetivas de avaliação. Isto porque inexiste qualquer forma de interferência do examinador na correção das provas. Esta tarefa, inclusive, é, na maioria das vezes, executada por computadores. Por outro lado, há o inconveniente de que, através dos testes não é possível avaliar o modo como o candidato se expressa, já que este se limita a selecionar entre as hipóteses dadas aquela que lhe parece correta. Além disso, é possível que o candidato acerte as questões sem saber realmente a resposta, escolhendo aleatoriamente alguma das alternativas." 1203
\end{abstract}

Aunque se reconozca que los exámenes tipo test tienen ventajas y desventajas, también se debe exigir que los mismos sean aplicados según los parámetros jurídicos exigidos por la Constitución.

En este contexto, puede ser destacado que el deber de lealtad de la Administración Pública (procedente de la moralidad administrativa), así como el principio de vinculación al instrumento convocatorio (derivación de la legalidad), imponen que las cuestiones elaboradas tengan conexión con el temario previsto en el edital del concurso público.

También se exige que las respuestas a las cuestiones ofrecidas por la Administración Pública efectivamente correspondan a la realidad, ya que en este aspecto, no hay espacio para discrecionalidad técnica, pues, en tal método selectivo, solo puede haber una única respuesta válida científicamente.

\footnotetext{
${ }^{1202}$ Para que uno pueda tener la exacta dimensión de como esto sucede, conviene exponer que hay métodos que enseñan a los aspirantes a contestar las preguntas de los examenes tipo test aunque cuando aquellos no sepan cuál es la respuesta correcta. El acto de arriesgar una respuesta sin seguridad es llamado en Brasil de "chutar". Sobre tal actitud, se ha dicho que: "Chutar" é, para quem conhece as técnicas, uma atividade tão inteligente quanto estudar e responder. Com técnica, às vezes é possível acerta uma questão apenas olhando as alternativas, sem precisar olhar o enunciado. $O$ candidato bem preparado deve estar preparado também para "chutar" bem." (DOUGLAS, Willian. Guia de aprovação em provas e concursos, $8^{\mathrm{a}}$ ed., Elsevier, Campus Concursos, Rio de Janeiro, 2009, p. 153).

${ }^{1203}$ LOBELLO DE OLIVEIRA ROCHA, Francisco. Op.cit., p. 136.
} 
Sobre tal constatación, se ha acentuado que:

"é preciso, desde logo, delinear os limites do poder discricionário da bancas examinadoras em sede de provas objetivas de concursos públicos. Entendemos que a discricionariedade, nessa seara, reside, em primeiro lugar, na própria elaboração do edital, por intermédio da delimitação in genere do conteúdo programático das provas, da escolha das disciplinas e tema objeto dos exames, da estipulação dos critérios de avaliação das questões e de sua correção, com a indicação, quando for o caso, dos respectivos pesos das matérias e métodos para sua adequada ponderação, da definição de parâmetros para a nota de corte, se cabível, e das respectivas fórmulas matemáticas representativas de tal metodologia. Em um segundo instante, o poder discricionário residiria na delimitação in concreto do conteúdo programático previsto no edital na ocasião de confecção das provas. (...) Após tal operação, a banca examinadora se vincula às conseqüências de sua prévia escolha, visto que as questões formuladas serão avaliadas, a partir de sua aplicação, sob o enfoque puramente técnico-científico." ${ }^{1204}$

La necesidad de que sólo pueda ser acepta como correcta una única respuesta hace con que la cuestión deba ser elaborada de forma clara ${ }^{1205}$ (sin que favorezca la presencia de muchas interpretaciones) y, preferencialmente, no deben ser preguntados al candidato temas que todavía no estén consolidados en la comunidad científica, que sean polémicos o dudosos. ${ }^{1206}$

\footnotetext{
${ }^{1204}$ BARBOSA MAIA, Márcio, y PINHEIRO DE QUEIROZ, Ronaldo. Op.cit., p. 106.

1205 En este sentido: "Não raramente uma questão objetiva parece aos olhos de seu elaborador perfeitamente correta, mas, quando submetida a uma revisão, observa-se contradição ou a existência de outras premissas igualmente corretas ou incorretas." (PACHECO BARROS, Wellington. Op.cit., p. 55).

${ }^{1206}$ Por eso, se ha acentuado que: "As respostas dadas na prova objetiva são transpostas para planilhas $e$ submetidas à leitura ótica, o que pode garantir um critério objetivo puro de correção. É certo que esta modalidade de prova sofre críticas especialmente por parte dos candidatos porque lhes retiraria "aquele algo mais" que cada um imagina ter impossibilitado vôos intelectuais mais altos. No entanto, é possível responder a tal crítica com a sustentação de que, como não se pode na prova objetiva perguntar-se sobre temas duvidosos ou dar-se como correta ou incorreta premissas que não tenham um alto padrão de aceitação técnica, salvo se expressamente previstas no edital, as questões deverão sempre ser formuladas sobre temas que tenham previsão legal, aceitação doutrinária plena ou que, se formuladas sobre temas excepcionais, tenham sido eles previstos no edital. Desta forma, como regra de segurança na formulação das questões objetivas, em tese, são sempre os temais gerais, e não os excepcionais ou duvidosos que serão perguntados pelo simples fato de que, se a questão proposta pode ser possível de outra resposta,
} 
Además de los exámenes tipo test, hay muchas otras posibilidades de manejo de pruebas escritas en los procesos selectivos brasileños. En términos generales, en la realidad del citado país, las pruebas escritas suelen ser divididas en dos grupos: las pruebas objetivas $^{1207}$ (exámenes tipo test) y las pruebas subjetivas ${ }^{1208}$ (pruebas discursivas).

Las llamadas pruebas subjetivas exigen que el candidato ofrezca su punto de vista a cuestiones formuladas de forma más abierta. Tales circunstancias tanto hacen con que sea posible una mejor evaluación de la capacidad intelectual del aspirante, como también imponen mucho más dificultad en la valoración objetiva del desempeño del mismo ${ }^{1209}$. Por esa razón, en las pruebas subjetivas "deverão ser criados mecanismos de controle ainda mais rígidos para evitar a influência de qualquer critério subjetivo na avaliação, impedindo privilégios e preterições não justificados."1210

Respecto a las pruebas discursivas, la doctrina ha subrayado que:

ela se torna nula, possibilitando o controle administrativo de ofício ou através de recurso do interessado ou mesmo o controle judicial da referida questão." (PACHECO BARROS, Wellington. Op.cit., pp. 2324).

${ }^{1207}$ Sobre tales pruebas, se ha dicho que: "As provas objetivas caracterizam-se por não deixarem margem nenhuma de subjetividade nas respostas dadas às questões formuladas, limitando-se o candidato a assinalar no local próprio a sua preferência pelas opções já colocadas: CERTO ou ERRADO, VERDADEIRO ou FALSO etc." (SÁTIRO FERNANDES, Flávio. A prova oral como elemento defraudador dos princípios da impessoalidade e da moralidade. Texto extraído del sitio Jus Navigandi (http://jus2.uol.com.br/doutrina/texto.asp?id=8691), publicado en 26.07.2006, acceso en 16.02.2010).

1208 "As provas subjetivas, também chamadas discursivas, são chamadas daquele ou deste modo, porque nelas é patente a subjetividade das respostas apresentadas, não estando o candidato preso às limitadas opções (certo ou errado, verdadeiro ou falso), mas, ao contrário, podendo responder consoante o seu entendimento e discorrendo sobre a indagação ou o tema proposto. É claro que o candidato deve demonstrar o acerto ou a verdade de suas conclusões, porém, sem as amarras que lhe são dadas nas provas objetivas.." (SÁTIRO FERNANDES, Flávio. A prova oral como elemento defraudador dos princípios da impessoalidade e da moralidade. Texto extraído del sitio Jus Navigandi (http://jus2.uol.com.br/doutrina/texto.asp?id=8691), publicado en 26.07.2006, acceso en 16.02.2010).

${ }^{1209}$ En este sentido: "As provas escritas ou dissertativas permitem ao examinador avaliar, além dos conhecimentos do candidato, o modo como se expressa por escrito: a clareza com que expõe seu raciocínio, o modo como utiliza a linguagem escrita, a ortografia, a gramática, etc. Podem tomar diversas formas, como a elaboração de descrição, narração ou dissertação, questões discursivas, etc. A aplicação dessas provas, no entanto, exige mais esforços para garantir-se a objetividade $e$ a padronização. Isto porque, em razão da grande variação entre as respostas que os candidatos darão à mesma questão, se torna impossível garantir uma padronização perfeita na pontuação das provas $e$ aumenta-se a possibilidade de interferências subjetivas do examinador no momento da correção. Tais interferências, no entanto, podem e devem ser coibidas com a adoção de mecanismos de controle. Uma primeira providência è garantir que os examinadores não possam identificar de que candidato é a prova que estão corrigindo. Isso pode ser feito com a substituição do nome do candidato por seu número de inscrição, por exemplo. Com isso garante-se a impessoalidade e evita-se, ao menos, interferências voluntárias do examinador." (LOBELLO DE OLIVEIRA ROCHA, Francisco. Op.cit., p. 139).

${ }^{1210}$ LOBELLO DE OLIVEIRA ROCHA, Francisco. Idem, p. 135. 
"Prova discursiva escrita é a modalidade de concurso de prova onde a Administração Pública procura aferir o grau de conhecimentos técnicos do candidato sobre determinados temas previstos anteriormente no edital, outorgando-lhe uma certa parcela de discricionariedade de explanação de pensamento na sua sustentação. Em geral, esta modalidade de prova é aplicada ou numa etapa posterior do concurso, em que já há uma redução considerável dos candidatos pela não-superação da prova objetiva ou em concurso onde a fluência dos candidatos é limitada pela própria exigência do cargo ou emprego a preencher. Penso que na realização desta prova a comissão do concurso deve elaborar parâmetros objetivos de correção mínimos e com isso evitar que pendores pessoais dos seus membros possam influir na correção da prova." 1211

No hay lugar a dudas que la gran preocupación en las pruebas discursivas es la previsión de parámetros de evaluación, que permitan que el órgano juzgador pueda valorar todas las pruebas de forma uniforme, lo que es una exigencia de la igualdad.

Sin embargo, la doctrina brasileña no es unánime respecto a la efectiva posibilidad de que sea garantizada la evaluación uniforme de todos los candidatos, ya que hay los juristas que reconocen la inviabilidad de definición de todos los parámetros objetivos para la valoración de las pruebas objetivas. ${ }^{1212}$

Aunque se admita como verdadera la afirmación respecto al hecho de que la evaluación de las pruebas objetivas no alcanza el nivel más alto de objetividad, esto no significa que tal valor no deba ser un reto para la Administración Pública ${ }^{1213}$.

\footnotetext{
${ }^{1211}$ PACHECO BARROS, Wellington. Op.cit., p. 24.

1212 En este camino: "Realmente, afigura-se de todo inviável, em linha de princípio, que a comissão de concurso, previamente, estabeleça todos os parâmetros objetivos para a aferição dos candidatos em sede de provas discursivas, uma vez que uma gama de fatores complexos e inter-relacionados contribuirão para a aplicação, a avaliação e a correção das proposições formuladas, o que impossibilita a confecção de uma solução unívoca e de caráter excludente de outras possibilidades abertas por essa espécie de prova de conhecimento." (BARBOSA MAIA, Márcio, y PINHEIRO DE QUEIROZ, Ronaldo. Op.cit., p. 112).

${ }^{1213}$ Por eso se ha afirmado que: "A subjetividade dessas provas não está relacionada com o julgador, que deve proceder a uma avaliação objetiva sobre o que o candidato, subjetivamente, escreveu e que está posto, às claras." (SÁTIRO FERNANDES, Flávio. A prova oral como elemento defraudador dos princípios da impessoalidade e da moralidade. Texto extraído del sitio Jus Navigandi (http://jus2.uol.com.br/doutrina/texto.asp?id=8691), publicado en 26.07.2006, acceso en 16.02.2010).
} 
No obstante, para que se pueda lograr tal objetivo, deben ser tomadas algunas medidas para que haya la evaluación más uniforme posible de las pruebas discursivas. En este sentido, se ha destacado que:

\begin{abstract}
"Em verdade, cada prova deveria ter um gabarito prévio, em que seria especificada a resposta correta - mesmo nas provas subjetivas isso poderia ser utilizado - o famoso "espelho" da prova, através da discriminação de tópicos os quais deveriam ser abordados pelos candidatos, estando também especificados os pontos relativos a cada um deles. Isso diminuiria o subjetivismo. Infelizmente, o que se verifica são correções de provas subjetivas sem critérios predeterminados, ficando a cargo de cada examinador apreciar as respostas como bem entenderem (subjetivismo); e pior, muitas vezes as respostas a tais provas não aparecem expressas ou aparecem sem motivação alguma, ou seja, o candidato não sabe sequer o que errou, quanto mais por que errou, pois tal aspecto não vem especificado na correção, o que dificulta o acesso a recursos" 1214
\end{abstract}

Otra medida relevante (que ya se ha analizado) está relacionada a no identificación de los candidatos (anonimato), que, al menos, hará con que la evaluación del juzgador no sea contaminada por perjuicios contra determinados aspirantes o hasta mismo preferencias por otros.

También deben ser tomadas otras medidas que favorezcan la uniformidad en la realización y en la evaluación de las pruebas escritas. En el primer aspecto, pueden ser citadas providencias como la previsión en el edital de una cuantidad mínima y máxima de líneas que deban ser utilizadas por el candidato para ofrecer sus respuestas, así como la utilización de los mismos medios para ejecución de la prueba ${ }^{1215}$.

Respecto a la evaluación de las pruebas discursivas, otras medidas útiles serían la prohibición de que un mismo evaluador pueda valorar una gran cuantidad de

\footnotetext{
${ }^{1214}$ MACHADO JÚNIOR, Agapito. Op.cit., p. 147.

1215 Sobre este aspecto, la doctrina ha considerado que "por aplicação do princípio da isonomia e de que muitos candidatos que ainda não dominam a informática, ou a comissão não pode disponibilizar computadores para todos ou, se permitidos, nem todos dispõem desse utensílio, a prova discursiva ainda é manuscrita. A dificuldade de correção de tal prova é que muitas vezes o candidato se expressa com uma grafia tão ilegivel que é difícil, quando não impossivel, entender o conteúdo escrito." (PACHECO BARROS, Wellington. Op.cit., pp. 57-58).
} 
pruebas discursivas, a fin de que el factor agotamiento no influya en la corrección ${ }^{1216}$, y la obligación de que, en el caso de que haya más de un evaluador, cada prueba no sea valorada por una solo persona.

\subsubsection{2 - Las pruebas orales}

Los ejercicios de los procesos selectivos también pueden ser realizados a partir de la verificación del rendimiento de los candidatos, cuando los mismos sean convocados a presentar oralmente, en sesión pública, sus consideraciones respecto a determinados temas, sorteados entre aquellos previstos en el programa.

La prueba oral es la modalidade de prueba en la que la Administración Pública "contata diretamente com o candidato, que nos concursos de massa era um número e agora tem um nome e um rosto, e o submete a nova aferição de conhecimentos técnicos, alinhando a isso a forma de como exterioriza seu conhecimento" $" 1217$.

Sobre los mencionados exámenes, se ha afirmado en el contexto español (y que también sucede en el brasileño) que "con carácter general, los exámenes más temidos por los opositores son los orales, ya que enfrentan a un tribunal, y eso suele generarles más nerviosismo e inseguridad."1218

Por esta razón, llama la atención que en las pruebas orales, no solamente la capacidad intelectual de los aspirantes se tiene en consideración, sino también su inteligencia emocional, y tal circunstancia proporciona matices propios a esta modalidad de examen.

Sin embargo, el papel del órgano seleccionador es concentrarse en el análisis de la capacidad de los aspirantes, y esta envuelve una serie de factores, lo que

\footnotetext{
1216 Sobre esta constatación, se ha destacado que: "É sabido, porque isso faz parte da natureza humana, que a repetição da correção de provas subjetivas ou mesmo o cansaço que disso decorre, são fatores que podem alterar a aferição isonômica. (...) o apuro técnico da correção das primeiras provas sofre variação com o passar do tempo. O cansaço mental decorrente da repetição da correção modifica a aferição positiva ou negativamente. Esta é uma crítica razoável que pode ser feita à implementação de prova discursiva escrita exclusiva para concursos públicos que envolvam um grande número de candidatos." (PACHECO BARROS, Wellington. Op.cit., p. 23).

1217 PACHECO BARROS, Wellington. Op.cit., p. 25.

1218 NAVARRO, Pilar. Op.cit., p. 157.
} 
hace que tal órgano deba depurar su evaluación con alta dosis de razonabilidad y objetividad, alejándose de las circunstancias que no guarden relación con los mencionados valores. ${ }^{1219}$

Para lograr la tan deseada objetividad, en el ámbito del derecho español, la doctrina ha destacado con mucha precisión la circunstancia de que los ejercicios orales “deben estar sometidos a unas reglas específicas, como es la elección al azar de los temas por el propio opositor de entre los distintos temarios, con indicación del número de los que tiene que exponer y el tiempo total o máximo que ha de utilizar en su exposición, con indicación también de un tiempo mínimo."1220

Sobre las observaciones arriba transcritas, conviene destacar que la estipulación del mismo tiempo para todos los aspirantes no es suficiente para garantizar la igualdad de trato. Es relevante también que el mencionado tiempo sea razonable, una vez que la previsión de un tiempo demasiado breve, aunque sea el mismo para todos, podrá favorecer a aquellos que tienen una capacidad de expresión verbal más desarrollada, sin que esto signifique que los opositores en cuestión tengan mayor conocimiento sobre el tema expuesto.

A su vez, la estipulación de un tiempo demasiado prolongado puede perjudicar a aquellos que tienen una mayor capacidad de síntesis, y como se sabe, hablar mucho no significa necesariamente saber más sobre determinado tema.

También es relevante que las circunstancias que envuelvan la realización de las pruebas orales sean adecuadas. Lo que aquí se subraya es que el entorno en cuestión debe ser protegido de interferencias que puedan perjudicar el rendimiento de los candidatos (especialmente de los más nerviosos).

En primer lugar, los aspirantes, para que tengan un rendimiento adecuado, deben estar protegidos de interferencias externas. En este sentido, medidas para evitar la

\footnotetext{
${ }^{1219}$ Sobre la cuestión arriba mencionada, ya se ha destacado en el derecho español que en las pruebas orales, "La imposibilidad de desarrollarlas por algún trastorno físico o nervioso que afecte a la comunicación verbal no puede modificar su naturaleza en función del hecho objetivo que la dificultad de exponer unos temas oralmente delante de un tribunal en un tiempo predeterminado es muy superior al hecho de efectuarlo por escrito, dada la rapidez ínsita en el propio proceso de comunicación verbal (STS de 3 de diciembre de 1999)" (MAURI BAJÓS, Joan. Op.cit., p. 335.)

${ }^{1220}$ PERÉZ LUQUE, Antonio. Op.cit., p. 324.
} 
realización de las pruebas orales en lugares de difícil y/o demorado acceso o donde haya excesivo ruido son relevantes.

A su vez, las interferencias internas, como demasiada cantidad de personas que vengan a asistir asistan a la realización de las sobredichas pruebas, la temperatura excesivamente alta o baja, etc., también deben ser eliminadas.

El uso de pruebas orales tiene dos grandes inconvenientes a la hora de seleccionar a los más aptos y, consecuentemente, riesgos a en la igualdad: a) la posibilidad de que los aspirantes simplemente repitan la información que han memorizado, lo que poco servirá para verificar la aptitud de los mismos; b) la evaluación menos objetiva por el tribunal seleccionador.

Sobre la primera posible dificultad de las pruebas orales (mera repetición de lo que fue memorizado), conviene hacer algunas referencias a los consejos de los libros que orientan a los opositores españoles ${ }^{1221}$.

Así, se recomienda que "la exposición debe ir muy preparada, especialmente ensayada y "cantada" varias veces ante un grupo de personas" ${ }^{1222}$ Para captar la atención de los miembros del tribunal, "cuida tu dicción, de modo que sea clara, pero no demasiado rápida ni excesivamente pausada. Cambia de tono, pues la monotonía produce cansancio y aburrimiento. Haz pequeñas pausas para diferenciar las ideas. Cambia de velocidad (acelera-frena). Enfatiza. Además es muy importante que pronuncies y articules muy bien."1223

Sobre la necesidad de simulación de la presentación del tema, se aconseja: "para lograr obtener el máximo beneficio ha de procurarse que la similitud de los contextos del simulacro y del examen real sea la mayor posible: sorteo de temas, tiempo disponible, disposición de la mesa del opositor frente al tribunal, jarra y vaso de agua,

\footnotetext{
${ }^{1221}$ En este trabajo, no se critica los mencionados consejos o los mencionados libros, que pueden ser útiles a los opositores, sino la concepción y utilización inadecuadas de las pruebas orales, así como de otros ejercicios que prestigian la capacidad de memorización y no valoran la capacidad intelectual relacionada al desempeño futuro del puesto de trabajo. .

${ }_{1222}$ PÉREZ COBACHO, Juan. Ganar oposiciones. El éxito de la experiencia, $5^{\mathrm{a}}$ ed., Editorial MAD, Sevilla, 2007, p. 73.

${ }^{1223}$ NAVARRO, Pilar. Op.cit., p. 164.
} 
etc., son factores que han de ser controlados para favorecer la similitud de contextos." 1224

Como se puede percibir, en las pruebas orales, los opositores se ven obligados por las circunstancias a memorizar los temas y a exponerlos de forma mecánica, repitiendo todo aquello que fue grabado en sus mentes a duras penas.

Evidentemente, en estas condiciones, los candidatos con buena capacidad de memorización tendrán la oportunidad de sobresalir, incluso sobre aquellos que presentan mejor aptitud para el desempeño del empleo público ofertado por la Administración Pública.

Así, para que el Tribunal pueda efectivamente verificar el nivel de conocimiento de los candidatos, es relevante que, tras la presentación, haya la posibilidad de diálogo entre los miembros del tribunal y el opositor.

Sobre esta cuestión arriba escrita, la doctrina española ha sostenido que es necesario que, “después de expuestos los temas, el Tribunal de selección dialogue con el aspirante sobre ellos, no para hacerle preguntas en su perjuicio, sino para comprobar esos conocimientos expuestos, lo que permitirá contrastar aún más su grado de ciencia." 1225

La otra (y principal) inconveniencia de las pruebas orales consiste en la dificultad encontrada para la objetivación de la evaluación, lo que causa grandes trastornos a la igualdad, e incluso torna el control de los actos administrativos mucho más precario. La cuestión bajo análisis tiene conexión con la menor posibilidad, en comparación con las pruebas escritas, de cumplimiento de los parámetros de evaluación objetivos delimitados por el Tribunal seleccionador.

Todo ello sucede porque tras la realización de las pruebas orales, las impresiones respecto al desempeño de los aspirantes van a ser captadas por los miembros del Tribunal, que, a su vez, pasarán inmediatamente a evaluar los sobredichos

1224 SALAS PARRILLA, Miguel. Op.cit., p. 164.

1225 PERÉZ LUQUE, Antonio. Op.cit., p. 324. 
candidatos. Todo pasa de forma muy rápida y no siempre hay la posibilidad de apreciación, de reflexión, de discusión, de comparación, etc.

Muchas veces, la percepción (y todos los factores, relevantes o no ${ }^{1226}$, que la influencian) pasa a ser más decisiva que otras actividades mentales (efectivamente evaluativas) de los miembros del Tribunal.

En las pruebas orales, debido al contacto entre los aspirantes y el Tribunal, la evaluación suele ser menos objetiva. Es notorio que las personas, cuando van a emitir juicios de valor, aunque estos sean considerados técnicos, no consiguen dejar de tener totalmente en consideración otras características del sujeto evaluado, aunque estas sean de poca o ninguna relevancia. Cabe subrayar que todo eso pasa sin que los evaluadores se den cuenta, pues es una circunstancia inherente a la condición humana.

También se puede mencionar que, en las pruebas orales, una vez realizada la evaluación, los aspirantes tendrán mayor dificultad de refutar las puntuaciones atribuidas por el Tribunal.

Por esa razón, la doctrina española ha acentuado que el problema de los ejercicios orales "es la imposibilidad de demostrar por el opositor que su exposición ha sido suficiente, correcta y acertada, si lo ha sido objetivamente, cuando es suspendido o recibe menos nota que la que esperaba. Aquí la discrecionalidad técnica del tribunal de selección a su más alto grado"1227.

Sobre la dificultad de control de la evaluación de las pruebas orales, el Tribunal Supremo de España ya destacó que:

"Es preciso tener en cuenta que así como la práctica actual hace que
las pruebas orales no sean reproducibles, lo que hace ineludible su
publicidad, por el contrario las pruebas escritas permanecen en la
posibilidad de ser revisadas y comparadas, lo que desde este punto de

${ }^{1226}$ Por esta razón, se aconseja que los candidatos se presenten de forma adecuada (vestido, peinado, aseo). Es que "estos factores influyen en la primera impresión del tribunal sobre ti. Es el llamado "efecto umbral", que consiste en que la primera impresión que se forma el tribunal sobre el opositor, influye en su manera de evaluar toda su exposición" (NAVARRO, Pilar. Op.cit., p. 162).

${ }^{1227}$ PERÉZ LUQUE, Antonio. Op.cit., p. 325. 
vista les da una garantía más intensa que las celebradas con publicidad, en forma oral." ${ }^{1228}$

Ante las circunstancias apuntadas, conviene que el ordenamiento jurídico establezca, en primer lugar, cuándo deben ser utilizadas las pruebas orales, y las condiciones de su utilización, especialmente para garantizar las exigencias de evaluación objetiva y posibilidad del efectivo control de la misma.

Practicamente todas las observaciones hechas respecto al concepto y a la ejecución de las preubas orales se aplican al contexto brasileño. Sin embargo, en este país, hay mucho más rechazo a su utilización como método de selección que en España. ${ }^{1229}$ Sobre esta cuestión, la doctrina no suele reconocer las finalidades ${ }^{1230}$ de la prueba oral y/o destacan sus grandes dificultades para la efectividad de la igualdad.

En los procesos selectivos de acceso a la función pública brasileña, las pruebas orales suelen ser utilizadas, de forma obligatoria, en pocos concursos públicos, como para el ingreso en algunas carreras jurídicas, como es el caso del Ministerio Público y de la Magistratura ${ }^{1231}$ Como destaca la doctrina brasileña, "a exigência de prova discursiva oral quase sempre se vincula a concurso público para preenchimento de cargo ou emprego público onde haja necessidade de trato público pelo agente."1232

\footnotetext{
${ }^{1228}$ STS de 13 de marzo de 1991.

1229 Para demostrar tal rechazo, se puede destacar que "Existem mesmo projetos de lei em trâmite no Congresso Nacional propondo a abolição das provas orais em concursos públicos, ante a ausência de impessoalidade na avaliação. Não prever o procedimento recursal contra as notas desse tipo de prova só contribui para ofender o princípio da impessoalidade." (DA SILVA OLIVEIRA, Luciano Henrique. $O$ contraditório e a ampla defesa nos concursos públicos, texto extraído del sitio Jus Navigandi (http://jus2.uol.com.br/doutrina/texto.asp?id=12006), inserido em 25.11.2008, acceso en 16.02.2010).

1230 La doctrina brasileña destaca que la prueba oral "tem por objetivo, avaliar:- o domínio do conhecimento jurídico- o emprego adequado da língua- a articulação do raciocínio- a capacidade de argumentação- o uso correto do vernáculo. Uma outra variante do exame oral, a chamada prova de tribuna (!), tem por fim apreciar:- a entonação - a correção de linguagem - o estilo - o convencimento o conteúdo lógico e jurídico - a segurança - a adequação técnica e desenvoltura. São exigências e requisitos que, como se vê, podem ser plenamente avaliados e comprovados em provas escritas de caráter discursivo." (SÁTIRO FERNANDES, Flávio. A prova oral como elemento defraudador dos princípios da impessoalidade e da moralidade. Texto extraído del sitio Jus Navigandi (http://jus2.uol.com.br/doutrina/texto.asp?id=8691), publicado en 26.07.2006, acceso en 16.02.2010).

${ }_{1231}$ Según el art. 16 de la Resolución 14, de 06 de noviembre de 2006, del Consejo Nacional del Ministerio Público, la realización de pruebas orales es obligatoria para los concursos públicos de ingreso en la referida carrera. A su vez, la misma obligatoriedad también está prevista en el art. $5^{\circ}$, IV, de la Resolución 75, de 12 de mayo de 2009, del Consejo Nacional de Justicia, para los concursos público para ingreso en la Magistratura.

${ }^{1232}$ PACHECO BARROS, Wellington. Op.cit., p. 25.
} 
No obstante, en las demás situaciones, su utilización es considerada facultativa, aunque se deba insistir que los medios jurídicos suelen criticar con mucha intensidad el uso de tal modalidad de prueba en el concurso público. ${ }^{1233}$

Las críticas expuestas por la doctrina brasileña a las pruebas orales derivan de la tradición de su manejo inadecuado en los concursos públicos realizados en este país, ya que el mencionado estilo de prueba, en muchas ocasiones, suele ser utilizado para favorecer o perjudicar determinados candidatos. ${ }^{1234}$

${ }^{1233}$ Más una vez, se puede percibir como las pruebas orales no son recomendables por la doctrina brasileña "Se o exame oral não é obrigatório e, por outro lado, poucas são as categorias em cujos concursos ele está presente, salta aos olhos a sua desnecessidade. Em outras palavras, a ausência de provas orais em nada prejudica a arregimentação, a escolha, o julgamento que se faz da aptidão ou inaptidão de candidatos a qualquer cargo ou emprego público." (SÁTIRO FERNANDES, Flávio. A prova oral como elemento defraudador dos princípios da impessoalidade e da moralidade. Texto extraído del sitio Jus Navigandi (http://jus2.uol.com.br/doutrina/texto.asp?id=8691), publicado en 26.07.2006, acceso en 16.02.2010).

${ }^{1234}$ El citado panorama puede ser aqui conocido: "Salta aos olhos a capacidade de a prova oral afrontar o princípio da impessoalidade. Em sua aplicação e uso, tudo se volta para uma utilização que nada tem de imparcial. Quaisquer que sejam os procedimentos adotados, a sua execução assumirá, sempre, feições de natureza pessoal. Note-se que se as provas objetiva e discursiva são cercadas de cuidados, relativamente à identificação dos candidatos, na prova oral essa preocupação, por motivos mais que óbvios, inexiste de maneira absoluta. Os candidatos são chamados pelo nome e se apresentam, pessoalmente, com identidade conhecida. Por outro lado, mesmo que ocorram cautelas editalícias tocante à sua aplicação, no que diz respeito à formulação das questões postas à consideração do candidato, há sempre uma larga margem de discricionariedade do argüente na apresentação das questões ou dos temas dados para dissertação oral. Note-se que, na maioria dos casos, o ponto não é o mesmo para todos os pleiteantes e, sim, sorteado para cada candidato. Além disso, o julgamento é inteiramente subjetivo, a critério exclusivo dos examinadores, diferentemente do que ocorre com as provas objetivas cujos parâmetros estão postos às claras, mediante respostas CERTO ou ERRADO, VERDADEIRO ou FALSO, não se podendo fugir a esses padrões de julgamento. O mesmo ocorre com as provas discursivas, nas quais os candidatos põem no papel suas respostas, as quais, mesmo representando o entendimento pessoal sobre as questões, estão ali colocadas de maneira clara, sem possibilidade, via de regra, de interpretações pessoais por parte dos argüidores. Tocante, pois, ao princípio da impessoalidade ou da imparcialidade, a prova oral é, como dito no título destas observações, um elemento defraudador daquele postulado, violando, também, pelas mesmas razões, o princípio da isonomia ou da igualdade. Com referência ao princípio da moralidade, os efeitos da prova oral são igualmente, deletérios, isto é, tal modalidade de prova esbulha aquele postulado constitucional. Salta aos olhos essa capacidade de afronta àquele princípio que orienta a administração pública. Não se pautando o julgador pela imparcialidade ou impessoalidade, impossível mesma pelas próprias condições do exame, abre-se o caminho para o favorecimento indecoroso de candidatos. À boca pequena essa crítica aos exames orais é feita largamente. Não adianta fazer ressalvas, até porque essa censura ao exame oral é tão divulgada que ninguém a ignora. Mas tudo isso, é óbvio, à boca pequena. Mas nem por isso desprezivel. Da mesma forma que o caminho está aberto ao favorecimento, está livre, também, para o inverso, ou seja, um comportamento, por parte do examinador, claramente desfavorável a um candidato. Não é difícil ouvir-se queixa de aspirante a cargo público, manifestada em relação a um ou outro dos argüentes. Em qualquer das hipóteses, violenta-se o princípio da moralidade $e$, conseqüentemente, malfere-se a probidade administrativa. O pior é que tais contrafações se apresentam sob o manto do julgamento subjetivo e não são jamais provadas e comprovadas. Em abono dessa assertiva veja-se que alguns editais trazem cláusula proibitiva de recurso contra a prova oral." (SÁTIRO FERNANDES, Flávio. A prova oral como elemento defraudador dos princípios da 
Los juristas brasileños insisten en exponer las dificultades de la ejecución de las pruebas orales, cuyas circunstancias están abajo demostradas:

"Convém assinalar que a fase da prova oral constitui um dos momentos mais delicados do concurso público, em face das seguintes circunstâncias: a) a identidade do candidato, nesta fase, é conhecida e as suas características físicas e psíquicas são reveladas para a banca examinadora, pois a prova é pública; b) via de regra, a prova oral é antecedida de sindicância social, a qual revela o perfil individual, social e econômico do candidato; c) o candidato já demonstrou o mínimo de conhecimento desejado para o cargo nas provas objetivas e discursivas e, por isso, a prova oral é decisiva; d) o grau de discricionariedade da banca examinadora na prova oral é o mais amplo dentre as provas de conhecimento; e) em conseqüência, o estado de sujeição do candidato em face da banca examinadora é extremamente acentuado. Ante tais perspectivas, constata-se que a prova oral pode propiciar um campo fértil para perseguições e preconceitos de cunho político, ideológico, religioso, racial, socioeconômico e, por outro lado, pode despertar preferências e favoritismos, em franco detrimento ao escopo magno do concurso público" 1235

Parece lógico que todas las denuncias realizadas por la doctrina brasileña no tienen como fundamento la imaginación fértil de los juristas, sino la realidad de los concursos públicos en el citado país.

Cabe añadir que muchas de las irregularidades apuntadas provienen de la intención deliberada de los miembros de la banca examinadora. Sin embargo, muchas otras existen debido a la inadecuada conformación jurídica del citado instrumento selectivo. En este sentido, se ha acentuado que:

"a maioria dos concursos em que é utilizada a prova oral também termina por violar princípios constitucionais, haja vista a forma como é implementada, dado o subjetivismo exacerbado da avaliação e da

impessoalidade $e \quad d a$ moralidade. Texto extraído del sitio Jus Navigandi (http://jus2.uol.com.br/doutrina/texto.asp?id=8691), publicado en 26.07.2006, acceso en 16.02.2010). ${ }^{1235}$ BARBOSA MAIA, Márcio, y PINHEIRO DE QUEIROZ, Ronaldo. Op.cit., p. 114. 
correção das provas, isso somado à impossibilidade de qualquer tipo de controle por parte do candidato e da coletividade. Muitas provas orais não são gravadas. Não há, portanto, como se preservar na memória o ato de avaliação, afastando-se assim qualquer tipo de possibilidade de controle dos motivos da correção da prova (atribuição de notas). Outrossim, não há motivação na atribuição das notas, não se podendo recorrer da correção efetuada. Ademais, é inevitável que o contato direto dos membros da Bancas Examinadoras com os candidatos, os quais muitas vezes já têm uma relação próxima ou muito distante com o examinador, sendo impossível preservar a imparcialidade ou a impessoalidade durante a avaliação." 1236

Debido a las circunstancias en las cuales las pruebas orales son ejecutadas en Brasil, se impone la observación de determinadas condiciones para que sea garantizada la igualdad entre los aspirantes a la función pública.

La primera exigencia que se impone es que las bases de la convocatoria establezcan con precisión todos los detalles relevantes para la realización de las pruebas orales, lo que servirá para reducir la arbitrariedad administrativa. ${ }^{1237}$

Otras cautelas ${ }^{1238}$ que deben ser observadas en la ejecución de las pruebas orales están relacionadas a las exigencias de cumplimento de los principios constitucionales, entre los cuales se destacan la publicidad ${ }^{1239}$, transparencia,

\footnotetext{
${ }^{1236}$ MACHADO JÚNIOR, Agapito. Op.cit., p. 149.

${ }^{1237}$ En este sentido: "O edital do concurso pode estabelecer que os temas sejam sorteados 24 horas ou mesmo 30 minutos antes de sua realização; se a prova consistirá de uma dissertação oral pura e simples, de uma dissertação mais perguntas ou simplesmente de perguntas; se o conteúdo será aferido de uma única vez ou de várias vezes. Enfim, o edital de concurso, coerente com a lei que o estabeleceu, pode regulamentar a execução da prova oral." (PACHECO BARROS, Wellington. Op.cit., p. 56).

${ }^{1238}$ Respecto a las referidas cautelas, se ha dicho que: "Em razão do amplo espaço para interferências subjetivas dos examinadores existentes neste tipo de prova, torna-se maior a necessidade de serem adotadas cautelas destinadas a evitar preferências e perseguições reprováveis, sem o que os candidatos acabariam ficando submetidos às vontades, empatias, antipatias, vaidades $e$ humores dos examinadores." (LOBELLO DE OLIVEIRA ROCHA, Francisco. Op.cit., p. 140).

${ }^{1239}$ Sobre tal principio, se ha afirmado que: "Um elemento que assume um importante papel na aplicação das provas orais é a publicidade. Deve ser facultado o acesso ao local das provas a qualquer pessoa interessada." (LOBELLO DE OLIVEIRA ROCHA, Francisco. Idem, p. 139).
} 
objetividad $^{1240}$, impersonalidad, todos corolários de la igualdad ${ }^{1241}$, y subrayados por la doctrina en los siguientes términos:

"Destarte, a fim de a prova oral permanecer sendo utilizada como fase de avaliação do concurso público, merece sofrer algumas adaptações sob pena de ser reconhecida como inconstitucional, entre as quais: (a) a prova deverá ser pública, com acesso à coletividade, não mais se aceitando a avaliaçao a portas fechadas; (b) a avaliaçao deverá ser gravada a fim de inibir qualquer abuso por parte da própria Banca Examinadora (ex.: discriminação quanto à pessoa do candidato em razão da cor, raça, opção sexual, etc.), além de permitir o futuro recurso do candidato, haja vista a possibilidade de conservar arquivado em registro o próprio ato de avaliação; (c) deverá haver afastamento de membros da comissão examinadora que tenham algum vínculo pessoal favorável ou desfavorável em relação a candidatos, sendo até desejável que a comissão examinadora seja composta por pessoas de fora do lugar para o qual se presta o concurso; (d) seja preservada a igualdade na competição entre os candidatos, o que se faz inicialmente através da utilização da mesma Banca Examinadora para avaliar todos os candidatos, a fim que todos se submetam à mesma dificuldade ou facilidade em face das perguntas formuladas" ${ }^{\prime 242}$

\subsubsection{3 - Las pruebas prácticas}

La Administración Pública puede considerar insuficientes los métodos usuales de selección (pruebas escritas y orales), especialmente cuando está delante de actividades cuya carga teórica es más reducida, en este caso, pues, predominarían las

\footnotetext{
${ }^{1240}$ Respecto a esta exigencia: "é preciso estabelecer diretrizes e regras para conferir à prova oral, como uma das espécies de prova de conhecimento, um grau mínimo de objetividade e retirar-lhe a pecha de instrumento inquisitório-ideológico da comissão de concurso." (BARBOSA MAIA, Márcio, y PINHEIRO DE QUEIROZ, Ronaldo. Op.cit., p. 114).

${ }^{1241}$ Como ejemplo: "deve ser conferido tratamento igual aos candidatos durante a realização da prova oral. Assim, caso tenha sido conferido tempo de dez minutos para certo candidato iniciar a sua resposta, não pode ser exigido, de outro, tempo inferior, sob pena de ferir a isonomia de tratamento." (TOURINHO, Rita. Op.cit., pp. 87-88).

${ }^{1242}$ MACHADO JÚNIOR, Agapito. Op.cit., pp. 149-150.
} 
actividades que requieren habilidades físicas (como las tareas manuales) o destrezas que demandan la debida pericia. ${ }^{1243}$

De la misma forma, es admisible la utilización de las pruebas sobredichas cuando se entiende, delante de actividades predominantemente intelectuales, que es necesaria la demostración del adecuado manejo práctico del contenido teórico acumulado por los opositores ${ }^{1244}$.

En el derecho español, el fundamento jurídico de las pruebas prácticas consiste en la previsión del art. 61.2 del Estatuto Básico del Empleado Público, que autoriza la realización de ejercicios que demuestren la posesión de habilidades y destrezas.

Cabe inicialmente destacar que las pruebas prácticas serán siempre complementarias, lo que significa que no deben, en ningún caso, sustituir totalmente a las pruebas intelectuales. Sin embargo, esta circunstancia no hace que las sobredichas pruebas sean del todo inútiles.

La amplia variedad de ejercicios prácticos impide su completa catalogación. En cambio, la doctrina española apunta algunos, que suelen ser los más utilizados: “ejercicio de mecanografía, tratamiento de textos, redacción de informes, redacción de proyectos, solución de supuestos y otros similares, que se consideren adecuados para juzgar la preparación de los aspirantes en razón del trabajo concreto que vayan a desempeñar"1245

Las bases de la convocatoria deberán indicar con precisión cuáles son los ejercicios prácticos, cómo los mismos deben ser realizados, qué criterios serán tomados en consideración para la atribución de puntuación y cómo se considera que el mismo fue superado por el opositor.

Además, "en el ejercicio práctico se han de poner ejercicios que se puedan hacer, que no falten medios técnicos para su realización"1246 No obstante, la calidad y la adecuación de los medios técnicos no son suficientes para garantizar la igualdad, ya que

${ }^{1243}$ Es lo que pasa cuando se exige en una oposición la ejecución de una tarea relacionada a las actividades de carpintería, fontanería, conducción de vehículos, entre otras.

${ }^{1244}$ Es lo que sucede cuando se exige, en una oposición para profesor, que los candidatos den una clase.

${ }^{1245}$ PERÉZ LUQUE, Antonio. Op.cit., p. 337.

${ }^{1246}$ PERÉZ LUQUE, Antonio. Idem, p. 338. 
se impone que todos los aspirantes dispongan de los mismos medios (igualdad de las armas).

Pese a su utilidad para una selección más apurada, la doctrina española también hace críticas a las pruebas prácticas, principalmente en lo que respecta a su ejecución y evaluación:
"en mi experiencia profesional, que me ha obligado a sentarme en diversos Tribunales, he de confesar que el ejercicio práctico no me ha proporcionado ningún elemento de juicio: fuera de algún ejercicio singularmente bueno y de algún otro particularmente malo, calificar de forma diversificada al resto es una tarea imposible si se quiere hacer con rigor." 1247

En el sistema jurídico brasileño, las pruebas prácticas también están siempre relacionadas a los concursos públicos que deben verificar la habilidad del candidato para la realización de tareas concretas, que tienen conexión con las actividades que son usualmente cumplidas en el ejercicio del cargo o empleo público.

Por supuesto, la decisión respecto a la utilización o no del mencionado método selectivo es discricionaria, aunque existan determinadas situaciones en las cuales su realización es prácticamente obligatoria.

En este contexto, por ejemplo, seria inadimible la realización de un proceso selectivo para cubertura de plazas de músico de una orchestra municipal sin la ejecución de pruebas practicas para verificar si los candidatos efectivamente saben tocar determinado instrumento musical ${ }^{1248}$.

\footnotetext{
${ }^{1247}$ SANTAMARÍA PASTOR, Juan Alfonso. Prólogo al libro El acceso del personal y la provisión de puestos de trabajo en la Administración del Estado y de las Comunidades Autónomas, Vicente M. Escuin Palop, INAP, Madrid, 1986, p. 9 y 10.

${ }^{1248}$ En este sentido: "As provas práticas ensejam a realização de atividades que demonstrem possuir o candidato as habilidades necessárias ao exercício de determinado mister. Assim, o desenvolvimento de práticas esportivas ou de práticas musicais seriam exemplo de provas desse tipo nas quais os concorrentes devem demonstrar que são hábeis nestas ou naquelas atividades, conforme o caso. Os métodos de realização e de avaliação são bastante objetivos." (SÁTIRO FERNANDES, Flávio. A prova oral como elemento defraudador dos princípios da impessoalidade e da moralidade. Texto extraído del sitio Jus Navigandi (http://jus2.uol.com.br/doutrina/texto.asp?id=8691), publicado en 26.07.2006, acceso en 16.02.2010).
} 
La doctrina ha apuntado las situaciones en las cuales la realización de pruebas prácticas es más usual:

"além de provas de conhecimento e testes físicos, os concursos podem incluir provas que simulem tarefas que farão parte do dia-a-dia do cargo ou emprego a ser preenchido. As provas práticas mais comuns são a elaboração de peças forenses nos concursos para carreiras da advocacia pública e Ministério Público e sentenças nos concursos para a Magistratura; ministrarão de aulas nos concursos para professor; execução de peças musicais nos concursos para músicos; elaboração de projetos por candidatos arquitetos ou engenheiros, entre outras. Nessas provas, através da simulação de tarefas que fazem parte do diaa-dia do cargo ou emprego público, pretende-se predizer o desempenho que o candidato terá no exercício do cargo, caso obtenha sucesso no concurso ${ }^{1249}$,

Así como sucede en el derecho español, en el contexto brasileño, "não poderá existir um concurso público que seja formado somente por prova prática. Um concurso público pode ser elaborado por prova escrita e prática, ou somente prova escrita, mas nunca por somente prova prática."1250

La realización de pruebas prácticas puede constituir en una contribución para dinamizar el proceso de selección de los funcionarios públicos, haciendo con que la Administración Pública pueda constatar la presencia de las efectivas condiciones técnicas de los aspirantes para la realización de las tareas del cargo público.

La realidad es que la propia Constitución brasileña, en su art. 37, II (alterado por la Enmienda Constitucional 19/1998), exige que el proceso selectivo se realice "de acordo com a natureza e complexidade do cargo".

Por esta razón, la doctrina brasileña ha confirmado la importancia de las pruebas prácticas, en la medida en que ha sostenido que:

${ }^{1249}$ LOBELLO DE OLIVEIRA ROCHA, Francisco. Op.cit., p. 124.

${ }^{1250}$ DA SILVA OLIVEIRA JÚNIOR, Dario, y CAMPOS OLIVEIRA, Isabel. Op.cit., p. 19. 
"o concurso público, antes concebido como um processo de seleção meramente intelectual, deixou de tal característica, introduzindo-se em seu conceito e na experiência administrativa a possibilidade e, até mesmo, necessidade de realização de provas práticas, a fim de que as funções a ele inerentes fossem disputadas e, posteriormente, prestadas por pessoas verdadeiramente habilitadas para o seu desempenho." ${ }^{1251}$

El nuevo perfil de los procesos selectivos brasileños debe evitar situaciones ya constatadas en la realidad, donde eran realizados concursos públicos para cargos o empleos públicos que exigen del aspirante poca actividade intelectual y una dosis elevada de habilidades físicas (como las tareas manuales), pero las bases de la convocatoria no previan la realización de pruebas prácticas.

Por esta razón, muchas personas con nivel intelectual elevado, pero sino cualquier habilitad para la realización de las tareas del cargo, se apuntaban para la participación en el proceso selectivo y eran aprobados, pues tenían un buen desempeño en las pruebas escritas. Resultado: eran seleccionadas personas sin las debidas condiciones para ejercicio del cargo o empleo público. ${ }^{1252}$

A fin de que las pruebas prácticas sean efectivamente útiles a la selección de los más aptos, se impone que a través de las mismas, sea verificada la posesión de las habilidades o destrezas que estén relacionadas de forma directa a las tareas del cargo o empleo público.

\footnotetext{
${ }^{1251}$ PINHEIRO MADEIRA, José Maria. Op.cit., p. 68

${ }^{1252}$ En este contexto, se ha destacado que: "As provas práticas têm pertinência, e adquiriram importância em razão do absurdo a que se chegou, em determinados casos, quando, oferecidos cargos e empregos para serem disputados mediante concurso público, compareciam pessoas muito preparadas, mas que buscavam apenas uma investidura em cargo de provimento efetivo ou em emprego público para valer-se de tais condições e obter comissionamentos vantajosos em outras funções, continuidade da percepção de vantagens garantidas apenas a servidores públicos, entre outros objetivos. Assim, houve situações de se colocar em disputas cargos de servente de escola pública para os quais concorriam e acabavam sendo aprovados advogados, médicos, dentistas, engenheiros, etc., os quais, evidentemente, tão logo eram nomeados, obtinham ser deslocados para o exercício de funções mais compatíveis com seus níveis de escolaridade, fazendo com que as funções próprias dos cargos de serventes continuassem sem servidores a prestá-las. Somente com a introdução de provas práticas tem-se conseguido determinar a nomeação de serventes, cozinheiras, merendeiras, etc., para os cargos de serventes, cozinheiras e merendeiras." (PINHEIRO MADEIRA, José Maria. Op.cit., p. 68).
} 
Además, en la ejecución de las citadas pruebas, deben ser observadas las exigencias de trato igualitario a todos los aspirantes (mismas condiciones de realización de los ejercicios) y de evaluación objetiva de sus desempeños.

En este contexto, se ha subrayado en la doctrina brasileña que:

\begin{abstract}
"Executa-se uma prova prática através de uma pequena amostragem de tarefas características do cargo ou função. Estas tarefas serão pinçadas na própria lei que criou o cargo, na parte das atribuições da função. Na avaliação da prova prática deverão ser considerados o tempo que o candidato levou para executar a tarefa exigida e o resultado final do seu trabalho." 1253
\end{abstract}

\title{
5.3.5.4 - Las pruebas físicas
}

Aunque no sean tan usuales, las pruebas físicas consisten en una modalidad más de método selectivo, de naturaleza complementaria, que puede ser utilizado para la selección de funcionarios en determinadas condiciones especiales.

Respecto al ámbito español, sobre las referidas condiciones, se ha dicho que "los ejercicios de pruebas físicas son típicos de la selección de plazas, cuya actividad funcional está ligada a la actividad física, siendo usados normalmente en la selección del personal de la Policía municipal y Personal de Extinción de Incendios”. ${ }^{1254}$

Para que las pruebas físicas sean utilizadas con éxito, se impone que las bases de la convocatoria precisen cuáles son los ejercicios físicos, cómo estos deben ser realizados y las marcas mínimas que han de ser superadas por los opositores.

En las pruebas físicas, se suele exigir la realización de ejercicios de aptitud física relacionados a: la sicomotricidad, fuerza, saltos (verticales, laterales, longitudinales), velocidad, agilidad, resistencia (carreras), trepar, flexiones, natación. ${ }^{1255}$

Conviene destacar que la previsión de pruebas físicas debe ser debidamente fundamentada en la necesidad de una aptitud física que permita el adecuado desempeño

\footnotetext{
${ }^{1253}$ DA SILVA OLIVEIRA JÚNIOR, Dario, y CAMPOS OLIVEIRA, Isabel. Op.cit., pp. 49-50.

${ }^{1254}$ PERÉZ LUQUE, Antonio. Op.cit., p. 327.

${ }^{1255}$ PÉREZ COBACHO, Juan. Ganar oposiciones. El éxito de la experiencia, $5^{\mathrm{a}}$ ed., Editorial MAD, Sevilla, 2007, p. 85.
} 
de las actividades administrativas (principio de razonabilidad), ya que, en condiciones normales, la capacidad que se exige del aspirante sólo es la de carácter intelectual.

En este sentido, no sería razonable exigir que los candidatos a plazas de administrativos se sometieran a pruebas de natación o que los que concuren a los puestos de medico deban demostrar que consiguen hacer un determinado número de flexiones o de saltos.

Además, cada uno de los mencionados ejercicios solamente puede ser previsto en el proceso selectivo si hay alguna relación entre los mismos y las actividades desarrolladas por el funcionario de la plaza a ser cubierta.

Así, la ya citada prueba de natación podría (y en muchos casos debe) ser realizada en las oposiciones para cubrir plazas de bomberos, cuando estos, por ejemplo, actúan en el resgate de personas en las playas o en otras situaciones en las cuales la referida actividad física suele ser utilizada con frecuencia.

Además, en la evaluación de los ejercicios físicos, debe ser respetado el nivel de exigencia adecuado, con la debida proporcionalidad, que tenga en consideración que el proceso selectivo debe permitir la elección de aspirantes a la función pública que sean aptos a desempeñar las actividades administrativas, y no atletas que van a los Juegos Olímpicos.

Al mismo tiempo, en la definición de los ejercicios físicos, así como en su evaluación, deberán tenerse en consideración las diferencias entre hombres y mujeres, y la situación de las personas con discapacidad.

Cabe añadir aún que las pruebas físicas deben ser realizadas en las instalaciones adecuadas, con los aparatos propios, que permitan el buen desempeño de los candidatos, evitando accidentes y otros hechos indeseables que pueden poner en riesgo la idoneidad de la disputa.

Conviene resaltar que todos los aspirantes (con las observaciones arriba mencionadas sobre las diferencias de género y la tenencia de ciertas limitaciones físicas) deben recibir de la Administración Pública un trato igualitario, lo que se traduce en las mismas oportunidades, los mismos medios, y los mismos criterios de evaluación. 
Todas estas observaciones, realizadas por la doctrina española, deben ser aplicadas a las pruebas físicas realizadas en los procesos selectivos brasileños. En este país, esta modalidad de ejercicio suele ser utilizada: a) siempre, en los concursos públicos para los cargos policiales (policía civil, militar y federal); b) en algunos casos, para determinados cargos que demandan la tenencia de una buena condición física ${ }^{1256}$.

Pese a la ausencia de una norma general (ley) que discipline los casos en los cuales debe ser realizada la prueba física (lo que debería ocurrir para impedir situaciones arbitrarias ${ }^{1257}$ ), la doctrina brasileña ha reconocido que:

"As provas de aptidão física, também denominadas testes físicos, têm
o objetivo de aferir se os candidatos possuem as habilidades físicas
relacionadas às atribuições do cargo. Devem ser aplicadas sempre que
o exercício do cargo envolver esforços físicos e, quanto mais as
funções inerentes ao cargo dependerem de esforços físicos, maior
deve ser a importância dada à prova de aptidão física no concurso."

Respecto a las pruebas físicas en el contexto brasileño, pueden ser destacadas algunas cautelas que deben ser observadas por la Administración Pública para que sea garantizado el trato igualitario entre los candidatos, así como también pueden ser subrayados algunas cuestiones polémicas.

Sobre las citadas cautelas, la primera exigencia que se impone es la necesidad de que el edital detalle los procedimientos que deberán ser observados en la ejecución de las pruebas físicas, a fin de que sean evitadas las decisiones improvisadas, la sorpresa y la arbitrariedad administrativa.

En este contexto específico, la doctrina administrativista brasileña ha subrayado que el edital debe describir de forma minuciosa cuáles y cómo los ejercicios que deberán ser realizados, así como también deberán ser contemplados en las normas

\footnotetext{
${ }^{1256}$ Para exemplificar esta segunda hipótesis, se puede citar el concurso público realizado en 2008 por la Agencia Brasileña de Intelencia (ABIN) para el cargo de Agente de Inteligencia. En el edital, estaba prevista la realización de prueba de capacidad física, de carácter eliminatorio, que consistía en dos tests físicos subsecuentes de natación y carrera de doze minutos.

${ }^{1257}$ En este caso, en las situaciones donde no hay ley expresa que defina las etapas del concurso público para determinada carrera, la arbitrariedad tanto sucedería cuando fuese exigida la prueba física de forna innecesaria como también en las situaciones en las que la Administración Pública deja de exigir la citada modalidad de prueba, cuando esta es imprescindible para la selección de los funcionarios más aptos.

${ }^{1258}$ LOBELLO DE OLIVEIRA ROCHA, Francisco. Op.cit., p. 145.
} 
del concurso "o critério de pontuação (tempo, distância, número de repetições, etc.), e o desempenho mínimo exigido, no caso de a prova ter caráter eliminatório. A ausência de qualquer uma destas informações deixa ao examinador margem de discricionariedade inadmissível, que dá ensejo a injustiças (ainda que inconscientes) e arbitrariedades"

La realidad es que la ausencia de la definición de las reglas de ejecución de las pruebas físicas es la condición primera para que los candidatos sean tratados de forma igualitaria. Esta exigencia en el trato de los aspirantes hará con que la Administración Pública pueda tener las debidas condiciones técnicas de verificar cuáles son aptos o no al ejercicio del puesto de trabajo a ser cubierto. Por esta razón:

\begin{abstract}
"Elemento que exige maior atenção quando se trata de provas de aptidão física é a padronização ou uniformização. $\mathrm{O}$ candidato tem direito a realizar as provas em igualdade de condições com os demais concorrentes. Isso inclui as condições dos locais e equipamentos utilizados na realização das provas, inclusive condições climáticas semelhantes no momento em que se realiza a prova." ${ }^{1260}$
\end{abstract}

Además de la preocupación con la previsión de las reglas y con la igualdad en la aplicación de las mismas en las pruebas físicas, otra cautela que debe ser estar en la mira de la Administración Pública es la necesidad de la convocación de profesionales capacitados para conducir los referidos ejercicios. Como ya se ha visto, esta exigencia proviene del principio de profesionalidad de los miembros de los órganos de selección.

En esto caso, aunque ya exista en el proceso selectivo una comisión del concurso o banca examinadora, deberá ser constituida un órgano colegiado específico para la aplicación de las pruebas físicas, a ser formado por profesionales de las áreas de educación física, deportes, salud, etc.

En este sentido, la doctrina brasileña ha acentuado que "como o objeto da avaliação nessa modalidade de prova é a capacidade mínima necessária para que o candidato exerça as atividades do cargo ou emprego do ponto de vista físico-orgânico, a

${ }^{1259}$ LOBELLO DE OLIVEIRA ROCHA, Francisco. Idem, p. 145.
${ }^{1260}$ LOBELLO DE OLIVEIRA ROCHA, Francisco. Op.cit., p. 146. 
banca examinadora deverá ser conduzida, nessa fase do certame, por pessoas com formação profissional compatível com a natureza dos testes a serem aplicados."1261

En la ejecución de las pruebas físicas, la doctrina brasileña, como lo hace la española, apunta la necesidad de observancia del principio de proporcionalidad, especialmente para evitar los excesos en el nivel de exigencia impuesto a los candidatos.

Respecto a este asunto, se ha destacado que, además de la proporcionalidad, deben ser respetados los principios de razonabilidad y finalidad:

"Tema relevante, o que tem sido vetado pelo Poder Judiciário, consiste no exagerado critério adotado pela Administração, por ocasião da prova de aptidão física. É verdade que não se pode afastar o exame de esforço físico do certame de certos cargos, por exemplo, de agente de polícia, mas por outro lado, revela-se um exagero a eleição de um índice duvidoso, que só os bem dotados fisicamente e os super atletas, lograrão obter êxito. (...) Há testes que não se prestam a comprovar a capacidade física dos candidatos para o desempenho das atribuições do cargo, devendo, em assim, ser invalidado tal ato. (...) Em que pese seja legal a realização do teste de capacidade física, resta aferir a legalidade e a legitimidade dos critérios adotados para a verificação da capacidade física dos candidatos. (...) É lógico que os critérios para verificação da capacidade física devem ser definidos pela Administração, não cabendo ao Judiciário adentrar na discricionariedade e conveniência da comissão do concurso. Contudo, mesmo quanto aos elementos discricionários do ato há limitações impostas pelos princípios gerais do Direito e pela moralidade administrativa. (...) Declara-se nulo o ato administrativo que exclui candidato do processo seletivo, quando os critérios adotados para aferição da capacidade física constituírem atentados aos princípios da razoabilidade e da finalidade." 1262

Sobre las cuestiones polémicas que suelen pasar en las pruebas físicas realizadas en los concursos públicos brasileños, se puede resaltar las situaciones en las

${ }^{1261}$ BARBOSA MAIA, Márcio, y PINHEIRO DE QUEIROZ, Ronaldo. Op.cit., p. 118.
1262 PINHEIRO MADEIRA, José Maria. Op.cit., p. 96-97. 
que los candidatos se encuentran imposibilitados de realizar los ejercicios en el día determinado por la Administración Pública.

Lo que sucede es que, en algunas situaciones, el aspirante es acometido de una enfermedad poco antes de la prueba que le impide de realizarla (es el caso de una fuerte gripe) o, en otras circunstancias, tiene algún problema durante el ejercicio de no le permite complétalo, (es el caso de una lesión durante una carrera).

En general, las opiniones doctrinarias respecto a este asunto suelen admitir la realización del ejercicio en nueva fecha, siempre que tal hecho no comprometa el cronograma del concurso. ${ }^{1263}$

A su vez, algunas decisiones judiciales también admiten tal posibilidad de forma más limitada, ya que muchas veces suelen alegar la ausencia de previsión en el edital o la existencia de norma en el referido instrumento que prohíbe la realización de nuevas pruebas físicas 1264

Sin embargo, para evitar el casuismo, conviene que las tales circunstancias excepcionales sean previamente regladas en el edital, a fin de que no se admita que la Administración Pública pueda, según cada caso, decidir de forma discrecional los

\footnotetext{
${ }^{1263}$ En este camino: "Pensamos que nada impede a designação de nova data para a realização do exame, caso o candidato comprove a incapacidade relativa para se submeter ao exame na data designada, por motivo de doença, desde que não prejudique o cronograma normal do concurso." (TOURINHO, Rita. Concurso público no ordenamento jurídico brasileiro, Lumen Juris Editora, Rio de Janeiro, 2008, p. 89).

${ }^{1264}$ Como se puede ver a continuación, la vinculación al edital es un principio muy destacado por los Tribunales. Sin embargo, en la presente decisión, fue admitida la realización de la prueba física en nueva fecha: "CONCURSO PÚBLICO. POLÍCIA FEDERAL. PROVA DE APTIDÃO FÍSICA. REPROVAÇÃO NA PROVA DE SALTO. ARGÜICÃO DE CASO FORTUITO PARA FUNDAMENTAR O INSUFICIENTE APROVEITAMENTO. CONCESSÃO DE NOVA OPORTUNIDADE PARA A REALIZAÇÃO DE UMA TENTATIVA. AUSÊNCIA DE PREVISÃO. IMPOSSIBILIDADE. INEXISTENNCIA DE PREVISÃO EDITALÍCIA. VIOLAÇÃO AO PRINCÍPIO DA ISONOMIA. 1 - A aplicação de teste de aptidão física para a habilitação ao cargo de Delegado da Polícia Federal é uma exigência legal, encontrando respaldo no Decreto-lei 2.320/87. 2 - O item 2.3 da Instrução Normativa $n^{\circ}$ 1/93 diz expressamente que "não será concedida segunda chamada. Os casos de alteração psicológica ou fisiológica (estados menstruais, gravidez, contusões, luxações, fraturas, etc.) que impossibilitem o candidato de submeter-se aos testes ou diminuam sua capacidade física e orgânica não serão aceitos, em nenhuma hipótese, para fins de tratamento benevolente por parte da Administração." 3 - Não obstante, a comprovação de fato exógeno ou imprevisivel que altere a capacidade fisiológica do candidato pode ser levada em consideração de modo a ensejar outra oportunidade, desde que tenha sido alegada e comprovada contemporaneamente ao momento da realização da prova. 4 - Não sendo a hipótese, o candidato reprovado não terá direito à segunda chamada, haja vista a inexistência de previsão dessa natureza no Edital, o qual vincula a Administração aos seus termos. 5 - Apelação e remessa oficial providas.".(Tribunal Regional Federal $1^{\mathrm{a}}$ Reg. Apelación Civil $01000599239-3^{\mathrm{a}}$ Turma Suplementar Rel. Juez Federal Carlos Albertos Simoes de Tomaz (conv.) - DJ en 12/06/2003).
} 
eventos que admitirán o no la realización de las pruebas físicas en otra oportunidad, o cuando se considerará que el cronograma del concurso será afectado.

Por esta razón, se debe subrayar que:

"O correto, portanto, seria o próprio edital trazer previsões gerais e impessoais, a cuidar de hipóteses excepcionais tais como lesões em provas físicas, traçando previamente soluções para tais ocorrências (...) Dessa forma, previamente estaria regulada uma situação excepcional (vinculação ao edital), mas de forma a preservar a impessoalidade e a isonomia, pois todos os candidatos do certame, em tese, poderiam se beneficiar de tal situação"1265

Otro tema polémico dice respecto a la posibilidad de la evaluación de la prueba física influenciar en la clasificación final de los candidatos, o si la referida modalidad de ejercicio será tan solamente de carácter eliminatorio.

Aunque no existan normas claras, la doctrina suele sostener que la prueba física "ostenta caráter exclusivamente eliminatório tendo em vista que o candidato só poderá prosseguir no certame se alcançar as condições físicas mínimas estabelecidas no regulamento e no edital do concurso e, caso seja aprovado, a sua classificação no certame será mantida, independentemente da performance obtida nos testes."1266

El último aspecto polémico que debe ser subrayado es lo que se refiere a la diferencia de trato entre hombres y mujeres. Como ya se ha destacado en este trabajo, hay innegables distinciones anatómicas y fisiológicas entre los géneros, lo que impone que la Administración Pública no haga las mismas exigencias en las pruebas físicas (especialmente respecto a los índices de evaluación del desempeño, como tiempos, distancias, número de repeticiones, etc.) a hombres y mujeres.

Pese a la legitimidad jurídica y científica de los argumentos destacados, debe ser subrayado que nada impide que la Administración Pública imponga los mismos índices a los dos géneros, siempre que aquellos digan respecto al desempeño

${ }^{1265}$ MACHADO JÚNIOR, Agapito. Op.cit., p. 121.

${ }^{1266}$ BARBOSA MAIA, Márcio, y PINHEIRO DE QUEIROZ, Ronaldo. Op.cit., p. 117. 
mínimo exigido para las mujeres y que las pruebas físicas no tengan carácter clasificatorio.

La opinión arriba proviene de los siguientes argumentos:

\begin{abstract}
"sendo os homens por sua composição física mais fortes que as mulheres de um modo geral, pode parecer que seria injusto avaliá-los nas provas físicas segundo os mesmos critérios. De fato, a praxe nos concursos públicos é aplicar-se critérios diferenciados para homens e mulheres.(...) O que causa estranheza, no entanto, é que os critérios eliminatórios nos concursos públicos devem limitar-se à necessidade da Administração, ou seja, corresponder ao desempenho mínimo necessário para o bom exercício do cargo ou emprego público oferecido. Diante deste quadro, quando as exigências mínimas são diferentes para homens e mulheres, só há duas opções: ou o desempenho exigido dos homens é mais do que a Administração necessita; ou o desempenho exigido das mulheres está aquém das necessidades da Administração. Nas duas há afronta ao princípio da igualdade e às regras gerais dos concursos públicos." ${ }^{1267}$
\end{abstract}

\title{
5.3.5.5 - Los tests psicotécnicos
}

Conscientes de que deben esforzarse para seleccionar a personas que ostenten las debidas aptitudes para el desempeño de las más distintas actividades, las Administraciones Públicas brasileña y española vienen utilizando métodos selectivos que suelen ser manejados con más frecuencia en el sector privado.

En este contexto, los tests psicotécnicos tienen un especial énfasis, pues representan el intento de la Administración Pública (no siempre exitoso) de reconocer en los aspirantes las aptitudes que deben poseer los funcionarios, según el perfil idealizado y trazado de acuerdo con las actividades peculiares a cada plaza.

También se puede afirmar, quizá con más convicción, que los referidos tests sirven para que el órgano seleccionador reconozca en los aspirantes determinadas características que serían incompatibles con el mencionado perfil. Por esa razón, se

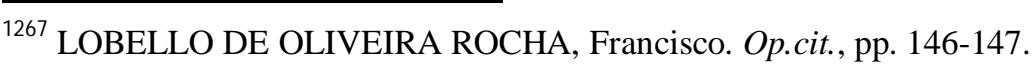


aduce de forma adecuada que el sobredicho método "es una técnica de selección y sobretodo de exclusión" 1268

Respecto a la utilización de los tests psicotécnicos en los procesos selectivos española, se ha dicho que aquellos "se hacen para conocimiento de la personalidad psíquica del aspirante. Es una técnica anglosajona, aplicada preferentemente a la empresa privada, que en nuestra Administración Pública tiene poca eficacia."1269

Como se percibe, en el contexto español (así como en el brasileño, quizá con más intensidad), hay una considerable resistencia a la utilización del mencionado método selectivo, especialmente porque presenta muchas dificultades referentes: a) a la dudosa evaluación objetiva de los aspirantes; b) a la discutible relación del mismo con el mérito y capacidad; y, principalmente, c) la inaccesibilidad de los parámetros de evaluación, lo que hace casi inviable la actividad de control que se puede ejercer respecto el referido método.

Sobre la primera cuestión, se puede decir que los tests psicotécnicos deben ser realizados a partir de parámetros previamente estipulados y científicamente fundamentados. También se impone que aquellos se evalúen a través de criterios objetivos, que no permitan que la calificación del perfil psicológico del aspirante dependa del hecho de haber sido realizada por el examinador A, B o C.

Respecto al segundo problema detectado, conviene mencionar que la realización de los tests psicotécnicos no puede estar disociada del perfil que se desea para cada una de las plazas ofertadas por la Administración Pública. Evidentemente, el perfil de un policía no es el mismo que el de un juez. De cada funcionario se exige características determinadas, que son relevantes para el buen desempeño de las tareas que le son peculiares.

En este sentido, destaca la doctrina española de que muchos exámenes psicotécnicos son valorados "por equipos técnicos - especialmente psicólogos - que

1268 NAVARRO, Pilar. Op.cit., p. 141.

1269 PERÉZ LUQUE, Antonio. Op.cit., p. 338. 
están muy alejados del conocimiento real de las funciones jurídico-públicas de las plazas que se pretenden solucionar."1270

La tercera dificultad de los tests psicotécnicos trata sobre la referida inaccesibilidad de los parámetros de evaluación, lo que hace que los aspirantes tengan una dificultad inmensa para refutar los resultados que les son desfavorables.

De la misma forma, los órganos encargados del control de los procesos selectivos, cuando son reclamados por los opositores insatisfechos con los resultados de los tests psicotécnicos, no suelen recibir explicaciones de los evaluadores que puedan permitir un análisis objetivo de la validez de la evaluación realizada.

Sobre esta cuestión, cabe destacar que los tests psicotécnicos solamente podrán ser utilizados de forma legítima si, efectivamente, permitieren el control de su valoración, lo que posibilitaría el alejamiento de determinados abusos.

Los tres problemas antes mencionados deben ser tenidos en consideración, siempre que se opte por la utilización de los tests psicotécnicos. De forma resumida, el Tribunal Supremo de España ya destacó que:

"El empleo del test psicológico de personalidad en el procedimiento de selección para el acceso a la función pública, y, en concreto, de los dirigidos a evaluar la dirección e intensidad de las aptitudes no proporcionan un perfil de la capacidad intelectual del candidato sino de aspectos de la personalidad en términos de tendencia a reaccionar hacia determinados estímulos, plantea el importante problema de su adecuación a criterios objetivos que permitan el control de la decisión selectiva en la que han de verse garantizados los principios constitucionales de igualdad, merito y capacidad." ${ }^{1271}$

En el contexto brasileño, hay una gran similitud con el panorama español respecto a las dificultades de aplicación de los tests psicotécnicos en los procesos selectivos de acceso a la función pública. Se puede afirmar que la dudosa evaluación objetiva de los aspirantes; la discutible relación del mismo con el mérito y capacidad; y

${ }^{1270}$ PERÉZ LUQUE, Antonio. Op.cit., p. 338.

1271 STS de 05 de octubre de 1989. 
la inaccesibilidad de los parámetros de evaluación son las principales críticas que la doctrina brasileña hace a la citada técnica de selección en el sector público.

Antes de que sean verificadas las mencionadas cuestiones, es relevante acentuar que también hay juristas brasileños que, además de acentuar los aspectos negativos, igualmente reconocen el papel de los tests psicotécnicos como método complementario en el proceso de selección de los más aptos ${ }^{1272}$. En este sentido: "Habilidades diversas das aferidas nas provas e a personalidade (características emocionais, motivacionais, interpessoais e de atitudes distintas das habilidades) do candidato também podem interferir em seu desempenho no exercício do cargo. Estes atributos podem ser aferidos por meio de testes psicológicos." 1273

La verdad es que, en general, los juristas brasileños subrayan que los beneficios de los tests psicotécnicos para la adecuada selección de los funcionarios públicos son comprometidos por la indebida ejecución de los mismos en la realidad de los concursos públicos. En este contexto:

\begin{abstract}
"A verdade é que aplicação de testes psicológicos para ser válida exige rigor e observância de muitos requisitos. Qualquer mínimo desvio na sua realização é suficiente para torná-lo inválido. E se a aplicação responsável e rigorosa desses testes pode ser legítima e útil na seleção dos melhores candidatos, desvios na sua aplicação criam distorções inadmissíveis em concursos públicos. Parece-nos que este segundo cenário tem prevalecido no Brasil."1274
\end{abstract}

También hay los que destacan que las malas experiencias en la ejecución de los tests psicotécnicos no deben impidir su utilización ${ }^{1275}$, y los que sostienen que en el

\footnotetext{
${ }^{1272}$ En este sentido, hay los que reconocen la relevancia del test psicotécnico, aunque le atribuya una función más cercana a la de los exámenes de sanidad: "Exame psicotécnico é aquele em que a Administração afere as condições psíquicas do candidato a provimento do cargo público. Trata-se de requisito legítimo, visto que as funções públicas devem ser exercidas por pessoas mentalmente sãs." (SANTOS CARVALHO FILHO, José dos. Op.cit., p. 561).

${ }_{1273}$ LOBELLO DE OLIVEIRA ROCHA, Francisco. Op.cit., p. 101.

${ }^{1274}$ LOBELLO DE OLIVEIRA ROCHA, Francisco. Idem, p. 102.

1275 En este sentido:. "Assim como o concurso é um dos instrumentos da qualidade no serviço público,o exame psicotécnico é um dos instrumentos da qualidade do concurso público. Tanto o concurso, para o serviço público, quanto o psicotécnico, para o concurso, não são a panacéia dos males e nem podem ser desprezados ou tidos como opcionais. Embora considerado com negatividade por muitos, afirmo inicialmente meu entendimento no sentido de que os exames psicotécnicos têm seu lugar reservado na seleção para cargos públicos: simplesmente não podemos abrir mão deles. Um dos maiores problemas
} 
caso de que el test psicotécnico sea considerado ilegítimo por un fallo judicial, debe ser repitido el referido examén ${ }^{1276}$, lo que comproba su relevancia.

Como se ha destacado de forma general en las primeras líneas de este apartado, en la realidad de los procesos selectivos brasileños, los tests psicotécnicos ejercen una función que está más relacionada a la exclusión de los aspirantes que poseen características incompatibles con el ejercicio de determinadas actividades públicas. ${ }^{1277}$

En estos términos, casi no hay preocupación de los órganos seleccionadores brasileños, cuando utilizan los referidos tests, con la verificación de la tenencia de características positivas ${ }^{1278}$ que deberían poseer los funcionarios públicos, como inteligencia emocional, capacidad de iniciativa, motivación, liderazgo, entre otras.

Para confirmar esta constatación, se ha afirmado en el contexto brasileño que los tests psicotécnicos en los concursos públicos deben "procurar aferir apenas as

do concurso público é que examina bem a quantidade de conhecimento adquirido pelo candidato, mas é pouco eficiente para medir caráter, ética, honestidade e outros valores inequivocamente mais importantes do que a competência técnica. A matéria do programa se aprende. Ser honesto, equilibrado, decente... isso é mais complicado. Os exames psicotécnicos têm, para as carreiras que há previsão legal de sua exigência, a virtude de ao menos contribuir para proteger o serviço público, e consequentemente a população, de pessoas desequilibradas ou que, por portar problema de saúde mental ou emocional, não estão suficientemente aptas para servir ao público. Registrada minha admiração pelo exame, devo registrar algumas de suas falhas. Sim, as falhas existem e elas fazem parte do sistema. Apesar de complexo, o exame psicotécnico não pode ser eliminado apenas por sua dificuldade de execução. Se fosse ser assim, os concursos e as licitações também deveriam deixar de existir (e voltaríamos à vetusta e infeliz opção pelos amigos, parentes e cabos eleitorais). Concursos, licitações e exames psicotécnicos têm seus desafios, dão "trabalho", mas igualmente têm suas vantagens, muito superiores às dificuldades que apresentam. Em vista disso, cabe à Administração Pública aprender a lidar com os instrumentos de seleção e de democratização do acesso aos cargos e contratos com a Administração Pública." (DOUGLAS, Willian. A qualidade do serviço público, o exame psicotécnico e o princípio da segurança jurídica, texto extraído del sitio Jus Navigandi (http://jus2.uol.com.br/doutrina/texto.asp?id=12854), publicado en 14.05.2009, acceso en 16.02.2010).

${ }_{1276}$ MARINELA DE SANTOS SOUZA, Fernanda. Op.cit., p. 201.

${ }^{1277}$ En este contexto: "Reconhecer que um dado traço de personalidade apresenta incompatibilidade com determinada atividade não é a mesma coisa que exigir que os candidatos estejam ajustados a um determinado esquema psicológico proposto como "padrão" previamente definido e qualificado como sendo o "perfil psicológico", fora do qual o concorrente será eliminado. "(BANDEIRA DE MELLO, Celso Antônio. Op.cit., p. 258, nota a pié de página 24).

${ }^{1278}$ Sin embargo, la Resolución 1/02, del Consejo Federal de Psicologia, que regulamenta la evaluación psicológica en los concursos públicos, no rechaza la posibilidad de utilización de la referida técnica para verificación de los aspectos psicológicos (positivos o negativos) del candidato : "Art. $1^{\circ} \mathrm{A}$ avaliação psicológica para fins de seleção de candidatos é um processo, realizado mediante o emprego de um conjunto de procedimentos objetivos e científicos, que permite identificar aspectos psicológicos do candidato para fins de prognóstico do desempenho das atividades relativas ao cargo pretendido." 
situações de manifesta incompatibilidade da estrutura psicológica dos candidatos em relação ao perfil traçado para o cargo disputado no certame" ${ }^{\text {"1279 }}$

Aun sobre la referida característica de los tests psicotécnicos, conviene ratificar la exigencia doctrinaria que rechaza los (...):

“(...) exames psicotécnicos destinados a excluir liminarmente candidatos que não se enquadrem em um pretenso "perfil psicológico", decidido pelos promotores do certame como sendo o "adequado" para os futuros ocupantes do cargo ou emprego. Exames psicológicos só podem ser feitos como meros exames de saúde, na qual se inclui a higidez mental dos candidatos, ou, no máximo - e, ainda assim, apenas no caso de certos cargos ou empregos -, para identificar e inabilitar pessoas cujas características psicológicas revelem traços de personalidade incompatíveis com o desempenho de determinadas funções. Compreende-se, por exemplo, que um teor muito alto de agressividade não se coaduna com os encargos próprios de quem deva tratar ou cuidar de crianças em creches ou escolas maternais" 1280

Respecto a las críticas realizadas por la doctrina brasileña a los tests psicotécnicos, las dos más usuales dicen respecto a la ausencia de objetividad y la dificultad de control de los resultados de la evaluación ${ }^{1281}$.

También se puede añadir que los juristas del citado país sudamericano exigen, como condición de su validez, que la referida técnica de selección deba estar

\footnotetext{
${ }^{1279}$ BARBOSA MAIA, Márcio, y PINHEIRO DE QUEIROZ, Ronaldo. Op.cit., p. 126.

${ }^{1280}$ BANDEIRA DE MELLO, Celso Antônio. Op.cit., p. 258.

${ }^{1281}$ Para ilustrar las grandes preocupaciones de la doctrina brasileña respecto a la realización de los tests psicotécnicos: "A discussão também ocorre em razão da objetividade exigida em provas de concurso público, o que não pode ser afastado nos exames psicotécnicos apesar da dificuldade em se materializar essa exigência. Dessa maneira, torna-se imprescindível que os nomes dos responsáveis pelo exame sejam devidamente publicados, para que se permita avaliar sua aptidão. Os procedimentos que serão adotados também devem ser previamente definidos no edital do certame, com a devida publicação. Por fim, exigese também a possibilidade de revisão do resultado, garantindo aos candidatos o direito à interposição de recursos." (MARINELA DE SANTOS SOUZA, Fernanda. Op.cit., p. 200).
} 
prevista en ley. ${ }^{1282}$ Cabe acentuar que la jurisprudencia brasileña también impone tal exigencia en los concursos públicos que analiza ${ }^{1283}$.

La necesidad de realización de los tests psicotécnicos bajo criterios objetivos de evaluación es un reto para la Administración Pública. En este sentido, el Supremo Tribunal Federal exige que los referidos tests sean realizados y evaluados según criterios científicos comprobados. ${ }^{1284}$

También ha destacado la doctrina que:

"não se pode considerar legítimo o exame, nem qualquer de suas etapas, quando a Administração promove entrevistas, diálogos, dissertações orais, sem que possa o candidato ter parâmetros para verificar o resultado. Sendo o exame calcado em pressupostos científicos e objetivos, terá licitude, pois que ao interessado será permitido confrontar o resultado a que chegaram os examinadores.". ${ }^{1285}$

La ausencia de objetividad conduce a la inaccesibilidad a los candidatos de los parámetros de evaluación, y esto, a su vez, resulta en la imposibilidad de los mismos contestaren los resultados, segunda principal critica realizada por la doctrina brasileña.

La realidad es que si los candidatos no saben la razones que condujeron a su eliminación del concurso público por recomendación de los psicólogos, no van a tener la posibilidad de demostrar la inadecuación de sua evaluaciones, lo que será un gra obstáculo al ejercicio del derecho del aspirante controlar la actuación de la

\footnotetext{
${ }^{1282}$ En este camino: "revela-se também passivel de questionamento a exigência de aprovação em teste psicotécnico que não tenha anterior previsão em lei, a teor da Súmula n. 686 do STF. A exigência de aprovação em exames dessa natureza, portanto, só se legitima diante de anterior previsão em lei e se os critérios adotados para a avaliação forem objetivos." (SPITZCOVSKY, Celso. Limitações constitucionais aos editais de concursos públicos. Texto extraído del sitio Jus Navigandi (http://jus2.uol.com.br/doutrina/texto.asp?id=5125).

${ }^{1283}$ Para ilustrar tal línea de pensamiento: "Serviço Público - Ingresso - Requisitos - Exame psicotécnico. Somente a lei, ato normativo primário, pode estabelecer requisitos para o ingresso no serviço público CF, art. 37, I. Se o exame psicotécnico estiver previsto em ato administrativo apenas, ocorre ilegitimidade." (Supremo Tribunal Federal, Recurso Extraordinario 232.571-7-RS, 2ª Turma, Rel. Min. Carlos Velloso, publ. DJ de 5/2/1999).

${ }^{1284}$ Sobre esta cuestión, el ministro Francisco Rezek, del Supremo Tribunal Federal, en el Recurso Extraordinario 112.676 ( $2^{\text {a }}$ Turma, RTJ 134/770), decidió que "não é exame, nem pode integrá-lo, uma aferição carente de qualquer rigor científico, onde a possibilidade teórica do arbítrio, do capricho e do preconceito não conheça limites"

${ }^{1285}$ SANTOS CARVALHO FILHO, José dos. Op.cit., p. 562.
} 
Administración Pública. Lo que sucede es que en el cotidiano de los procesos selectivos brasileños, la situación es tan grave que en, muchos casos, hay hasta mismo la realización de tests psicotécnicos de forma sigilosa ${ }^{1286}$, donde los candidatos solamente sabrán, al final de los referidos exámenes, si fueron o no considerados aptos. ${ }^{1287}$

Para evitar los hechos mencionados (ausencia de criterios objetivos, o inaccesibilidad a los mismos), la doctrina sugere que en el edital del concurso público, ya se establezcan los parámetros de evaluación que serán utilizados:

"Se por um lado houve um elogiável avanço, por outro, os órgãos responsáveis pela realização dos concursos, ou suas terceirizadas, têm atualmente incidido erro que exclui indevidamente muitos candidatos dos concursos, bem como compromete a validade do certame. Não é um erro novo, mas antigo. O que existe de novo é podermos percebêlo a partir das evoluções já proporcionadas pela submissão do tema aos areópagos pátrios. Trata-se da omissão em editais quanto à apresentação previa dos critérios que serão levados em conta no momento da análise do perfil psicológico dos candidatos. Não se apresentam os critérios, o que será levado em conta, o que tecnicamente é considerado apto ou inapto; é omisso em relação às respectivas pontuações, ferindo assim o sacramental princípio da segurança jurídica." 1288

\footnotetext{
1286 Tal circunstancia no es admitida por los Tribunales brasileños. En este sentido: "Apesar de ser constitucional a exigência de exame psicotécnico para a aprovação no concurso para Delegado de Polícia Federal, o mesmo não pode se revestir de sigilo quanto aos critérios de avaliação, nem seu resultado pode ser irrecorrível. Violação aos princípios da ampla defesa, do contraditório e da publicidade no processo administrativo configurados. Precedentes.". (Tribunal Regional Federal $3^{\text {a }}$ Reg. - AC 97.03.063192-4 - $1^{\text {a }}$ T. - Rel. Juiz Casem Mazloum - Unánime - DJU 27.04.1999)."

${ }^{1287}$ Sobre tal constatación: "Alguns órgãos administrativos, não se sabe bem por quê, ou se é para alguma ocultação escusa, já que não se vislumbra qualquer razão plausível, insistem em conferir ao exame psicotécnico caráter sigiloso, chegando mesmo ao ápice de inserir essa qualificação em cláusula de edital de concurso. Essa imposição é notoriamente ilegítima e ofende literalmente o princípio que assegura a qualquer indivíduo o direito à obtenção de informações perante os órgãos públicos (art. $5^{\circ}$, XXXIII, CF). Afinal, todos têm o direito de saber quais os motivos que conduziram o examinador a considerar o candidato inapto no exame psicotécnico, e, aliás, em qualquer tipo de prova. $O$ resultado, já se disse, precisa ser suscetível de apreciação por outro técnico, permitindo, inclusive, que o interessado, se for o caso, recorra ao Judiciário para análise da legalidade ou não da conclusão do exame." (SANTOS CARVALHO FILHO, José dos. Op.cit., p. 563).

${ }_{1288}$ DOUGLAS, Willian. A qualidade do serviço público, o exame psicotécnico e o princípio da segurança jurídica, texto extraído del sitio Jus Navigandi (http://jus2.uol.com.br/doutrina/texto.asp?id=12854), publicado en 14.05.2009, acceso en 16.02.2010.
} 
En el ámbito de la Unión, el Decreto Federal 6.944, de 21 de agosto de 2009, ha estipulado algunas condiciones para la realización de los tests psicotécnicos $^{1289}$, lo que ciertamente podrá contribuir para la reducción de las dudas y polémicas respecto el referido instituto, al menos en la esfera federal. ${ }^{1290}$

Conviene subrayar sobre los tests psicotécnicos que la complejidad del tema exigiría una profundización incompatible con los objetivos de este trabajo y con los escasos conocimientos de psicología de su autor.

Aunque sus propósitos sean legítimos y muchas veces, la ausencia o inadecuación de su manejo pueda traer consecuencias terribles para la sociedad ${ }^{1291}$, se impone que el ordenamiento jurídico establezca reglas más claras para que su utilización no permita la transgresión del derecho de igualdad de los aspirantes a la función pública.

\footnotetext{
1289 "Art. 14. A realização de exame psicotécnico está condicionada à existência de previsão legal expressa específica e deverá estar prevista no edital.

$\S 1^{\circ}$ O exame psicotécnico limitar-se-á à detecção de problemas psicológicos que possam vir a comprometer o exercício das atividades inerentes ao cargo ou emprego disputado no concurso.

$\S 2^{\circ} E$ vedada a realização de exame psicotécnico em concurso público para aferição de perfil profissiográfico, avaliação vocacional ou avaliação de quociente de inteligência".

${ }^{1290}$ Sobre la introducción de las referidas reglas en el sistema jurídico brasileño, se ha dicho que: "Sem sombra de dúvida, qualquer iniciativa no sentido de tornar mais transparente e isonômico o certame deve ser aplaudida, posto que há muitos processos que inundam o Poder Judiciário com questões que poderiam ser facilmente resolvidas administrativamente. No que tange ao exame psicotécnico, a Administração Federal tem insistido em cobrar, principalmente nas carreiras ligadas à segurança pública, um perfil profissiográfico. Ora, certo é que a Administração deve escolher aqueles candidatos que apresentem equilíbrio emocional, posto que portarão armas de fogo e tratarão diretamente com os cidadãos em momentos, via de regra, difíceis, entretanto, a atuação do Estado é baseada na Lei, por isso o Estado de Direito. Saber se um candidato tem ou não tem equilíbrio emocional diferencia-se, sobremaneira, de exigir que tenha um perfil psicológico que o Administrador, unilateralmente entende ser o mais adequado ao cargo. O que quero dizer, é que os candidatos estão sendo reprovados não porque tem desequilíbrio emocional, mas porque não atendem a um perfil fixado pelo administrador, que não encontra respaldo na Lei, o que, viola frontalmente a Legalidade Administrativa e, em última instância, a Constituição da República. Dessa forma, andou muito bem a Presidência da República ao proibir que em concurso públicos federais seja exigido perfil profissiográfico, avaliação vocacional ou avaliação de quociente de inteligência. Determina, ainda, o decreto, que o exame psicotécnico limitar-seá à detecção de problemas psicológicos que possam vir a comprometer o exercício das atividades inerentes ao cargo ou emprego. Trata-se de uma Vitória dos cidadãos, da sociedade brasileira e da transparência. Entendo que os candidatos eliminados com fundamento em inadequação ao perfil profissiográfico devem formular requerimentos administrativos visando a revisão do ato que, se negados, devem ser guerreados através de medida Judicial." (BRANDAO COSTA, Bernardo. Exame Psicotécnico - Novas Regras, texto extraído del sitio: http://www.pciconcursos.com.br/consultoria/exame-psicotecnico-novas-regras), acceso en 27 de junio de 2010.

${ }^{1291}$ Es lo que pasaría si fueran seleccionados, debido a la no realización de los tests psicotécnicos o delante de su mala aplicación, policías con tendencia a la violencia extrema, jueces deshumanos, fiscales cobardes, profesores que no toleran la interacción con los alumnos, entre otros ejemplos. Evidentemente, aunque se realicen los referidos tests, tampoco se puede garantizar de forma absoluta que no serán seleccionados funcionarios con las citadas características.
} 


\subsubsection{6 - Otros medios}

Además de las técnicas tradicionales que ya se ha analizado en este trabajo, que resumidamente dicen respecto a la realización de pruebas (escritas, orales, físicas o prácticas), conviene investigar otros mecanismos que pueden aportar alguna contribución a la difícil tarea de selección de los aspirantes más aptos.

Asimismo, cabe verificar las condiciones jurídicas de ejecución de los otros instrumentos de selección, para que se pueda constatar la compatibilidad de estos medios con las exigencias de trato igualitario entre los candidatos.

En el derecho español, se puede afirmar que la fórmula genérica utilizada en el art. 61.2 del Estatuto Básico del Empleado Público permite la previsión de otros métodos selectivos, que pueden ayudar en la comprobación de los conocimientos y la capacidad analítica de los aspirantes.

Las posibilidades de que dispone el órgano seleccionador son diversas. Lo que se impone es la demonstración de la utilidad y pertinencia del método elegido con las tareas que se van a desarrollar, y que el mismo esté previsto en las bases de la convocatoria, permitiendo que los aspirantes puedan prepararse adecuadamente.

Aunque la legislación haya optado por una catalogación abierta de los métodos selectivos, estos encuentran limites en los principios constitucionales de igualdad, merito y capacidad, así como en la necesidad arriba destacada, de conexión entre el tipo de pruebas a superar y la adecuación al desempeño de las tareas de los puestos de trabajo convocados (art. 61.2 del EBEP).

Respecto a los referidos métodos auxiliares de selección, la doctrina española enfatiza tres medios: los exámenes de idiomas, la entrevista personal y el análisis curricular. Sobre el primer método, ya se han realizado diversas consideraciones en este trabajo, cuando fue analizada la exigencia de conocimiento de lenguas cooficiales, lo que ocurrió en el tercer capítulo.

Lo que se subraya aquí es que además de las lenguas cooficiales al castellano (el catalán, el vasco, el gallego, el valenciano, etc.), hay procesos selectivos 
que prevén pruebas de conocimiento de idiomas extranjeros (inglés, francés, alemán, portugués, chino, árabe, etc.).

Sobre la referida situación, la doctrina destaca que "los exámenes de idiomas son cada vez más frecuentes en las oposiciones, debido a la creciente internacionalización de numerosas instituciones y organismos en los que participa España."1292

Conviene resaltar que los exámenes de idiomas deben tener una justificación plausible, así como deben ser realizados según el grado de necesidad de su utilización en el desempeño de las tareas de cada plaza.

Los otros dos medios destacados (la entrevista personal y el análisis curricular) son de discutible utilización en los procesos selectivos, debido a que no siempre proporcionan el deseado nivel de objetividad en su realización y evaluación.

La entrevista personal es un recurso que solamente debe ser utilizado ante una fuerte justificación (por ejemplo, en la selección del personal directivo, es releante para la verificación de la capacidad de iniciativa y de liderazgo, entre otras características), ya que su componente subjetivo es altísimo.

Aún así, para que haya la validez de las entrevistas en los procesos selectivos de acceso a la función pública, deben ser definidos previamente qué parámetros serán utilizados en las preguntas y en la evaluación, para que no haya un trato distinto entre los aspirantes.

A su vez, sobre el análisis curricular, se puede añadir que en los sistemas selectivos españoles del concurso, así como en el concurso-oposición, la experiencia profesional y académica de los aspirantes puede ser evaluada como mérito, según el baremo previsto en las bases de la convocatoria.

En el contexto brasileño, las técnicas de selección ya mencionadas, como las entrevistas y 1 análisis curricular, son consideradas poco convencionales por las Administraciones Públicas del citado país, y por esta razón, son raramente utilizadas en los concursos públicos.

$\overline{{ }^{1292} \text { NAVARRO, Pilar. Op.cit., p. } 167 .}$ 
Además, se puede añadir que la doctrina suele rechazar los referidos instrumentos de selección, especialmente bajo el argumento de que no están conformados a los principios constitucionales de igualdad y mérito.

En el contexto que se ha destacado, se puede subrayar que:

"Outras modalidades de provas podem ser exigidas, de acordo com a natureza do concurso ou do cargo público para cujo preenchimento se esteja realizando o certame, devendo, porém, todas elas, guardar consonância com os princípios constitucionais aqui referidos. Até mesmo as chamadas provas didáticas para professor, tidas como o único meio pelo qual o candidato ao magistério superior é capaz de comprovar suas habilitações pedagógicas, essenciais para o desempenho da atividade docente, se não podem ser supridas pela demonstração escrita dos conhecimentos relacionados às técnicas de ensino-aprendizagem, devem se cercar de máximas cautelas, visando à obediência dos princípios constitucionais da administração." 1293

De hecho, llama la atención la oposición de los juristas brasileños al manejo, en el concurso público, de las técnicas de selección que suelen ser utilizadas con frecuencia en el sector privado.

Esto sucede sea porque se entiende que, en teoría, los referidos instrumentos no se adecuan a las exigencias constitucionales de trato igualitario de los candidatos, o porque se verifica que, en la realidad de los concursos públicos brasileños, la Administración Pública, cuando hace uso de los citados medios, no respecta las imposiciones jurídicas necesarias a la selección impersonal de los funcionarios públicos.

En el contexto que se ha acentuado, no hay dudas de que la entrevista la técnica de selección que más criticas ha recibido del medio jurídico brasileño, sea de los doctrinadores $^{1294}$, sea de los Tribunales ${ }^{1295}$.

1293 SÁTIRO FERNANDES, Flávio. A prova oral como elemento defraudador dos princípios da impessoalidade e da moralidade. Texto extraído del sitio Jus Navigandi (http://jus2.uol.com.br/doutrina/texto.asp?id=8691), publicado en 26.07.2006, acceso en 16.02.2010.

${ }^{1294}$ Para ilustrar tal constatación:"Alguns concursos públicos costumam prever a realização de entrevistas, ou ainda, camuflá-las como fase do exame psicotécnico, quando não no lugar do próprio. As entrevistas são um expediente muito utilizado, na iniciativa privada como forma de estabelecer um primeiro contato entre o candidato à vaga e o empregador e determinar se há empatia entre estes. São 
A partir de un análisis de los (pocos) estudios sobre el tema, se constata fácilmente que la doctrina brasileña considera que las entrevistas no suelen proporcionar el necesario grado de objetividad en el proceso de selección, circunstancia que hace con que el referido medio sea rechazado con mucha intensidad.

En verdad, se ha denunciado que el manejo de las entrevistas en los concursos públicos es un expediente usualmente utilizado por las Administraciones Públicas brasileñas para cambiar subjetivamente las calificaciones obtenidas de forma objetiva en las pruebas, y esto se hace tanto para favorecer como para perjudicar determinados candidatos ${ }^{1296}$.

En este sentido, se ha resaltado que:

"Hipótese semelhante, e também de flagrante ilegalidade, ocorre com
as denominadas entrevistas, que, na realidade, escondem forma de
eliminação de candidatos, ao sabor, freqüentemente, de selecionadores
nem sempre habilitados para extrair qualquer tipo de aferição do
candidato. Trata-se de prática que, não raro, conduz a abusos que
prejudicam gravemente o candidato e não lhe oferecem qualquer

feitas perguntas sobre a vida profissional e pessoal do candidato a fim de identificar seus planos, gostos, valores e outras características. Se a utilização de tal critério é legítima na iniciativa privada e até mesmo no provimento de cargos públicos comissionados, o mesmo não ocorre nos concursos públicos em que a discriminação deve basear-se tão somente em critérios impessoais, objetivos e relevantes. Assim, por ser critério absolutamente subjetivo e afrontar os princípios da impessoalidade e da igualdade que devem nortear os concursos públicos, as entrevistas não podem ser utilizadas, seja como critério eliminatório ou classificatório. A existência de tais entrevistas daria à Administração verdadeiro poder de veto baseado exclusivamente em critérios subjetivos, inserindo os caprichos e preconceitos do examinador como critérios válidos de seleção, o que não é em nada compatível com a sistemática dos concursos públicos inserida na Constituição Federal." (LOBELLO DE OLIVEIRA ROCHA, Francisco. Op.cit., p. 96).

${ }^{1295}$ En este camino: "Concurso público - Posse impedida em razão de entrevista pré-admissional impossibilidade. Tendo o impetrante sido aprovado em concurso público de provas e títulos, não pode ser impedido de tomar posse em razão de resultado de entrevista pré-admissional, cujos resultados não lhe foram comunicados e onde não the foi possível defender-se de acusações que lhe foram feitas." (Tribunal de Justicia del Estado de Rio de Janeiro, ApCív. 13619/98-Capital, $10^{\text {a }}$ CCív, unán., Res. Des. Sylvio Capanema, publ. DO de 6/9/1999)

${ }^{1296}$ En esta línea de pensamiento: "A entrevista em concurso público deve ser repudiada, pois a possibilidade teórica do livre arbítrio, do capricho e do preconceito não possui limites, sendo vulnerável à discriminação desarrazoada. Mesmo que seja de caráter classificatório e não eliminatório, conforme determinado no citado edital, a entrevista pode prejudicar, de formar irremediável, um candidato que teve a sua classificação piorada, podendo gerar a ausência de nomeação. Assim, qualquer forma de análise subjetiva em um concurso público, como ocorre com a entrevista pessoal, deve ser absolutamente abolida dos processos seletivos públicos, caso interfira na classificação ou aprovação/reprovação no certame, através de uma ação anulatória ou um mandado de segurança dependendo do caso." (Extraído del texto Entrevista em concurso público,. publicado en el sitio: http://www.pciconcursos.com.br/consultoria/entrevista-em-concurso-publico, acceso en 28 de junio de 2010). 
oportunidade de defesa contra o abuso nem ensejo para rechaçar os motivos (quando existem) eventualmente invocados." 1297

En un contexto tan grave como lo que ha sido destacado, la doctrina y la jurisprudencia brasileñas prácticamente no admiten la realización de entrevistas en el concurso público. En este sentido, se ha dicho que "não é admissível, em hipótese alguma, a utilização de entrevistas a qualquer propósito nos concursos públicos, por tratar-se de expediente desprovido de qualquer objetividade e utilidade que não a de sujeitar o candidato ao arbítrio do examinador.",1298

De forma resumida, se puede decir que el gran riesgo de que se repitan las malas experiencias del pasado hace con que las pocas ventajas de la utilización de las entrevistas en los procesos selectivos de acceso a la función pública sean totalmente despresadas por aquellos que analizan el tema.

La situación arriba acentuada es uno de los muchos ejemplos, en el ámbito de los procesos selectivos, en el que la indebida utilización de institutos jurídicos, cuando compromete la igualdad, hace con que los juristas recomenden de forma incisiva que los citados instrumentos sean eliminados, aunque pudiesen tener alguna utilidad en la selección de los más aptos.

Como se vé, es una clara demostración del papel relevante desempeñado por la igualdad en el sistema selectivo, aunque compruebe la incapacidad de la Administración Pública de manejar de forma correcta determinadas herramientas frecuentemente utilizadas en el sector privado.

\subsection{6 - Divulgación de la relación de aprobados}

Tras la realización de los ejercicios (y evaluación de los méritos, si estos fueron previstos), la Administración Pública ya dispondrá de la relación de los aspirantes aprobados, según la evaluación llevada a cabo por el órgano seleccionador.

A continuación, como todo proceso selectivo está sometido al deber de publicidad, se impone que la Administración Pública divulgue la relación de aprobados según las exigencias de la legislación (en general, esto se hace en el diario oficial).

${ }^{1297}$ SANTOS CARVALHO FILHO, José dos. Op.cit., p. 563.

${ }^{1298}$ LOBELLO DE OLIVEIRA ROCHA, Francisco. Op.cit., p. 98. 
En el derecho español, el órgano seleccionador deberá proponer, respecto a los aspirantes aprobados, el acceso a la condición de funcionario, lo que está previsto en el Estatuto Básico del Empleado Público, en su art. 61.8. ${ }^{1299}$

Como se ve, en el sistema jurídico español, no es suficiente que el aspirante supere todas las pruebas. El mismo, para que sea contemplado en la propuesta del tribunal, deberá tener una calificación que le sitúe entre los mejores, según el orden de puntuación. Y más: el límite para que sean contemplados "los mejores" en la propuesta del tribunal tiene en consideración el número de plazas ofertadas.

Sobre esta cuestión, se dijo que "no debe confundirse una relación de aptos con una relación de aprobados, ya que la primera no confiere derecho ni expectativa alguna, pudiendo ser distinta en su contenido respecto a la relación de aprobados debido, fundamentalmente, al condicionante legal de que no podrán aprobarse a más candidatos que el número de plazas convocadas." 1300

Así, la propuesta del Tribunal, que no debe rebasar el límite mencionado, será elevada a la autoridad competente, que deberá publicarla en el diario oficial. Sobre este momento del proceso selectivo, lo que llama la atención, por su conexión con el tema de este trabajo, es el elevado grado de vinculación de la propuesta del Tribunal hacia la Administración Pública.

Evidentemente, la evaluación de los miembros del Tribunal no puede ser sustituida por eventuales consideraciones de gestores públicos que no tienen la legitimidad técnica debida. Sin embargo, pueden ser detectadas irregularidades en el procedimiento administrativo, que justifiquen su anulación.

En el contexto brasileño, el deber de publicación del resultado final del concurso público es una imposición que tiene como fundamento el principio constitucional de publicidad, previsto en el art. 37.

\footnotetext{
1299 "Los órganos de selección no podrán proponer el acceso a la condición de funcionario de un número superior de aprobados al de plazas convocadas, excepto cuando así lo prevea la propia convocatoria. No obstante lo anterior, siempre que los órganos de selección hayan propuesto el nombramiento de igual número de aspirantes que el de plazas convocadas, y con el fin de asegurar la cobertura de las mismas, cuando se produzcan renuncias de los aspirantes seleccionados, antes de su nombramiento o toma de posesión, el órgano convocante podrá requerir del órgano de selección relación complementaria de los aspirantes que sigan a los propuestos, para su posible nombramiento como funcionarios de carrera."

${ }^{1300}$ IDELFONSO HUERTAS, Rosa María. En Lecciones de función pública. Federico A. Castillo Blanco (Director), Ana Olmedo Gaya (Coordinadora), Cemci, Granada, 2002, p. 233.
} 
En verdad, la publicación del resultado del concurso público impone la divulgación de las calificaciones no sólo de aquellos que hayan obtenido éxito en las pruebas, sino de todos aquellos que hayan participado de la competición.

Con la divulgación en el diario oficial de la lista de los aprobados, se entiende que el concurso público fue homologado, acto que debe ser realizado por la autoridad competente (según la legislación del ente federativo que conduce la selección), siempre que no haya circunstancias que impogan la invalidación del procedimiento administrativo.

El acto de homologación del concurso público posee gran relevancia, ya que es a partir de su fecha que se empieza el transcurso del plazo de validez del concurso público, que, según el art. 37, III, de la Constitución Federal, es de hasta dos años, prorrogable una vez por igual periodo ${ }^{1301}$.

Solamente durante el plazo de validez del concurso público podrá la Administración Pública realizar los nombramientos de los candidatos aprobados, y además, durante el referido plazo, tales candidatos tendrán prioridad sobre los que sean aprobados en concursos posteriores. ${ }^{1302}$

En los concursos públicos brasileños, siempre ha habido una cierta duda respecto al significado de los términos "aprobado" y "clasificado", que son dos condiciones distintas de los candidatos que hayan superado las calificaciones mínimas exigidas en el proceso selectivo.

En general, se suele sostener que el candidato es clasificado cuando supera el mínimo exigido ${ }^{1303}$, mientras es aprobado cuando su clasificación le sitúa entre los

\footnotetext{
1301 “Art. 37. III - o prazo de validade do concurso público será de até dois anos, prorrogável uma vez, por igual período"

1302 Sobre tal circunstancia, cabe añadir que: "Os concursos públicos terão validade de até dois anos, prorrogáveis uma vez, por igual período (art. 37, III), isto é, por tempo igual ao que lhes seja originariamente consignado (art. 37, IV). No interior de tal prazo os aprovados terão precedência para nomeação sobre novos concursados (art. 37, IV). Como conseqüência desta prioridade, a Administração só com eles poderá preencher as vagas existentes dentre de seu período de validade, quer já existissem quando da abertura do certame, quer ocorridas depois" (BANDEIRA DE MELLO, Celso Antônio. Op.cit., pp. 258-259).

${ }^{1303}$ Esto "mínimo exigido" puede ser previsto en forma de calificación o de clasificación, o de las dos forma a la vez. En este sentido, el Decreto Federal 6944/2009 ha establecido en el art. $12 \S 6^{\circ}$ que:" $E$ admitido, observados os critérios estabelecidos no edital de abertura do concurso, o condicionamento da aprovação em determinada etapa à, simultaneamente, obtenção de nota mínima e obtenção de classificação mínima na etapa.”
} 
que serán convocados, según el número de plazas ofertadas en el concurso público. Así, todo candidato aprobado hay de estar clasificado, pero ni todos los candidatos clasificados están aprobados. ${ }^{1304}$

Dos cuestiones polémicas del derecho brasileño que serán tratadas en el apartado sobre el nombramiento de los aprobados, y que tienen muchas repercusiones en la igualdad, tratan de la posibilidad o no de realización de concurso público aunque no existan plazas ofertadas inicialmente (concurso para formación de cadastro de reserva) y de la existencia de discrecionariedad para la Administración Pública efectuar o no los citados nombramientos.

\subsection{7 - Aportación de documentos}

En el derecho español, una vez publicada la relación de aprobados, estos serán convocados por la Administración Pública para que aporten los documentos comprobatorios del cumplimiento de los requisitos de participación en el proceso selectivo, conforme previsión de las bases de la convocatoria.

Como ya se ha visto, la presentación de instancias no es el momento de aportación de documentos, sino que esto se realiza tras la celebración de las pruebas y divulgación de los resultados del proceso selectivo.

En primer lugar, para que se garantice la igualdad de trato entre los aspirantes, se impone que la Administración Pública respete el plazo previsto en el ordenamiento jurídico español para la aportación de los sobredichos documentos (20 días naturales tras la publicación de la lista de aprobados en el diario oficial).

Sin embargo, la exigencia de mayor relevancia trata sobre la verificación del cumplimiento de las exigencias de las bases de la convocatoria, debido a que en esta

\footnotetext{
${ }^{1304}$ Sin embargo, en el derecho brasileño, como regla general, hay la posibilidad del candidato que, en el momento inicial estaba solamente clasificado, ser convocado posteriormente por la Administración Pública, como es lo que pasa cuando los candidatos aprobados renuncian al nombramiento o cuando surgen nuevas plazas vacantes. No obstante, tal posibilidad ha cambiado en el ámbito de la Unión, ya que el Decreto Federal 6944/2009 ha definido en el art. 16, § $1^{\circ}$, que: "Os candidatos não classificados no número máximo de aprovados de que trata o Anexo II, ainda que tenham atingido nota mínima, estarão automaticamente reprovados no concurso público". El citado decreto establece, en el anexo II, que según el número de plazas ofertadas, serán considerados aprobados una determinada cuantidad de clasificados (por ejemplo, si hay 5 plazas, la cuantidad máxima de aprobados es 22). En este caso, solamente podrán ser convocados (sea en un momento inicial o posteriormente) los candidatos considerados aprobados, aunque en el caso de que el candidato no esté situado dentro del número de plazas ofertadas.
} 
oportunidad, el aspirante puede ser indebidamente perjudicado por la Administración Pública, cuando esta alegue que aquel no cumplió los requisitos, sea porque no aportó determinado documento, o porque lo aportado no atiende a las exigencias de las bases de la convocatoria.

La mencionada circunstancia tiene gran repercusión en la condición del aspirante, puesto que impedirá su nombramiento, pues "en caso de no presentarse los documentos en dicho plazo no podrá realizarse el preceptivo nombramiento sin perjuicio de las responsabilidades penales en que eventualmente se incurra por falsedad en la instancia." 1305

Cabe resaltar que la actividad de verificación del cumplimiento de los requisitos de participación debe ser pautada en los principios de razonabilidad y proporcionalidad, para que no se cometan abusos e injusticias. Sin embargo, nunca debe ser olvidado el carácter competitivo del proceso selectivo, especialmente cuando la exclusión de determinado aspirante favorecerá a otro.

En este sentido, el Tribunal Supremo de España entiende que: "de no presentarse la documentación en plazo o si presentada, el aspirante no reúne los requisitos exigidos, su actuación será nula y el nombramiento debe recaer en el que siga en puntuación",1306

En el contexto brasileño, el momento previsto para la aportación de los documentos suele ocurrir cuando la Administración Pública realiza los nombramientos de los candidatos aprobados ${ }^{1307}$. Lo que sucede es que los referidos documentos comprueban la tenencia de los requisitos para acceso a la función pública.

Por esta razón, tras los respectivos nombramientos y antes que los candidatos tomen posesión en sus cargos, los candidatos deberán aportar los documentos exigidos en el edital del concurso público.

\footnotetext{
${ }^{1305}$ CASTILLO BLANCO, Federico A. Op.cit., p. 147.

${ }^{1306}$ STS de 07 de febrero de 1991.

${ }^{1307}$ Como ya se ha visto, durante la presentación de las solicitudes de participación de los candidatos, ellos también suelen aportar algunos documentos, como carnet de identidad, autorización para que que tercera persona pueda hacer presentar la solicitud, comprobante del pago de la tasa de inscripción, etc.. Sin embargo, tan solo por ocasión de la toma de posesión del funcionario es que deben exigidos los requisitos de acceso a la función pública.
} 
Como se puede percibir, la sistematica prevista en el derecho brasileño es distinta de la contemplada en el sistema jurídico español, donde los candidatos aportan su documentación antes de sus nombramientos.

Sin embargo, el en análisis de los documentos aportados, también deberán ser tomadas las mismas cautelas que ya se han destacado, especialmente en lo que se refiere a la utilización de los principios de razonabilidad y proporcionalidad, que deberán ser apreciados en armonía con el principio de la competitividad.

Sobre la aportación de los documentos, otra exigencia acentuada por la doctrina brasileña es el deber de motivación, especialmente cuando el acto de la Administración Pública genera perjuicios al candidato. Sobre esto, se ha dicho que:

\footnotetext{
"Em caso de indeferimento do pedido de inscrição, assim como em qualquer ato administrativo, a autoridade deve demonstrar os motivos que justificaram a exclusão do candidato. Nesse sentido é a orientação do Supremo Tribunal Federal que, para consolidar a posição, editou a Súmula $\mathrm{n}^{\circ}$ 684, a qual plasma: "É inconstitucional o veto não motivado à participação de candidato em concurso público." 1308
}

\subsection{8 - Período de prácticas y cursos selectivos}

Antes de la realización de los nombramientos de los aspirantes aprobados, el ordenamiento jurídico español prevé la posibilidad de la previsión en las bases de la convocatoria de periodo de prácticas y de cursos selectivos.

Sobre los referidos instrumentos, estos, si son utilizados, permitirían que los aspirantes pudieran acceder a la función pública en condiciones de actuar, inmediatamente tras sus nombramientos, de forma adecuada, pues tendrían la oportunidad de tener previo contacto con las actividades administrativas.

Sin embargo, la doctrina española enfatiza su poco manejo, y cuando son utilizados, estos tienen poca importancia en la selección. Así, añade que "sería necesario realizar una reflexión profunda con relación a estos instrumentos, dado que, a nuestro

${ }^{1308}$ MARINELA DE SANTOS SOUZA, Fernanda. Op. 197. 
juicio, los mismos podrían desarrollar un papel fundamental en la necesaria renovación de los procesos selectivos",1309

También conviene subrayar que, en el contexto del derecho español, "la principal diferencia entre curso selectivo y periodo de prácticas es que en el primero la no superación del mismo acarrea que se pierda el derecho al nombramiento como funcionario de carrera, mientras que el periodo de prácticas es un trámite más a completar pero sin naturaleza selectiva."

A su vez, también se ha afirmado que "los aspirantes que no superen el curso selectivo de acuerdo con el procedimiento de calificación del mismo perderán el derecho a ser nombrados como funcionarios de carrera". ${ }^{1311}$

Como se puede verificar, en el contexto analizado en este trabajo, los cursos selectivos ejercen un papel más relevante que los períodos de práctica, ya que aquellos pueden influir de forma más decisiva en el derecho del ciudadano a acceder a la función pública en condiciones de igualdad.

Así, conviene que las bases de la convocatoria establezcan de forma detallada las condiciones que deberán caracterizar el curso selectivo, especialmente para que este no sea utilizado como instrumento de exclusión indebida de determinados aspirantes.

Si en el derecho español los cursos selectivos y los períodos de prácticas son poco utilizados, lo mismo se puede afirmar respecto al manejo de los citados institutos en los concursos públicos brasileños.

Respecto a la capacitación del funcionario público, la misma suele ser realizada tras la toma de posesión. Al menos, el hecho de que la propia Constitución haya establecido que la estabilidad solamente será concedida tras tres años de efectivo ejercicio del cargo (art. 41), hizo con que los estatutos de empleo público de los entes federativos hayan previsto la figura del estagio probatório, "durante o qual a sua aptidão e capacidade serão objeto de avaliação para o desempenho do cargo", según redacción del art. 20 del Estatuto federal (Ley 8.112/90).

\footnotetext{
${ }^{1309}$ FONDEVILA ANTOLÍN, Jorge. Op.cit., p. 157.

${ }^{1310}$ ILDEFONSO HUERTAS, Rosa María. Op.cit., p. 365.

${ }^{1311}$ MAURI BAJÓS, Joan. Op.cit., p. 338.
} 
En los pocos casos en los cuales son utilizados los expedientes de los cursos selectivos, es más usual la previsión de cursos de formación, que constituyen una etapa del concurso público en la cual se mezclan las finalidades formativa y selectiva, a partir de la instrucción de las tareas propias del cargo que será cubierto y de la verificación de su aprendizaje por los candidatos, respectivamente.

Sobre tal etapa del concurso público (que recibe denominaciones distintas), se ha destacado que:

\begin{abstract}
"Prova de estágio de avaliação é a modalidade de concurso de prova recentemente implantada por algumas administrações pública e que visa aferir, ainda na constância do concurso, se o candidato tem condições técnicas e pessoais para exercer o cargo pretendido. Em verdade, é uma antecipação daquilo que deveria se fazer no estágio probatório, ou naquele período pós-concurso, mas que historicamente não tem muita eficiência."1312
\end{abstract}

Respecto al citado método selectivo, también llamado de "estágio experimental $^{1313}$,, la doctrina brasileña ya subraya que hay editales que establecen:

\footnotetext{
1312 PACHECO BARROS, Wellington. Op.cit., p. 25.

${ }^{1313}$ En el Estado de Rio de Janeiro, hay el Decreto-Ley Estadual 220/1975, que prevé la figura del estágio experimental, en los siguientes términos: “Art. $2^{\circ}$. $\$ 2^{\circ}$ - O candidato habilitado nas provas e no exame de sanidade físico-mental será submetido a estágio experimental, mediante ato de designação do Secretário de Estado, titular de órgão integrante da Governadoria do Estado, ou dirigente de autarquia e pelo prazo que for estabelecido, em cada caso, pelo Órgão Central do Sistema de Pessoal Civil do Estado.

$\S 3^{\circ}$ - A designação prevista no parágrafo anterior observará a ordem de classificação nas provas e o limite das vagas a serem preenchidas, percebendo o estagiário retribuição correspondente a $80 \%$ (oitenta por cento) do vencimento do cargo, assegurada a diferença, se nomeado afinal.

$\S 4^{\circ}$ - O prazo de validade das provas será fixado nas instruções reguladoras do concurso, aprovadas pelo Órgão Central do Sistema de Pessoal Civil do Estado e poderá ser prorrogado, uma vez, por período não excedente a 12 (doze) meses.

$\S 5^{\circ}$ - $O$ candidato que, ao ser designado para o estágio experimental, for ocupante, em caráter efetivo, de cargo ou emprego em órgão da Administração Estadual direta ou autárquica ficará dele afastado com a perda do vencimento ou salário e vantagens, observado o disposto no inciso IV do art. 20 e ressalvado o salário-família, continuando filiado à mesma instituição de previdência, sem alteração da base de contribuição.

$\S 6^{\circ}$ - $O$ candidato não aprovado no estágio experimental será considerado inabilitado no concurso e voltará automaticamente ao cargo ou emprego de que se tenha afastado, na hipótese do parágrafo anterior.

$\S 7^{\circ}$ - O candidato aprovado permanecerá na situação de estagiário até a data da publicação do ato de nomeação, considerada a mesma data, para, todos os efeitos, início do exercício do cargo ressalvado o disposto no parágrafo terceiro antecedente e no artigo seguinte".
} 
"como etapa do concurso, um período de exercício antecipado das funções do cargo, denominado estágio experimental. Esse estágio tem a natureza jurídica de prova de habilitação, a mesma, aliás, das demais provas de conhecimento, e, como é óbvio, antecede à nomeação. $\mathrm{O}$ estagiário, assim, ainda não é servidor, mas mero candidato em fase de concurso. Em tais sistemas, parece-nos legítimo exigir do candidato que preencha os requisitos do cargo ao momento da designação para o estágio, e não ao momento da futura nomeação, e isso porque, embora ainda não ocupe cargo, o candidato já vai exercer as funções a ele relativas." $" 1314$

Como se puede percibir, los cursos de formación que suelen ser manejados por las Administraciones Públicas brasileñas pueden hacer con que los candidatos (aún tienen esta condición) sean excluidos del proceso selectivo. En este contexto, "a jurisprudência tem entendido que, na maioria dos casos, tais cursos constituem um prérequisito para nomeação, que depende da aprovação e da classificação no curso de formação profissional.",1315

También hay que ser destacada (y elogiada) la existencia del curso superior (licenciatura) de Administración Pública ofertado por la Escuela de Gobierno Profesor Paulo Neves de Carvalho, del Estado de Minas Gerais, que permite que los que hacen la referida carrera puedan acceder a la función pública, siempre que reúnan los requisitos legales para ingreso. ${ }^{1316}$

Conviene destacar que el proceso selectivo, en este caso, ya empieza cuando es realizada la prueba de selectividad (vestibular, en portugués) y continua durante la realización del citado curso. Seguramente, al final serán nombradas personas que hayan tenido la oportunidad de conocer íntimamente los temas más relevantes de las actividades administrativas, lo que será muy relevante para el desempeño del cargo.

\footnotetext{
${ }^{1314}$ SANTOS CARVALHO FILHO, José dos. Op.cit., p. 558.

1315 TOURINHO, Rita. Op.cit., p. 92.

1316 Según información extraída el sitio electrónico de la Escola de Governo Professor Paulo Neves de Carvalho (http://eg.fjp.mg.gov.br/index.php/cursos/curso-superior-de-administracao-publica/beneficios), accesado en 29 de junio de 2010: "O Curso de Administração Pública oferecido pela EG é gratuito e os candidatos aprovados recebem bolsa de estudos no valor de um salário mínimo. Nos casos de servidores públicos civis estaduais do poder executivo de Minas Gerais, há a possibilidade de dispensa de ponto durante o período letivo, a critério do órgão de origem. Após a conclusão do Curso, caso o aluno atenda a todos os requisitos previstos na Lei Estadual 15.304/2004, será nomeado para ingresso na carreira de Especialista em Políticas Públicas e Gestão Governamental"
} 
En este trabajo, se sostiene que la utilización de cursos de formación y períodos de prácticas en los concursos públicos, no sólo garantiza una evaluación más completa de la capacidad de los candidatos, sino también permite el ingreso de personas más aptas a la función pública.

El gran reto, en este caso, es el manejo de las referidas medidas a partir de criterios objetivos claramente definidos en ley, y sin que sea olvidado que, durante los citados períodos, aún permanece la exigencia de respecto a la igualdad de trato en el acceso y a los principios que provienen del carácter competitivo del proceso selectivo.

\subsection{9 - Nombramiento y toma de posesión}

Ápice del proceso selectivo, el acto de nombramiento (y la consecuente toma de posesión) hace que el aspirante pase a integrar las plantillas de la Administración Pública.

En el contexto de este trabajo, la primera y más relevante cuestión dice respecto al análisis de la posibilidad o no de la Administración Pública realizar el acto de nombramiento de forma discrecional.

Respecto a la citada cuestión, conviene subrayar que en el derecho español, los aspirantes, una vez aprobados, deberán ser nombrados, sin que haya la posibilidad de decisión discrecional respecto a tal acto.

De la misma forma, no podrá la Administración Pública impedir la adjudicación del puesto de trabajo a aquel que fue nombrado. Así, tanto hay el derecho al nombramiento, como se puede afirmar que la toma de posesión es un derecho del aspirante que fue válidamente nombrado.

El citado derecho del candidato al nombramiento tras la aprobación en el proceso selectivo es algo que parece absolutamente coherente, y así lo es tratado en el derecho español, tanto que no se ha encontrado cualquier polémica respecto a esta circunstancia en la doctrina del mencionado país europeo. 
No obstante, como se verá a continuación, en el sistema jurídico brasileño, es muy intenso el debate sobre la existencia o no del derecho del aspirante aprobado en el concurso público exigir de la Administración Pública su nombramiento. ${ }^{1317}$

Antes de este análisis, conviene destacar que en Brasil, también causa mucha polémica la realización de concursos público para formación de catastro de reserva. En tal modalidad de proceso selectivo, no es ofertada una determinada cuantidad de plazas, sino la posibilidad de que el candidato pueda ser nombrado, siempre que surja alguna plaza tras la apertura del concurso público ${ }^{1318}$.

En el ámbito federal, la Unión ha definido en el Decreto 6.944, de 21 de agosto de 2009, que la realización de concurso para catastro de reserva sólo puede ser realizada de forma excepcional ${ }^{1319}$, medida que debe ser aplaudida, ya que toda la movimentación del aparato administrativo para la ejecución de un proceso selectivo,

${ }^{1317}$ Sobre tal debate: "Entre os doutrinadores, o assunto é igualmente polêmico. Ante a ausência de previsão constitucional expressa, a doutrina também é antagonicamente dividida acerca da matéria, travando-se intenso debate sobre a questão. Defendendo o posicionamento tradicional já esposado, autores como o eminente Hely Lopes Meirelles, José dos Santos Carvalho Filho, Diógenes Gasparini, José Maria Pinheiro Madeira e outros, ao argumento de que o ato de nomeação subordina-se à análise meritória de conveniência e oportunidade da Administração, sustentam que a prática de tal ato de provimento originário fica à inteira discrição do Poder Público, não gerando ao candidato qualquer direito subjetivo à nomeação a classificação dentro do quadro de vagas anunciado pelo ente promotor do concurso público. (...) Por outro lado, oxigenando o entendimento doutrinário e jurisprudencial dominante, a doutrina mais moderna vem adotando posicionamento diferenciado em relação ao tema discutido. Evocando os princípios da moralidade administrativa e da finalidade, sustenta essa corrente haver o dever jurídico da Administração de nomear os candidatos aprovados dentro do número das vagas publicadas no edital.(...). Tem-se como defensores dessa corrente os distintos juristas Marçal Justen Filho, Cármen Lúcia Antunes Rocha, Márcio Barbosa Maia, Ronaldo Pinheiro de Queiroz, Fabrício Motta, dentre outros." (ALVES DIAS, Fábio Henrique. Concurso público: uma vinculação recíproca. $O$ direito subjetivo à nomeação de candidatos aprovados em concurso público. Texto extraído del sitio electrónio Jus Navigandi (http://jusvi.com/artigos/36202), publicado en 19 de septiembre de 2008 , con acceso en 30 de junio de 2010).

${ }^{1318}$ Según la Asesoria del Ministerio del Planeamiento brasileño, "a formação de cadastro de reserva é útil para a administração pública, pois permite que as vagas que venham a surgir em função de aposentadorias, pedidos de exoneração ou falecimentos, por exemplo, sejam ocupadas de forma ágil. $O$ importante é que no edital esteja explícito que o concurso é para a formação de cadastro, pois assim nenhum candidato poderá alegar que foi enganado. A assessoria do ministério frisa ainda que o fato de ter sido classificado em um cadastro de reserva não dá ao candidato o direito ao cargo. A classificação gera apenas uma "expectativa de direito". Por isso, nesse tipo de concurso, é importante conseguir uma boa classificação, aumentando as chances de nomeação quando surgirem vagas". (Información extraída del reportaje Em ano eleitoral, concursos para formação de cadastro de reserva voltam a gerar polêmica, redactado por Ione Luques, publicada en 23 de marzo de 2010 en el sítio electrónico Globo.com (http://oglobo.globo.com/economia/boachance/mat/2010/03/22/em-ano-eleitoral-concursospara-formacao-de-cadastro-de-reserva-voltam-gerar-polemica-916140853.asp), acceso en 30 de junio de 2010.

1319 “Art.12. Excepcionalmente o Ministro de Estado do Planejamento, Orçamento e Gestão poderá autorizar a realização de concurso público para formação de cadastro reserva para provimento futuro, de acordo com a necessidade, de cargos efetivos destinados a atividades de natureza administrativa, ou de apoio técnico ou operacional dos planos de cargos e carreiras do Poder Executivo federal'. 
además del esfuerzo de los candidatos, tienen como justificación la necesidad de cubertura de plazas existentes.

En estos términos, aquí se sostiene que el hecho de que haya plazas disponibles impone que el concurso público que sea abierto sea para cubertura de las referidas plazas, y no para la formación de catastro de reserva. Tal instituto, además de su carácter excepcional, debe ser utilizado de forma motivada, a partir de la exposición de las circunstancias que justifican su manejo.

Como explicación, conviene destacar que el uso del expediente del concurso público para catastro de reserva se ha intensificado en Brasil tras las primeras decisiones judiciales que dejaron de considerar que la aprobación en el proceso selectivo genera el derecho del candidato al nombramiento.

Con este nuevo entendimiento, la Administración Pública, que estaba habituada a la posibilidad de decidir de forma discrecional si el nombramiento sucedería o no ${ }^{1320}$, a partir de ahora empezó a hacer uso, de forma indebida, de la figura del catastro de reserva, lo que le permitiría continuar ejerciendo su potestad respecto a la conveniencia o no del nombramiento de los candidatos aprobados.

Como ya se ha subrayado, como todo este panorama proviene del cambio de entendimiento respecto a la existencia de derecho del aspirante aprobado al nombramiento, se impone la exposición del referido debate. ${ }^{1321}$

\footnotetext{
${ }^{1320}$ Hasta hoy en día se considera que la potestad discrecional de la Administración Pública incluye la posibilidad de decisión si habrá o no la prorrogación del plazo de validez del concurso público, aunque existan candidatos aprobados aún no nombrados. En este sentido: "ainda no que diz respeito ao ingresso, o artigo 37, inciso III, fixa o prazo de validade de dois anos para validade do concurso, prorrogável uma vez, por igual período; a prorrogação fica a critério da Administração, inexistindo, para os candidatos aprovados, direito subjetivo a essa prorrogação." (ZANELLA DI PIETRO, Maria Sylvia. Op.cit., p. 499).

${ }^{1321}$ Para explicar este debate, conviene acentuar que: "O tema é extremamente controverso. A partir de definições antagônicas acerca da natureza jurídica do ato administrativo que dá provimento ao cargo público, a doutrina mais encorpada divide-se basicamente em duas vertentes: a primeira entende ser o ato discricionário, condicionando o provimento dos cargos públicos ao talante do respectivo ente administrativo que promoveu a sua criação, ao passo que a segunda, insurgindo-se contra esta visão tradicional, defende que as normas editalícias publicadas no instrumento próprio vinculam tanto o candidato como a Administração" (ALVES DIAS, Fábio Henrique. Concurso público: uma vinculação recíproca. $O$ direito subjetivo à nomeação de candidatos aprovados em concurso público. Texto extraído del sitio electrónico Jus Navigandi (http://jusvi.com/artigos/36202), publicado en 19 de septiembre de 2008, con acceso en 30 de junio de 2010).
} 
Durante muchos años, se sostenía que los candidatos aprobados en el concurso público no tenían derecho al nombramiento ${ }^{1322}$, sino una expectativa de que esto pudiera suceder, dependiendo de la discrecionalidad administrativa.

En este momento histórico, el derecho al nombramiento solamente existía cuando la Administración Pública no respectaba el orden de clasificación ${ }^{1323}$, y, tras una cierta evolución doctrinaria y jurisprudencia, en un segundo momento, cuando cubría las plazas reservadas a los funcionarios de carrera a través de expedientes ilícitos ${ }^{1324}$, como la tercerización, los contratos temporarios o los cargos de libre designación.

Las referidas hipótesis han sido resumidas por la doctrina brasileña en los siguientes términos:

"A jurisprudência majoritária dos tribunais brasileiros reconhece tranquilamente ao candidato, em duas hipóteses, o direito subjetivo à nomeação. A primeira hipótese representa orientação pacífica na doutrina e na jurisprudência e ocorre quando o candidato é preterido na ordem de classificação, conforme estabelecido na Súmula $n^{\circ} 15$ do STF que preceitua: "Dentro do prazo de validade do concurso, o candidato aprovado tem o direito a nomeação, quando o cargo for preenchido sem observância da classificação.” Também já se reconheceu direito à nomeação na hipótese em que a Administração demonstra a necessidade do preenchimento de vagas, nomeando candidatos de concurso posterior quando ainda não exaurido o prazo

\footnotetext{
${ }^{1322}$ Así, se puede afirmar que: "Por muito tempo a doutrina e a jurisprudência dos tribunais superiores, alheias à evolução do Estado de Direito, vêm repetindo que os candidatos aprovados em concurso público detêm apenas mera expectativa de direito à nomeação. Assim sendo, realizado o concurso público, não estaria a Administração Pública obrigada a convocar os aprovados, cabendo-lhe uma análise quanto à conveniência e oportunidade de tal convocação. Logo, considerando-se este entendimento, ou seja, que o ato de nomeação é uma liberalidade da Administração Pública, mesmo os aprovados dentro do número de vagas oferecidas no edital, ficam sem qualquer garantia ao ingresso no serviço público”. (TOURINHO, Rita. Op.cit., pp. 94-95).

${ }^{1323}$ En este sentido: "A jurisprudência já definiu que, dentro do prazo de validade do concurso, o candidato tem direito subjetivo à nomeação, caso seja preterido na ordem de classificação. do concurso." (SANTOS CARVALHO FILHO, José dos. Op.cit., p. 547).

${ }^{1324}$ En este contexto: “a aprovação em concurso não cria, para o aprovado, direito à nomeação. Tratase, como já decidido pelo STF, de mera expectativa de direito. (...) Não obstante, se o candidato é aprovado no concurso e há omissão ou recusa para a nomeação, apesar de ficar comprovado que a Administração, certamente por incompetência ou improbidade, providenciou o recrutamento através de contratação precária para exercer as mesmas funções do cargo para o qual o candidato foi aprovado, passa este a ter direito subjetivo ao ato de nomeação. Tal direito subjetivo tem fundamento na constatação de que a Administração tem necessidade da função e, por conseguinte, do servidor para exercê-la, não podendo suprir essa necessidade por contratação precária se há aprovados em concurso para supri-la." (SANTOS CARVALHO FILHO, José dos. Idem, p. 546).
} 
de validade de concurso anterior, caracterizando preterição (...) A segunda hipótese ocorre nas situações em que, tendo a Administração realizado o concurso, durante o seu prazo de validade, não nomeie os candidatos aprovados, suprindo as suas necessidades por meio de vínculos precários. Nesses casos, a Administração reconhece que precisa daquele servidor e que tem totais condições de arcar com as despesas, não existindo assim justificativa para contratar estranhos ao concurso e não nomear os candidatos aprovados no certame."1325

Otra situación que exigía el nombramiento de los candidatos aprobados ocuría cuando la Administración Pública nombraba inicialmente aquellos aspirantes que habían sido aprobados en concurso posteriormente abierto. ${ }^{1326}$

Como se puede percibir, la teoría hasta entonces admitida no reconocía que el candidato aprobado pudiera exigir que la Administración Pública le nombrara ${ }^{1327}$, circunstancia que fragilizaba la situación jurídica del ciudadano, ya que había la posibilidad de que circunstancias políticas influenciaran la decisión administrativa, como, por ejemplo, la circunstancia del aprobado pertenecer a otro grupo partidario.

\footnotetext{
${ }^{1325}$ MARINELA DE SANTOS SOUZA, Fernanda. Op.cit., pp. 207-208.

${ }^{1326}$ En esta línea de pensamiento: "É certo, outrossim, que não poderá deixá-lo escoar simplesmente como meio de se evadir ao comando de tal regra, nomeando em seguida os aprovados no concurso sucessivo, que isto seria um desvio de poder. Com efeito, se fosse possivel agir deste modo, a garantia do inciso IV não valeria de nada, sendo o mesmo que uma "letra morta". Na legislação federal, por força do artigo 12, $\$ 2^{\circ}$, da Lei 8.112 (que dispõe sobre o regime jurídico dos servidores civis da União, suas autarquias e fundações federais), "não se abrirá novo concurso enquanto houver candidato aprovado em concurso anterior com prazo de validade não expirado."” (BANDEIRA DE MELLO, Celso Antônio. Op.cit., pp. 258-259).

${ }^{1327}$ La referida teoría tenía la siguiente argumentación: "Por muito tempo, desenvolveu-se no direito pátrio a sólida doutrina que defende a inexistência de direito subjetivo do candidato aprovado em concurso público à respectiva nomeação, refletindo esse entendimento nas decisões proferidas pelas cortes mais altas do país, em especial o Supremo Tribunal Federal, que sumulou a matéria sob o verbete de $\mathrm{n}^{\circ}$ 15. Aprovada em 1963, sob a égide da Constituição Federal de 1946, à súmula 15, como toda jurisprudência e legislação pré-constitucional, reconhece-se a necessidade de um reexame à luz do que dispõem os princípios constitucionais estatuídos pela Carta de 1988. Nessa orientação sumular, o Pretório Excelso, ao declarar expressamente que o candidato aprovado em concurso público só teria direito subjetivo à nomeação se o Estado violasse a ordem classificatória do certame em desfavor do candidato preterido, tornou tal candidato, em caso de não preterição, detentor de mera expectativa de direito à sua convocação, não gerando a aprovação, por conseguinte, ainda que dentro do quadro de vagas ofertadas pelo edital, direito subjetivo à respectiva nomeação ao cargo para o qual fora aprovado. Assim, rejeitou-se a tese que sustenta o direito subjetivo à nomeação em prestígio à que se baseia na premissa de que o ato de nomeação se encerra no exercício discricionário da atividade estatal, submetendo-se a expectativa do candidato ao juízo de conveniência e oportunidade da Administração." ((ALVES DIAS, Fábio Henrique. Concurso público: uma vinculação recíproca. O direito subjetivo à nomeação de candidatos aprovados em concurso público. Texto extraído del sitio electrónico Jus Navigandi (http://jusvi.com/artigos/36202), publicado en 19 de septiembre de 2008, con acceso en 30 de junio de 2010).
} 
La admisión de la referida teoría, en la realidad administrativa brasileña, hizo con que muchos concursos públicos hayan sido abiertos con la finalidad de arecaudación de recursos.

En otros casos, la Administración Pública realizaba el concurso público, y, solamente después que sabía quiénes habían sido los aprobados, decidía de forma arbitrária si iba o no realizar los nombramientos.

Además, debe ser añadido el relevante hecho de que miles de candidatos se sentían desalentados, ya que sus esfuerzos, aunque inmensos, no eran suficientes para les garantizar la realización de sus proyectos de vida. ${ }^{1328}$.

Debido a todas las circunstancias apuntadas, la doctrina, y después la jurisprudencia $^{1329}$, empezaron a cambiar sus puntos de vista, admitiendo que los

${ }^{1328}$ La doctrina ya denunciaba que: "Durante muito tempo em nosso País, a doutrina e a jurisprudência firmaram o entendimento de que a aprovação em concurso público gerava mera expectativa de direito a nomeação. Somente quando violada a ordem de classificação, o candidato poderia ter direito perante o Judiciário. Levado ao extremo, esse entendimento permitiu a ocorrência de situações esdrúxulas como a de candidatos que, após intensa dedicação, obtinham a aprovação dentro do número das vagas oferecidas e amargavam o dissabor de ver expirar-se o prazo de validade de um concurso sem nomeação" (JACOBY FERNANDES, Jorge Ulisses. Concurso público e os direitos dos candidatos. Texto extraído del sitio Jus Navigandi (http://jus2.uol.com.br/doutrina/texto.asp?id=389), con acceso en 30 de junio de 2010).

1329 Sobre tal hecho: "Após o julgamento do RE $n^{\circ}$ 192568-0-PI, DJU de 13.09.96, pelo Supremo Tribunal Federal é possível reconhecer o dever da Administração Pública de nomear os candidatos aprovados para as vagas disponíveis ou oferecidas no edital. O voto lúcido do Ministro-relator, Marco Aurélio, acompanhado dos Ministros Maurício Correa e Francisco Rezek, teve a ementa redigida nos seguintes termos: "CONCURSO PÚBLICO - EDITAL - PARÂMETROS - OBSERVAÇÃO. As cláusulas constantes do edital de concurso obrigam candidatos e Administração Pública. Na feliz dicção de Hely Lopes Meirelles, o edital é lei interna da concorrência. CONCURSO PÚBLICO - VAGAS NOMEAÇÃO. O princípio da razoabilidade é conducente a presumir-se, como objeto do concurso, o preenchimento das vagas existentes. Exsurge configurador de desvio de poder ato da Administração Pública que implique nomeação parcial de candidatos, indferimento da prorrogação do prazo do concurso sem justificativa socialmente aceitável e publicação de novo edital com idêntica finalidade. "... Como o inciso IV (do artigo 37 da Constituição Federal) tem o objetivo manifesto de resguardar precedências na seqüência dos concursos, segue-se que a Administração não poderá, sem burlar o dispositivo e sem incorrer em desvio de poder, deixar escoar deliberadamente o período de validade do período de concurso anterior para nomear os aprovados em certames subsequentes. Fora isto possível e o inciso IV tornar-se-ía letra morta, constituindo-se na mais rúptil das garantias" Na mesma linha de entendimento tem se pronunciado o Superior Tribunal de Justiça em outros casos, parecendo firme a iniciativa de tutelar o direito dos candidatos aprovados. Se a Administração oferece no edital determinado número de vagas é evidente que os candidatos aprovados no limite tem efetivamente direito a nomeação. Se, contudo, não foi fixado o número de vagas cuja ocupação se pretende, - o que em princípio não nos parece correto, - é razoável presumir-se que o concurso se destina as vagas existentes $e$ as que vierem a ocorrer no período de validade do concurso. A não nomeação nessas condições viola direito líquido e certo do cidadão-candidato, passível de ser contrastado não só perante o Judiciário, mas também junto aos Tribunais de Contas." (JACOBY FERNANDES, Jorge Ulisses. Concurso público $e$ os direitos dos candidatos. Texto extraído del sitio electrónico Jus Navigandi (http://jus2.uol.com.br/doutrina/texto.asp?id=389), con acceso en 30 de junio de 2010). 
candidatos aprobados (aquellos cuya califación les situa en una clasificación entre las plazas ofertadas) tienen el derecho al nombramiento ${ }^{1330}$.

La doctrina brasileña pasó a destacar que los principios constitucionales que deben caracterizar la actuación administrativa, como la igualdad, la legalidad, la impersonalidad, la moralidad y la eficacia, además de otros que les son correlatos (lealtad, vinculación a las bases de la convocatoria, transparencia, etc.) imponen que los candidatos aprobados no tengan su derecho de acceso a la función pública en condiciones de igualdad transgredido, circunstancia que pasaba cuando mientras era adoptada la teoría anterior. En este sentido:

"O entendimento doutrinário e jurisprudencial evoluiu para essa nova interpretação, a qual é adequada aos preceitos constitucionais que exigem que a Administração Pública seja séria e responsável. Nota-se, portanto, que a tese explanada - o direito subjetivo à nomeação $\mathrm{e}$ posse dos concursados aprovados dentro do limite das vagas abertas pelo edital - encontrou guarida na doutrina e na jurisprudência dos Tribunais Superiores (STF e STJ). Exige-se seriedade da Administração Pública quando lança um concurso público. Se ela lançou o edital com determinado número de vagas é por que essa é a sua real necessidade administrativa, a qual foi, obrigatoriamente, apurada em processo administrativo sério e transparente. É que nenhum concurso público pode ser aberto sem que exista vaga aberta para ser preenchida e necessidade de novos serviços exigindo o ingresso de mais servidores públicos Atribui-se, assim, à Administração Pública total responsabilidade quando da abertura de um concurso público. Há discricionariedade para o lançamento do referido edital. Porém, efetivada a publicação, o ente estatal fica vinculado à nomeação de todos os aprovados dentro do número de vagas disponibilizadas, ainda que já tenha decorrido o prazo de

${ }^{1330}$ Según la doctrina, esta nueva teoría, consagrada en el ámbito del Superior Tribunal de Justicia, ya ha incluso evolucionado, "pois desvinculou o direito à nomeação das vagas previstas no edital, reconhecendo que, não obstante seja “...unânime na jurisprudência o entendimento de que os aprovados em concurso público possuem mera expectativa de direito à nomeação, todavia, essa expectativa faz. nascer direito subjetivo se, dentro do prazo de validade do concurso, surgem novas vagas não previstas no edital"” (FERRAZ, Luciano. Concurso público e direito à nomeação, en Concurso público e Constituição, Fabrício Motta (Cordinador), Editora Fórum, Belo Horizonte, 2005, p. 252-253). La referida decisión del STJ es ROMS 15180/PR, 6a Turma, REL. Min.. Paulo Medina, DJ 06.10.2003, p. 328 
validade do concurso público $\mathrm{O}$ mínimo que se espera da Administração Pública, em matéria de concurso público, é que a sua ação - lançamento do edital de concurso público para seleção de cidadãos aptos à investidura nos cargos públicos - seja marcada pelos princípios da lealdade, da moralidade, da segurança jurídica e da boafé."1331

Respecto a este nuevo posicionamento de la jurisprudencia brasileña, se puede destacar que el mismo, como regla general, impone el nombramiento del candidato aprobado, siempre que su clasificación es suficiente.

Así, solamente bajo circunstancias especiales debidamente comprobadas por la Administración Pública, será admisible que el nombramiento no suceda. Sobre esta teoría, se ha subrayado que:

“o Superior Tribunal de Justiça, vem, repetidamente, através da quinta e sexta turmas, afirmando que o candidato aprovado dentro do número de vagas previstas em edital tem o direito líquido e certo de ser nomeado no cargo. (...). Cria-se então no candidato uma legítima expectativa que não pode ser frustrada pela administração, principalmente porque esta existe em função do bem estar do povo, salvo na hipótese de motivo relevante. Explique-se: se a administração pública tem motivos relevantes e indiscutíveis (comprovada falta de recursos, entre outros), poderá então se recusar em convocar os candidatos aprovados, entretanto, deverá expor tal situação a todos os interessados, de forma pública e transparente. Nesse sentido foi a decisão da $1^{a}$ turma do Supremo Tribunal Federal ao reconhecer o direito líquido e certo de candidatos aprovados dentro do número de vagas previstas em edital de concurso público. No RMS 23657/DF e mais recentemente no RE 227480, entendeu a Excelsior Tribunal que candidatos aprovados dentro do número de vagas previstas em edital têm direito de serem nomeados ou admitidos, conforme o caso. Irretocável a decisão, pois acolhe o clamor de milhares de candidatos que, prejudicados pela quase que freqüente torpeza da administração

\footnotetext{
${ }^{1331}$ TAVARES DE JESUS, Noel Antônio. O direito subjetivo à nomeação dos concursados aprovados e os limites de despesas com pessoal. Texto extraído del sitio Jus Navigandi (http://jus2.uol.com.br/doutrina/texto.asp?id=13545).
} 
pública, sofrem lesões irreparáveis em seus direitos, passando por toda a sorte de privações, muitos deles sem condições de discutir a questão no âmbito do Poder Judiciário." 1332

Sobre las citadas circunstancias especiales que autorizarían la no realizacion de acto de nombramiento de los candidatos aprobados, impone que las mismas, además de la exigencia de su justificación, hayan surgido después de la apertura del proceso selectivo, ya que cuando el concurso público fue iniciado, se supone que la Administración Pública tomó las medidas que demostraran su necesidad y legalidad. ${ }^{133}$

Entre las citadas causas, una de las que más se destaca dice respecto a la prohibición, prevista en el art. 22 de la Ley Complementar 101/2000, de la realización de gastos con la admisión de personal cuando el ente federativo ya haya superpasado el límite definido en la Ley de Responsabilidad Fiscal. ${ }^{1334}$ En esta referida situación, hay que subrayar que el carácter transitorio de la prohibición legal, lo que hace con que tan

${ }^{1332}$ BRANDÃO COSTA, Bernardo. Aprovação dentro do número de vagas: direito à nomeação? Texto extraído del sitio: http://www.pciconcursos.com.br/consultoria/aprovacao-dentro-do-numero-de-vagasdireito-a-nomeacao.

${ }^{1333}$ Lo que pasa es "Nos dias atuais, não é aceitável um padrão comportamental da Administração Pública que desprestigie a confiança, a certeza de que suas atitudes devem pautar pela máxima previsibilidade. Ao dar início às solenidades que antecedem a realização de um concurso público, constatada a existência de vagas em cargos públicos, criados por lei e em número certo, frente às previsões orçamentárias, impõe-se à Administração certificar-se da premente necessidade dos provimentos decorrentes. Assim é porque a realização de uma competição desse jaez implica em movimentação, inclusive emocional, da comunidade interessada, gerando nos candidatos aprovados, com classificação consentânea com o número de vagas, a certeza da nomeação. Alguns candidatos, como é cediço, são compelidos a romperem vínculos contratuais e empregatícios ou a substabelecerem mandatos, diante da premente investidura." (BACELLAR FILHO, Romeu Felipe. O concurso público e o processo administrativo, en Concurso público e Constituição, Fabrício Motta (Coordinador), Editora Fórum, Belo Horizonte, 2005, p. 75). Además "quando a Administração Pública decide realizar um concurso público, significa que reconheceu a necessidade de suprir cargos ou empregos públicos vagos. Assim, elabora edital prevendo o número de vagas oferecidas em razão da necessidade administrativa e da disponibilidade orçamentária. A partir da publicação do edital, havendo candidatos aprovados, deverão ser convocados para preencher as vagas oferecidas. Trata-se não de expectativa de direito do candidato, mas sim de direito subjetivo à nomeação ou contratação." (TOURINHO, Rita. Op.cit., pp. 9495).

${ }^{1334}$ Respecto a tal circunstancias, se ha destacado que "no transcorrer da execução do concurso público, as despesas com pessoal do Poder ou Órgão ficarão sujeitas às alterações, atingindo o limite prudencial, que é de 95\% (noventa e cinco por cento) do limite máximo. O aumento do percentual da despesa com pessoal em relação à receita corrente líquida pode decorrer de eventos que podem escapar da análise prévia feita pela autoridade competente, como foi o caso da crise global ocorrida no final de 2008, que ocasionou a redução drástica de receita em função da queda violenta da arrecadação decorrente da queda de consumo. Verificado que o Poder ou Órgão excedeu seu limite prudencial, as nomeações dos concursados aprovados ficarão vedadas (art. 22, da LRF), salvo a reposição de decorrente de aposentadoria ou falecimento de servidores das áreas de educação, saúde e segurança. Nestes casos, ficou assegurada a continuidade administrativa naquelas áreas, que são prioritárias para o interesse público." (TAVARES DE JESUS, Noel Antônio. O direito subjetivo à nomeação dos concursados aprovados e os limites de despesas com pessoal. Texto extraído del sitio Jus Navigandi (http://jus2.uol.com.br/doutrina/texto.asp?id=13545), con acceso en 30 de junio de 2010. 
pronto sea normalizada la cuestión financiera del ente federativo, deberán ser realizados los nombramientos. En este sentido:

"a nomeação restará vedada enquanto persistir o quadro fiscal precário. Portanto, caso a despesa com pessoal atinja o limite prudencial ou máximo, a nomeação dos concursados aprovados ficará expressamente vedada, salvo para as exceções já declinadas. Neste caso, deve-se realizar uma interpretação sistemática que viabilize a interrupção do crescimento das despesas com pessoal, para evitar o comprometimento dos orçamentos futuros e a inviabilização das novas gestões públicas. A regularidade fiscal terá prevalência sobre o direito subjetivo dos concursados à nomeação aos cargos públicos. Mas o direito à nomeação ficará obstado apenas enquanto os gastos com pessoal estiverem no limite prudencial ou máximo. Porém, se no prazo de validade do concurso público ocorrer a alteração deste quadro fiscal, a nomeação dos concursados aprovados dentro do número de vagas disponibilizados pelo edital será impositivo."1335

1335 TAVARES DE JESUS, Noel Antônio. O direito subjetivo à nomeação dos concursados aprovados e os limites de despesas com pessoal. Texto extraído del sitio Jus Navigandi (http://jus2.uol.com.br/doutrina/texto.asp?id=13545), . con acceso en 30 de junio de 2010. 


\section{CONCLUSIÓN}

Como se ha intentado demostrar de la forma más exhaustiva posible en la presente investigación, la simple previsión constitucional del derecho del ciudadano a acceder a la función pública en condiciones de igualdad, aunque se trate de uno importante corolario de la democracia y del racionalismo, está lejos de ser suficiente para garantizar su eficacia, que exige una serie de medidas posteriores a fin de que los frutos del citado derecho sean desarrollados en el ordenamiento jurídico, convertiéndole en una realidad visible.

En este trabajo, se ha realizado el análisis de dos ordenamientos jurídicos (el español y el brasileño) que han consagrado el acceso meritorio como forma prioritaria de ingreso en la función pública. Tal hecho ha permitido el cotejo de dos sistemas jurídicos que hasta hoy intentan garantizar que la selección de los funcionarios públicos sea, a la vez, igualitaria y eficaz.

Todas las páginas del presente trabajo han sido escritas con el intento de que puedan ser contestadas las siguientes indagaciones:

I - ¿En qué consisten exactamente las "condiciones de igualdad" referidas por la Constitución española (art. 23.2), como exigencia que debe caracterizar el acceso de los 
ciudadanos a la función pública?, y ¿cuál es el verdadero significado de las normas de la Constitución brasileña que declaran que la accesibilidad a los cargos y empleos públicos es universal (art. 37, I) y que la aprobación en el concurso público es el criterio definitivo para ingreso en el servicio público (art. 37, II)?;

II - En la actual configuración de los ordenamientos jurídicos y en la actuación de las Administraciones Públicas española y brasileña, ¿cuáles son los obstáculos que reducen el nivel de efectividad de la reivindicación constitucional de trato igualitario de los ciudadanos en la selección de los funcionarios?; y

III - ¿Qué se puede hacer para ampliar las garantías de acceso igualitario de los ciudadanos a las funciones públicas española y brasileña?

A partir de estos tres puntos de partida, este trabajo ha empezado a analizar el tema del acceso a la función pública, oportunidad en que inmediatamente verificó su indiscutible relevancia en el contexto de las relaciones "Administración/ciudadanos", no sólo por el interés colosal de una gran parcela de estos en las plazas ofertadas (que tanto en Brasil como en España llegan a cifras que impresionan), sino también (y principalmente) por el manifiesto vínculo entre la selección de los funcionarios públicos y la calidad de los servicios prestados a la sociedad.

Conforme se ha destacado, la primera indagación que ha motivado la elaboración del presente estudio analítico y comparativo ha sido la averiguación del verdadero sentido y alcance del acceso igualitario a la función pública, ya que la respuesta a esta cuestión sería el presupuesto de todas las demás investigaciones.

En la citada labor, ha habido la necesidad de emprender la siempre difícil tarea de inquirir el significado de 'igualdad', concepto que posee un núcleo indisoluble (que dice respecto a factores comunes a los ordenamientos jurídicos analizados), y distintos otros elementos variables en el tiempo y en el espacio.

Debido a este último motivo, este estudio ha elegido como referencia las normas de la Constitución española de 1978 y de la Constitución brasileña de 1988 como parámetros para la contextualización de la igualdad.

Debido al mencionado análisis, se ha constatado que la igualdad supera los meros formalismos jurídicos (igualdad ante la ley) y alcanza una dimensión material 
(que empieza con el reconocimiento de la igualdad en la ley y en su aplicación) que impone el respeto de las diferencias entre las personas, pero no tolera las discriminaciones ilegítimas.

Sin embargo, en las primeras páginas de este trabajo, se ha identificado que la incesante y ardua tarea de la humanidad consiste en el reconocimiento de cuáles son las hipótesis que reclaman la sumisión de las personas a las mismas reglas o cuándo se debe autorizar un determinado trato diferenciado.

No sólo es necesario reconocer cuándo se debe actuar de una forma o de otra, sino también distinguir cuáles son los instrumentos jurídicos, políticos y administrativos que deben ser utilizados a fin de que se logre el éxito en esta tarea.

Para todo ello, será posible, conforme el caso, hacer uso de los más distintos expedientes, como las generalizaciones, equiparaciones, diferenciaciones, establecimiento de procedimientos, prohibición de discriminaciones y realización de acciones afirmativas.

El manejo de las mencionadas herramientas debe ser previamente comprendido en el ámbito del Poder Legislativo, que podrá aportar a las leyes funciones compatibles con los objetivos del Estado Democrático y Social de Derecho, que tiene el papel de aumentar la inclusión de derechos y de ciudadanos en el goce de ellos.

En este contexto, se ha verificado que debido a las grandes desigualdades sociales existenten en Brasil, ya hay algunas acciones positivas que han intentado garantizar la inclusión, sea en el espacio educativo superior o en la función pública, de segmentos que suelen ser marginalizados, como los negros y los índios. A su vez, en España, pueden ser destacadas iniciativas que han logrado aumentar el grado de participación de las mujeres y de las personas con discapacidad en el mercado laboral, incluso en la Administración Pública.

Sin embargo, como ya se ha acentuado, tras la previsión constitucional, la elaboración de leyes adecuadas que favorezcan la igualdad, aunque imprescindible, no es el último paso en el intento de disminución de las diferencias ilegítimas entre los ciudadanos. 
En este contexto, la actuación cotidiana de la Administración Pública para ejecución de las políticas públicas de inclusión social representa el reconocimiento de que la efectividad de la igualdad siempre exigirá la incesante labor que todos los organismos públicos, hasta mismo porque si las demandas de la igualdad cambian, estas siempre reclamarán nuevas intervenciones de los poderes públicos.

Por todo ello, se ha comprobado que la igualdad es un valor que ejerce un papel supremo en los ordenamientos jurídicos español y brasileño, puesto que influencia la creación e interpretación de todas sus normas, determina los paradigmas de actuación de las instituciones (especialmente las públicas), así como impone la creación de institutos destinados a garantizar su efectividad.

En este contexto, se llega a la exigencia constitucional de acceso de los ciudadanos a la función pública en condiciones de igualdad, lo que no sólo es una característica heredada del modelo burocrático de Administración, sino también una reclamación de la democracia participativa.

El derecho previsto en el art. 23.2 de la Constitución española y en el art. 37, I de la brasileña impone que los procesos selectivos emprendidos por la Administración Pública sean conducidos de forma imparcial y objetiva, y por ello, fueron elegidos por el ordenamiento constitucional de los mencionados Estados los únicos criterios válidos para servir como referenciales en la selección: el mérito y la capacidad (art. 103.3 CE y art. 37, II CB).

En el ámbito del Estado Social y Democrático de Derecho, la selección meritoria es la única forma de garantizar la igualdad en el acceso. Sobre eso, no hay duda. Solamente a través de un sistema selectivo abierto y pautado por criterios de elección relacionados al mérito de los candidatos es posible certificar que todos los ciudadanos tendrán las mismas oportunidades de acceder a la función pública y, del mismo modo, permitir que los resultados de la selección satisfagan la reivindicación de eficacia administrativa exigida por el interés general.

Se puede añadir que la selección meritoria de los funcionarios públicos, además de ser una garantía del acceso igualitario y de la eficacia de la Administración Pública, es un expediente de indiscutible utilidad en la prevención de la corrupción, especialmente porque no permite el manejo de expedientes patrimonialistas 
(clientelismo, nepotismo), que hacen que los funcionarios públicos no siempre actúen con la imparcialidad que se espera y según las exigencias de la sociedad.

Por esto, se pregunta: ¿a quiénes puede interesar una selección de funcionarios que no sea conducida por criterios igualitarios? Ciertamente a aquellos que desean hacer uso indebido de la necesidad de cubrir puestos de trabajo para practicar actos de favoritismo personal o de terceros, y a aquellos que quieren beneficiarse de las referidas prácticas.

Merece la pena destacar que en el curso del presente trabajo, se ha verificado que en las realidades española y brasileña, aunque presenten rasgos muy diferenciados, las Administraciones Públicas de los referidos países han utilizado distintos expedientes para fraudar la exigencia de igualdad de los ciudadanos en la selección de los funcionarios.

En este aspecto, es posible subrayar el manejo casi sin frenos de los cargos de libre designación en España y de los cargos en comisión en Brasil; o la utilización demasiada de los funcionarios interinos españoles y de las contrataciones temporarias brasileñas. Todas estas situaciones representan, en muchas ocasiones, subtefurgios en los cuales la Administración Pública consigue apartarse de la regla impersonal de la selección meritoria.

Respecto a la contestación a la indagación respecto a las circunstancias que envuelven el acceso en condiciones de igualdad, se puede decir que este se debe caracterizar por tres exigencias: en primer lugar, que todos puedan efectivamente tener el derecho a participar en los procesos selectivos, lo que impone que en la definición de los requisitos de acceso a la función pública se tengan en consideración la necesidad de demostrar que la eventual restricción al citado derecho se apoya en una justificación razonable.

Las circunstancias que suelen diferenciar las personas (género, edad, raza, religión, condición física, lengua, entre otras) representan la diversidad que caracteriza la humanidad, lo que corresponde a un valor que debe ser preservado. 
No obstante, tales factores, en diversas oportunidades, son utilizados de forma ilegítima (ya que son basados en prejuicios que no poseen base científica ${ }^{1336}$ ) para introducir prácticas discriminatorias, vedando o dificultando el acceso a la función pública de segmentos importantes de la sociedad.

De la misma forma, se ha demostrado que la tarea atribuida al ordenamiento jurídico no sólo es decretar un trato de la más absoluta equivalencia entre las personas, sino también, en determinadas oportunidades, de exigir que se adopten medidas de compensación para que se garantice el acceso de determinados segmentos que, debido a circunstancias distintas (naturales, sociales, económicas, etc.), no disponen de las mismas oportunidades para poder competir en condiciones de igualdad.

Como se ha podido verificar en el cuerpo del trabajo, aunque se pueda destacar el trato ejemplar bajo varios aspectos concedido a determinadas cuestiones en el derecho español (como el acceso de las mujeres y de las personas con discapacidad), aún existen temas cuyas soluciones normativas deben ser perfeccionadas por el ordenamiento jurídico del referido país, como las que se refieren a la exigencia de conocimientos de lenguas cooficiales, la valoración de servicios prestados a la Administración, la posibilidad de estipulación de edad máxima, entre otros asuntos.

A su vez, respecto a los requisitos de acceso a la función pública brasileña, pese a las buenas iniciativas en lo que se refiere a la ampliación de la participación de los ciudadanos en los concursos públicos, como es el caso de los jóvenes y de las personas que padecen determinadas enfermedades, debe ser mejor desarrollado el sistema de acceso del extranjero, aún muy restringido, y perfeccionado el acceso de aquellos que hayan sido punidos disciplinarmente, de las personas mayores (donde todavía hay mucha discriminación), además de la necesidad de definición de la situación de algunas minorías religiosas (respecto a la fecha de las pruebas) y de los negros y índios (debe haber un debate más conclusivo sobre la cuestión de las cotas).

También se ha visto que la segunda circunstancia que debe caracterizar el acceso igualitario consiste en la definición de reglas objetivas para la selección, lo que impone que estas establezcan que las actuaciones de los seleccionadores (así como de

\footnotetext{
${ }^{1336}$ Es lo que pasaría con el argumento que sosteniera que las mujeres, las personas más jóvenes, mayores o con discapacidad no estarían aptas a desempeñar determinadas actividades.
} 
los aspirantes a las plazas ofertadas) sean previamente detalladas, alejando la posibilidad de arbitrariedades, apreciaciones subjetivas y ausencia de profesionalismo.

Sobre esta cuestión, se puede afirmar que aunque la configuración políticoconstitucional del Estado español contemple la existencia de distintos niveles de competencia (entidades estatales, autonómicas y locales), la definición de normas generales aplicables a todas entidades ha proporcionado un relativo grado de seguridad jurídica, una vez que garantiza una aplicación similar del derecho en las más distintas regiones geográficas.

Sin embargo, aunque sea innegable la relevancia de la definición de un conjunto de actos procedimentales generales, también se ha detectado la existencia de tratos distintos respecto a asuntos que repercuten en la situación de los aspirantes a la función pública, como es lo que sucede con la cuestión lingüística.

Sobre este asunto, la situación brasileña es mucho más preocupante, ya que hasta hoy en día, el citado país no disponde de una legislación nacional sobre concurso público, circunstancia lamentable que ha permitido la realización de procesos selectivos que son sometidos casi exclusivamente a las reglas definidas por la Administración Pública para cada disputa.

Además, la ausencia de una ley general sobre el acceso a la función pública ha hecho con que la Unión, los Estados y los Municípios hayan creado reglamentos que definen de derechos y deberes de los candidatos y del órgano seleccionador, cuando esta función debería ser ejercida por la ley.

También se puede añadir el hecho de que cada ente federativo está creando sus propias reglas sin que haya la sumisión a una norma general que al menos definiera parámetros generales, lo que sería muy relevante para garantizar una cierta uniformidad del trato de los candidatos en todo el país.

Por todas estas razones, en este trabajo se defiende la necesidad de alteración de la Constitución brasileña para que sea otorgada competencia legislativa a la Unión para la creación de una ley general de concursos públicos, tal cual existe en relación a las licitaciones públicas (art. 22, XXVII). La referida ley general deberá 
definir los principios y reglas más relevantes para que sea garantizado el derecho constitucional de igualdad en el acceso a la función pública.

En el caso de que no sea alterada la Constitución Federal (o mientras esto no suceda), se impone al menos que cada uno de los entes federativos elaboren sus respectivas leyes de acceso a la función pública, que deberán buscar en los valores previstos en la Constitución sus fundamentos de validad.

Para impedir los efectos negativos que la diversidad inevitable de normas provenientes de las más distintas fuentes supone, conviene que sean sistematizados y bien manejados los principios jurídicos que contribuyen con la efectividad de la exigencia de igualdad en el acceso a la función pública, especialmente cuando irradian efectos que atenderán sus más distintas reclamaciones y en la medida que proporcionan una mayor armonización de la aplicación de normas procedimentales muchas veces tan dispares.

Así, en España, se impone que la doctrina tenga una mayor preocupación con la sistematización, con la interpretación y con el desarrollo de los principios de los procesos selectivos de acceso a la función pública ya contemplados en la legislación vigente (especialmente, en el Estatuto del Empleado Público).

A su vez, en Brasil, es imprescindible que la legislación (en un primer momento, y la doctrina y jurisprudencia, a continuación), inspirada en las normas constitucionales y en las características de los procesos selectivos (carácter abierto, reglado, obligatorio, controlado y eficaz), desarrolle los principios propios de los procedimientos de competición por las plazas de funcionarios públicos.

En este contexto, fueron catalogados en este trabajo principios que, si mejor comprendidos y manoseados, podrán facilitar la realización de las exigencias de la igualdad, como la competitividad, la vinculación a las bases convocatorias, la publicidad, la transparencia, la imparcialidad y profesionalidad de los miembros de los órganos de selección, la adecuación entre el contenido de los procesos selectivos y las funciones o tareas a desarrollar y la sumisión a control.

Cabe subrayar que los destacados principios de los procesos selectivos, sea en Brasil como en España, aunque no estén contemplados en textos legales, ya son 
vinculantes, puesto que derivan de los valores consagrados en sus Constituciones. Por esta razón, en el curso del proceso de selección de los funcionarios públicos, deben las Administraciones Públicas de los referidos países realizar todos los esfuerzos para que los mencionados principios sean observados en su plenitud.

También se ha visto que el procedimiento administrativo de selección deberá proporcionar las debidas condiciones para que la decisión administrativa pueda efectivamente elegir a los más aptos, que, a su vez, deberán ser aquellos que se encuadren en el perfil necesitado por la Administración Pública de acuerdo con las plazas que se cubrirán.

La tercera exigencia para que se pueda considerar que determinado acceso a la función pública se realiza a partir de la concesión de condiciones iguales a los aspirantes es la posibilidad de que el procedimiento esté sometido a la fiscalización que garantice las debidas represiones y correcciones de las actuaciones ilegítimas.

En este contexto, ha sido destacado en el presente trabajo que el actual sistema de control de los procesos selectivos, aunque presente algunas ventajas (posibilidad de control administrativo y judicial, fiscalización de todos los actos del proceso selectivo, legitimidad de los aspirantes), posee algunas dificultades que deberán ser superadas.

En este contexto, pueden ser acentuadas como puntos débiles que comprometen la eficacia de control de los procesos selectivos la ausencia de un posicionamiento uniforme de la jurisprudencia respecto a la discrecionalidad técnica de los órganos seleccionadores, el excesivo tiempo llevado por los órganos jurisdiccionales para atender las demandas que le son entregadas por los aspirantes, la baja fiabilidad del control administrativo y el reducido grado de sumisión a control de determinados actos del procedimiento, como las pruebas orales y los tests psicotécnicos.

Como se ha demostrado, la adopción por la Constitución de un sistema meritorio de selección de los funcionarios públicos no es suficiente para garantizar la igualdad de oportunidades en el acceso a la función pública. Por ello, también se impone la definición de reglas jurídicas que establezcan un procedimiento administrativo selectivo adecuado, que pueda superar los obstáculos que reducen el nivel de efectividad de la reivindicación constitucional analizada. 
De hecho, en diversas oportunidades durante el trámite del proceso selectivo, hay la posibilidad de transgresión de la igualdad entre los ciudadanos. En el presente estudio, se ha demostrado que, sea en el contexto español como en el brasileño, desde la evaluación de las necesidades de personal hasta el nombramiento y toma de posesión, son muy numerosas las ocasiones favorables a la práctica de favoritismos.

Por esa razón, ha habido la necesidad de análisis de los más distintos actos que componen el proceso selectivo de acceso a la función pública española y brasileña, siempre con la perspectiva de que el cotejo entre los dos sistemas pudiera ofrecer soluciones interesantes para el perfeccionamento de los mismos. En otras oportunidades, la citada labor podrá hacer que determinado sistema jurídico no adopte soluciones que no tuvieron éxito en otros lugares.

En este contexto, se ha visto que actos que supuestamente ofrecerían pocos problemas, como la composición de los órganos de selección, la publicación de los actos de la selección, las solicitudes de participación y la admisión de candidatos y la aportación de documentos, desgraciadamente han representando la oportunidad ideal para la realización de prácticas que han atropellado la igualdad, sean cuando tales actos hayan facilitado o cuando hayan dificultado ilegítimamente la situación de los aspirantes.

Pese a la importancia de los mencionados actos del proceso selectivo y las cuestiones polémicas que los mismos pueden suscitar, se ha verificado que los momentos más propicios a la transgresión de la igualdad en el proceso selectivo son la elaboración de las bases de la convocatoria y la celebración y evaluación de las pruebas.

En la primera ocasión, hay distintas circunstancias que pueden representar la negación de la igualdad. En primer lugar, cuando hay la definición de forma indebida de los requisitos de acceso al proceso selectivo. En este caso, el ciudadano ni siquiera llega a poseer la condición de candidato (no hay, así, la igualdad para que se pueda competir).

En este trabajo, han sido analizadas las condiciones que deben caracterizar el acceso a la función pública de las personas con discapacidad, las mujeres, los extranjeros, los jóvenes y las personas mayores, así como también se han investigado los requisitos relacionados al conocimiento lingüístico, a la titulación, a la ausencia de separación del servicios y de inhabilitación para el ejercicio de funciones públicas. 
También han sido verificadas cuestiones más polémicas (y que no suele ser subrayadas por la doctrina), como es el caso de la participación de grupos religiosos minoritarios en el proceso selectivo, la definición de cotas para que sea garantizado el mayor acceso de determinados segmentos raciales (como es el caso de los negros en Brasil) o mismo el traumático ingreso de homosexuales en determinados organismos públicos, como es lo que pasa con las Fuerzas Armadas.

En este momento, cabe subrayar que cada uno de los citados temas, pese su análisis en este trabajo, es merecedor de un estudio específico y mucho más profundizado, especialmente delante de las más variadas cuestiones que suscita.

Además, se puede añadir que a pesar de los avances detectados en los ordenamientos jurídicos de España y de Brasil, los mismos aún tienen mucho que progresar a fin de que se pueda llegar a un grado de participación universal de los ciudadanos en los procesos selectivos de acceso a la función pública.

En la elaboración de las reglas del proceso selectivo, también hay otras ocasiones utilizadas por la Administración Pública para la práctica de favoritismos, como es el caso de la definición de los méritos evaluables y el peso atribuido a cada uno de ellos; la estipulación de las pruebas, especialmente cuando hay la previsión de su evaluación subjetiva; la negación de la debida publicidad de los actos de la selección o de la posibilidad de amplia fiscalización de los actos administrativos.

El segundo momento del proceso selectivo donde hay más prácticas que transgreden la igualdad es la celebración de las pruebas y su evaluación. En verdad, en estas ocasiones, la competición entre los candidatos ocurre intensamente, lo que exige del órgano seleccionador la conducción del proceso de la forma más objetiva e imparcial posible. Por esta razón, los procesos selectivos deben ser conducidos por órganos especializados, que actúen de forma profesional.

En este contexto, se ha destacado los riesgos e inconvenientes de la contratación de entidades extrañas a la Administración Pública para la conducción del proceso selectivo, actual realidad de los concursos públicos brasileños. 
Para esto, se impone que la Administración Pública no sólo califique a sus funcionarios para que puedan ejercer las actividades de planificación y fiscalización de los mencionados procesos, sino también de conducción.

Además, es imprescindible que los órganos seleccionadores estén protegidos de presiones externas que pueden puedan comprometer la idoneidad de los resultados de la selección. A su vez, los aspirantes también deben estar resguardados de la arbitrariedad de los órganos seleccionadores.

En el camino apuntado, algunas providencias ya han sido realizadas en los últimos cambios normativos en España y otras deberán ser adoptadas en Brasil. Lo que no se puede olvidar es que la actuación de los órganos de selección siempre deberá sujetarse a la fiscalización, lo que recomienda una mejor definición normativa de la utilización de institutos que amplían la subjetividad de la decisión, como las pruebas orales, las entrevistas, las pruebas de redacción, entre otras.

Sobre la última indagación que ha motivado la elaboración del presente trabajo, cabe destacar que hay distintas medidas que pueden realizarse para la ampliación de las garantías de acceso igualitario a la función pública.

En los distintos análisis realizados a lo largo de la investigación, se han hecho sugerencias respecto a algunas alteraciones legislativas en el contexto español, principalmente en los temas de los requisitos de acceso (por ejemplo, la posibilidad de que se exijan conocimientos linguiísticos tras el curso selectivo), del procedimiento de selección (como la ampliación de las formas de divulgación, la exclusión, siempre que posible, del sistema selectivo del concurso, de las entrevistas y el perfeccionamiento de las pruebas orales, para impedir las evaluaciones subjetivas, y mecanismos de control (por ejemplo, la diminución de los plazos para la apreciación judicial de las demandas de los aspirantes).

Respecto a la realidad brasileña, también se han realizado en el curso del trabajo distintas sugerencias, muchas de ellas tomando como referencia el contexto español, como la adopción de la figura de la oferta de empleo público, de los cursos de formación, o realización de los concursos públicos a través de órganos seleccionadores formados por funcionarios calificados, la ampliación del acceso del extranjero, y, 
especialmente, la creación de una ley general que trate de las condiciones de acceso de los ciudadanos a la función pública.

También se han hecho críticas al contenido de las pruebas selectivas, sea en España como en Brasil, que muchas veces tienen más en consideración aspectos no tan relevantes para el desempeño de los funcionarios (por ejemplo, la memoria), circunstancia que no necesariamente favorece a los más capacitados.

Otra circunstancia que debe ser tenida en consideración es que, debido a la gran búsqueda de los empleos públicos, los procesos selectivos de acceso a la función pública en España y en Brasil suelen reunir miles de candidatos, lo que impone, de forma general, que la Administración Pública sea obligada a celebrar pruebas más sencillas, que facilitan la evaluación de los candidatos y la rapidez de la divulgación de los resultados.

Esta masificación de los procesos selectivos no siempre es favorable a la igualdad de trato, pues estimula las simplificaciones, que reducen los aspirantes a números, y dejan de considerar factores relevantes para la selección de los más calificados. Además, desestimula las correcciones de irregularidades que puedan retardar el proceso selectivo.

En definitiva, para que el acceso a la función pública se convierta en un instrumento a favor de las exigencias de las sociedades española y brasileña, conviene que estas pasen a poner mayor interés en los procesos selectivos, para que puedan exigir los debidos cambios (ante todo, de concepción), adaptando los mencionados procesos a las exigencias del siglo XXI (utilización de la tecnología para facilitar el acceso, mayor transparencia y divulgación, inclusión de segmentos marginalizados, utilización de métodos selectivos más avanzados), lo que, por fin, garantizará que el ingreso en los cuadros de la Administración Pública pueda ser una opción del ciudadano cuyos resultados sólo dependan de su esfuerzos.

En realidad, la igualdad en el acceso a la función pública impone que todos tengan el derecho de hacer parte de la competición, que todos puedan competir en 
condiciones iguales ${ }^{1337}$, que todos sean sometidos a los mismos criterios de evaluación, que estos sean justos (adecuados y razonables) y uniformes, y que todos tengan la más amplia posibilidad de fiscalizar el cumplimiento de las condiciones anteriores.

Es innegable que cada una de las mencionadas repercusiones de la igualdad ha avanzado en los últimos tiempos, tanto en España como en Brasil. De la misma forma, es evidente lo mucho que se puede caminar adelante en esto sentido, lo que impone un debate más amplio de estas cuestiones, no sólo en los ambientes académicos y jurídicos, sino también en los círculos propios de la sociedad (asociaciones, ONG's, partidos políticos, iglesias, etc.), pues esta es la principal interesada en una Administración Pública eficaz y que sepa respectar los valores constitucionales, entre los cuales se destaca la igualdad.

\footnotetext{
${ }^{1337}$ Respecto a la exigencia de que todos puedan competir en condiciones iguales, se impone incluso la adopción de políticas públicas que ofrezcan oportunidades de preparación adecuada a los candidatos, especialmente para que haya la inclusión de aquellos que no hayan tenido, por motivos económicos, una buena formación educativa. En Brasil, los opositores "deslocam-se milhares de quilómetros para ir atrás de uma melhor preparaçao e cruzam o país em busca de concursos que lhes ofereçam a chance de realizar o sonho de ser um servidor (...) A estimativa é de que, só com mensalidade, os concorrentes que se matriculam em um curso preparatório gastem em média $R \$ 10$ mil por ano" (Extraído del reportaje: Concurso:o sonho da estabilidade, elaborado por Wilson Aquino, Adriana Nicacio y Fabiana Guedes, publicado en la revista Isto é, $\mathrm{n}^{\circ}$ 2099, de 3 de febrero de 2010,Três Editorial Ltda, Sao Paulo, p. 80). Como ha destacado la doctrina: "a igualdade do conhecimento e no saber é um direito fundamental para que qualquer outro possa ser eficaz" (ANTUNES ROCHA, Cármen Lúcia. O principio constitucional da igualdade. Editora Lê, Belo Horizonte, 1990, p. 119).
} 


\section{BIBLIOGRAFIA}

\section{LIBROS Y ARTÍCULOS JURÍDICOS}

ABREU DALlARI, Adilson. Princípio da isonomia e concurso público, en Concurso público e Constituição, Fabrício Motta (Cordinador), Editora Fórum, Belo Horizonte, 2005.

ABREU DAllari, Adilson. Regime Constitucional dos Servidores Públicos. 2 ed., São Paulo:Revista dos Tribunais, 1990.

ALEGRET BURGUÉS, María Eugenia, presentación y introducción del libro La discriminación positiva, Directora María Eugenia Alegret Burgués, Consejo General del Poder Judicial, Madrid, 2006.

ANTUNES ROCHA, Cármen Lúcia. O principio constitucional da igualdade. Editora Lê, Belo Horizonte, 1990.

ANTUNES ROCHA, Cármen Lúcia. Princípios constitucionais dos servidores públicos, Editora Saraiva, São Paulo, 1999.

AYRES DE BRITTO, Carlos. Concurso público: requisitos de inscrição, en Revista Trimestral de Direito Público, nº 6, Editora Malheiros, São Paulo, 1994.

BACELLAR FILHO, Romeu Felipe. O concurso público e o processo administrativo, en Concurso público e Constituição, Fabrício Motta (Coordinador), Editora Fórum, Belo Horizonte, 2005.

BACELlAR FILHO, Romeu Felipe. Profissionalização da função pública: a experiência brasileira, en La profesionalización de la Función Pública en Iberoamérica, Instituto Nacional de Administración Pública - INAP, Madrid, 2002.

BANDEIRA DE MELLO, Celso.Antônio. Conteúdo jurídico do princípio da igualdade, $3^{\text {a }}$ ed., Editora Malheiros, São Paulo, 1999.

BANDEIRA DE MELLO, Celso Antônio. Curso de direito administrativo. $26^{\mathrm{a}}$ ed. rev. e atual., Editora Malheiros, São Paulo, 2009.

BAÑO LEÓN, J.M., El ejercicio del pluralismo lingüístico en la Administración Pública, Revista Española de Derecho Administrativo, Civitas, 54 abril-junio 1987, Madrid.

BARBOSA GOMES, Joaquim Benedito. Ação afirmativa e princípio constitucional da igualdade, Editora Renovar, Rio de Janeiro, 2001. 
BARBOSA MAIA, Márcio, y PINHEIRO DE QUEIROZ, Ronaldo. O regime jurídico do concurso público e o seu controle jurisdicional, Editora Saraiva, São Paulo, 2007.

BARBOSA, Rui. Oração aos moços, Ed. Martin Claret, Sao Paulo, 2003.

BARRACHINA JUAN, Eduardo. La función pública: su ordenamiento jurídico, Parte General I, Promociones y publicaciones Universitarias, Barcelona, 1991.

BATISTA GOMES MOREIRA, João. Princípios constitucionais da legalidade e da eficiência nos concursos públicos, en Concurso público e Constituição, Fabrício Motta (Cordinador), Editora Fórum, Belo Horizonte, 2005.

BAUTISTA VIVERO SERRANO, Juan. El acceso al empleo público en régimen laboral tras el estatuto básico del empleado público: algunas luces y demasiadas sombras, Revista Española de Derecho Administrativo, $\mathrm{n}^{\mathrm{o}}$ 143, julio-septiembre 2009.

BELADIEZ ROJO, Margarita. "El derecho fundamental de acceder en condiciones de igualdad a las funciones públicas (artículo 23.2 CE)", Justicia Administrativa Revista de Derecho Administrativo, Lex Nova, n 45, octubre 2009, (Director Miguel Sánchez Morón).

BELTRÁN DE FELIPE, Miguel. Discrecionalidad administrativa y Constitución, Temas Clave de la Constitución Española, Tecnos, Madrid, 1995

BERNAL PULIDO, Carlos. El principio de proporcionalidad y los derechos fundamentales, Centro de Estudios Políticos y Constitucionales, Madrid, 2003.

BOBBIO, Norberto. Igualdad y libertad, Ediciones Paidós, Barcelona, 1993.

BOCKMANN MOREIRA, Egon. Processo Administrativo: princípios constitucionais e a Lei 9.749/99, Editora Malheiros, São Paulo, 2000.

Boletín Estadístico del Personal al Servicio de las Administraciones Públicas (Extracto de la redacción impresa de julio de 2008)

BRANDAO CAVALCANTI, Themistocles. Tratado de Direito Administrativo, vol. IV, 3 ed., Livraria Freitas Bastos, Rio de Janeiro, 1956.

CABRA DE LUNA, Miguel Ángel, y GAZTELU SAN PÍO, Clara. Derecho Internacional y Comunitario. La protección jurídica de las personas con discapacidad en la normativa comunitaria $y$ en los instrumentos internacionales, en Régimen Jurídico de las personas con discapacidad en España y en la Unión Europea, Esperanza Alcaín Martínez, Juan GonzálezBadía Fraga y Carmen Molina Fernández (Coordinadores), Editorial Comares, Granada, 2006. 
CAMMAROSANO, Márcio. Concurso Público. Avaliaçao de provas. Vinculaçao ou discricionariedade?, in Concurso público e Constituiçao, Fabrício Motta (Coordenador), Editora Forum, Belo Horizonte, 2005.

CANTERO MARTÍNEZ, Josefa. Apartado sobre "Sistemas selectivos", que hace parte del capítulo sobre Acceso al empleo público y adquisición de la relación de servicio, del libro Comentarios a la Ley 7/2007, de 12 de abril, del Estatuto Básico del Empleado Público. Alberto Palomar Olmeda, Antonio V. Sempere Navarro (Directores), R. Yolanda Quintanilla Navarro (Coordinadora), Thomson Aranzadi, Cizur Menor (Navarra), 2008,.

CASTILlO BLANCO, Federico A., Acceso a la función pública local (políticas selectiva y control jurisdiccional), Comares Editorial, Granada, 1993.

CAVAS MARTINÉZ, Faustino. El Estatuto Básico del Empleado Público. Comentario Sistemático de la Ley 7/2007, de 12 de abril de 2008, José Luis Monareo Perez y otros (dirección y coordinación), Editorial Comares, Granada, 2008.

COBREROS MENDAZONA, E., Cooficialidad lingüística y discriminación por razón de la lengua, Revista Española de Derecho Administrativo, Civitas, 42, abriljunho de 1984, Madrid.

CRETELlA JÚNIOR, José. Comentários à Constituição Brasileira de 1988, $2^{\text {a }}$ edição, volume 4, 1992.

CRETELLA JÚNIOR, José. Tratado de Direito Administrativo, volume IV, Editora Forense, Rio de Janeiro, 1967.

CUNHA JÚNIOR, Dirley da. Curso de Direito Constitucional, $2^{\mathrm{a}}$ ed., Editora Podium, Salvador, 2008.

DA SILVA, José Afonso. Curso de Direito Constitucional Positivo, 23ª ed., Editora Malheiros, São Paulo, 2004.

DA SILVA OLIVEIRA JÚNIOR, Dario, y CAMPOS OLIVEIRA, Isabel. Concurso público. Teoria e prática. Lumen Juris Editora, Rio de Janeiro, 2008.

DIAS DA SILVEIRA, Raquel. Discriminações legais em concursos públicos e o princípio da igualdade: um estudo sob o paradigma das ações afirmativas e das políticas públicas de inclusão das minorias nas últimas décadas. Revista Eletrônica de Direito do Estado (REDE), Instituto Brasileiro de Direito Público, Número 19, julho, agosto e setembro de 2009, Salvador.

DOMínGUEZ-BERRUETA DE JUAN, Miguel. y NEVADO MORENO, Pedro.T., "La libre circulación de servidores públicos. Un estudio sobre el acceso de ciudadanos comunitarios a la función pública de los Estados miembros". Notícias de la Unión Europea, núm. 145, 1997. 
DOUGLAS, Willian. Guia de aprovação em provas e concursos, $8^{\mathrm{a}}$ ed., Elsevier, Campus Concursos, Rio de Janeiro, 2009.

ERKOREKA GERVASIO, J.I., Exigencia de preceptividad en los perfiles lingüísticos como requisito de capacidad en el ejercicio de funciones públicas, Revista Vasca de Administración Pública, n. 44-II, 1996, p. 266 y ss, apud FONDEVILA ANTOLÍN, Jorge. La selección y pérdida de la condición de empleado público: especial referencia a su aplicación en la Administración local, Atelier, Barcelona, 2008.

FÉREZ FERNÁNDEZ, Manuel. La capacidad y el mérito en el acceso al empleo público profesional, Información, Documentos y Estudios para la Modernización de la Administración Pública, Número 22, Zaragoza, Julioagosto 1994.

FÉREZ, Manuel. El sistema de mérito en el empleo público: principales singularidades $y$ analogías respecto del empleo en el sector privado. Documentación Administrativa, n. 241-242, enero-agosto, 1995, Madrid.

FERNÁNDEZ DE GATTA SÁNCHEZ, Dionisio. El principio de igualdad de género en la Unión Europea, capítulo del libro Igualdad ¿Para qué ?, A propósito de la Ley Orgánica para la igualdad efectiva de mujeres y hombres, Ángela Figueruelo Burrieza, María Luisa Ibañez Martínez y Rosa María Merino Hernández (Editoras), Editorial Comares, Granada, 2007.

FERNÁNDEZ DE GATTA SÁNCHEZ, Dionisio. Fórmulas asociativas para la mejor prestación de los servicios públicos: mancomunidades de municipios y consorcios. Revista de Estudios Locales. Los Servicios Públicos Locales, Valentín Merino Estrada, Extra 2007, Madrid., pp. 203-227.

FERNÁNDEZ DOMÍNGUEZ, Juan J. y RODRÍGUEZ ESCANCIANO, Susana. El acceso al empleo público, Ediciones Estudios Financieros, Madrid, 2005.

FERNANDÉZ-ESPINAR, L.C., El alcance de la cooficialidad lingüística en el procedimiento administrativo y la administración de justicia. Revista Española de Derecho Administrativo, 58 abril-junio de 1988, Civitas, Madrid.

FERNÁNDEZ, Encarnación. Igualdad y derechos humanos, Tecnos, Madrid, 2003.

FERNÁNDEZ RAMOS, Severiano. Algunas proposiciones para una ley de acceso a la información, Boletín Mexicano de Derecho comparado, Instituto de Investigaciones Jurídicas de la UNAM, número 105, septiembre-deciembre 2002, p. 881-916. 
FERNÁNDEZ RAMOS, Severiano. Proposiciones para la articulación de la carrera horizontal de los funcionarios, Justicia Administrativa, Revista de Derecho Administrativo, n. 47, 2010.

FERRAZ, Luciano. Concurso público e direito à nomeação, en Concurso público e Constituição, Fabrício Motta (Cordinador), Editora Fórum, Belo Horizonte, 2005.

FERREIRA FERNÁNDEZ, A. Xavier. La provisión de puestos de trabajo en la Administración General del Estado, INAP, Madrid, 2002.

FERREIRA MENDES, Gilmar; MÁRTIRES COELHO, Inocêncio; GONET BRANCO, Paulo Gustavo. Curso de direito constitucional. $2^{\mathrm{a}}$ ed., Editora Saraiva, São Paulo, 2008.

FIGUEIREDO MOREIRA NETO, Diogo de. Direito da participação política: legislativa, administrativa, judicial (fundamentos e técnicas constitucionais da legitimidade), Editora Renovar, Rio de Janeiro, 1992.

FIGUERUELO BURRIEZA, Ángela. Políticas públicas previstas para la igualdad real y efectiva, capítulo del libro Igualdad ¿Para qué ?, A propósito de la Ley Orgánica para la igualdad efectiva de mujeres y hombres, Ángela Figueruelo Burrieza, María Luisa Ibañez Martínez y Rosa María Merino Hernández (Editoras), Editorial Comares, Granada, 2007.

FONDEVILA ANTOLÍN, Jorge. Constitución y empleo público. Estudios y propuestas en relación a un régimen jurídico común, Comares, Granada, 2000.

FONDEVILA ANTOLÍN, Jorge. La selección y pérdida de la condición de empleado público. Especial referencia a su aplicación en la Administración Local, Atelier Libros Jurídicos, Barcelona, 2008.

FREITAS, Juarez. Carreiras de Estado e o direito fundamental à boa administração, artículo publicado en Interesse Público - Revista Bimestral de Direito Público, no 53, Editora Forum, São Paulo, 2009.

FREITAS, Juarez. Concurso público e regime institucional: as carreiras de Estado, en Concurso público e Constituição, Fabrício Motta (Cordinador), Editora Fórum, Belo Horizonte, 2005.

GAMERO CASADO, Eduardo, y FERNÁNDEZ RAMOS, Severiano. Manual Básico de Derecho Administrativo. $6^{\mathrm{a}}$ ed., Tecnos, Madrid, 2009.

GARCÍA DE ENTÉRRIA, Eduardo. Democracia, jueces y control de la Administración, $4^{a}$ ed., Editorial Civitas, Madrid, 1998. 
GARCÍA DE ENTERRÍA, Eduardo. La lucha contra las inmunidades del poder, tercera eddción, Thomson Civitas, Madrid, 1983

GARCÍA DE ENTERRÍA, Eduardo. La lengua de los derechos. La formación del Derecho Público europeo tras la Revolución Francesa, Alianza Editorial, Madrid, 1994.

GARCÍA DE ENTERRÍA, Eduardo. "Un punto de vista sobre la nueva Ley de Régimen Jurídico de las Administraciones Públicas y del Procedimiento Administrativo Común", RAP, no 130, enero-abril de 1993.

GARCÍA MACHO, Ricardo. Secreto profesional y libertad de expresión del funcionario. Tirant lo blanch, Valencia, 1994.

GASPARINI, Diógenes. Concurso público - imposição constitucional e sua operacionalização, en Concurso público e Constituição, Fabrício Motta (Coordinador), Editora Fórum, Belo Horizonte, 2005.

GASPARINI, Diógenes. Direito Administrativo. $4^{\mathrm{a}}$ ed., Editoria Saraiva, São Paulo, 1995.

GAVARA DE CARA, Juan .Carlos. Contenido y función del término de comparación en la aplicación del principio de igualdad, Cuadernos Aranzadi del Tribunal Constitucional, Thompson Aranzadi, Cizur Menor (Navarra), 2005.

GONÇALVES CARVALHO, Kildare. Direito constitucional: teoria do estado e da constituição: direito constitucional positivo. $15^{\mathrm{a}}$ ed. rev. atual. e ampl., Editora Del Rey, Belo Horizonte, 2009.

GONZÁLEZ BUSTOS, María Ángeles. El trato de la igualdad en el ordenamiento jurídico administrativo español. Especial incidencia en la Comunidad Autónoma de Castilla y León. Capítulo 3 de la obra La mujer ante el ordenamiento jurídico: soluciones a realidades de género, María Ángeles González Bustos (Coordinación), diversos autores, Atelier Libros Jurídicos, Barcelona, 2009.

GONZÁLEZ BUSTOS, María Ángeles. La actuación de los poderes públicos en materia de libertad sexual, en La igualdad como compromiso, estudios de género en homenaje a la Profesora Ana Díaz Medina, Ediciones Universidad de Salamanca, septiembre 2007.

GONZÁLES BUSTOS, María Ángeles. La mujer ante el siglo XXI: una perspectiva desde el ordenamiento jurídico-administrativo, Editorial @ becedario, Badajoz, 2006.

GUIMARAES TABORDA, Maren. O princípio da igualdade em perspectiva histórica: conteúdo, alcance e direções, en Revista de Direito Administrativo, $\mathrm{n}^{\circ}$ 211, enero-marzo 1998, Renovar - FGV, Rio de Janeiro. 
HERNÁNDEZ VITORIA, María José, Una lectura de la Ley 51/03 desde las aportaciones del ordenamiento comunitario en materia de derechos fundamentales y del principio de no discriminación, en La protección jurídica civil, penal, administrativa y social de la persona con discapacidad, Cuadernos de Derecho Judicial, Consejo General del Poder Judicial, Madrid, 2007.

ILDEFONSO HUERTAS, Rosa.María., in Lecciones de función pública, Federico A. Castillo Blanco (Director), Ana Olmedo Gaya (Coordinadora), CEMCi, Granada, 2002.

ILDEFONSO HUERTAS, Rosa María. Tres modelos comparados de función pública y sus procesos de selección, Instituto Andaluz de Administración Pública, Sevilla, 2004.

Informe de la Comisión para estudio y preparación del Estatuto Básico del Empleado Público, INAP, Madrid, Miguel Sánchez Morón (Presidente), abril 2005.

JARA ANDRÉU, Antonio. Derecho Constitucional, Estado Social, Orden Jurídico e Integración Social, en Régimen Jurídico Administrativo de las Personas con Discapacidad, en Régimen Jurídico de las Personas con Discapacidad en España y en la Unión Europea, Esperanza Alcaín Martínez y otros (Coordinadores), autores varios, Editorial Comares.

JÍMENEZ LARA, António. La población con discapacidad: estudios demográficos, en Tratado sobre discapacidad, Rafael de Lorenzo y Luís Cayo Pérez Bueno (Directores), Thomson Aranzadi, Pamplona.

JUNQUERA GONZÁLEZ, Juan. El sistema de oposición, Revista de Derecho Administrativo, no 137, Septiembre-octubre de 1970.

JUSTEN FILHO, Marçal. Curso de direito administrativo, $4^{\mathrm{a}}$ ed., Editora Saraiva, São Paulo, 2009.

LÁZARO ALBA, Eduardo. y GONZÁLEZ BOTIJA, Fernando. A vueltas con la discrecionalidad técnica en oposiciones y concursos: jurisprudencia reciente y reflexiones críticas. Revista Española de Derecho Administrativo, Civitas n. $127,2005$.

LÁZARO, José Luis. Capitulo intitulado “Acceso al empleo público y adquisición de la relación de servicio" del libro Comentarios al Estatuto Básico del Empleado Público, Salvador del Rey Guanter (Dirección), Manuel Férez Fernández y Esther Sánchez Torres (Coordinación), La Ley, Madrid, 2008.

LINS DE LESSA CARVALHO, Fábio. O principio da impessoalidade nas licitações, Edufal, Maceió, 2005. 
LOBELLO DE OLIVEIRA ROCHA, Francisco. Regime jurídico dos concursos públicos, Editora Dialética, São Paulo, 2006.

LOPES MEIRELLES, Hely. Direito Administrativo Brasileiro. $15^{\text {a }}$ ed., Ed. Revista dos Tribunais, São Paulo, 1990.

LORENZO DE MEMBIELA, Juan B., El acceso y provisión de puestos de trabajo en la Administración Pública, Manual Práctico de Función Pública, vol. III, Thomson, Aranzadi, Cizur Menor (Navarra), 2009.

LORENZO DE GARCÍA, Rafael. Las personas con discapacidad en la Constitución Española y el constitucionalismo comparado, en Tratado sobre discapacidad, Rafael de Lorenzo y Luís Cayo Pérez Bueno (Directores), Thomson Aranzadi, Pamplona, 2007.

MACHADO JÚNIOR, Agapito. Concursos públicos, Editora Atlas, São Paulo, 2008.

MALEM SEÑA, Jorge F.. El error judicial y la formación de los jueces, Editorial Gedisa, Barcelona, 2008.

MALEM SEÑA, Jorge F., La corrupción: aspectos éticos, económicos, políticos y jurídicos, Gedisa Editorial, Barcelona, 2002.

MARINELA DE SANTOS SOUZA, Fernanda. Concursos públicos - acessibilidade e grandes polêmicas, extraído del libro Leituras complementares de Direito Administrativo - Advocacia Pública, Fernanda Marinela e Fabrício Bolzan (organizadores), Editora Podium, Salvador, 2008.

MARTÍNEZ MARÍN, Antonio. Régimen jurídico de los funcionarios, Editorial Tecnos, 1999.

MARTÍNEZ VERGEL, Joan. De 8 a 3, anécdotas de funcionarios, Styria, Barcelona, 2008.

MARTÍN MORENO, José Luís. El control de las oposiciones y concursos en el Estado Constitucional, Liberlex, 2007.

MARTÍN REBOLLO, Luís. Prólogo del libro La selección y pérdida de la condición de empleado público. Especial referencia a su aplicación en la Administración Local, Jorge Fondevila Antolín, Atelier Libros Jurídicos, Barcelona, 2008.

MARTÍN VIDA, María. Ángeles. Evolución histórica del principio de igualdad y paradojas de exclusión, Colección Feminae (Instituto de Estudios de la Mujer), Editorial Universidad de Granada), Granada, 2004. 
MARTHÍN Y GUIX, E. Manual del empleado (1905), Ministerio de Administraciones Públicas, Madrid, 2007.

MAURI BAJÓS, Joan. Capítulo Cuarto "El acceso al empleo público", Manual de Empleo Público, Federico A. Castillo Blanco (Director), Javier E. Quesada Lumbreras (Coordinador), primera edición, Ilustel, Madrid, 2009.

MEDAUR, Odete. Direito Administrativo Moderno, Editora Revista dos Tribunais, São Paulo, 1996.

MORAES, Alexandre de. Direito constitucional. 21 a ed., Editora Jurídico Atlas, São Paulo, 2007.

MORAES, Alexandre de. Princípio da eficiência e controle jurisdicional dos atos administrativos discricionários, artículo publicado en la Revista de Direito Administrativo, no 243, Fundação Getúlio Vargas - Direito Rio, Rio de Janeiro.

MORA RUIZ, Manuela. Informe de impacto de gênero em las disposiciones administrativas de carácter general: ¿Una garantia efectiva de la igualdad desde el derecho administrativo?, capítulo del libro Formación y objeto del Derecho antidiscriminatorio de género: perspectiva sistemática de la igualdad desde el Derecho público, Manuela Mora Ruiz (Directora), Atelier Libros Jurídicos, Barcelona, 2010.

MORELL OCAÑA, Luís. El sistema de confianza política en la Administración Pública, Ed. Civitas, Madrid, 1994.

MOREY JUAN, Andrey. La función pública: necesidad de un análisis conceptual y de la revisión del sistema de libre designación, INAP, Madrid, 2004.

MOTTA, Fabrício. A reserva de vagas nos concursos públicos para os portadores de deficiência - análise do art. 37, inc. VIII da Constituição Federal, en Concurso público e Constituição, Fabrício Motta (Cordinador), Editora Fórum, Belo Horizonte, 2005.

MOTTA, Fabrício. Concurso público e confiança na atuação administrativa: análise dos princípios de motivação, vinculação ao edital e publicidade, en Concurso público e Constituição, Fabrício Motta (Cordinador), Editora Fórum, Belo Horizonte, 2005.

MOTTA, Fabrício. Concurso público e Constituiçao, Fabrício Motta (Coordinador), Editora Fórum, Belo Horizonte, 2005.

MOZO SEOANE, A., La discrecionalidad de la Administración Pública en España. Análisis jurisprudencial, legislativo y doctrinal, 1834-1983, Editorial Montercorvo S.A., Madrid, 1985. 
NAVARRO, Pilar. Prepara oposiciones con éxito. Las técnicas y los trucos para superar todas las pruebas, Editorial Planeta, Barcelona, 2006.

NETTO DE ARAÚJO, Edmir. Curso de direito administrativo. Editora Saraiva, São Paulo, 2005.

NIETO, Alejandro. Corrupción en la España democrática, Ariel, Barcelona, 1997.

NIETO, Alejandro. El desgobierno de lo público, Ariel, Barcelona, 2007.

NIETO, Alejandro. Función pública local. Cuadernos de documentación e Información, $\mathrm{n}^{\mathrm{o}}$ 4/1978. Delegación Interprovincial del Instituto de Estudios de Administración Local, Granada, 1978.

NIEVES SALDAÑA DÍAS, María. La participación equilibrada de género en el ámbito autonómico: balance y perspectivas, capítulo del libro Formación y objeto del Derecho antidiscriminatorio de género: perspectiva sistemática de la igualdad desde el Derecho público, Manuela Mora Ruiz (Directora), Atelier Libros Jurídicos, Barcelona, 2010.

OLIVEIRA MORAES, Germana de. Controle jurisdicional da Administração Pública, Editora Dialética, São Paulo, 1999.

ORTEGA Y GASSET, J. Democracia morbosa, in Obras completas, Alianza Editorial \& Revista de Occidente, Madrid, 1983, vol. II.

PABLO, Marcos Fernando. La motivación de los actos administrativos, Ed. Tecnos, Madrid, 1993.

PACHECO BARROS, Wellington. Direito Administrativo. Concurso público. Teoria e prática, Livraria do Advogado Editora, Porto Alegre, 2007.

PALOMAR OLMEDA, Alberto. Derecho de la función pública: régimen jurídico de los funcionarios públicos, 7 ed., Dykinson, Madrid, 2003.

PARADA, Ramón. Derecho administrativo II, organización y empleo público, 20 ed., Marcial Pons, Madrid, 2008.

PARADA, Ramón. Derecho del empleo público, Marcial Pons, Barcelona, 2007.

PAREJO ALFONSO, Luciano, JIMÉNEZ-BLANCO, A., ORTEGA ÁlVAREZ, L., Manual de Derecho Administrativo, vol. 2, 5 ed., Editorial Ariel, Barcelona, 1998.

PENDÁS GARCÍA, B. (coordinación), Administraciones Públicas y Ciudadanos (Estudio sistemático de la Ley 301992, de 26 de noviembre, de Régimen Jurídico de las Administraciones Públicas y del Procedimiento Administrativo Común), Praxis. 
PÉREZ COBACHO, Juan. Ganar oposiciones. El éxito de la experiencia, $5^{\mathrm{a}}$ ed., Editorial MAD, Sevilla, 2007

PÉREZ GÓMES, José María. Capítulo “Acceso al empleo público y adquisición de la relación de servicio", del libro Comentarios a la Ley 7/2007, de 12 de abril, del Estatuto Básico del Empleado Público. Alberto Palomar Olmeda, Antonio V. Sempere Navarro (Directores), R. Yolanda Quintanilla Navarro (Coordinadora), Thomson Aranzadi, Cizur Menor (Navarra), 2008.

PÉREZ LUÑO, Antonio .Enrique. Dimensiones de la igualdad, $2^{\mathrm{a}}$ edición, Dykinson, Madrid, 2007.

PEREZ, Marcos Augusto. A Administração Pública Democrática: Institutos de participação popular na Administração Pública, Editora Fórum, Belo Horizonte, 2004.

Pesquisa ENAP, Gênero, raças e competências no serviço público federal, ENAP Cadernos, Brasília, 2004

PICÓ LORENZO, Celsa., La discriminación positiva en la función pública, en el libro La discriminación positiva, Consejo General del Poder Judicial, Centro de Documentación Judicial, Directora María Eugenia Alegret Burgués, Madrid, 2006.

PIÑAR MAÑAS, J. L., El pleno control jurisdiccional de los concurso y oposiciones, Documentación Administrativa, n.220 (octubre-diciembre 1989), Madrid.

PINHEIRO MADEIRA, José Maria. Servidor público na atualidade, $3^{\mathrm{a}}$ ed., Editora América Jurídica, Rio de Janeiro, 2006.

PULIDO QUECEDO, Manuel. El acceso a los cargos y funciones públicas (Un estudio del articulo 23.2 da la Constitución), Parlamento de Navarra, Editorial Civitas S.A., Madrid, 1992.

QUINTANA LÓPEZ, Tomás. Las mancomunidades en nuestro derecho local. Instituto Nacional de Administración Pública - INAP, Madrid, 1991.

QUINTANA LÓPEZ, Tomás. La responsabilidad patrimonial de la Administración Pública: estudio genera y ámbitos sectoriales. Ed. Tirant lo Blanc, 2009.

RAMÓN CHAVES GARCÍA, José. Control de concursos y oposiciones en la jurisprudencia, Editorial Reus, Colección Claves de la Jurisprudencia, Madrid, 2009.

REY MARTÍNEZ, Fernando. El derecho fundamental a no ser discriminado por razón de sexo, McGraw-Hill, Madrid, 1995. 
R.FERNANDEZ, Tomás. De la arbitrariedad de la Administración, tercera edición, Civitas, Madrid, 1999.

RIBEIRO BASTOS, Celso. Curso de Direito Constitucional. 13 ed $^{\mathrm{a}}$., Editora Saraiva, São Paulo,.1990.

RIVERO ORTEGA, Ricardo, Acceso a la función pública autonómica y doctrina constitucional (Comentario a la STC de 11 d febrero de 1989), Revista de Administración Pública, número 151, enero-abril 2000, Madrid.

RODRÍGUEZ ESCANCIANO, Suzana. La familia en el ámbito jurídico-laboral. Editorial Tirant lo Blanch, Valencia, 2008.

RODRÍGUEZ ESCANCIANO, Suzana. La promoción del los cupos de reserva a favor de las personas con discapacidad en el nuevo contexto normativo sobre empleo público. Aranzadi Social, vol. 3, no 4 (jun), 2010, p. 81-113.

RODRÍGUEZ GARCÍA, E.B., Prólogo del libro “Acceso a la función pública local (Políticas selectivas y control jurisdiccional), CASTILLO BLANCO, F.A., Editorial Comares, Granada, 1993.

RODRÍGUEZ LÓPEZ, Fernando. ¿Puede el Derecho sancionador frenar la corrupción? Reflexiones desde el análisis económico del Derecho, en La corrupción en un mundo globalizado: análisis interdisciplinar, Nicolás Rodríguez García y Eduardo A. Fabián Caparrós (Coordinadores), Ratio Legis, Salamanca, 2004.

RODRÍGUEZ-PIÑERO, Miguel. y FERNÁNDEZ LÓPEZ, María. Fernanda. Igualdad y discriminación, Tecnos, Madrid, 1986.

SALAS PARRILLA, Miguel. Cómo aprobar oposiciones, Pedagogía Alianza Editorial, Tercera reimpresión, Madrid, 2008

SAMANIEGO VILLASANTE, Carlos y DÍAS BRETONES, Francisco. Capítulo intitulado Selección, formación y desarrollo de carreras en la Administración Pública, del libro Los recursos humanos en la Administraciones Públicas, Andrés Rodríguez Fernández (Director), Tecnos, Madrid, 1995.

SÁNCHEZ MORÓN, Miguel. Autor del capítulo décimo del libro Comentarios a la Ley del Estatuto Básico del Empleado Público, Miguel Sánchez Morón (Director); Federico A. Castillo Blanco, Alberto Palomar Olmeda, Tomás Sala Franco y Miguel Sánchez Morón (Autores) $2^{\mathrm{a}}$ ed., Editorial Lex Nova, Valladolid, 2008.

SANCHÉZ MORÓN; Miguel. Derecho de la Función Pública, quinta edición, Tecnos, Madrid, 2008. 
SÁNCHEZ MORÓN, Miguel. Igualdad de oportunidades en el acceso a la función pública y estabilización funcionarial de los interinos (Comentario a la Sentencia 12/1999, de 11 de febrero, del Tribunal Constitucional), en Revista Andaluza de Administración Pública, núm. 34, 1999.

SÁNCHEZ MORÓN, Miguel. La distribución de competencias entre el Estado y las Comunidades Autónomas en materia de Administración Local, en el libro Tratado de Derecho Municipal, Santiago Muñoz Machado (Dirección), vol. I, $2^{\text {a }}$ ed., Civitas, Madrid, 2003, p. 215.

SANCHÉZ MORÓN, M. Siete tesis sobre el control judicial de la discrecionalidad administrativa, in Cuadernos de Derecho Judicial. Eficacia, discrecionalidad y control judicial en el ámbito administrativo, Consejo General del Poder Judicial, Madrid, 1994

SÁNCHEZ SÁNCHEZ, Zulima, Estudio práctico de las asociaciones, democracia directa y otras formas de participación ciudadana, doctrina, jurisprudencia y formularios, Editorial Lex Nova, 2004, Valladolid.

SANTAMARIA PASTOR, Juan .Alfonso. y PAREJO ALFONSO, Luciano. Derecho Administrativo: la jurisprudencia del Tribunal Supremo, Editorial Centro de Estudios Ramon Areces S.A., Madrid, 1989.

SANTAMARÍA PASTOR, Juan Alfonso. Prólogo al libro El acceso del personal y la provisión de puestos de trabajo en la Administración del Estado y de las Comunidades Autónomas, Vicente M. Escuin Palop, INAP, Madrid, 1986

SANTOS CARVALHO FILHO, José dos. Manual de Direito Administrativo, $17^{\mathrm{a}}$ ed. Lumen Juris Editora, Rio de Janeiro, 2007.

SERRANO GARCÍA, Ignacio, Protección patrimonial de las personas con discapacidad, tratamiento sistemático de la Ley 41/2003, Iustel, Madrid, 2008.

SERRANO GUIRADO, Enrique. El régimen de oposiciones y concursos de funcionarios, Instituto de Estudios Politicos, Madrid, 1956.

SESÍN, Domingos. El control judicial de la discrecionalidad administrativa, Documentación Administrativa, n. 269-270 (mayo-diciembre 2004), Madrid.

SEVILLA MERINO, Julia. Igualdad, paridad y democracia. Capítulo del libro El reto de la efectiva igualdad de oportunidades, editoras Ángela Figueruelo Burrieza y María Luisa Ibáñez Martínez, Universidad de Salamanca, Comares Editorial, Granada, 2006.

SIERRA MORÓN, Susana de la. Tutela cautelar contencioso-administrativa y derecho europeo. Ed. Aranzadi, Cizur Menor (Navarra), 2004. 
SILVA, José Afonso da. Curso de Direito Constitucional Positivo, 23 ${ }^{\mathrm{a}}$ ed., Editora Malheiros, São Paulo, 2004.

SILVA, De Plácido e. Vocabulário jurídico, Editora Forense, Rio de Janeiro, 1999.

SUAY RINCÓN, José. El principio de igualdad en la Justicia Constitucional, Instituto de Estudios de Administración Local, Madrid, 1985.

TARDIO PATO, José Antonio. Control jurisdiccional de concurso de meritos, oposiciones y exámenes académicos, Editorial Civitas, Madrid, 1984

TORNOS MAS, Joaquín. Los ciudadanos y su posición jurídica. Lección 1 del libro Lecciones y materiales para el estudio dl Derecho Administrativo, tomo IV, Las Garantías de los ciudadanos y el control de las Administraciones Públicas, Tomás Cano Campos (Coordinador), Iustel, Madrid, 2009.

TORRES LÓPEZ, María Asunción. Derecho Administrativo, Régimen Jurídico Administrativo de las Personas con Discapacidad, en Régimen Jurídico de las Personas con Discapacidad en España y en la Unión Europea, Esperanza Alcaín Martínez y otros (Coordinadores), autores varios, Editorial Comares.

TOURINHO, Rita. Concurso público no ordenamento jurídico brasileiro, Lumen Juris Editora, Rio de Janeiro, 2008.

VAQUER CABELLERÍA, M., Derechos de los ciudadanos: lengua de los procedimientos, registros administrativos y subsanación de solicitudes. Documentación Administrativa n 254-255 (mayo-diciembre 1999), Madrid.

VICENTE DOMINGO, Ricardo de. El puesto de trabajo en el derecho de la función pública, Tirant lo Blanch, "Colección administrativo", Valencia, 1997.

VILACORTA MANCEBO, Luís. Principio de igualdad y Estado Social, Servicio de publicaciones de la Universidad de Cantabria, Santander, 2006.

VILLORIA MENDIETA, Manuel. El servicio civil de carrera en Latinoamérica: diagnóstico, causas y propuestas, Instituto Nacional de Administración Pública INAP, Madrid, 2007

VILLORIA MENDIETA, Manuel La corrupción política, Ed. Sintesis, Madrid, 2006.

Voto de Joaquim Falcão, miembro del Consejo Nacional de Justicia brasileño, en el análisis del procedimiento de control administrativo $\mathrm{n}^{\circ} 510$, en Revista de Direito Administrativo, $\mathrm{n}^{\circ}$ 248, maio-agosto de 2008, Fundaçao Getúlio Vargas Jurídico Atlas, Ed. Atlas, Sao Paulo, p. 163.

XAVIER FERREIRA FERNANDES, A. La provisión de puestos de trabajo en la Administración General del Estado, Ministerio de las Administraciones Pública, INAP, Madrid, 2002. 
ZANCANER, Weida. O concurso público e os princípios da razoabilidade e da proporcionalidade, en Concurso público e Constituição, Fabrício Motta (Cordinador), Editora Fórum, Belo Horizonte, 2005.

ZANELLA DI PIETRO, Maria Sylvia. Direito Administrativo, $21^{\mathrm{a}}$ ed., Editora Atlas, São Paulo, 2008.

\section{REPORTAJES EXTRAÍDOS DE MEDIOS ESCRITOS}

Concurso público: o sonho da estabilidade, publicado en la revista Istoé, 3 de febrero de 2010 , p. 78

Las oposiciones a mosso vuelven a batir récords, publicado en el periódico 20 minutos (Barcelona), en el día 8 de febrero de 2010, p. 7.

Obeso se acorrenta e recupera emprego, publicado en el periódico Diário de Pernambuco, 11 de septiembre de 2009, p. A16 


\section{REFERENCIAS ELECTRÓNICAS: ARTÍCULOS JURÍDICOS}

ALENCAR CARVALHO, Antônio Carlos. A efetivação de servidores precariamente empossados "sub judice" em cargos de provimento efetivo à luz da Constituição Federal, Texto extraído del sitio electrónico Jus Navigandi (http://jus2.uol.com.br/doutrina/texto.asp?id=12017=), acceso en 14 de agosto de 2010.

ALVES DIAS, Fábio Henrique. Concurso público: uma vinculação recíproca. O direito subjetivo à nomeação de candidatos aprovados em concurso público. Texto extraído del sitio electrónico http://jusvi.com/artigos/36202., acceso en 20 de junio de 2010.

BARCAROL, Amarildo José. Exigência de experiência prévia em concursos públicos é ilegal?, texto extraído del sitio electrónico: http://forum.jus.uol.com.br/2268/exigencia-de-experiencia-previa-emconcursos-publicos-e-ilegal/, acceso en 15 de junio de 2010.

BENDINI MADALENA, Lenoar. Controle jurisdicional nos concursos públicos. Texto extraído do sitio electrónico Jus Navigandi (http://jus2.uol.com.br/doutrina/texto.asp?id=6560, acceso en 17 de agosto de 2010.

BRAGA CALHAU, Lélio. Da inconstitucionalidade da decisão irrecorrível de bancas examinadoras de concurso público. Texto extraído del sitio electrónico: http://jus2.uol.com.br/doutrina/texto.asp?id=390, acceso en 16 de agosto de 2010.

BRANDÃO COSTA, Bernardo. Aprovação dentro do número de vagas: direito à nomeação? Texto extraído del sitio: http://www.pciconcursos.com.br/consultoria/aprovacao-dentro-do-numero-devagas-direito-a-nomeacao, acceso en 19 de julio de 2010.

BRANDAO COSTA, Bernardo. Deficiente Físico - Forma de convocação, texto extraído del sitio electónico PCI Concursos (http://www.pciconcursos.com.br/consultoria/deficiente-fisico-forma-deconvocacao), acceso en 16.02.2010.

BRANDAO COSTA, Bernardo. Exame Psicotécnico - Novas Regras, texto extraído del sitio electrónico: http://www.pciconcursos.com.br/consultoria/examepsicotecnico-novas-regras), acceso en 27 de junio de 2010.

BRANDAO COSTA, Bernardo. Idade no concurso público. Texto extraído del sitio electrónico http://www.pciconcursos.com.br/consultoria/idade-em-concursopublico, acceso en 02.02.2010. 
BRANDAO COSTA, Bernardo. Investigação Social. Texto extraído del sitio electrónico: http://www.pciconcursos.com.br/consultoria/investigacao-social, acceso en 09 de junio de 2010.

CERELlO, Anselmo. Suspensão de Direitos Políticos para o Condenado Beneficiado pelo Sursis e Liberdade Condicional. Texto extraído del sitio electrónico del Tribunal Regional Electoral del Estado de Santa Catarina, RESENHA ELEITORAL - Nova Série, v.9, n.1 (jan./jun. 2002), http://www.tresc.gov.br/site/institucional/publicacoes/artigos-doutrinarios-publicados-naresenha-eleitoral/resenhas/v9-n1-janjun-2002/a-suspensao-de-direitos-politicospara-o-condenado-beneficiado-pelo-sursis-e-liberdade-condicional/index.html, publicado en enero de 2002, con acceso en 10 de junio de 2010.

DA SILVA OLIVEIRA, Luciano Henrique. O contraditório e a ampla defesa nos concursos públicos, texto extraído del sitio electrónico Jus Navigandi (http://jus2.uol.com.br/doutrina/texto.asp?id=12006), inserido em 25.11.2008, acceso en 16.02.2010.

DE MORAES, Alexandre. Condenaçao criminal e suspensao dos direitos políticos, texto publicado en el sitio electrónico del Ministerio Público del Estado de Goiás,http://www.mp.go.gov.br/portalweb/hp/7/docs/artigo_alexandre_de_morai s.pdf, acceso en 10 de junio de 2010.

DE OLIVEIRA GÓIS, Ewerton Marcus. O concurso público, da razoabilidade e dos vinte dentes. Texto extraído del sitio Jus Navigandi (http://jus2.uol.com.br/doutrina/texto.asp?id=10497), publicado en 09.2007, acceso en 17.02.2010.

DIETZ, Gunther. La educación religiosa en España ¿Contribución al diálogo interculturalo factor de confl icto entre religiones?, Estudios sobre las culturas contemporáneas, vol. XIV, número 28, diciembre 2008, pp. 11-46, Universidad de Colima (Colima-Mexico), extraído del sitio electrónico http://redalyc.uaemex.mx/src/inicio/ArtPdfRed.jsp?iCve=31602802, acceso en 07 de junio de 2010.

DOUGLAS, Willian. A qualidade do serviço público, o exame psicotécnico e o princípio da segurança jurídica, texto extraído del sitio Jus Navigandi (http://jus2.uol.com.br/doutrina/texto.asp?id=12854), publicado en 14.05.2009, acceso en 16.02.2010.

DOUGLAS, Willian. Fraude no concurso. Carta aos aprovados honestamente e aos demais interessados. Texto extraído del sitio electrónico de la Associação Nacional de Proteção e Apoio aos Concursos - ANPAC (http://www.anpac.org.br/portal/index.php/artigos/70-fraude-no-concurso-daprf), acceso en 20 de abril de 2010.

FERREIA DE ALMEIDA, Péricles. Discriminação em concurso público por motivo de idade. Extraído del sitio electrónico Jus Navigandi (http://jus2.uol.com.br/doutrina/texto.asp?id=5364), acceso en 02.02.2010. 
Instituto Nacional de Administración Pública - INAP. Los Recursos Administrativos: concepto y clases. Recursos de alzada, reposición y extraordinário de revisión. La Jurisdicción contencioso-administrativa. Extraído del sitio electrónico del INAP: $\quad$ http://www.inap.map.es/NR/rdonlyres/D472D70A-AE0C-4874A6518A5D49587DEA/0/adm_adm3.pdf, acceso en 13 de agosto de 2010.

JACOBY FERNANDES, Jorge Ulisses. Concurso público e os direitos dos candidatos. Texto extraído del sitio electrónico Jus Navigandi (http://jus2.uol.com.br/doutrina/texto.asp?id=389), acceso en 05 de Julio de 2010.

KÜMPEL, Vitor Frederico. Limite de idade para concurso público. Texto extraído del sitio electrónico Jus Navigandi (http://jus2.uol.com.br/doutrina/texto.asp?id=4725), acceso en 02.02.2010.

LEOPOLDINO KOEHLER, Frederico Augusto. Da obrigatoriedade de isenção de taxa de inscrição para os reconhecidamente pobres em edital de concurso para o provimento de cargos públicos, texto extraído del sitio electrónico Jus Navigandi (http://jus2.uol.com.br/doutrina/texto.asp?id=9008), publicado en 05.10.2006, acceso en 16.02.2010.

LUIZILO FREDERICO JÚNIOR, José. A reserva de vagas para deficientes em concursos: a lei e a jurisprudência, texto extraído del sitio electrónico Jus Navigandi (http://jus2.uol.com.br/doutrina/texto.asp?id=8874), publicado en 04.09.2006, acceso en 16.02.2010.

MEDINA OSÓRIO, Fábio. Os limites da discricionariedade técnica e as provas objetivas nos concursos públicos para ingresso nas carreiras jurídicas, em Revista Diálogo Jurídico, no 13, abril-mayo de 2002, Salvador, p. 13, extraído del sitio electrónico: http://www.direitopublico.com.br/PDF_13/DIALOGOJURIDICO-13-ABRIL-MAIO-2002-FABIO-MEDINA-OSORIO.pdf, acceso en 16 de agosto de 2010

MESQUITA DANTAS, Adriano. Os portadores de deficiência e o concurso para provimento de cargos e empregos públicos. A ineficácia dos dispositivos constitucionais e infraconstitucionais, texto extraído del sitio electrónico Jus Navigandi (http://jus2.uol.com.br/doutrina/texto.asp?id=7150), publicado en 12.08.2005, acceso en 16.02.2010.

MONTERO GONZÁLEZ, David. Derechos Humanos y Derechos LGBT desde una perspectiva internacional, Seminario: "Orientación sexual e identidad de género. Los derechos menos entendidos", Organiza: Institut de Drets Humans de Catalunya Barcelona, 21 de Mayo de 2007, texto publicado en el sitio electrónico http://www.felgtb.org/files/docs/01f268e9e436.pdf, acceso en 08 de junio de 2010.

MORHY, Lauro. A realidade dos concursos públicos. Texto extraído del sitio electrónico de la Universidade de Brasilia - UnB 
(http://www.unb.br/administracao/reitoria/artigos/20050616.php), acceso en 18 de abril de 2010.

MOTTA, Fabrício. A contratação de pessoal por prazo determinado pela administração pública vista pelo Supremo Tribunal Federal. Texto extraído do sitio eletrônico Jus Navigandi (http://jus2.uol.com.br/doutrina/texto.asp?id=8045), acceso en 21 de mayo de 2010.

MOTTA, Fabrício. Concursos públicos e o princípio da vinculação ao edital. Texto extraído del sitio electrónico Jus Navigandi (http://jus2.uol.com.br/doutrina/texto.asp?id=8035, elaborado em 03.2005, acceso en 22 de mayo de 2010.

NOGUEIRA JÚNIOR, Alberto. Eliminação de candidato em concurso público: a “investigação social dos bons antecedentes" $x$ o princípio da presunção da inocência, texto extraído del sitio electrónico JusVigilantibus, http://jusvi.com/artigos/29386, publicado en 29 de octubre de 2007, com acceso en 10 de junio de 2010.

OTADUY, Jorge. Relación jurídica de los profesores de religión en España. La dimensión canónica. Extraído del sitio electrónico http://www.accessmylibrary.com/article-1G1-160029695/relacion-juridica-delos.html, publicado en 01 de julio de 2006, acceso en 07.06.2010.

PIMENTEL, Ernani. O decreto presidencial e os concursos públicos. Texto extraído del sitio electrónico de la Associação Nacional de Proteção e Apoio aos Concursos ANPAC (http://www.anpac.org.br/portal/index.php/artigos/52-anpac-e-odecreto-presidencial-dos-concursos), acceso en 25 de junio de 2010.

PINTO DE OLIVEIRA, Renato. Sobre a reserva de vagas em concurso público para os portadores de deficiência, texto extraído del sitio electrónico Jus Navigandi (http://jus2.uol.com.br/doutrina/texto.asp?id=8963), publicado en 24.09.2006, acceso en 16.02.2010.

QUEIROZ, Tiago. Isenção da taxa de inscrição. Trecho extraído del sitio electrónico: http://www.pciconcursos.com.br/consultoria/isencao-da-taxa-de-inscricao, acceso en 13 de julio de 2010.

RODRÍGUEZ ESCANCIANO, Suzana. El fomento de empleo de los colectivos más desfavorecidos en la legislación de contratos del sector público. Especial referencia a las personas con discapacidad, Revista Electrónica de la Facultad de Derecho de la Universidad de Granada, disponible en el sitio electrónico www.refdugr.com, fecha de publicación: 30 de octubre de 2008.

SAMPAIO ANGELIM, Augusto. Perda e suspensão dos direitos políticos I, texto extraído del sitio electrónico DireitoNet, 
http://www.direitonet.com.br/artigos/exibir/1530/Perda-e-suspensao-doDireitosPoliticos-I, publicado en 08 de abril de 2004, con acceso en 10 de junio de 2010.

SANTOS, Waldir. Concurso público e exigência de nível superior. Texto extraído del sitio electrónico Jus Navigandi (http://jus2.uol.com.br/doutrina/texto.asp?id=12782), acceso 15 julio de 2010.

SANTOS, Waldir. Concurso público.Uma ferramenta democrática subutilizada. Texto extraído del sitio electrónico: http://jus2.uol.com.br/doutrina/texto.asp?id=3726, acceso en 16 de agosto de 2010.

SÁTIRO FERNANDES, Flávio. A prova oral como elemento defraudador dos princípios da impessoalidade e da moralidade. Texto extraído del sitio electrónico Jus Navigandi (http://jus2.uol.com.br/doutrina/texto.asp?id=8691), publicado en 26.07.2006, acceso en 16.02.2010.

SCHIER, Paulo Ricardo. Constitucionalização e 20 anos da Constituição. Reflexão sobre a exigência de concurso público (entre a isonomia e a segurança jurídica), Texto extraído del sitio Jus Navigandi, (http://jus2.uol.com.br/doutrina/texto.asp?id=13167), acceso 20.06.2010.

SETTE DE BARROS, Maria Magdala. Portadores de deficiência e o concurso público, texto extraído del sitio Jus Navigandi (http://jus2.uol.com.br/doutrina/texto.asp?id=2639), Elaborado em 11.2001, acceso en 16.02.2010.

SEVIDANES DA MATTA, Marco Antonio. Contratação temporária de pessoal na Administração Pública: desvirtuamento do uso da exceção prevista no art. 37, IX, da Constituição Federal. Texto extraído do sitio Jus Navigandi (http://jus2.uol.com.br/doutrina/texto.asp?id=8695), acceso en 16.05.2010.

SGARBOSSA, Luís Fernando y JENSEN, Gesiela. O princípio da ampla acessibilidade aos cargos públicos. A exigência de três anos de atividade jurídica para os concursos à Magistratura e ao Ministério Público, texto extraído del sitio electrónico Jus Navigandi (http://jus2.uol.com.br/doutrina/texto.asp?id=7427), acceso en 16 de junio de 2010.

SOARES DA COSTA, Wagner. Concurso público: inconstitucionalidade da exigência dos requisitos ao momento da inscrição, texto extraído del sitio electrónico Jus Navigandi (http://jus2.uol.com.br/doutrina/texto.asp?id=3596), publicado en enero de 2003, acceso en 16 de febrero de 2010.

SOARES JÚNIOR, Jair. Estado laico versus direito constitucional à liberdade de crença religiosa.Uma análise crítica acerca da imposição de data e horário de provas, exames e concursos público em colidência com crenças religiosas, texto extraído del sitio electrónico Jus Navigandi (), 14.01.2010, acceso en 16.02.2010). 
SOARES, Evanna. Percalços na implementação do concurso público. Texto extraído del sitio electrónico Jus Navigandi (http://jus2.uol.com.br/doutrina/texto.asp?id=13424), acceso 15.05.2010.

SPITZCOVSKY, Celso. Limitações constitucionais aos editais de concursos públicos. Texto extraído del sitio electrónico Jus Navigandi (http://jus2.uol.com.br/doutrina/texto.asp?id=5125), acceso 18.05.2010.

SANTOS, Waldir. Concurso público e exigência de nível superior. Texto extraído del sitio Jus Navigandi (http://jus2.uol.com.br/doutrina/texto.asp?id=12782), acceso en 15 de junio de 2010.

TAVARES DE JESUS, Noel Antônio. O direito subjetivo à nomeação dos concursados aprovados e os limites de despesas com pessoal. Texto extraído del sitio Jus Navigandi (http://jus2.uol.com.br/doutrina/texto.asp?id=13545), acceso en 08.02.2010.

\section{REPORTAJES PUBLICADOS EN SITIOS ELECTRÓNICOS}

Adiós clase media, adiós, la recesión golpea con dureza al principal sustento del Estado del bienestar, publicado en elpais.com, (http://www.elpais.com/articulo/primer/plano/Adios/clase/media/adios/elpepuec oneg/20090531elpneglse_2/Tes), en el día 31 de mayo de 2009 y con acceso en el día 10 de mayode 2010.

Alta concorrência em concursos faz candidatos desistirem de disputar os cargos, publicado en 25.04.2010 en el sitio electrónico http://www.dnonline.com.br/noticia/tag/concursos/ver_noticia/38880/, con acceso en 17 de mayo de 2010.

Assegurada posse no cargo de cotista negro aprovado em concurso público, publicado en el sitio JusBrasil (http://www.jusbrasil.com.br/noticias/57582/asseguradaposse-no-cargo-de-cotista-negro-aprovado-em-concurso-publico), acceso en 10.02.2010.

El número de inmigrantes empadronados en España se ha multiplicado por 5 en una década, publicado en 07.02.2010, extraído del sitio electrónico HERALDO.ES(http://www.heraldo.es/noticias/sociedad/el_numero_inmigrantes _registrados_padron_multiplicado_por_una_decada.html), con acceso en 04.06.2010.

El Supremo condena al Ejército español a indemnizar a un homosexual al que vejó y expulsó de la mili, publicado en el sitio: http://www.nodo50.org/tortuga/ElSupremo-condena-al-Ejercito, publicado en 12.07.2007, acceso en 16.02.2010

El Tribunal Constitucional otorga un amparo histórico al control de oposiciones y concursos, publicado en el blog Contensioso es José Ramón Chaves García, El blog de Derecho Público de Sevach, disponible en la pagina web http://contencioso.es/2009/02/28/el-tribunal-constitucional-otorga-un-amparohistorico-al-control-de-oposiciones-y-concursos/, acceso 16 de agosto de 2010. 
Em ano eleitoral, concursos para formação de cadastro de reserva voltam a gerar polêmica, redactado por Ione Luques, publicada en 23 de marzo de 2010 en el sítio electrónico

Globo.com (http://oglobo.globo.com/economia/boachance/mat/2010/03/22/em-anoeleitoralconcursos-para-formacao-de-cadastro-de-reserva-voltam-gerar-polemica 916140853.asp), acceso en 30 de junio de 2010.

Ensino religioso na escola pública: o retorno de uma polêmica recorrente, elaborado por Carlos Roberto Jamil Cury, Revista Brasileira de Educaçao, set-out-nov-dez 2004, São Paulo, p. 183-191, publicado en el sitio electrónico http://redalyc.uaemex.mx/redalyc/pdf/275/27502713.pdf, acceso en 07 de junio de 2010.

Homofobia en el trabajo. .Texto escrito por Carlos Mora Vanegas y publicado en el sitio electrónico Gestiopolis.com (http://www.gestiopolis.com/organizaciontalento/homofobia-en-el-trabajo.htm), en 21-de enero de 2008, acceso 08.07.10.

Homossexualidade nas Forças Armadas, publicado en el sitio electrónico http://www.rea.pt/forum/index.php?topic=2166.0; wap2, con acceso en $08 \mathrm{de}$ Julio de 2010.

Justiça privilegia candidato em concurso por motivo religioso, texto extraído del sitio Consultor Jurídico (http://www.conjur.com.br/2004-nov23/justica_privilegia_candidato_concurso_motivo_religioso), publicado en 23.11.2004, acceso en 16.02.2010).

Lei estadual define cota para negros em concursos públicos, publicado en el sitio JusBrasil (http://www.jusbrasil.com.br/noticias/370059/lei-estadual-define-cotapara-negros-em-concursos-publicos), acceso en 10.02.2010.

Mujeres en la Administración Pública: muchas y cada vez más, escrito por Esther Riobó, publicado en el sitio electrónico (http://www.aprendemas.com/Reportajes/EspecialMujeres/P6.asp), acceso en 24 de Febrero de 2010

Mulheres debatem liderança na Administraçao Pública, publicado en el sitio electrónico de la Escola Nacional de Administraçao Pública - ENAP, http://www.enap.gov.br/index.php?option=com_content\&task=view\&id=665\&It emid=158, acceso en 01 de junio de 2010.

Obrigatoriedade do Serviço Militar é polêmica, escrito por Fabiana Born, publicado en el sitio electrónico Ibase., Juventudes Sudamericans/Sulamericanas., (http://www.juventudesulamericanas.org.br/index.php/noticias/38-materias/107obrigatoriedade-do-servico-militar-e-polemica), en 19 de noviembre de 2008, con acceso en 09 de junio de 2010

Papá, ¿qué es la clase media?, extraído del sitio http://blogs.que.es/mirandoelhorizonte/2009/6/6/papa-es-clase-media, publicado en el día 06 de junio de 2009 y con acceso en 10 de mayo de 2010.) 
PSOE anuncia fin de educación religiosa y violación del Concordato con la Santa Sede, publicado en el sitio electrónico Aciprensa (http://www.aciprensa.com/noticia.php?n=3863), en el día 22 de marzo de 2004 y con acceso en 07 de junio de 2010.

Saiba como são escolhidas as entidades responsáveis por concursos, publicado en 25 de diciembre de 2009, el sitio Globo.com (http://g1.globo.com/Noticias/Concursos_Empregos/0,,MUL14206709654,00.html), con acceso en 17 de junio de 2010.

Servicio Militar. Cuenta atrás para que el último recluta vaya a la mili, publicado en el sitio electrónico Aula de El Mundo (http://aula2.elmundo.es/aula/noticia.php/2000/11/09/aula973701814.html), en 09 de noviembre de 2000, con acceso en 09 de julio de 2010.

Tenente coronel é aposentado pelo STM porque é homossexual', publicado en 12 de marzo de 2010 en el sitio electrónico direitoshumanos, de la Comisión de Derechos Humanos y Legislación Participativa del Senado Federal brasileño (http://www.direitoshumanos.etc.br/index.php?option=com_content\&view=artic le\&id=8315:so-preconceito-tenente-coronel-e-aposentado-pelo-stm-porque-e homossexual\&catid=41:lgbtt\&Itemid=174), acceso en 08 de julio de 2010

Tropa não obedece a militar homossexual, diz general no Senado, publicado en el sitio Globo.com(http://g1.globo.com/Noticias/Brasil/0,,MUL14758385598,00TROP $\mathrm{A}+\mathrm{NAO}+\mathrm{OBEDECE}+\mathrm{A}+\mathrm{MILITAR}+\mathrm{HOMOSSEXUAL+DIZ+GENERAL+NO}$ +SENADO.html), con acceso en 04.02.2010

Ufpel não pode exigir comprovação de experiência profissional no cargo de Assistente Administrativo, publicado en el sitio JusBrasil (http://www.jusbrasil.com.br/noticias/55444/ufpel-nao-pode-exigicomprovacaode-experiencia-profissional-no-cargo-de-assistenteadministrativo), acceso en 11 de julio de 2010.

Un mando militar hace pública su homosexualidad, publicado en el sitio El Mundo periódico (http://www.elmundo.es/2000/09/04/sociedad/04N0080.html) en 04.09.2000, acceso en 16.02.2010 